Neostructuralism and heterodox thinking in Latin America and the Caribbean in the early twenty-first century ALICIA BÁrCENA
ANTONIO PRADO ALICIA BÁRCENA
ANTONIO PRADO Editors

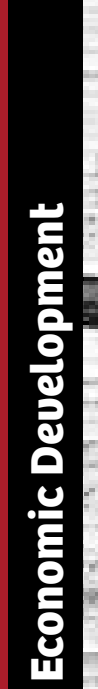




\section{Neostructuralism and heterodox thinking in Latin America and the Caribbean in the early twenty-first century}

Alicia Bárcena

Antonio Prado

Editors

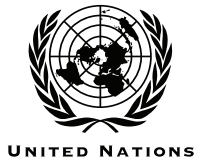

E C L A C

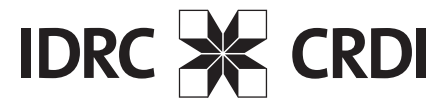

Economic Commission for Latin America and the Caribbean (ECLAC) Santiago, December 2016 


\section{ECLAC Books}

\section{2}

\section{Alicia Bárcena}

Executive Secretary

Antonio Prado

Deputy Executive Secretary

\section{Ricardo Pérez}

Chief, Publications and Web Services Division

Work on this book was coordinated by Alicia Bárcena, Executive Secretary, and Antonio Prado, Deputy Executive Secretary, of the Economic Commission for Latin America and the Caribbean (ECLAC). It was prepared by Esteban Pérez-Caldentey, Economic Affairs Officer with the Economic Development Division; Miguel Torres, Technical Editor of CEPAL Review; and Romain Zivy, Deputy Coordinator of the Office of the Executive Secretary.

The document was prepared in the framework of the project "Raúl Prebisch Raúl Prebisch and the challenges of the twenty-first century", conducted by ECLAC and the International Development Research Centre (IDRC) of Canada between 2011 and 2013. The authors are grateful to Federico Burone, Regional Director for Latin America and the Caribbean of IDRC; Luis Bértola, Professor of the Universidad de la República of Uruguay and technical coordinator of the project; and Vicente Neira, project research assistant, as well as the participants at the seminar on neo-structuralism and heterodox economics held at ECLAC headquarters in Santiago on 22 and 23 April 2013.

The views expressed in this document are those of the authors and do not necessarily reflect the view of the Organization.

United Nations publication

ISBN: 978-92-1-329032-3 (print)

ISBN: 978-92-1-057534-8 (pdf)

ISBN: 978-92-1-358031-8 (ePub)

Sales No.: E.14.II.G.23

LC/G.2633-P/Rev.1

Copyright (C) United Nations, 2016

All rights reserved

Printed at United Nations, Santiago

S.16-00999

This publication may be cited as: Neostructuralism and heterodox thinking in Latin America and the Caribbean in the early twenty-first century, ECLAC Books No. 132 (LC/G.2633-P/Rev.1), Santiago, Chile, Economic Commission for Latin America and the Caribbean (ECLAC), 2016.

Applications for authorization to reproduce this work in whole or in part should be addressed to the Secretary of the Publications Board, United Nations Headquarters, New York, N.Y. 10017, United States of America. Member States and their governmental institutions may reproduce this work without prior authorization, but are requested to mention the source and inform the United Nations of such reproduction. 


\section{Contents}

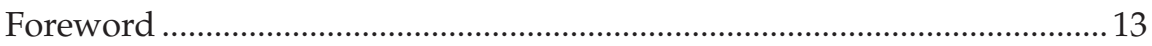

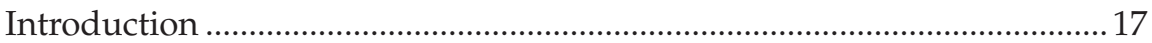

Part I

Schools of economic thought and the regional context in the early twenty-first century

\section{Chapter I}

A time to reflect on opportunities for debate and dialogue between (neo)structuralism and heterodox schools of thought

Esteban Pérez Caldentey

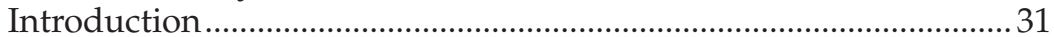

A. Economists and the Great Moderation ..........................................33

B. The economics of the mainstream: its theoretical underpinnings and economic policy implications ..................... 35

C. Criticisms of the mainstream economic paradigm

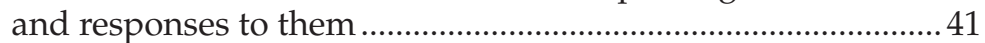

D. The structuralist view of economics and the heterodoxy..........44

E. The methodological approach of neostructuralism

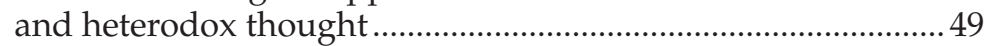

F. The external context: centre-periphery and dynamics .............. 53

G. The external context: the centre and periphery

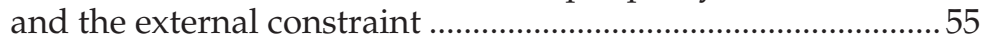

H. Structural change, technological progress and innovation.......62 62

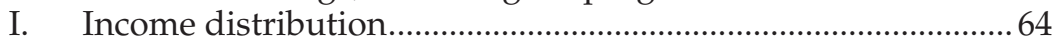

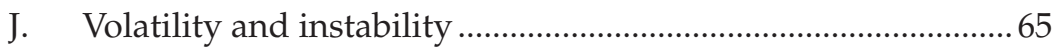




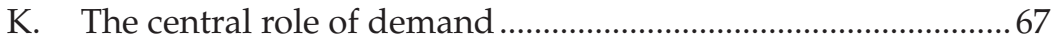

L. The role of the market and the State............................................. 68

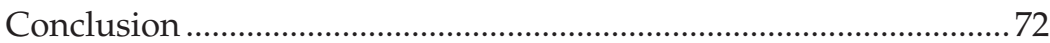

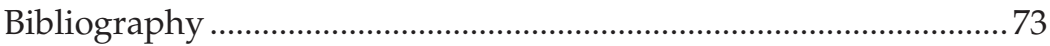

Chapter II

Latin America and world economic turmoil

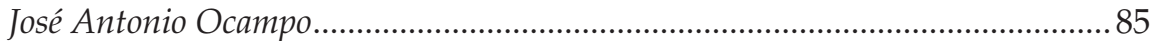

A. Dramatic changes at the international level .................................8 86

B. Changes in international trade and the region's

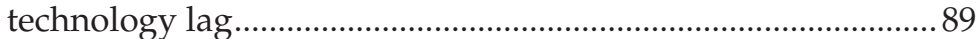

C. External financing and underlying world balances ....................92

D. Is it time for a new strategy?.......................................................96

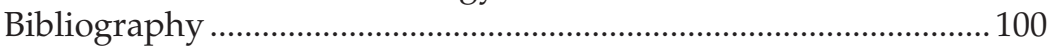

Chapter III

The recent internationalization of capitalization

Luiz Gonzaga Belluzzo

Part II

Macroeconomics for development

Chapter IV

Neostructuralism and macroeconomics for development

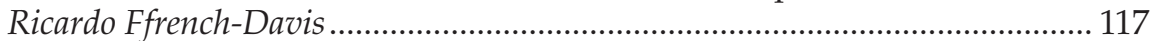

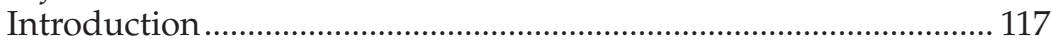

A. The mainstream approach since 1990 and its effects .............. 119

B. Recessionary and regressive asymmetries .................................123

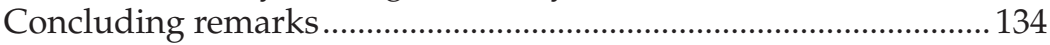

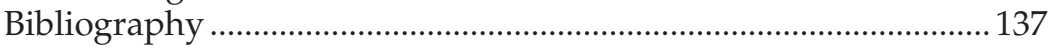

Chapter V

Macroeconomics for development in Latin America and the Caribbean:

new thoughts on countercyclicality

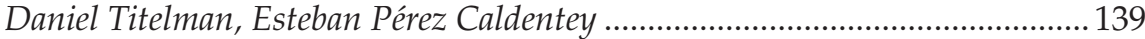

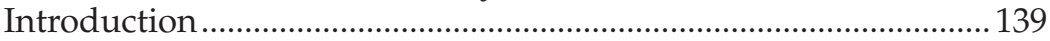

A. The long-run performance of Latin America and the Caribbean: high volatility and low growth ........................142

B. Balance-of-payments dominance ............................................. 145

C. Volatility also reflects the specific features of the business cycle in Latin America and the Caribbean ................ 148

D. The relationship between the cycle and long-run growth: the real channel (productivity and investment) ........................ 153

E. The relationship between the cycle and long-run growth:

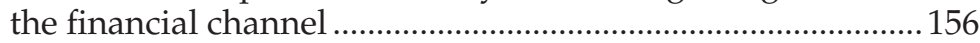

F. Completing the macroeconomics for development blueprint view of countercyclicality 


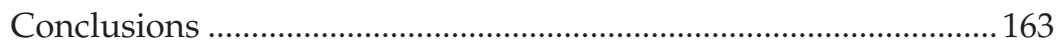

Bibliography ……........................................................................... 164

Chapter VI

Towards a Robinsonian interpretation of capital accumulation in Latin America

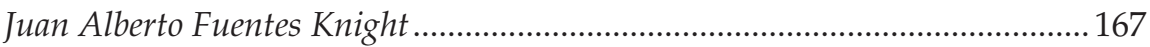

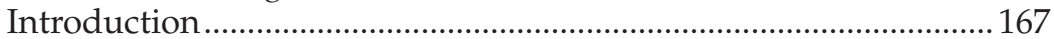

A. Joan Robinson's growth theory .................................................... 168

B. Capital accumulation and the ages of growth in Latin America from 1980 to 2012 ............................................. 181

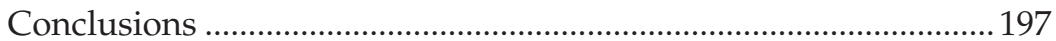

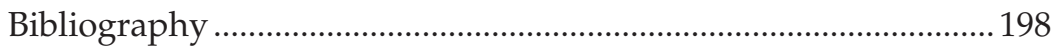

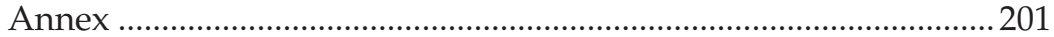

Part III

Structural change and production development..........................................2203

Chapter VII

Productivity and structural change: structuralism and its dialogue with other heterodox currents

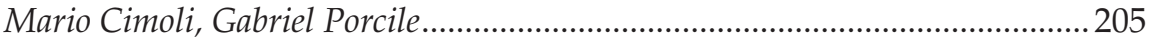

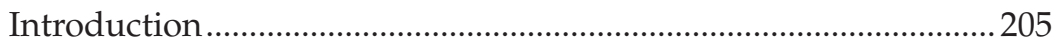

A. Economic growth, specialization and technology ....................206

B. Microeconomic foundations of learning and convergence....212

C. An example: ind ustrial policy ......................................................214

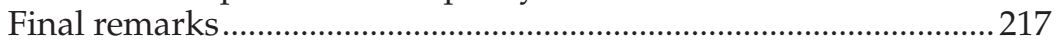

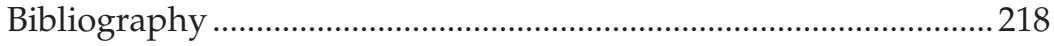

Chapter VIII

The macro- and microeconomics of natural-resource-based growth Jorge Katz

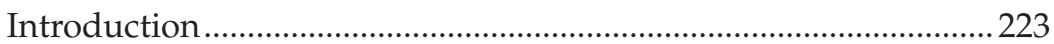

A. Reflections on the new macroeconomic policies ......................227

B. More unfinished business: the long-term sustainability

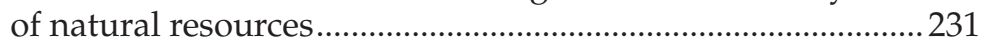

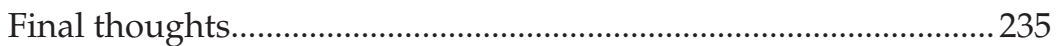

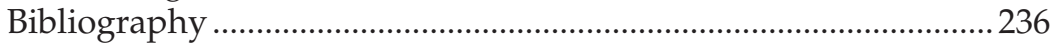

Chapter IX

Development patterns and welfare States in Latin America

Luis Bértola

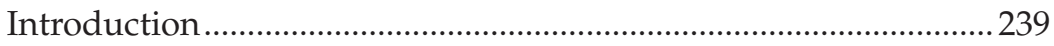

A. Economic growth and natural resources: a long-term perspective.

B. The unequal and interdependent growth of the centre and periphery. 
C. Development and welfare States ................................................246

D. Development and the welfare State in Latin America.............2252

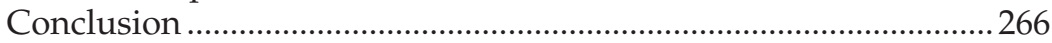

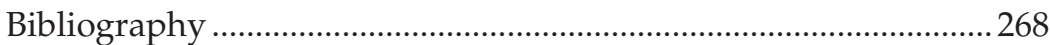

\section{Part IV}

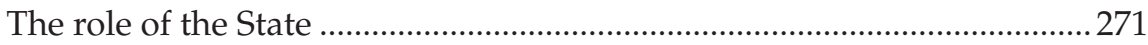

Chapter X

Growth, employment and equality: the new role of the State

Robert Boyer 273

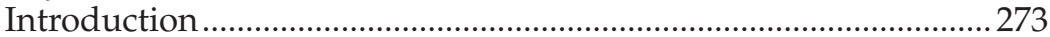

A. Reducing inequality in developed economies with high and stable growth .....................................................244

B. The end of the "golden age": the success of market-led regimes and their crises................................................................ 278

C. The State and economic policy: a new paradigm......................285

D. The welfare State and growth......................................................28

E. The consequences of globalization ………………………….......290

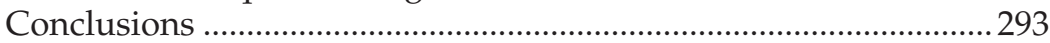

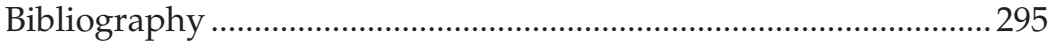

\section{Chapter XI}

Transformation of the State and development paradigms

in Latin America

René A. Hernández.

Introduction

A. Concepts of state and development: a number of approaches

B. An approach to Latin American development paradigms ...312

C. An approach to Prebisch's contribution

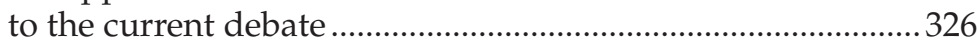

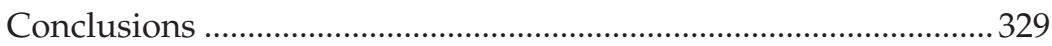

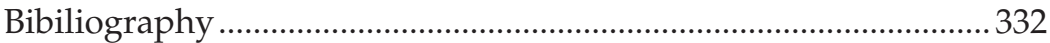

Chapter XII

The State, heterodoxy and the contribution of feminism

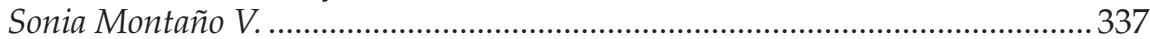

A. The contributions of feminism .......................................................338

B. The role of the State, democracy and the economy...................340

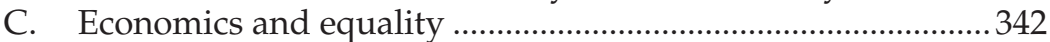

D. Heterodox economics and the role of the State...........................345

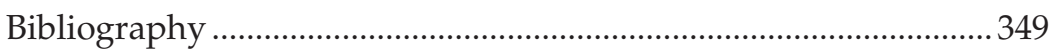


Part V

Case studies of major economies in the region.

Chapter XIII

Development and macroeconomics: reflections from the Mexican case

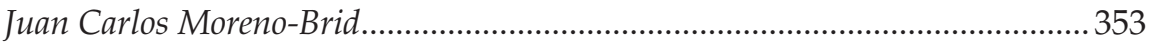

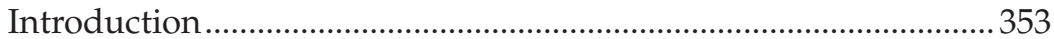

A. Progress, unresolved issues and reverses in Mexican macroeconomic policy over the last three decades ...................355

B. Some lessons from the international financial crisis on how to apply a macroeconomic policy for development........363

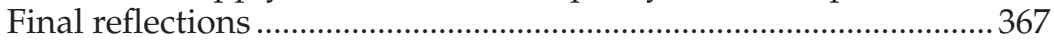

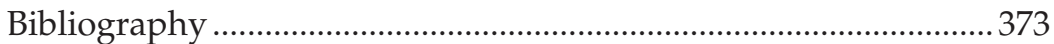

Chapter XIV

Where next for Brazilian development?

Francisco Eduardo Pires de Souza, João Carlos Ferraz ......................................375

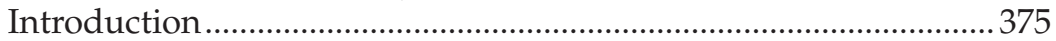

A. Background: from the Real Plan to the external boom ............377

B. The inclusive growth model: virtues and limitations ...............379

C. (The early signs of) an emerging model .....................................384

D. The underpinnings and challenges of an inclusive and productive development model ..........................................386

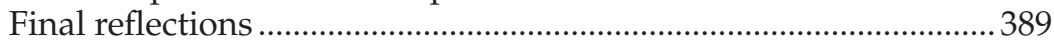

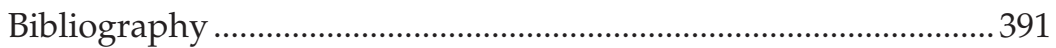

Chapter XV

Structural change trajectories and industrial policy approaches:

a proposal based on the Argentine experience

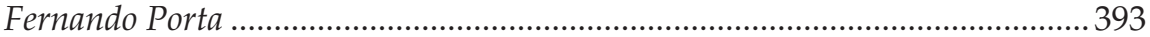

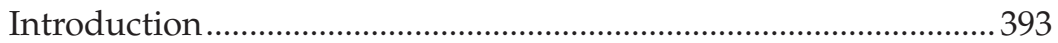

A. Recent manufacturing performance.............................................395

B. Limitations of productive specialization .....................................401

C. Industrial policy approaches: towards

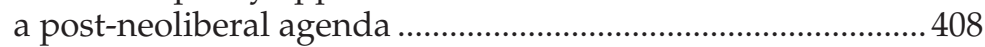

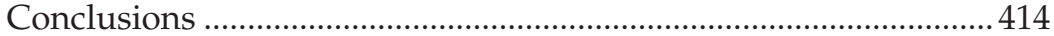

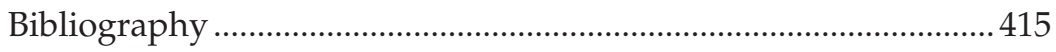

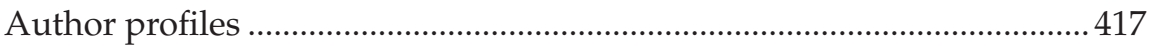

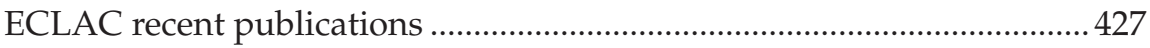




\section{Tables}

II.1 World: average annual growth in international commodity price indices, 2000-2013.

II.2 World (selected countries and regions): balance-of-payments current account balance as a percentage of GDP, 2005-2012 ...........8 87

II.3 World: per capita GDP growth, by region, 1971-2011 .......................8 88

II.4 World: specialization, production structure and growth, 1996-2007.

IV.1 Latin America: per capita GDP compared to the United States and the Group of Seven (G7), 1970-2012

V.1 Selected regions and groupings: coefficient of variation of the rate of growth of per capita GDP, 1960-2011

V.2 Selected regions and groupings: per capita GDP growth, 1971-2011

V.3 Latin America and the Caribbean and subregions (including Mexico): coefficient of business cycle synchronicity with respect to the United States, the eurozone and China, 1990-2012

V.4 Selected regions: mean duration and amplitude of the expansionary and contractionary phases of the business cycle, 1990-2012

V.5 Latin America and the Caribbean: mean duration and amplitude of the upswing and downswing phases of the cycle, 1990-2012

V.6 Selected regions and groupings: duration and amplitude of the expansionary phase of the labour productivity cycle, using the classical cycle methodology, 1990-2012

V.7 Latin America (selected countries): duration and amplitude of expansionary and contractionary phases of the cycle of public investment in infrastructure, 1980-2010.

V.8 Latin America and the Caribbean (selected countries): duration and amplitude of the expansionary and contractionary phases of the real credit cycle in relation to real GDP, 1990-2012..................................................... 158

VI.1 Basic features of growth ages according to Joan Robinson ............. 174

VI.2 High inflation episodes and changes in the ratio of wages to GDP.....

VI.3 Argentina, Brazil, Chile and Mexico: average annual growth in investment, employment and labour productivity, 1993-2010....... 195

VIII.1 Chile: impact of the tragedy of the commons on salmon farming, 2003-2007.

IX.1 Structure of per capita wealth, by region, 2005 ….............................24

IX.2 Selected country groupings: the heterogeneity of structural productivity 
IX.3 Latin America (10 countries): the heterogeneity of labour

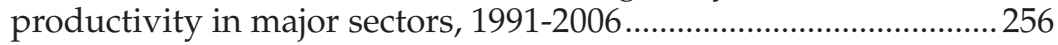

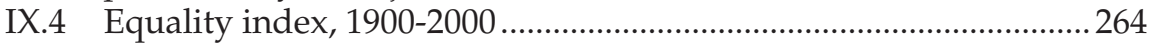

IX.5 Historical human development index (HHDI) and inequality-adjusted historical human development

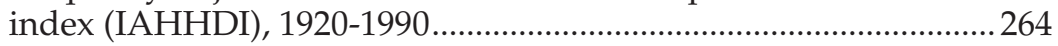

X.1 Types of economic policy, 1945-2014 .............................................283

X.2 Factors increasing the likelihood of twin crises, 2009 ......................291

XIV.1 Latin America: terms of trade, selected years.....................................378

XIV.2 Brazil: supply-side GDP growth, 2005-2012 …................................. 381

XV.1 Tentative matrix of objectives and policy strategies........................413

\section{Figures}

II.1 Growth of world trade and GDP, 1950-2012 _..................................90

II.2 World: exports by volume and value, January 2006

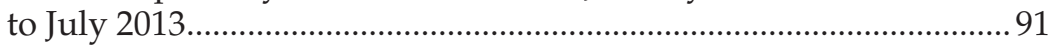

II.3 Latin America: risk margins and bond yields, 2003-2013 .................92

II.4 Latin America (17 countries): real currency appreciation or depreciation, 1990-2011 compared with 2012 and 2003-2007 compared with 2012 ................................................. 93

II.5 Latin America (17 countries): real currency appreciation or depreciation, 2012-2013 ....................................................................... 94

II.6 Latin America: current account balance with respect to gross

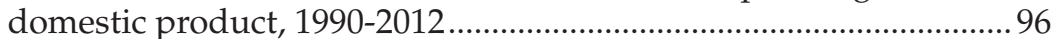

IV.1 Latin America (19 countries): GDP volatility, 1977-2012 ................. 121

IV.2 Latin America: terms of trade for goods and services, 1990-2012.

IV.3 Latin America: volume of exports and imports of goods, FOB, 2003-2012.

IV.4 Latin America (19 countries): gross capital formation, 1970-2012.

V.1 Latin America (20 countries): ratio between investment volatility and the rate of growth of GDP, 1971-2008.

V.2 Latin America and the Caribbean: trend of the rolling correlation coefficient between GDP cycles and financial flows, and between GDP cycles and the terms of trade with a five-year window, 1993-2011

V.3 East Asia and the Pacific and high-income countries: average cumulative output gain compared with Latin America and the Caribbean, 1990-2012

V.4 Latin America and the Caribbean and East Asia and the Pacific: GDP trend, 1960-2010

V.5 Latin America: countries in which the credit cycle is endogenous to the GDP cycle, first quarter 1995 to fourth quarter 2011 
VI.1 Latin America: relationship between per capita GDP growth and investment growth in different periods

VI.2 Latin America: domestic and external investment and saving, 1980-2012

VI.3 Latin America: ratio between growth in output per worker and in employment over different periods

VI.4 Argentina, Brazil, Chile and Mexico: real effective (reciprocal) exchange rate and ratio between wages and value added in tradable sectors, 1993-2007

VII.1 Specialization, wages and growth in the centre-periphery system

VII.2 Impact of industrial and technology policy.....

VII.3 Selected countries: technology intensity of the production structure, 1990-2008

VII.4 Selected countries: relative productivity, 1990-2008 ……................217

VIII.1 Price of industrial commodities.........................................................224

VIII.2 Latin America: annual growth of GDP and aggregate demand, 1990-2004

VIII.3 Currency appreciation before the 2008-2009 crisis ..........................228

VIII.4 Latin America: gross capital formation, 1971-2011 ………................ 229

VIII.5 Selected countries: salmon production, 1990-2002 …...................... 232

IX.1 Total wealth and types of wealth per capita, seven regions, 2005 ...243

IX.2 Latin America and the "West": per capita GDP at purchasing power parity and average years of education of the population aged 15 and above, 1870-1930

IX.3 Latin America and the Caribbean (selected countries): rents captured by the State through taxes on natural resource exploitation, 1970-2010.

IX.4 Uruguay: land rents as a share of agricultural and total GDP, 1908-1966

IX.5 Uruguay: real land price deflated by the consumer price index and estimated rents, 1902-2010

XII.1 Latin America (18 countries): economic activity rate by sex, national total, survey rounds

XII.2 Latin America (simple average of 17 countries): income distribution inequality by income quintile, by sex, urban areas, around 2012

XII.3 Latin America (7 countries): total time spent on paid and unpaid work by sex, by country, latest available data

XII.4 Latin America (18 countries): femininity index of poverty by country and region, around 2002 and 2012

XII.5 Latin America (simple average of 18 countries): ratio between women's and men's average labour income, by years of education, national total, around 2012 
XIII.1 Mexico and selected countries: real per capita GDP as a share of United States per capita GDP, 1980-2012

XIII.2 Mexico: annual growth rate of GDP and trade balance as a percentage of GDP, average for selected periods, 1960-2012..........358

XIV.1 Brazil and Latin America: terms-of-trade index, 2002-2012 ............378

XV.1 Argentina: production, employment and average productivity in manufacturing, 1992-2011

XV.2 Argentina: exports by line of business, 1991-2011 ...........................398

XV.3 Argentina: total imports and their composition by economic use, 1991-2011

XV.4 Argentina and United States: industrial output in selected sectors, by worker, 1993-2007.

XV.5 Argentina: growth in productivity and comparison with the United States, 2000-2010.

XV.6 Argentina: indicators of innovation and learning and linkages in manufacturing sectors, 2005-2007.

XV.7 Argentina and Brazil: differences between the indicators of innovation, learning and complementarities in manufacturing sectors compared with Germany, 2005

XV.8 Argentina: sectors with comparative advantages according to indicators of innovation and learning and linkages, 2005-2007

XV.9 Argentina: sectors with potential comparative advantages according to indicators of innovation and learning and linkages, 2005-2007

\section{Diagrams}

X.1 Institutional changes in favour of growth and inequality reduction after the Second World War.

X.2 Types of capitalism and relationship between efficiency and equality, until the 1970s.....

X.3 The paradigm shift of the 1980s: social inequality as an incentive for growth

X.4 The emergence of market capitalism in a context of financial instability, 1960-1990.

X.5 Finance-led accumulation regime ...................................................228

X.6 How some welfare systems enhance dynamic efficiency ……........ 289

X.7 Complementarity of national inequality regimes and development models

XV.1 Structural change trajectories and policy action ................................410

XV.2 Objectives and strategies of structural change ................................. 411

\section{Boxes}

IV.1 Recessionary and regressive asymmetries

IV.2 Current situation in Latin America 



\section{Foreword}

The two crises that struck in the early years of this century - the global economic and financial crisis (2008-2009) and the eurozone crisis (20092013) - have been the worst since the Great Depression of the 1930s in terms of their intensity, economic and social impacts and duration. These crises and their fallout are further evidence not only of the inability of the vast majority of public and private institutions and academics to foresee crises, identify unsustainable imbalances and warn of risks inherent in the financial sector, but also of the major drawbacks of a single predominant school of thought on economics and development and the resulting macroeconomic and financial policies.

In this context, the mainstream economic thinking that has almost exclusively dominated both academic research and teaching in recent years and international economic policy for more than three decades has attracted criticism, and become a topic of intense debate among economists, academics and policymakers — whether adherents to the mainstream or not—as to its conceptual and empirical soundness and coherence.

In the late 1980s and early 1990s a new school of thought, termed neostructuralism, began to take shape within ECLAC. The failure of what are paradoxically known as structural adjustment policies and the development experiences in Southeast Asia paved the way for the emergence of alternative paradigms. Indeed, even in the 1980s, while the Latin American countries were pursuing structural adjustment programmes amid economic stagnation and the worst debt crisis in their history — a period known as the "lost decade" 
in the region-, the Asian economies achieved unprecedented growth and gained traction in the global economy by relying on low-cost, technologyintensive export goods. This Asian experience was both very important and highly enlightening, as it called into question the policy precepts of the Washington Consensus and their logical continuation, structural adjustment programmes.

Neostructuralism arose not only as an alternative paradigm to the neoliberal adjustment model but also as a way of going beyond the original structuralist paradigm that inspired it. It also represented the adaptation of structuralism to the new reality of openness and globalization. Fundamentally, neostructuralists ${ }^{1}$ and structuralists see the Latin American and Caribbean region's main economic problems not as the result of distortions caused by economic policy or market imperfections, but rather as wholly endogenous and structural issues rooted in the region's history.

Neostructuralism has thus given rise to alternative perspectives grounded basically in the structural changes the economy need to foster development and inclusive economic growth, improve the position of Latin American countries in external trade, encourage productive employment, reduce structural heterogeneity and achieve a fairer distribution of income with balanced finances to underpin these changes in production, backed up by support from society and the State.

State action, within a renewed relationship between the market and society, is at the core of the new strategy proposed by neostructuralists. ECLAC has sought to contribute to this tradition by proposing lines of enquiry and responses in some of its latest position papers, Time for equality: Closing Gaps, Opening Trails (2010), Structural Change for Equality: An integrated approach to development (2012) and Compacts for Equality: Towards a Sustainable Future (2014).

These documents set out a vision of development in which equality is the ethical objective, with structural change the path towards achieving it, and politics and policymaking the instrument. They also stress the importance of forging compacts within a renewed relationship between the State, the market and society. Placing equality at the core means breaking with the economic paradigm that has prevailed in the region for at least three decades, proposing a vision of development that encompasses economic, social and environmental dimensions and contributing to the process of drawing up and implementing a universal and transformative 2030 development agenda.

Luiz Carlos Bresser Pereira, Ricardo Bielschowsky, Fernando Fajnzylber, Ricardo Ffrench-Davis, Roberto Frenkel, Jorge Katz, José Antonio Ocampo, Joseph Ramos, Octavio Rodríguez, Jaime Ros, Osvaldo Sunkel and Lance Taylor, among others. 
Far from being a self-contained set of ideas, (neo)structuralism is an open system that lends itself to dialogue with other schools of economic thought, such as heterodox currents, which include a diverse set of methodologies encompassing evolutionary and institutional economics, the regulation school, Marxists and radicals as well as Post Keynesians. For many years, these currents have fed into the critical analyses of economic thought and policy.

Once again, these approaches help explain the regional effects of the economic and financial crisis that broke out in 2008, the current uncertainty in the industrialized economies - in particular, the European Union countriesglobal paradigm shifts and the need for alternative policies.

Building on these foundations, this book offers a fresh perspective on neostructuralism and heterodox thinking at the start of the twenty-first century. A perspective that draws on the work of some of the foremost experts in the various currents and paves the way for a new generation of researchers and academics to broaden research and enrich development strategies in the region.

The book has five parts: economic thinking and the regional context at the beginning of the twenty-first century, macroeconomics for development, structural change and production development, the role of the State and case studies of major economies of the region.

This publication is the outcome of an ambitious collaborative effort by ECLAC and the International Development Research Centre (IDRC) of Canada on the project "Raúl Prebisch and the challenges of the twenty-first century" over the period 2012-2013. The project gave fresh impetus to the thinking and legacy of Raul Prebisch and other historical figures of Latin American development thought by analysing their application to the current context of global paradigm shifts. A series of research activities were carried out and documented on the project's website, ${ }^{2}$ a portal offering innovative multimedia material which made full use of modern technologies to share this knowledge with new generations. A further aim was to promote and support academic cooperation networks in the region for both teaching and research on major development topics in Latin America and the Caribbean and the long-standing challenges and emerging issues in this regard. ${ }^{3}$

\footnotetext{
See [online] prebisch.cepal.org.

Brazilian Network of Economic Development Education (REDESENV), Union of Universities of Latin America and the Caribbean (ULAU), Association of Universities of the Montevideo Group and Red Prebisch (Prebisch network), among others.
} 
ECLAC aims to provide and facilitate alternative forums for thought and critical thinking in which Latin American academics, economists, politicians and intellectuals can discuss the underpinnings and progress of neostructuralism, heterodox economic currents in Latin America and the Caribbean, and implications for the design, formulation and evaluation of public policies.

One of our most cherished aspirations is to share theoretical and conceptual advances in neostructuralism with new generations of economists and political and social scientists, in the hope that they in turn will enrich Latin American development thinking.

\author{
Alicia Bárcena \\ Executive Secretary \\ Economic Commission for Latin America \\ and the Caribbean (ECLAC)
}




\title{
Introduction
}

\author{
Alicia Bárcena and Antonio Prado ${ }^{1}$
}

The economic thinking that held sway over academic teaching and economic policy for more than five decades has been severely criticized in recent years, and is now at the centre of an intense debate among the economists who support this school of thought, as well as between its advocates and opponents. This intellectual discussion alternates between positions that either defend or question the prevailing paradigm in terms of its conceptual and empirical coherence and validity. This situation was largely brought about by onset of the two largest, longest and most intense crises since the Great Depression: the international economic and financial crisis (2008-2009) and the eurozone crisis (2009-2013). The huge economic and social repercussions of these historically unprecedented events has generated heated discussion over the need to review or reformulate policies to respond to these challenges, taking into account the implications that such actions will have for the prevailing economic model. Yet the socioeconomic vulnerabilities that have resulted from the recent crises have also allowed for rethink of policy tools considering alternative approaches, founded on heterodox schools of economic thought such as the evolutionary, institutional, regulatory and post-Keynesian schools, as well as the approaches that emerged from developmentalism, essentially structuralism and neostructuralism.

In common with most emerging economies, the Latin American and Caribbean region has shown a degree of economic and social resilience in

The authors are grateful to Esteban Pérez Caldentey, Miguel Torres and Romain Zivy for their input and comments. 
dealing with the fallout from the global economic and financial crisis of 2008 and 2009. Despite posting an average overall contraction in 2009, the region recovered quickly amid favourable external conditions and initially returned to robust economic growth, coupled with an improvement in labour markets and the maintenance of social spending levels. Some of the region's countries, particularly raw materials exporters, were even able to implement countercyclical policies and measures, especially on the fiscal front, in order to alleviate the external impacts of the crisis. That they had the capacity to do so reflected a combination of factors: domestically, most countries managed to keep public and private debt on a sound footing, recorded modest rates of inflation in keeping with the international conditions, and -especially in South America - reaped the rewards of the commodity supercycle, in which high prices were largely driven by booming external demand from Asia (especially China) and the increasing financialization of global commodity markets. In terms of social progress, in the period 2002-2013 the region achieved a notable reduction in poverty and, for the first time in its recent history, inequality.

Latin America and the Caribbean now faces new challenges in its future growth and development. Since 2011, the region as a whole has experienced a gradual slowdown in its growth rate, albeit with the usual variances between countries. The favourable external conditions of the 2000s may have come to an end, chiefly owing to the fall in raw material prices and the possibility that these will remain at lower levels, as well as softening external demand, slower growth in visible trade since the mid-2000s, and the gradual reduction of economic recovery measures by the United States authorities. The region's economies also face the risk of deterioration in the conditions of access to financing that they currently enjoy, while investment and export levels are too low to boost growth. Against this backdrop of more modest growth and a slowing business cycle, the macroeconomic policy trade-offs facing the region's countries will be different to those of the previous period and will focus on preventing a sharper downturn in job creation and growth. Potential problems include external constraints, limited investment and the consequences of maintaining a production matrix geared towards primary goods (reprimarization) and of failing to fully leverage the proceeds of the boom to develop more knowledge-intensive sectors. It is also legitimate to question the sustainability of continued poverty and inequality reduction in the absence of a stable and robust long-term economic growth path. The policy trade-offs raised by these questions must be at the heart of the ongoing debate over the currents of thought that may or may not prevail in the immediate future. These economic policy issues, dilemmas and approaches will assume even greater significance if the region's current slowdown corresponds to an underlying trend rather than short-term factors. 
The debate surrounding the impact of the crises, the limitations of traditional policy responses and the current uncertainty in the world economy partly mirrors the limitations of the dominant paradigm and the economic policies by which it seeks to remedy the main shortcomings of free-market economies. In the thinking of John Maynard Keynes and Raúl Prebisch, these shortcomings can be summed up as the inability to ensure full employment and to create decent work as a rule (rather than an exception); the tendency to distribute income and wealth in an uneven and arbitrary manner, and the propensity for financial fragility and instability. ${ }^{2}$

The above-mentioned scholars suggest that these shortcomings are endogenous to the functioning of developed and developing economies alike. To this day, they remain relevant and in need of resolution. In Latin America and the Caribbean, they are associated with the structural dimensions that were highlighted some time ago with the emergence, in the developing world, of a body of thought on economic policy, termed "structuralism". ${ }^{3}$ This school of thought identified a technology lag, external constraints, inequality, structural heterogeneity, instability (real volatility) and the political economy of power-dependence relations in a core-periphery arrangement as some of the structural obstacles to the economic and social development of the region. ${ }^{4}$ Although structuralist thought is a purely Latin American creation, it did not develop in isolation from contemporary critical currents, but rather it absorbed, incorporated and benefited from intellectual exchange with some of the most prominent heterodox economists of the day.

Following a period in which the primacy of the current paradigm and the defence of the Washington Consensus - and its mantra of "stabilize, liberalize and privatize" - relegated structuralism to a less visible position, the tradition was recovered in the form of neostructuralism and revitalized through adaptation to the most recent developments in the region.

Developed from the document produced by the Economic Commission for Latin America and the Caribbean (ECLAC) entitled Changing Production

See J.M. Keynes, The General Theory of Employment, Interest and Money, New York, Harcourt Brace Jovanovitch Publishers, 1936, chap. 24; R. Prebisch, Obras 1919-1949, vol. 4, Buenos Aires, Fundación Raúl Prebisch, pp. 346-361, 301 and 303. More recently, similar opinions were expressed in C. Furtado, En busca de un nuevo modelo: reflexiones sobre la crisis contemporánea, Mexico City, Fondo de Cultura Económica, 2003, and in H. Minsky, Can "It" Happen Again?, New York, M.E. Sharpe, 1982; and Stabilizing an Unstable Economy, New Haven, Yale University Press, 1986

3 This is almost a direct quotation from C. Furtado, Ibid. p. 30.

4 Some of these issues were the focus of the first coordinated analysis of Latin America's development problems. See R. Prebisch, The Economic Development of Latin America and Its Principal Problems [online] http://prebisch.cepal.org/en/works/economic-development-latinamerica-and-its-principal-problems. Although this text refers to Latin America, its analysis is perfectly applicable to the economies of the Caribbean. 
Patterns with Social Equity (1990), ${ }^{5}$ neostructuralism retains its focus on the issues and concerns that constitute the Gordian knot of structuralism, and explores them in greater depth. At the same time, it has expanded the focus and framework of analysis and refined the methodological and empirical approach, with a view to integrating regional and global changes since the late 1980s into structuralist thought. These changes include "open trading arrangements, international capital mobility, privatization and deregulation, against a backdrop of closer relations with the rest of the world and greater regional integration" (Bielschowsky, 2009; see also Sunkel and Zulueta, 1990, and Ffrench-Davis, 1991 and 2006). ${ }^{6}$

The neostructuralist approach included the analysis of fiscal policy, liquidity and the regulation of the balance of payments, including the capital account (Ffrench-Davis, 2000). ${ }^{7}$ Since the 2000s, neostructuralism has focused on four broad thematic areas: macroeconomics and finance, international trade, social development and environmental sustainability. These issues were explored in detail in several of the institutional publications of ECLAC, notably Globalization and development (2002) and Productive development in open economies (2004). ${ }^{8}$ More recently, the subject of equality has acquired central importance for the economic, social and environmental dimensions of sustainable development, as expressed in three ECLAC position papers known as the equality trilogy (Time for Equality: Closing Gaps, Opening Trails (2010), Structural Change for Equality: an Integrated Approach to Development (2012) and Compacts for Equality: Towards a Sustainable Future (2014)) ${ }^{9}$. Neostructuralism as conceived by ECLAC has resulted in a programme that is "heterodox in macroeconomics, development-oriented in terms of resource allocation and State intervention, universalist in the social field and conservationist on the environment" (Bielschowsky, 2009).

\footnotetext{
Fernando Fajnzylber played a key role in conceiving the document Changing Production Patterns with Social Equity, ECLAC Books, No. 25 (LC/G.1601-P), Santiago, 1990. See also F. Fajnzylber, "Industrialization in Latin America: from the "black box" to the "empty box": a comparison of contemporary industrialization patterns", Cuadernos de la CEPAL series, No. 60 (LC/G.1534/ Rev.1-P), Santiago, 1990.

6 R. Bielschowsky, "Sixty years of ECLAC: structuralism and neo-structuralism", CEPAL Review, No. 97 (LC/G.2400-P), Santiago, Economic Commission for Latin America and the Caribbean (ECLAC), 2009; O. Sunkel and G. Zuleta, "Neo-structuralism versus neo-liberalism in the 1990s", CEPAL Review, No. 42, Santiago, 1990, pp. 35-53; R. Ffrench-Davis, "Formación de capital y marco macroeconómico: bases para un enfoque neo estructuralista", El desarrollo desde dentro: un enfoque neoestructuralista para America Latina, O. Sunkel (comp.), 1991, pp. 192-232; R. Ffrench Davis, Reforming Latin America's Economics after Market Fundamentalism, New York, Palgrave Macmillan, 2006.

7 Reforming the Reforms in Latin America: Macroeconomics, Trade, Finance (Ffrench-Davis, 2000) was one of the most comprehensive and detailed contributions to the inclusion of these themes in neo-structuralist thinking.

8 LC/G.2157(SES.29/3), Santiago, 2002 and LC/G.2247(SES.30/4), Santiago, 2004.

9 For an analysis of the evolution, stages and hallmarks of neostructuralism, see R. Bielschowsky, "Sixty years of CEPAL...", op. cit.
} 
In keeping with the traditional structuralist approach, neostructuralism does not regard itself as a self-contained analytical system. Moreover, it examines the behaviour of economic and social agents and structures and the relationships between them in a historical and evolutionary context (they are dynamic and change over time according to context and circumstances). It is therefore an open system of ideas ${ }^{10}$ that lends itself to the establishment of dialogues with other traditions of economic thought, such as the heterodox current ${ }^{11}$ which, like neostructuralism, recognizes the limitations of the dominant paradigm in the present circumstances and opposes its methodological monism.

This book is specifically intended to create spaces for dialogue and collaboration between the neostructuralist and heterodox schools, advancing the idea that intellectual cooperation between the two currents might culminate in the emergence of an alternative political agenda.

The book is based on the presentations and debates that took place during the seminar on neostructuralism and heterodox economics held by ECLAC at its headquarters in April 2013. In the context of a slowly recovering world economy, the seminar's main goal was to promote academic discussion and reflection on economic policies and development, allying the structuralist and neostructuralist traditions with different strands of heterodox economics to examine the challenges currently facing development in Latin America and the Caribbean.

The 15 essays included in this volume are grouped into five parts, by subject area:

1. Currents of thought and the regional context in the early twentyfirst century

2. Macroeconomics for development

3. Structural change and productive development

4. The role of the State

5. Case studies of the region's major economies

Each of these parts (and the respective chapters therein) briefly describes the latest events and analysis in relation to development in Latin America and the Caribbean, in the new context of the post-crisis world and in keeping with the general canons of the structuralist and neostructuralist tradition. An in-depth reading of this work also reveals the similarities between the

10 For a definition of open systems, see V. Chick, "On open systems", Brazilian Journal of Political Economy, vol. 24, No 1, 2004; S.C. Dow, Economic Methodology: an Inquiry, New York, Oxford University Press, 2002; and Lawson, Reorienting Economics, New York, Routledge, 2003.

11 The heterodox current includes a diverse array of approaches, including the Marxist, radical, regulatory, post-Keynesian, institutional and evolutionary schools. 
(neo)structuralist and heterodox traditions; identifies common perspectives and denominators, and suggests potential linkages for future joint research.

The first part comprises three chapters. Chapter I, written by Esteban Pérez Caldentey, introduces the essential core of the book, namely the methodological and conceptual foundations for a debate between the heterodox currents of economic thought and (neo)structuralism. The chapter provides an apposite framework for the different themes and perspectives that are developed and analysed in the subsequent chapters, commencing with a description of the context that led to the current debate surrounding the dominant paradigm and the shortcomings that became apparent during the economic and financial crises of the 2000s. This paradigm is then described and its specific features and hallmarks are identified. One important aspect of the essay is that it analyses how the advocates of the dominant paradigm respond to the criticisms and questions that have been put to them in the course of the debate. It is thus possible to discern, within the orthodox current, economists who adopt a stance resistant to innovation, while others downplay the enormous magnitude of the issues at stake, merely adding new equations to the model before proceeding to resolve the reformulated system. Faced with this incapacity for understanding and dialogue, the author proposes a third feasible alternative based on enhancing the dialogue between structuralist (and neostructuralist) and heterodox thought, seeking spaces in which the two currents may converge. The chapter ends with a summary of the main conclusions.

In chapter II, José Antonio Ocampo's essay, “Latin America and world economic turmoil", gives a broad overview of the global context facing Latin America in the early twenty-first century. Ocampo describes this context as turbulent, with a world economy that has recovered from the 2007-2008 crisis that originated in the United States, but which still faces ups and downs in Europe, a possible end to the commodity price supercycle and the prospect of a slowdown in the emerging economies. Against this backdrop, the author examines the scope for action and the strategy that the region's economies should adopt in order to maintain and accelerate a virtuous cycle of growth and development. The chapter comprises a brief introduction followed by four sections, the first of which describes the global situation between 2003 and 2007, especially the combination of favourable external factors (remittances, strong trade growth, increased prices for raw materials exports, and external financing) that enabled a commodity-driven boom. In the second section, Ocampo analyses changes in international trade and the technology lag that (persistently) weakens Latin America's production structure. The third section deals with external financing, in global and regional terms, and determines positive impacts and adverse side effects, with special reference to the trend for real exchange-rate appreciation and the consequent loss of trade competitiveness. In the final section, entitled 
"Time for a new strategy?", the author answers that question in the affirmative and concludes that the current weakness of trade indicates that export-led growth strategies and the orthodox policies that underpin them have run their course. The counterargument is highly structuralist: the production structure must be transformed and spaces for intraregional integration expanded, overcoming the obstacles that have long prevented and delayed progress towards this goal.

Chapter III is an essay by Luis Gonzaga Belluzzo, which was presented at the twelfth Raúl Prebisch Lecture in April 2012. Belluzzo places the internationalization of capitalism and the current stage of this process in a historical perspective, in an analysis incorporating some highly eclectic approaches and theories ranging from the principles set out by Marx and Engels in The Communist Manifesto, to the completely opposing viewpoints of Hayek and Friedman. The historical development of the internationalization of capitalism, as described by Belluzzo, is also particularly applicable to Latin American experiences and especially that of Brazil.

Part II of the book comprises three chapters on macroeconomics and economic polices. Chapter IV is an essay by Ricardo Ffrench-Davis entitled "Neostructuralism and macroeconomics for development", which seeks to position macroeconomics for development, in other words, a set of macrofunctional policies within a strategy of growth with equity, from a theoretical and descriptive perspective. This set of policies focuses on the need to speed up the convergence between actual and potential GDP and to keep macro prices (especially real exchange rates) consistent with sustainable external balances. Ffrench-Davis also highlights the importance of considering how these macro policies can help reduce the high level of structural heterogeneity that typifies the economies of Latin America and the Caribbean. Reducing structural heterogeneity should be at the heart of macroeconomics for development, since the uneven distribution of sectoral and territorial productivity creates large wage inequalities, which are the primary cause of high, persistent and unacceptable levels of inequality in the income distribution. The author offers a critical analysis of the approach that has predominated in the region since the 1990s (inspired by the Washington Consensus), in the light of its economic and social consequences. He then focuses on certain aspects described as recessionary and regressive asymmetries, three of which are examined in detail: (i) the recessionary gap and capital formation, (ii) exchange-rate instability and productive development, and (iii) the creation of quality jobs and instability in the real economy. Lastly, the author presents the main conclusions.

Chapter V, by Esteban Pérez Caldentey and Daniel Titelman, also looks at the problems facing macroeconomics for development and introduces new considerations in relation to countercyclical policies. The authors propose that 
cycle and trend are interdependent and that consequently, countercyclical policies (in other words, policies related to aggregate demand) are not neutral in respect of an economy's long-term performance. The manner in which countercyclical policies are formulated and applied, including factors such as the time when they are implemented and the type of instrument used, shapes and determines the economy's long-term growth trend. The non-neutrality of countercyclical policies is reflected in three specific characteristics of the business cycle in Latin America and the Caribbean: (i) expansion cycles are shorter and less intense than in other regions; (ii) short-term fluctuations in real and financial variables exert influence over long-term results, and (iii) the financial system tends to amplify the fluctuations of real variables, with recovery in the credit cycle lagging behind that of GDP. This analysis suggests that countercyclical policies should not be limited to managing the cycle through variations in the level of aggregate demand, but should also focus on the composition of aggregate demand. This entails the need to maintain the duration and intensity of expansion and to avoid using public investment as an adjustment lever during cyclical fluctuations. It also implies the use of macroprudential policies as a countercyclical resource in order to manage the level and composition of aggregate demand.

Chapter VI, "Towards a Robinsonian interpretation of capital accumulation in Latin America", was prepared by Juan Alberto Fuentes Knight. As the title suggests, the initial aim of the text is to identify the scope and limitations of Joan Robinson's theory of growth, considering certain stylized features of long-term economic growth in Latin America. This is an important theoretical and empirical endeavour, considering that one of the consequences of the 2008-2009 international financial crisis was a revalidation of Keynesian short-term macroeconomic policies, and in view of the lack of long-term macroeconomic policies deriving from Keynesian and neo-Keynesian approaches, such as the theories advanced by Robinson. To fulfil the chapter's purpose, Fuentes Knight first describes Robinson's theory of growth in great detail, in an analysis underpinned by a simple mathematical model whose equations illustrate the main relationships between the macroeconomic variables involved; he then sets out the most significant economic implications. Next, the author describes how Joan Robinson conceived growth dynamics according to different ages of constant or variable growth: the golden age, the limping golden age, the leaden age, the restrained golden age, the bastard golden age, the galloping platinum age and the creeping platinum age. For each of these growth paths, Fuentes Knight states the relationships between potential and expected investment, between the GDP growth, employment, population and productivity, and between savings, profit, consumption, wages and investment. He then calibrates Robinson's model using long-term data for the region's economies, and identifies an extensive growth path centred on the leaden age: a pattern of 
development characterized by insufficient capital accumulation, which does not permit the generation, assimilation or adaptation of technical progress and therefore entails the stagnation of productivity, employment and overall economic activity. The stylized facts of the region unquestionably matched this trajectory in the period 1980-2013, especially during the 1980s as a result of the recession brought about by the Latin American debt crisis. While the author recognizes exceptions in the form of subperiods characterized by more virtuous growth paths, the important conclusion underlying the analysis - and doubtless the greatest contribution of this chapter-is that the persistent leaden age that characterized Latin American and Caribbean development in the past four decades largely coincides with the diagnosis of structuralist and neostructuralist economists, chiefly those of ECLAC, in documents such as the "Prebisch Manifesto" and Changing Production Patterns with Social Equity (inspired by Fernando Fajnzylber). This diagnosis has been recently updated and developed in the "equality trilogy".

Part III comprises chapters VII to IX and deals with the issues of structural change and productive development. Chapter VII by Mario Cimoli and Gabriel Porcile summarizes the structuralist, evolutionary and Keynesian visions of the relationship between technology, structural change and economic growth, and seeks to demonstrate the theoretical convergence of these visions. To this end, the authors provide an overview of a static theoretical model that summarizes patterns of productive specialization, wages and economic growth in a centre-periphery system. The results support the evidence and knowledge obtained previously in relation to the region's persistent structural gap, which is due to a lack of production diversification, the slow spread of technological advances and the widening of internal and external productivity gaps, with the inevitable consequences of low productivity, slow GDP growth, wage inequality and, therefore, a regressive income distribution.

In chapter XIII, Jorge Katz addresses the macro- and microeconomic dimensions of natural-resource-based growth and analyses the make-up of the development pattern followed by most of the region's economies in the past decade. Katz reflects on the macro- and microeconomic impacts of refocusing the region on comparative advantages based on natural resources, lower value added activities and the production chains involved in resource extraction. He also attempts to determine how this pattern of specialization affects the production structure, natural resources endowment, and environmental and ecological sustainability.

Chapter IX by Luis Bértola focuses on the relationship between development patterns and welfare States and explores the scope of this relationship in Latin American economies. First, the characteristics of economic development, in the modern sense of the term, are identified and 
then linked and applied to natural-resource-intensive economies. Next, the author examines the interdependence between different regions, emphasizing the importance of international heterogeneities and their implications for development, before studying the relationship between economic growth and welfare. The main conclusion suggests that it is not feasible to devise welfare States independently of production structures. Bértola therefore recommends that this symbiotic relationship be taken into consideration when proposing the construction of a welfare State in the region.

The fourth part of the book consists in chapters X to XII. In the first of these, entitled "Growth, employment and equality: the new role of the State", Robert Boyer discusses the responsibility of the State in a new global context marked by the evident and increasingly frequent failures of market mechanisms (which the author describes as collapses), to guarantee and manage the three main attributes of development: growth, employment and equality. The author begins by reviewing the way in which developed countries reduced inequalities in a scenario of fast, stable economic growth, as was the case in the 1950s, 1960s and 1970s. He then goes on to describe the collapse of this "golden age of capitalism" and the transition towards market-dominated regimes; he also gives an account of their successive crises, covering the 1980s, 1990s, 2000s and early 2010s. In the chapter's third section, Boyer lays the foundations for what he calls a new paradigm in respect of the State and economic policy. This section aims to demythologize several of the premises of the dominant paradigm, which were generally indisputable before the crisis of 2007 and 2008. The author suggests that the belief in the efficiency and self-regulation of the financial markets has been a failure, which in turn demands and legitimizes State intervention in the economic sphere. He then questions the neutrality of monetary policy, while highlighting the role of fiscal policy as a valuable instrument for boosting effective demand during recessions. Similarly, the author reviews and questions certain other aspects of the paradigm, such as competition policy and bailouts for productive and financial sectors, the adverse impacts of exchange-rate volatility and the fallacy (i.e. failure) of the trickle-down effect of economic growth. The analysis then centres on the relationship between welfare and growth, and presents considerations in respect of the role of globalization. The chapter concludes with a summary.

In chapter XI, René Hernández examines the transformation of the State and proposes some of the models available to Latin America. The text outlines the main concepts in the debate concerning the nexus between the State and economic development, and presents some of the literature produced by ECLAC in this field. The author also sheds light on the main development models that have been advanced in the region, and analyses the validity of Prebisch's ideas and their contribution to the current regional debate. Some comments and reflections are set out at the end of the essay. 
Chapter XII was written by Sonia Montaño and examines the links between the State, heterodoxy and the contributions of feminist thought to the theory and praxis of development. The author ultimately seeks to demonstrate the extent to which feminist thinking enriches the quality of politics and economics, and addresses three themes in this regard: critical thought in questioning certain dogmas regarding the State and the market; criticism of the assumptions underlying public policies, and the implications of heterodox thinking for the role of the State.

Part V is formed of three chapters and looks at the region's largest economies, focusing on specific development issues in the areas that were examined, at a more general level, in the preceeding chapters. In chapter XIII, entitled "Development and macroeconomics: reflections from the Mexican case", Juan Carlos Moreno-Brid seeks to identify core elements of Mexico's economic structure that should be taken into account when formulating macroeconomic policies for development. Adopting a neostructuralist perspective, MorenoBrid places special emphasis on productive heterogeneity as a determinant of the pattern of economic growth. The author also critically examines the conventional macroeconomic policies that were applied, in various forms, following the international financial crisis of 2008 and 2009. By way of illustration, Moreno-Brid takes as a reference point the macroeconomic policy applied in Mexico in the last 30 years and its relationship with the performance of the Mexican economy. The author claims that Mexico's scant progress in growth and development during this period, in a context of policies fundamentally geared to preserving nominal stability (low inflation and a small fiscal deficit) and of reduced State involvement in the economic sphere, with everything that this implies for the orientation of macroeconomic (fiscal, monetary and exchange-rate), trade and production policies, lays the necessary foundation for reflecting on the basics of a macroeconomic policy for development.

In chapter XIV, Francisco Eduardo Pires de Souza and João Carlos Ferraz analyse Brazil's development between 2002 and 2012. The authors begin with an overview of that country's economic situation and show how it was affected by the external boom of the 2000s. Next, they outline the characteristics of the model implemented over the past decade, which they describe as one of "inclusive growth". They identify the strengths and weaknesses of this approach and briefly discuss how the windfall gains resulting from the international context were put to use. The chapter continues with a section that looks at some ongoing shifts in the economic management of President Dilma Rousseff's government which, it is argued, might signal the emergence of a new model designed to improve the inclusive growth approach. The authors then describe some of the challenges that must be addressed in order to consolidate this new model. Lastly, they present their main conclusions and examine briefly whether the implications of the Brazilian model may be extrapolated to other Latin American and Caribbean economies. 
In chapter XV, Fernando Porta analyses the dynamics of structural change and different industrial policy approaches in Argentina. The author sets out his arguments along three lines of analysis. The first gives a brief description of Argentina's economic performance since the change in the macroeconomic regime in 2002, with an emphasis on developments in the industrial sector; the second looks at Argentina's production dynamics from a neostructuralist perspective, and the third sets out a conceptual and methodological proposal for the formulation of an industrial policy within the framework of an inclusive development strategy. 


\section{Part I}

Schools of economic thought and the regional context in the early twenty-first century 

Chapter I

\section{A time to reflect on opportunities for debate and dialogue between (neo)structuralism and heterodox schools of thought}

Esteban Pérez Caldentey ${ }^{1}$

\section{Introduction}

In keeping with some of the most recent thinking on the subject, this study establishes that the global financial crisis of 2007-2009 has dealt a blow to the methods used to manage the macroeconomy under the so-called "new consensus" (Blanchard, Dell'Ariccia and Mauro, 2013, p. 3). It also argues that this claim can easily be applied to the period of the Great Moderation (1980-2006) and extended to the whole of mainstream economics, of which the new consensus is merely the latest expression.

Almost a decade on from the outbreak of the 2007 crisis in the United States subprime mortgage market and of the resulting debates about the economic mainstream, the outlines of an alternative approach have yet to take shape. The answer to scrutiny1 of mainstream economic positions ranges from doing nothing to tweaking the system, usually in the financial sector, without altering the substance of the theoretical framework concerned.

The author is grateful for valuable comments and suggestions received from Ramon Pineda, Antonio Prado, Miguel Torres and Romain Zivy. 
Nonetheless, insofar as the current juncture represents a break in the practice of normal science (in the sense of Kuhn, 1996), it is a good time to begin rethinking the content of economic theory and the orientation of the resultant economic policies. A step forward in this direction is to join forces and open up spaces for dialogue and debate between schools of thought that are outside the mainstream and indeed have developed in outright opposition to it.

In the case of Latin America and the Caribbean, there is no need to start from scratch or reinvent the wheel in order to make a start on this. The region has a long tradition of economic theory linked to structuralism and neostructuralism. Indeed, as Celso Furtado (2003, p. 30) pointed out, this body of theoretical economic thinking is the only one to have arisen in the developing world.

Far from being a set of self-contained ideas, structuralism or neostructuralism is an open system that lends itself to dialogue with other traditions of thought in economics, such as heterodox schools. The latter include a heterogeneous set of approaches encompassing evolutionists and institutionalists, the regulation school, Marxists and radicals, and post-Keynesians.

The structuralist or neostructuralist and heterodox schools of thought broadly identify three basic failings in the workings of market economies: (a) their inability to ensure full employment and create decent jobs as standard, (b) their tendency to generate an arbitrary and unequal distribution of incomes and wealth, and (c) their propensity to financial fragility and instability. ${ }^{2}$ Similar concerns arise in the sphere of economic research and policy, meanwhile: the emphasis on reality-based theorizing, the conception of the individual as a social and institutional animal, the autonomy of institutions, the perception that individuals are under major constraints when it comes to obtaining and processing information, the centrality of production (rather than trade) and of the economic structure, and the importance of the State (government) in regulating the functioning of markets.

There are seven thematic areas of convergence between neostructuralism and heterodox thinking: (i) the methodological approach, (ii) the characterization of the system of international economic relations and the related issues, including the external constraint, (iii) the relationship between income distribution and accumulation and growth and development, (iv) volatility and instability, (v) technical progress and innovation, (vi) the relationship between the short and long terms, and (vii) the role of the State.

This chapter starts by laying out the context that gave rise to the current debate on mainstream economics and its limitations, as revealed by the

See J.M. Keynes (1936, chap. 24) and Prebisch (1993, vol. 4, pp. 301, 303 and 346-361). More recently, a similar opinion has also appeared in Furtado (2003) and Minsky (1982 and 1986). 
economic and financial crises of the 2000s. This paradigm is then described, identifying its specificities and fundamental traits. Next, it is argued that mainstream economists have responded to the debate and the criticisms against them in essentially two ways: change nothing or simply add some extra ingredients and stir. Given this difficult situation, this chapter puts forward the possibility of a third alternative based on dialogue between structuralist (neostructuralist) and heterodox thinking, and to this end the viewpoints common to both schools are detailed.

\section{A. Economists and the Great Moderation}

There is no doubt that the global financial crisis (2007-2009) and the eurozone crisis (2009-2013) were the most potent in their effects and duration since the Great Depression of 1930. Between them, they have given rise to an intensive debate about the conceptual and empirical validity of the dominant economic paradigm.

With few exceptions, economists were unable to sense or foresee that the economic policies applied in the decade prior to the crisis in the United States and the eurozone would set up imbalances that were unsustainable for these economies, and for the world economy in general. Still less were they able to predict either event or hazard at their intensity and duration. In 2007, the Organization for Economic Cooperation and Development (OECD) stated that its predictions pointed to strong job creation and falling unemployment. Similarly, in the same year, the International Monetary Fund (IMF, 2007) affirmed that the global expansion was proceeding unchecked, leading it to raise its prediction for global economic growth and warn of the dangers of overheating and inflation. At the start of the recession, many economists simply dismissed the possibility that it might be long-lasting (see, among others, Posen, 2007a and 2007b; Rogoff, 2008).

This limited, or rather non-existent, ability to detect factors of imbalance that could translate into a serve and lasting recession was due to the prevailing optimistic outlook about the economic state of the advanced economies (including the United States and eurozone), and of the world generally, prior to the crisis. Perhaps one of the most emblematic statements about the subject came from IMF, which claimed in 2006, a year before the outbreak of the global financial crisis, that the economic state of the world had never been better. Many economists, furthermore, dismissed suggestions that supposed global imbalances, financial liberalization and deregulation or growing private-sector indebtedness in developed countries might be a source of concern, risk or fragility (Bernanke, 2005; Mussa, 2006; Hausmann and Sturzenegger, 2006; Posen, 2007a; Greenspan, 2005). 
In the run-up to these crises, economists and politicians around the world feted the prevailing calm, or, more precisely, the Great Moderation in the most advanced economies. The term "Great Moderation" was coined to capture a period lasting over two decades (1980-2006) that was characterized by increasing stability in prices and GDP levels (Bernanke, 2005 and 2004).

The Great Moderation was not seen as being confined to the most developed countries, but as extending, albeit later, to the developing world. From the 1990s onward, the developing world also experienced less real volatility and less volatile inflation (Coric, 2011; De Gregorio, 2007). ${ }^{3}$ As a region, Latin America and the Caribbean saw real volatility ease in the 2000s. ${ }^{4}$

The developing world not only saw lower volatility, but achieved high rates of growth by historical standards. In the period of strongest growth prior to the crisis (2002-2008), emerging and developing economies as a group expanded by an average of 4 to 5 percentage points more than developed economies, the largest ever growth gap between the two. This growth difference, in turn, made it possible to refloat the idea of convergence between living standards in the developing world and in the more industrialized economies.

For several developing regions, strong growth in that pre-crisis period (the strongest in three decades in the case of Latin America and the Caribbean) was accompanied by an external situation that was unusually comfortable by the standards of their economic history. ${ }^{5}$ A number of regions in the developing world grew very vigorously while running a balance-of-payments current account surplus and keeping inflation and public borrowing under control. This eased the problem of external constraint, which has been one of the main obstacles for raising growth, even in our region.

Lastly, a third factor inducing a sense of optimism in the case of Latin America and the Caribbean was the improvement in social conditions (essentially poverty reduction and an incipient decline in inequality), the

Going by a sample of 98 countries around the world, both developed and developing, Coric (2011) observes that real volatility fell across the board in most cases from the 1980s onward. Using a sample of 180 countries around the world, Pérez Caldentey and Vernengo show that in over $80 \%$ of cases, inflation volatility began to fall in the mid-1990s.

4 Nonetheless, country-by-country analysis indicates that real volatility in Latin America began to fall in the 1990s in some cases.

5 In the most recent period of expansion before the crisis (2003-2007), Latin America and the Caribbean registered a growth rate of $3.7 \%$, a very large rise on the contraction seen in the $1980 \mathrm{~s}$ $(-0.8 \%)$ and more than double the low rate of the 1990s. Indeed, economic performance in 20032007 was somewhat higher than that of the 1970s. This depiction of a cycle of growth with a well-cushioned external sector applies to regional averages and the region's larger economies, as the same did not occur in the smaller economies, including those of the Caribbean and Central America. For the region as a whole, the 2003-2007 cycle was one with very particular characteristics. Taking a regionwide view, Latin America and the Caribbean had not had a cycle of expansion with a current account surplus for over three decades. 
consolidation of democracy and a period characterized, with few exceptions, by the absence of armed conflict. ${ }^{6}$

The Great Moderation in the developed and developing world was quickly hailed as the result of improved macroeconomic management and the ability of the monetary and fiscal authorities to cope with the entire economic cycle. ${ }^{7}$ In the case of Latin America and the Caribbean, the Great Moderation was interpreted as a successful outcome of the application of the Washington Consensus policies, to a greater or lesser degree, with their mantra of "stabilize, liberalize and privatize".

By virtue of the Washington Consensus rationale, it was argued that the region's fundamentals improved in the 1990s and 2000s because standard economic prescriptions were being properly implemented, and that this boosted growth and made the co more resilient to adverse external shocks (IDB, 2008; IMF, 2008; Corbo and Schmidt-Hebbel, 2013; Porzecanski, 2009). Obviously, not all policies followed the dictates of the market as the only way of allocating resources, and indeed new social policies were adopted, with social spending in the region increasing from 15\% to 19\% of GDP between 2000-2001 and 2013-2011 (Cornia and Martorano, 2010).

The complacency with which economists regarded the state of the world economy in the run-up to the crisis, their inability to give warning of the national and international imbalances that triggered it, their lack of predictive power and their failure to understand the nature and effects of the crisis have exposed mainstream economics to major criticisms, from both within and without. These criticisms have included challenges to its conceptual and empirical validity.

At this point, and before looking in greater detail at these criticisms of mainstream economics and the counter-responses, it is necessary to establish what is meant by the "dominant paradigm". This is done in the following section, from the perspective of the new consensus.

\section{B. The economics of the mainstream: its theoretical underpinnings and economic policy implications}

The set of suppositions and ideas that have traditionally dominated economic theory and policy in the past six decades, so-called mainstream economics, was developed on the basis of long-term analysis. This was conceived as an

The number of non-indigent poor in the region dropped from 225 million to 167 million between 2002 and 2011, or from $44 \%$ to $29 \%$ of the population (see ECLAC, 2013).

7 Some economists, such as Lucas (2002), claimed that the macroeconomy had solved its central problem: preventing slumps and crises.

8 Ocampo (2008 and 2011) and Pérez Caldentey and Vernengo (2010) are exceptions. 
analytical category and reference framework for conducting a coherent abstract characterization of the workings of free market economies, which, despite lacking direct coordination mechanisms, display a systematic regularity (Arrow-Debreu, 1954; Hahn, 1984; Friedman, 1975).9

Long-term analysis generally consists of specifying equilibrium positions which reflect this systematic regularity, being the result of all the types of transactions that can be carried out under a regime of free competition. For practical purposes, these equilibrium positions have been characterized at different times in terms of the natural price or long-run normal price (Smith, 1776; Marshall, 1920), the natural rate of interest (Wicksell, 1898; Mankiw, 2010), potential GDP or the natural unemployment rate (Friedman, 1968; Gali, 2008; Wren-Lewis, 2014).

The essential distinguishing feature of mainstream economics relative to other schools of thought is that the long run, and thus the systematic regularity of free market economies, is established on the basis of an analytical structure that includes three independent categories of data: endowments and their distribution, preferences and utility functions, and technology. ${ }^{10}$ Thus framed, the theory can be used to determine quantities of goods and services (and output) and prices (relative prices and prices levels) simultaneously. In other words, the theory determining quantities and output is also used to determine relative prices and the price level (i.e. the theory of value is the same as the theory of output determination) (Eatwell, 1983 and 1987; Garegnani, 1990). This gives mainstream economics a consistency and unity with few precedents in the history of economic thought.

Long-term equilibrium positions, in turn, have a positive aspect and a normative one. The positive aspect is the description of how the market mechanism sets prices and allocates resources.

The normative aspect involves evaluation of how efficiently the market carries out the functions of price-setting and allocation of goods and services, when it is treated as part of a set of possible resource allocation mechanisms. The normative aspect is summarized in the idea of the Pareto (1906) optimum. This requires that no resources are wasted in resource allocation, insofar as there is no way of reallocating resources that is satisfactory for all (Debreu, 1959).

Competitive equilibrium relates to the Pareto optimum through two theorems: (i) any competitive equilibrium is a Pareto optimum, and (ii) any Pareto optimum can be represented as the final outcome of the mechanism of

\footnotetext{
9 Mainstream economics includes Keynesians of the neoclassical synthesis schools, monetarists, the new classical macroeconomics, the new Keynesians and the Austrian school.

10 Preferences obviously need to be independent of endowments, and endowments need to be able to be expressed independently of prices and distribution and be appropriated to the production technique that best minimizes costs.
} 
market trading through an income redistribution system. The second theorem allows the possibility of outside intervention, whether by a government or a socially planner, to be considered from the outset in the determination of a competitive market equilibrium. Taken together, in fact, the two theorems imply that criticisms of market workings come down to issues of equity, and not of efficiency (unless there are market failures). ${ }^{11}$ Equity issues, furthermore, can be resolved through an initial redistribution of resources. ${ }^{12}$

This long-term vision became the hard core and genuine consensus of mainstream thinking, and was analysed both statically and dynamically, although dynamic analysis through economic growth theory became consolidated as the instrument of long-term analysis par excellence (Acemoglu, 2009). Growth theory is based around the idea of the steady state (a situation in which all the variables considered are growing at the same rate) and its properties, and analysis of convergence on this state (Solow, 2000, p. 4). A steady state situation, including price-setting for the factors of production and income level, is the outcome of factor endowment and the technical production conditions operating in a given competition regime. Issues such as the production structure, structural change and income distribution are rather tangential or secondary in this approach. ${ }^{13}$

The debates that have taken place within the mainstream have rarely or never impinged on its long-term theoretical underpinnings but have rather centred on the short term. ${ }^{14}$

11 Market failures are intrinsic to the workings of the market and prevent an efficient allocation of resources from being attained. They arise in four main cases: public goods and externalities, increasing returns to scale, natural monopolies and information asymmetries.

12 According to the logic of the theory, however, intervention to redistribute resources and endowments occurs before economic begins. Redistribution of resources does not distort the workings of the market, as all agents have to deal with the same set of prices and the same marginal opportunity costs.

13 A preoccupation with structural change is an important part of economic development theories and the literature on the subject generally, as is attested to in part 2 on structural transformation and chapter 7 on patterns of structural change in Chenery and Srinivasan (1988). Conversely, it has no place in the neoclassical growth model; economic activities are, in fact, structurally similar and can be aggregated into a representative sector. Endogenous growth theories, although centred on variables such as productivity and human capital, do not usually take account of shifts in the composition of output and employment. Murphy, Shleifer and Vishny (1989), Hansen and Prescott (2002) and perhaps Lucas (2004) are an exception to this. The seminal contributions to growth theory in mainstream economics include Solow (1956 and 1957), Lucas (1988), Romer (1986 and 1990), Grossman and Helpman (1991) and Aghion and Howitt (1992). See the treatment of structural change in Ishikawa (1987) for development theories and in Matsuyama (2008) for the growth approaches of mainstream economics.

14 The best-known debates include the one between monetarists and Keynesians on the parameters of IS-LM functions, the consumption function and the velocity of money circulation (Friedman, 1975; Tobin, 1975), the debates on stabilization policies (Modigliani, 1977), the debates on the supply curve or Phillips curve (Friedman, 1968; Lucas, 1972b; Sargent and Wallace, 1976) and the debates on price rigidity. The most recent debates have focused on monetary policy and on the possibility of conducting monetary policy in an economy without money (Woodford, 2003). The most important debate on the long run is the capital theory controversy (Harcourt, 1991; Cohen and Harcourt, 2003; Eatwell and Milgate, 1999). 
The short run is specified only with reference to the long run and, paraphrasing Samuelson (1947, pp. 36-39), in terms of "auxiliary constraints" that modify the basic equilibrium principle (Le Châtelier's principle), according to which a move away from equilibrium in a given direction necessarily entails a convergent movement in the opposite direction. In the literature, short-term positions came to be identified with the existence of a menu of market imperfections ${ }^{15}$ From this viewpoint, imperfections superimposed on long-run equilibrium positions could explain the occurrence of economic fluctuations and the cycle, the suboptimal use of production factors, including unemployment, and output and inflation. Thus, for example, the cycle can only be seen as a consequence of mismatch between aggregate supply and demand (Wren-Lewis, 2014).

The existence of imperfections has a further advantage, however, as they allow a rationale to be established for outside intervention in markets in the short-run and, more precisely, for the use of fiscal policies, and monetary policy in particular. Indeed, the ability to control price level and fluctuations by altering the interest rate stems from the existence of monetary frictions (Woodford, 2003; Gali, 2008).

The relationship between the long and short run has never been straightforward. It is, rather, a distant relationship, as is attested to by the treatment of the two in most economics textbooks as two separate categories of analysis having their own methods and approaches and being little interrelated. This relationship has also given rise to inconsistencies in the foundations of the mainstream paradigm itself and has given rise to conflict on occasion, as is reflected by the debate on microfoundations and the perennial emergence of dichotomies within the mainstream. ${ }^{16}$

Eventually, rationalizing the workings of the short term with reference to rational behaviour, and in particular the principle of maximization subject to constraints, created the bridge needed to unify the short and long run within a single theory. The mainstream came to illustrate the adage of Samuelson's Foundations of Economic Analysis (1947), according to which the existence of analogies between central features of various theories implies the existence of a general theory (i.e. maximization subject to constraints) which underlies the particular theories and unifies them with respect to those central features.

15 Market imperfections are not the same as market failures. While market failures (see footnote 13) are inseparable from the workings of the market, market imperfections impose themselves on a competitive equilibrium. The imperfections best known in the literature are price rigidity (for wages or interest rates), institutional barriers preventing the market from allocating resources efficiently in the short run and the lack of an appropriate response from agents to price incentives (Eatwell, 1987, p. 727).

16 See Weintraub (1979) on microfoundations, Patinkin (1956 and 1987) on the invalid dichotomy between the real and monetary sectors and Akerlof (2006) on five neutralities in mainstream economics. 
Thus, the same logic, the same conceptual apparatus and, most particularly, the same principle that had been applied to a wide range of subjects, including not just economic subjects as such but also environmental and social ones (such as education, social protection, and gender and family) could be extended to cover short-run specificity and its relationship with the long run. ${ }^{17}$ As Allais (1966, p. 1156) put it, human societies in different settings, under capitalist or communist regimes, now or half a century ago, obey the same law: the maximization of utility. That author, who was awarded the Nobel prize in economics in 1988, also stated that similarity of behaviour should be interpreted as reflecting the invariance of human psychology in time and in space, at least collectively speaking.

This effort to devise a single theory, based on the application of utility maximization to the whole spectrum of economic theory, did not substantially change either the conceptual underpinnings of the long run and economic growth or the associated policies. Nor did it alter the main thrust of microeconomic policies. However, it did provide a way of settling, almost for good, some of the most important debates relating to the short run and, more precisely, about the role of aggregate demand and the effectiveness of its main instruments.

This consensus unifying the long and short run in a single theory (also known as the "new consensus" or "new neoclassical synthesis") is built around three ideas: ${ }^{18}$ (i) the existence of "natural" levels for output and the interest rate to characterize long-term positions (Gali, 2008, p. 186), (ii) the introduction of rigidities and imperfections microfounded on rational expectations; and (iii) short-term analysis (cycle and aggregate demand) as a matter of deviation between actual variables and their natural levels (WrenLewis, 2014). ${ }^{19}$ The main implications of this approach in economic policy terms have to do with the primacy of monetary policy via management

17 See Friedman (1962), Coddington (1976), Becker (1978 and 1981) and Lucas (1986 and 1991) for an application of this conceptual framework to different aspects of human behaviour and economic activity. The logic underlying these studies was applied to education, health and pension issues in Latin America and the Caribbean in the 1980s and 1990s. The treatise on the family by Becker (1981) is highly illustrative of this approach, as it argues, among other things, that rational people marry even when they are sure of finding a better prospect by searching further, when the cost of the further search exceeds the benefits expected from a better prospect, and that the application of comparative advantages implies men specializing in the market sector and women in the household sector. As a result, the wage rate will be higher for men than for women. Similarly, applying this framework to the environment leads to the conclusion that the intertemporal rate of non-renewable natural resource exploitation should be left to the market unless it can be shown that there is a market failure and a corrective policy can be applied (Solow, 1974; Davidson, 1979).

18 See Blanchard (2008), Woodford (2009) and Gali (2008) for an exposition of the new consensus.

19 The new consensus is identified with the new Keynesians. The presence of rigidities allies them with the neoclassical synthesis, but with the advantages of having microfounded and grounded them in agents' rational behaviour. In this they resemble the new classical macroeconomics. As they themselves recognize, the new Keynesians have much in common with the monetarists and could very well be called "the new monetarists". See Mankiw and Romer (1991). 
of the interest rate to administer the cycle and the primacy of aggregate demand generally, as well as the subordination of fiscal policy to monetary policy ends. ${ }^{20}$ This framework also has two properties that are essential to its acceptance because they justify its validity in economic and social terms: (a) the countercyclical character of monetary policy and (b) the idea that stabilizing inflation around its target is equivalent to stabilizing real output around its natural level or equivalence between nominal and real stability (the "divine coincidence") (Blanchard, 2006; Blanchard and Gali, 2005; Pérez Caldentey and Vernengo, 2013).

Alongside the development of a new consensus in economics, a consensus also formed on finance, whose basic principles are no different from those of the new consensus. ${ }^{21}$ The consensus on finance can be encapsulated in four components: the efficient market hypothesis, the relationship between risk and return, the Modigliani-Miller theorem and the Black-Scholes-Merton approach. The most important component is the efficient market hypothesis because it is the basis on which the other theorems rest.

In its strongest form, the efficient market hypothesis excludes the possibility of trading systems that are based only on currently available information, such as securities markets, yielding expected profits or returns in excess of the equilibrium profit or return (Fama, 1970, p. 384). The relationship between risk and return is assumed to be positive, such that an investor wishing to gain a higher rate of return must be prepared to take on a higher level of risk. The Modigliani-Miller theorem states that, under certain assumptions (complete, perfect markets without government), the way a firm finances its production activities does not affect the cost of capital or have any influence whatsoever on its market value or on the production and consumption decisions of other economic agents. According to the BlackScholes-Merton approach, anything can serve as an asset, every asset has a price and can be traded, and any risk can be diversified. This paved the way for a spiral of financial innovation aimed at creating a utopia of complete markets and zero transaction costs.

Taken together, these theorems are wholly compatible and complementary, and establish a common logic and consistency for finance in mainstream economics, which can be spelled out as follows.

20 As Blinder (1986) put it, the current conventional wisdom maintains that discretionary changes in fiscal policy do little good and may even do harm. Why is this so? First, lags are long, perhaps longer than a typical recession. Second, the effects of the most plausible fiscal policy instrument, changes in income taxes (or transfer payments) may be weakened by temporary use. Third, there is a better stabilization instrument immediately available: monetary policy.

21 As Fama (2007) puts it, equilibrium models cannot be tested without market efficiency, as the great majority of market equilibrium models set out from the supposition that markets are efficient. They start with a strong version of this hypothesis whereby everyone has the relevant information. Market efficiency tests are market equilibrium tests and vice versa, and the two are indissolubly linked. 
Any asset can be traded (this applies both to ordinary assets and to more sophisticated ones such as options and derivatives). Consequently, every asset has a price and a rate of return in an efficient market (Black-ScholesMerton theorem and efficient market hypothesis). In asset markets there are no opportunities for arbitrage and prices must be equal to the discounted present value of future revenues over the lifetime of the asset (efficient market hypothesis, relationship between risk and return, Modigliani-Miller, Black-Scholes-Merton). The best predictor of future revenue flows are current revenue flows and the discount rate is the risk-free rate (efficient market hypothesis, relationship between risk and return, Modigliani-Miller, BlackScholes-Merton). This is because an asset's riskiness is independent of the way it is financed (Modigliani-Miller), being determined by systematic risk (relationship between risk and return). In addition, any asset can become less risky and have a risk-free interest rate (Black-Scholes-Merton).

Just as the new economic consensus ruled out the use of fiscal policy to manage the cycle, leaving it up to monetary policy to administer aggregate demand, the consensus on finance excluded finance from the sphere of government action. Ultimately, it created the basis (more precisely, the "scientific basis") for market forces to control national, regional and global finance.

\section{Criticisms of the mainstream economic paradigm and responses to them}

Although criticisms have rained down on different aspects of mainstream economics, most have centred on the inconsistency between economic models, their economic policy prescriptions and the realities of the workings of market economies, particularly in light of changes in the financial system over the past three decades. ${ }^{22}$ More particularly, there has been criticism of the excessive importance afforded to mathematical technique, formalization and elegance to the detriment of realism and the applicability of models to real-world conditions. ${ }^{23}$

The counterreponses to these criticisms were not slow in coming, and are of two kinds. One group of economists came out in defence of the

22 Economists have flagged some major deficiencies in the theory, such as the failure to incorporate the banking and financial sector into analyses (Woodford, 2010; Clarida, 2010; Mishkin 2010; Blanchard, Dell'Ariccia and Mauro, 2013), the excessive weight of formalization and modelling in economic analysis, the lack of heterogeneity (Caballero, 2010), financial market efficiency (Bean and others, 2010) and undue use of quantitative techniques (Juselius, 2009).

23 This is actually an old dispute brought back to the fore by the global financial crisis (Hahn, 1984). Interestingly enough, Friedman (1953b and 1975) made a similar criticism of Oscar Lange's neoWalrasian approach and also of the approach to the economy of the scholars who developed the neoclassical synthesis. 
mainstream approach and asserted that its more formal aspects needed to be strengthened (Sargent, 2010; Lucas, 2009 and 2012; Cochrane, 2011; Fama, 2011; Taylor, 2004). Eugene Fama (2011), a recent winner of the Nobel Prize in Economics, claimed that the global financial crisis did not contradict the efficiency hypothesis for financial markets, but was a perfect illustration of its basic principles. For Fama, as for Taylor, the global and financial crisis was a product of government regulation and the financial sector was merely a "victim" of that regulation. As the efficient market hypothesis predicts, the crisis generated greater volatility in financial markets simply because news and opinions about the future changed so quickly, and agents incorporated these changes into their projections (Fama, 2011).

This group of economists have defended the mainstream paradigm by arguing that the outbreak of the crisis and its effects demonstrated the need for more thorough formalization and use of mathematical instruments to characterize the workings of market economies.

Thus, for example, another winner of the Nobel Prize in Economics, Sargent (2010), argues that the more dynamic, uncertain and ambiguous the economic context to be modelled is, the greater the need for people to roll up their sleeves and learn and use some mathematics. Similarly, Cochrane (2011) argues that the problem is a lack of mathematics. In economics, mathematics keeps the logic straight and makes sure that the "then" really does follow the "if" - which it often does not in prose alone. The challenge is how hard it is to write down explicit artificial economies with these ingredients, actually solve them, in order to see what makes them tick.

This position has been taken most forcefully in the developing world, including Latin America and the Caribbean, where the effects of the crisis have been less intense and lasting than in the developed world. Comparatively, not only have the effects been more benign than in other episodes of crisis, but the recovery has been much faster (Didier, Hevia and Schmukler, 2012; Corbo and Schmidt-Hebbel, 2013; Alvarez and De Gregorio, 2013).

Mainstream economists in the region argue that the economic fundamentals improved substantially because mainstream policies were successfully applied. The improvement in fundamentals derived, firstly, from changes in the macroeconomic regime and, more precisely, from the conduct of fiscal, monetary and exchange-rate policy.

On the fiscal front, the adoption of orthodox policies reduced public debt, saved windfall revenues from rising raw material prices and allowed the use of countercyclical policies in the 2008-2009 recession. Second, the move from fixed exchange-rate regimes to more flexible ones warded off recurrent foreign-exchange crises, cushioned adverse external shocks and supported the use of independent monetary policies. A third element in 
this policy array is central bank independence, which in turn secures the independence of monetary policy and prevents government interference and the subordination of monetary policy to fiscal policy. All this helped to substantially reduce inflation in Latin America and improve the credibility and reputation of its monetary authorities.

A second element explaining the performance of Latin America and the Caribbean is the expansion of the financial sector in terms of the depth and diversity of its services. Besides macroeconomic stability, this is explained by liberalization, deregulation and privatization of the commercial banking sector and the financial system. Capital market reform is also sometimes included as a determinant, as it is held to have spurred the development of markets for private debt and for securities, together with reform of insurance markets and pensions funds (Henry, 2007, p. 60).

Lastly, the explanation adds increased participation in international trade and finance to the two preceding factors. Greater trade openness brought down tariff and non-tariff barriers, which drove trade growth. Financial openness, meanwhile, allowed external assets and liabilities to build up, contributing to more efficient resource allocation and better guarantees against idiosyncratic national shocks, and thence to higher growth and less volatile incomes and output (Henry, 2007, p. 62). ${ }^{24}$

In contraposition to this "change nothing" position, other economists have spoken of the need to modify economic theory, and macroeconomic theory in particular. The most frequently expressed view is that the design of the economic models of the new consensus goes in the right direction, but they have kept the financial sector in the shadows and should incorporate it explicitly (see Krugman, 2009; Acemoglu, 2009; Lux and Westerhoff, 2009; Akerloff and Schiller, 2009; and Romer, 2013 for the developed world, and Calvo, 2010; Mendoza, 2010; and De Gregorio, 2009 for the developing world and Latin America and the Caribbean). ${ }^{25}$ Thus, IMF has spoken of the need to reconsider some of the principles of conventional macroeconomics and stated that the 2008-2009 global and financial crisis shook the consensus on how to run macroeconomic policy, reminded us of the dangers associated with financial sector imbalances, showed the limitations of monetary policy

24 See Henry (2007) for a detailed analysis of the way that, according to the neoclassical growth model, financial liberalization translates into a rise in North-South financial flows, permanently increasing living standards in the South. The intertemporal balance-of-payments approach presents similar reasoning (Obstfeld and Rogoff, 1996). Jara, Moreno and Tovar (2008) also emphasize the positive aspects of the accumulation of external assets and the progress made in developing domestic debt markets.

25 See also Calvo (2012). According to Calvo, the defining characteristic of macroeconomics in the twenty-first century is that the financial sector can be a source of major macroeconomic shocks. This was the hallmark of macroeconomics at the start of the twentieth century. For more information, see Bernanke, Gertler and Gilchrist (1999) and Borio (2012) have taken some steps to introduce factors of this type. 
and cast doubt over some of the tenets of its intellectual foundations, and led to a reevaluation of the levels of public debt that could be considered safe. This prompted a reconsideration of what worked and what did not, and to a debate about how to fix things, ranging from nitty-gritty technical points to broad-based institutional design questions. Five years from the beginning of the crisis, the contours of a new macroeconomic policy consensus remain unclear (Blanchard, Dell'Ariccia, and Mauro, 2013, p. 3).

Nonetheless, the steps that have been taken in this direction do not alter the substance either of the new consensus or of mainstream economics. The aim is again to incorporate some type of imperfection to be able to generate positions and a short-run dynamic that ultimately tends to converge on or adapt to the long run, characterized by the real forces of the system. In short, the aim is to modify mainstream economics so that nothing has to change. ${ }^{26}$

A genuine effort to alter the new consensus must involve not only reformulating the determination of the short and long run and the relationship between them, but also changing microeconomics and rethinking the approach of economic theory in general. As has been argued, modern macroeconomics is grounded in microeconomics, and both are built upon the same principle. Ultimately, the defects being attributed to macroeconomics in consequence of the recent crises and their effects actually reveal the weakness of the microeconomic foundations of mainstream economics. ${ }^{27}$

\section{The structuralist view of economics and the heterodoxy}

This study sets out from the premise that the diagnosis of the need to "rethink the economy", both from the perspective of greater balance between traditional, alternative and innovative schools of thought and with respect to methods of teaching these, is correct. In fact, in the history of the social sciences, and the economy in particular, new theories tend to arise when "settled" or "normal" science comes up against events and anomalies within its own precepts that it is unable to explain or resolve (Kuhn,1996). ${ }^{28} \mathrm{At}$

${ }^{26}$ In some cases, this comes down to the introduction of financial frictions in the aggregate demand curve (Woodford, 2010). A more extensive effort is that of Borio, Disyatat and Juselius (2013), who try to introduce financial factors into the measurement of potential output (a supply concept), but their approach rather seems to come down to introducing these factors into the output gap.

27 Calvo (2012) alludes to this by admitting that microeconomics might have feet of clay.

28 According to Kuhn, the development of science in "normal" periods is guided by adherence to a paradigm. The function of a paradigm is to throw up problems and puzzles and provide tools for resolving them. A crisis occurs when the dominant paradigm is unable to resolve an anomaly. In our opinion, this is a good description of the evolution of the mainstream in economic theory, and its response to the recent crises (Boumans and Davis, 2010). See Lakatos (1970) for a more sophisticated version of the concept of normal science. 
present, mainstream economics is in just such a predicament: the validity and coherence of this approach is rooted essentially in its predictive capacity (Friedman, 1953a and 1953b; Allais, 1966; Lucas, 1988, 2002 and 2012). A window of opportunity thus opens for seeking out alternative propositions and sketching out new principles for the theory and practice of economic policy. A step in this direction is to focus efforts on opening up spaces for debate and dialogue between schools of thought that have developed outside of and in opposition to the mainstream.

There is no need to reinvent the wheel to embark on this task in the particular case of Latin America and the Caribbean. The elements of a sound alternative approach already exist, as this is one of the few regions of the developing world that has a long tradition of home-grown economic thinking about its problems and challenges. If, as Ocampo (2011) has pointed out, Latin America and the Caribbean has perhaps the longest-established and most extensive system of institutions of any developing region, this is partly the outcome of long-standing national and regional thought.

There can be no doubt that the most comprehensive economic thinking to have arisen in the region is that associated with the group of structuralist economists who, working out of the Economic Commission for Latin America and the Caribbean (ECLAC) and the Higher Institute of Brazilian Studies (ISEB) between 1940 and 1965, laid the groundwork for and worked on different aspects of development economics. These economists are Celso Furtado (1920-2004), William Arthur Lewis (1915-1991), Raúl Prebisch (1901-1986), Juan Noyola Vásquez (1922-1962), Aníbal Pinto Santa Cruz (1919-1996), Osvaldo Sunkel (1929) and Ignacio Rangel (1914-1994). ${ }^{29}$

Structuralist thought focused on the following subjects, which, with differing emphasis, constituted its essential pillars: relationships of power and dependency organized into the centre-periphery duality, criticism of the law of comparative advantages and the predominance of the external constraint, the dual character of economic development at different levels (as revealed in phenomena such as structural heterogeneity), the existence

29 Among the economists who worked at ISEB are Helio Juaguaribe, Guerreiro Ramos, Candido Mendes de Almeida, Alvaro Vieira Pinto, Roland Corbisier and Nelson Werneck Sodre. The terms "structuralist" and "structuralism" appeared in the early 1960s in the context of the debate with the monetary school about inflation, and they originally had a verbal connotation equating the monetarist and structuralist schools from a terminological point of view (Campos, 1961; Danby, 2005). However, it is possible to argue, as Mallorquín (1998, p. 40) does, that the basic outlines of structuralism were already in place in the 1950s, in Furtado's 1954 study A economia brasileira and in the 1956 article by Noyola. The term "structuralist" is obviously an analytical category and not all the authors mentioned called themselves structuralists. In relation to this, Prebisch remarked when he began writing Capitalismo periférico in 1970: "I don't know if I am to be called a structuralist after this exposition. I refuse to classify myself and be classified. But I admit that a thorough structural review of capitalism is needed." (Prebisch, 1976, quoted in Mallorquin, 1998, p. 36). See Vera (2013) for a recent analytical discussion of inflation in line with structuralist thinking. 
of an unlimited supply of work (which affects income distribution), a view of development as structural change, the need for State-guided development in respect of investment in infrastructure and production development, inflation as an economic development problem, and the need for integration into the regional and international economy to overcome the problem of underdevelopment. ${ }^{30}$

The thinking of this group of economists benefited from intellectual exchanges with other economists from outside the region, whose analysis focused on economic development from similar viewpoints and positions. The main economists from outside the region who worked in Latin America and the Caribbean included Albert Hirschman (1915-2012), Gunnar Myrdal (1898-1987), Ragnar Nurske (1907-1959), Hans Singer (1910-2006), Paul RosensteinRodan (1902-1985) and Hollis B. Chenery (1918-1994). ${ }^{31}$ Because of the similarity of the two groups' positions on key subjects such as international trade, industrialization and inflation, and a common methodological approach centred on empirical observation, they are collectively also commonly classified under the umbrella of structuralism.

Structuralist ideas were also developed on the basis of the thinking of economists belonging to the Keynesian, post-Keynesian and Schumpeterian traditions. Particular mention should be made of the influence on the Latin American structuralist school of John Maynard Keynes (1883-1946), Roy Harrod (1900-1978), Nicholas Kaldor (1908-1986), Michael Kalecki (1899-1970) and Joseph Aloys Schumpeter (1883-1950). ${ }^{32}$

Kaldor was closest to Latin America and the Caribbean, structuralism and ECLAC, and covered a wide spectrum of subjects, including issues affecting developing countries and Latin America. At the request of Prebisch, in 1956

30 On one occasion, Furtado argued that the Latin American structuralist school explained the specificity of underdevelopment by turning the parameters of conventional analysis into variables. As will be seen over the course of this article, the structuralist school not only replaces the parameters of conventional analysis with variables but includes variables that traditional analysis does not consider and offers a novel approach to combining and establishing relationships between variables and to identifying their determinants.

31 This classification follows Pereira (2012b, p. 348).

32 Love (1996, p. 155) referred to the influence of Kalecki, Kaldor and Chenery in structuralist inflation theory. He began by saying that Kalecki impressed Noyola. Kalecki, Kaldor and Chenery wrote before Sunkel, and the two latter spent some time in Santiago while structuralist theory was being developed. They cannot be said to have brought structuralism to Latin America, but there can be little doubt that they provided a large intellectual stimulus for its formulation. They were the link between the structuralist thinking that had arisen in Great Britain (and in a lesser degree the United States) and Latin American structuralist inflation theory. For his part, Noyola (1956) cites Kalecki (1969) and Aujac (1954). It was Sunkel (1958) who most aptly articulated the structuralist approach to inflation that provided the basis for the debates of the 1960s by distinguishing between the forces causing inflation (basic factors) and circumstantial and propagation mechanisms. This methodology is characteristic of the structuralist approach; it is not confined to the analysis of inflation, and is very similar to the way Prebisch analysed the origin and propagation of cycles. 
Kaldor worked as an ECLAC consultant and prepared the study Economic Problems of Chile, which mainly analysed the problem of income inequality and advocated a structuralist interpretation of inflation. ${ }^{33}$

In the most recent advances of structuralist thought, such as neostructuralism (1992-2012), work has continued on the subjects and concerns that are the Gordian knot of structuralism, while their framework and object of analysis have been broadened and their methodological and empirical approach refined.

Neostructuralism developed from the document Changing Production Patterns with Social Equity. The Prime Task of Latin American and Caribbean Development in the 1990s (ECLAC, 1990) and the book compiled by Osvaldo Sunkel, Development from Within: Toward a Neostructuralist Approach for Latin America (1993). ${ }^{34}$ The development of this theory has involved an effort to integrate into structuralist thought the changes that occurred in the region and internationally from the late 1980s, including trade opening, international capital mobility, privatization and deregulation in a context of closer relations with the rest of the world and greater regional integration (Bielschowsky, 2009; Sunkel and Zulueta, 1990). ${ }^{35}$

The analysis of the neostructuralist approach incorporated considerations relating to fiscal matters, liquidity and balance-of-payments regulation, including capital account regulation (Ffrench-Davis, 1993). ${ }^{36}$ From the 2000s, neostructuralism began to be organized around four main areas: macroeconomics and finance, international trade, social development and environmental sustainability.

33 Kaldor was impressed by the structuralist analyses of inflation carried out at ECLAC, which would be given final expression in the analyses of Noyola and Sunkel (Harrod, 1965; King, 2009, p. 116). During his first visit to the region, in the talks he gave at the University of Chile and in Brazil, Kaldor developed a number of concepts that would dominate his thinking (such as cumulative causation, technical progress, industrial concentration and the limits to industrial growth) and that are fundamental to the conceptualization of structural change. Kaldor often returned to Latin America, and particularly to Mexico, where he addressed the problems of development financing and an exchange-rate strategy for promoting economic development.

34 Fernando Fajnzylber played a central role in the conception of Changing production patterns with social equity (Fajnzylber, 1990). Among the authors who contributed to the book compiled by Sunkel, particular mention should be made of Ricardo Ffrench-Davis, Joseph Ramos and Victor E. Tokman.

35 Structuralist thought lost visibility in the 1980s with the debt crisis and during part of the 1990s because of the supremacy of the Washington Consensus. Structuralist thinking responded weakly to the debt crisis, whose intensity and duration were due more to financial factors than to the clumsiness or incompetence of policymakers (Diaz Alejandro, 1984) or a mismanaged and inefficient State-centred development model. Indeed, the debt crisis was the first modern financial crisis experienced by Latin America, and it occurred because of a lack of global financial regulation.

36 Reforming the Reforms in Latin America: Macroeconomics, Trade, Finance (Ffrench-Davis, 2006) is one of the fullest and most thorough studies on the incorporation of these subjects into neostructuralist thought. 
These issues were dealt with in depth in a number of ECLAC institutional publications, most particularly Globalization and Development (2002) and Productive Development in Open Economies (2004). More recently, equality issues have been treated as a core aspect of economic and social development in publications such as Time for equality: Closing Gaps, Opening Trails (2010), Structural Change for Equality: An Integrated Approach to Development (2012a) and Compacts for Equality: Towards a Sustainable Future (2014). ${ }^{37}$ ECLAC neostructuralism has given rise to a programme that is heterodox in macroeconomics, development-oriented in terms of resource allocation and State intervention, universalist in the social field and conservationist on the environment (Bielschowsky, 2009).

The neostructuralist approach bears a remarkable resemblance to the new developmentalism, which is also characterized by its emphasis on incorporating Keynesian ideas more profoundly into some of the basic structuralist positions. ${ }^{38}$ This means treating demand as an essential determinant of economic growth. In this view, as argued by Keynes and Kaldor (at least in the latter part of his life), the greatest obstacle to growth and full employment lies in demand-related factors.

In keeping with the traditional structuralist approach, the various types of neostructuralism can be characterized as an open system or set of ideas. Open systems are not considered to be self-contained, but analyse the behaviour of agents and economic and social structures, and the relationship between them, in a historical and evolutionary context (they are dynamic and change over time with context and circumstances).

This means that in open systems knowledge is not complete, either of all the relevant variables or of their possible interrelationships. ${ }^{39}$ The classification into exogenous and endogenous variables is also a shifting one. A variable may be exogenous in a particular context and endogenous in another. Furthermore, the relationships among agents and between agents and economic and social structures are interdependent and shift over time. ${ }^{40}$ Accordingly, open systems are not deterministic but offer the possibility of

37 See Bielschowsky (2009) for an analysis of the evolution of neostructuralism, with its stages and distinctive features.

38 As Pereira (2012a) has put it, structuralist macroeconomics for development sets out from the assumption that the main bottleneck to growth and full employment is on the demand side. The supply side is obviously essential. Nonetheless, the countries are working to resolve those problems. The main problem for economic development lies in the lack of profitable investment opportunities because of a lack of external and domestic demand, and thence a low rate of investment and saving. See also Pereira (2012b).

39 This being so, an open system resembles a complex system. Conversely, a closed system is a complete and essentially unalterable system (of ideas, doctrines, things, etc.), one that is selfcontained, unalterable and unaffected by outside forces. See Chick (2004).

40 See Chick (2004), Dow (2002) and Lawson (1997 and 2003). An illustrative example of an open analysis is the concept of fiscal sociology presented by Schumpeter (1954). 
generating different types of solutions to the different problems economies may face in their historical and dynamic evolution.

Because (neo)structuralism is an open system, it can enter into dialogue with other traditions of economic thinking, such as the heterodox tradition, which encompasses a heterogeneous array of approaches, including the Marxist and radical schools, the regulation school, the post-Keynesians, the institutionalists and the evolutionists. This chapter makes reference to the regulation school, the post-Keynesians, the institutionalists and the evolutionists. The features common to heterodox thinking include an emphasis on reality-based theorizing, a conception of the individual as a social and institutional animal, the autonomy of institutions, the perception that individuals face major constraints on their ability to obtain and process information, the centrality of production (as opposed to trade) and of the economic structure, and the importance of the State in regulating the workings of markets.

More specifically, there are seven thematic areas in which neostructuralism and heterodox thinking converge: (i) the methodological approach, (ii) the characterization of the system of international economic relations and related issues, including the origin and propagation of cycles, long-term growth issues and the external constraint, (iii) the relationship between income distribution, accumulation, and growth and development, (iv) volatility and stability, (v) technical progress and innovation, (vi) the relationship between the short and the long run, and (vii) the role of the State/government.

\section{E. The methodological approach of neostructuralism and heterodox thought}

Structuralist theory was developed not on the basis of hypotheses about general and universal behaviour, or of predetermined axioms, as mainstream economics was, but from the analysis and study of reality, more specifically the reality of Latin America. To paraphrase Love (1995, p. 395), structuralism was a practice before it was a policy and a policy before it was a theory. Prebisch (1984) said that the economic policy he proposed aimed to confer theoretical justification upon the industrialization policy already being followed (particularly in the large countries of Latin America, such as Brazil), ${ }_{11}$ to encourage other countries to follow suit and to provide all of them with an orderly strategy for implementing it. Even more explicitly, Mallorquín stated in 1998 that although ECLAC scholars had begun writing in the late 1940s and early 1950s, industrialization had begun long before. Accordingly, ECLAC was not to be credited with influencing industrialization, but rather

${ }^{41}$ The remark about Brazil is by the author of this article and is based on Furtado (2003). 
the opposite. The theorizing came later. Furtado, for his part, after arriving at ECLAC for the first time in 1948 and familiarizing himself with the Manifesto, realized that there was a need for free-standing theoretical work that took the situation in Latin America as a starting point (Furtado, 2003, p. 101). ${ }^{42}$

Reality-based theorizing is also one of the distinctive characteristics of heterodox approaches, and one that distinguishes them from mainstream economics. Just as Keynes (1936, p. 3) criticizes classical theory, heterodox approaches maintain that the characteristics of the type of economies considered by mainstream theory differ from those of our society, which means that they are disastrous if applied to real events (Keynes, op. cit). For this school, reality-based theorizing means that history, institutions, production and market structures and distributive relationships across the whole production and social spectrum play a central role in determining the behaviour and performance of economies. ${ }^{43}$

Constructing the analysis on the basis of reality understood as a historical context means recognizing that reality is neither static nor immutable, but rather shifts over time and, even more importantly, is transmutable. This is no trivial observation, insofar as many economic analyses, particularly mainstream economics, treat reality as immutable. ${ }^{44}$ Under the structuralist approach, an illustrative case is the identification of basic pressures and propagation mechanisms in the analysis of both cycles and inflation (Sunkel, 1958), which, far from being constant and forming a homogenous material, change over time.

Similarly, in Pereira's new developmentalism some of the tendencies in Latin American development identified by the structuralists no longer operate, so that the analysis needs to incorporate new stylized facts reflecting the current situation. Accordingly, on the basis of the empirical evidence available for a period of almost 150 years (1865-2009), Erten and Ocampo (2012) show the existence of four raw material price supercycles lasting from 30 to 40 years (1894-1932, 1932-1971, 1971-1999 and 2000 to the present).

The mutability and transmutability of reality entails a notion of time different to the one traditionally applied in the economic sciences. Generally speaking, most models are atemporal or consider time only from a logical

42 Furtado (1987) adds that research into the reasons for underdevelopment makes sense only in a historical context, which calls for a different theoretic approach.

43 See Taylor (2004) and Davidson (2011).

44 An illustrative example is the rational expectations hypothesis, which makes the expectations of economic agents equal to objective probability. As Muth (1961) points out in his foundational article on the subject, the hypothesis can be paraphrased more precisely as follows: expectations (or, more generally, the distribution of subjective probability) will tend to be distributed, for the same set of information, around what theory predicts (or the objective probability distribution), since expectations — as informed predictions about future events - are essentially the same as the predictions of the relevant economic theory. Some authors argue that this is tantamount to assuming that all agents are homogeneous. 
perspective; i.e. they operate in a logical time context. This implies that the past, present and future are determined simultaneously; equilibrium is a mechanical concept and equilibrium positions are characterized by the use of the steady state. ${ }^{45}$

Heterodox economists place the notion of historical time in contraposition to this concept (Robinson, 1979; Lavoie, 2006). Historical time means that events occur in a one-directional sequence (it is only possible to go forwards). In other words, time is irreversible and it is almost impossible or very costly to reverse agents' decisions. Furthermore, decisions are often crucial (they permanently alter the environment in which they were taken, so that this environment will never again exist) (Shackle, 1955).

The notion of historical time that prevails in post-Keynesian thinking is also at the heart of Schumpeter's thought and in the process of destructive creation. By definition, this is based on the fact that the action of businesses destroys the very context in which an innovation was made. As the author argued, the impetus from new consumption goods, new methods of production and transport and new forms of industrial organization incessantly revolutionize the economic structure from within, destroying the old structure and creating a new one (Schumpeter, 1997, p. 83). In the world of financial globalization, a similar logic applies to financial innovation.

Structuralist economists have always been preoccupied with the notion of time as an essential factor to be taken into account and as a hallmark of their analyses. The introduction of time into economic theory was one of the main concerns and challenges faced by Prebisch before he came to head up ECLAC. This lead him to develop a theory of the economic dynamic for the periphery (and for the interrelationship between centre and periphery), opposing this to the static analysis that ensures optimum exploitation of the factors of production and the distribution of income between production factors in accordance with their respective marginal productivity. Any shock to the equilibrium of the economic system tends to take it to a new position. If this does not actually happen, it is because outside factors intervene. ${ }^{46}$ This theory, which incorporates time as an essential factor, encompasses

45 In the Arrow-Debreu model, the one of most significance to mainstream economics and which forms the basis of all economic modelling, the introduction of time is intrinsically related to issues of certainty and uncertainty. In the basic model, all transactions take place at a single point in time. Agents (consumers and producers) have perfect knowledge of the future (their role as consumers is to pick a consumption plan made for the whole future) and future markets are complete. Uncertainty is introduced via the idea of contingent goods, i.e. goods whose delivery as part of the trade is conditional on events occurring (e.g. delivery of wheat that is conditional on good or bad weather).

46 Prebisch developed his theory of the economic dynamic between 1945 and 1949. It is reproduced in Prebisch (1993, pp. 410-489). See footnotes 121 and 141 in volume III of Prebisch (1991) and page 2 of volume IV of Prebisch (1993). 
all the phenomena in the economy —not just employment and production phenomena, but distribution phenomena too. ${ }^{47}$

In addition, the notion of time that comes out of structuralist and neostructuralist studies equates to historical time. Referring to development theory, Furtado argued this operates on two levels: first, abstract formulations of the current growth mechanism, based on models with stable relationships, and then the application of this to real historical situations (1954, p. 211 and 1964, p. 1). The role of historical research lies in acknowledging the irreversibility of the historical economic process, which makes it impossible to eliminate the time factor and the structural differences of economies at the different stages of development (Boianavosky, 2008a, p. 7). ${ }^{48}$

Acknowledging time as historical implies, for one thing, that development processes are not linear through time. They are not a succession of stages characterized by common, homogeneous elements and similar policies, as was once conceived, or as is still conceived when development is equated with linear increases in per capita GDP over a given threshold. Furtado (2003, p. 94) spoke of underdevelopment not as a stage necessarily passed through by economies that have now achieved a higher level of development, but as a certain configuration of the economic structure deriving from the way technical progress spreads internationally (Furtado, 1999, p. 79). ${ }^{49}$

Similarly, ECLAC has argued that development and its different stages cannot be measured or evaluated by a per capita GDP indicator, reflecting the linear conception of development. The idea, rather, should be to seek a broader configuration of indicators, such as structural gaps (ECLAC, 2010 and 2012b).

According to this approach, there is no clear pre-established order whereby certain countries have the smallest or largest gaps across all the indicators considered. The relative size and importance of each gap differ from one country to another and reflect different bottlenecks and needs. This being so, the relevance of the different gaps is different in each country, with some being highly relevant for one country and less so for another, and vice versa.

For another thing, the idea of "historical time" implies that economic policy decisions, whether to undertake or refrain from an action in a given situation, have consequences that are difficult to reverse. Economic policy does not come down to "doing and undoing"

Prebisch (1950).

48 Later, Furtado (2003, p. 88) continued to uphold this position by arguing that efforts to ascertain the causes of backwardness only become relevant if historically conceived, which requires another theoretical and critical approach, as Minsky (1986, pp. 4-5) and Davidson (2011) have done, criticizing traditional economic theory for lack of realism.

49 This obviously means that development is not synonymous with reproducing the profile and economic habits of the industrialized countries (the consumption profile, for example). 


\section{F. The external context: centre-periphery and dynamics}

The methodological approach based on observation of a shifting reality and of a conception of historical time led the structuralists to recognize that development took place within "a [particular] system of international relations". ${ }^{50}$ For the purposes of analysis, this system of international relationships was characterized by the dichotomy between centre and periphery, which captured the specificity of developing countries relative to more developed ones and showed the qualitative differences between their structures.

The centre-periphery dichotomy arose out of Prebisch's work to characterize the interdependence of economic evolution between countries, its peculiarities and, more specifically, the way business cycles in Latin America were coupled with those of developing countries. Prebisch, like Marx and Schumpeter, thought that capitalism was essentially a dynamic form of economic organization, and one that endogenously generated mechanisms for its future development as it evolved over time. At the same time, though, capitalism does not operate in a single country, but in a shared fashion around the world, so that coupling necessarily became a rule of the economic evolution of countries, including those of Latin America. In his own words (Prebisch, 1993, vol. 4, p. 224):

"I believe that the cyclic movement is universal, that there is only a single movement which spreads from country to country [...] It is not one cycle in the United States [the centre] and a different cycle in each of the countries on the periphery. It is all a single movement divided into very different phases, but with markedly different characteristics, depending on whether it is a question of the cyclic centre or the periphery. For this reason, although the process is a single one, its manifestations differ depending on where we are situated."

The categories of centre and periphery, far from being static, are an evolving concept that changes along with the world economy. From the mid-nineteenth century to the early twentieth, the centre par excellence was Great Britain, after which it passed to the United States. Furtado coined the expression "shift in the dynamic centre" to describe the expansion and diversification of Brazil's domestic market in the 1930s, which enabled it to pursue a strategy for domestic-market-driven growth and thus counteract the impact of the Great Depression. Growth in Brazil did not drop below its historical average during the decade of the Great Depression (Furtado, 1999, pp. 69-73). By this same logic, China too is currently acting as a cyclic centre, since the country is a source for some of the fluctuations in raw material prices

50 The phrase is Prebisch's, but the text in square brackets is the author's. 
and the terms of trade that have played a primary role in the dynamism of the economies of Latin America over the last decade.

The most recent characterization by neostructuralist authors of the interrelationships between Latin America and the rest of the world in concepts such as balance-of-payments dominance and the role attributed to financial flows or the terms of trade in the region's performance, and the external constraint propounded by neostructuralists and heterodox economists, are implicitly or explicitly framed by the centre-periphery concept as conceived by Prebisch.

Balance-of-payments predominance refers to a macroeconomic regime whereby the short-term dynamic is determined by external shocks, whether positive or negative. The idea of balance-of-payments predominance recognizes the influence of international trade on the dynamic of this balance through terms-of-trade shocks, as happened in Latin America and the Caribbean in the 2003-2008 period. Nonetheless, it ascribes a central role to the capital account and external financing in determining economic fluctuations in developing countries. Consistently with Prebisch's idea that cycles in the periphery are tied to external conditions, Ocampo argues that the dominant characteristics of recent decades in Latin America the predominant factor in recent decades has been the steep fluctuations in private expenditure and balance sheets associated with these cycles (Ocampo, 2011, p. 13) Similarly, Ffrench-Davis attributes the marked volatility of aggregate demand in Latin America in the 1990s and 2000s to external factors (ECLAC, 2010, p. 58). He also notes that while aggregate demand fluctuations in the past were often due to fiscal deficits financed through money creation, generally speaking, it may be stated that more recent variations have been due to external shocks, which have impacted especially the financial account and the terms of trade (ECLAC, 2010, p. 61).

Heterodox thinking also treats the external sector as a source of stimulus for aggregate demand and cycles. Going by Kalecki (1969, pp. 45-58), the cycle theory of Minsky (1982, pp. 36-44; and 1986, pp. 150-151), in an economy with no government that was closed to the rest of the world, investment decisions by the non-financial corporate sector would determine expected aggregate profits. ${ }^{51}$ Expected profits, in turn, determine firms' self-financing capacity and debt structure. Expected profits, debt structure and lender's and borrower's risk then determine the volume of investment made. ${ }^{52}$ In the case of an open economy, apart from investment, the external

51 Minsky (1982, p. 40) argues that profits are the cash flow validating or invalidating any corporate debt structure. The expected level and stability of profits determine the debt structure that businesses, bankers and the ultimate holders of assets in the economy will accept.

52 Two types of risk affect the volume of investment. The first is enterprises' or lender's risk, which arises from doubts about the likelihood of the expected returns actually being achieved. If someone is risking their own money, this is the only risk that counts. However, given the 
sector (and specifically the current account balance) is another of the determinants of profits, and thus too of firms' investment and employment decisions, as well as their debt structure. Minsky (1982, p. 43) remarks that in the case of a small economy with a small government sector, which is a very good description of some countries of Latin America, any sudden increase in the current account deficit or reduction in the surplus will lead to a deterioration in profits and, possibly, in the financial structure as well.

\section{G. The external context: the centre and periphery and the external constraint}

The centre-periphery dichotomy serves as an analytical basis not only for examining the origins, drivers and mechanisms behind the spread of cycles, but also for characterizing longer-term growth and its determinants. Here, one of the most important efforts, in both the heterodox tradition and the structuralist and neostructuralist one, has been the attempt to tie longerterm growth to the external constraint.

In heterodox thinking, the most significant contribution has undoubtedly been the balance-of-payments-constrained growth model (Thirlwall, 1979; McCombie and Thirlwall, 1994), based on a dynamic version of Roy Harrod's foreign trade multiplier. In structuralism, the relationship between growth and the external constraint was originally analysed by Prebisch (1991) in the form of the coefficient of expansion (around 1935), which is analogous to Harrod's multiplier. ${ }^{53}$ The constraints imposed by the external sector on the region's growth and development are a central plank of the ECLAC Manifesto (1950) and of the ideas that stemmed from it and shaped the thinking of ECLAC and neostructuralism. One of the most significant manifestations of the importance attributed to the external sector by structuralism and

existence of a system for applying for and granting loans, there is a second type of relevant risk that might be called "borrower's risk". This may be the result of moral hazard, voluntary noncompliance or some other way out of complying with the obligations accepted, or the possible inadequacy of the margin of security, i.e. involuntary non-compliance owing to expectations not being met (Keynes, 1936, p. 144; Minsky, 1975, p. 106). Borrower's risk is subjective and never appears in contracts. It reflects uncertainty and "animal spirits". The lender's risk is objective and appears in financial contracts in a number of ways: higher interest rates, shorter maturities, collateral requirements, restrictions on dividends, etc. (Minsky, 1975, pp. 109- 110; Minsky, 1986, pp. 190-193). Minsky (1975, p. 114) argued that a way of looking at investment had been constructed whereby the "popular estimation" of borrower's risk and lender's risk, admittedly influenced by the past performance of the economy, acts as an immediate determinant of the dynamic of investment, and thence the economy.

53 Prebisch (1991, vol. 3, pp. 249-298, 301-310, 335-342 and 349-370). The coefficient of expansion measures the strength with which an increase in income caused by higher exports or higher financial flows leads to greater expansion of domestic economic activity. Prebisch's analysis of the foreign trade multiplier is static, an explanation of the switch from one equilibrium position to another. 
by ECLAC was the concept of the "external bottleneck" deriving from the constraints on the industrialization process. ${ }^{54}$

Consistently with their methodological approach of the structuralist school, the importance of the external constraint was something that was observed in practice before it came to form part of their conceptual baggage. Martínez argues that ECLAC thinking about the external constraint was in large part developed directly from the Mexican experience. ${ }^{55}$

The notion of growth under external constraint places the organization of international economic relations via the centre-periphery dynamic at the heart of the analysis, albeit implicitly. The economic performance of developing countries (i.e. the countries of the periphery) is largely determined by the international financial architecture. The current financial and monetary system is anchored in the United States dollar as the reserve currency, and countries which do not issue the international reserve currency (such as the countries of the periphery, including those in Latin America and the Caribbean), need to acquire and have access to this currency that they cannot issue (for example through an international reserves accumulation policy) in order to be able to import (and develop) and conduct international financial transactions.

Consequently, the domestic policy of the periphery countries is in large part permanently delimited and restricted by external conditions. It is in this sense that the growth efforts of these economies are confronted with an external constraint. More specifically, countries face an external constraint when their performance (current and expected) in external markets and the response of the financial markets to this (current and expected) performance delimit and restrict their scope for conducting domestic policies, including fiscal, exchange-rate and monetary policy. ${ }^{56}$

54 Constraints originally arose because of the growing need to import capital goods and intermediate goods in excess of exports' capacity for generating foreign exchange. At ECLAC, this problem came to be known as the "external bottleneck". Growing import requirements should be offset by a greater volume of financial flows. Although the structuralist approach always conceived of development as a process of structural change, it always showed concern as well about the imbalances this process could entail, and one of the basic imbalances it identified was the external imbalance.

55 He made this claim in an interview organized by Carlos Mallorquin in 1997 (Mallorquin, 1998, p. 147). ECLAC (1957) analysed the problem of the external imbalance for the case of Mexico.

56 This definition is based on McCombie and Thirlwall (1999, p. 49), according to whom countries face an external constraint when their performance in foreign markets and the response of the financial markets to this performance restrict growth to a rate lower than external conditions require. This definition assumes that countries grow at a rate lower than the one compatible with full employment. Consequently, the organization of the global economic system, including its financial architecture, has a restrictive bias and prevents countries subject to external constraints from realizing their growth potential. Keynes made a similar criticism of the international monetary system prior to Bretton Woods (and his "clearing union" consisted precisely in replacing the contractionary bias with an expansionary character (Keynes, 1980, vol. 25, p. 74: "This transfer would substitute an expansionist, in place of a contractionist, pressure 
The external constraint implies that an economy (especially on the periphery) is unlikely to be able to maintain a current account deficit for a long period, except in the case of countries that usually receive substantial amounts of foreign direct investment or official assistance flows (McCombie and Thirlwall, 1999). In the long run, countries have to keep their current account (CA) or basic balance (the current account (CA) plus long-term financial flows $(\mathrm{FF})$ ) in equilibrium. In other words:

$$
\text { (1) } C A-F F=0 \Leftrightarrow P_{d} X+F=P_{f} M E+\mathrm{OCN}
$$

Where, $C A=$ current account; $X$ and $M=$ volume of exports and imports; $E=$ nominal exchange rate; $P_{d}$ and $P_{f}=$ price of exports expressed in local currency and price of imports expressed in the foreign currency of the imports; $O C N=$ nominal value of other components of the current account.

Setting out from this equation (1), the real growth rate of an economy can be expressed in relation to the terms of trade [1], changes in long-term financial flows measured in real terms [2] and exogenous changes in the level of real external aggregate demand [3].

$$
\text { (2) } y_{b p c f}=\frac{(1+\theta \psi+\gamma)\left(p_{d}-e-p_{f}\right)}{\xi}+\frac{\eta\left(f-p_{d}\right)}{\xi}+\frac{\pi y_{R M}}{\xi}
$$

Where the variables include $y_{b p c f}=$ rate of variation in the real growth of a country at the periphery that is compatible with the external equilibrium as defined earlier; $p_{d}$ rate of variation of domestic prices (domestic inflation); $p_{f}=$ rate of variation in external prices (imported inflation); $e=$ rate of variation in the nominal exchange rate; $f=$ rate of variation in real financial flows; $y_{R M}=$ rate of variation of real growth in the rest of the world.

on world trade."). This inability to achieve the potential growth rate has implications for the labour market, since under these conditions countries cannot absorb the labour supply, which results in unemployment, underemployment and informality. The idea that the countries of the periphery show a tendency to grow below potential is also an important element in the thinking of Ffrench-Davis, organized around the recessionary gap concept, which will be explained in more detail in section I. Prebisch (1993, vol. 4, p. 351) thought, along similar lines, that under the classical schema the volume of production was regular and there was a tendency towards full employment of production factors and maximization of output. In fact, though, growth comes in waves because of the way the accumulation process operates. Output does not remain close to the optimum, but moves alternately towards and away from it in a way that is very wasteful of production factors and, it may be added, of resources. 
The parameters comprise: $\gamma, \psi=$ price elasticities of imports and exports $\gamma, \psi<0 ; \xi, \pi=$ income elasticities of imports and exports, $\xi, \pi>0 ; \theta$ and $\eta=$ proportion of current account debits financed from export earnings and financial flows, respectively. ${ }^{57}$

According to (2), the real growth rate of a peripheral country is positively related to external demand growth weighted by the import and export elasticity ratio, with increases in the terms of trade (there being a negative relationship with currency appreciation weighted by price elasticities) and with higher rates of growth in long-term financial flows. ${ }^{58}$

There are four ways in the external constraint on growth can be eased: (i) a permanent increase in the rate of growth in external demand, (ii) a permanent increase in the rate of growth in long-term financial flows, (iii) a permanent improvement in the terms of trade (real exchange rate), and (iv) the implementation of policies for structural change in the countries of the periphery.

Adopting various simplifications for (1) allows the analysis to be focused on different issues connected with these four alternatives. For example, an assumption that changes over time in the exchange rate and the terms of trade tend to cancel out or amount to little variation in the long run results in the growth rate compatible with the balance-of-payments constraint being expressed with reference to financial flows and aggregate demand in the rest of the world.

$$
\text { (3) } y_{b p c f}=\frac{\eta\left(f-p_{d}\right)}{\xi}+\frac{\pi y_{R M}}{\xi}
$$

In the extreme case where the current account remains in balance over the long run (i.e., where $\theta=1 y \eta=0$ ), the growth rate compatible with the balance-of-payments constraint depends exclusively on the growth rate of the centre and the income elasticities of exports and imports.

$$
\text { (4) } y_{b p c f}=\frac{\pi y_{R M}}{\xi}
$$

57 The growth rate of a peripheral economy compatible with long-term equilibrium in the balance of payments derives from a three-equation model. The first equation expresses the growth rate of imports with reference to the real exchange rate and the growth rate of the periphery $\left(m_{f}=\psi\left(p^{*}+e-p_{d f}\right)+\xi y_{f}\right)$, the second expresses the export growth rate with reference to the real exchange rate and the growth rate of the centre $\left(x_{f}=\gamma\left(p_{d f}-p^{*}-e\right)+\pi y_{*}\right)$, and the third shows the dynamic equilibrium of the balance of payments $\left(\theta\left(p_{d f}+x\right)+\eta f=p^{*}+m_{f}+e\right)$. The solution is obtained by substituting the export and import equations into the dynamic equilibrium condition and resolving this for the growth rate of the periphery.

58 These make it possible to finance long-run growth to a greater degree than is compatible with a current account in balance (McCombie and Thirlwall, 1994). This accords with the position of ECLAC that only long-term financial flows can raise economic growth. 
This formulation is known in the heterodox literature as Thirwall's Law (Thirlwall, 1979). According to this law, which is a particular case of (1), the long-term growth of the periphery depends on its export and import income elasticities.

In its analyses of the external constraint, the structuralist tradition emphasizes the impact of price and income elasticities on long-term growth. ${ }^{59}$ This emphasis is particularly relevant when it comes to characterizing the production structures of the centre and periphery. The production structure of the centre is diversified and homogeneous, while that of the periphery is specialized and heterogeneous.

In turn, the specialized production structure of the periphery means that many of its productive resources go into successive expansions of the primary export sector, while the demand for goods and services is largely met from imports (Rodríguez, 1977, p. 206). Demand for agricultural products is fairly inelastic to price because they are used as inputs for a final product or good. Consequently, a fall (rise) in their price is not passed on in full to the final product; the input price is just one component of the price of the final good. Furthermore, they have a low income elasticity of demand because they are regarded as (or approximate to) inferior goods (i.e. the Engel curve is concave). To this factor must be added the technological superiority of the centre in the export of manufactures. These two properties of the goods exported and imported by the periphery, together with the technological superiority of the centre and the structure of goods and factor markets, formed the explanation for the secular deterioration in the terms of trade. ${ }^{60}$

59 This suggests a standard external constraint formulation without financial flows, i.e. $y_{b p c f}=\frac{(1+\theta \psi+\gamma)\left(p_{d}-e-p_{f}\right)}{\xi}+\frac{\pi y_{R M}}{\xi}$.

60 For a reinterpretation of the theses upheld in 1950, see Prebisch (1991) and Singer (1950 and 1987). According to Singer, in 1938 and later in his proposal for a clearing union, Keynes also stress the peculiarities and characteristics of the goods and markets of the periphery, which once again marks a convergence of viewpoints between structuralism and the heterodox tradition. It is important to note that the deterioration of the terms of trade was remarked by Prebisch in 1926 and that his analysis in the Manifesto associates it directly with the subject of cycles. As this states (op. cit., 1950, p. 504), the reason for this phenomenon (a secular tendency towards a worsening of the terms of trade) could not be grasped unless it was related to the cyclical movement of the economy and the way this manifested itself in the centres and the periphery. Primary prices rose more quickly than final prices in the up phase of the cycle, but also dropped by more in the down phase, so that final (industry) prices progressively moved away from primary prices across the cycles. This worsening tendency in the terms of trade is not something common to all structuralist thinkers. Furtado does not mention this factor in his historical analysis of the centre and periphery or in his classic study on Brazil. Boianovsky (2008, p. 14) argues that the Prebisch-Singer thesis of a secular decline in the terms of trade did not play a major role in Furtado's historical analysis of the dynamic of growth in the centre and periphery or in his theoretical interpretation of underdevelopment, and it was absent from both his books (1954 and 1959) on Brazilian economic history and his 1961 publication on economic development. See Bielschovsky (1998) for a similar assessment and Bielschovsky (2009) for an analysis of Furtado's contributions to structuralist thought. 
Nonetheless, structuralist thought gave particular importance to income effects. In fact, like Thirlwall, it emphasized that the impact of price effects was not enough on its own to affect long-run growth. Alfred Navarrete, in his pioneering 1951 study of the subject of the external constraint in Mexico, Estabilidad de cambios, el ciclo y el desarrollo economico: una investigation sobre los problemas de la balanza de pagos, 1929-1946, concluded that exchange-rate adjustments could be ineffective in correcting the external imbalance if there was secular stagnation in the cyclical centres.

Similarly, in his paper "Economic development or monetary stability: the false dilemma" (1961a), Prebisch stressed the role of income elasticities in determining peripheral growth and said that export growth set an upper bound on the development of a peripheral country. This upper bound was set by the strength with which the demand for imports rose as per capita income increased (i.e. the income elasticity of import demand). As per capita income grew, the demand for industrial items tended to increase more strongly than the demand for primary items (peripheral countries import the former and export the latter). The situation of the major industrial centres was completely the opposite. For a given population growth rate, a peripheral country could not grow spontaneously at the same rate as the trading centres it traded with because of the disparity of elasticities, and since the population of the countries of the Latin American periphery was growing much more rapidly than that of these centres, the process must be even more intensive. ${ }^{61}$

The similarity between heterodox and structuralist thought is revealed by the fact that the formulation of the external constraint known as Thirlwall's Law is actually identical to the one put forward by Octavio Rodríguez (1977, pp. 235-236) to characterize the ECLAC approach. ${ }^{62}$ It is worth quoting Rodríguez's exposition of this concept:

61 Leaving aside the matter of population growth, and in line with the centre-periphery interpretation as an analytical and evolutionary dichotomy, this paragraph is easily applicable to trade relations between China and Latin America. Latin America exports mainly natural resources with a low technology content (and low income elasticity of exports) to China, but imports products with a higher technology content (high income elasticity of demand for imports). There is a clear convergence between this characterization of the external constraint by Prebisch and the one outlined by the post-Keynesian economist Paul Davidson in a number of his writings (1992-2011). In full accord with Prebisch (1963), Davidson (1992, pp. 94-95) states that if less developed economies have a comparative advantage in primary goods and other commodities, for which Engel curves suggest a low income elasticity of demand, while having a high income elasticity of demand for manufactured products from the developed world, they will be condemned to relative poverty. If the population growth rate is higher in these countries, their future will be still bleaker.

62 The author is grateful to Gabriel Porcile for pointing out Rodríguez's article and its similarity with Thirlwall's Law. 
"Let $G_{p}$ and $G_{c}$ be the growth rates of income in the periphery and in the centre, and $E_{p}$ and $E_{c}$ the respective income-elasticities of demand for imports. The equation $G_{p}{ }^{*} E_{p}=G_{c}{ }^{*} E_{c}$ indicates what condition must be fulfilled if the external equilibrium of the two economies is to be maintained through time, ceteris paribus in respect of prices and capital movements. An alternative equation

$$
\text { (5) } G_{p}=\frac{E_{C}}{E_{P}} * G_{C}
$$

makes it easier to see that if elasticity is lower in the centre than in the periphery (if $E_{c}<E_{p}$ ), the maintenance of external equilibrium requires that the rate of income growth be slower in the periphery than in the centre, and all the slower, the greater the disparity in elasticities. If this limit is exceeded, disequilibrium will probably result." ${ }^{\prime 63}$

The Thirlwall-Rodríguez Law, being a particular form of the external constraint (1), does not exclude long-term changes in financial flows and the terms of trade (real exchange rate). Rather, it abstracts them to focus on the importance of income elasticities (of exports and imports) as determinants of long-term growth. ${ }^{64}$

This has two important implications for economic theory and policy. First, it implies that trade between countries is not governed by the gross substitution axiom, according to which any good or service is a gross substitute for any other. Accordingly, the composition of the export and output basket matters to economic growth. Second, and as a consequence of the first implication, higher growth requires a change in income elasticities or, what is equivalent, in the composition of exports and output. To put it another way, higher growth requires a structural shift, which requires in turn technological progress.

This is precisely the point of chapter VII, by Cimoli and Porcile, who establish a functional relationship between the income elasticities of demand for exports and imports $\left(\varepsilon_{p}\right.$ and $\varepsilon_{p}$, respectively) and a function of the degree of diversification of the peripheral production structure $\left(f\left(N^{P}\right)\right)$, such that

$$
\text { (6) } \frac{y_{b p c p}}{y_{c}}=\frac{\varepsilon_{p}}{\varepsilon_{c}}=f\left(N^{P}\right), f_{1}>0
$$

63 If $G_{p}$ is substituted for $y_{b p f^{\prime}} G_{c}$ for $y_{R M^{\prime}} \xi$ for $E_{p}$ and $E_{c}$ for $\pi$, the formula in (5) is identical to the formula in (4).

${ }^{64}$ In a seminal article, Moreno-Brid (1998-1999) introduced the possibility of a current account deficit in the Thirlwall model. 
A higher degree of production diversification translates into an increase in the elasticity ratio and thence into a rise in the growth rate consistent with the balance-of-payments constraint for the periphery $\left(y_{b p c p}\right) .{ }^{65}$

\section{H. Structural change, technological progress and innovation}

Technical progress has played a central role in the development of structuralist and neostructuralist thought. According to traditional structuralist thinking, the uneven spread of technological progress explains the historical development of the centre-periphery poles. ${ }^{66}$ The advantages of technical progress are concentrated in the industrial centres and quickly spread in those centres, thus increasing incomes across the board there. At the periphery, conversely, the new production techniques are implemented in primary export sectors and in export-linked activities. These activities then coexist alongside sectors that lag in terms of the penetration of new techniques and the productivity of labour. ${ }^{67}$

According to traditional structuralist thinking, although productivity is higher in industry than in the production of primary goods, the price relationship between the two tends to move against the periphery. This tendency, which is by no means immutable but can change with the historical context, is explained by the fact that the profits of enterprises and factor income tend to above productivity at the centre and below it at the periphery. In other words, although productivity is higher at the centres than at the periphery, the former retain the fruits of the technical progress of their industry, i.e. final goods prices do not fall commensurately with the increase in productivity, while countries at the periphery have transferred some of their own technological progress to the centre (Prebisch, 1951, p. 501).

65 In this formulation, it is the growth rate of the centre. See McCombie and Thirlwall (1994, p. 244). As Ocampo (2011) has pointed out, in line with traditional (see Furtado, 2003) and more recent structuralist thought, growth is conceived as a process of structural change. ECLAC (2012a) has once again stressed the importance of structural change as something central to equality.

${ }_{66}$ As Rodríguez (1977, p. 206) put it, centres and the periphery are conceived as having been constituted historically by the way technical progress spreads in the world economy. Furtado's (2003, pp. 110-111) interpretation of the evolution of the centre-periphery evolution may be the most complete, since it indicates that in a synthetic presentation of his theoretical studies, Prebisch referred to the idea of "a system of international relationships" which he called centreperiphery and which was a by-product of his reflections on the cyclical fluctuations that arise in the international sphere. From this reflection on the spread of cycles he perceived that the system of international division of labour had arisen primarily to serve the interests of countries at the head of the industrialization process. Countries producing and exporting raw materials were linked to this centre by their natural resources, constituting a vast and heterogeneous periphery that was incorporated into the system in different ways and in differing degrees. This overview of the capitalist economy, which made it possible to identify a structural faultline created by the slow spread of technical progress and perpetuated by the international division of labour, wasPrebisch's greatest theoretical contribution and was the starting point for underdevelopment theory.

67 As noted, this gives rise to two kinds of production structure: (i) specialized and heterogeneous at the periphery, and (ii) diversified and homogenous at the centre. 
The explanation for this lies in the fact that advances in technical progress and accumulation at the centre lead to shifts in social structures that allow income distribution to be altered and the effects of technical progress to be retained (Furtado, 2003, p. 58).$^{68}$ Prebisch's more detailed explanation in the ECLAC Manifesto (1950) combines, in line with the thrust of heterodox thinking, the effects of the cycle (short run) on the trend (long run) (Kalecki, 1966). ${ }^{69}$ According to Prebisch, the increase in profits resulting from technical progress produces booms and rising wages because of labour scarcity. A process of social homogenization also occurs. At times of lower growth and recession, wage earners are better placed to withstand reductions in their purchasing power. At the periphery, on the other hand, the lack of organization that is the rule among the working masses in primary production prevents them from securing pay rises comparable to those in industrial countries. Compression of income, whether profits or wages, is thus easier at the periphery (Prebisch, 1951, page 505).

Technical progress and its unequal distribution not only result in a worsening of the trade relationship to the disadvantage of the periphery but also, given existing institutions, represent an obstacle to improving real incomes and living standards for populations at the periphery. The answer structuralism has found to this dilemma is to introduce modern technology into the production process in primary sectors while at the same time pursuing a process of accumulation and technological improvements in industry. ${ }^{70}$ Industrialization or structural change is a way of capturing the fruits of technical progress and raising the living standards of the region's inhabitants.

Technical progress was a central component of the structuralist approach long before it was discovered by mainstream economics or even formed part of heterodox growth models. ${ }^{71}$

68 According to Furtado (2003, p. 97), the pressure of social forces has led to the establishment of social security systems and the design of assistance policies for less developed regions.

69 Pérez Caldentey, Titelman and Carvallo (2013) argue that low trend growth in Latin America and the Caribbean by comparison with other regions is partly explained by shorter and weaker cycles of expansion.

70 Prebisch stated that what he was trying to get across was the idea of a dynamic equilibrium between the two sectors. If there is no industrialization in the developing countries, at the periphery, and if there is technical progress in agriculture, the trade price ratio will tend to deteriorate. The only way to check this trend is industrialization (Pollock, Kerner and Love, 2006). In structuralist thinking, technical progress is not always independent of accumulation, as the latter entails the former. On this subject, Furtado $(1957$, p. 40) writes that the assimilation of more advanced techniques is usually achieved by incorporating new equipment into the production process, i.e. by accumulating capital. This is the essential factor in the growth process in an underdeveloped economy.

${ }_{71}$ The seminal articles of the economic growth paradigm including the subject of technological progress date from the mid-1950s (Abramovitz, 1956; Solow, 1956; Kaldor, 1957; Robinson, 1956). Solow's analysis sets out to compare growth trajectories in different countries, assuming they all have the same technology, the same capital depreciation, the same rate of technological progress, etc. It was not until the 1980s that mainstream economics addressed the problems associated with developing countries (see Lucas, 2002). 
Following this line of thinking, Ocampo (see chapter II) warns of the large technology deficit the region has built up in recent years, something that increases its vulnerability to longer-term shifts in the external context, such as the end of the raw materials boom and, most particularly, the significant decline in international trade growth since 2007. This technology deficit can be seen by comparing Latin America and the Caribbean with other regions of the world on indicators such as the percentage share of industrial production accounted for by engineering-intensive industries, research and development as a percentage of GDP, and patents per million inhabitants. The evidence presented shows that engineering-intensive industries' share of industrial production is $23 \%$, while the figure is over $95 \%$ in the emerging economies of Asia and the industrialized countries. Similarly, research and development spending is less than $0.5 \%$ of GDP in Latin America and over $1 \%$ in the emerging economies of Asia and the industrialized countries. Lastly, the number of patents per million inhabitants is 60 and 235 times greater in emerging Asia and the developed world, respectively, than in Latin America and the Caribbean.

\section{Income distribution}

In heterodox and structuralist theory, the process of accumulation (understood as the ratio between net investment and capital stock) is ultimately what determines income distribution. In the simplest proposition of the heterodox school, the causal link is direct. The incentive to invest guides capital accumulation, and the Cambridge equation is used to determine the rate of return and the real wage (Robinson, 1956, p. 11; Marglin, 1984, pp. 474-475). It is assumed that when there is excess capacity, accumulation can generate a pattern of distribution that is favourable to wages. When the opposition situation obtains, as happens when spare capacity is lacking, an increase in accumulation translates into higher prices. Higher prices in turn reduce the real wage and increase the rate of return and the profit share of output.

Structuralist theories included an additional causal link between accumulation and income distribution: the transformation of social structures.

According to structuralist theory, capital accumulation historically improved income distribution and general living standards in the most developed economies because it resulted in a scarcity of labour, creating the conditions for social pressures conducive to higher real wages and social homogenization (Furtado, 2003, p. 58). The opposite effect occurred in developing countries, where the accumulation process did not lead to a transformation of social structures. What happened, rather, was that accumulation reinforced traditional structures. This gave rise to a process of circular causation that structuralist thinkers recognized from the outset 
and related to two key concepts that are also present in neostructuralism and that have taken on a preponderant role in the current thinking of ECLAC: structural heterogeneity and social heterogeneity.

Furtado (1965, p. 97) argues the this strengthening of traditional social structures tends to direct the application of production resources in a way that reduces economic efficiency and concentrates income yet further in a process of circular causation. More generally, economic inefficiency leads to economic stagnation. Furthermore, the adoption by the dominant classes of the consumption patterns of countries with a much higher level of accumulation explains the great concentration of income and the persistence of social heterogeneity (Furtado, 1999, pp. 75-76).

Over and above considerations of structural and social heterogeneity, income distribution is also related to the evolution of economies over time. In Minsky, for example, income distribution explains the cycle and its dynamic (Kalecki, 1969; Minsky, 1982 and 1986). According to Kalecki and Minsky, investment spending determines profit, which in turn determines enterprises' self-financing capacity and the basis on which they take their external financing (borrowing) decisions. In the upturn of a cycle, a rise in profits can change enterprises' investment and external financing decisions, as they may be willing to take on more debt relative to their flows, which creates financial fragility (Minsky, 1975, pp. 113-116). ${ }^{72}$

\section{J. Volatility and instability}

Volatility has been a crucial issue for the analytical work of ECLAC, for the neostructuralist thought of the last two decades (ECLAC, 2002, 2004, 2010 and 2012a) and for heterodox thought (as shown in the previous section).

Consistently with the methodological approach, the analysis of volatility in Latin America and the Caribbean sets out from an empirical observation: since the 1980s, not only has real volatility in Latin America and the Caribbean increased, but the region has had one of the highest levels of real volatility in the world. The coefficient of variation for the region was below 1 between 1960 and 1980, whereas since the latter year it has been above 1.

The volatility is accounted for in part by the characteristics and specificities of the cycle itself (Pérez Caldentey, Titelman and Carvallo, 2013). By comparison with other developed and developing regions of the

72 In structuralist thought, similarly, the social structure and distribution have played a significant role in specific subject areas such as the analysis of inflation. The fiscal deficit that arises as a consequence of redistributive conflicts is one of the propagation mechanisms accounting, along with basic pressures, for the dynamic of inflation (Noyola 1956; Sunkel, 1958 and 1963; Olivera, 1960). Furtado also makes inertial inflation, which he calls neutral inflation, part of the initial analysis (Furtado, 1954 and 1959; Boianovsky, 2009). 
world, the economic cycle of Latin America and the Caribbean presents two distinctive features. First expansions in the region are weaker and shorterlived than in other regions of the developing world, particularly East Asia and Asia-Pacific. Second, contractions in Latin America and the Caribbean tend to converge with those in other regions of the developed and developing world, on average, in terms of duration and scale. These two characteristics mean that the full cycle of expansions and contractions takes place more frequently than in other regions (greater volatility) because it tends to be shorter and less intense.

In turn, volatility has an asymmetrical effect on economic sectors and producers and tends to endogenize trend GDP to its cyclical movement. This is summed up by Ffrench-Davis (2010) and in chapter IV of this book using the concept of the recessionary gap. Ffrench-Davis argues that, during a contractionary period in the business cycle, actual GDP may be well below trend GDP consistent with full employment for long periods, which significantly affects its future evolution owing to the depressive effects on productive investment, employment and innovation. During upturns, conversely, potential GDP or the production frontier set a bound on the recovery of actual GDP. Actual GDP can only rise temporarily above potential GDP. What Ffrench-Davis means by a recessionary gap is the gap between potential output and actual output, because when actual GDP is below potential, capital and labour are being underutilized.

Ffrench-Davis argues that the recessionary gap impacts capital formation and labour, and can thus turn potential GDP into an endogenous variable. Thus, at times when the recessionary gap is larger and longer-lasting, potential GDP is lowered, whence the importance of using macroeconomic policy to avoid recessionary gaps that can impair the production capacity of an economy and to raise capital formation, sustainable employment, innovation and thus trend GDP.

This emphasis on the volatility of the real economy is not new, as it was one of the subjects Prebisch stressed most in relation to the workings of free-market economies, noting that economic activity expanded and contracted continuously in an uninterrupted succession through phases of income, employment and output growth followed by slowdowns, with the concomitant decline of production and employment. There is no point of rest: what goes up must come down, and what goes down must come up. There is no point of equilibrium in this movement; it is a continuous succession of disequilibria (Prebisch, 1991, vol. 3, p. 499).

Furtado also emphasized the issue of instability and argued that whichever angle it is considered from, the capitalist industrial economy seems doomed to instability (2003, p. 60). Similarly, instability is treated by heterodox thought (Minsky, 1982 and 1986) as one of the main failings of capitalism. 


\section{K. The central role of demand}

Traditional structuralism, be it Prebisch's or that of Furtado and other thinkers, like the new structuralist approaches and most economists, affords a central role to aggregate demand as a driver and engine of accumulation, growth and economic and social welfare.

Both Prebisch and Furtado originally argued that the periphery countries, including those of Latin America, could grow outward by exporting or inward through a process of industrialization and structural change. Both reached the conclusion that, notwithstanding the importance of the external sector, the main way of growing is inward; the domestic market is the dynamic centre of the economy (Prebisch, 1951, p. 496); Furtado, 1999, pp. 69-73; 2003, p. 54). It should be noted, however, that this prescription applied essentially to the region's larger countries. Obviously this does not mean either closing the economy or adopting protectionist practices. Furtado (1999, pp. 102-103) argued that only in ignorance or bad faith was it possible to take this opinion as a call to close the economy.

The idea of inward growth was associated with the use of demand as an instrument for driving economic growth (Furtado, 1964). Furthermore, this view of demand was by no means unknown in the economic history of Latin America; indeed, in the case of Brazil in the 1930s, it preceded the recommendations that Keynes would subsequently make to combat the effects of the Great Depression. As Furtado argued with reference to the support policy used to hold up coffee prices in the early 1930s (1999, p. 71), no one realized that, by accumulating and burning mountains of coffee, Brazil was building the pyramids that Keynes would recommend years later as a last resort to vanquish the depression. ${ }^{73}$

This approach does have a certain consistency with one of the basic postulates of heterodox economics: the "principle of effective demand" According to this principle, the path taken by an economy is determined in the short and long run by demand, in the sense that output of goods and services adjusts to demand, and constraints on the demand side outweigh constraints on the supply side.

\footnotetext{
73 As Keynes wrote in his 1933 letter to President Roosevelt: "The object is to start the ball rolling." This is why his preferred instrument ("my favourite remedy", Clarke, p. 115) for increasing investment were public works financed out of borrowing. In "The means to prosperity" (1933), Keynes argued for a programme of public works using the logic of the multiplier. Under conditions of less than full employment, Keynes argued that programmes of this type did not create a fiscal deficit and stressed that it was completely mistaken to think there was any dilemma between job creation schemes and schemes to balance the fiscal accounts. On the contrary, it was not possible to balance the budget without increasing national income, which was more or less the same as increasing employment (1980, IX, p. 347).
} 
The effective demand principle has a key implication that the originators of the most recent versions of structuralism uphold: the fact that the long run cannot be specified independently of the short run. Pereira (2012b, p. 2) argues that the cyclical component of economic activity traditionally associated with short-run changes in aggregate demand affects long-run trend growth in capitalist economies.

For their part, Titelman and Pérez Caldentey (see chapter V) argue that the particular dynamics and characteristics of the cycle in Latin America and the Caribbean are important for the short and long run. More specifically, briefer and weaker expansions imply that the accumulation period will also be briefer and weaker. The weakness of expansions is reflected in structural variables such as productivity and investment, which are deemed to be essential determinants of an economy's growth trajectory. ${ }^{74}$

A key variable linking the short and long run, and forming part of the core analysis of structuralism and neostructuralism, as well as of heterodox thought, is investment. In the short run, investment is one of the main components of aggregate demand and total spending, as well as a determinant of installed capacity utilization. Furthermore, since investment has a high degree of irreversibility, it links decisions taken in the short run with mediumand long-term outcomes, which entails a process of dependent trajectories.

Irreversibility has two elements. First, it means that investment decisions endure in time, since firms cannot uninvest (or can only do so at a high cost or very gradually through depreciation of fixed assets), so that investment spending becomes an irrecoverable cost. ${ }^{75}$

The irreversibility of investment is also a major determinant of the decision itself to invest or not invest. Thus, investment becomes particularly sensitive to the different forms of risk, such as uncertainty about the evolution of future prices, the operating costs that determine cash flows, uncertainty about the evolution of interest rates and, in general, uncertainty about the future macroeconomic environment.

\section{The role of the market and the State}

In structuralist and heterodox thought, the roles of the State and government are indissolubly linked to the emergence and consolidation of market economies.

74 Schumpeter also shared the idea that the short and long run were interrelated. As he put it (1939, vol. 1, p. v), cycles are not like tonsils, separable things that might be treated by themselves, but are, like the beat of the heart, of the essence of the organism that displays them. Interdependence between the short and long run is one of the defining characteristics of heterodox economics (Pereira, 2012b; Arestis and Sawyer, 2009).

75 The idea of investment irreversibility can be found in different schools of thought (Bertola and Caballero, 1999; Arestis and Sawyer, 2009). 
Analysis of the empirical evidence shows that, in the early stages, developed economies used a combination of public policies in manufacturing, trade and technology to pursue growth and development. These involved the active use of subsidies and tariffs, as well as the distribution of monopoly rights to stimulate the establishment of particular sectors and ensure the survival of newer industries. Public policies also included the development of national capacities through research, education, encouragement of acquisition, learning of foreign technologies and public-private cooperation practices (Chang, 2002 and 2008; Pérez Caldentey, 2008).

Furthermore, the evidence shows that these strategies and practices were extensively used to consolidate the technological supremacy of today's major industrial powers. Between 1950 and 1978, for example, the United States federal government provided $50 \%$ of the country's research and development financing. More specifically, the government has directed technological development and the drive to innovate into new areas, such as information technology, biotechnology, nuclear energy and nanotechnology (Phelps, 2013). The major technological achievements of the twentieth and twenty-first centuries may well never have seen the light of day without firm government backing, including Apple's innovation in computers, magneto resistance, new molecular entities (biology) and the birth of Silicon Valley in California (Mazzucato 2013; Janeway, 2012).

Nonetheless, experience also shows that strategies of this type are not exclusive to developed countries or particularly successful developing countries such as those of East Asia, but have also been a recurring feature of the history of Latin America and the Caribbean. At least from the late nineteenth century until the 1980s debt crisis, the region's governments, and particularly those of its large economies, intervened actively in an effort to consolidate their territory and promote long-term development in their economies. The heyday of intervention was unquestionably that of "State-led industrialization" (Ocampo, 2004), which lasted from the end of the Second World War until the 1960s, and in some economies even until the early 1970s.

Intervention policies in the region focused on the development of infrastructure, the protection of export sectors and of particular products and industries (and sectors), and on encouraging immigration of specialized labour. ${ }^{76}$ As in the more developed economies, the main instruments used by the region's governments at the outset included import and export taxes, tariff exemptions, quantitative controls and a wide range of subsidies, exchangerate controls and cheap credit. By contrast with the more industrialized countries, those of Latin America, with some exceptions, paid little attention to technological development and education. Ultimately, on the whole, their

$76 \quad$ Baer (2008, p. 303) considers that the policy of immigration subsidies adopted in Brazil in the late nineteenth century acted as a substitute for a policy of investment in human capital. 
interventionist policies were less effective than those applied in developed countries, being unbalanced in some cases and lacking the flexibility to adapt to shifting situations and contexts. Still less were they capable of promoting structural change as had been hoped.

In accordance with its methodological principles, structuralism not only recognized intervention as a fact, but also tried to identify the constraints on it. On this basis, it also proposed changes in the design and scope of government interventions. Thus it was that State-led industrialization gave way in the 1970s to a development strategy focusing on the relationship between growth and trade. The core considerations included the need to foment raw material exports to finance imports and promote manufacturing exports, which averaged just $4 \%$ of total goods exports in Latin America in 1950-1962 (Pérez Caldentey, Sunkel and Torres, 2012). ${ }^{77}$

Following this line, neostructuralism advocates a renewal of the style and form of State intervention with respect to efforts centred purely on industrialization (ECLAC, 1990). At this stage, although priorities continued to stress sectoral and micro-level action, there was a shift towards strengthening competitiveness through uptake of technological progress and towards the attainment of greater social equity and equality. The document Changing Production Patterns with Social Equity (ECLAC, 1990, p. 149) notes that the style of government intervention consistent with changing production patterns with equity would obviously have to be different from the style which favoured industrialization in the preceding phase. At present, the two key tasks for the State are to participate in the effort to deal with cumulative shortfalls in equity and international competitiveness (innovation).

These lines of government action are the ones that have marked neostructuralist thought and research in this area. There is a consensus that the accumulation of technological capabilities needs to be the subject of a policy pursuing production transformation. This means that export structures with greater

7 Prebisch recognized the shortcomings of this strategy in the mid-1950s and was cautious about making it institutionally public in 1961 in the document Economic Development, Planning and International Co-operation (Prebisch, 1961b). As he argued over 20 years later, in 1984, national markets isolated from external competition weakened and even destroyed the incentive to improve production quality and reduce costs under the private enterprise system. This strategy of State-regulated industrialization had stifled enterprise in the domestic and external markets. He stressed the limitations of this strategy again in his last interview at ECLAC, when he said: "At ECLAC we argued from the beginning that protection was indispensable as a tool for dealing with the technical and economic superiority of the centres. Unfortunately, protection [...] has been grossly overdone to the point of being abusive, and has been maintained for a long period, removing the incentive for industries to cut production costs" (1986). Other economists in the structuralist tradition such as Maria da Conceição Tavares and Santiago Macario also recognized the limits of State-led industrialization in the 1960s. See Pérez Caldentey, Sunkel and Torres (2012). 
technology content need to be developed in a way that does not neglect the domestic market, or rather that linkages between the external and domestic sectors need to be fostered..$^{78}$ As Changing Production Patterns with Social Equity argued, public policy for production needs to be sectorally selective in its production activity development initiatives (Ocampo, 2011).

The new developmentalism deals with very similar points, concentrating in particular on export-oriented industrialization, the creation of investment opportunities and the reduction of economic inequalities (Pereira, 2012a and 2012b, p. 361). In addition, both neostructuralism and the new developmentalism afford the private sector a greater role in the production and allocation of goods and services.

To government action of a sectoral and microeconomic character, neostructuralism has added a macroeconomic aspect that was not present in structuralist thought: the use of fiscal policy to manage aggregate demand and its cyclical fluctuations. As Ocampo (2011, p. 15) points out, in open economies, it is very difficult to use monetary policy as a countercyclical tool, especially when the capital account has been opened. For this reason, fiscal policy is unquestionably the best countercyclical management instrument. ${ }^{79}$

Neostructuralism ties in here with heterodox thought, and particularly with the post-Keynesian approach, which essentially emphasizes government intervention as a macroeconomic factor centred on fiscal policy. According to the post-Keynesian school, the role of fiscal policy is to shorten the distance between investment and saving, preventing the burden from falling on the level of economic activity. More formally, the government's budgetary constraint is equal to:

$$
\text { (7) } \mathrm{G}-\mathrm{T}=\mathrm{S}\left(\mathrm{Y}^{\mathrm{e}}\right)-\mathrm{I}\left(\mathrm{Y}^{\mathrm{e}}\right)+\left(\mathrm{M}\left(\mathrm{Y}^{\mathrm{e}}\right)-\mathrm{X}\left(\mathrm{Y}^{*}\right)\right)
$$

Where $\mathrm{G}$ = government spending, $\mathrm{T}=$ taxes, $\mathrm{S}=$ saving, $\mathrm{I}=$ investment, $\mathrm{M}=$ imports, $\mathrm{X}=$ exports, $\mathrm{Y}^{*}=$ rest of world output and $\mathrm{Y}^{\mathrm{e}}=$ domestic output (Creel and Sawyer, 2009).

Put like this, the fiscal constraint means that government spending can absorb the excess of saving (S) over investment (I). In other words, the government deficit arises when there is an excess of saving (S) over investment (I).

78 Policies to diversify the production and export structure and promote greater productivity in small and medium-sized enterprises, because of their ability to create jobs and support medium-productivity sectors in connecting more dynamically with larger firms or more productive sectors.

79 See Ffrench-Davis (2010). 
Similarly, a surplus is required when investment (I) exceeds saving (S). Thus, the basic justification for fiscal policy in this framework is that there is no automatic tendency towards equality between saving and investment. ${ }^{80}$

\section{Conclusion}

It has been argued here that the events of the past three decades have marked a break in the practice of mainstream economics. The validity and justification of the mainstream approach centred, above all, on a predictive ability that events have thrown into doubt. It is, then, a good time to explore new alternatives, in terms both of a better balance between traditional and new ways of thinking and of the ways in which these are taught.

Latin America and the Caribbean has a long and through-going tradition of economic thought. The most complete school of thought that has arisen in the region is structuralism and, in its more modern version, neostructuralism. Structuralism arose in part as a reaction to orthodox economics, to which is attributed a false sense of universality and a limited applicability to the real world (Prebisch, 1951, p. 498; Furtado, 2003, pp. 85-87) and, it may be said, to the developing world. Neostructuralism is an effort to adapt structuralist theory to a shifting context and suggest new subject areas and standards for methodological development and related economic policymaking.

Since (neo)structuralism is an open system of ideas, it can benefit from dialogue and the creation of forums for debate with other traditions of economic thought, such as the heterodox school. The heterodox school encompasses a heterogeneous collection of approaches, including Marxist and radical thinkers, the regulation school, post-Keynesians, institutionalists and evolutionists.

This article has identified seven areas that can provide the basis for a rapprochement between the two traditions of thought and for an economic policy agenda aimed — as Keynes and Prebisch advocated in their respective ways and times- at enabling autonomous decision-making to confront the three great shortcomings of market economies: their inability to generate full employment, their tendency to distribute income and wealth arbitrarily, and their propensity to volatility and instability.

80 Although some neostructuralists argue, in contrast to the post-Keynesian position, that the most advisable thing is to set fiscal rules (Ffrench-Davis, 2010), they also recognize the difficulty of doing so because the trend of a variable (i.e. GDP) may not be independent of its cycle (Heymann, 2000; Ocampo, 2011; Pérez Caldentey, Titelman and Carvallo, 2013), as already remarked. This is another point of intersection between neostructuralist and post-Keynesian thought. 


\section{Bibliography}

Abramovitz, M. (1956), "Resource and output trends in the United States since 1870", American Economic Review, vol. 46, No. 2, Nashville, Tennessee, American Economic Association.

Acemoglu, D. (2009), "The crisis of 2008: structural lessons for and from economics" [online] http:/ / economics.mit.edu/files/3703.

(2008), Introduction to Modern Theories of Economic Growth, Princeton, Princeton University Press.

Aghion, P. and P. Howitt (1992), "A model of growth through creative destruction", Econometrica, vol. 60, No. 2, New York, Econometric Society.

Akerlof, G. (2006), “The Missing Motivation in Macroeconomics" [online] http:/ / www.aeaweb.org/annual_mtg_papers/2007/0106_1640_0101.pdf.

Akerlof, G. and R. Shiller (2009), Animal Spirits: How Human Psychology Drives the Economy, and Why It Matters for Global Capitalism, Princeton, Princeton University Press.

Allais, M. (1966), "A restatement of the quantity theory of money", American Economic Review, vol. 56, No. 5, Nashville, Tennessee, American Economic Association.

Alvarez, R. and J. De Gregorio (2013), "Why did Latin America and developing countries perform better in the global financial crisis than in the Asian crisis?", paper presented at the 14th Jacques Polak Annual Research Conference, Washington, D.C., International Monetary Fund (IMF) [online] http://www. imf.org/external/np/res/seminars/2013/arc/pdf/deg.pdf.

Arestis, Ph. and M. Sawyer (2009), Path Dependency in Macroeconomics, New York, Palgrave MacMillan.

Arrow, K.J. and G. Debreu, (1954), "Existence of an equilibrium for a competitive economy", Econometrica, vol. 22, No. 3, New York, Econometric Society.

Aujac, Henri. 1954. "Inflation as the Monetary Consequence of the Behaviour of Social Groups: A Working Hypothesis." International Economic Papers No. 4.

Baer, W. (2008), The Brazilian Economy: Growth and Development, Boulder, Co, Lynne Rienner.

Bean, Ch. and others (2010), "Monetary Policy after the Fall" [online] http:/ / www. kansascityfed.org/publicat/sympos/2010/2010-08-23-bean.pdf.

Becker, G. (1981), A Treatise on the Family, Cambridge, Massachusetts, Harvard University Press.

(1978), The Economic Approach to Human Behavior, Chicago, The University of Chicago Press.

Bernanke, B. (2005), "The global saving glut and the U.S. current account deficit", paper presented at the Sandridge Lecture, Virginia Association of Economists, Richmond, Virginia, 10 March.

(2004), "The Great Moderation. Remarks by Governor Ben S. Bernanke", Washington, D.C. [online] http:/ / www.federalreserve.gov/Boarddocs / Speeches/2004/20040220/.

Bernanke, B., M. Gertler and S. Gilchrist (1999), "The financial accelerator in a quantitative business cycle framework", Handbook of Macroeconomics, vol. 1, J.B. Taylor and M. Woodford (eds.), Amsterdam, Elsevier.

Bertola, G. and R. Caballero (1994), "Irreversibility and aggregate investment", Review of Economic Studies, vol. 61, No. 2, Wiley Blackwell. 
Bielschovsky, R. (2010), "Vigência das contribuições de Celso Furtado ao estruturalismo", CEPAL Review, special issue (LC/G.2444-P), Santiago, Economic Commission for Latin America and the Caribbean (ECLAC). (2009), "Sixty years of ECLAC: structuralism and neo-structuralism", CEPAL Review, No. 97 (LC/G.2400-P), Santiago, Economic Commission for Latin America and the Caribbean (ECLAC), April.

(1998), "Evolución de las ideas de la CEPAL", CEPAL Review, special issue (LC/G.2037-E), Santiago, Economic Commission for Latin America and the Caribbean (ECLAC).

Blanchard, Olivier (2008), "The State of macro is good", NBER Working Paper, No. 14259, Cambridge, Massachusetts, National Bureau of Economic Research [online] http:/ / www.nber.org/papers/w14259.pdf.

(2006), "Monetary policy; science or art?" [online] http:/ / economics.mit.edu/ files / 742 .

Blanchard, O. and J. Gali (2005), "Real wage rigidities and the New Keynesian Model", NBER Working Paper, No. 11806, Cambridge, Massachusetts, National Bureau of Economic Research.

Blanchard, O., G. Dell'Ariccia and P.M. Mauro (2013), "Rethinking macro policy II: getting granular", IMF Staff Discussion Note (SDN/13/03), Washington, D.C., International Monetary Fund (IMF), April [online] https://www.imf.org/ external/pubs/ft/sdn/2013/sdn1303.pdf.

Blinder, A. (1986), "The case against the case against discretionary fiscal policy", The Macroeconomics of Fiscal Policy, R.W. Kopcke, G. Tootell and R. Triest (eds.), Cambridge, Massachusetts, The MIT Press.

Boianovsky, M. (2012) "Furtado and the Structuralist-Monetarist Debate on Economic Stabilization in Latin America" History of Political Economy, Vol. 44-2, Summer 2012.

(2008a), "A view from the tropics: Celso Furtado and the theory of economic development in the 1950s", Textos para Discussão, No. 247, Universidade Federal Fluminense [online] http:/ / www.uff.br/econ/download/tds/UFF_TD247.pdf. (2008b), "Furtado, Celso (1920-2004)", The New Palgrave Dictionary of Economics [online]http:/ / www.dictionaryofeconomics.com/article?id=pde2008_F000293.

Borio, C. (2012), "The financial cycle and macroeconomics: what have we learnt?", BIS Working Papers, No. 395, Basel, Bank for International Settlements.

Borio, C., P. Disyatat and M. Juselius (2013), "Rethinking potential output: embedding information about the financial cycle", BIS Working Paper, No. 404, Basel, Bank for International Settlements.

Boumans, M. and J. Davis (2010), Economic Methodology. Understanding Economics as a Science, New York, Palgrave MacMillan.

Caballero, Ricardo J. (2010), "Macroeconomics after the crisis: time to deal with the pretense-of-knowledge syndrome", Journal of Economic Perspectives, vol. 24, No. 4, Nashville, Tennessee, American Economic Association.

Calvo, G. (2012), “21st Century Macroeconomics" [online] http://vox.lacea. org $/$ ?q=node $/ 193$.

(2010), "Financial crises and liquidity shocks. A bank-run perspective" [online] http:/ / econ.tulane.edu/seminars/CalvoLiquidityCrisis.pdf.

Campos, R. de O. (1961), "Two views on inflation in Latin America", Latin American Issues, A.O. Hirschman (ed.), New York, Twentieth Century Fund. 
Ceballos, F. and others (2012), "Respuestas de política a la crisis financiera global: ¿Qué hicieron diferente las economías emergentes?", Revista Estudios Económicos, vol. 24.

Chang, H.J. (2008), Bad Samaritans: The Myth of Free Trade and the Secret History of Capitalism, New York, Bloomsbury Press.

(2002), Kicking Away the Ladder: Development Strategy in Historical Perspective, London, Anthem Press.

Chenery, H. and T.N. Srinivasan (eds.) (1988), Handbook of Development Economics, Amsterdam, Elsevier.

Chick, V. (2004), “On open systems”, Brazilian Journal of Political Economy, vol. 24, No. 1 (93), January-March.

Clarke, P. (1990) The Keynesian Revolution in the Making 1924-1936, New York, Oxford University Press.

Clarida, R. (2010), "What has - and has not - been learned about monetary policy in a low inflation environment? a review of the 2000s" [online] http://www. bostonfed.org/economic/conf/conf55/papers/Clarida.pdf.

Cochrane, J.H. (2011), "How did Paul Krugman get it so wrong", Institute of Economic Affairs (IEA) [online] http://faculty.chicagobooth.edu/john. cochrane/research/papers/ecaf_2077.pdf.

Coddington, A. (1976), "Keynesian economics. The search for the first principles", Journal of Economic Literature, vol. 14, No. 4, American Economic Association.

Cohen, A.J. and G.C. Harcourt (2003), "Retrospectives: whatever happened to the Cambridge capital theory controversies?", Journal of Economic Perspectives, vol. 17, No. 1, Nashville, Tennessee, American Economic Association.

Colander, D. and others (2009), "The financial crisis and the systemic failure of academic economics", Kiel Working Papers, No. 1489, Kiel Institute for the World Economy, [online] http://www.ifw-members.ifw-kiel.de/publications/thefinancial-crisis-and-the-systemic-failure-of-academic-economics/KWP_1489_ ColanderetalFinancial\%20Crisis.pdf.

Corbo, V. and K. Schmidt-Hebbel (2013), "La crisis internacional y América Latina", Monetaria, vol. 35, No. 1, January-June.

Coric, B. (2011), "The global extent of the great moderation", Oxford Bulletin of Economics and Statistics, vol. 74, No. 4, Wiley.

Cornia, G.A. and B. Martorano (2010), "Policies for reducing income inequality: Latin America during the last decade", Social and Economic Policy Working Paper, February [online] http://www.unicef.org/socialpolicy/files/Postscript_ Formatted_Policies_for_reducing_income_inequality.pdf.

Creel, J. and M. Sawyer (2009), Current Thinking on Fiscal Policy, New York, Palgrave Macmillan.

Danby, C. (2005), "Noyola's institutional approach to inflation", Journal of the History of Economic Thought, vol. 27, No. 2, Taylor \& Francis.

Davidson, P. (2011), Post Keynesian Macroeconomic Theory, North Hampton, Edward Elgar. (1992), International Money and the Real World, New York, St. Martin's Press. (1979), "Natural resources", A Guide to Post-Keynesian Economics, A.S. Eichner (ed.), New York, M.E. Sharpe. Inc.

Debreu, G. (1959), Theory of Value, New York, Wiley.

De Gregorio, J. (2009), "La macroeconomía, los economistas, y la crisis”, Documentos de Politica Económica, No. 33, Santiago, Central Bank of Chile. 
(2007), "Algunas reflexiones sobre el crecimiento económico en Chile", Documentos de Política Económica, No. 20, Santiago, Central Bank of Chile.

Díaz Alejandro, C. (1984) Latin American Debt: I Don't Think We Are in Kansas Anymore, Brookings Papers on Economic Activity, 1984, vol. 15, issue 2, pages 335-403

Didier, T., C. Hevia and S.L. Schmukler (2012), "How resilient and countercyclical were emerging economies during the global financial crisis?", Journal of International Money and Finance, vol. 31, No. 8, Amsterdam, Elsevier.

Dow,S.C.(2002),EconomicMethodology:AnInquiry,New York,OxfordUniversityPress.

Eatwell, J. (1987), "Imperfectionist models", The New Palgrave Dictionary of Economics [online]http:/ / www.dictionaryofeconomics.com/article?id=pde1987_X001084. (1983), Keynes's Economics and the Theory of Value and Distribution, Oxford, Duckworth.

Eatwell, J. and M. Milgate (1999), "Some deficiencies of Walrasian general intertemporal equilibrium", Value, Distribution and Capital. Essays in Honour of Pierangelo Garegnani, G. Mongiovi and F. Petri, New York, Routledge.

ECLAC(Economic Commission for LatinAmerica and theCaribbean)(2014), Compacts for Equality: Towards a Sustainable Future (LC/G.2586(SES.35/3)), Santiago.

(2013), Social Panorama of Latin America, 2013 (LC/G.2580), Santiago.

(2012a), Structural Change for Equality: An Integrated Approach to Development (LC/G.2524(SES.34/3)), Santiago.

(2012b), Middle-income Countries: A Structural Gap Approach (LC/G.2532/Rev.1), Santiago.

(2010), Time for equality: closing gaps, opening trails (LC/G.2432(SES.33/3)), Santiago.

(2004), Productive Development in Open Economies (LC/G.2234(SES.30/3)), Santiago. (2002), Globalization and Development (LC/G.2157(SES.29/3)), Santiago.

(1990), Changing Production Patterns with Social Equity. The Prime Task of Latin American and Caribbean Development in the 1990s (LC/G.1601-P), Santiago.

(1957), El desequilibrio externo en el desarrollo de México económico latinoamericano. El caso de México (E/CN/T2/428), April.

Erten, B. and J.A Ocampo (2012), "Super-cycles of commodity prices since the midnineteenth century", DESA Working Paper, No. 110 (ST/ESA/2012/DWP/110), New York, United Nations.

Fajnzylber, Fernando (1990), "Industrialization in Latin America: from the "black box" to the 'empty box': a comparison of contemporary industrialization patterns", Cuadernos de la CEPAL, No. 60 (LC/G.1534/Rev.1-P), Santiago.

(1983), La industrialización trunca de América Latina, Mexico City, Editorial Nueva Imagen, S.A.

Fama, E.F. (2011), "Examining the financial crisis with Professor Eugene Fama", Chicago Booth News [online] http://www.chicagobooth.edu/news/2011-1028_fama.aspx.

(2007), "Interview with Eugene Fama" [online] http:/ / www.minneapolisfed. org/pubs/region/07-12/fama.cfm.

(1970), "Efficient capital markets: a review of theory and empirical work", The Journal of Finance, vol. 25, No. 2, Wiley.

Ffrench-Davis, R. (2010), “Macroeconomics for development: from 'financierism' to 'productivism"', CEPAL Review, No. 102 (LC/G.2468-P), Santiago, Economic Commission for Latin America and the Caribbean (ECLAC). (2006), Reforming Latin America's Economics after Market Fundamentalism, New York, Palgrave Macmillan. 
(1993), "Capital formation and the macroeconomic framework: a neostructuralist approach", Development from Within: Toward a Neostructuralist Approach for Latin America, Boulder, Lynne Rienner Publishers.

Friedman, M. (1975), Milton Friedman's Monetary Framework. A Debate with His Critics, Robert Gordon (ed.), Chicago, Chicago University Press.

(1968), "The role of monetary policy", The American Economic Review, vol. 58, No. 1, Nashville, Tennessee, American Economic Association. (1962), Capitalism and Freedom, Chicago, Chicago University Press.

(1953a), "Lange on price flexibility and employment: a methodological criticism", Essays in Positive Economics, M. Friedman, Chicago, The University of Chicago Press. (1953b), "The methodology of positive economics", Essays in Positive Economics, M. Friedman, Chicago, The University of Chicago Press.

Furtado, Celso (2003), En busca de un nuevo modelo: reflexiones sobre la crisis contemporánea, Mexico City, Fondo de Cultura Económica. (1999), El capitalismo global, Mexico City, Fondo de Cultura Económica. (1987), "Underdevelopment: to conform or to reform", Pioneers in Development. Second Series, G. Meier (ed.), New York, Oxford University Press.

(1978), Prefacio a una nueva economía política, Mexico City, Siglo Veintiuno Editores. (1965), "Development and stagnation in Latin America: a structuralist approach", Studies in Comparative International Development, vol. 1, No. 11, Springer. (1964), Development and Underdevelopment. A Structuralist View of the Problems of Developed E Underdeveloped Countries, Berkeley, University of California Press. (1959), Formação economica do Brasil, Rio de Janeiro, Fundo de Cultura.

(1957), "Fundamentos da programação económica", Economica Brasileira, vol. 3. (1954), A economia brasileira, Rio de Janeiro, Editora a Noite.

Gali, J. (2008), Monetary Policy, Inflation and the Business Cycle. An Introduction to the New Keynesian Framework, Princeton, Princeton University Press.

Garegnani, P. (1990), "Quantity of capital”, Capital Theory, J. Eatwell, M. Milgate and P. Newman (eds), London, Macmillan.

Greenspan,Alan(2005), "RemarksbyChairmanAlan Greenspan.Economicflexibility. To the National Association for Business Economics Annual Meeting, Chicago, Illinois", 27 September [online] http:/ /www.federalreserve.gov/BoardDocs/ Speeches/2005/20050927/default.htm.

Grossman, G.M. and E. Helpman (1991), Innovation and Growth in the Global Economy, Cambridge, Massachusetts, The MIT Press.

Hahn, F. (1984), "General equilibrium theory", Equilibrium and Macroeconomics, F.H. Hahn, Cambridge, Massachusetts, The MIT Press.

Hansen, G. and E. Prescott (2002), "Malthus to Solow", American Economic Review, vol. 92, No. 4, Nashville, Tennessee, American Economic Association.

Hansen, L.P. and Th. Sargent (2010), "Wanting robustness in macroeconomics" [online] https:/ / files.nyu.edu/ts43/public/research/wanting.pdf.

Harcourt, G.C. (1991), Some Cambridge Controversies in the Theory of Capital, Brookfield, Gregg Revivals.

Harrod, R.F. (1965), [Review of] “Essays in economic policy. By N. Kaldor”, Economic Journal, vol. 75.

Hausmann, R. and F. Sturzenegger (2006), "Global imbalances or bad accounting? The missing dark matter in the wealth of nations", CID Working Paper, No.127, Harvard University [online] http://files.wcfia.harvard.edu/Haussman_Global.pdf. 
Henry, P.B. (2007), "Capital account liberalization: theory, evidence, and speculation", Journal of Economic Literature, vol. 45, No. 4, Nashville, Tennessee, American Economic Association.

Heymann, D. (2000), "Major macroeconomic disturbances, expectations and policy responses", CEPAL Review, No. 70 (LC/G.2095-P), Santiago, Economic Commission for Latin America and the Caribbean (ECLAC).

Hirschman, A.O. (1995), A Propensity to Self-Subversion, Cambridge, Massachusetts, Harvard University Press.

(1963), Journeys Toward Progress: Studies of Economic Policy Making in Latin America, New York, The Twentieth Century Fund.

(1958), The Strategy of Economic Development, New Haven, Yale University Press.

IDB (Inter-American Development Bank) (2008), All That Glitters May Not Be Gold. Assessing Latin America's Recent Economic Performance, Washington, D.C.

IMF (International Monetary Fund) (2008), Regional Economic Outlook: Western Hemisphere, Washington, D.C., April. (2007), World Economic Outlook Update. An Update of the Key WEO Projections, July [online] http://www.imf.org/external/pubs/ft/weo/2007/update/01/ pdf/eng/0707.pdf.

Ishikawa, S. (1987), "Structural change", The New Palgrave Dictionary of Economics [online]http:/ / www.dictionaryofeconomics.com/article?id=pde1987_X002096.

Janeway, W.H. (2012), Doing Capitalism in the Innovation Economy: Markets, Speculation and the State, New York, Cambridge University Press.

Jara, A., R. Moreno and C.E. Tovar (2009), "The global crisis and Latin America: financial impact and policy responses", BIS Quarterly Review, June [online] http:/ / www.bis.org/publ/qtrpdf/r_qt0906f.pdf.

Juselius, Katarina (2010), "Is Beauty Mistaken for Truth?", Copenhagen, Department of Economics, University of Copenhagen.

Kaldor, N. (1957), "A model of economic growth", Economic Journal, vol. 67, No. 268. (1956), "Economic problems of Chile", Santiago, Economic Commission for Latin America and the Caribbean, unpublished.

Kalecki, M. ( 1969), Theory of Economic Dynamics, New York, Kelley Publishers. (1966), Studies in the Theory of Business Cycles, New York, Basil Blackwell.

Keynes, J.M. (1980), Collected Works, vol. 25, London, Macmillan. (1936), The General Theory of Employment, Interest and Money, New York, Harcourt Brace Jovanovitch Publishers.

(1933), "An open letter to President Roosevelt", New York Times, 31 December.

King, J.E. (2009), Nicholas Kaldor, New York, Palgrave Macmillan.

Krugman, P. (2009), "How did economists get it so wrong?", New York Times, 2 September [online] http://www.nytimes.com/2009/09/06/magazine/ 06Economic-t.html?pagewanted=all\&_r=0.

Kuhn, Thomas (1996), The Structure of Scientific Revolutions, Chicago, University of Chicago Press.

Lakatos, I. (1970), "Falsification and the methodology of scientific research programmes", Criticism and the Growth of Knowledge, Imre Lakatos and Alan Musgrave (eds.), London, Cambridge University Press.

Lavoie, M. (2006), Introduction to Post-Keynesian Economics, New York, Palgrave MacMillan.

Lawson, T. (2003), Reorienting Economics, New York, Routledge. 
(1997), Economics and Reality, New York, Routledge.

Leamer, E. (2007), "Housing and the business cycle", paper presented at the Symposium "Housing, housing finance and monetary policy", Jackson Hole, Wyoming, 30 August-1 September [online] http://www.anderson.ucla.edu/ Documents/areas/adm/media/leamer_housing_business_cycle.pdf.

Love, J.L. (1996), Crafting the Third World. Theorizing Underdevelopment in Rumania and Brazil, Stanford, Stanford University Press.

(1995), "Economic ideas and ideologies in Latin America since 1930", The Cambridge History of Latin America, vol. 6, No. 1, L. Bethel (ed.), Cambridge, Cambridge University Press.

Lucas, R.E. (2012), “Economic Dynamics Interviews Robert Lucas on Modern Macroeconomics" [online] http:/ / www.economicdynamics.org/News271.htm \#interview.

(2009), "In defense of the dismal science", The Economist [online] http:/ / www. economist.com/node/14165405.

(2004), "Life earnings and rural-urban migrations", Journal of Political Economy, vol. 112, Chicago, The University of Chicago Press.

(2002), Lectures on Economic Growth, Cambridge, Massachusetts, Harvard University Press.

(1991), "Methods and problems in business cycle theory", Studies in BusinessCycle Theory, R.E. Lucas, Jr. Cambridge, Massachusetts, The MIT Press.

(1988), "On the mechanics of economic development", Journal of Monetary Economics, vol. 22, No. 1, Amsterdam, Elsevier.

(1986), "Adaptive behavior and economic theory", Rational Choice. The Contrast between Economics and Psychology, R.M. Hogarth and M.W. Reder, Chicago, The University of Chicago Press.

(1972a), "Econometric testing of the natural rate hypothesis", The Econometrics of Price Determination, O. Eckstein (ed.,) Washington, D.C., Board of Governors of the Federal Reserve System.

(1972b), "Expectations and the neutrality of money", Journal of Economic Theory, vol. 4, No. 2, Amsterdam, Elsevier.

Lux, Th. and F. Westerhoff (2009), Nature Physics, vol. 5.

Mallorquín, C. (1998), Ideas e historia en torno al pensamiento latinoamericano, Mexico City, Plaza y Valdés Editores.

Mankiw, G. (2010), Macroeconomics, New York, Worth Publishers.

Mankiw, G. and D. Romer (1991), New Keynesian Economics, Cambridge, Massachusetts, The MIT Press.

Marglin, S.A. (1984), Growth, Distribution and Prices, Cambridge, Massachusetts, Harvard University Press.

Marshall, A. (1920), Principles of Economics, London, Macmillan.

Matsuyama, K. (2008), "Structural change", The New Palgrave Dictionary of Economics [online] http:/ / www.dictionaryofeconomics.com/article?id=pde2008_S000440.

Mazzucato, M. (2013), The Entrepreneurial State, New York, Anthem Press.

McCombie, J.S.L. and A.P. Thirlwall (1999), "Growth in an international context: a post Keynesian view", Foundations of International Economics. Post Keynesian Perspectives, J. Deprez and J.T. Harvey (eds.), New York, Routledge. (1994), Economic Growth and the Balance-of-Payments Constraint, New York, St. Martin's Press. 
Mendoza,E.G.(2010), "Suddenstops, financialcrises, andleverage”,AmericanEconomic Review, vol. 100, No. 5, Nashville, Tennessee, American Economic Association.

Mishkin, F.S. (2010), "Monetary policy strategy: lessons from the crisis", NBER Working Paper, No. 16755 [online] http:/ / www.nber.org/papers/w16755.

Minsky, H. (1986), Stabilizing an Unstable Economy, New Haven, Yale University Press. (1982), Can "It" Happen Again?. Essays on Instability and Finance, New York, M.E. Sharpe.

(1975), John Maynard Keynes, New York, Columbia University Press.

Modigliani, F. (1977), "The monetarist controversy; or, should we forsake stabilization policies?", American Economic Review, vol. 67, No. 2, Nashville, Tennessee, American Economic Association, March.

Moreno-Brid. J.C. (1998-1999), “On capital flows and the balance-of-paymentsconstrained growth model", Journal of Post Keynesian Economics, vol. 21, No. 2, Taylor \& Francis.

Murphy, K., A. Shleifer and R. Vishny (1989), "Income distribution, market size, and industrialization", Quarterly Journal of Economics, vol. 104, No. 3, Cambridge, Massachusetts, The MIT Press.

Mussa, M. (2006), "Comments", An Equilibrium Model of "Global Imbalances" and Low Interest Rates, R. Caballero, E. Farhi and P.O. Gourinchas, BIS Working Papers, No. 222, Basel, Bank for International Settlements.

Muth, J. (1961), "Rational expectations and the theory of price movements", Econometrica, vol. 29, No. 3, New York, Econometric Society.

Navarrete, A. (1951), Estabilidad de cambios, el ciclo y el desarrollo económico: una investigación sobre los problemas de la balanza de pagos de México, 1929-1946, Mexico City, Panamericana.

Noyola, J. (1956), “El desarrollo económico y la inflación en México y otros países latinoamericanos", Investigación Económica, No. 4.

Obstfeld, M. and K. Rogoff (1996), Foundations of International Macroeconomics, Cambridge, Massachusetts, The MIT Press.

Ocampo, J.A. (2011), “Macroeconomy for development: countercyclical policies and production sector transformation", CEPAL Review, No. 104 (LC/G.2498-P/E), Santiago, Economic Commission for Latin America and the Caribbean (ECLAC). (2008), "The impact of the global financial crisis on Latin America", CEPAL Review, No. 97 (LC/G.2400-P), Santiago, Economic Commission for Latin America and the Caribbean (ECLAC), April. (2004), "La América Latina y la economía mundial en el largo siglo XX", El Trimestre Económico, vol. 71, No. 284(4), Fondo de Cultura Económica.

Olivera, J.H. (1960), “La teoría no monetaria de la inflación”, El Trimestre Económico, vol. 28, No. 4, Fondo de Cultura Económica.

Patinkin, D. (1987), "Real balances", The New Palgrave Dictionary of Economics, vol. 4, J. Eatwell, M. Milgate and P. Newman (eds), New York, The MacMillan Press. (1956), Money, Interest, and Prices, Cambridge, MIT Press.

Pereira, C.B. (2012a), "From old to new developmentalism in Latin America", The Oxford Handbook of Latin American Economics, José Antonio Ocampo and Jaime Ros (eds.), New York, Oxford. (2012b), "Structuralist macroeconomics and the new developmentalism", Brazilian Journal of Political Economy, vol. 32, No. 3, July-September.

Pérez Caldentey, E. (2008), "The concept and evolution of the developmental State”, International Journal of Political Economy, vol. 37, No. 3, Taylor \& Francis. 
PérezCaldentey, E. and M. Vernengo(2013), “Is inflation targeting operativein an open economy setting", Review of Keynesian Economics, vol. 1, No. 3, Edward Elgar. (2010), "Back to the future: Latin America's current development strategy", Journal of Post Keynesian Economics, vol. 32, No. 4, Taylor \& Francis.

Pérez Caldentey, E., D. Titelman and P. Carvallo (2013), "Weak expansions: a distinctive feature of the business cycle in Latin America and the Caribbean", Working Paper, No. 749, Levy Economics Institute [online] http://www. levyinstitute.org/pubs/wp_749.pdf.

Pérez Caldentey, E., O. Sunkel and M. Torres (2012), Raúl Prebisch. Un recorrido por las etapas de su pensamiento [online] http://prebisch.cepal.org/sites/default/ files/Etapas_pensamiento_Prebisch.pdf.

Phelps. E. (2013), Mass Flourishing: How Grassroots Innovation Created Jobs, Challenge, and Change, Princeton, Princeton University Press.

Pindyck, R. (1990), "Irreversibility, uncertainty and investment", MIT Working Paper, No. 3137-90-EFA [online] http://dspace.mit.edu/bitstream/handle/1721.1/ 2299/SWP-3137-21583472.pdf.

Pollock, D., D. Kerner and J. Love (2006), "Raúl Prebisch. CEPAL, ortodoxia monetaria e inflación", Suplemento de la Revista BCV, vol. 20, No. 1, Caracas [online] http: / / www.bcv.org.ve/Upload/Publicaciones/rbcvs012006.pdf.

Porzecanski, A. (2009), "Latin America: the missing financial crisis", Estudios y Perspectivas series, No. 6 (LC/WAS/L.104), Washington, D.C., ECLAC Office in Washington, D.C.

Posen A. (2007a), "Don't worry about U.S. mortgages”, Welt am Sonntag, 12 April. (2007b), "A drag not a crisis", Welt am Sonntag, 27 September [online] http:/ / www.iie.com/publications / opeds/oped.cfm?ResearchID=812.

Prebisch, R. (1993), Obras 1919-1949, vol. 4, Buenos Aires, Fundación Raúl Prebisch. (1991), Obras 1919-1948, vols. 1 to 3, Buenos Aires, Fundación Raúl Prebisch. (1986), "Notes on trade from the standpoint of the periphery", CEPAL Review, No. 28 (LC/G.1392), Santiago, Economic Commission for Latin America and the Caribbean (ECLAC), April.

(1984), "Five stages in my thinking of development", Pioneers in Development, G. Meyer and D. Seers (orgs.), Washington, D.C., World Bank. (1976), "A critique of peripheral capitalism", CEPAL Review, No. 1, Santiago, Economic Commission for Latin America and the Caribbean (ECLAC). (1961a), "Economic development or monetary stability: the false dilemma", Economic Bulletin for Latin America, vol. 6, No. 1.

(1961b), Economic Development, Planning and International Cooperation (E/CN.12/582/Rev.1), Santiago, United Nations.

(1951), "Growth, disequilibrium and disparities: interpretation of the process of economic development", Economic Survey of Latin America, 1949 (E/CN.12/164/Rev.1), New York.

(1950), The Economic Development of Latin America and its Principal Problems (E/CN.12/89/Rev.1), New York, United Nations.

(1947), Introducción a Keynes, Buenos Aires, Fondo de Cultura Económica. (1943), La moneda y el ritmo de la actividad económica, unpublished.

Robinson, J. (1979), "History versus equilibrium", Collected Economic Papers, vol. 5, Cambridge, Massachusetts, The MIT Press.

(1956), The Accumulation of Capital, London, MacMillan. 
Rodríguez, O. (1977), "On the conception of the centre-periphery system", CEPAL Review, No. 3, Santiago, Economic Commission for Latin America and the Caribbean (ECLAC).

Rogoff, K. (2008), "The world's runaway train", Project Syndicate, July [online] http:/ / www.project-syndicate.org/commentary/the-world-s-runaway-train.

Romer, D. (2013), "Preventing the next catastrophe: where do we stand?", iMFdirect [online] http://blog-imfdirect.imf.org/2013/05/03/preventing-thenext-catastrophe-where-do-we-stand/\#more-6239.

(1990), "Endogenous technological change", Journal of Political Economy, vol. 98, No. 5, Chicago, The University of Chicago Press.

(1986), "Increasing returns and long-run growth", Journal of Political Economy, vol. 94, No. 5, Chicago, The University of Chicago Press.

Samuelson, P. (1947), Foundations of Economic Analysis, Cambridge, Harvard University Press.

Sanders, B. (2009), "Bernanke in his own words", 3 December [online] http:/ / www. sanders.senate.gov/newsroom/recent-business/bernanke-in-his-own-words.

Sargent, Th. (2010), "Interview with Thomas Sargent", Federal Reserve Bank of Minneapolis [online] http://www.minneapolisfed.org/publications_papers/ pub_display.cfm?id $=4526 \&$.

Sargent, Th. and N. Wallace (1976), "Rational expectations and the theory of economic policy", Journal of Monetary Economics, vol. 2, No. 2, Amsterdam, Elsevier.

Schumpeter, J.A. (1997), The Theory of Economic Development, New Bunswick, Transactions Publishers.

(1976), Capitalism, Socialism and Democracy, New York, Harper and Row.

(1954), History of Economic Analysis, New York, Oxford.

(1939) Business Cycles: A Theoretical, Historical, and Statistical Analysis of the Capitalist Process, London, McGraw-Hill.

Shackle, G.L.S. (1955), Uncertainty in Economics and Other Reflections, Cambridge, Massachusetts, Cambridge University Press.

Singer, H.W. (1987), "Terms of trade and economic development", The New Palgrave Dictionary of Economics [online] http://www.dictionaryofeconomics.com/ article?id=pde1987_X002149.

(1950), "The distribution of gains between investing and borrowing countries", American Economic Review, vol. 40, No. 2, Nashville, Tennessee, American Economic Association.

Smith, Adam (1776), An Inquiry into the Nature and Causes of the Wealth of Nations, Edwin Cannan (ed.), Chicago, Chicago University Press.

Solow, R. (2000), Growth Theory: An Exposition, New York, Oxford University Press. (1974), "The economics of resources or the resources of economics", American Economic Review, vol. 64, No. 2, Nashville, Tennessee, American Economic Association. (1957), "Technical change and the aggregate production function", Review of Economics and Statistics, vol. 39, No. 3, Cambridge, Massachusetts, The MIT Press. (1956), "A contribution to the theory of economic growth", Quarterly Journal of Economics, vol. 70, No. 1, Oxford, Oxford University Press.

Sunkel, O. (1993), Development from Within: Toward a Neostructuralist Approach for Latin America, Lynne Rienner Publishers.

(1963) "El fracaso de las políticas de estabilización en el contexto del proceso de desarrollo latinoamericano", El Trimestre Económico, vol. 120, Mexico City, Fondo de Cultura Económica. 
(1958), "La inflación chilena: un enfoque heterodoxo", El Trimestre Económico, vol. 25, Mexico City, Fondo de Cultura Económica.

Sunkel, O. and G. Zulueta (1990), "Neo-structuralism versus neo-liberalism in the 1990s", CEPAL Review, No. 42, Santiago, Economic Commission for Latin America and the Caribbean (ECLAC).

Sunkel, O. and P. Paz (1970), Subdesarrollo latinoamericano y la teoría del desarrollo, Mexico City, Siglo Veintiuno.

Taylor, J. (2008), "The financial crisis and the policy responses: an empirical analysis of what went wrong" [online] http:/ / www.stanford.edu/ johntayl/FCPR.pdf. (2004), Reconstructing Macroeconomics, Cambridge, Massachusetts, The MIT Press.

Thirlwall, A.P. (1979), "The balance-of-payments constraint as an explanation of international growth rate differences", BNL Quarterly Review, vol. 32, No. 128, Rome, Banca Nazionale del Lavoro.

Tobin, J. (1975), "Friedman's theoretical framework", Milton Friedman's Monetary Framework. A Debate with His Critics, Robert Gordon (ed.), Chicago, The University of Chicago Press.

Vera, L. (2013), "Inflación estructural redux", Ensayos Económicos, vol. 69, Buenos Aires, Central Bank of Argentina.

Wade, R.H. (2010), “Economist's contribution to the 2nd Great Depression and what theyshouldlearn"[online]http://inctpped.ie.ufrj.br/spiderweb/pdf_1/2_RW_ economists_contributions.pdf.

Weintraub, R. (1979), Microfoundations: The Compatibility of Microeconomics and Macroeconomics, New York, Cambridge University Press.

Wicksell, K. (1898), Interest and Prices, New York, Kelley Publishers.

Woodford, M. (2010), "Financial intermediation and macroeconomic analysis", Journal of Economic Perspectives, vol. 24, No. 4, Nashville, Tennessee, American Economic Association.

(2009), "Convergence in macroeconomics: elements of the new synthesis", American Economic Journal: Macroeconomics, vol. 1, No. 1, Nashville, Tennessee, American Economic Association. (2003), Interest and Prices: Foundations of a Theory of Monetary Policy, Princeton, Princeton University Press.

World Bank (2011), Latin America and the Caribbean's Long-term Growth. Made in China?, Washington, D.C.

Wren-Lewis, S. (2014), "Are new Keynesian DSGE models a Faustian bargain?" [online]http:/ / mainlymacro.blogspot.com/2014/02/are-new-keynesian-dsgemodels-faustian.html. 

Chapter II

\title{
Latin America and world economic turmoil
}

\author{
José Antonio Ocampo ${ }^{1}$
}

I would like first of all to thank ECLAC and ILPES for their invitation to participate in this conference on neostructuralism, in response to a suggestion from me, in fact. This is a good time to expand the influence of this Latin American school of thought. It is also particularly timely since many of our ideas have prevailed in the international arena, as reflected, for example, in the International Monetary Fund's recognition of the role of capital flow regulation, the Inter-American Development Bank's acknowledgement of the importance of proactive production development policies, and the World Bank's recognition of the merits of universalism in social policy in its recent report on the middle classes.

All of these are ultimately victories of standpoints advocated by this organization, some of them long-held, but which were dismissed until recently as unorthodox. I hope that this is only the beginning, and that our ideas continue to gain currency in thinking and economic policy. I would

José Antonio Ocampo is Professor of the School of International and Public Affairs and Member of the Committee on Global Thought at Columbia University. Prior to this appointment, he served as United Nations Under-Secretary-General for Economic and Social Affairs, Executive Secretary of the Economic Commission for Latin America and the Caribbean (ECLAC), and Minister of Finance and Public Credit of the Government of Colombia. This chapter is the translation of a presentation he delivered at the seminar on neostructuralism and heterodox economics held at ECLAC on 22 and 23 April 2013. A few of the tables and figures used in the presentation are reproduced here, although the data have been updated. 
also like to make special mention of Osvaldo Sunkel, who two decades ago brought us all together at an event and whose book introduced us to the concept of neostructuralism.

\section{A. Dramatic changes at the international level}

We have been asked to discuss the crisis and the new world economic reality, and my intention here to analyse the impact of this reality on Latin America. I will begin by pointing out that the boom that lasted from 2003 to 2007 (until mid-2008 in some countries) is the only one seen in Latin America in 30 years. It was the result of a convergence of extraordinary external factors, an alignment of the stars that will not recur.

During this period, many migrants left Latin America for the United States and Spain, and remittances experienced double-digit growth. It also marked the end of a boom in international trade that had begun at the start of the 1980s, the start of a supercycle of high commodity prices and a return to external financing costs similar to those of the late 1970s. The only negative factor was China's strong competition with Mexico in the United States market and with every country in our region in our own markets.

This convergence of so many favourable factors in the world economy was remarkable, and will never be repeated. In fact, it was the first time it had ever occurred in Latin American economic history. With this in mind, we can proceed to analyse how this scenario has changed.

Two of these factors have disappeared since the 2007-2008 crisis. The first concerns the migration of labour and the surge in remittances. A net return of migrants from Spain is taking place, while migration to the United States has stalled or even declined a little; in fact, the migration policies that govern entry to that country do not, in principle, allow for new waves of migration; they address regularization of the status of some of the illegal migrants. As a result, remittances fell in 2009 and have not completely recovered.

The second phenomenon that has disappeared since the crisis, and to which I will devote a little more attention here, is the international trade bonanza. It is my view that the crisis put an end to an extraordinary period in the history of international trade, a boom that began in the mid-1980s and accelerated on a par with the one seen during the golden age ${ }^{2}$ of the post-war industrialized economies. This most recent boom ended in 2007 (mid-2008, in some cases) and will not be repeated. This fact is insufficiently recognized.

During the golden age of the industrialized economies (1950-1973), their GDP expanded by $5.9 \%$. Growth has never returned to this level, even during the Great Moderation. GDP growth during the 1980s, $1990 \mathrm{~s}$ and $2000 \mathrm{~s}$ was $3 \%, 2.5 \%$ and $1.7 \%$, respectively. 
Two positive factors, however, have endured since the crisis: ready access to external financing; and the commodity price boom ${ }^{3}$ (see table II.1). High commodity prices may not be around for much longer, in view of the slowdown in China, which has been the main driving force behind them. As we shall see, this is also borne out by commodity price trends over the past two years.

Table II.1

World: average annual growth in international commodity price indices, 2000-2013 (Percentages, 2010=100)

\begin{tabular}{lccccc}
\hline Period & Energy & Foods & Grains & Metals and minerals & Average \\
\hline $2000-2007$ & 17 & 10 & 11 & 14 & 13 \\
\hline $2008-2009$ & -9 & -2 & -4 & -7 & -5.5 \\
\hline $2010-2011$ & 16 & 8 & 14 & 3 & 10.25 \\
\hline $2012-2013$ & 0 & -1 & -7 & -3 & -2.75 \\
\hline
\end{tabular}

Source: Prepared by the author on the basis of figures provided by World Bank, Commodity Price Data, "Pink Sheet", 2013.

Despite abundant capital flows, however, one underlying factor is proving to be less favourable for the region: the post-crisis adjustment of the world economy. Several countries have decided to reduce their external deficit, in particular the United States and the peripheral European countries, and other countries have found themselves compelled to move in the opposite direction, towards negative balances. This is precisely what has happened in Latin America (see table II.2).

Table II.2

World (selected countries and regions): balance-of-payments current account balance as a percentage of GDP, 2005-2012

\begin{tabular}{lccc}
\hline & $2005-2007$ & $2008-2009$ & $2010-2012$ \\
\hline China & 7.2 & 7.1 & 2.7 \\
\hline India & -1.1 & -2.2 & -3.1 \\
\hline United States & -5.9 & -3.8 & -3.0 \\
\hline Latin America $^{\text {BRICS }}{ }^{\text {a }}$ & 1.3 & -0.8 & -1.4 \\
\hline OECD & 4.7 & 3.6 & 1.3 \\
\hline Eurozone & -1.5 & -1.0 & -0.4 \\
\hline
\end{tabular}

Source: Prepared by the author on the basis of figures provided by World Bank, 2013.

a Brazil, Russian Federation, India, China and South Africa.

3 The average commodity price index (UNCTAD, 2011) for energy, food, grains and metals and minerals expanded by 13\% between 2000 and 2007, contracted by 5.5\% during the global financial crisis (2008-2009), and recovered quickly during the two years that followed, posting a growth rate of $10.3 \%$. 
The mode of transmission of this phenomenon is abundant financing, and it has been referred to as a "tsunami of capital" by the president of Brazil and as a "currency war" by that country's finance minister. The finance ministers of Chile and Colombia and the governor of the Central Bank of Mexico also voiced their agreement with this assessment a few months ago.

As belts are tightened around the world, Latin America suffers currency appreciation. This has a negative impact on production diversification, which we neostructuralists have always described as the main driver of economic growth. As a result, the region is once again growing at mediocre rates, and if 2007 is taken as the starting point and the forecasts for 2013 are included, annual growth in Latin America actually stands at 3.0\%, which is slightly below average since 1990. This is a mediocre result, and one of the worst in the developing world.

Table II.3 shows GDP growth during the period 1971-2011 in Latin America and the Caribbean, East Asia and the Pacific, Europe and Central Asia, the high-income countries belonging to the Organization for Economic Cooperation and Development (OECD), the Middle East and North Africa, South Asia and Sub-Saharan Africa. During the first period under consideration (1971-1980), Latin America and the Caribbean recorded the highest growth rate in the developing world after East Asia and the Pacific. Yet, starting in the 1980s, Latin America and the Caribbean systematically posted some of the lowest GDP growth rates in the developing world.

Table II.3

World: per capita GDP growth, by region, 1971-2011

(Percentages)

\begin{tabular}{cccccccc}
\hline $\begin{array}{c}\text { East Asia } \\
\text { and the } \\
\text { Pacific }\end{array}$ & $\begin{array}{c}\text { Europe } \\
\text { and } \\
\text { Central } \\
\text { Asia }\end{array}$ & $\begin{array}{c}\text { OECD } \\
\text { (high-income } \\
\text { economies) }\end{array}$ & $\begin{array}{c}\text { America } \\
\text { and the } \\
\text { Caribbean }\end{array}$ & $\begin{array}{c}\text { Middle East } \\
\text { and North } \\
\text { Africa }\end{array}$ & $\begin{array}{c}\text { South } \\
\text { Asia }\end{array}$ & $\begin{array}{c}\text { Sub-Saharan } \\
\text { Africa }\end{array}$ \\
\hline $1971-1980$ & 4.5 & $\ldots$ & 2.7 & 3.2 & 2.7 & 0.7 & 0.9 \\
\hline $1981-1990$ & 5.7 & -1.7 & 2.7 & -0.8 & 0.2 & 3.0 & -0.9 \\
\hline $1991-2000$ & 7.1 & -1.7 & 1.9 & 1.6 & 1.8 & 3.2 & -0.3 \\
\hline $2003-2007$ & 9.3 & 7.4 & 1.9 & 3.7 & 3.3 & 6.6 & 3.0 \\
\hline $2001-2011$ & 8.2 & 4.7 & 0.9 & 2.2 & 2.6 & 5.3 & 2.1 \\
\hline
\end{tabular}

Source: Prepared by the author on the basis of World Bank, World Development Indicators and Global Finance Development Database (GFDD), 2013.

The most recent period of expansion (2003-2007), which was the most dramatic seen in Latin America and the Caribbean in four decades, was no exception. The region posted a growth rate of $3.7 \%$, far higher than the contraction recorded during the 1980s $(-0.8 \%)$ and more than double the 
meagre growth rate of the 1990s. Its economic performance during 2003-2007 was even slightly better than that of the 1970s.

All the same, Latin America and the Caribbean lagged behind other developing regions during this period, in particular East Asia and the Pacific (9.3\%), Europe and Central Asia (7.4\%) and South Asia (6.6\%).

\section{B. Changes in international trade and the region's technology lag}

We will now analyse some of these points in greater detail. Figure II.1 illustrates the main phases of international trade since the Second World War. The first period, which covers 1950 to 1974, was a golden age for economic growth in the developed countries, especially in Europe. International trade expanded by over $7 \%$ a year in real terms during this period - the fastest growth rate in world economic history to that point. The second period runs from the first oil shock to the mid-1980s, and was dominated by slow growth in both GDP and world trade. The third period began in the mid-1980s and ended in 2007. During this time, trade picked up (but not world GDP at market prices ${ }^{4}$ ) thanks to the liberalization of several economies, the break-up of value chains and the expansion of foreign direct investment. ${ }^{5}$ International trade once again grew at annual rates of over $7 \%$ in real terms for more than two decades.

A fourth period began in 2008, and has been marked by the slowest growth in international trade since the war. This is the result of two factors: world GDP has grown very little, while the elasticity of trade to GDP has fallen, that is, the ratio of trade growth to GDP growth. During the earlier boom period, elasticity reached 2.4, but it then dropped to 1.5 , a level similar to the 1950-1974 period. On the basis of these data a few simple forecasts may be made. Let us assume that the world economy starts growing again at between $2.5 \%$ and $3 \%$ a year. With this degree of elasticity, trade would expand by up to $4 \%$ a year, which is three percentage points below than the earlier growth rate. As I said before, this fundamental fact must be borne in mind when designing any future approach or strategy. Most importantly, there is a need to compete in both quality and technology terms. This is not possible with the export-led, orthodox model of growth adopted by Latin America in the 1980s, which has placed us at a disadvantage compared with countries that have been strongly promoting higher-tech export sectors.

\footnotetext{
Not at parity prices, since it is not possible to compare the corresponding data with trade trends. Factors that explain the growth of international trade include: technological innovations in transport and communications; changes in production methods that facilitated new product development; the expansion of production; and efficiency gains. Changes in the way international trade is organized, such as international supply chains, are important factors, as are the removal of trade barriers and financial expansion and globalization (including the lifting of some of the restrictions on cross-border payments).
} 
Figure II.1

Growth of world trade and GDP, 1950-2012

(Percentages)

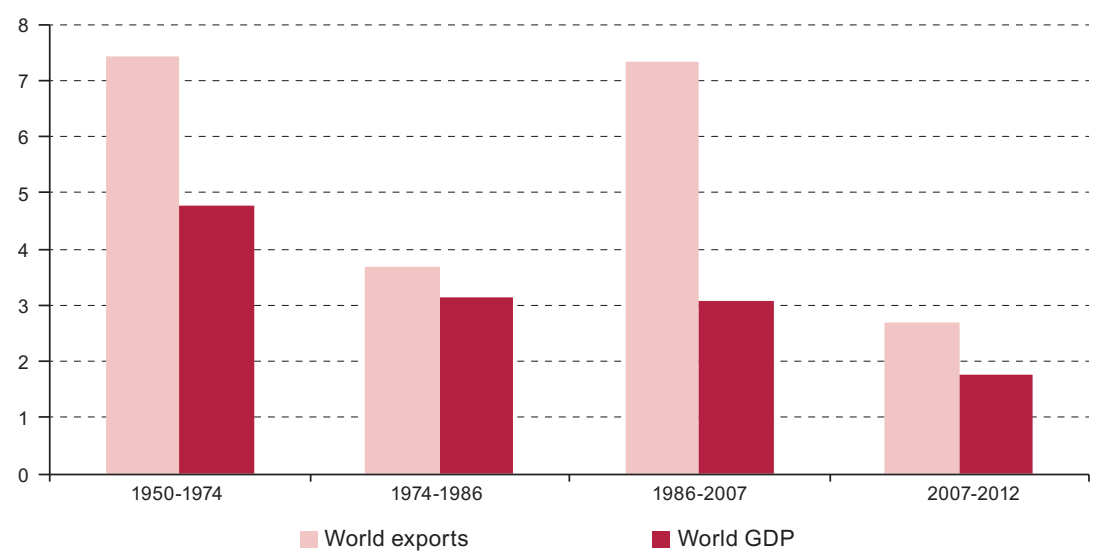

Source: Prepared by the author on the basis of figures provided by United Nations (to 2007) and International Monetary Fund (recent years).

Average growth rates for international trade in recent years have been dampened by a sharp decline in trade since the collapse of Lehman Brothers in 2008. Figure II.2 illustrates the contraction in trade in late 2008 and early 2009, particularly in value terms, which was followed by a strong subsequent recovery. Nevertheless, international trade quickly slowed again and since early 2011 it has expanded very slowly, at rates of $2 \%$ and $3 \%$ a year. In fact, using the basic data provided in the figure, trade growth may be estimated at $2.1 \%$ a year during the first half of 2011 and the first half of 2013, a somewhat lower result than that shown in the previous figure for the period 2007-2012 overall. A new era of international trade is upon us and this fact should remain at the centre of our countries' economic policies.

A matter of particular concern is the huge technology lag that has accumulated in the region. This subject has been analysed in great depth by the Division of Production, Productivity and Management at ECLAC in recent years. Table II.4 presents the division's indicators in three technological domains: participation of engineering-intensive industries in industrial production; investment in research and development as a percentage of GDP; and patents per million inhabitants. In all three cases, regional averages are compared with two competitive points of reference [Author: should this be three?]: developed countries with natural-resourcebased production structures, and emerging countries of Asia. The lag is considerable with regard to the first two indicators and dramatic in the case of the third. 
Figure II.2

World: exports by volume and value, January 2006 to July 2013

(Index 100 = first half of 2008)

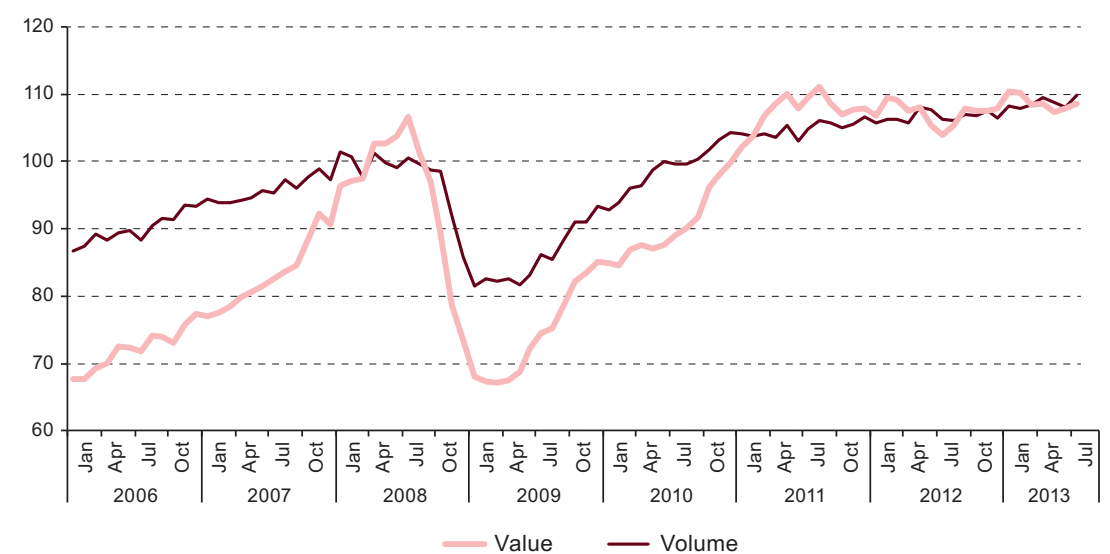

Source: Prepared by the author on the basis of figures provided by Netherlands Bureau of Economic Policy Analysis (CPB).

Table II.4

World: specialization, production structure and growth, 1996-2007

\begin{tabular}{|c|c|c|c|}
\hline & $\begin{array}{c}\text { Relative participation } \\
\text { of engineering } \\
\text { industries }^{a}\end{array}$ & $\begin{array}{l}\text { Investment in } \\
\text { research and } \\
\text { development }^{\mathrm{b}}\end{array}$ & Patents $^{c}$ \\
\hline Latin America & 0.23 & 0.40 & 0.5 \\
\hline $\begin{array}{l}\text { Natural-resource-based } \\
\text { developed economies }{ }^{d}\end{array}$ & 0.72 & 1.89 & 65.4 \\
\hline Emerging Asian economies & 0.99 & 1.21 & 30.5 \\
\hline Mature economies ${ }^{e}$ & 0.97 & 2.43 & 132.6 \\
\hline
\end{tabular}

Source: Mario Cimoli and Gabriel Porcile, "Learning, technological capabilities and structural dynamics", Handbook of Latin American Economics, José Antonio Ocampo and Jaime Ros (eds.), New York, Oxford University Press, 2011.

a Relative participation in total manufacturing value added (ratio with respect to participation in the United States, 2002-2007).

b As a percentage of GDP, 1996-2007.

c Accumulated patents per million inhabitants, 1996-2007.

d Countries where natural-resource-based products make up $40 \%$ of exports.

e France, Italy, Japan, Sweden, United Kingdom and United States.

This is the product of a three-decade-long failure to pay sufficient attention to improving the technology of our production structure, compounded by a trend towards de-industrialization. In relative terms, Latin America's coefficient of industrialization peaked during the second half of the 1970s and has declined ever since, even during the most recent growth period. The slowdown in international trade in conjunction with weakening competitiveness is worrying and suggests that reversing these trends, and in particular structural change, should once again be placed at 
the top of the region's economic policy agenda. This fact has been receiving increasing attention in Latin American discussions.

Here, I will make a small digression, if I may. Economists such as Prebisch — and the structuralists in general—argued that structural change was necessary. Nevertheless, one of their main concerns was the impact of the structural change process on the external sector. In fact, part of the analysis of external constraints (for example, the concept of external strangulation) is presented in this context.

\section{External financing and underlying world balances}

The news is much more positive when it comes to external financing, but some of its consequences, in particular currency appreciation, are exacerbating the region's competitiveness problems. Figure II. 3 illustrates the favourable effects of an abundant availability of financing. Just before the crisis, the cost of external financing was at its lowest level since the late 1970s. One interpretation is that external financing costs were high for almost a quarter century, but this problem eventually disappeared thanks to a healthier external balance sheet, in particular to a combination of lower external debt and larger international reserves.

Figure II.3

Latin America: risk margins and bond yields, 2003-2013

(Percentages)

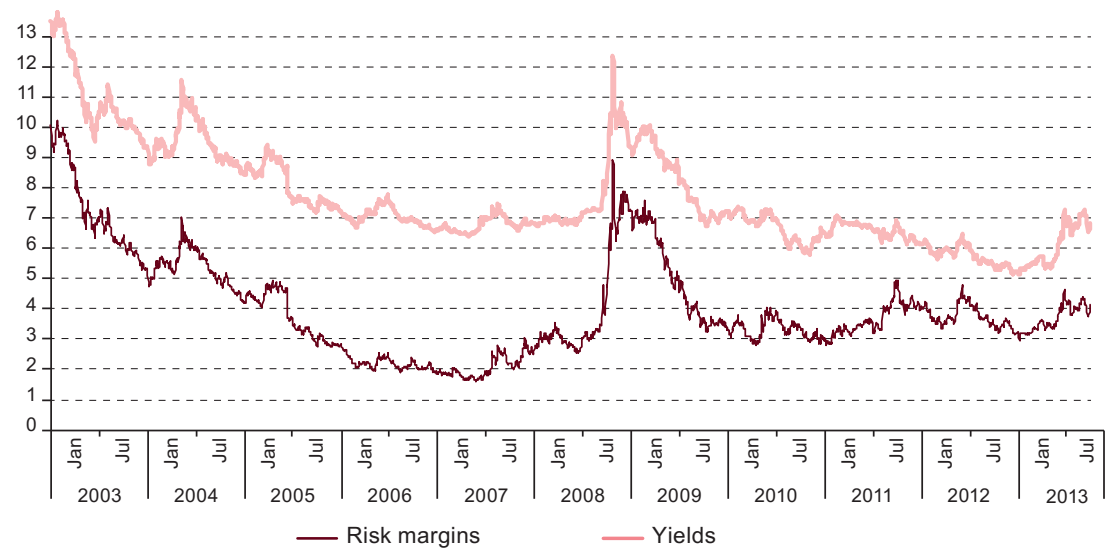

Source: Prepared by the author on the basis of figures provided by J.P. Morgan.

The crisis brought about a temporary reversal of this trend, but this lasted less than a year, unlike the Asian crisis, whose effects endured six years, or the debt crisis, whose impact lasted eight years. Negative movements 
also occurred later, which between 2010 and 2012 were invariably linked to the European crisis, in particular to the turmoil in the Spanish and Italian markets, and in the North American market following the Federal Reserve's announcement that it would begin to curb monetary expansion. Nevertheless, despite these episodes, the cost of external financing for Latin America is still the lowest it has been for 30 years. In fact, if we were to include data on international-market bond issues, we would see that access has been plentiful, much more so than was typically the case pre-crisis.

Of course, the position varies widely between countries. For economies with greater access to the private market, in particular Brazil, Chile, Mexico and Peru, the cost of financing was two percentage points lower during the second half of 2012 than it had been during the first half of 2007, that is, prior to the subprime crisis in the United States. The situation was very different in economies with no access to the private market: Argentina, the Bolivarian Republic of Venezuela and Ecuador. These countries, have, on the other hand, gained access to a new source of financing: China.

The drawback is widespread currency appreciation. Figure II.4 illustrates this phenomenon. Using ECLAC data, I compare the 2012 real exchange rate with the average since 1990 and with the period 2003-2007. As may be seen, currency appreciation has occurred everywhere, with only two exceptions: Mexico and Nicaragua. Argentina is not included because it is not possible to produce a reliable estimate on the basis of its official figures, but there has been a significant deterioration in the real exchange rate over the past three or four years.

Figure II.4

Latin America (17 countries): real currency appreciation or depreciation, 1990-2011 compared with 2012 and 2003-2007 compared with 2012

(Percentages)

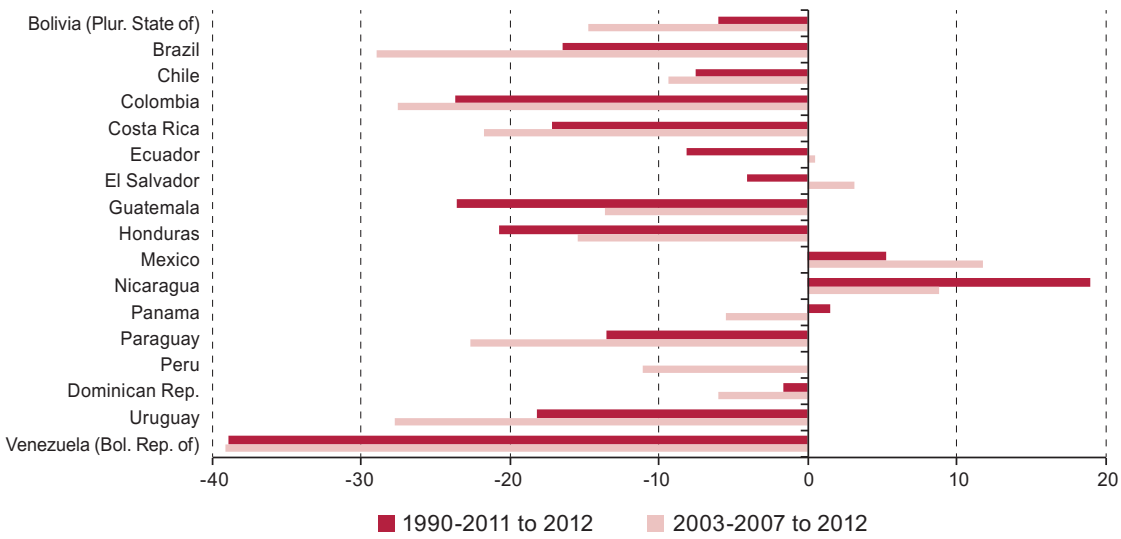

Source: Economic Commission for Latin America and the Caribbean (ECLAC). 
One way of interpreting currency appreciation in conjunction with a sounder external balance sheet and greater access to financing is that the risk of financial crisis is low, but there is a higher risk of Dutch disease, which has exacerbated the persistent de-industrialization in the region. Hence, the downside of easy access to external financing is a worsening of the structural lag which, as shown by the analysis above, is the main obstacle to growth in the region.

Figure II.5

Latin America (17 countries): real currency appreciation or depreciation, 2012-2013 (Percentages)

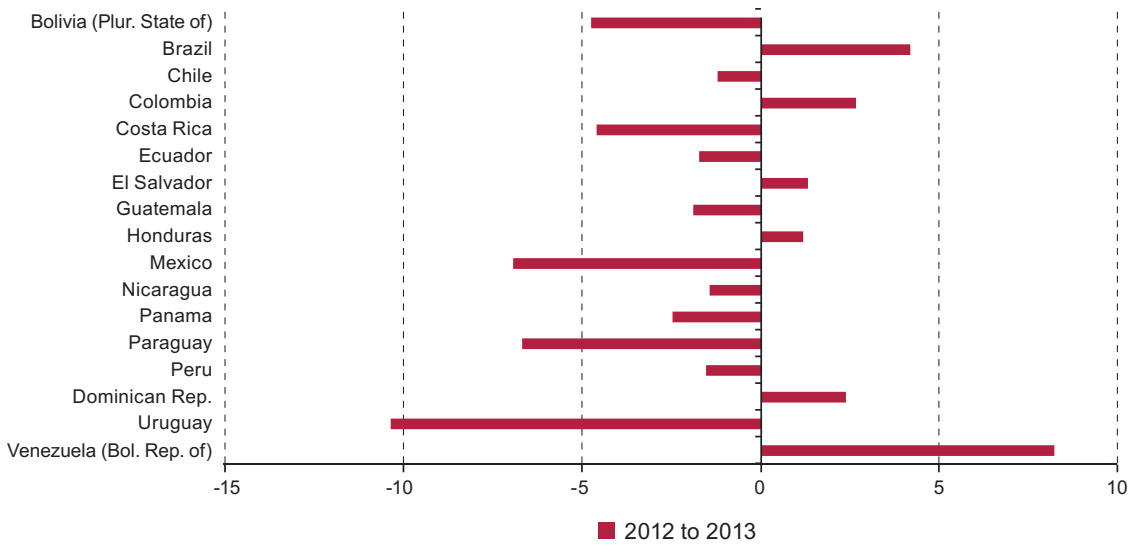

Source: Economic Commission for Latin America and the Caribbean (ECLAC).

a Averages for January to September 2012 and January to September 2013.

Given the current, opposite process of depreciation or slowing appreciation, it may be said that real depreciation in the region has done little to improve the current account balance. Just as the 2003-2007 growth cycle led to currency appreciation and an improvement in the current account, the current cycle is characterized by real currency depreciation and an unfavourable impact on the balance of payments.

In this regard, too, as I have already mentioned, there are problems associated with the way that the world economy is adjusting post-crisis. In three regions, external balances have improved: in the oil-producing countries, which are the main source of a surplus in the world today; in Europe, which is unnecessarily generating a current account surplus -a very different scenario to that which prevailed pre-crisis; and in the United States, which has corrected a deficit that was indeed too large. Obviously, these trends exert a corresponding pressure in other parts of the world, in particular on China, which has reduced its external surplus; on Japan, 
which has also done so, but more moderately; and on the non-oil emerging economies (which includes most of Latin America), whose external deficits have been widening.

All of this suggests that the deteriorating current account in the region is part of a reconfiguration of external balances around the world. It may be described as Latin America's contribution to a balanced world economy, but it has created two different problems. First, as has already been demonstrated, structural problems have become even more complex and the macroeconomic risks have increased, despite robust external balance sheets. The region has learned that current account deficits are a potential source of balance-of-payment crises. In fact, emerging economies with deep current account deficits, such as Turkey and South Africa, are particularly vulnerable to a balance-of-payment crisis.

However, changes in the terms of trade as a result of the commodity price boom that began in 2004 must be taken into account if we are to analyse this problem in Latin America correctly. According to ECLAC data, countries with a mining or energy export base have reaped the greatest benefits: the Bolivarian Republic of Venezuela, Chile, the Plurinational State of Bolivia, Peru, Colombia and Ecuador, in descending order based on improvements in the terms of trade between 2003 (year prior to the boom) and 2010 (year in which commodity prices peaked). Argentina and Brazil follow, which have an agriculture-based export structure. Small economies have almost universally lost out owing to higher oil prices.

Worryingly, the region is generating current account deficits despite a substantial improvement in the terms of trade. In other words, Latin America is spending (overspending, even) its gains from the improvement in the terms of trade. This is illustrated by figure II.6, which shows the annual current account balance in dollars and the estimated current account balance according to the 2003 terms of trade - that is, deducting from the value of exports the purchasing power gains made owing to an improvement in relative prices with regard to that year. Based on these calculations, in 2012 the region made a terms-of-trade gain equivalent to 4.5 percentage points of GDP and yet it ran a current account deficit. The "potential" deficit was, thus, around 6 points of GDP, more or less double the 1997-1998 level.

The region is therefore very exposed in the event of any fall in commodity prices. Prices have already begun to drop, but the extent of this fall will essentially depend on the growth rate of the Chinese economy, which is the main factor behind such buoyant prices. Metal prices began falling in 2011 and agricultural prices have followed suit, but fuel prices remain extremely high owing to serious political problems in the Middle East. The slowdown in China is already evident and the big question is whether its economy 
will continue to slow gradually, as forecast by the authorities, or whether this process will accelerate given the structural imbalances it is contending with, in particular the imbalance between the shares of consumption and investment in GDP.

Figure II.6

Latin America: current account balance with respect to gross domestic product, 1990-2012

(Percentages)

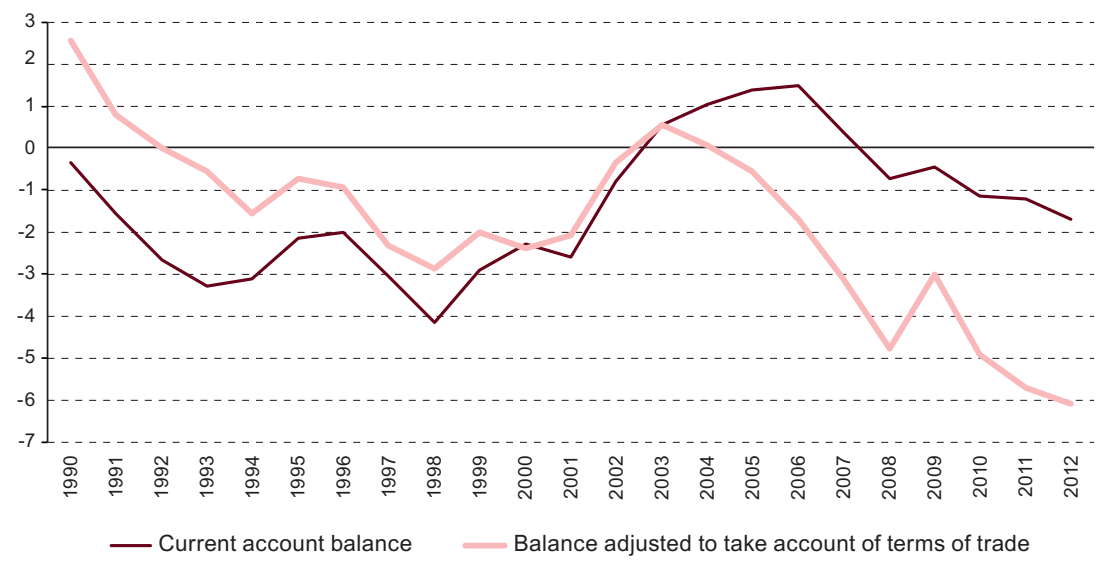

Source: Prepared by the author on the basis of figures provided by United Nations (to 2007) and International Monetary Fund.

My research leads me to think that commodity prices tend to have long cycles, or "supercycles". In an essay I published recently, I found that there have been three complete supercycles since the late nineteenth century, of 30 or 40 years in length, and we are in the upswing phase of a fourth. The main characteristic of the downswings is that their intensity depends on world demand. This is the reason the downswing was so sharp in the 1920s and 1930s and in the 1980s and 1990s, yet was much gentler following the boom that ended with the Korean War, because the world economy was growing rapidly. Based on this historical pattern, it is highly likely that there will be a pronounced downswing, given that the international economy - and the Chinese economy in particular-is weak.

\section{Is it time for a new strategy?}

This brings me to the fundamental question, with which I wish to conclude: is it time for a new strategy? My answer is yes, definitely. The recent slackening of international trade signals the end of the era of orthodox, export-led growth policies. Indeed, this strategy has not been particularly beneficial 
for Latin America, given that a growth rate of 3.3\% is unremarkable when international trade is growing at an annual rate of $7.3 \%$.

Other positive trends, however, suggest that there may be alternative paths to growth, in particular an internal Latin American market that could bring about fairer distribution, poverty reduction and the expansion of the middle classes. This opportunity may take different forms. If we think purely in terms of domestic markets, it would mainly be an opportunity for Brazil. But if we think in terms of an expanded internal market, as provided for by the various integration processes under way, it is a much broader opportunity.

The main hurdle is the political crisis afflicting our integration processes. I would go so far as to say that South American integration has reached its lowest point since the 1980s. The Andean Community is in the midst of a profound crisis, and there is persistent conflict between the main members of the Southern Common Market (MERCOSUR). The two main trade flows in Latin America, between Colombia and the Bolivarian Republic of Venezuela and between Argentina and Brazil, are experiencing serious problems owing to the actions of one member or both. Capitalizing on the opportunities offered by the region's domestic markets will require, therefore, a firm renewal of our commitment to integration.

Besides the matter of integration, the analysis I have presented here indicates that more proactive production and technology policies are needed for technological transformation of the production and export structure. This has been one of the key ECLAC messages since the 1990s, highlighted in particular in the main institutional document of 2012, Structural Change for Equality: An Integrated Approach to Development.

One of the most important elements is to formulate a strategy for our trade relations with China. This relationship needs to move on from its nineteenth-century export structure, whereby Latin America exports a handful of commodities yet imports an extremely diverse basket of increasingly hightech manufactured goods. To put it another way: China has a clear Latin American strategy, but Latin America does not have a clear China strategy.

Better exploitation of the opportunities offered by the internal market, combined with a more proactive production development policy that focuses on higher-tech sectors, should form the basis of the region's new strategy, not forgetting the main problem history has bequeathed us: extremely high levels of social inequality.

What are the alternatives for a new agenda? In economic terms, there are two basic options, which should be combined with better designed countercyclical economic policies. 
The first involves focusing on the opportunities presented by domestic markets. A return to inward-looking growth strategies is clearly undesirable, and unviable, given the radical changes wrought by market reform and the globalization process within which this has taken place. Nonetheless, in view of the poor outlook for growth in international trade, the internal market offers undeniable opportunities, including, for example, a burgeoning middle class and the need to address the region's significant infrastructure gaps.

While these opportunities could be exploited by domestic policy alone, this would suit only Brazil. A better alternative for the other countries could be an "expanded domestic market" created by a robust integration process.

This includes the opportunities presented by the construction of an integrated infrastructure network, an area in which progress has been limited; in addition, as the European experience demonstrates, this could benefit all countries. In order to move forward in this matter, the political tensions that have accompanied the integration processes must be resolved, in particular in South America.

The second option is to follow the principal points of the emerging "structuralist consensus" and pursue integration in accordance with the opportunities offered by the global economy. The orthodox, export-led growth strategies that most countries have pursued have not resulted in high growth rates, with the exception of a few periods, and are likely to generate even slower growth in a globalized, less dynamic world. Moreover, slower growth in international trade makes greater demands on the ability to compete. This makes it necessary to define and establish a robust strategy for development of the production sector - or industrial policy, if we understand the term in the broad sense attributed to it by the international literature, whose sphere of action includes not only manufacturing, but also opportunities offered by the natural resource base and the services sector. The key goal of this strategy should be technological progress, which will require the creation of strong national innovation systems. Given the high-tech nature of intraregional trade, an "expanded domestic market" offers numerous opportunities for developing new, higher-tech economic activities. Innovation systems should include a regional component, which may be particularly useful to small economies.

For integration to be more in tune with the opportunities offered by the global economy, trade relations with China must be redefined. These need to go beyond a nineteenth-century and early twentieth-century trade pattern, whereby a handful of goods are traded for a myriad of manufactures. If this relationship is to contribute to comprehensive development in Latin America, it should be a South-South, investment-based relationship, allowing Latin America to export a more diverse range of goods and services to China, and allowing its larger companies to exploit the investment opportunities 
offered by the Asian giant. This will require a more profound dialogue in common high-level forums, such as those that form the framework of dialogue between Latin America and the Caribbean and Europe (or, in fact, China-Africa dialogue).

Important strides have been made with regard to macroeconomic policy, although this remains limited in many respects; above all, little progress has been made in the design of countercyclical macroeconomic policies, with the exception of Chilean fiscal policy and a wider use of countercyclical monetary policy.

A key factor is to mitigate the sharp fluctuations in the real exchange rate that characterize most (if not all) countries. Competitive, more stable exchange rates are an essential ingredient of reindustrialization and better integration in the world economy.

In the area of social policy, there are two interesting approaches to future challenges. The first is a proposal put forward by ECLAC (2000 and 2010), which consists of a new social contract with a human rights-based framework at its centre (thus founded on the principle of equality that underpins these rights).

The second is the proposal made by the World Bank (2013), which consists of reframing the existing, implicit social contract, according to which the upper and middle classes expect a low tax burden that enables the State to offer social services of a limited quality, as a result of which middle class families opt to use services outside the public sector whenever their incomes allow them to do so.

The most important challenge is to create high quality universal social services and use the tax system to redistribute income in a more robust way than has been the case in the past - through greater tax progressivity as well as higher spending.

It goes without saying that a stronger, broader tax base is a prerequisite for financing an ambitious social strategy. The explicit focus of such a strategy should be to eliminate the transmission of inequality from one generation to the next. When redesigning social policy, it is vital to avoid different types of government failings. A key ingredient of this strategy is the development of a culture focused on high quality returns and robust accountability. The participation, in various ways, of solidarity-based private actors (such as non-profit institutions and cooperative organizations) can help overcome government shortcomings. Moreover, a more ambitious social policy must be accompanied by an increase in economic opportunities, to be provided through proactive economic policies, in particular a policy for consistent, ongoing technological progress in economic activities. 


\section{Bibliography}

Banco Mundial (2013a), "Commodity Price Data (Pink Sheet)" [en línea] http:/ / econ.worldbank.org/WBSITE/EXTERNAL/EXTDEC/EXTDECPROS PECTS/0,,contentMDK:21574907 menuPK:7859231 pagePK:64165401 piPK:6 4165026 theSitePK:476883,00.html.

(2013b), World Development Indicators [en línea] http:/ / data.worldbank.org/ data-catalog/world-development-indicators.

CEPAL (Comisión Económica para América Latina y el Caribe) (2014a), Estudio Económico de América Latina y el Caribe, 2014 (LC/G.2619-P), Santiago de Chile. Publicación de las Naciones Unidas, $N^{\circ}$ venta: S.14.II.G.3.

(2013), base de datos CEPALSTAT [en línea] http:/ / estadisticas.cepal.org/ cepalstat/WEB_CEPALSTAT/Portada.asp.

Cimoli, M. y G. Porcile (2011), "Learning, technological capabilities and structural dynamics", The Oxford Handbook of Latin American Economics, J.A. Ocampo y J. Ros, Oxford University Press.

CPB (Netherlands Bureau of Economic Policy Analysis) (2015), "Data" [en línea] http://www.cpb.nl/en/data.

Erten, B. y J.A. Ocampo (2013), "Super cycles of commodity prices since the midnineteenth century", World Development, vol.44, abril.

FMI (Fondo Monetario Internacional) (2013), “Regional Economic Outlook. Western Hemisphere: time to rebuild policy space", World Economic and Financial Surveys, Washington, D.C., 13 de mayo.

Hausmann, R. (2011), "Structural transformation and economic growth in Latin America", The Oxford Handbook of Latin American Economics, J.A. Ocampo y J. Ros, Oxford University Press.

J.P. Morgan (2014), EMBI [en línea] https:/ / www.jpmorgan.com.

Ocampo, J.A. (2014a), "Latin America's mounting economic challenges", Issue Brief, Houston, Baker Institute for Public Policy, Rice University, 17 de octubre. (2014b), "Latin America in the midst of the global quicksands", documento preparado para el Programa de las Naciones Unidas para el Desarrollo (PNUD). (2011), “Macroeconomía para el desarrollo: políticas anticíclicas y transformación productiva", Revista CEPAL, No 104 (LC/G.2498-P/E), Santiago de Chile, Comisión Económica para América Latina y el Caribe (CEPAL).

UNCTAD (Conferencia de las Naciones Unidas sobre Comercio y Desarrollo), UNCTADSTAT [en línea] http://unctad.org/en/pages/Statistics.aspx. 


\section{Chapter III \\ The recent internationalization of capitalization}

The true and fundamental nature of capitalism was revealed by Marx and Engels in the Communist Manifesto: "The bourgeoisie cannot exist without constantly revolutionizing the instruments of production, and thereby the relations of production, and with them the whole relations of society... Constant revolutionizing of production, uninterrupted disturbance of all social conditions, everlasting uncertainty and agitation distinguish the bourgeois epoch from all earlier ones."

Marx and Engels wrote that in 1848, before the industrial rise of the United States, Germany and Japan confirmed their suspicions regarding the role of "universal" competition in expanding the capital system. Captivated by the revolutionary and "progressive" power of capitalism as a force for universal commodification, Marx and Engels did not foresee the crucial role of nation States and anti-imperialism in "deforming" markets and competition conditions, which led to the decline of England. In the midnineteenth century, the struggling economies of Europe and North America were the first to develop in the environment of free trade championed by high-finance interests based in cities. Later, in the last three decades of that century, especially after the Long Depression that began in the 1870s, these lagging economies grew under the shelter of protectionism and the monetary rules of the gold standard. 
In the second half of the twentieth century, the global expansion of capitalism under the hegemony of the United States changed the international division of labour and the centre-periphery system of the British hegemony. Since the nineteenth century, the growth of the economy of the continental United States had relied on expansion of the domestic market and, secondarily, on diversification of exports. Characterized by a relatively closed economy, but with tremendous capacity for production and export of manufactured goods, raw materials and food, the economy of the United States found in foreign trade an adjustment mechanism that facilitated rapid growth.

The international economic landscape in the wake of the Second World War was shaped by the efforts of the United States to promote economic integration between its economy and that of other countries. It exercised its hegemony through the expansion of large United States corporations and banks. Following the economic reconstruction of Europe, the competitive response of the large European companies - the rivalry between business systems - led to cross-investment in production between the United States and Europe and the first round of Fordist industrialization in the periphery. During the "golden age" of capitalism (1947-1973), the expansion of international trade was based, above all, on the exchange of final consumer goods and capital between the North Atlantic partners.

The Chinese Revolution and the Korean War gave rise to the Asian style of development. Japan would later join in the development game, followed by the Republic of Korea and Taiwan Province of China, each with its own business system.

Japan emerged as an economic power in the 1960s, pioneering the Asian development style, which then spread to the Republic of Korea and Taiwan, both of which boasted strong performance in the 1970s and 1980s. Leaders and technocrats in these two countries were inspired by the performance of their neighbour, Japan, which, thanks to the Korean War, had already succeeded in the 1950s in freeing its economy from the liberal reforms of General MacArthur.

What did the United States really have in mind for Japan? To dismantle the large conglomerates and "westernize" the economy, bringing it into line with the Anglo-Saxon market economy model.

The Asian economies undoubtedly took advantage of the historical and geopolitical circumstances created by the Cold War. The Republic of Korea and Taiwan benefited from their status as outposts of the West in a region that was critical to the confrontation between the two major powers and to competition between the two systems.

The success of Japan and the Asian tigers such as the Republic of Korea and Taiwan is not attributable to the economic virtues of their models alone. 
Geopolitical conditions obviously played a crucial role, as they afforded the opportunity to make needed changes without having to abandon the practices and institutions that distinguished the management of their economies.

The United States turned a blind eye to the economic nationalism taking root in Asia, accepting accelerated growth strategies that featured protectionist industrial policies and strong export incentives. Always in the name of freedom, the United States ignored or pardoned all possible and imaginable violations of the rules of the free market. Its tolerance included the opening of its markets to a flood of products from Japan and, later, from the Republic of Korea and Taiwan.

In "developmentalist" Latin America, the drive for growth was accompanied by political instability engendered by the Cold War and the resistance of local oligarchies still committed to economic relations based on the primary export model.

Brazil put in place national industrialization policies that sought to promote the "internationalization" of the economy in the domestic sphere - that is, a division of labour between multinational corporations, Stateowned enterprises and domestic private concerns, with these last two taking responsibility for the production of intermediate goods and semi-processed raw materials.

In the 50 years leading up to the 1980s, the Brazilian economy grew rapidly and underwent a notable transition from primary exports to industry. Its development ethos arose from the perception -among the nascent business classes, the military and bureaucratic establishment, some leading intellectuals and the emerging proletariat - that the country's objectives with regard to forms of production and coexistence could not be achieved simply through the operation of natural market forces.

However, it would be totally wrong to attribute a dominant role to these seemingly progressive forces in defining the path of development. The industrialization approach was built on political, regional and class alliances that not only attracted the most conservative and reactionary interests to the developmentalist camp, but also forged agreements with the forces of capitalist internationalism.

This period culminated in the dollar crisis of 1971 and the unilateral decision to suspend the convertibility of the dollar to gold at the rate of US\$ 35 per troy ounce.

The history of the global economy since the mid-1940s cannot be told without understanding the vicissitudes of the dollar in its role as the currency of international settlements and the universal reserve asset. Immediately after the Second World War, under the Bretton Woods system, the power of 
the convertible dollar fuelled three simultaneous processes: (1) the capital account deficit - which resulted from the increase in military spending and direct investment in the recovering European market- ensured the supply of liquidity needed for the growth of world trade; (2) this, in turn, supported the reconstruction of industrial systems in Europe and Japan; and (3) industrialization occurred in many countries of the periphery, spurred by direct investment in production and the implementation of national development policies.

Growing imbalances in the United States balance of payments brought an end to the Bretton Woods system of convertibility and fixed rates, with the delinking of the dollar from gold in 1971 and the introduction of floating exchange rates in 1973.

Libertarians rose from the grave, revived by the stench of "stagflation" in the late 1960s and early 1970s. From different theoretical perspectives, the spectre of free market fundamentalism came back to haunt the Keynesian consensus. For the libertarians, the achievements of the golden age of capitalism ultimately proved to be a painful deception which fuelled economic populism, a perverse form of extreme politicization of the economy. The conservatives' recommendation, to paraphrase Eric Hobsbawm, was to say "goodbye to all that" and immediately launch the reforms needed to restore true economic mechanisms as the only means of ensuring the freedom of the individual and fostering long-term stability and growth.

From a liberal conservative standpoint, trying to protect citizens from the ups and downs and uncertainties of the market would ultimately backfire. Despite their analytical and methodological differences, Hayek and Friedman both argued that the "glorious years" were inexorably doomed to fail in their senseless attempt to interfere with "natural" market movements. Accommodative monetary policy, combined with "corporatist" pacts between social classes and interest groups, would inevitably lead to sluggish growth and chronic high inflation.

Immediately thereafter, the proponents of neoclassical economics, placing their faith in the rational expectations theory, joined the ranks of the liberal reformists. They spoke out even more forcefully against State intervention, proclaiming the ineffectiveness of fiscal and monetary policies in their vain attempt — as the neoclassicists saw it — to limit cyclical instability and promote economic growth.

Governments would come to learn that the rational agents that populate markets are fully aware of the structure of the economy and are able to use the information available to them to predict how the market will likely evolve. They were not to be fooled, even for a moment, by the old trick of boosting economic activity with the supposed stimulus of lax monetary 
policy. If headstrong politicians and bureaucrats insisted on pursuing this strategy, they would create not more jobs but more inflation, unless they could continually confound and mislead the shrewd, relentlessly rational private agents, which was unlikely.

In the early 1980s, supporters of supply-side economics would go so far as to claim that excessive taxes were suffocating the wealthiest and discouraging saving, thereby hindering investment and reducing the supply of jobs and the income of the poorest. Neo-corporatist practices, in their view, created serious "microeconomic" deformations by deliberately promoting intervention in the price system, exchange rates, interest rates and tariffs. In order to induce the expansion of certain sectors and protect business segments threatened by competition, governments distorted the price system and thus obstructed the noble and indispensable function of markets in generating information for economic agents. Such violations of the golden rules of competitive markets led to generalized inefficiency and the proliferation of "income predators" in the environment created by the State's financial profligacy.

As if that were not enough, labour markets, hit by nominal wage rigidity and policy rules (such as the minimum wage) that hindered their smooth operation, were no longer able to express the equilibrium price of this factor of production through the unfettered interaction of the forces of supply and demand.

In the financial realm, the "efficient market" theory attempted to show that all relevant information on the fundamentals of the economy is continually available to all market participants who analyse debt securities and property rights. Rational action by economic agents in response to the available information would ensure the best possible distribution of resources among various assets. Thus, this theory held, under competitive conditions there can be no "winning" strategies capable of bringing about above-average outcomes.

The dollar resumed its role as the universal standard following an unprecedented rise in interest rates in 1979. The strengthening of the dollar as the main reserve currency and the currency of choice for trade and financial transactions caused profound changes in the structure and dynamics of the global economy. The rehabilitation of the dollar standard provided new impetus for the redistribution of production capacity in the global economy, prompted the mergers and acquisitions of the 1980s and exacerbated the imbalances in the balance of payments between the United States, Asia and Europe, while also advancing so-called "financial globalization".

After the hegemony and "productivity" crisis of the 1970s, the United States embarked upon another period of expansion, which enabled 
it to attract capital to its markets and allowed it the luxury of maintaining moderate interest rates. This trend accentuated in the 1990s, giving rise to three interrelated phenomena: (1) large capital inflows into the United States, despite its current account deficit; (2) accumulation of reserves in the Asian countries, as the corollary to the growth of the current account deficit in the United States; and (3) spectacular credit expansion and asset inflation in the economies of the centre.

The "Asian model" in its current form has a symbiotic relationship with the financial and organizational changes that spawned new forms of competition among the leading companies in the developed triad: the United States, Europe and Japan. The direction taken in this new competitive environment was, in fact, a response to the liberalizing policies of the 1980s, in the face of which large corporations took steps to reconfigure the international environment. The metastasis of the business system of the developed triad, particularly that of the United States and Japan, led to a marked change in trade flows. Intra-firm trade took on growing importance, with "global supply" playing a crucial role. The latter is a phenomenon present, above all, in strategies for the internationalization of production chains, from which the Asian economies, especially that of China, have benefited since the 1990s.

The new competition simultaneously brought about (1) centralization of control through the waves of mergers and acquisitions that have occurred since the 1980s and (2) a new spatial distribution of production or, in other words, the internationalization of value chains. The centralization of control, on the one hand, and the decentralization of production, on the other, changed the nature and direction of direct investment in new capacity, reconfigured the division of labour between producers of parts and components and assemblers of final goods, and, as noted above, altered countries' shares of trade flows. The aim of competition between large capital blocs is to ensure both adequate spatial diversification of the productive base of large corporations and "free" access to markets.

Globalization entails, above all, generalization and intensification of competition among large transnational corporations. The location strategies of modern transnational corporations were accompanied by significant structural changes, including the creation of networked companies that concentrated decision-making and innovation functions and the outsourcing of commercial, industrial and general service operations.

The changes in forms of competition led to a "questioning" of the "stable" oligopolistic structures that had regulated competition from the 1950s to the 1980s, in the era of Fordism. From the 1940s to the 1970s, the pattern of competition had been based on the stability of oligopolized market structures and characterized by standardized production, codified technology, a tendency towards vertical integration and an aversion to cooperation. 
Oligopolies "concentrated" the manufacture of homogeneous products, such as steel, and other basic or differentiated inputs, such as consumer durables. These oligopolistic structures were "protected" by strong technological, financial and trade barriers that hindered the entry of new competitors.

This competition model was characterized by a rigidly hierarchical, bureaucratic organizational structure, resulting from the separation of ownership and control, a phenomenon that emerged in the last three decades of the nineteenth century.

The changes that have occurred in recent decades have given rise to correlated but seemingly contradictory phenomena: (1) a new era of "centralization" of ownership and control by capital blocs following the wave of business mergers and acquisitions encouraged by strong capitalization of stock markets in the decades between 1980 and 2010, despite episodes of price "adjustment"; and (2) "outsourcing" of functions deemed non-essential to core business activities, which has intensified the social division of labour and fostered specialization and productivity gains.

Large corporations that opt to expose themselves to the uncertainties of global competition increasingly need to be supported by institutional and legal conditions that enable them to compete against rivals in their home market and in other regions. They rely on the support and political influence of their home countries in order to penetrate third-country markets (through investment guarantee agreements and patents, among other things). They cannot do without public financing for their exports in the most dynamic sectors, they must not be subject to excessive taxation and they are at risk of being displaced by the competition unless they enjoy the benefit of national education and science and technology systems.

The new business paradigm overemphasizes the importance of these advantages, which include: (a) cumulative learning processes (learning-bydoing in flexible production and product development); (b) dynamic economies of scale (volume increase linked to time and learning); (c) structuring of electronic data exchange networks that maximize efficiency throughout the value chain (working capital savings, in particular through minimization of inventory and transport and storage costs); (d) new agglomeration economies (purchasing and technical assistance centres and technical and managerial knowledge hubs); and (e) economies derived from technological cooperation and joint product and process development.

Under these competitiveness policies, the primary concern is to create synergies based on knowledge and ability to respond to information. The new role of structural policies is to encourage cooperation and coordination among actors. It is not about "picking winners", but about creating conditions that will enable winners to emerge. 
The changes in the spatial location strategy of the dominant companies have recently been accompanied by financial and organizational changes, especially shifts in the direction of foreign direct investment and its impact on the international division of labour.

The extent to which economies opened up to foreign investment -including the absorption of technology, the densification of industrial chains and the growth of exports- depended primarily on national policies. Among emerging countries, those that experienced the greatest growth and achieved the highest export levels were those that succeeded in maintaining a favourable combination of competitive real exchange rates and low interest rates, coupled with the formation of internal networks between integrator firms and suppliers of parts, components, equipment and logistics systems.

As already mentioned, the change in the spatial configuration of industry was marked by an intense process of centralization of productive capital in manufacturing at the global level, accompanied by a major effort by transnational corporations to focus their strategies on their "core business".

The consequences of these changes are not negligible. The centralization of capitalist control in large corporations has resulted in the "outsourcing" of the production of parts, components and final goods under the "intelligent" management of "integrator" firms, which are responsible for strategic design. That move has greatly reduced the costs and boosted the efficiency of manufacturing systems. It should be noted that the "globalized industrial economy" would not have advanced without innovations in information and communications technology and without major logistical changes, in particular the expansion of containerization. These factors were crucial to shortening productive capital turnover and circulation times.

The world is witnessing an upheaval in the international division of labour. Asia has become a formidable producer and processor of economic parts and components (as well as final consumer goods and capital goods), a manufacturing region and a major importer of raw materials, with China leading the charge, having rejoined the capitalist ranks following the reforms of the late 1970s.

For nearly three decades China has been applying national industrialization policies tailored to the movement towards expansion of the "global" economy. The Chinese leadership realized that the development of the "new" global economy hinged on the movement of large transnational corporations in pursuit of competitive advantages, which altered the course of trade flows. China therefore adjusted its national strategy of accelerated industrialization to the new realities of global competition. 
The Chinese experience combines maximum competition —using the market as a tool for development - and maximum control. Chinese leaders have clearly understood that emerging countries should not "copy" the liberal policies recommended by the Washington Consensus. They also understood that the United States "proposal" for the global economy offered opportunities for China's national development. They maintained control of the central institutions of a modern competitive economy: the credit system and foreign trade policy, including management of the exchange rate. Public banks were used to direct and facilitate investment in production and infrastructure.

As is well known, China runs a large trade surplus with the United States, but it has a growing trade deficit with the rest of Asia and other trading partners. The industrialized Asian bloc, with China at its core, has functioned and still functions as a nexus between demand in the countries of the centre and supply from "natural resource-exporting" economies.

For producers of raw materials and food, the rapid industrialization of China and the countries of South-East Asia shifted a significant portion of global demand.

Brazil and the rest of Latin America, however, remained largely outside the process of global value chain restructuring. Shortly after joining the North American Free Trade Agreement (NAFTA), Mexico made some headway in terms of its share of global value added, but since the early 2000s it has rapidly lost ground to China and its Asian neighbours.

Both before and after the introduction of the stabilization plan introduced in 1994, Brazil was unable to bring about the growth and differentiation of its industrial structure. Before the Plano Real, the acute crisis in the balance of payments and the threat of hyperinflation made the country an unattractive destination for large transnational companies seeking to relocate and reorganize. After the country succeeded in reining in inflation, appreciation of the real, in addition to increasing external vulnerability, discouraged Brazil's participation in global production chains, especially in sectors most affected by the structural and technological changes described above. The sectors in which Brazil's "outlier" status is most obvious include: telecommunications infrastructure, mobile telecommunications infrastructure, computers, laptops, plasma screen and liquid crystal display (LCD) televisions, digital cameras and electronic components.

In the past two years the performance of Brazilian industry has been disappointing. The period ended with an overall decline of around $2 \%$, after scant growth of $0.6 \%$ in 2011 was followed by a $2.7 \%$ drop in 2012. Thus, although expectations of higher growth in the Brazilian economy (of around 3.5\%) were met in 2013, average industrial performance for the three-year period remained unsatisfactory. 
The poor performance of industry, especially the manufacturing industry, is rooted in external and internal factors, for which there is no short-term solution.

In the external sphere, as noted above, the last two decades have seen major changes in the spatial distribution of manufacturing chains. This does not mean that transnational corporations have stopped pursuing the Brazilian market and the Southern Common Market (MERCOSUR). But what prompts investment is clearly the attraction of the domestic market and the prospects for greater integration of the South American market. In most cases, Brazil participates in global production chains at the tail end of the production process. It is worth noting, however, that from the Brazilian point of view participation in such chains entails a unique dynamic between exports and imports, in which it produces in order to export and imports in order to produce.

Brazil has long remained outside the production and business restructuring movement known as "globalization". It began to distance itself in the second half of the 1970s, when, in seeking to further its industrial development, it chose to focus on basic and traditional sectors. In the last 40 years, the country has made marginal contributions to the manufacturing structure and shown low capacity for innovation and integration into production chains.

Limited modernization, in an environment of currency overvaluation and complete lack of active industrial policy, resulted in a sharp rise in the importation of capital goods and the abandonment of Brazil's own equipment industry. This heavy dependence on imports became structural, with repercussions on current production, even under low-growth conditions.

Indeed, the 1990s were characterized by deindustrialization, understood as a decline in internal value added as a proportion of the gross value of production, and a reduction in jobs. With inter-industry links in the main production chains broken, today Brazil's industrial structure can be compared to a nebula in which a few large and medium-sized enterprises stand out in each sector because of their partially globalized support structure. It is thus possible to understand why business modernization in the 1990s led to structural weakening of the manufacturing industry.

As noted above, this has been occurring for decades. Policies that are based simply on openness to imports cannot be deemed successful with respect to integration of the Brazilian economy, nor will policies based on pure and rigid protection. At the current juncture of global economic development, Brazil can and should expand its trade agreements, beginning with regional integration. 
In trade negotiations, following the lead of successful emerging countries, it is essential to enhance Brazil's position and its import potential in order to boost its export capacity.

The advantages of China and its Asian partners are not assured. Capitalism does not rest. After the crisis of 2008 and its consequences, countries that had lost ground in the manufacturing stakes, especially the United States, are showing signs of a new round of innovations, which those who still embrace production functions would classify as "labour-saving".

Marco Annunziata, chief economist at General Electric, and Kenneth Rogoff have heralded the advent of an intensive movement towards automation based on the use of networks of "intelligent machines". Nanotechnology, neuroscience, biotechnology, new forms of energy and new materials make up a set of innovations with great potential to revolutionize yet again the technical foundations of capitalism. Any method arising from these technical foundations can only confirm capitalism's internal rationale: they are production methods aimed at continually increasing the social productivity of labour. Their continued application makes immediate labour increasingly redundant. Autonomization of the technical structure means that the application of science becomes the dominant criterion in the development of production.

The big business game is played on a board on which capital mobility simultaneously engenders trade liberalization, control over the dissemination of technical progress (through patent laws and other means) and weakening of workers' bargaining power. "New" forms of competition thus mask, under the transparent veil of freedom, a brutal increase in the centralization of capital, the concentration of power over markets, and an enormous ability to occupy and abandon territories and alter the living conditions of populations.

\section{The macroeconomics of globalization}

When seen from a macro standpoint, the economy can be conceived of as a broad panorama of interrelated balances. The balances of banks, businesses, families, governments and the external sector show, at all times, the results of financing and spending decisions taken privately by each of the participants in the market game. Private spending decisions supported by credit (and thus by debt) are the independent variables that determine job creation and therefore income formation. Hence, to the extent that the payment of wages and purchases made between companies create global revenue flows in the economy, debit and credit operations modify the distribution of accumulated rights to wealth and, therefore, the financial position of the protagonists. In the upward phase of the cycle, the flow of profits, household savings and government revenues work to ensure the service and stability of the value of 
debts and financial costs. The savings derived from the new revenue stream serve as financing for the banking system and the capital market. The latter, in their role as intermediaries, promote the validation of credit and liquidity (money creation) "advanced" originally by banks to enable investment and consumer spending.

The crisis that began in the second half of 2007 and deepened in the wake of the disastrous collapse of Lehman Brothers in September 2008 offered some analysts (such as Paul Krugman, Nouriel Roubini, Michel Aglietta, Martin Wolf and Claudio Borio) the opportunity to further understanding of the transformations that had occurred in the relationship between financial innovations, financing of household consumption and business investment costs, and income generation and employment in the global economy.

The economist Claudio Borio of the Bank for International Settlements has revealed the truth that most banking industry analysts strive to hide behind their ineffable knowledge: gross private capital flows were at the root of the development and configuration of the financial cycle that culminated in the crisis, especially the flows that occurred in transactions between Europe and the United States. Financial interpenetration gave rise to the global diversification of assets and "internationalization" of the portfolios of wealth managers.

A number of factors intervened in the cycle of internationalized financial expansion, including (1) innovative methods of financial "leverage"; (2) appreciation of real estate assets; (3) migration of manufacturing to countries with low-cost labour; (4) growth of inequalities; (5) lack of significant changes in the earnings of the working population; and (6) degradation of progressive taxation systems.

Slow wage growth combined with the rapid expansion of credit to bolster household consumption. As a result of the opportunity for "value extraction" offered by the rise in real estate prices, consumer spending came to account for a large share of the composition of final demand formation in almost all countries in the developed regions. Meanwhile, companies in the "consumerist" countries sought to intensify the strategy of separating the building of new capacity from the obtention of results.

During the period of euphoria, large companies shifted their manufacturing to regions with low wages, undervalued exchange rates and high productivity. Many United States and European firms flocked to Asia, while German firms, though cautious, turned suddenly towards their eastern neighbours. They exported cheap manufactures from these cities to countries and regions of origin or influence. Buoyed by the growth in household spending, they earned profits and accumulated cash (generally in tax havens). The displacement of United States companies generated deep 
current account deficits in that country's economy. Meanwhile, the Germans, despite their shift to Eastern Europe, financed the expenditures that led to the huge current account deficits of their neighbours in the eurozone.

The world has not uniformly embraced floating exchange rates. Quite the contrary: the coexistence of floating and managed or fixed-rate systems has become the hallmark of the global economy. The number of countries that have "pegged" their currency to the dollar or to a basket of currencies has risen sharply. Since the Asian crisis, the countries of the region, particularly China, have pursued export-oriented strategies, with strong accumulation of reserves and highly pragmatic capital control measures. In the face of a flood of capital employed in covered interest arbitrage and rampant currency speculation, both developed and emerging countries have fought to prevent the creation of credit bubbles and avoid the unwanted adverse effects of currency appreciation.

The rise of China and other emerging countries as major players in international manufactures trade prompted a strong deflationary movement, which contributed to price stability in the global economy. Commodity prices remained under control until the end of the first decade of the 2000s. Then the situation changed. After the crisis, commodity prices began to respond elastically to Chinese demand and, above all, to the excess liquidity generated by the actions of central banks in developed economies.

The acceleration of this component of spending in emerging Asian countries more than offset the decline in investment in the formation of aggregate demand in the countries of the centre. The global balance thus reflected the widespread creation of excess productive capacity, particularly in the high- and medium-technology sectors affected by international competition.

When the engines reversed as a result of the drop in real estate prices and the devaluation of financial assets linked to consumption, household debt was found to be "excessive" when calculated in terms of expected flows of income and falling housing prices. Stifled by the abundance of capacity across the globe, companies further curtailed their capital expenditures. Relieved of the burden of toxic assets thanks to the action of central banks, financial institutions accumulated excess reserves, but were reluctant to make loans even to other financial institutions. In a context of falling incomes, automatic increases in spending and the rescue of dying banks, fiscal deficits grew, increasing the volume of government debt in bank portfolios. At the same time, the current account imbalances in the balance of payments remained unchanged.

In the past three years, households with negative equity and companies with excess capacity have sought peace of mind in liquidity and asset rebalancing. Some countries and regions have struggled to reduce 
their external deficit, while others have sought to maintain their surpluses. Governments have tested fiscal austerity policies. Such decisions are "rational" from a microeconomic point of view and virtuous from the standpoint of managing domestic finance, but are detrimental to the economy as a whole. If everyone seeks to reduce costs, achieve surpluses and increase liquidity at the same time, the result can only be a drop in income and employment and growth in the "weight" of debts whose "value" is fixed in nominal terms. This is the paradox of deleveraging, which has been called the hell at the end of the road paved with good intentions, whose flames crackle in the known but always neglected territory of the fallacy of composition. If interpreted correctly, that fallacy might point to a need to discern the macroeconomic underpinnings of microeconomics. 
Part II

Macroeconomics for development 



\section{Chapter IV \\ Neostructuralism and macroeconomics for development}

Ricardo Ffrench-Davis ${ }^{1}$

\section{Introduction}

One of the fundamental responsibilities of the State in the field of economic and social development is for the environment in which the producers and consumers of goods and services of the national economy operate, known as the macroeconomy. When designing the macroeconomic environment, two basic features should be borne in mind: that it should enable the full use of productive resources, with sustainable domestic and external balances, and that it should support the building of new capacities. Among other conditions, domestic demand needs to evolve in step with productive capacity, or potential GDP, and macroeconomic prices (particularly, the exchange rate) needs to be compatible with a sustainable external balance. This is what has been called macroeconomics for development, which is essential to developing a strategy for growth with equity. This chapter examines the recessionary and regressive impacts of mainstream macroeconomic policies, inspired by

The autor wishes to thank the editors of this book for their comments as well as the participants of the seminar on neostructuralism and heterodox economics, organized by ECLAC on 22-23 April 2013; he also appreciates the efficient research support of Felipe Correa. Some of the earlier work on neostructuralism by the coauthor can be found in Ffrench-Davis (1988) and (2010), developed on the basis of the pioneering work of authors such as Anibal Pinto, Raul Prebisch, Osvaldo Sunkel and Fernando Fajnzylber. 
the Washington Consensus or neoliberal approaches, on economic growth and employment, focusing in particular on the implications of the presence of deep structural heterogeneity among diverse types of economic agents, and outlines the main policy features and effects of a macroeconomics-fordevelopment approach.

Deep structural heterogeneity is characteristic of developing economies, such as those of Latin America. It can be seen in the great productivity diversity between companies of different sizes and between workers with different skills, in the differing capacity for action and reaction of the agents typically operating in different markets (large versus small businesses, high- versus low-skilled workers, GDP-generating versus rent-seeking financial investors or buyers of existing assets, productive investors versus consumers) and the asymmetries in their respective responses to instability of economic activity and macroeconomic prices.

The less stable the macroeconomy, the greater the asymmetries of reactions and effects will be. This is very significant, as the region's economies are characterized by repeated boom and bust cycles, which traps average actual output below the productive capacity of labour and capital and produces extreme fluctuations in macroeconomic prices, such as the exchange rate, as well as liquidity squeezes in the credit market and sharp swings in the external balance. This instability is closely linked with fluctuations in financial capital flows and commodity export prices.

The document Time for equality: Closing Gaps, Opening Trails (ECLAC, 2010) shows that the combination of structural heterogeneity and instability leads to considerable public policy challenges; if they are not taken into consideration, both equality and growth usually remain elusive. The supposedly "neutral" policies of neo-liberalism often have significant negative effects on both heterogeneity and instability: (i) regressive effects that harm small- and medium-sized enterprises (SMEs), start-ups and lessskilled workers, and (ii) a drop in the utilization rate of available potential GDP (GDP*) and in capital formation, the quality of exports and jobs, and innovation. Therefore, reducing the structural heterogeneity and instability of the real macroeconomy is crucial for achieving development.

Consequently, macroeconomic policies must take structural heterogeneity into account in order to even out different agents' response capacity. This is essential for development, which, inevitably, requires the constant narrowing of productivity gaps, by raising average productivity rates and reducing their range.

To achieve these goals, policies -including in the macroeconomic, social and productive development domains- must be coordinated and consistent. Under this comprehensive approach, macroeconomic policies 
can contribute to transforming productive structures by introducing a bias that promotes equal opportunities, and to boost economic dynamism to foster capital formation, job creation and innovation. This chapter focuses on macroeconomic and their impact on equity, productivity and capital formation.

This chapter has three sections, in addition to this introduction. Section A summarizes the macroeconomic performance of the region since 1990. Section B examines three types of asymmetry, which are regressive and depress development under conditions of instability in the real economy and structural heterogeneity, owing to their effects on capital formation, the quality of participation in external markets, employment rates and job insecurity. The conclusions are presented in the last section.

\section{A. The mainstream approach since $\mathbf{1 9 9 0}$ and its effects}

In recent years, the prevailing view has been that inflation control and fiscal balance are enough to ensure macroeconomic balance. Many reformers believed that achieving these objectives would be facilitated by a free exchange rate and an open capital account, because these would attract external savings that would supplement domestic savings to finance stronger capital formation. This combination would also help to "import" macroeconomic stability, as it would limit possible irresponsible actions by domestic authorities. Under this rationale, financial agents, with their votes of (no) confidence in national economies, would curb national authorities' tendency to create fiscal and monetary imbalances. In addition, financial market capital flows would determine equilibrium liquidity levels, interest rates and exchange rates.

For this configuration to function, monetary policy had to be isolated from political pressures. Monetary policy thus revolved around independent central banks and inflation targeting. Exchange rate appreciation caused by capital inflows was often welcomed, because it anchored the consumer price index (CPI), regardless of its negative impact on the production of tradable goods and the stability of the real economy.

Consequently, over the past few decades mainstream macroeconomics in Latin America has given clear priority to nominal price stability and fiscal discipline. Therefore, macroeconomic policy design and evaluation have become disconnected from their effects on employment and growth, concentrating instead on inflation control. This approach has yielded satisfactory results with regard to controlling inflation, which has been in single digits in most countries of the region since the mid-1990s. But it has not produced sustained growth in GDP or in wages (Ffrench-Davis, 2005). 
The pace of GDP growth has been disappointing (Williamson, 2003). Between 1990 and 2012, GDP rose by barely 3.2\% per year, compared with $5.6 \%$ over the course of the 1970s. In fact, the region overall has seen virtually no convergence with the developed world. For example, in 2008 (the year before the effects of the global financial crisis spread to the region), per capita GDP in Latin America was $27 \%$ of the average figure for the Group of Seven (G7) countries - similar to the percentage the region had already reached by 1989 (see table IV.1). Between 1990 and 1997, at the height of the Washington Consensus reforms in the region, per capita income rose at similar rates in the two groups of countries. Thereafter and until 2003, the region's per capita GDP declined, eroded by the Asian crisis. From 2004 it increased significantly on the back of strengthening terms of trade, to reach slightly over $27 \%$ of the per capita GDP of G7 countries in 2008, and $29 \%$ in 2012. ${ }^{2}$ Over these 23 years, then, the region shaved a mere 2 points off the 73 point gap that existed in 1989 .

Table IV.1

Latin America: per capita GDP compared to the United States and the Group of Seven (G7), 1970-2012

(Percentages, on the basis of dollars at 2012 purchasing power parity (PPP) rates)

\begin{tabular}{lcc}
\hline Year & Latin America/United States & Latin America/G7 \\
\hline 1970 & 26.5 & 32.5 \\
\hline 1980 & 30.3 & 35.6 \\
\hline 1989 & 23.5 & 27.2 \\
\hline 1997 & 23.0 & 26.6 \\
\hline 2008 & 23.3 & 27.4 \\
\hline 2012 & 24.6 & 29.1 \\
\hline
\end{tabular}

Source: Prepared by the author on the basis of World Bank estimates for GDP per capita in PPP of the three regions in 2012, and World Bank reports for real rates of change in GDP per capita, 1970 to 2012.

After the contagion from the global crisis of 2008-2009, GDP rallied in 2010-2011 (5.8\% and 4.4\%, respectively). However, once again, a longer average covering both the contagion-induced contraction period and the post-crisis recovery show GDP performance remaining similarly poor. What is more, by 2012 it had already slipped back to 3\%. This reflects policy weaknesses in the microeconomic (not examined in this paper) and macroeconomic approaches.

Boom periods (those starting in 1990-1991, 1995-1996, 2003-2004 and 2010) have brought with them macroeconomic imbalances affecting exchange rates and the external balance, as well as share price and consumer credit bubbles, leading to increasingly unsustainable situations and new recessive adjustments. ${ }^{3}$ These imbalances (or vulnerability indicators) are at the root of

2 The five years between 2004 and 2008 exhibited the strongest growth since the 1970s, with an average annual growth rate of 5.3\%. The region's relative gain in 2009-2012 was due more to decline in the developed economies than to its own performance.

3 See ECLAC (2010) and Ffrench-Davis (2010). 
the highly unstable GDP growth in most of the region's medium-sized and large economies, which determine the weighted regional average (see figure IV.1). In most countries of the region, fluctuations in GDP are undeniably due not to sudden structural or microeconomic changes, but to cyclical macroeconomic changes associated chiefly with the pattern of financial and trade integration.

Figure IV.1

Latin America (19 countries): GDP volatility, 1977-2012

(Annual growth rates, percentages)

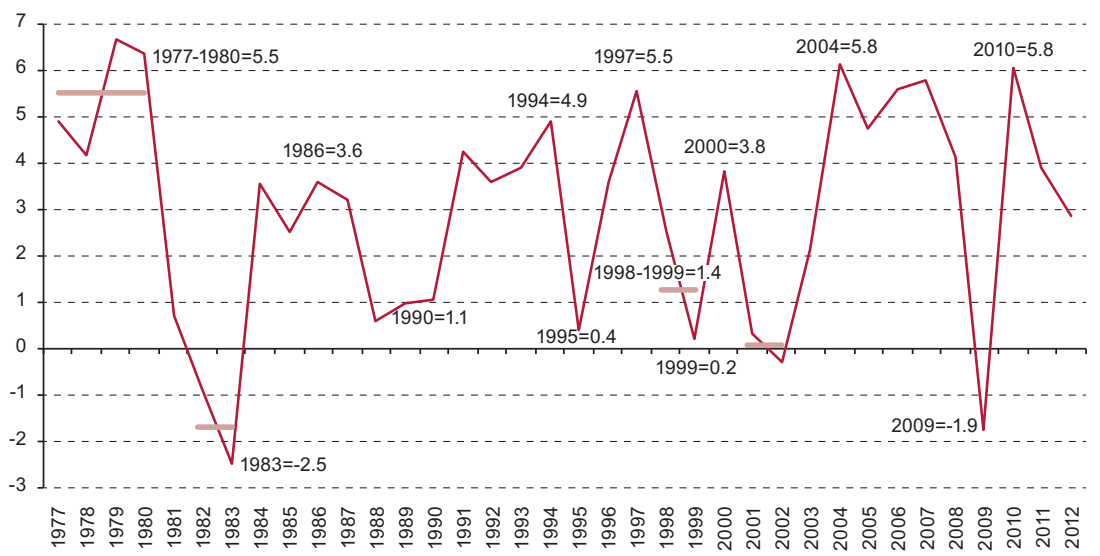

Source: Prepared by the author on the basis of Economic Commission for Latin America and the Caribbean (ECLAC), data from 19 countries.

Until 2003, fluctuations in economic activity were associated primarily with capital flows. Since then, the economic boom, particularly in South America, has been mostly the result of steady improvements in the terms of trade, rather than foreign savings; ultimately, it was based more on domestic resources than foreign. This, together with the adoption of countercyclical reforms, such as the creation of stabilizing sovereign funds, conferred greater sustainability over time. However, by 2008 most of the indicators of macroeconomic vulnerability had become evident and, in 2010-2012, a disequilibrium process again took hold.

The most obvious indicators are persistent currency appreciations and their effect on current accounts. Currency appreciations have been led by significantly higher prices for commodity exports of several countries of the region, which underpin strong improvements in the terms of trade (see figure IV.2). ${ }^{4}$ While these gains last, rising currencies mistakenly appear sustainable;

The increase of almost $50 \%$ in the terms of trade index overstates the positive effect of exports on income, because part of the impact leaks abroad through the remittances of profits on foreign direct investment (FDI) in the export sector. During the recent boom, around a third of the increase leaked abroad. See the terms-of-trade trend in Erten and Ocampo (2012). 
however, they have a distorting effect on the quality of exports and damage the ability of SMEs to compete with imports. In fact, the volume of imports climbed $108 \%$ since 2003, compared to a $47 \%$ in export volumes (see figure IV.3).

Figure IV.2

Latin America: terms of trade for goods and services, 1990-2012

(Index: 1990=100)

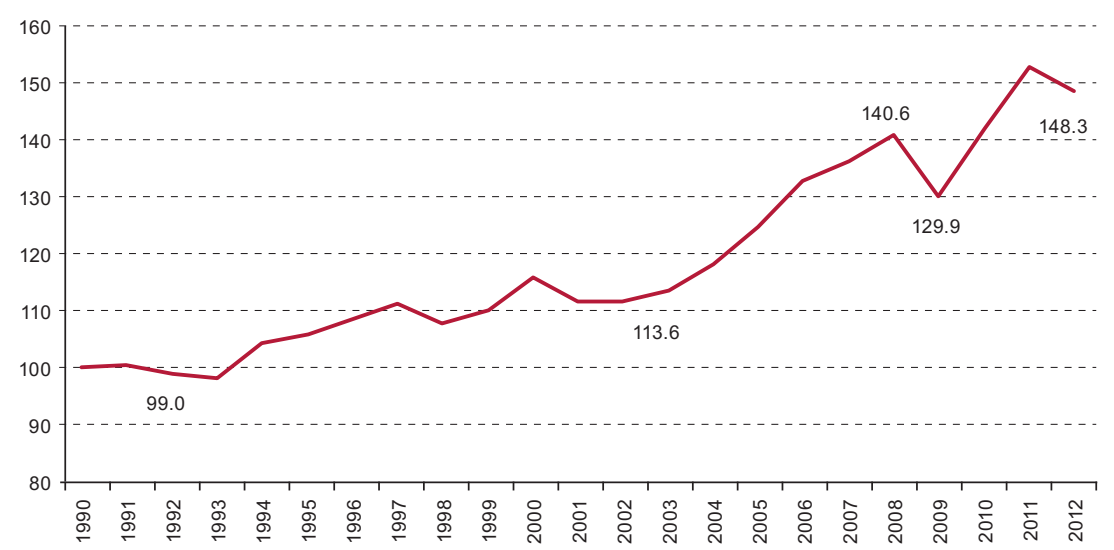

Source: Prepared by the author on the basis of data from Economic Commission for Latin America and the Caribbean (ECLAC).

Figure IV.3

Latin America: volume of exports and imports of goods, FOB, 2003-2012

(Index: 2003=100)

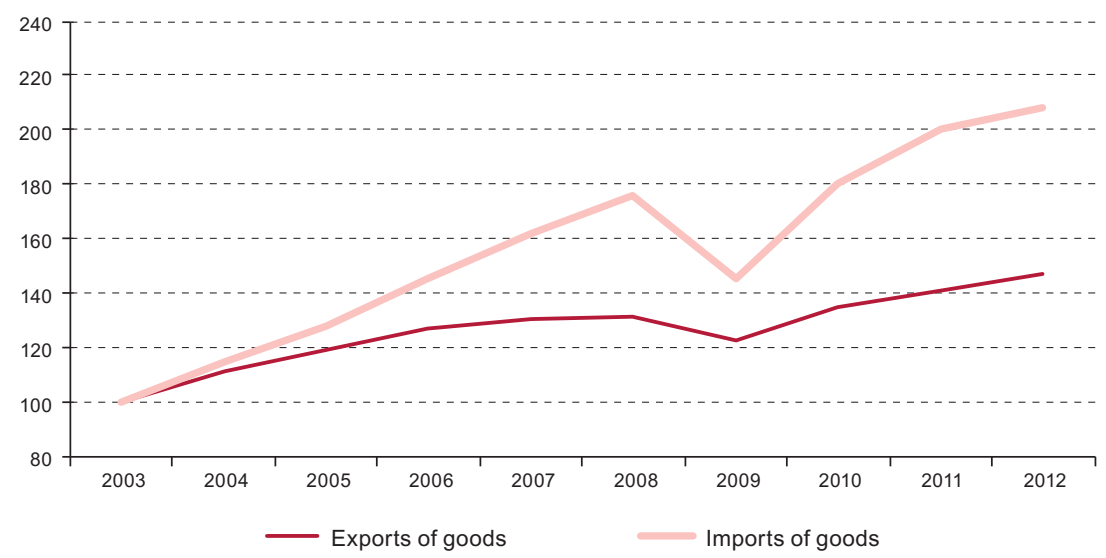

Source: Prepared by the author on the basis of CEPALSTAT for 2003-2009 and ECLAC, Economic Survey of Latin America and the Caribbean, 2012 (LC/G.2546-P), Santiago, for 2010-2012. 
In short, parallel to the aforementioned nominal balances (low inflation and fiscal discipline), the GDP growth rate - the main real economy indicatorshowed sharp fluctuations. Variations in GDP performance in the region are not, on the whole, due to sharp structural or microeconomic changes but to shifts in macroeconomic variables, mainly those associated with inflows and outflows of financial capital, and in terms of trade. These factors, whose impact is multiplied by passive or procyclical macroeconomic policies (Kaminsky, Reinhart and Vegh, 2004; Ffrench-Davis, 2010), cause substantial instability in aggregate demand, exchange rates and the expectations of economic agents. These macroeconomic variables clearly reveal serious imbalances in the real economy, however steady the inflation rate and controlled the fiscal accounts. As will be discussed here, this instability has severely undermined GDP growth and equity, owing to its impact on productive investment and on job quality.

The lesson for macroeconomic policymaking is that it is not enough to keep inflation rates low and observe fiscal discipline, as this has tended to create imbalance between objectives. Of course, both those goals are necessary, but it matters how they are achieved and, in any case, by themselves they cannot ensure real-economy stability and growth. The different goals must be evenly balanced in light of particular circumstances, and the means to achieve them must be coordinated. It is necessary to make an explicit priority of the links between macroeconomic policies, productive development and the implications for equality.

\section{B. Recessionary and regressive asymmetries}

A hallmark of the economies of the region is the repetition of cyclical fluctuations in economic activity, with strong booms followed by often sudden downturns, and the sharpest swings occurring in the medium-sized and large economies. This cyclicality is damaging for productive capacity and its distribution among the different producers of GDP (workers and owners of capital). Potential GDP is effectively a ceiling on actual GDP at any given time. Actual GDP cannot grow sustainably unless GDP* is growing as well - which will depend on the inputs it receives and on macroeconomic conditions.

The cyclical nature of economic performance is associated with large swings in aggregate demand, access to credit, exchange rates and the external balance. And the structural heterogeneity in the region means that different GDP producers are affected in different directions and intensities. 
Box IV.1

Recessionary and regressive asymmetries

- During the economic cycle, actual GDP tends to be lower than potential GDP. The ceiling is a maximum, not an average trend. Therefore, in general, instability is not neutral, but depresses actual total factor productivity (TFP) and employment, and the recessionary gap (the difference between actual GDP and GDP*) depresses gross capital formation.

- The allocative capacity of the exchange rate is weakened under a free rate, reducing the value added of exports and undermining the ability of SMEs to compete with imports.

- Financial investors can instantly adjust to abrupt changes in expectations and relative prices. Conversely, productive investors make irreversible allocation of resources and need quite long times. Instability favours speculative rather than real-sector investment. This depresses growth.

- Over the cycle, labour participation and employment rates fall for those who are least employable -i.e. the poorest - and informality rises. This is a regressive effect.

- A macroeconomic approach that neglects real economy stability hurts growth and equity, since it is both recessionary and regressive.

Source: Prepared by the author.

Real macroeconomic instability implies that, during recessions, actual GDP may be well below GDP* for long periods of time, which would affect its future growth, as it dampens real capital formation, employment and innovation. However, actual GDP, at most, can exceed potential GDP for only short periods. Of course, during recovery, actual GDP tends to grow more quickly than potential GDP, but will not match it until there is full employment. The gap between the two is termed a "recessionary gap", because it indicates underutilization of capital and vacant jobs. The fact that, in conditions of instability, the economy does not vary around GDP*, but mostly below it, points to an asymmetry that has a significant effect on economic growth and its distribution.

As discussed below, as long as there is a recessionary gap, downward pressure will remain on capital formation, the production of tradables and their value added and the quality of employment. Consequently, in order to promote growth and equity, economic output must come close to the production frontier, which will pull it upwards. However, the two have not been close often or for long enough. For the region overall, during most years between 1981 and 2012 there is evidence of significant recessionary gaps. 


\section{Recessionary gap and capital formation}

The question that arises from the information available is: why was gross capital formation so low during the heyday of the neoliberal reforms? The imbalances in the real economy, including significant gaps between real and potential GDP, are a major culprit. As numerous empirical studies have shown, the recessionary gap between real and potential GDP (a crucial macroeconomic imbalance) significantly reduces the investment rate, a key variable for economic growth. The experience of Latin America reveals a strong negative correlation between the size of the recessionary gap and the capital formation ratio. ${ }^{5}$ That close relationship with fixed capital investment is evidence of one of the main negative effects that factor underutilization has over time.

Several factors are responsible for this pernicious link: (i) a recessionary gap implies that available capacity is being underused, which lowers actual productivity (the standard measure of residual or total factor productivity); (ii) if sales decline, business owners cannot justify expanding capacity until their businesses are utilizing almost all of their existing capacity; (iii) lower profits mean that businesses have less cash of their own to finance new investments, while at the same time deterring investors from risking funds over the long term - which is precisely what irreversible investments imply; (iv) the resulting deterioration in companies' balance sheets usually coincide with a procyclical reluctance by capital market agents to finance firms facing recession-induced liquidity squeezes; (v) the volatile, uncertainty-breeding environment discourages irreversible investment; (vi) the recessionary gap and its fluctuations tend to affect the quality of project evaluations and discourage productive innovation; and (vii) large recessionary fluctuations tend to depress public revenue, leading to cuts in the public investment needed to complement private investment (Easterly and Servén, 2003). ${ }^{6}$

Thus, an array of compelling reasons, related to real macroeconomic imbalances, explain why the poor capital formation rate is so closely linked to economic cycles. The negative procyclical macroeconomic impact on

The issue is examined in further detail in Ffrench-Davis (2005, chapter III). Estimates for 1970-2003 for nine Latin American countries, concerning the majority of the population and regional GDP, are based on the work of ECLAC and of Hofman and Tapia (2003). Ffrench-Davis (2010) revisits this issue, with updated estimates covering up to2009 performed by those two coauthors. Investment refers to gross fixed capital formation (GFKF)).

6 The cycle's depressive impact on gross fixed capital formation is exacerbated by the fact that the drop in investment is often rather sudden, while recovery tends to be gradual. This new asymmetry produces lower average investment flows than would be obtained if both adjustments were symmetrical. 
capital formation overshadows the achievements of a more structural nature by the region to raise productivity and reduce structural heterogeneity through microeconomic and mesoeconomic reforms.

If recurrent recessionary gaps can be avoided, with a countercyclical policy that brings aggregate demand close to potential GDP and leads to a sustainable real exchange rate, potential investors could be encouraged to engage more fully. The dynamic effect will be much greater if economic actors have solid expectations about the ability of public policies to maintain the balance of the real economy, and if the authorities also undertake reforms to complement long-term capital markets, stimulate industrial innovation and improve labour force training.

As the recessionary gap disappears, many entrepreneurs who had mothballed potential projects will try to revive them. This requires time, given the array of factors needed to get an investment project off the ground. If the gap is closed for only a short time, however, as a result of imbalances that had been building up during the economic recovery, many potential investors will not have time to take their project to fruition before the next recession begins. This is another asymmetric impact of cyclicality and it helps to explain the meagre development achieved with neoliberal policies.

In this regard, the sustainability of the expansionary part of the cycle is crucial to promoting investment (see chapter V). Figure IV.4 shows that during economic recoveries, after a certain lag, gross capital formation gains momentum, only to lose it and slow down again when the next recession occurs. Therefore, the longer the capacity of capital and labour (that is, potential output) is close to being fully utilized, the larger the increase in the investment ratio will be. Consequently, real macroeconomic imbalances, such as increasing currency appreciation, with imports rising consistently faster than exports, high consumer debt or aggregate demand systematically outpacing production capacity, must not be allowed to develop during economic booms.

As noted earlier, since the 1980s, it has become customary for the economy to begin to recover, peak at close to full capacity and immediately slip into a new recession. In the last three decades, the economy has spent little time near to full use of productive capacity. The 1980s were marked by a major recessionary gap; in 1994 the economy peaked then fell in 1995; over the course of 1997-1998 it peaked again, followed by another contraction in late 1998; in 2003-2004 another boom began, which was stopped short by the brief contagion of 2008-2009, with a return to growth in 2010-2012, which slowed during 2013. 
Figure IV.4

Latin America (19 countries): gross capital formation, 1970-2012a

(Percentages of GDP, on the basis of dollars at constant 2005 prices)

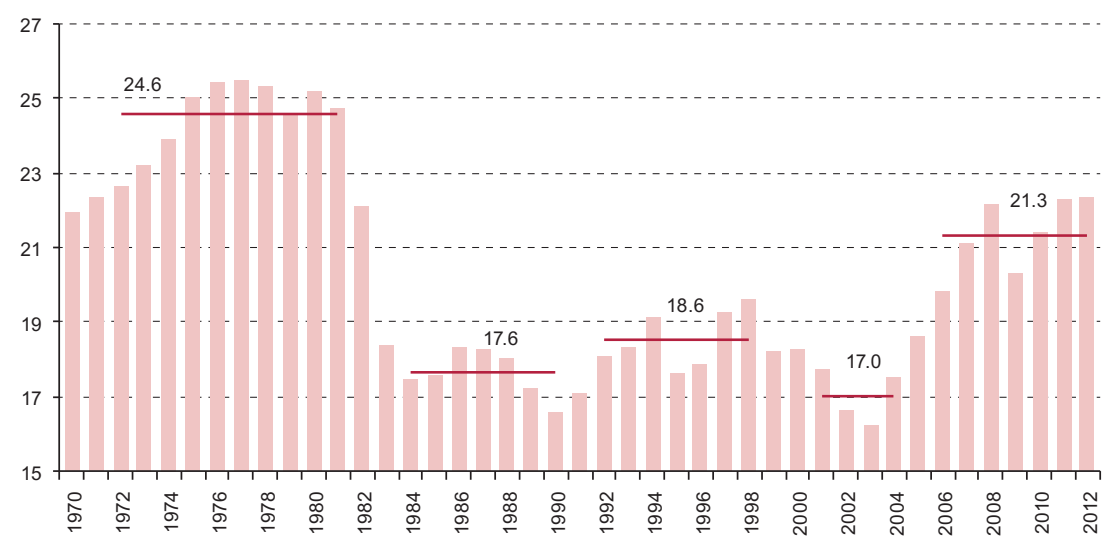

Source: Prepared by the author, on the basis of data from the Economic Commission for Latin America and the Caribbean (ECLAC).

a The horizontal lines indicate the average gross capital formation ratio in subperiods when it was growing (1972-1981, 1992-1998 and 2006-2012) or declining (1984-1990 and 2001-2004).

In summary, capital formation declines heavily in each recession and its recovery in boom periods tends to be gradual and lagged, indicating another large asymmetry. The gap thus remains and holds down the aggregate investment flows during the entire adjustment process, even if the marginal flow by the end of the cycle is similar to what it was at the beginning. Unfortunately, since the 1970s, the region has failed to keep production close to potential GDP for prolonged periods of time. Rather, high rates of capacity underutilization have been the norm, owing to real macroeconomic instability, generated by volatile capital flows and export prices, as well as procyclical macroeconomic policies, which have, on the whole, prevented strong gross fixed capital formation ratios from becoming the normal pattern.

\section{Exchange-rate instability and productive development ${ }^{7}$}

Development macroeconomics affords a strategic role to exchange rates, as the relative price that links the domestic and international economies, which is essential for the sustainability of macroeconomic balances and resource allocation. It is a key variable in decisions concerning resource allocation and consumption of tradable and non-tradable goods. The real average and

\footnotetext{
See, for example, Williamson (2008), Agosin (2007), Rodrik (2008), Eichengreen (2008), Ffrench-
} Davis (2010) and Ocampo (2011). 
the stability of the exchange rate are both crucial; in conditions of structural heterogeneity and asymmetric responses, exchange-rate instability exacerbates heterogeneity and inequality.

Some countries in the region formally adopted a free-floating exchange rate, with sporadic or exceptional interventions in certain cases. The region's experience shows that the real exchange rate has exhibited extremely procyclical behaviour: the evolution of the exchange rate has responded more strongly to changes in the financial account of the balance of payments than to changes in the current account. In fact, for lengthy periods, the exchange rate has been determined by short-term capital flows either managed by experts in creating capital — not productivity - gains, or driven by reversible terms-oftrade changes, a set up that fails to take into consideration current account misalignment. Given the protracted currency appreciation processes, which imply medium-term volatility, they tend to generate structural misallocation of resources. For example, it acts as a disincentive for adding value to exports of primary resources and leads producers to borrow in foreign currency in periods of mid-term appreciation, then followed by a recessionary situation and a sharp depreciation.

The free-floating exchange-rate regimes in place in most of the region during the 2000s may well have prevented the sort of exchange-rate crises typical of fixed nominal exchange rates. Paradoxically, however, many of the countries' exchange rates became highly sensitive to procyclical changes in the external funding supply, which had severe negative impacts on resource allocation and, particularly, on growth-enabling capital accumulation. The reforms freeing imports of multiple quantitative and tariff restrictions gave a leading role to exchange rates as key drivers of international competitiveness in the production of tradables.

It is often argued that agents can ride out sharp exchange-rate fluctuations by means of derivatives transactions, that is, buying or selling futures. When exporters can access them, futures are an effective means of insuring current production against price and interest rate fluctuations with respect to today's price relations. However, futures prices are, in fact, quite similar to spot prices, and equally variable. They are not effective at preventing the distorting medium-term allocative effects of instability on investment, which, it must be stressed again, is a fundamental variable in building productive capacity.

Consequently, another asymmetry often emerges. In cyclical booms, when expectations improve and capital markets become more receptive to new projects, the real exchange rate usually starts to rise and creates the expectation that appreciation will persist. This of course discourages investment in the production of tradables and in boosting their value added. This has not stopped governments from welcoming exchange-rate 
appreciation on occasions, insofar as inflation targets take precedence over growth, exports and sustainable employment; this is a clear example of pursuing inflation targets at the expense of growth. At the same time, import volume tends to increase much faster than export volume, weakening the structural current account.

The large currency devaluations that often occur in the next stage of the cycle, together with the economy's downward adjustment, tend to stimulate investment in tradable goods. However, this can be accompanied by considerable uncertainty, such that financial institutions generally restrict financing for new projects. Consequently, the market misses opportunity of the depreciation to boost productive capacity in tradables. The net result, after both stages of the cycle, is to weaken the allocative capacity of exchange-rate shifts and decrease both the production of tradables and their value added.

Exchange-rate instability clearly distorts project evaluations for resource allocation, promotes speculative rather than real investment, artificially crowds-out domestic production of importable tradable goods (many produced by SMEs), and discourages value added in exports.

This serious failure of exchange-rate policy constitutes a massive disadvantage for an export-led development strategy, particularly one aimed at non-traditional exports and those with a higher value added. These exports are the most likely to transmit externalities and to interact with SMEs. A managed flexible exchange rate - in any of its varieties- is an essential component of the variables needed for such a successful exportled development strategy.

To this end, the economic authorities must adopt a set of countercyclical policies. For example, the central bank could buy or sell foreign exchange, regulate the level and composition of flows, and establish stabilization funds of export revenue. Economic literature and the media often label exchangerate intervention as "anti-market" and that "the market" always trumps the intended aims. Since there is no single homogeneous market, but many markets with very different stakeholders, it is essential to determine which market is most relevant for achieving development. The real exchange rate must be consistent with its economic fundamentals (mainly the current account trend and the Balassa-Samuelson productivity theorem), in a world where foreign exchange is, partly, a financial asset that often behaves with regard for whether the evolution of the current account is sustainable until operators realize that the real exchange rate has become badly misaligned and abruptly realign it.

In a pro-development, functional approach, then, what is needed is to make real market forces - the producers of exportables and the importers and producers of importables, who are the key players in driving development 
in relation to the domestic economy's link with international markets- the strongest influence in determining the exchange rate; this must be made under the guidance of the authorities, focused on the sustainability of the current account. Any of the models of managed exchange-rate flexibility can be used for this purpose, adapted to the needs of each country (Williamson, 2008). This is "the market" that should gain ground, the market of generators of real-sector investment, innovation and productivity, not the market of short-term operators and rent-seekers.

In this context, the economic authority must implement a coherent and targeted countercyclical capital account policy, in conjunction with an array of other macroeconomic policies to ensure effectiveness. Without that capital account approach, there is no policy space for an effective macroeconomics for development in today's international financial markets, implying a cost in terms of both economic growth and equality. It is inherently contradictory for a developing economy to aspire to converge towards development if the determination of such strategic macroeconomic prices as real exchange rates is delegated to financial operators.

In short, in order to be consistent with a development strategy based on the production of tradable goods and services, exchange-rate policy must be radically reformed to better allocate productive resources and strengthen linkages (value chains) between tradables and the rest of the economy.

\section{Quality jobs and instability in the real economy}

The labour market structure is the most influential variable in income distribution, especially in economies with low tax burdens and modest levels of social expenditure (such as Latin American economies).

Despite the strides made in poverty reduction in the 1990s, a lasting breakthrough in employment conditions -with more stable jobs, adequate social protection and conditions in which workers can associate and enjoy bargaining power- remains elusive. Regardless of the significant progress made during the economic and social upturn of 2004-2008, precarious labour conditions were still common even before the global financial crisis which, naturally, made them worse. In 2009, when the economic boom came to a sudden stop, poverty and job insecurity increased, and the informal sector, far from continuing to recede before the increase in formality, regained ground. From 2007 to 2009-2010, own account workers increased as a proportion of the total employed, with most of the increase reflecting forced resort

8 The impact of the macroeconomic environment and the capital account on the level and quality of employment is examined in Ffrench-Davis (2012). 
to self-employment (ILO, 2010, table 2). The recovery of economic activity seen since 2010 is a return to the path of progress of 2004-2008. This led to an increase in employment, job formalization, income and real GDP, until the available production capacity limit was reached and the challenge of boosting the creation of new capacity had to be addressed, as capacity had increased only slightly.

Creating more and better jobs is crucial to gradually reducing severe inequalities in markets and societies. Macroeconomic policy must therefore look specifically at how the various policies affect large and small businesses, investment and consumption, and skilled and unskilled workers in different ways. Graduality and sound coordination among monetary, foreign-exchange, capital account, financial and fiscal policies, for example, have a substantial impact on economic growth and its distributive effects, particularly on the level and quality of employment.

A considerable social gap remains in the region, as the ratio between the richest and the poorest income quintile in Latin American countries duplicates that of G7 countries. Thus, the region remains highly regressive (World Bank, 2005), which is a direct consequence of its productive structures. As noted earlier, the sharp structural heterogeneity among companies of different sizes and workers with different skills permits inequalities in the functioning of markets. ${ }^{9}$ Vigorous growth requires much faster gains in the productivity of low-income sectors and, thus, in the employability of middle- and low-income workers. Contrary to the most commonly held neoliberal belief, there is a high level of complementarity among policies that simultaneously contribute to growth and reducing inequality in the labour market (Bourguignon and Walton, 2007; FfrenchDavis, 2014, chap. VII).

Instability in domestic demand and in the exchange rate has both static and dynamic effects on employment. Static effects include fluctuations in the utilization rate of available productive capacity in labour and capital stock. The large gaps that emerge repeatedly between installed capacity and actual GDP in turn cause gaps between full employment and actual employment. These recessionary gaps and the volatility of variables such as the real exchange rate, have had profound dynamic effects, as discussed above, on: (i) the expansion of the domestic capital stock; (ii) the weakening of labour organizations since, when unemployment rises, unskilled workers and smaller businesses suffer the most; (iii) the value-added intensity of exports and their linkages

For further discussion and empirical data on the severe structural heterogeneity in Latin American economies and its distributive implications, see Infante (2011). For information about Chile, see Sunkel (2011). 
with the rest of domestic output; (iv) the development of SMEs, which tend to be more labour-intensive and to compete with imports; and (v) the degree of formality or precariousness of employment and the rate of labour market participation.

One of the links between real macroeconomic instability and inequality is the widespread structural heterogeneity that characterizes developing economies. Given how dominant the neoliberal approach still is, with its belief in homogeneity and policy "neutrality", it is essential to understand the diverse capacities for action and reaction of typical agents in different markets. Therefore, the heterogeneity between large- and small-scale entrepreneurs, highly skilled and unskilled workers, productive and financial investors, and productive investors and consumers, must be taken into account, as well as the high domestic and international mobility of financial capital and highly skilled labour, in contrast with the limited mobility of physical capital and unskilled workers.

The asymmetries resulting from this heterogeneity are intensified by highly unstable economic activity and macroprices. For example, income distribution tends to worsen during recessions and improve, albeit more gradually, during recoveries; an asymmetry that has regressive effects on the balance sheets of households and businesses. Another effect is to weaken economic reform efforts, which need to be sustained over the long term. In addition, when financial inflows are abundant, a substantial part of them is consumed, because consumption responds faster than investment to an increased supply of funds, and the financial market has become more adept at financing the consumption or purchase of existing assets than at the long-term financing of productive investment. If this is accompanied by currency appreciations, as is often the case, the bias is exacerbated by higher imports of consumer goods, which diverts "foreign savings" into national "dissavings".

So, a boom period leaves large liabilities without a countervailing payment capacity. The usual shift in expectations, reversal of financial flows and sudden devaluations lead to a recessionary adjustment, with drops in domestic demand. This, in turn, exerts a downward pull on production, employment and its degree of formality, and, therefore, on tax revenue. This has been the dynamic in the region in recent years, with a persistently low gross capital formation ratio (despite high export prices and capital inflows) and a growing imbalance between import and export volumes (see box IV.2 and figure IV.3). This is compounded by the limited impact of social protection institutions, which have little countercyclical and progressive capacity to transfer income in the event of a crisis, whether for purposes of reintegration into the labour market, training or compensation for lost earnings (ILO/ECLAC, 2011). 


\section{Box IV.2}

\section{Current situation in Latin America}

In 2010-20111 Latin America underwent a significant economic recovery, similar to the one in 2004-2008.. By 2012, it was hitting the productive ceiling, which explains why actual GDP growth slowed in 2012.

- Terms-of-trade and positive financial shocks increased domestic demand in 2004-2008 and 2010-2012, in an environment dominated by external restrictions in 2003 and 2009. These reactivated GDP, sweeping the real economy towards the ceiling (positive) and causing the exchange rate to appreciate (negative). No radical structural or macroeconomic change can explain the jumps in GDP growth; it was caused by the effect of positive external shocks on aggregate demand and existing underutilized productive capacity.

- Exports continued to focus on natural resources, with low domestic value added and cyclically unstable prices. In this period of high prices, the volume of imports grew significantly faster than the volume of exports.

- Gross capital formation increased and reached its highest level since the Washington Consensus. This is quite positive and was mainly due to the closeness to GDP* during a longer period (about 8 years). However, the gross capital formation rate is still lower than the average for the decade prior to the debt crisis, and national savings have dwindled (duly controlling for terms-of-trade effects). The region is dangerously dependent on highly favourable, but extremely transitory, terms of trade and financial flows.

Source: Prepared by the author, on the basis of figures from the Economic Commission for Latin America and the Caribbean (ECLAC).

As noted earlier, highly cyclical changes in many countries' real exchange rate have distorted investment decisions. The booms, with the attendant currency appreciation, tend to generate excesses in luxury construction and in marketing imports, which create temporary jobs that will not be sustainable when the ever-growing external deficit is corrected. On the other hand, they artificially crowd out production of tradables that compete with imports (many produced by SMEs). They also discourage diversification towards non-traditional goods more intensive in value added and the addition of value to traditional exports; they all negatively affect sustainable employment and job quality. So, economic booms imply some creation of temporary employment and destroy some more permanent jobs.

An unstable real economy has asymmetrical distributive effects and inevitably implies underutilization of potential productivity, with lower actual output, fewer jobs and an expanding informal sector, compared with a more stable real economy. It would appear obvious that higher rates of capital utilization indicate a higher rate of average employment and the 
combination of the labour force with a larger volume of utilized physical capital. The resulting increase in actual productivity means that the well-being of workers and investors (wages and profits) can be improved, by making better use of capacity and promoting a virtuous circle of more investment, innovation and jobs. That is the mission of macroeconomic policies, which should be complemented with industrial development and training policies and reforms, including of capital markets.

In short, the large upswings and downturns in economic activity, caused by unstable aggregate demand and exchange rates, affect the level of employment, job formality, the nature of employment contracts and wage trends. Given the structural heterogeneity of the markets in the region, instability in the real macroeconomy has a distinctly regressive effect on income distribution and job quality.

\section{Concluding remarks}

The macroeconomic environment has several effects on development, including on: (i) the investment ratio; (ii) the value added generated by exports and their interaction with the rest of GDP; (iii) innovation and its distribution among different sectors of the economy; (iv) the development of SMEs; (v) the degree of formality or precariousness of the labour market; and (vi) the budget. The style of macroeconomic policy significantly affects all of these variables

Productive investors and employment have been subjected to great instability in the real macroeconomy, with large recessionary gaps, in a notably incomplete financial market, particularly in the case of financing for smaller businesses. In turn, real economy instability has been closely associated with the cycles of financial flows to and from abroad, which, in addition to their great procyclical volatility, have little connection with real-sector investment. "Financierism" has dominated instead of productivism (FfrenchDavis, 2010). The main reason for this is the existence of an international financial market dominated by short-term operators, whose behaviour is often inherently procyclical and flows mostly in a manner disconnected from capital formation. This deficiency is compounded by the fact that international financial market volatility has caused financial and currency crises in emerging economies open to these flows, the recessionary effects of which have discouraged capital formation and job creation. Increasing integration with more volatile international financial markets, which often means indiscriminately opening the capital account, has led to greater instability and thinning of financial markets. A fact as obvious as the large increase in financial savings and the persistently low and concentrated productive investment ratios cannot be ignored. 
Given that fluctuations do not occur symmetrically around full employment, but asymmetrically with clear depressive and regressive biases, the economies of the region have often exhibited activity levels well below full employment, in other words, with large recessionary gaps. This strongly discourages real investment and introduces a regressive bias because of its negative effect on employment and on smaller firms. As long as certain stability is achieved in the real economy, thus narrowing the recessionary gaps, it will help to increase capital formation, sustainable employment and potential GDP. These consequences are not distributively neutral, given the prevailing structural heterogeneity, since the existence of the gap often has particularly severe negative repercussions for SMEs, less skilled workers, and non-wealthy sectors. Heterogeneity in access to financing reinforces inequalities in productive capacity, a vicious circle that renders less capitalized businesses vulnerable and makes it difficult for them to grow, thereby increasing the income gap as a result of real macroeconomic instability; thus, the recessionary bias is also regressive. Therefore, policies must be formulated to promote and sustain growth for longer periods, avoiding the vulnerabilities that have led to new recessionary adjustments in each economic boom; they must seek to stabilize domestic demand and macroeconomic prices, such as the exchange rate.

Additionally, reform of the neoliberal reforms should make it a priority to link the financial system (both the national financial market and the capital account) to the domestic investment process, rather than the short-termist, speculative external financial markets. It must help to stabilize domestic demand and macroeconomic prices, such as the exchange rate.

The challenge of a macroeconomics for development is to design a set of instruments - fiscal, monetary, exchange-rate, domestic financial market and capital account regulations - that takes into account the relationship between the short and long terms, reconciles real economic stability with more dynamic long-term growth and promotes social inclusion. This requires a set of efficiently coordinated policies. There is no room for independent functioning that could upset this coordination, or for more importance to be given to one objective at the expense of others. Specifically, this requires: (i) fiscal and tax policies consistent with financing social development programmes, public investment and development policies; (ii) an aggregate demand consistent with full employment GDP; and (iii) an exchange-rate evolution that is sustainable over the long term, in line with the current account balance. These are basic conditions for real macroeconomic balances.

Given the current and foreseeable international situation, for these policies to be viable, countercyclical regulation of the capital account and mechanisms to stabilize export earnings are needed, as their prices are highly 
cyclical. Countercyclical regulation of capital account inflows and outflows must seek to achieve sustainable balances in the real macroeconomy, that is, the opposite of trying to perpetuate imbalances. ${ }^{10}$

In fact, in emerging economies, such as those of Latin American countries, effective and efficient capital account countercyclical regulation would allow active monetary and exchange-rate policies to be implemented simultaneously in a countercyclical fashion and, in parallel, the local financial system to be reorganized, in order to channel resources towards productive investment, with an inclusive bias, helping to reduce structural heterogeneity between different productive and social sectors. Therefore, this regulation is a prerequisite for progress towards a macroeconomics for development (Ocampo, 2011).

For vigorous growth, the productivity of poor and middle-income groups must be improved, since inequality and poverty are increasingly seen to be a drag on economic development (Bourguignon and Walton, 2007). To this end, the design of a reformed financial system is crucial to reducing the high structural heterogeneity of the region's economies. This means actively developing SME financing at different scales and through a variety of institutions. The incompleteness of existing capital markets has been an insurmountable barrier, preventing many SMEs from making development strides.

The manner in which domestic capital markets are reformed and the linkages with international financial markets will be crucial to achieving a sustainable macroeconomics for development and reducing structural heterogeneity, and thus inequality. Productive structures must be created to gradually foster more equitable markets, by narrowing the productivity and income gaps among companies of different sizes and workers from different social backgrounds and with different skills, thanks to the steady decline in structural heterogeneity.

10 There are examples of highly procyclical controls or attempts to perpetuate unsustainable imbalances. By contrast, several Latin American countries have engaged in interesting countercyclical regulation efforts (see, for example, ECLAC (2010)). These include Chile's successful attempt in the first half of the 1990s, which illustrates that countercyclical capital controls can be efficient in terms of development when they are consistent and comprehensive (see Ffrench-Davis (2014, chap. VIII) and Magud and Reinhart (2007)). 


\section{Bibliography}

Agosin, M. R. (2007), "Trade and growth: Why Asia grows faster than in Latin America", Economic Growth with Equity: Challenges for Latin America, R. FfrenchDavis and J.L. Machinea (eds.), New York, Palgrave Macmillan.

Blanchard, O., G. Dell'Ariccia and P. Mauro (2010), "Rethinking macroeconomic policy", IMF Staff Position Note, SPN/10/03, Washington, D.C., International Monetary Fund (IMF), February.

Bourguignon, F. and M. Walton (2007), "Is greater equity necessary for higher longterm growth in Latin America?", Economic Growth with Equity; Challenges for Latin America, R. Ffrench-Davis and J.L. Machinea (eds.), New York, Palgrave Macmillan.

Easterly, W. and L. Serven (2003), The Limits of Stabilization: Infrastructure, Public Deficits and Growth in Latin America, Stanford, Stanford University Press.

ECLAC (Economic Commission for Latin America and the Caribbean) (2013a), Economic Survey of Latin America and the Caribbean, 2013 (LC/G.2574-P), Santiago. (2013b), Social Panorama of Latin America, 2013 (LC/G.2580), Santiago.

(2012), Structural Change for Equality: An Integrated Approach to Development (LC/G.2524(SES.34/3)), Santiago.

(2010), Time for equality: closing gaps, opening trails (LC/G.2432 (SES.33/3)), Santiago.

Eichengreen, B. (2008), "The real exchange rate and economic growth", Working Paper, No. 4, Washington, D.C., Commission on Growth and Development.

Erten, B. and J.A. Ocampo (2012), "Super cycles of commodity prices since the midnineteenth century", World Development, vol. 44.

Ffrench-Davis, R. (2014), Chile, entre el neoliberalismo y el crecimiento con equidad. Cuarenta años de políticas económicas y sus lecciones para el futuro, Santiago, JC Sáez Editor.

(2012), "Employment and real macroeconomic stability: the regressive role of financial flows in Latin America", International Labour Review, vol. 151, No. 1, Geneva, International Labour Organization (ILO).

(2010), "Macroeconomics for development: from "financierism" to "productivism"", CEPAL Review, No. 102 (LC/G.2468-P/E), Santiago, Economic Commission for Latin America and the Caribbean (ECLAC), December.

_(2005), Reforming Latin AmericanEconomies:After Market Fundamentalism London and New York, Palgrave Macmillan.

(1988), "An outline of a neo-structuralist approach", CEPAL Review, No. 34 (LC/G.1521-P), Santiago, Economic Commission for Latin America and the Caribbean (ECLAC), April.

Gallagher, K., S. Griffith-Jones and J.A. Ocampo (eds.) (2012), Regulating Global Capital Flows for Long-Run Development, Boston, Boston University.

Hofman, A. and H. Tapia (2003), "Potential output in Latin America: a standard approach for the 1950-2000 period", Estudios estadisticos y prospectivos series, No 25 (LC/L.2042-P), Santiago, Economic Commission for Latin America and the Caribbean (ECLAC).

ILO (International Labour Organization) (2010), 2010 Labour Overview. Latin America and the Caribbean, Lima.

ILO/ECLAC (International Labour Organization/Economic Commission for Latin America and the Caribbean) (2011), "Countercyclical policies for a sustained 
recovery in employment", The employment situation in Latin America and the Caribbean, No. 5 (LC/G.2475-P), Santiago, June.

Infante, R. (2011) (coord.), El desarrollo inclusivo en América Latina y el Caribe: ensayos sobre politicas de convergencia productiva para la igualdad, Libros de la CEPAL, No. 112 (LC/G.2500-P), Santiago, Economic Commission for Latin America and the Caribbean (ECLAC).

Kaminsky, G., C. Reinhart and C. Vegh (2004), “When it rains, it pours: procyclical capital flows and macroeconomic policies", NBER Working Paper, No. 10780, January.

Krugman, P. (2011), "How did economists get it so wrong?", New York Times, 6 September.

Magud, R. and C. Reinhart (2007), "Capital controls: an evaluation”, Capital Controls and Capital Flows in Emerging Economies: policies, practices and consequences, S. Edwards (ed.), Chicago, University of Chicago Press.

Ocampo, J. A. (2011), "Macroeconomy for development: countercyclical policies and production sector transformation", CEPAL Review, No. 104 (LC/G.2498-P/E), Santiago, Economic Commission for Latin America and the Caribbean (ECLAC), August.

Ocampo, J.A. and J. Ros (2011), (eds.), The Oxford Handbook of Latin American Economics, New York, Oxford University Press.

OECD (Organization for Economic Cooperation and Development) (2013), OECD Economic Surveys: CHILE, Paris.

Ostry, J. and others (2011), "Managing capital inflows: What tools to use?", IMF Staff Discussion Note, No. 11-06, Washington, D.C., International Monetary Fund (IMF).

Rajan, R. (2011), Fault Lines: How Hidden Fractures Still Threaten the World Economy, Princeton, Princeton University Press.

Rodrik, D. (2011), The Globalization Paradox, New York, W.W. Norton. (2008), "The real exchange rate and economic growth", Brookings Papers on Economic Activity, Washington, D.C., Brookings Institution Press.

Sunkel, O. (2011), El presente como historia: dos siglos de cambios y frustración en Chile, Santiago, Catalonia.

Tapia, H. and J.C. Guataqui (2013), "Politicas economicas para el crecimiento", Santiago, Economic Commission for Latin America and the Caribbean (ECLAC), unpublished.

Williamson, J. (2008), "Do development considerations matter for exchange rate policy?", Current Account and External Financing, K. Cowan and S. Edwards (eds.), Santiago, Central Bank of Chile. (2003), "Overview: an agenda for restarting growth and reform", After the Washington Consensus: Restarting Growth and Reform in Latin America, P.P. Kuczynski and J. Williamson (eds.), Washington D.C., Institute for International Economics.

World Bank (2005), World Development Report 2006: Equity and Development, New York, Oxford University Press. 
Chapter V

\title{
Macroeconomics for development in Latin America and the Caribbean: new thoughts on countercyclicality
}

\author{
Daniel Titelman \\ Esteban Pérez Caldentey ${ }^{1}$
}

\section{Introduction}

Macroeconomics for development in Latin America and the Caribbean is traditionally structured around two issues: an active production development and diversification strategy and a countercyclical policy stance (Ocampo, 2011; Ffrench-Davis, 2010).

The production development strategy seeks, among other things, to improve productivity, foster innovation to promote the accumulation of technological capabilities and boost the region's capacity to export higher value added goods and services. Countercyclical policies are required to moderate the pronounced macroeconomic volatility that has characterized the region's performance over the past three decades.

Financing for Development Division of the Economic Commission for Latin America and the Caribbean (ECLAC). The authors wish to thank Pablo Carvallo and Manuel Cruz for their valuable research assistance. They are also grateful for the comments they received on an earlier version of this paper, which was presented at the ECLAC seminar on Neostructuralism and Heterodox Economics (22 and 23 April 2013). 
This chapter focuses on macroeconomic countercyclicality. The blueprint model of macroeconomics for development views volatility as harmful to long-term growth, because it shortens economic agents' planning horizons and heightens risk, and it discourages productive investment and distorts macroeconomic prices such as exchange rates and real interest rates. ${ }^{2}$

Increased volatility is mainly associated with external shocks in the capital account and, more recently, in the terms of trade. This balance of payments dominance has occurred against a backdrop of greater financial openness, which makes the region's countries vulnerable to the changes taking place in the modalities and availability of external financing, interest-rate fluctuations (the narrowing of risk spreads is accentuated in boom periods) and externally determined prices.

Reducing volatility means moderating fluctuations in real and monetary variables and stabilizing them around their long-term trends. This in turn requires controlling the level of aggregate demand through monetary and fiscal policies and capital account management, to restrain demand during the upswing of the cycle and boost it in the downswing. In the expansionary phase, countercyclical policies aim to avert situations of excess domestic expenditure and overheating that fuel unsustainable debt levels, inflationary pressures or current account deficits. In the contractionary phase, an expansion of aggregate demand mitigates the costs generated by high levels of unemployment and social vulnerability.

This chapter argues that while nominal volatility has declined, real volatility has remained at high levels; and this reflects not only balance-ofpayments dominance but also the specific characteristics of the business cycle in the region. In particular, it shows that growth phases in Latin America and the Caribbean are less intensive, in terms of duration and extent, than those of other regions; and, consequently, the frequency of the region's business cycle is relatively greater.

Another key feature of the cycle highlighted in this chapter is that short-term fluctuations have a bearing on long-term outcomes; and that the relation between the short and longer run is mediated by real and financial variables. First, the cyclical behaviour of real variables, such as productivity and investment, that are linked to long-term growth performance, mimics the weak expansionary phase of the general business cycle. Second, the behaviour of credit cycles shows that the financial system magnifies GDP fluctuations during expansions and even more so during contractions.

Ffrench-Davis (2010) argues that volatility affects long-term economic growth through its effect on fixed capital investment. 
Another specific feature of the Latin American business cycle is that credit contractions outlast GDP downswings, which means that GDP recovers ahead of credit, and variations in credit tend to lag GDP fluctuations. Creditless recoveries, in conjunction with the behaviour of real variables such as productivity and investment, can account for the tenuous nature of cyclical upswings in Latin America.

Pulling these stylized cycle facts together, this chapter argues that the received wisdom on macroeconomics for development needs to develop further and explicitly recognize the interdependence that exists between cycle and trend, and between countercyclicality and the production structure. ${ }^{3}$

More precisely, an effective countercyclical policy should focus on the behaviour of the real and financial variables that link short-term fluctuations to long-term outcomes.

This analysis has two important policy implications. First, countercyclical and production development policies should not be presented as dichotomous elements of fully fledged macroeconomics for development; rather, the interrelationship between the two should constitute its starting point. Second, countercyclical policies should focus not only on managing the level of aggregate demand, but also on influencing its composition.

This chapter is divided into seven sections. Sections A and B describe empirical tests that corroborate the two main propositions of macroeconomics for development, as applied to Latin America and the Caribbean. One is that the region has experienced high levels of volatility relative to its own past history and also compared with other developing regions; and, secondly, volatility is explained by balance-of-payments dominance. Section $C$ argues that the region's high levels of volatility and meagre growth performance can also be explained by the specific features of the business cycle in Latin America and the Caribbean. Sections D and E focus on the real and financial transmission mechanism that mediates the cycle and trend. Section F reviews countercyclical policies in the context of the blueprint model of macroeconomics for development, and suggests ways to modify it. The concluding section sets forth final thoughts.

Cycle-trend interdependency was first identified by Kalecki (1968). See also Davidson (2011) and Arestis and Sawyer (2009). Ocampo (2011) and Ffrench-Davis (2010) have also analysed linkages between macroeconomic conditions and the production structure, focusing on the behaviour of macroprices, including in particular the real exchange rate, which is considered as a key "transmission variable" in emerging market economies such as those of Latin America and the Caribbean. Another transmission channel is the size of the gap between real demand and the production frontier (Ffrench-Davis, 2010). A higher rate of capacity utilization (a smaller gap) can help increase average productivity, which in turn would stimulate the creation of new capacity. In contrast, a recessionary gap could involve less investment, which would have the effect of depressing an economy's productive capacity. 


\section{A. The long-run performance of Latin America and the Caribbean: high volatility and low growth}

Over the last three decades, the economic performance of Latin America and the Caribbean has been characterized by increasing volatility in production and investment. ${ }^{4}$ As shown in table V.1, production volatility, measured by the coefficient of variation of GDP, was below 1 in the 1960s and 1970s but has been systematically above that threshold since the 1980s.

Table V.1

Selected regions and groupings: coefficient of variation of the rate of growth of per capita GDP, 1960-2011

\begin{tabular}{|c|c|c|c|c|c|c|}
\hline Region or grouping & $\begin{array}{c}1960- \\
1970\end{array}$ & $\begin{array}{c}1970- \\
1980\end{array}$ & $\begin{array}{c}1980- \\
1990\end{array}$ & $\begin{array}{l}1990- \\
2000\end{array}$ & $\begin{array}{l}2000- \\
2007\end{array}$ & $\begin{array}{c}2000- \\
2011\end{array}$ \\
\hline East Asia and the Pacific & 2.92 & 0.53 & 0.27 & 0.40 & 0.23 & 0.20 \\
\hline Europe and Central Asia & $\ldots$ & $\ldots$ & $\ldots$ & -3.17 & 0.33 & 0.83 \\
\hline Latin America and the Caribbean ${ }^{b}$ & 0.71 & 0.39 & -6.77 & 1.39 & 1.17 & 1.22 \\
\hline Middle East and North Africa & 0.65 & 1.77 & -15.76 & 0.88 & 0.54 & 0.47 \\
\hline South Asia & 1.25 & 3.72 & 0.43 & 0.50 & 0.45 & 0.43 \\
\hline Sub-Saharan Africa & 0.84 & 1.81 & -1.98 & -3.81 & 0.58 & 0.62 \\
\hline World & 0.34 & 0.95 & 0.96 & 0.64 & 0.50 & 1.26 \\
\hline $\begin{array}{l}\text { High-income countries (Organization } \\
\text { for Economic Cooperation } \\
\text { and Development - OECD) }\end{array}$ & 0.32 & 0.81 & 0.60 & 0.46 & 0.44 & 1.90 \\
\hline North America & 0.70 & 1.30 & 1.27 & 0.78 & 0.58 & 2.27 \\
\hline
\end{tabular}

Source: Prepared by the authors on the basis of World Bank, World Development Indicators and Global Finance, 2013.

Note: Three dots (...) indicate that data are not available.

a The coefficient of variation is defined as the ratio between the standard deviation $(\sigma)$ and mean $(x)$ of the per capita GDP growth rate. The period 2007-2011 was excluded to prevent the effect of the 2008-2009 global crisis from biasing the average for that period, since the aim is to show a GDP growth rate trend (the crisis impacted Latin America and the Caribbean in 2009 and the GDP growth rate contracted by 1.9\%).

b The sample includes 33 of the region's countries.

\footnotetext{
In contrast, nominal volatility diminished significantly. The region made major progress on inflation, in terms of both its level and its volatility. Between 1980 and 1989, inflation averaged around $130 \%$ per year, with the highest rates being recorded in South American countries, where the average was $270 \%$. Central America recorded significantly lower rates, although prices surged by around 122\% between 1985 and 1989. By the second half of the 1990s, however, the region reported an average inflation rate of around $14 \%$, and much lower in Caribbean and Central American countries. The downward trend in inflation has been maintained over time, and between 2000 and 2012, it averaged around 6\%. Along with the reduction in the rate, there was a significant reduction in price level volatility. Despite the significance of this structural break in the inflation trend, the reduction of inflation and its volatility was a regionwide phenomenon. More specifically, the reductions were achieved independently of the specific monetary regime prevailing in each country and its initial inflation level. Between 1982 and 1990, all Latin American countries, except for Haiti, Honduras and Panama, had inflation rates above single-digit levels; but from 1997 onwards, most countries reduced their inflation rates from two digits to one.
} 
Moreover, not only has volatility increased over time, but it has been greater in Latin America and the Caribbean than in other regions of the developing world (Titelman, Pérez Caldentey and Minzer, 2008; ECLAC, 2002 and 2012).

The trend of volatility in the Latin American and Caribbean economies stands in stark contrast to that of other regions of the world, which have seen volatility diminish in the period under consideration. An emblematic case is East Asia and the Pacific, which reported a coefficient of variation of 2.9 between 1960 and 1970 but just 0.22 in the 2000 decade. Africa and the Middle East also registered coefficients above 1 between 1970 and 1980 and below 1 in the 1990s and in the 2000 decade; and the trend in South Asia has been similar.

The increase in real volatility has been detrimental to growth in both the short and the long runs. Evidence for 1971-2008 shows that measures of volatility in GDP growth rates and investment are inversely related, with correlation coefficients of -0.70 and -0.73 , respectively, and significant at the 95\% confidence level.

It is therefore unsurprising that, partly as a result of the increase in real volatility over time and its detrimental effects on growth, the Latin American and Caribbean region has experienced not only mediocre growth on average but also lower long-run growth than other regions. Table V.1 shows the trend of per capita GDP growth in the region and in countries that are members of the Organization for Economic Cooperation and Development (OECD) (high-income countries), along with selected regions of the developing world in 1960-2011.

Figure V.1

Latin America (20 countries): ratio between investment volatility and the rate of growth of GDP, 1971-2008

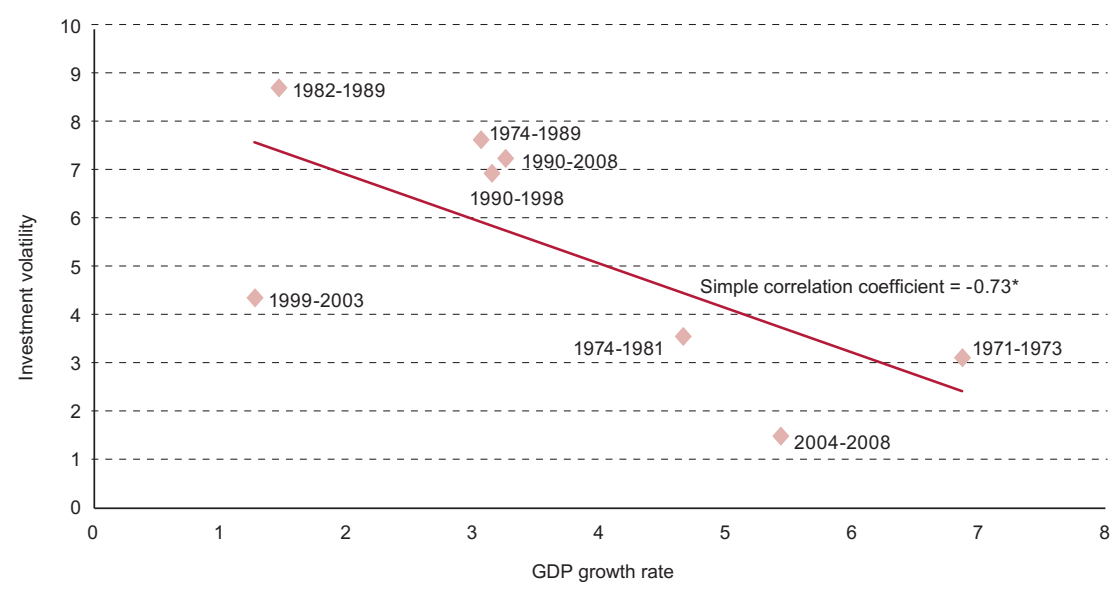


Figue V.1 (concluded)

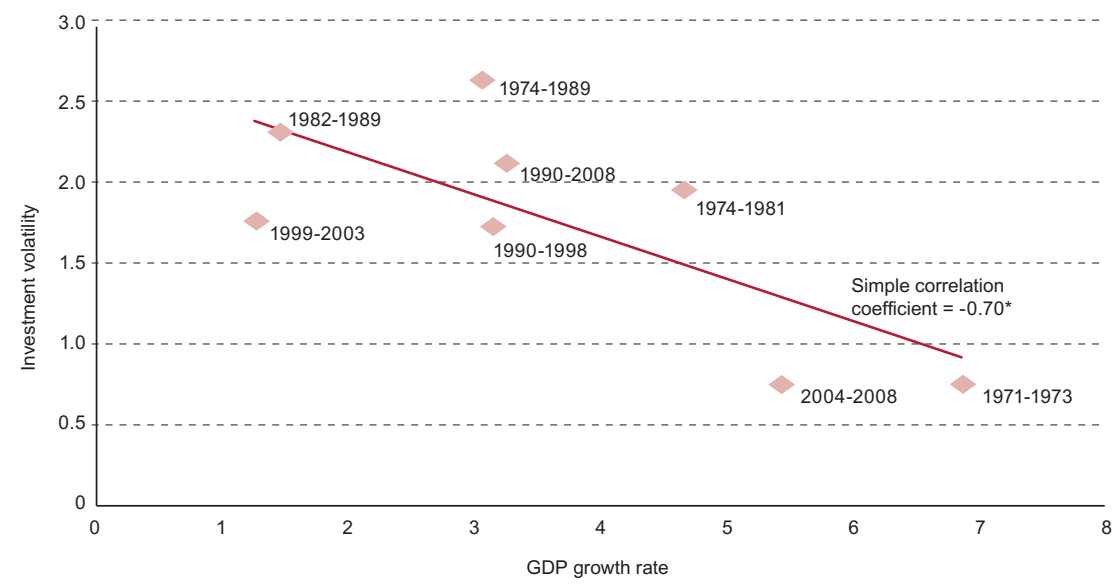

Source: Economic Commission for Latin America and the Caribbean (ECLAC), 2012.

a Although volatility in GDP and investment is measured here by the standard deviation, similar results are obtained when the coefficient of variation is used as an alternative measure. The sample includes countries from South America and Central America, along with Cuba, the Dominican Republic, Haiti and Mexico.

b An asterisk $\left({ }^{*}\right)$ denotes a coefficient that is significant at the $95 \%$ confidence level.

The evidence shows that, in the 1970s, Latin America and the Caribbean recorded higher levels of per capita GDP growth than any other region except for East Asia and the Pacific. Since then, it has had one of the lowest per capita GDP growth rates among developing regions in most of the periods studied (1981-1990; 1991-2000; 2001-2009; 2001-2011). Moreover, the growth differential between Latin America and the Caribbean and other regions, such as East Asia and the Pacific, has widened over time (see table V.2).

The most recent upswing (2003-2007) is not an exception to the observed trend, even though the region achieved its highest average growth rates for over three decades. The regional average per capita growth rate was 3.7\%, which not only surpassed the rate recorded in the lost decade of the 1980s and the $1.6 \%$ achieved in the era of market-based structural reforms (1991-2000), but also the 3.2\% attained in the 1970s.

Nonetheless, compared with other regions, the performance of Latin America and the Caribbean was by no means exceptional. In fact, the region's growth rate lagged far behind those of East Asia and the Pacific (9.3\%), Europe and Central Asia (7.4\%) and South Asia (6.6\%). 
Table V.2

Selected regions and groupings: per capita GDP growth, 1971-2011 (Percentages)

\begin{tabular}{cccccccc}
\hline & $\begin{array}{c}\text { East } \\
\text { Asia } \\
\text { and the } \\
\text { Pacific }\end{array}$ & $\begin{array}{c}\text { Europe } \\
\text { and } \\
\text { Central } \\
\text { Asia }\end{array}$ & $\begin{array}{c}\text { High- } \\
\text { income } \\
\text { countries } \\
\text { (OECD) }\end{array}$ & $\begin{array}{c}\text { Latin } \\
\text { America } \\
\text { and the } \\
\text { Caribbean }\end{array}$ & $\begin{array}{c}\text { Middle } \\
\text { East and } \\
\text { North } \\
\text { Africa }\end{array}$ & $\begin{array}{c}\text { South } \\
\text { Asia }\end{array}$ & $\begin{array}{c}\text { Sub- } \\
\text { Saharan } \\
\text { Africa }\end{array}$ \\
\hline $1971-1980$ & 4.5 & $\ldots$ & 2.7 & 3.2 & 2.7 & 0.7 & 0.9 \\
\hline $1981-1990$ & 5.7 & -1.7 & 2.7 & -0.8 & 0.2 & 3.0 & -0.9 \\
\hline $1991-2000$ & 7.1 & -1.7 & 1.9 & 1.6 & 1.8 & 3.2 & -0.3 \\
\hline $\mathbf{2 0 0 3 - 2 0 0 7}$ & $\mathbf{9 . 3}$ & $\mathbf{7 . 4}$ & $\mathbf{1 . 9}$ & $\mathbf{3 . 7}$ & $\mathbf{3 . 3}$ & $\mathbf{6 . 6}$ & $\mathbf{3 . 0}$ \\
\hline $2001-2011$ & 8.2 & 4.7 & 0.9 & 2.2 & 2.6 & 5.3 & 2.1 \\
\hline
\end{tabular}

Source: Prepared by the authors on the basis of World Bank, World Development Indicators and Global Finance, 2013.

a Three dots (...) indicate that data are not available.

\section{B. Balance-of-payments dominance}

High levels of real volatility in Latin America and the Caribbean are associated with a second characteristic of the region's economies, namely balance-of-payments dominance in a context of financial openness. Balanceof-payments dominance is defined as a macroeconomic system in which the short-term macroeconomic dynamic is determined essentially by external financial and terms-of-trade shocks that may be either positive or negative (Ocampo, 2011).

Balance-of-payments dominance has traditionally been associated with capital account shocks and cycles. This is because the main procyclical shocks that have affected the region, including the 1981-1984 debt crisis, the Mexican crisis of 1995, the 1997 Asian crisis, the 2001-2002 Argentine crisis and the most recent global financial crisis of 2008-2009, were all triggered by sudden stops in external financing.

This is illustrated in figure V.2, which shows the trend of the rolling correlation coefficients between the GDP cycle and financial flows, and between the GDP cycle and the terms of trade in 1993-2011. As the figure shows, the correlation coefficient between GDP and the financial cycle is statistically significant throughout most of the period (in other words it is above the dotted line which indicates the statistical significance threshold). 
Figure V.2

Latin America and the Caribbean: trend of the rolling correlation coefficient between GDP cycles and financial flows, and between GDP cycles and the terms of trade with a five-year window, 1993-2011

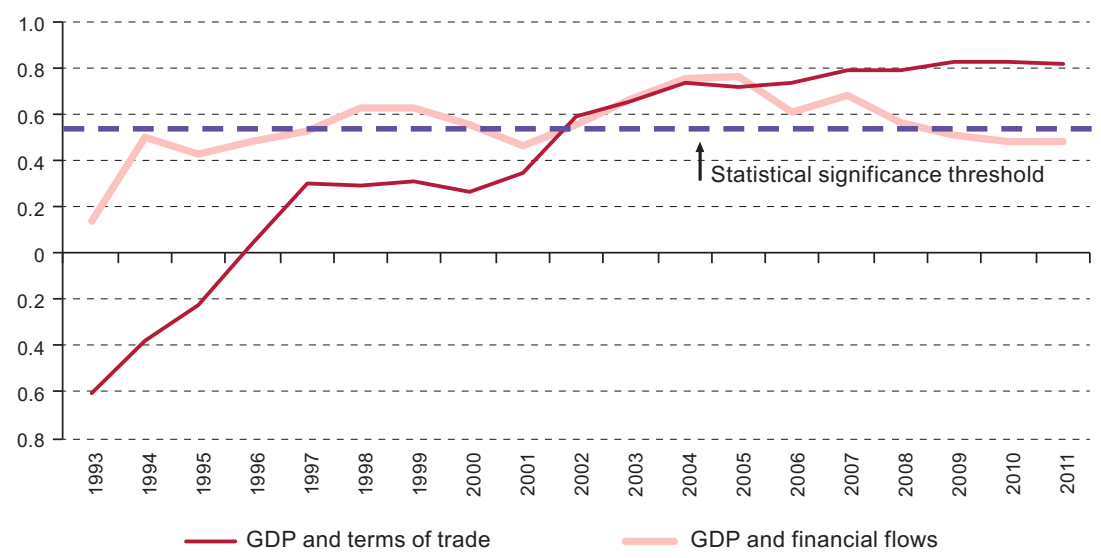

Source: Prepared by the authors on the basis of World Bank, World Development Indicators and Global Finance, 2013.

Note: The statistical significance threshold refers to a $95 \%$ confidence level.

Moreover, in more recent periods and particularly since the decade of the 2000s, fluctuations in economic activity have not only depended on the availability of external financing, but have also been closely related to commodity price movements and thus to the terms of trade. The correlation coefficient between the GDP cycle and the terms of trade is not significant (at a 95\% confidence level) in 1993-2001; but it becomes significant thereafter, reflecting the influence of the commodity price boom and the terms of trade on the region's national economies.

Consequently, balance-of-payments dominance reflects the fact that regional and national fluctuations depend not only on external financial cycles but also on real (terms-of-trade) cycles.

Table V.3 provides further evidence of balance-of-payments dominance, which is reflected in a coefficient of synchronicity between the Latin American cycle and that of its subregions with the cycles of the United States, Europe and China. Synchronicity between a country or region (region i) and a benchmark region (for example the United States, Europe and China, or one of them separately) (region $\mathrm{r}$ ) is calculated using the following formula (Mink, Jacobs and de Haan, 2012):

$$
\text { (1) } \varphi(t)=\frac{1}{n} \sum_{i=1}^{n} \frac{g_{i}(t) g_{r}(t)}{\left|g_{i}(t) g_{r}(t)\right|}
$$


where $g_{i}(t)$ and $g_{r}(t)$ represent the growth rates of country or region $i$ and those of the benchmark country or region $r$. The synchronicity indicator $\varphi$ measures the fraction of time for which, during a specific period, country or region $i$ is in the same phase of the cycle as country or region $r .{ }^{5}$

The data available for 1990-2012 show that Latin America and the Caribbean and all of its subregions generally display a high level of synchronicity with all of the benchmark regions studied (the United States, the eurozone and China). More specifically, on average, the Latin American and Caribbean cycle is synchronized with that of the benchmark regions or countries $75 \%$ of the time (in other words, the region is in the same phase of the cycle as the benchmark regions or countries $75 \%$ of the time).

The highest degree of synchronicity occurs in the four-year period 2003-2007 leading up to the global financial crisis in 2008-2009, reflecting the fact that most of the world's countries were growing in that period. In contrast, the lowest level of synchronicity was recorded during the 2008-2009 global financial crisis, thereby highlighting the differentiated impact of the global crisis in the various regions and countries (see table V.3).

Table V.3

Latin America and the Caribbean and subregions (including Mexico): coefficient of business cycle synchronicity with respect to the United States, the eurozone and China, 1990-2012 ${ }^{a}$

\begin{tabular}{|c|c|c|c|c|}
\hline & $\begin{array}{l}\text { Latin America and } \\
\text { the Caribbean }\end{array}$ & South America & Central America & Mexico \\
\hline \multicolumn{5}{|c|}{ United States } \\
\hline 1990-1994 & 74 & 68 & 85 & 80 \\
\hline $1995-2002$ & 73 & 72 & 78 & 75 \\
\hline 2003-2007 & 89 & 99 & 80 & 100 \\
\hline $2008-2009$ & 57 & 45 & 73 & 75 \\
\hline $2010-2012$ & 83 & 92 & 80 & 100 \\
\hline Average & 75 & 75 & 79 & 86 \\
\hline \multicolumn{5}{|l|}{ Eurozone } \\
\hline 1990-1994 & $\ldots$ & $\ldots$ & $\ldots$ & $\ldots$ \\
\hline $1995-2002$ & 73 & 72 & 78 & 75 \\
\hline 2003-2007 & 89 & 99 & 80 & 100 \\
\hline $2008-2009$ & 64 & 58 & 80 & 88 \\
\hline $2010-2012$ & 68 & 74 & 67 & 70 \\
\hline Average & 74 & 76 & 76 & 83 \\
\hline \multicolumn{5}{|l|}{ China } \\
\hline 1990-1994 & $\ldots$ & $\ldots$ & $\ldots$ & $\ldots$ \\
\hline $1995-2002$ & 69 & 64 & 77 & 77 \\
\hline 2003-2007 & 87 & 87 & 86 & 90 \\
\hline $2008-2009$ & 64 & 68 & 60 & 50 \\
\hline $2010-2012$ & 75 & 76 & 71 & 78 \\
\hline Average & 74 & 74 & 74 & 74 \\
\hline
\end{tabular}

Source: Economic Commission for Latin America and the Caribbean (ECLAC), 2012.

a Three dots (...) indicate that data are not available.

In the extreme case of $g_{i}(t) g_{r}(t)>0,\left(g_{i}(t) g_{r}(t)<0\right)$, for all components of the sum $\varphi(t)=\frac{1}{n}\left(-\frac{1}{n}\right)$. 
In general, the evidence shows that, instead of being decoupled from the business cycle of the developed countries, the regional economy remains closely linked to fluctuations in economic activity in those countries. Moreover, the high and rising degree of synchronicity between Latin America and the Caribbean and China underscores the fact that the region's business cycle has also become dependent on those of other developing countries. This is explained by China's influence on the commodity terms of trade, since it is a major consumer of commodities, such as non-renewable energy resources, agricultural crops and base metals $(20 \%, 23 \%$ and $40 \%$ of global production, respectively) (Roache, 2012).

\section{Volatility also reflects the specific features of the business cycle in Latin America and the Caribbean}

The high levels of volatility prevailing in Latin America and the Caribbean are explained not only by the region's dependence on its external performance, as shown in the macroeconomics for development blueprint, but also by the specifics of its business cycle.

The regional business cycle displays two distinctive characteristics. Firstly, and more importantly, the region's upswings tend to be weaker than other regions of the world; but, secondly, its downswings are generally similar to those of other developing countries in duration and amplitude. As a result, each complete cycle in Latin America occurs more frequently than in any of the other regions considered.

The specific characteristics of the business cycle were obtained from the classical cycle approach, ${ }^{6}$ which characterizes the business cycle in terms of its duration and intensity. The duration (D) of an upswing is defined as the ratio between the total number of growth quarters and the total number of cycle peaks, in other words:

\footnotetext{
The classical cycle methodology views the cycle as a set of turning points in a time series that represents the level of aggregate economic activity without considering trends (Harding and Pagan, 2002a and 2002b; Pagan, 2003). The turning points of the series are then used as a basis for analysing the cycle in terms of indicators such as the duration and intensity of an expansion (trough-to-peak) and a contraction (peak-to-trough), and the degree of coincidence between the two time series in question. Identification of the turning points is central to this approach. These are generally identified using the Bry-Boschan algorithm (1971), which was initially developed to process monthly data and was then adapted to quarterly observations by Harding and Pagan (2002a and 2002b). The algorithm consists in identifying local maxima and minima in a given series, following a logarithmic transformation using specific censoring rules (Bry and Boschan, 1971). These include specifying a minimum duration of two quarters for a single phase and a minimum of five quarters for a complete cycle (Harding and Pagan (2002a and 2002b). The peak of the series $y_{t}$ is found when $y_{t}>y_{t \mp k}$ for $k=1$.2. Similarly, the minimum of the series $y_{t}$ is found when $y_{t}<y_{t \mp k}$ for $k=1$.2. The algorithm excludes the occurrence of two successive peaks or troughs.
} 
(2) $D=\frac{\sum_{t=1}^{T} S_{t}}{\sum_{t=1}^{T-1}\left(1-S_{t+1}\right) S_{t}}$

where $S$ is a binary variable that takes a value of 1 during the upswing and 0 on the downswing. ${ }^{7}$ The numerator of equation (2) $\left(\sum_{t=1}^{T} S_{t}\right)$ denotes the total duration of the expansions, and the denominator $\left.\sum_{t=1}^{T-1}\left(1-S_{t+1}\right) S_{t}\right)$ measures the number of peaks in the series.

The intensity or amplitude $(A)$ of the expansion is measured as the ratio between the total change in aggregate economic activity and the total number of cyclical peaks. In other words:

(3) $A=\frac{\sum_{t=1}^{T} S_{t} \Delta Y_{t}}{\sum_{t=1}^{T-1}\left(1-S_{t+1}\right) S_{t}}$

where $Y$ is a parameter of economic activity (GDP in the cases analysed here), and the numerator of equation (3) $\left(\sum_{t=1}^{T} S_{t} \Delta Y_{t}\right)$ represents the total change in economic activity.

Application of this methodology to a comprehensive sample of 83 countries (including 44 emerging market economies and 39 developed or high-income economies), using quarterly data for 1998-2012, gives the following results. ${ }^{8}$

Compared with other developed and developing regions of the world, the business cycle of expansions and contractions in Latin America and the Caribbean has two distinctive features. First, the region generally has weaker expansions than other developing regions, particularly compared with East Asia and the Pacific. Second, Latin America and the Caribbean on average has contractions that tend to converge with those of other countries, developed and developing, in both duration and amplitude.

Similarly, the duration and amplitude of the contractions are calculated using the formula $c_{i, t}=1-s_{i . t}$

8 The sample of emerging market economies comprises 21 countries from Latin America and the Caribbean, 5 from East Asia and the Pacific, 11 from Europe and Central Asia, 3 from the Middle East and North Africa, one from South Asia and three from sub-Saharan Africa. The subsample of high-income economies, include European (23), Asian (4), North American (2), Caribbean (2) and other countries, including Cyprus, Israel, Macao (China) and Malta. The Caribbean countries include Barbados, Belize, the Dominican Republic, Grenada, Jamaica, Saint Lucia, and Trinidad and Tobago. In comparison with other analyses on the subject, the data set used in this study is one of the largest and most representative at both the regional and subregional levels for Latin American and Caribbean. Unlike other studies on the subject, it includes most countries of South and Central America along with Caribbean economies, thus avoiding introducing a subregional bias in the results obtained. Data for 1989-2012 were not available for all countries. Quarterly GDP was used for all countries in the sample with the sole exception of Barbados. In that case, data shortcomings meant that quarterly GDP had to be calculated on the basis of information on tourist arrivals. In Barbados, the annual data on tourist arrivals and GDP show that the two variables exhibit a high degree of coincidence (including turning points) and association (very high and significant correlation coefficient). 
The combination of weaker expansions and convergent contractions means that the complete cycle of expansion and contraction tends to be shorter and of smaller amplitude in Latin America and the Caribbean than in other regions of the world. In other words, the cycle in Latin America and the Caribbean has a higher frequency than that of other regions.

In terms of the duration of the upswing, the data show that expansionary cycles in Latin America and the Caribbean last on average for 14 quarters (three and a half years). ${ }^{9}$ With the exception of the Middle East and North Africa (one year), upswings in Latin America and the Caribbean are shorter than those of the other regions studied and, in particular, than those of East Asia and the Pacific, where growth phases last around eight years, or nearly five years longer than those of Latin America and the Caribbean. In high-income countries, the expansions also last longer (six years, or roughly two years longer than in Latin America and the Caribbean) (see table V.4).

Table V.4

Selected regions: mean duration and amplitude of the expansionary and contractionary phases of the business cycle, 1990-2012 ${ }^{\mathrm{a}}$

\begin{tabular}{lccccc}
\hline & \multicolumn{2}{c}{ Contraction } & & \multicolumn{2}{c}{ Expansion } \\
\cline { 2 - 3 } \cline { 5 - 6 } & $\begin{array}{c}\text { Duration } \\
\text { (quarters) }\end{array}$ & $\begin{array}{c}\text { Amplitude } \\
\text { (percentages) }\end{array}$ & & $\begin{array}{c}\text { Duration } \\
\text { (quarters) }\end{array}$ & $\begin{array}{c}\text { Amplitude } \\
\text { (percentages) }\end{array}$ \\
\hline East Asia and the Pacific & 3.3 & -10.6 & & 32.5 & 39.0 \\
\hline Europe and Central Asia & 3.8 & -11.6 & & 25.0 & 43.8 \\
\hline Latin America and the Caribbean & 3.8 & -4.6 & & $\mathbf{1 3 . 6}$ & $\mathbf{2 6 . 3}$ \\
\hline Middle East and North Africa & 7.3 & -7.0 & & 3.5 & 15.6 \\
\hline South Asia & $\ldots$ & $\ldots$ & & $\ldots$ & $\ldots$ \\
\hline Sub-Saharan Africa & 2.7 & -7.1 & & 37.5 & 40.9 \\
\hline High-income countries & 4.0 & -4.9 & 23.0 & 26.3 \\
\hline
\end{tabular}

Source: E. Pérez Caldentey, D. Titelman and P. Carvallo, "Weak expansions: a distinctive feature of the business cycle in Latin America and the Caribbean", Working Paper, No. 749, Levy Economics Institute, 2013.

a Three dots (...) indicate that data are not available.

The cyclical analysis of the most recent expansion does not alter the conclusions. In most Latin American and Caribbean countries the latest upswing started early in the 2000s and ended with the global financial crisis in 2009. It was one of the longest and most intense for over three decades.

\footnotetext{
9 The Bry-Boschan algorithm was computed using MatLab, with the help of computer code provided by Professors John Rand and Finn Tarp (University of Copenhagen). Stata was used to compute the cycle indicators.
} 
Nonetheless, this upswing was weaker in both duration and amplitude than the most recent expansion experienced by other regions, particularly East Asia and the Pacific (26.5 quarters and 29.8\% in Latin America and the Caribbean compared with 40 quarters and 53.9\% in East Asia and the Pacific, respectively). ${ }^{10}$

In line with these results, the region also achieves one of the most meagre output gains in the cyclical upswing, with an average $26.3 \%$ increase in output, compared with a gain of 39\% in the benchmark region, East Asia and the Pacific - 48\% more than Latin America and the Caribbean (see table V.5).

Table V.5

Latin America and the Caribbean: mean duration and amplitude of the upswing and downswing phases of the cycle, 1990-2012

\begin{tabular}{lcccccc}
\hline & \multicolumn{2}{c}{ Contraction } & & \multicolumn{2}{c}{ Expansion } \\
\cline { 2 - 3 } \cline { 5 - 6 } & $\begin{array}{c}\text { Duration } \\
\text { (quarters) }\end{array}$ & $\begin{array}{c}\text { Amplitude } \\
\text { (percentages) }\end{array}$ & & $\begin{array}{c}\text { Duration } \\
\text { (quarters) }\end{array}$ & $\begin{array}{c}\text { Amplitude } \\
\text { (percentages) }\end{array}$ \\
\hline Latin America and the Caribbean & $\mathbf{1 3 . 6}$ & $\mathbf{2 6 . 3}$ & & $\mathbf{3 . 8}$ & $\mathbf{- 4 . 6}$ \\
\hline South America & 15.3 & 27.9 & & 3.6 & $-\mathbf{7 . 1}$ \\
\hline Central America & 25.0 & 27.0 & & 3.5 & -3.8 \\
\hline Mexico & 23.0 & 25.6 & & 3.7 & -7.9 \\
\hline
\end{tabular}

Source: E. Pérez Caldentey, D. Titelman and P. Carvallo, "Weak expansions: a distinctive feature of the business cycle in Latin America and the Caribbean", Working Paper, No. 749, Levy Economics Institute, 2013.

The lacklustre performance of the Latin American and Caribbean economies during the cyclical upswing, compared with those of other regions, is clearly reflected in the cumulative output gain. Figure V.3 shows the cumulative output gain of East Asia and the Pacific and of high-income countries compared with that achieved by Latin America and the Caribbean. East Asia and the Pacific reports cumulative output growth gain equivalent to almost three times that achieved by Latin America and the Caribbean, according to most of the criteria used. The increase in output gain of the high-income economies is $10 \%$ more than that of Latin America and the Caribbean (see figure V.3).

10 These numbers represent the duration and amplitude of a single episode. They refer to the numerator of the duration and amplitude formulas (equations 2 and 3 above) and in this sense are not strictly comparable to the other cycle indicators provided in the study. In the case of Europe and Central Asia, the duration and amplitude of the latest expansion episode are also greater than those of Latin America and the Caribbean (36.5 quarters and 63.2\%). 
Figure V.3

\section{East Asia and the Pacific and high-income countries: average cumulative output} gain compared with Latin America and the Caribbean, 1990-2012

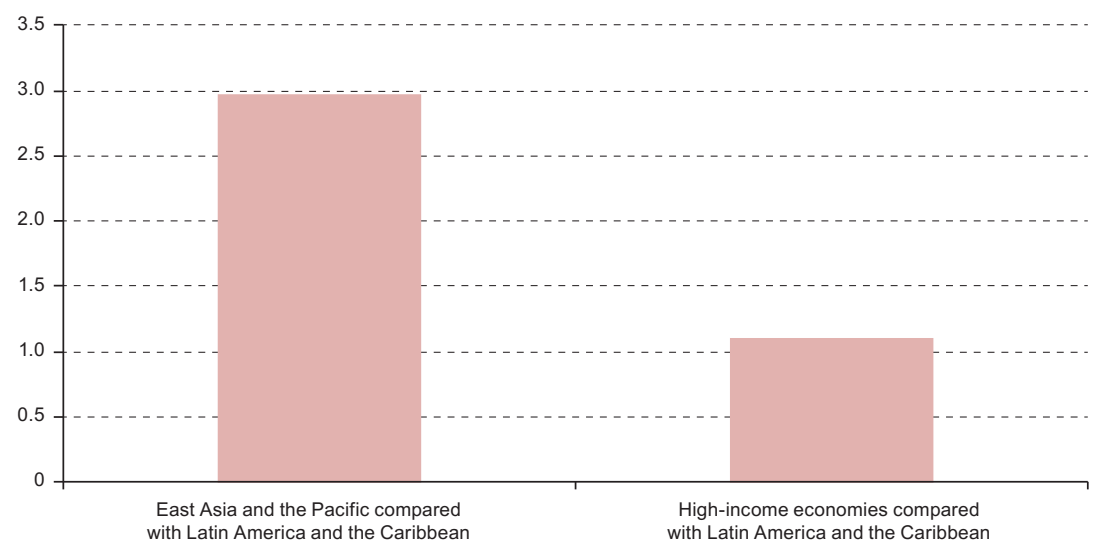

Source: E. Pérez Caldentey, D. Titelman and P. Carvallo, "Weak expansions: a distinctive feature of the business cycle in Latin America and the Caribbean", Working Paper, No. 749, Levy Economics Institute, 2013.

a Represents the average of the values obtained using the Bry-Boschan, calculus algorithm, Okun and deviation cycle methods with respect to 1990-2012. The cumulative growth of production is computed as the product of the amplitude and duration of the upswing phase in East Asia and in high-income economies compared with those of Latin America and the Caribbean.

In contrast to the results obtained for expansionary phases, the duration and intensity of the downswings in Latin American and Caribbean countries tend to match to those of other regions. Except for the Middle East and North Africa, contractionary phases tend to last for less than a year, ranging from 2.7 to 3.8 quarters (in other words between 8 and 11 months). Contractions in Latin America and the Caribbean, Europe and Central Asia, and East Asia and the Pacific have a very similar duration of between 3.3 and 3.8 quarters (between 10 and 11 months).

In terms of intensity, the contractions are also no deeper in Latin America and the Caribbean than elsewhere -in fact they tend to be the shallowest of all developing and developed regions. The average amplitude of contractions in Latin America and the Caribbean is equivalent to 4.6\%, which is close to that of the high-income country group (4.9\%), and below those of East Asia and the Pacific (10.6\%), Europe and Central Asia (11.6\%), the Middle East and North Africa (7.0\%) and sub-Saharan Africa (7.1\%).

Combining these two stylized facts (weaker expansions and convergent contractions) means that a complete cycle in Latin America and the Caribbean usually lasts less time than in other regions. In other words, the frequency of the Latin American and Caribbean regional cycle is the highest of all the regions in the world. 
The duration of a complete cycle, using the classical cycle methodology (in conjunction with the Bry-Boschan criterion, for reference), is roughly 17 quarters in the case of Latin America and the Caribbean. This is less than in high-income countries ( 27 quarters) and in most developing regions. In the specific case of East Asia and the Pacific, the benchmark used in this study, the cycle lasts 36 quarters, in other words nearly five years longer than in Latin America and the Caribbean.

While Latin America and the Caribbean has the shortest cycles, these are usually also the smallest in amplitude, measured by the distance between the trough and peak of the cycle. The amplitude of the cycle in East Asia and the Pacific is $60 \%$ larger than that of Latin America and the Caribbean.

\section{The relationship between the cycle and long-run growth: the real channel (productivity and investment)}

The dynamic and specific features of the business cycle in Latin America and the Caribbean are not only relevant in the short run: they also affect longrun performance. From the standpoint of this analysis, that means that the traditional view of macroeconomics for development needs to incorporate another dimension, namely the relationship between short-run fluctuations and long-run growth, or between the cycle and the trend.

The fact that Latin America and the Caribbean has shorter and weaker expansions than other regions of the world also means that the accumulation period is shorter and less intense. As noted above, shorter durations mean that the Latin American and Caribbean cycle has a higher frequency than that of other regions. This is possibly one of the causes of higher volatility in the region.

The specifics of the cycle also link short-run fluctuations to long-run performance, since these features are reflected in structural (real) variables, such as productivity and investment, which are considered fundamental determinants of the long-run growth path of any economy.

Table V.6 shows the duration and amplitude of the growth of labour productivity in Latin American and Caribbean countries, compared with the others in the sample. In line with the previous results, the productivity upswing in the region is generally one of the shortest.

On this point, it is worth highlighting the differences in the cumulative productivity gain (the product of amplitude and duration) between Latin America and the Caribbean and East Asia and the Pacific. The cumulative gain in labour productivity during the expansionary phase of the cycle is 25\% in Latin America and the Caribbean, but double this amount (50\%) in East Asia and the Pacific. 
Table V.6

Selected regions and groupings: duration and amplitude of the expansionary phase of the labour productivity cycle, using the classical cycle methodology, $1990-2012^{\text {ab }}$

\begin{tabular}{lc}
\hline & $\begin{array}{c}\text { Duration } \\
\text { (years) }\end{array}$ \\
\hline East Asia and the Pacific & 4.3 \\
\hline Europe and Central Asia & 5.5 \\
\hline Latin America and the Caribbean & $\mathbf{3 . 8}$ \\
\hline Middle East and North Africa & 3.3 \\
\hline South Asia & 4.8 \\
\hline Sub-Saharan Africa & 2.6 \\
\hline High-income countries & 6.3 \\
\hline & Amplitude \\
\hline East Asia and the Pacific & (percentages) \\
\hline Europe and Central Asia & 23.4 \\
\hline Latin America and the Caribbean & 33.7 \\
\hline Middle East and North Africa & $\mathbf{1 3 . 6}$ \\
\hline South Asia & 17.2 \\
\hline Sub-Saharan Africa & 16.0 \\
\hline High-income countries & 8.5 \\
\hline
\end{tabular}

Source: E. Pérez Caldentey, D. Titelman and P. Carvallo, "Weak expansions: a distinctive feature of the business cycle in Latin America and the Caribbean", Working Paper, No. 749, Levy Economics Institute, 2013.

a Refers to labour productivity per person employed, in 2011 dollars (converted at the 2011 price level based on purchasing power parity in 2005 dollars (EKS method, updated).

b Corresponds to annual data.

In conjunction with the fact that Latin America and the Caribbean experiences weaker expansions than other regions, particularly compared with East Asia and the Pacific, this type of evidence could help explain why the countries of East Asia and the Pacific have managed to stay on a high GDP growth path over time compared with Latin America and the Caribbean. This is illustrated in figure V.4, which plots the 1960-2010 GDP trend in both regions.

Whereas the East Asia and Pacific region has maintained an upward path throughout the period, Latin America and the Caribbean experienced a structural break in the 1980s, which was most likely due to the effects of the debt crisis, from which the region has not been able to recover in the two ensuing decades. At a more detailed level of analysis, figure V.4 shows that the GDP trend between 1960 and the early 1980s (period I) in Latin America and the Caribbean is similar to that of East Asia and the Pacific. Then, starting with the lost decade of the 1980s, it trends down and does not recover in the 1990s or in the 2000s, which means that in this subperiod growth rates are lower than before the debt crisis (period II). 
Figure V.4

Latin America and the Caribbean and East Asia and the Pacific:

GDP trend, 1960-2010sa

(Logarithmic scale)

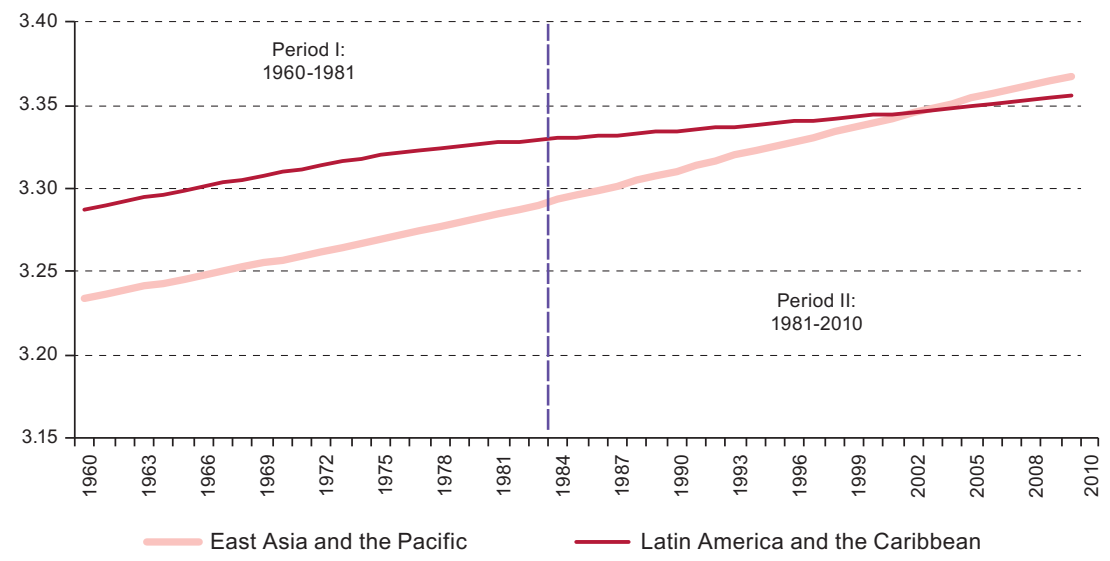

Source: Economic Commission for Latin America and the Caribbean (ECLAC), on the basis of World Bank, World Development Indicators y Global Finance [online] http://www.gfmag.com/.

a Calculations based on the deviation cycle methodology; annual data

The long-term effects of the crisis are seen in the structural break in the region's GDP trend. At the same time, the weakness of the recoveries is underscored by the fact that the economic policies implemented in the two post-crisis decades failed to reverse those effects. Even in 2003-2007, which was the fastest growth period in Latin America and the Caribbean in the last 30 years, hardly any of the region's countries were able to reverse the structural break or improve the trend. This contrasts with what happened in Asia: the 1997 crisis, one of the most intensive to affect East Asian countries, did not alter the course of trend GDP.

Another piece of evidence that links cyclical fluctuations to long-run growth is the behaviour of public investment. This is also clearly asymmetrical because it falls much more steeply in recessions than it rises during growth phases. As shown in table V.7, which reports data for six of the region's countries, public investment in infrastructure declined on average by $36 \%$ in the contractionary phase of the business cycle. ${ }^{11}$

11 Argentina, Brazil, Chile, Colombia, Mexico and Peru: countries which jointly account for $85.5 \%$ of the region's GDP. 
Table V.7

Latin America (selected countries): duration and amplitude of expansionary and contractionary phases of the cycle of public investment in infrastructure, 1980-2010

\begin{tabular}{lccccc}
\hline & \multicolumn{2}{c}{ Contraction } & & \multicolumn{2}{c}{ Expansion } \\
\cline { 2 - 3 } \cline { 6 - 6 } & $\begin{array}{c}\text { Duration } \\
\text { (quarters) }\end{array}$ & $\begin{array}{c}\text { Amplitude } \\
\text { (percentages) }\end{array}$ & & $\begin{array}{c}\text { Duration } \\
\text { (quarters) }\end{array}$ & $\begin{array}{c}\text { Amplitude } \\
\text { (percentages) }\end{array}$ \\
\hline Total & 2.7 & 25.6 & & 2.2 & -35.6 \\
\hline Energy sector & 1.9 & 34.7 & & 2.0 & -51.5 \\
\hline Roads and railroads & 2.1 & 32.3 & & 1.7 & -33.1 \\
\hline Telecommunications & 1.8 & 28.1 & & 1.9 & -58.0 \\
\hline Water and sanitation & 1.6 & 24.2 & & 1.7 & -23.8 \\
\hline
\end{tabular}

Source: Economic Commission for Latin America and the Caribbean (ECLAC), 2012.

a The Bry-Boschan algorithm was used to identify turning points, based on annual data.

Reductions in public infrastructure investment tend to be steeper than any increase during the recovery phase - on average $40 \%$ greater than the subsequent expansion in the sectors analysed. In the energy and telecommunications sectors, the difference between the reduction in investment during a contraction and its increase during an expansion is even greater (a $35 \%$ increase compared with a $52 \%$ reduction in the energy sector and a $28 \%$ increase and 58\% reduction in the telecommunications sector). This pattern has negative effects on capital accumulation over time.

While cuts in investment can have short-term effects on aggregate demand, they also influence the economy's long-term growth path. This is because public investment contributes not only to economic growth, but also to the fact that investment decisions are often irreversible ("once installed, capital has little or no value unless it is used in production"); and this characteristic serves as a link between short-term decisions and medium-to-long-term results.

Irreversibility can often be an important factor in a decision not to invest in the downswing of the cycle, for instance because of the increasing risks attached to the current and future macroeconomic context. In that sense, a downswing in the economic cycle can be associated with scant capital accumulation, which, in turn, contributes even more to the reduction in investment, and undermines not only the economy's job-creating capacity but also its recovery potential.

\section{E. The relationship between the cycle and long-run growth: the financial channel}

The long-run growth dynamic not only reflects the path of real variables such as productivity and investment, but also depends on the behaviour of credit 
and financial stability. ${ }^{12}$ In this connection, alongside the real channel, the financial channel is another mechanism through which cyclical fluctuations affect an economy's long-run growth path.

The importance of the financial channel is underscored by the asymmetric behaviour of lending to the private sector over the cycle. Table V.8 shows the relationship between the credit cycle and GDP in terms of duration, amplitude and cumulative effect in selected Latin American countries (Argentina, Bolivarian Republic of Venezuela, Brazil, Chile, Colombia, Costa Rica, Dominican Republic, Mexico, Paraguay and Peru) in 1990-2012 on the basis of quarterly data.

The evidence shows that credit expansions tend to have a broadly similar average duration to GDP expansions, but they are stronger. On average, credit expansions last one quarter longer than GDP upswings; but their amplitude is generally $50 \%$ larger.

Credit contractions also tend to last $60 \%$ longer GDP contractions and are five times more intensive (four times if measured by the median rather than the mean) (see table V.8).

Consequently, while the credit cycle tends to outpace GDP in terms of intensity in both the expansionary and the contractionary phases, the effect is much more pronounced in the downswing; and credit over-shooting in the latter phase is also compounded by the fact that credit contractions last much longer. ${ }^{13}$

This asymmetry in the behaviour of credit (or the fact that credit contractions are not necessarily commensurate with credit expansions) has major repercussions for understanding the GDP cycle and the relationship between fluctuations and longer-term trends.

12 Traditionally, in mainstream economics, financial factors do not affect long-run growth. The Modigliani-Miller (1958) theorem exemplifies this point as it presents the market value of a firm and that firm's liability structure as dichotomous. As put by Modigliani (1980) p. viii: “... with well-functioning markets (and neutral taxes) and rational investors, who can 'undo' the corporate financial structure by holding positive or negative amounts of debt, the market value of the firm - debt plus equity - depends only on the income stream generated by its assets. It follows, in particular, that the value of the firm should not be affected by the share of debt in its financial structure or by what will be done with the returns - paid out as dividends or reinvested (profitably)." More recently, international organizations such as the International Monetary Fund, the Organization for Economic Cooperation and Development and also the European Union have recognized that recessions that are generated by financial factors may affect potential GDP. This has led some economists (Borio, Disyatat and Juselius, 2013) to attempt to introduce financial factors in the determination of potential GDP. In contrast, a fundamental tenet of non-mainstream economics is that the link between financial factors and the behavior of real variables is indissoluble (Keynes, 1936; Minsky, 1982 and 1986).

13 See Borio (2012) and Drehman, Borio and Tsatsaronis (2012) on the relationship between credit and financial cycles and the GDP trend growth. 
Table V.8

Latin America and the Caribbean (selected countries): duration and amplitude of the expansionary and contractionary phases of the real credit cycle in relation to real GDP, 1990-2012 ${ }^{\mathrm{a}}$

\begin{tabular}{|c|c|c|c|c|c|c|}
\hline & \multicolumn{2}{|c|}{$\begin{array}{l}\text { Duration } \\
\text { (quarters) }\end{array}$} & \multicolumn{2}{|c|}{$\begin{array}{c}\text { Amplitude } \\
\text { (percentages) }\end{array}$} & \multicolumn{2}{|c|}{ Cumulative effect } \\
\hline & Expansion & Contraction & Expansion & Contraction & Expansion & Contraction \\
\hline Argentina & 1.0 & 2.5 & 1.5 & 6.3 & 0.8 & 7.9 \\
\hline Brazil & 0.6 & 2.4 & 0.9 & 3.0 & 0.3 & 3.5 \\
\hline Chile & 1.0 & 0.7 & 1.6 & 0.8 & 0.8 & 0.3 \\
\hline Colombia & $\ldots$ & 1.7 & $\ldots$ & 3.2 & $\ldots$ & 2.8 \\
\hline Costa Rica & 1.1 & 1.5 & 2.7 & 3.9 & 1.5 & 2.9 \\
\hline Dominican Republic & 2.8 & 1.3 & 8.1 & 12.1 & 11.1 & 8.1 \\
\hline Mexico & 0.5 & 1.2 & 1.4 & 0.8 & 0.3 & 0.4 \\
\hline Paraguay & 0.8 & 1.4 & 0.9 & 11.6 & 0.3 & 8.3 \\
\hline Peru & 0.9 & 1.8 & 1.5 & 3.0 & 0.7 & 2.6 \\
\hline $\begin{array}{l}\text { Venezuela (Bolivarian } \\
\text { Republic of) }\end{array}$ & 1.1 & 1.6 & 3.4 & 4.6 & 1.9 & 3.7 \\
\hline Median & 1.0 & 1.6 & 1.5 & 3.6 & 0.8 & 2.8 \\
\hline Mean & 1.1 & 1.6 & 2.4 & 4.9 & 1.3 & 4.0 \\
\hline
\end{tabular}

Source: Prepared by the authors on the basis of official information from the countries and Inter-American Development Bank (IDB), Latin America and the Caribbean Macro Watch Data Tool [online] http:// www.iadb.org/research/latinmacrowatch/lmw.cfm.

a Three dots (...) indicate that data are not available.

One of these stems from the fact that credit crunches are much more pronounced than output contractions. A way to interpret this result, in the light of the evidence described above, is that the financial system amplifies fluctuations in real variables such as GDP. ${ }^{14}$ This finding corroborates the perspective of the macroeconomics for development blueprint model in the sense that credit aggravates real fluctuations (ECLAC, 2002, 2004 and 2012).

A second repercussion that has not yet been taken into account in the blueprint model is that, if credit contractions last longer than GDP recessions, this means that GDP recoveries and expansions precede credit. GDP recovers and expands first, and then credit follows suit. ${ }^{15}$ In other words, credit is endogenous to GDP.

This at least partially reflects the available empirical evidence for Latin America, which shows that the GDP cycle leads the credit cycle in time.

14 These results bear some resemblance to the financial accelerator concept (Bernanke and others, 1999). The financial accelerator is based on the notion that there is an ex-post information asymmetry that gives rise to an external financing premium that reflects the difference between internal and external financing costs. In the upward phase of the cycle, higher creditworthiness, net worth and generally improved payment capacity translates into a lower external finance premium. The opposite occurs during contractions. Thus the external financing premium behaves countercyclically, by falling in expansions and rising in contractions. In this sense the external finance premium can amplify a shock to real variables in the financial sphere.

15 These results are compatible with Calvo's "phoenix miracles" or creditless recoveries (Calvo and others, 2006). 
Figure V.5 shows the percentage of Latin American countries in which GDP "Granger causes" credit in the periods 1995-2003, 1999-2007, 2001-2009 and 2003-2011. In the first period studied (1995-2003), GDP “Granger causes" credit in $20 \%$ of the countries of the sample, In the last period (2003-2011), the proportion of countries in which credit was an endogenous factor rises to $70 \%$.

Figure V.5

Latin America: countries in which the credit cycle is endogenous to the GDP cycle, first quarter 1995 to fourth quarter $2011^{a}$

(Percentages of countries)

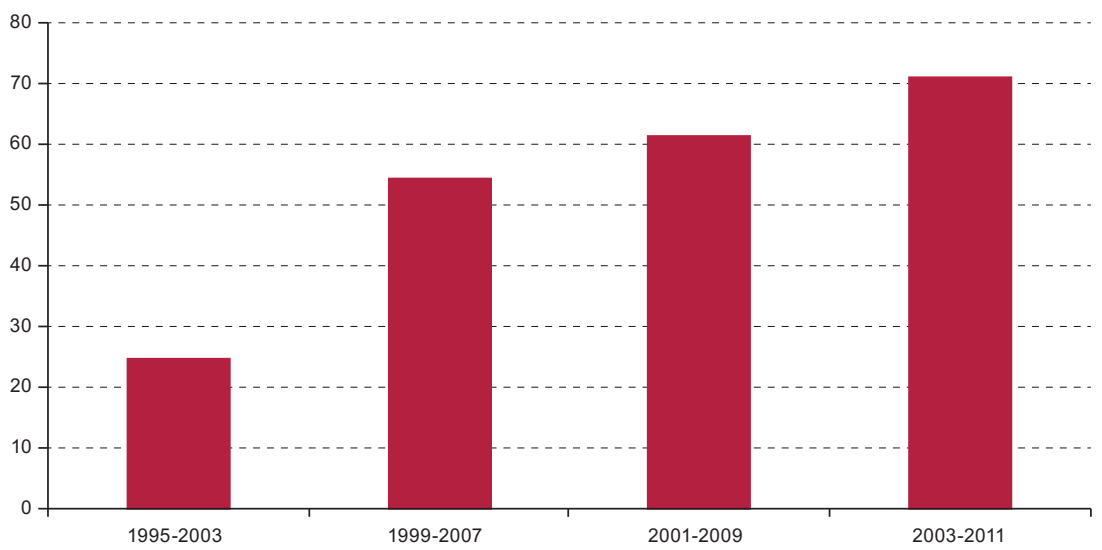

Source: Prepared by the authors on the basis of official information from the countries and Inter-American Development Bank (IDB), Latin America and the Caribbean Macro Watch Data Tool [online] http:// www.iadb.org/research/latinmacrowatch/lmw.cfm.

a The percentage is estimated on the basis of the Granger continuous causality test. The countries included in the sample are: Argentina, Brazil, Colombia, Costa Rica, Chile, Dominican Republic, Ecuador, El Salvador, Honduras, Mexico, Paraguay, Peru, Plurinational State of Bolivia and Uruguay.

Lastly, a third novel feature is the fact that credit shrinks by a multiple of GDP and continues to contract after GDP has started to grow again, which means that credit acts at least partially as a brake on the upswing of the GDP cycle. When combined with the behaviour of real variables such as productivity and investment, analysed in the previous section, this can explain the tenuous nature of the cyclical upswing in Latin America and the Caribbean. ${ }^{16}$

16 These results are in line with the authors' previous finding that if the expansionary phase of the cycle is broken down into its two subphases - acceleration and deceleration - then Latin America and the Caribbean displays one of the weakest growth rates for both the acceleration and deceleration subphases compared with other developing and developed regions (acceleration is defined by a GDP growing at an increasing rate, in other words by a first and second positive derivative of the GDP level series; deceleration refers to a GDP growing at decreasing rates, which means that the first derivative of the GDP level series is positive while the second derivative is negative). The average rate of growth in the acceleration phase reaches $6.1 \%$ for Latin America and the Caribbean, while for other regions such as East Asia and the Pacific it reaches roughly 7\%. Similarly, Latin America and the Caribbean also experiences a 
The importance of the financial channel as a transmission mechanism between cycle and trend is a solid argument for regulating the financial system as a whole, in other words from the macroprudential standpoint, in order to promote long-term growth.

The main purpose of macroprudential regulation is to maintain the stability of the financial system at the aggregate level by minimizing systemic risk. This means taking active steps to limit the accumulation of financial risks and the build-up of fragile financial structures, including the prevention of asset and credit bubbles (Minsky, 1982 and 1986).

Of particular relevance to this analysis, it also means monitoring credit expansions and controlling the economic and social costs generated by the credit crunches that develop as a result of excessive contractions in the general balance sheet of financial institutions facing a common shock (Hanson and others, 2011), or owing to an increase in interconnectedness (Shin, 2010). ${ }^{17}$ Monitoring the behaviour of credit over the cycle entails identifying the type of linkages that exist between the real and financial sectors, and identifying which of them cause the financial system to overshoot in the upswing and downswing phases of the cycle. Macroprudential policies can thus be seen as a countercyclical tool to manage aggregate demand, in terms not only of its level but also of its composition - that is, in terms of the sectoral sources that expand and contract aggregate demand.

\section{F. Completing the macroeconomics for development blueprint view of countercyclicality}

The recognition of volatility as a major stumbling block to the pursuit of stable and sustained growth implies that an appropriate countercyclical policy should be the foundation of a sound and development-oriented macroeconomic policy.

slower deceleration phase than other regions except for the Middle East and North Africa and sub-Saharan Africa. See, Pérez-Caldentey, Titelman and Carvallo (2013).

17 Macroprudential regulation should be seen as a complement to microprudential regulation in which the scope is limited to the individual financial institution. The norms that guide international financial regulation are dictated by the Basel Committee on Banking Supervision (BCBS). The BCBS approach to regulation focuses on capital requirements for individual financial institutions, which were first established in the 1988 Basel Capital Accord (Basel I) and later revised in 2004 giving rise to Basel II. Most recently, following the global financial crisis, an agreement on new capital requirements was reached, namely Basel III. According to the BCBS, implementation of Basel III is expected to start in 2016 and it should be fully operational by 2019. In contrast to the two earlier accords, Basel III has introduced a number of macroprudential elements, including a countercyclical capital buffer to be activated when credit expands beyond a certain threshold above its long-term trend. Note however, that the guiding logic to the countercyclical buffer is that of the boom and bust, whereby the credit bust is a direct consequence of the preceding boom. 
According to the traditional view of macroeconomics for development, the essence of countercyclical policy consists in managing the level of aggregate demand through monetary, exchange-rate and fiscal policies, aimed at smoothing business-cycle fluctuations in nominal and real variables around their long-term trends (ECLAC, 2002 and 2004).

This view recognizes the limitations of monetary policy as a countercyclical tool in a context of balance-of-payments dominance and financial openness. Moreover, greater nominal stability, which is usually the objective of monetary policy, does not necessarily mean greater real and financial stability.

Given those limitations, the importance of fiscal policy as a countercyclical tool is stressed. ${ }^{18}$ Countercyclical fiscal policy is understood as a strategy to expand fiscal space in the cyclical upswing, during expansions, by increasing fiscal saving and drawing down external debt, so as to "ease financial constraints and reduce the need for belt-tightening" (ECLAC, 2004).

Governments should therefore pay particular attention to managing expansions, so as to increase their economies' saving capacity, and thus provide greater leeway for countercyclical management in the downswing. To that end, fiscal laws and regulations are proposed that are not based on short-term targets, but on long-term structural variables (such as the growth trend). ${ }^{19}$

Expanding space for countercyclical policies and increasing their effectiveness requires regulating financial (capital) inflows. The main objective here is to reduce the volatility of capital inflows in the upswing of the cycle and moderate their expansionary effect on aggregate demand. Managing capital inflows also has the effect of cushioning the nominal and real exchange-rate appreciations that occur in the cyclical upswing. Lastly, it also makes it possible to give monetary and fiscal policy greater room for manoeuvre over the business cycle.

18 This view stands in sharp contrast to mainstream economics, which sees monetary policy as the main stabilization tool. Fiscal policy has a subsidiary role to play at most, although in some mainstream circles it is recognized as useful, either in a deep recession or when monetary policy ceases to be operative (as is the case when monetary policy rates approach the zero lower bound (Blinder, 2006)).

19 Lastly, the use of structural variables as anchors for fiscal policy design gives automatic stabilizers more room to operate. The adoption of fiscal responsibility laws and rules by some Latin American countries between 1990 and 2005 is seen as a positive step towards achieving "dynamic consistency in fiscal policy" (ECLAC, 2004). The countries that passed such laws or rules (and the corresponding dates) were Argentina (1999 and 2004), the Bolivarian Republic of Venezuela (2003), Brazil (2000), Chile (2000), Colombia (2003), Ecuador (2002 and 2005), Panama (2002 and 2004) and Peru (2000 and 2002). In all cases the responsibility laws set numerical targets for the fiscal balance and defined transparency norms (Brazil, Chile, Colombia, Ecuador, Panama and Peru), and provided for the creation of stabilization funds to avert public finance procyclicality and help mitigate business-cycle fluctuations (Argentina, Chile, Ecuador, Paraguay and Peru). 
Given the relationship that exists between short-term fluctuations, long-term growth and productive development, the analyses and empirical results presented in this study add another dimension to the design and implementation of countercyclical macroeconomic policy.

As noted above, countercyclical policies (that is, aggregate demand policies) are not neutral with respect to the long-run behaviour of the economies in which they are implemented. The way in which countercyclical policies are designed and implemented -including their timing and the type of tools used-combines with other factors to shape and determine the economy's growth trend. Thus, economies succeed in growing sustainably over time not only because of the right kind of innovation, productivity and diversification policies, but also thanks to an adequate and growth-friendly countercyclical policy.

In the case of Latin America and the Caribbean, the interrelationship between the cycle and trend is reflected in specific characteristics of the cycle that are not conducive to accumulation and high growth rates. In this connection, the key factor is that Latin America and the Caribbean experiences weaker expansions than other regions, particularly when compared with East Asia and the Pacific.

The specific features of the cycle in the region are reflected in the behaviour of variables such as productivity and investment, which are linked to long-run growth performance. In the particular case of Latin America and the Caribbean, the behaviour of these variables reflects the weak nature of the region's expansions. In fact, a study of the specifics of the cycle, including weak output and productivity growth, may be central to explaining, at least partly, why the region has been unable to maintain sustained growth that is comparable to that achieved by other regions, particularly East Asia and the Pacific.

Apart from real variables, there are also financial factors - in particular, the behaviour of credit - which play an important role in explaining the tenuous nature of the expansions and the effect of this on long-term growth. Specifically, the evidence shows that credit is an endogenous factor in the GDP cycle, and that the financial system tends to prolong the contractions by putting sand in the wheels of the recovery and acting as a brake on the expansion.

The interrelationship that exists between cycle and trend has three important implications that should be taken into account for the purpose of building a coherent and fully fledged macroeconomics for development.

A first important implication to arise from the analysis is that macroeconomics for development should not present cycle and trend or the short and long run as dichotomous elements. Short-term fluctuations do affect long-term outcomes. 
A second implication is that countercyclical policy should not focus solely on mitigating cyclical fluctuations. It should also address the challenge of changing the specific features of the cycle that have an adverse effect on growth and the productive structure of the region's countries.

This means that countercyclical policy should not merely steer the cycle through variations in the level of aggregate demand; it should also target the composition of demand. This first raises the need to maintain the duration and intensity of the upswing and prevent public investment being used as the adjustment variable during cyclical fluctuations.

It also means that countries should open the toolkit of macroprudential regulation, beyond managing the balance-of-payments capital account and applying countercyclical financial regulations, to be able to manage the level and composition of aggregate demand. In fact, monitoring the level and composition of aggregate demand requires a variety of instruments which should be seen as context- and state-contingent specific. This means identifying and thinking about the type of instruments that are appropriate in different contexts and scenarios.

\section{Conclusions}

The Latin American and Caribbean region is characterized by high levels of volatility compared both with its own past and with other regions of the world. High levels of volatility are associated with a short-term macroeconomic dynamic that is determined by external real and financial shocks (in other words balance-of-payments dominance).

Volatility is a major obstacle to long-term and stable growth. It shortens economic agents' planning horizons and heightens risk, discourages productive investment and distorts key macroeconomic prices. In this sense, a solid development-oriented macroeconomic policy should be founded on an appropriate countercyclical policy.

According to the traditional perspective on which macroeconomics for development is based, countercyclical policies involve managing aggregate demand to smooth fluctuations in real and monetary variables around their longterm trends.

This chapter argues that macroeconomics for development should give a broader scope and greater depth to macroeconomic countercyclicality, and this means not only moving beyond volatility but explicitly recognizing the relationship between the cycle and long-term growth and the production structure.

This argument is based on three stylized features of the business cycle in Latin America and the Caribbean. First, expansionary phases are shorter 
and weaker in Latin America and the Caribbean than in other regions. Second, short-term fluctuations affect long-term outcomes through real and financial variables. Third, the financial system tends to amplify real fluctuations; and real-sector recoveries tend to precede credit recoveries.

This analysis has two major implications for countercyclical policy formulation. First, macroeconomics for development should not present the short and long terms as dichotomous. Second, countercyclical policy should not focus only on managing the level of aggregate demand, but also on affecting its composition.

This means maintaining the expansion in the real sector through investment and preventing the latter being used to leverage adjustment. It also means using macroprudential policies as a countercyclical tool to manage both the level and composition of aggregate demand.

\section{Bibliography}

Arestis, P. and M. Sawyer, (2009), Path Dependency in Macroeconomics, New York, Palgrave MacMillan.

Bernanke, B.S., M. Gertler and S. Gilchrist (1999), "The financial accelerator in a quantitative business cycle framework", Handbook of Macroeconomics, J.B. Taylor and M. Woodford, (eds.), vol.1, Amsterdam, Elsevier.

Blinder, A. (2006), "The case against the case against discretionary fiscal policy", The Macroeconomics of Fiscal Policy, R.W. Kopcke and others (eds.), Cambridge, MIT Press.

Borio, C. (2012), "The financial cycle and macroeconomics: What have we learnt?", BIS Working Papers, No. 395.

Borio, C., P. Disyatat and M. Juselius (2013), "Rethinking potential output: Embedding information about the financial cycle", BIS Working Paper, No. 404.

Bry, G. and C. Boschan (1971), Cyclical Analysis of Time Series: Selected Procedures and Computer Programmes, New York, National Bureau of Economic Research (NBER).

Calvo, G., A. Izquierdo and E. Talvi (2006), "Phoenix miracles in emerging markets: Recovery without credit from systemic financial crises", American Economic Review, vol. 96, No. 2.

Davidson, P. (2011), Post Keynesian Macroeconomic Theory, New York, Edward Elgar.

Drehman, M., C. Borio and K. Tsatsaronis (2012), "Characterizing the financial cycle: don't lose sight of the medium term!", BIS Working Papers, No. 380.

ECLAC (Economic Commission for Latin America and the Caribbean) (2012), Structural Change for Equality: An Integrated Approach to Development (LC/G.2524 (SES.34/3)), Santiago, Chile.

(2004), Productive Development in Open Economies (LC/G.2234(SES.30/3)), Santiago.

(2002), Globalization and Development (LC/G.2157(SES.29/3)), Santiago.

Ffrench-Davis, R. (2010), “Macroeconomics for development: from 'Financierism' to 'Productivism'”, CEPAL Review, No. 102 (LC/G.2468-P/E), Santiago, Economic Commission for Latin America and the Caribbean (ECLAC). 
(2006), Reforming Latin America's Economics after Market Fundamentalism, New York, Palgrave Macmillan.

Hanson, S. and others (2011), "A macroprudential approach to financial regulation", Journal of Economic Perspectives, vol. 25, No. 1.

Harding, D. and A. Pagan (2002a), "A comparison of two business cycle dating methods", Journal of Economic Dynamics and Control, No. 27. (2002b), "Dissecting the cycle: a methodological investigation", Journal of Monetary Economics, No. 49.

IDB (Inter-American Development Bank), Latin America and the Caribbean Macro Watch Data Tool [online] http:/ / www.iadb.org/research/latinmacrowatch/lmw.cfm.

Kalecki, M. (1968), "Trend and business cycles reconsidered", The Economic Journal, vol. 78 , No. 310 .

Keynes, J.M. (1936), The General Theory of Employment, Interest and Money, New York, Harcourt Brace Jovanovich Publishers.

Mink, M., J. P.A.M. Jacobs and J. de Haan (2012), "Measuring coherence of output gaps with an application to the euro area", Oxford Economic Papers, vol. 64, No. 2, Oxford University Press.

Minsky, H. (1982), Can "It" Happen Again. Essays on Instability and Finance, New York, M.E. Sharpe. (1986), Stabilizing an Unstable Economy, New Haven, Yale University Press.

Modigliani, F. (1980), "Introduction", The Collected Papers of Franco Modigliani, A. Abel (ed.),vol. 3, Cambridge, MIT Press.

Modigliani, F., and M. Miller (1958), "The cost of capital, corporation finance and the theory of investment", American Economic Review, vol. 48, No. 3.

Ocampo, J.A. (2011), "Macroeconomy for development: countercyclical and production sector transformation", CEPAL Review, No. 104 (LC/G.2498-P/E), Santiago, Economic Commission for Latin America and the Caribbean (ECLAC).

Pagan, A. (2003), "Three views of the business cycles and their implications", paper presented at SMU, unpublished.

Pérez Caldentey, E., and R. Pineda (2011), “Does Latin America lag behind due to shaper recessions and/or slower recoveries?", MPRA Working Paper, No. 25036, University Library of Munich [online] http://mpra.ub.unimuenchen.de/25036/.

Pérez Caldentey, E., D. Titelman and P. Carvallo (2013), "Weak expansions: a distinctive feature of the business cycle in Latin America and the Caribbean", Working Paper, No. 749, Levy Economics Institute [online] http://www. levyinstitute. org/pubs/wp_749.pdf.

Roache, S.K. (2012), "China's impact on world commodity markets", IMF Working Paper (WP/12/115), Washington, D.C., International Monetary Fund (IMF).

Shin, H. S. (2010), "Financial intermediation and the post-crisis financial system", BIS Working Papers, No. 304.

Titelman, D., E. Pérez-Caldentey and R. Minzer (2008), “Comparación de la dinámica e impactos de los choques financieros y de términos del intercambio en América Latina", Financiamiento del Desarrollo series, No. 203 (LC/L.2907-P), Santiago, Economic Commission for Latin America and the Caribbean (ECLAC).

World Bank (2013), World Development Indicators [database]. 

Chapter VI

\section{Towards a Robinsonian interpretation of capital accumulation in Latin America}

Juan Alberto Fuentes Knight ${ }^{1}$

\section{Introduction}

The implementation of countercyclical macroeconomic policies in many countries of Latin America in response to the international financial crisis of 2008-2009 (ECLAC, 2012) coincided with something of a revival in short-term Keynesian macroeconomic policies, but this did not extend to the adoption of policies informed by long-term Keynesian or post-Keynesian thinking. This is particularly evident in the case of Joan Robinson's contributions. The lack of mathematical formalization in the original model put forward by Robinson has, along with the sheer diversity of the formalizations proposed by numerous academics, been regarded as one of its weaknesses (Skott, 2004) or one of the factors militating against its use (Backhouse, 2003). ${ }^{2}$ This contrasts

1 The author is grateful for Esteban Pérez's invaluable comments and suggestions and his permission to include in the annex the equations formalizing Joan Robinson's model in terms of short-term equilibrium relationships. He is also grateful for the tremendous support of Giannina López and Nicole Favreau in compiling and processing the statistical data used in this study.

2 Although Joan Robinson did not favour them, there are mathematical formalizations of her theory based on neoclassical interpretations, examples being those of Johnson (1960) and Findlay (1963), as well as Marxist interpretations (Harris, 1975) and post-Keynesian ones such as those of Asimakopulos (1991, chapter 8) and Backhouse (2003), besides a version based on empirical estimates (Lovinsky and Gibson, 2004). While Robinson laid out the essence of her postulates in The Accumulation of Capital (1956), a partial version, which she herself acknowledged to be fuller 
with the situation of post-Keynesian models that have been mathematically formalized to some degree, such as those of Kalecki (1969) and Kaldor (1957).

It could also be argued, however, that the absence of a closed, formalized analytical model opens the way to broader inductive interpretations that do not necessarily sacrifice analytical rigour. Thus, the identification of different stages (ages of growth) based on causal rather than equilibrium relationships may help to bring out certain features of economic growth in Latin America that other models lacking analytical flexibility are too rigid to fully convey.

The basic components of Joan Robinson's growth theory will now be presented, with a special focus on the different ages of growth she identified, without overlooking the fact that the development literature has not on the whole attached much importance to them. ${ }^{3}$ In the second part, an attempt will be made to link certain stylized facts for Latin American economic growth in the 1980-2012 period to Robinson's theory, drawing in particular on those provided by the Economic Survey of Latin America and the Caribbean, 2013. What is aimed at is thus a preliminary assessment of the possible scope and limitations of Robinson's theory in the light of certain characteristics of economic growth in Latin America.

\section{A. Joan Robinson's growth theory}

\section{Factors affecting the growth path}

\section{(a) The relationship between the capital accumulation rate and the rate of return, and between potential and expected investment}

Robinson saw investment and the urge to accumulate as the drivers of economic growth, and she set out from this to propose two types of relationship between investment (or the capital accumulation rate) and the rate of return, with different time dimensions. First, there is a function in which the expected rate of return depends on investment, i.e., the returns on investments. These are the earnings expected from existing investments, which go to swell firms' savings and are then reinvested. Because they are a source of future investment, these earnings place a limit on capital accumulation in future. It could be argued, then, that this relationship between returns and investment,

and clearer, can be found in a later work, Essays in the Theory of Economic Growth (1963). The early, partly negative reactions to The Accumulation of Capital and Robinson's subsequent responses are explained in chapter 8 of Harcourt and Kerr (2009). See also Asimakopulos (1984) for a summary of Robinson's thinking and Harcourt (2006) for an evaluation of her contributions to the postKeynesian tradition.

3 Asimakopulos (1969 and 1991, pp. 179-182) and Kurdas (1991) are the exceptions. 
which Lavoie (2009, pp. 108-109) treats as a function of saving, with the focus on the expected rate of return $(r)$, is also reflected in potential investment. ${ }^{4}$

Robinson also proposes a second investment function in which the causality is reversed, positing that the rate of return causes or induces a certain accumulation rate $(g)$. This is reflected in investment plans, which will be realized in future investments whose choice reflects the rate of return expected and also, more vaguely, financial conditions and so-called "animal spirits", i.e., expectations. ${ }^{5}$ Investment associated with this function, which Taylor (2011, p. 182) calls the animal spirits function, could be defined as expected investment. ${ }^{6}$

The two functions can give rise to overlapping or intersecting situations. A special situation, which Robinson calls the desired rate of accumulation and Asimakopulos (1991, pp. 175-176) the entrepreneurial rate of growth or equilibrium, arises when the rate of return on investment (first function) matches the rate of investment that would supposedly produce this rate of return (second function). This is the ideal growth path, corresponding to the mythical golden age of growth posited by Robinson. Annex I presents the equations that can explain the Robinson model under conditions of short-term equilibrium and with installed capacity as a given. However, other growth paths that do not necessarily involve comparisons of different equilibrium points, and that depend on the relationship between the two types of function, can also be evaluated.

Joan Robinson's first investment function makes the rate of return depend on investment. In particular, Kalecki's contribution maintains that in a closed economy where workers do not save, profits $(P)$ can be broken down into consumed profits $(\mathrm{Cg})$ on the one hand and invested profits $(I)$ on the other, i.e., $P=C g+I$. In establishing relationships of causality between these variables, Kalecki argued that prior decisions about consumption and investment were more likely to determine future profits (Lavoie, 2009, p. 86), a proposition that Robinson reformulated as "expected returns on investment" and that can be expressed by the following equation:

This is not a concept used by Robinson, but it is employed in this study for heuristic purposes. The following quote from Robinson (1963, pp. 37 and 38) clearly illustrates her thinking on the subject: "Capitalism develops the spirit of emulation: without a competitive urge to grow, modern managerial capitalism could not flourish. At the same time there are costs and risks attached to growth that keep it within certain bounds. To attempt to account for what makes the propensity to accumulate high or low we must look into historical, political and psychological characteristics of an economy; with that sort of inquiry a model of this kind cannot help us. It seems reasonably plausible, however, to say that, given the general characteristics of an economy, to sustain a higher rate of accumulation requires a higher level of profits, both because it offers more favourable odds in the gamble and because it makes finance more readily available. For purposes of our model, therefore, the 'animal spirits' of the firms can be expressed in terms of a function relating the desired rate of growth of the stock of production capital to the expected level of profits."

6 This concept is not used by Robinson either. 
(1) $P=\frac{P I}{1-\left(1-S_{P}\right) \beta}$

A positive relationship is thus maintained between gross investment (I) and consumption of profits, in that higher consumption and investment produce higher profits. The propensity of businesses to consume can be expressed as $\left(1-S_{p}\right) \beta$, where $\beta$ represents the proportion of profits distributed in the form of interest and dividends, $\left(1-S_{P}\right)$ is the propensity to consume profits and $S P$ equates to the propensity to save these retained earnings, but channelled into investments. ${ }^{7}$ The expression $1-\left(1-S_{p}\right) \beta$ thus represents the propensity to save gross earnings, which depend both on the proportion of earnings distributed $(\beta)$ and on the proportion saved $\left(S_{P}\right){ }^{8}$

A number of authors have used the following equation, known as the Cambridge equation, to express this relationship in a more general way:

(2) $r=g / s$

Here, $r$ represents the rate of return and is equivalent to $P / K$ (where $K$ is capital), $g$ is the capital accumulation rate (equivalent to $I / K$ ) and $s$ represents the propensity to save. ${ }^{9}$

More precisely, this means that a lesser propensity to consume or a greater propensity to save would mean a lower rate of return from a given capital accumulation rate. ${ }^{10}$ When this function (potential investment) is combined with the other function that makes investment dependent on the expected rate of return, on expectations and on financial conditions

(expected investment), the deduction is that higher consumption or lower

The simplest model assumes that only rentiers receiving profits and interest save, while workers consume all their income. However, it is possible to carry out more complex exercises that include worker saving and maintain the same results, provided rentiers have a higher propensity to save than workers (Asimakopulos, 1969).

8 This is derived from the equation $S=P-C g$, where consumed profits $(C g)$ can be expressed as $\left(1-S_{p}\right) \beta P$. Accordingly, we get $S=P-\left(1-S_{p}\right) \beta P$, a formula equivalent to $S=P\left(1-\left(1-S_{p}\right) \beta\right)$, which then yields equation (1). Here Robinson assumes the existence of a competitive, closed capitalist economy without government. Her book Exercises of Economic Analysis (1961) presents a first expression of the relationship between profits, saving and investment. Some information on this theory can be found in Kalecki (1969, chapters 4 and 9), who argues that firms' investment plans depend on their prior savings and expected returns. Firms' savings, meanwhile, are a portion of the earnings produced by investments in the past, while expected returns depend on both current and past investments (Lavoie, 2009, p. 86). Robinson argues that her investment approach, unlike Kalecki's, is based on desired economic growth, which is similar to what Harrod terms warranted growth, rather than on the capital desired (Robinson, 1963, p. 87).

9 The equivalence between the two equations is obtained by dividing both terms of the equation by $K$ and expressing the denominator of the right-hand side of (1) as s.

10 In the simpler versions of this approach, only capitalists save; accordingly, what they do not end up consuming determines the pattern of saving in the economy as a whole. 
saving is associated with greater investment. These arguments match the idea put forward by Robinson as the fundamental paradox that arises when Keynesian analysis is projected into the long term (Robinson, 1963, p. 60), as it goes against the neoclassical thesis that higher saving leads to higher investment.

However, Robinson (p. 61) also acknowledges the possibility of a twoway relationship between capital accumulation and saving, a postulate that is not necessarily reflected in the simpler equations deployed in efforts to explain her model. It transpires, then, that just as a lower propensity to save is associated with a higher capital accumulation rate, a higher accumulation rate can also bring an increased propensity to save by forcing profits to be reinvested rather than distributed as dividends or interest, which would be consumed.

This can be taken as an example of how the dynamic of investment leads to an adjustment and an increase in saving and how the second function (expected investment), which makes the accumulation rate dependent on the rate of return and is subject to faltering animal spirits, can alter the first one, centred as it is on the relationship between investment, profit and saving (potential investment, expressed as $r=g / s$ ). It also exemplifies how the capital accumulation process (with expected investment higher than potential investment) can alter income distribution indirectly, in this case by delaying the consumption carried out by those in receipt of dividends or interest. This idea reflects a Keynesian perspective on the relationship between investment and saving: the ex post equivalence between saving and investment would imply the need for prior adjustments so that saving is adequate to cover expected investment.

When there is an intention to increase capital accumulation, an equivalent situation could be envisaged in which workers' consumption and real wages were reduced by inflation to produce the additional profits needed for reinvestment. The same could happen if the consumption of profits rose or fell, with this potentially being offset by a reduction or increase in real wages. Robinson argues that any attempt to reduce real wages could be thwarted if there were unions defending workers' purchasing power via an inflationary rise in real wages, creating an inflation barrier that would prevent the rate of return from increasing (Robinson, 1963, pp. 58-59). In general, not only is it possible to adjust the distribution of income between workers and other parts of the population to facilitate or impede capital accumulation, but the propensity to consume or save profits can also be altered (in the simpler model where workers consume all they earn). 


\section{(b) The relationship between output growth, employment and technical progress}

Looking beyond the short-term equilibrium situation in which installed capacity is a given and technical progress is considered neutral, in Robinson's approach, unlike Harrod's growth theory, the accumulation process can affect the nature of technical progress, without this being exogenous. ${ }^{11}$ It is driven by competition, and the relative scarcity or abundance of labour can stimulate the adoption of more or less mechanized production techniques, although not in a mechanical or deterministic fashion. This becomes particularly apparent when the existence of independently occurring innovations is recognized (Robinson, 1963, pp. 36 and 51-52).

In turn, the nature of technical progress is reflected in the evolution of labour productivity, which, along with employment growth, determines output growth, as can be seen in the following equation, where $g_{y}$ represents output growth, $g_{d}$ productivity growth and $g_{l}$ employment growth:

(3) $g_{y}=g_{d}+g_{l}$

Likewise, technical progress and population growth as manifested in the labour supply (n) determine the possible growth rate, as opposed to the desired or equilibrium growth rate discussed earlier. Thus, whereas full employment can be expected in the ideal situation of desired growth, thanks to development which ensures that employment growth matches working-age population growth, other paths would give rise to a variety of situations with different starting points for unemployment. This idea can be expressed in the following formula: ${ }^{12}$

(4) $g_{u}=n-\left(g_{y}-g_{d}\right)$

In this case, the change in the unemployment rate $\left(g_{u}\right)$ depends on the gap between working-age population growth $(n)$ and job creation $(g)$, which depends in turn on the difference between output growth and labour productivity growth $\left(g_{y}-g_{d}\right)$, obtained from equation (3). The existence of long-term unemployment is one of the characteristics of Robinson's analysis that distinguishes it from other post-Keynesian approaches like Kaldor's.

\section{(c) Institutional structures: the (antagonistic) relationships between classes and their effects on income distribution}

Robinson's model includes institutional aspects pertaining to the relationship between workers and capitalists. She also considers both situations of harmony in some scenarios, with no union impact at all, and

\footnotetext{
11 In this context, technical progress improves the relationship between output and employment without altering the relationship between capital and output, which would be neutral on Harrod's definition of technical progress (Asimakopulos, 1969).

12 See Backhouse (2003) for a similar explanation.
} 
situations of conflict or bargaining where there are worker organizations capable of influencing wage-setting. In particular, Robinson addresses two types of situations that can have an impact on wage changes and bring consequences for the capital accumulation rate (Asimakopulos, 1976). The impact on wages arises when there is surplus demand for labour leading to pay increases which restrict the growth rate, an aspect that can be partly offset by growing mechanization and incorporation of technical innovations, which would increase the potential growth rate of the economy. ${ }^{13}$

The second situation arises when the increase in the accumulation rate (or profit consumption) creates pressure to lower real wages to levels that workers are unwilling to accept, giving rise, when union power exists, to the inflation barrier described in the previous sections. A variant on this situation can arise when real wages are at a barely tolerable level and can be reduced no further, and thus likewise set bounds to the accumulation rate, although not necessarily by way of the inflation barrier. This variant differs from the one where the causality operates in reverse, with the constrained accumulation rate holding living standards down to a minimum (Robinson, 1963, p. 59).

\section{The ages of growth}

\section{(a) The ages of constant or variable growth}

Although Robinson's theory set out from the comparative analysis of short-term equilibrium points, reflected in a characterization of growth that posits a golden age where various ideal conditions are met, her explanation about alternative paths is particularly valuable. These paths incorporate variations on the golden age, as well as platinum ages, which are based not on the comparison of equilibrium points, but on processes of change that are more analogous to hypothetical situations. In addition, Robinson classifies ages by their growth rate, this being constant in golden ages and rising or falling in platinum ages. Golden ages are part of the post-Keynesian tradition, represented especially by Kaldor and Pasinetti, and centre on constant growth paths, while platinum ages open up perspectives, albeit incipient ones, for models where imbalances are greater. The basic features of these ages are summarized in table VI.1 and described below.

13 In a context where expected investment is higher than potential investment (i.e., a vigorous animal instinct prevails), Robinson assumes that the adjustment between current investment and past saving is covered by lending from the banking system. In an economy which is close to full employment and where the credit supply, inflation and the interest rate are rising, a higher real interest rate can constrain the accumulation process (Backhouse, 2003; Robinson, 1971, p. 74). 
Table VI.1

Basic features of growth ages according to Joan Robinson

\begin{tabular}{|c|c|c|c|c|c|}
\hline Age & $\begin{array}{l}\text { Starting } \\
\text { conditions }\end{array}$ & $\begin{array}{l}\text { Relationship } \\
\text { between } \\
\text { potential } \\
\text { investment } \\
(A) \text { and } \\
\text { expected } \\
\text { investment }(I)\end{array}$ & $\begin{array}{l}\text { Relationship } \\
\text { between growth } \\
\text { in output }\left(g_{y}\right) \text {, } \\
\text { employment }\left(g_{l}\right) \text {, } \\
\text { population }(n) \\
\text { and productivity } \\
\left(g_{d}\right)\end{array}$ & $\begin{array}{l}\text { Saving, profit, } \\
\text { consumption, } \\
\text { wages and } \\
\text { investment }\end{array}$ & Comments \\
\hline $\begin{array}{l}\text { Golden } \\
\text { age }\end{array}$ & $\begin{array}{l}\text { Full } \\
\text { employment. } \\
\text { Harmonious } \\
\text { labour relations. }\end{array}$ & $I=A$ & $\begin{array}{l}g_{y}=g_{d}+g_{l} \\
g_{l}=n\end{array}$ & $\begin{array}{l}\text { Higher } \\
\text { investment } \\
\text { is associated } \\
\text { with lower } \\
\text { saving } \\
\text { (Keynesian } \\
\text { paradox) and } \\
\text { a larger profit } \\
\text { margin. }\end{array}$ & $\begin{array}{l}\text { Lasting } \\
\text { equilibrium. }\end{array}$ \\
\hline $\begin{array}{l}\text { Limping } \\
\text { golden age }\end{array}$ & $\begin{array}{l}\text { There is } \\
\text { unemployment. } \\
\text { Labour relations } \\
\text { are harmonious. }\end{array}$ & $I \leq A$ & $\begin{array}{l}g_{y}=g_{d}+g_{l} \\
g_{l}>n, \\
\text { so unemployment } \\
\text { falls. }\end{array}$ & $\begin{array}{l}\text { Redistribution } \\
\text { from rentiers } \\
\text { to the } \\
\text { unemployed } \\
\text { could increase } \\
\text { investment and } \\
\text { employment. }\end{array}$ & $\begin{array}{l}\text { Lasting } \\
\text { equilibrium, } \\
\text { but with } \\
\text { unemployment. }\end{array}$ \\
\hline $\begin{array}{l}\text { Leaden } \\
\text { age }\end{array}$ & $\begin{array}{l}\text { There is } \\
\text { unemployment. }\end{array}$ & $\begin{array}{l}I<A \\
\text { Animal spirits } \\
\text { weak. }\end{array}$ & $\begin{array}{l}g_{y}=g_{l} \\
\text { Since } g_{d}=0 \\
g_{l}<n, \text { so } \\
\text { unemployment } \\
\text { rises. }\end{array}$ & & $\begin{array}{l}\text { Population }(n) \\
\text { keeps pace with } \\
\text { employment } \\
\left(g_{l}\right) \text {, but wages } \\
\text { do not increase. }\end{array}$ \\
\hline $\begin{array}{l}\text { Restrained } \\
\text { golden age }\end{array}$ & $\begin{array}{l}\text { Full } \\
\text { employment. }\end{array}$ & $\begin{array}{l}I>A \\
\text { Strong animal } \\
\text { spirits. }\end{array}$ & $\begin{array}{l}g_{y}=g_{l}+g_{d} \\
g_{l}>n\end{array}$ & $\begin{array}{l}\text { A situation of } \\
\text { greater saving } \\
\text { could lead to } \\
I=A \text {, via a } \\
\text { lower } I \text {. }\end{array}$ & $\begin{array}{l}\text { Adjustment } \\
\text { towards } \\
g_{l}=n \text { occurs } \\
\text { via an (unlikely) } \\
\text { increase in the } \\
\text { interest rate or } \\
\text { an employers' } \\
\text { agreement } \\
\text { aimed at } \\
\text { reducing wage } \\
\text { pressures. } \\
\text { Short-term } \\
\text { instability. }\end{array}$ \\
\hline $\begin{array}{l}\text { Bastard } \\
\text { golden } \\
\text { age }\end{array}$ & $\begin{array}{l}\text { There is } \\
\text { unemployment. } \\
\text { There is } \\
\text { antagonism } \\
\text { between the } \\
\text { classes and } \\
\text { union power. }\end{array}$ & $I>A$ & $\begin{array}{l}g_{y}=g_{l}+g_{d} \\
g_{l \gtrless} n \\
\text { There may be } \\
\text { a tendency for } \\
\text { unemployment } \\
\text { to rise or for the } \\
\text { value of } g_{y} \text { to drop. }\end{array}$ & $\begin{array}{l}\text { Lower (higher) } \\
\text { consumption } \\
\text { (saving) could } \\
\text { make up for } \\
\text { higher wages. }\end{array}$ & $\begin{array}{l}\text { Union pressure } \\
\text { for higher } \\
\text { wages leads to } \\
\text { higher inflation } \\
\text { (inflation } \\
\text { barrier) that } \\
\text { restricts } \\
\text { accumulation. }\end{array}$ \\
\hline $\begin{array}{l}\text { Galloping } \\
\text { platinum } \\
\text { age }\end{array}$ & $\begin{array}{l}\text { There is } \\
\text { unemployment. } \\
\text { Problems with } \\
\text { the composition } \\
\text { of capital: } \\
\text { not enough } \\
\text { capital goods to } \\
\text { produce other } \\
\text { capital goods. } \\
\text { There is union } \\
\text { power and } \\
\text { antagonism. }\end{array}$ & $\begin{array}{l}I>A \\
\text { Strong animal } \\
\text { spirits. }\end{array}$ & $\begin{array}{l}g_{y}=g_{l}+g_{d} \\
g_{l}>n\end{array}$ & $\begin{array}{l}\text { Higher } \\
\text { investment } \\
\text { is associated } \\
\text { with a larger } \\
\text { share for } \\
\text { profits and a } \\
\text { lower share } \\
\text { for wages. }\end{array}$ & $\begin{array}{l}\text { Adjustment } \\
\text { may be due } \\
\text { to inflation } \\
\text { barriers, to full } \\
\text { employment or } \\
\text { to the fact that } \\
\text { the right capital } \\
\text { share has been } \\
\text { reached. }\end{array}$ \\
\hline
\end{tabular}


Table VI.1 (concluded)

\begin{tabular}{|c|c|c|c|c|c|}
\hline Age & $\begin{array}{l}\text { Starting } \\
\text { conditions }\end{array}$ & $\begin{array}{l}\text { Relationship } \\
\text { between } \\
\text { potential } \\
\text { investment } \\
(A) \text { and } \\
\text { expected } \\
\text { investment }(I)\end{array}$ & $\begin{array}{l}\text { Relationship } \\
\text { between growth } \\
\text { in output }\left(g_{y}\right) \text {, } \\
\text { employment }\left(g_{l}\right) \text {, } \\
\text { population }(n) \\
\text { and productivity } \\
\left(g_{d}\right)\end{array}$ & $\begin{array}{l}\text { Saving, profit, } \\
\text { consumption, } \\
\text { wages and } \\
\text { investment }\end{array}$ & Comments \\
\hline $\begin{array}{l}\text { Creeping } \\
\text { platinum } \\
\text { age }\end{array}$ & $\begin{array}{l}\text { Full } \\
\text { employment. } \\
\text { Problems with } \\
\text { the composition } \\
\text { of capital: } \\
\text { overinvestment } \\
\text { in the production } \\
\text { of capital goods } \\
\text { to manufacture } \\
\text { other capital } \\
\text { goods. }\end{array}$ & $I>A$ & $\begin{array}{l}g_{y}=g_{l}+g_{d} \\
g_{l}>n\end{array}$ & & $\begin{array}{l}\text { Adjustment } \\
\text { may lead to } \\
\text { a restrained } \\
\text { golden age, but } \\
\text { with greater } \\
\text { potential for } \\
\text { imbalances. }\end{array}$ \\
\hline
\end{tabular}

Source: Joan Robinson, Essays in the Theory of Economic Growth, London, Macmillan, 1963; Athanasios Asimakopulos, Keynes's General Theory and Accumulation, Cambridge, Cambridge University Press, 1991; and "A Robinsonian growth model in one-sector notation", Australian Economic Papers, No. 8, 1969.

\section{(i) The golden age}

Robinson's initial reference path is the golden age, not because of any purported validity, but because it highlights the conditions that would have to obtain for a high and stable growth rate with full employment to be achieved. In this age, which Robinson considers mythical, the increase in expected investment (associated with animal spirits) is matched by that in possible investment (permitted by the level of profits). Capital has the composition needed to match the equilibrium rate of the accumulation desired, given by the match between possible and expected investment. This gives rise to an output growth path where, setting out from a situation of full employment, jobs growth matches population growth $(n)$ and, assuming neutral technical progress, real wages increase in line with labour productivity, the rate of return stays constant and labour relations are harmonious. Price flexibility, the result of competitive markets, allows demand to adjust so there is no increase in idle installed capacity, which grows at the same rate as the economy. ${ }^{14}$

\section{(ii) The limping golden age}

In the limping golden age, expected and potential investment tend to match and the growth rate is constant, but there is unemployment at the starting point, which distinguishes this age from the golden age as such. Nonetheless, unemployment is not associated with inadequate aggregate

14 This assumes competition. Robinson's model can also be adjusted for a situation of imperfect competition, with differing degrees of installed capacity utilization, as set out in the following sections. 
demand (Keynesian unemployment), but is of a nature that Robinson describes as chronic and sees as resulting from restricted growth in production capacity in the past (Robinson, 1961, p. 102). In this age, output growth continues to depend on labour productivity and employment growth, driven by capital accumulation, and if employment grows faster than the population there will be a tendency for the jobless rate to drop and tend towards a situation of full employment. The opposite will happen if the accumulation process entails employment growth that is slower than population growth, whereupon the rate of employment will drop.

Robinson identifies three reactions that can lead to a drop in unemployment: a higher accumulation rate, lower mechanization and voluntary transfers (she assumes there is no government) of resources from rentiers to the families of the unemployed (Robinson, 1961, pp. 102-103). She sees no particular reason why the first process (a rising accumulation rate) should occur spontaneously in a capitalist economy. Nor does she see grounds for optimism about the second type of reaction, arguing that, while there may be incentives to reduce the degree of mechanization because of the wage decline brought about by unemployment, the change in the use of techniques entailed by this may be as problematic for firms as investing in improved production techniques. Furthermore, it would be odd if this change occurred in a context that showed firms to be slow-moving and incapable of realizing the growth potential of the economy.

Robinson seems to have a more favourable appreciation of the third type of reaction, which is equivalent to a fiscal policy of income redistribution. Transferring resources from those with a lower propensity to consume (rentiers) to other sectors with a greater propensity (the families of the unemployed) would boost aggregate demand and bring two effects in its train: it would increase prices (which would reduce workers' real wages), but it would also be an incentive for investment, and so would in turn help to combat unemployment (Robinson, 1961, p. 104).

\section{(iii) The leaden age}

The outcome in the leaden age (a perverse variation on the limping golden age) is more drastic, showing the combined effect of unemployment and a lack of technical progress, both the result of inadequate capital accumulation. In this case, expected investment, associated with animal spirits, is below possible investment, probably because the business class is undynamic or faces very uncertain prospects..$^{15}$ Restricted capital accumulation means

15 In Exercise in Economic Analysis (1961, p. 107), Robinson argues that the reason for firms' lack of dynamism may be that the risks are too great, that financing is hard to obtain or that businesses have ceased to struggle for competitiveness and are now following a policy of live and let live. 
slower incorporation of technical advances, so that labour productivity does not increase and employment grows more slowly than the population. In these circumstances, the labour market and wages contract because there is a surplus supply of labour, and Robinson therefore argues, from a Malthusian perspective, that with this path the population growth rate would have to adjust to the rate of employment growth. ${ }^{16}$

\section{(iv) The restrained golden age}

The restrained golden age is the outcome of an accumulation process where expected investment is greater than possible investment, with expectations (or animal spirits) favouring a level of investment higher than is feasible (an accumulation rate that would cause employment to grow more quickly than the population). In this situation, forces arise that continually tend to hold down capital accumulation to a level consistent with the rate of expansion permitted by employment growth, setting out from a situation where there is already full employment.

According to Robinson, there are two possible factors restraining the accumulation rate so that the expected rate of capital accumulation can converge with the possible rate. First, the interest rate may rise in a context where demand for credit and inflation are increasing because of wage rises caused by the growing demand for labour in a situation of full employment. In this case, the interest rate will have to rise until it constrains investment, although Robinson expresses deep scepticism about the prospect of monetary policy being able to control investment via the interest rate, especially in contexts where monetary policy is conditioned by the balance of payments and exchange rates (Robinson, 1963, p. 43). ${ }^{17}$

The other way to bring about convergence between potential investment and expected investment is for firms to take a collective decision to exercise monopsony in the labour market and reduce the accumulation rate to avoid competing for extra workers (via higher pay) in the face of the threat of higher wages. This situation would stimulate investment in more mechanized production techniques, which would constrain the rate of return until the capital

${ }_{16}$ A less radical interpretation of the demographic adjustment is that it might take place through emigration. See Galor (2011, pp. 9-17) for a very precise characterization, based on historical facts, of growth with population adjustments, enabling this to be regarded as a stage of Malthusian growth similar to the leaden age posited by Robinson.

17 Without government intervention, the increase in credit would be endogenous (the money supply would not be a given, as it is in orthodox monetary approaches), but would be adjusted to facilitate the accumulation process with adequately low interest rates, so that it did not tend to trigger hyperinflation. Robinson recognizes that this process is uncertain and not error-free. See Backhouse (2003) in particular for this approach. 
accumulation rate dropped, although it would also increase the potential growth rate of the economy (Asimakopulos, 1976). Conversely, each firm could make investments and underutilize its installed capacity, which would also drive down the rate of return and thence investment growth. Either of these could cause strains and a possible path of instability in the short run (Robinson, 1963, pp. 55-56).

\section{(v) The bastard golden age}

A variant on the restrained golden age is the bastard golden age, which illustrates the way in which high real wages unrelated to a labour shortage constrain the accumulation process. The starting point is a situation where unemployment coincides with an institutional environment in which unions are capable of preventing real wages from collapsing below the lower bound required to ensure a high rate of capital accumulation and greater job creation. This union capability would be reflected in rising money wages, so that the accumulation process would come up against an inflation barrier, resulting in a financial constraint. Even if the accumulation rate is lower than the rate that could have been attained without this barrier, the employment growth rate could still rise and, depending on whether it is higher or lower than the population growth rate, the effect could be to bring down unemployment.

Expectations of rising inflation and higher wages could drive inflation still higher in two ways that would encourage higher spending. The first is that expectations of higher prices would strengthen the propensity of rentiers to consume their profits, especially by purchasing durable goods. The second is that they might bring forward their investment plans in anticipation of higher wages (Robinson, 1963, p. 72).

Robinson posits two variants for the bastard golden age: one with high wages thanks to union action, and a low-level bastard golden age in which the real wage that constrains the accumulation process is at the tolerable minimum. Robinson adds, for example, that at these subsistence-level wages, higher food prices may force employers to pay better cash wages to ensure their workers' survival (p. 70). This low-level variant of the bastard golden age resembles the leaden age insofar as minimal living standards constrain the accumulation process in the former, while in the leaden age the accumulation process holds living standards down to a minimum (Robinson, 1963, p. 59).

The negative effect of wages on the accumulation rate could be offset by a lower propensity to consume profits (a greater propensity to save, in other words). This would offset the lower rate of return resulting from higher wages and thus be conducive to a higher rate of capital accumulation and a larger reduction in unemployment. 


\section{(vi) The galloping platinum age}

The galloping platinum age is characterized by very favourable animal spirits that speed up the accumulation rate, a situation which widens the gap between expected investment and possible investment and is due to a problem of capital composition. ${ }^{18}$ Unlike investment whose purpose is to produce consumer goods, this investment does not suffice to produce capital goods in the quantities needed to manufacture other goods of the same type (Robinson, 1963, p. 56), the result being growth lower than would be obtained with a continuous process of adjustment that ensured the composition of the capital goods produced was the right one. ${ }^{19}$ In addition, and by contrast with the restrained golden age, potential investment matches expected investment, with a rise in the rate of return and a reduction in the real wage, and with a higher rate of employment growth, factors that make it possible to produce more capital goods for the manufacture of other goods of the same type. This growth trajectory could stop when full employment is reached or real wages rise too far (inflation barrier), or it could continue until the share-out of capital goods between consumption and investment reaches the proportion required to attain the desired level of accumulation. This once again illustrates how the conjunction of certain starting conditions (full employment or unemployment, institutional agreements and the composition of capital goods production) can give rise to situations different to those of the golden age.

\section{(vii) The creeping platinum age}

The creeping platinum age differs from the galloping platinum age in that there has been excessive investment in the production of capital goods whose purpose is to manufacture other goods in this class, because full employment has been reached and because the accumulation rate has peaked and is slowing, even if the expected investment rate remains greater than the possible rate. Under these conditions, the growth rate of the population (available labour) is lower than the rate at which demand for labour is growing in the capital goods-producing sector. As with the restrained golden age, Robinson introduces the possibility of raising the interest rate to reduce the accumulation rate, with this cutting the rate of return and offering the possibility of a new adjustment path. This includes the transfer of workers from the capital goods-producing sector to the consumer goods-producing

18 Asimakopulos (1969) prefers to simplify Robinson's growth model and confine it to one sector, without distinguishing between a capital goods sector that produces consumer goods and another that produces capital goods. Thus, he assumes that in platinum ages capital is subject to physical constraints that may limit investment. Asimakopulos (1991, p. 182) analyses two relevant sectors.

19 This involves maintaining a particular ratio between the capital goods used to manufacture other capital goods and those used to produce consumer goods (Robinson, 1963, p. 56). 
sector, increasing mechanization that can hold rates of return and real wages steady, and a gradual decline in the accumulation rate until a situation similar to that of the restrained golden age is reached, but with the threat of possible short-term disequilibria.

\section{Some broader applications of Robinson's theory}

An extension of Robinson's approach with a view to analysing accumulation and growth in Latin America can be facilitated by broadening it in certain directions, in particular to reflect the importance of the external sector. Lovinsky and Gibson (2004) did this by combining Robinson's approach with Keynesian theory for open economies, a method that enabled them to integrate the external saving that covers the current account deficit with the public-sector deficit and the interest payments entailed by the creation of public debt. As a result, and after some mathematical processing, they adjusted the Cambridge equation so that it took account of the effects of external saving, the public-sector deficit and debt interest payments. Consequently, equation (2) looks like this:

(5) $g=s \bar{r}+\left(s j+p^{\star}-p\right) q u$

In this equation, $g$ is the accumulation rate and $s$ is the propensity to save, while $\bar{r}$ represents after-tax profits, $j$ interest paid to holders of public debt, $p^{*}$ the external saving ratio (as a share of output), $p$ the public-sector deficit, $\mathrm{u}$ the degree of installed capacity utilization as defined by the ratio between current output and potential output $(Q)$, and $q$ the ratio between $Q$ and capital (K). When $q$ is multiplied by $u, Q$ is left out, so that the second term of the equation becomes the proportion of additional net saving resulting from the current account (external saving), adjusted for the fiscal deficit and interest payments, and multiplied by $X / K$ (output generated per unit of capital).

This basically means that external saving can be added to national saving and that its effect will increase or diminish depending on whether the fiscal deficit is smaller or larger. When the same equation is expressed in terms of profits $(r)$ as a dependent variable, this will have a (paradoxically) negative relationship with saving (domestic and external) and a positive one with the fiscal deficit, which is consistent with the projection of Keynesian theory into the long run.

If Robinson's approach is interpreted on the basis of this broader application, the conclusion is that the adjusted version of the first investment or potential investment function would have to be combined with expected investment (depending on expected yields), financial conditions and expectations (animal spirits). When external saving is introduced as a variable, one that is at least partially dependent on the 
flow of foreign direct investment insofar as it is financed out of external resources, a case where (external) saving responds to (external) investment is also exemplified.

Another extension of Robinson's approach, which she herself dealt with in her last writings, is to include the degree of installed capacity utilization as a variable affecting investment and growth. This idea was taken up by Lovinsky and Gibson (2004) in their model and formalized by Asimakopulos (1969 and 1970). In her basic model and in her growth hypotheses, Robinson assumes that consumer goods markets are competitive; consequently, prices are adjusted to ensure full use of installed capacity, although she recognizes that in conditions of imperfect competition the existence of higher prices may create situations where capacity lies idle, resulting in a lower level of investment (Robinson, 1961, pp. 105-107).

In her last writings, Robinson expanded the scope of this subject, consistently with Kalecki's approach of setting a premium over the prices prevailing in a competitive market that varies with firms' monopoly power. Since this premium affects prices and installed capacity utilization, it has further repercussions on employment and investment, as explained by Asimakopulos (1970 and 1977).

For one thing, the increase in the premium can act as a mechanism offseting union pressure for higher wages, which can give rise to the inflation barrier. For another, in imperfect markets, unlike situations where competitive markets exist and prices adjust to ensure full use of installed capacity, employment adjusts according to the level of effective demand. Although idle capacity may usually be assumed to exist in imperfect markets, it is possible to conjecture different growth paths depending on the assumption taken, such as the possibility that limited investment may result in firms deciding to lower their prices by reducing the premium, a measure that would increase employment and reduce profits as a share of output (Asimakopulos, 1970). This once again reveals that the Robinsonian approach does not entail a closed analytical model but is open to different possibilities.

\section{B. Capital accumulation and the ages of growth in Latin America from 1980 to 2012}

\section{The relationship between capital accumulation, growth and saving in Latin America}

Consistently with her Keynesian orientation, Joan Robinson assigns investment a fundamental role as a driver of growth. This can be evaluated in five periods of economic growth in Latin America, defined on the basis 
of criteria that take account of the region's economic cycles, and particularly the main shocks of external origin suffered during these three decades: (i) 1982-1989, marked by the debt crisis; (ii) 1990-1997, affected by financial instability and the Asian crisis of 1997-1998; (iii) 1997/1998-2002, regarded by some observers as a lost half-decade following the shock caused by the Asian crisis, culminating in the Argentine crisis of 2001-2002; (iv) the period that began in 2003, marked by the price boom for the commodities exported by the region, except in 2008-2009; and (v) 2009-2012, the aftermath of the global financial crisis, when the region's growth began to fall off somewhat. Setting out from Robinson's approach and this time division, and with the assistance of studies by Jiménez and Manuelito (2012 and 2013) and ECLAC (2012 and 2013), it is possible to identify a number of features that characterize the investments made in Latin America between 1980 and 2012.

First, total investment in Latin America followed a fluctuating path, with particularly low levels during the 1980s because of the debt crisis and the global recession and something of an upturn in the following stages, albeit with differences between countries. It fell steadily during the first half of the 1980s, averaging 17.7\% of GDP between 1980 and 1989. After recovering to some extent (to $19.0 \%$ of GDP) during the 1990s, when many countries in the region suffered severe financial instability but had access to foreign investment and saving, it grew in the 2000s, especially between 2003 and 2010, when it reached $20.4 \%$ of GDP, although investment patterns differed greatly by country in this last stage.

Second, there was a close relationship between investment and GDP growth in the region (Ffrench-Davis, 2005, pp. 109-112), something that is consistent with the post-Keynesian approach in general. When the coefficient of correlation between investment growth and per capita GDP growth is estimated, a significant and positive correlation is found in all the periods analysed, represented by the simple regression lines in figure VI.1. ${ }^{20}$

Besides this correlation, the upward shift in the lines for each period indicates that investment growth coincided with higher rates of per capita GDP growth as time went on (see figure VI.1).

\footnotetext{
20 Although investment is part of GDP, each of the latter's components evolves with its own dynamic, investment being the most volatile. Consequently, the coefficient of correlation between the two variables fluctuates from period to period, as the following values show: 0.7 (1982-1989), 0.53 (1990-1997), 0.83 (1998-2002), 0.7 (2003-2008) and 0.63 (2009-2012). Statistical significance is $99 \%$ in all the periods analysed except 1990-1997, when the confidence level drops to $98 \%$.
} 
Figure VI.1

Latin America: relationship between per capita GDP growth and investment growth in different periods

(Percentages)

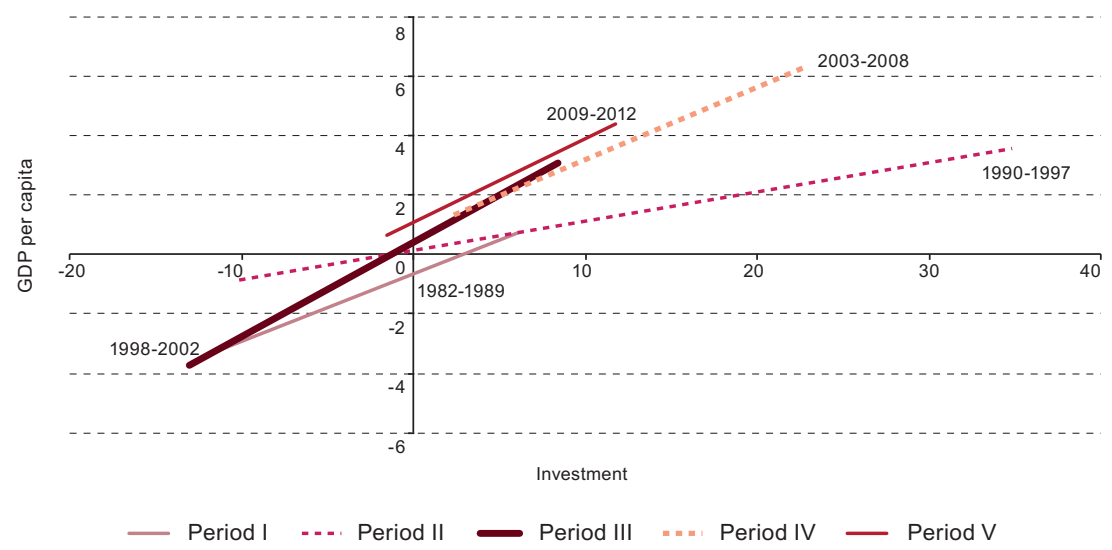

Source: Economic Commission for Latin America and the Caribbean (ECLAC), on the basis of official figures.

Some estimates of the causal relationships between investment and GDP (evaluated with Granger's method) suggest that the two variables affected each other, even if general GDP growth preceded investment growth in a greater number of countries (Jiménez and Manuelito, 2013; ECLAC, 2013, pp. 116-119). In some countries, such as Brazil and to an extent Mexico, the causal relationship ran from investment to GDP, while in others (Chile, Colombia, Nicaragua and Uruguay) it went in the opposite direction, and in several (Argentina, Costa Rica and Panama) the relationship was twoway. These findings suggest that fluctuations in the capital accumulation rate were closely linked to changes in aggregate demand pressures of both domestic and external origin. They also suggest that, by contributing to full use of installed capacity, aggregate demand and its management by means of countercyclical policies were essential to ensure a high and fairly stable capital accumulation rate.

Third, following on from the previous point, there are indications in a number of Latin American countries of a positive relationship between investment growth and the degree of installed capacity utilization, as measured by the output gap. Between 1990 and 2010, in particular, there were high and significant coefficients of correlation between the two variables in Latin America, and particularly in Argentina, Chile, Colombia, Guatemala, Mexico, Panama, Paraguay and Uruguay, while they were somewhat lower but still significant in the cases of Brazil and Peru (ECLAC, 2013, table II.4, 
p. 113). This would indicate a possible accelerator effect, insofar as they can be treated as growth expectations (associated with aggregate demand growth) driving investment dynamism. At the same time, there is some evidence that the mediocre performance of labour productivity in the region is partly due to limited utilization of installed capacity in a number of countries (Aravena and Fuentes, 2013).

Fourth, animal spirits, as reflected in businesses' willingness to increase the rate of capital accumulation in Latin America, may have varied depending on the stage and the context in each country, but do not seem to have been very vigorous, particularly by comparison with other countries. Investment was substantially lower than in other fast-growing regions, particularly Asia, but also the Middle East and North Africa. Defined as gross capital formation, it averaged more than $40 \%$ of GDP in China and India and ranged from $25 \%$ to $30 \%$ in the Middle East and North Africa in 2012, whereas in Latin America it averaged just over 20\%. ${ }^{21}$

Lastly, the evolution of the relationship between saving and investment (see figure VI.2) tends to confirm the importance of the investment dynamic as a determinant of saving, without higher saving necessarily leading to more investment, although this is a complex and interdependent relationship where saving does not automatically match investment and can condition it. ${ }^{22}$ Thus, the virtual disappearance of external saving in Latin America during the 1980s in consequence of the debt crisis, a time when investment was significantly lower than at earlier and later stages, brought to light the existence of profound external constraints that resulted in a lower level of investment.

${ }^{21}$ Since the decision to invest determines the profits that will be reinvested (saved profits), it can be hypothesized that investment is constrained by the high level of consumption and the marked propensity to consume displayed by higher-income business strata as compared to the same business groupings in other regions of the world. This would be the opposite of the positive effect on aggregate demand that a higher propensity to consume among workers or the general population can have.

22 Notwithstanding the necessary ex post accounting equivalence between investment and saving, Asimakopulos (1984) explains that Robinson found a shortcoming in the way Keynes dealt with the time it took for saving to adjust to investment: although this adjustment could be made through changes in the multiplier (specifically the propensity to consume) brought about by investment, it was hard to conceive of it as an adjustment taking place simultaneously with the change in investment. This meant that the equivalence between the investment and saving rates did not arise simultaneously in practice. In arguing that business profits were spent on investment or consumption, Kalecki adopted a simpler and clearer approach, suggesting that the decision to invest determined what share of profits went on consumption and what share (the remainder, i.e., saved profits) on investment. In deciding how much to invest and consume, businesses also determine their (future) profits (Lavoie, 2009, p. 86; Kalecki, 1969, chapters 4 and 9). 
Figure VI.2

Latin America: domestic and external investment and saving, 1980-2012

(Percentages of GDP)

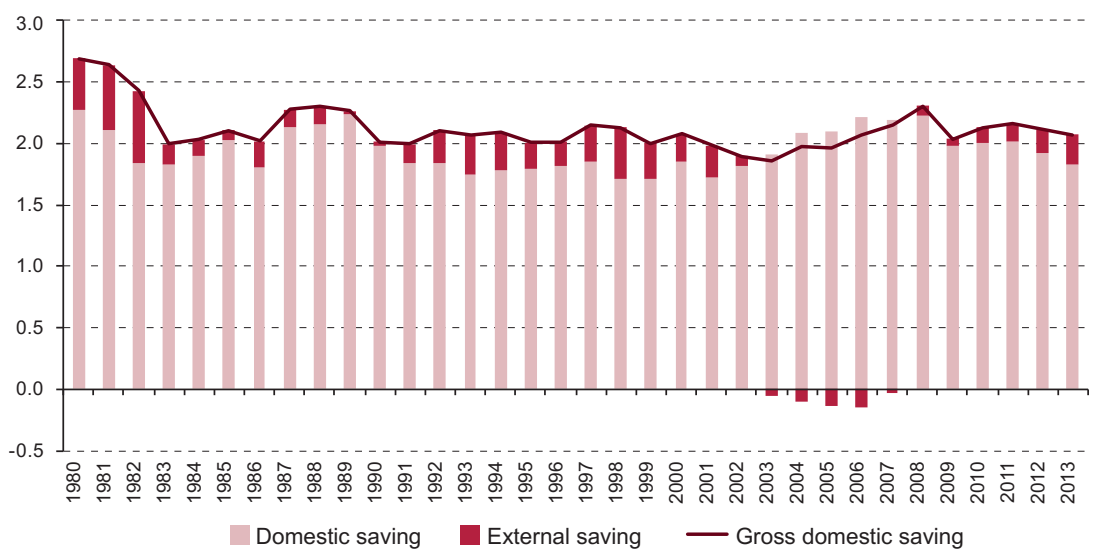

Source: Economic Commission for Latin America and the Caribbean (ECLAC), on the basis of official figures.

The sharp increase in external saving during the 1990s progressively weakened this constraint, but although this was favourable to investment, it did not result in equivalent growth in this either. For one thing, it was the result of a sharp rise in foreign direct investment, especially from 1995, which clearly revealed the existence of a new dynamic whereby (external) investment produced (external) saving, but also of short-term capital flows that were not reflected in an increase in production capacity in the destination countries. For another, everything suggests that, while total external saving was on the rise, a substantial share of domestic saving was adjusted to and replaced by this, so that overall investment did not rise but held steady at around $20 \%$ of GDP (see figure VI.2).

Uthoff and Titelman (1998), in particular, detected a negative substitution relationship between external and domestic saving in 1972-1993 and realized that this relationship was particularly solid when capital flows were above trend. They concluded that when this was so, capital inflows caused the exchange rate to appreciate and the value of local assets to rise, thereby increasing private consumption and reducing national saving. They also found that investment had a positive effect on saving.

Domestic saving grew substantially as a share of GDP from 2003, owing to a rise in national income caused by a substantial improvement in the prices of the raw materials exported by the countries of South America. Although investment expanded, though, it did not do so in the same proportion as saving, and there was an outflow of savings from the region's countries between 2003 and 2007. Once again, this can be interpreted as a 
higher level of saving (local this time) that replaced external saving and did not necessarily give rise to an equivalent rise in investment. It would also appear to be a reflection of the way investment determined the level of saving employed by each country. ${ }^{23}$

The fact that the domestic saving available to cover investment between 2003 and 2008 was underutilized (some of it being directed towards external saving) is, with some caveats, an indication that animal spirits were still too weak for each country's investment opportunities (the potential investment reflected in the Cambridge equation) to be exploited to the full. ${ }^{24}$ This situation suggests that the Cambridge equation does not fully account for investment even when adjusted to reflect domestic and external saving and the fiscal balance, but it also suggests that Robinson's second investment function (investment that is expected or driven by animal spirits), even if imprecise, does help to explain what happened.

\section{The leaden age of Latin American growth}

When the evolution of investment, employment and productivity is analysed in the light of Robinson's approach, it can be seen that most of the region's countries were characterized at some point between 1980 and 1989 by a growth path akin to the leaden age posited by the British scholar. In this period, inadequate capital accumulation prevented technical progress from occurring, with the result that productivity growth stagnated, with output growth tracking employment growth. Capital accumulation was obviously limited in the 1980s, but this translated into falling rather than merely stagnant labour productivity, making this stage even more extreme than Robinson's leaden age. This was due to the peculiarities of the labour market, as a result of which the lower rate of accumulation and output growth $\left(g_{y}\right)$ coincided with a lower employment growth rate $(g)$ that did not equate to the output growth rate, as posited for the leaden age $\left(g_{l}>g_{y}\right.$ instead of $\left.g_{y}=g_{l}\right)$.

In particular, employment growth was positive and there was substantial growth in self-employment because of the weak demand for wage employment that characterized a number of crisis or slowing growth episodes in the region (Weller and Kaldewei, 2013). Consequently,

23 It is also a reason to have policies, especially capital account management policies, that encourage the use of local savings for investment rather than external savings, which are prone to greater fluctuations and put countries on a more vulnerable footing, especially when the current account deficit is covered with short-term capital that may suddenly be withdrawn at times of uncertainty (Bresser-Pereira, 2012).

24 The caveat is that some of the external savings took the form of direct investment by Latin American countries in other countries of the region or the world. Increased national saving was the corollary of a current account surplus (reflecting a greater increase in the value of exports than of imports), something that led in turn to a substantial rise in available gross national income (a concept that takes the terms-of-trade effect into account) over and above GDP growth (which is calculated at constant prices). 
average labour productivity contracted in all the countries except Colombia during the 1980s.

Although the growth of self-employment partially cushioned the effects of the crises, what comes out is the fact that the unemployment rate reported by the countries does not necessarily reflect the dynamics of underemployment or disguised unemployment, which can increase at times of recession. This rate rose sharply in most of the countries during the 1980s, especially during the first half of the decade. In general, living conditions deteriorated sharply, with rising poverty and a Malthusian adjustment that took the form of increased emigration in a number of countries. Broadly speaking, then, the growth path of the 1980s displays the characteristics of a leaden age.

The line in figure VI.3 relating GDP per employed worker to employment growth in 1982-1989 as a simple regression speaks volumes: although employment grew, GDP growth per person employed (labour productivity) was negative. If the intersection points for each country were included, only Colombia would show an increase in labour productivity.

\section{Figure VI.3}

\section{Latin America: ratio between growth in output per worker} and in employment over different periods

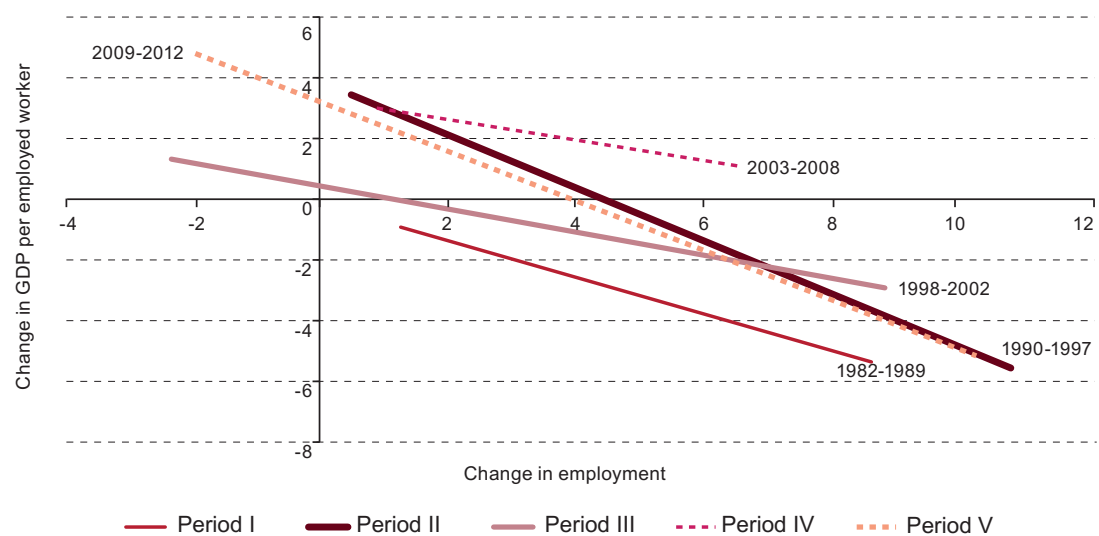

Source: Economic Commission for Latin America and the Caribbean (ECLAC), on the basis of official figures.

The negative evolution of productivity persisted in a number of countries during the subsequent stages (1990-1997 and 1998-2002). A larger increase in employment tended to be the rule in this context, which suggests that even when investment recovered at least partially and provided work for more labour, the accumulation process was not accompanied by adequate measures to steadily incorporate technical progress capable of creating increasingly productive employment, and that a substantial proportion of jobs continued 
to originate on the labour supply side in the shape of informal own-account workers instead of wage workers employed by the formal labour market. Thus, countries where productivity fell in both periods subsequent to the 1980s included the Bolivarian Republic of Venezuela, Ecuador and Peru, although productivity rose in a growing number of countries in the following decades, so that the pall of the leaden ages was gradually cast off.

\section{Possible inflation barrier episodes}

The extreme financial volatility between 1990 and 2002, together with the instability of growth and investment, makes it hard to associate what happened in Latin America during this period with the ages posited by Robinson, which reflect higher or lower rates of constant growth or prolonged upturns or slowdowns, in accordance with the logic of her model. Furthermore, focusing as she did on the analysis of a closed capitalist economy, Robinson did not introduce analysis of financial flows and the exchange rate into her model. Although she did analyse the way external shocks or situations of instability impacted growth, these considerations are not directly incorporated into the ages of growth she proposed, so that integrating these subjects fully into her fundamental model and its variations (ages) remains a pending task.

Between 1990 and 2002, investment and productivity partially recovered in Latin America, but this occurred in a context of profound financial instability in the region and internationally that adversely affected most of the region's countries, and especially the largest (Argentina, Brazil and Mexico). During this stage, the process of capital accumulation in the region presented some of the features described by Robinson, as well as others associated more directly with capital inflows and financial booms in a context of market opening and deregulation with fixed exchange rates.

As Frenkel and Repetti (2009) have explained, the response to most of the financial crises of this period was financial liberalization and an inflexible exchange rate that introduced a margin of speculative profit to stimulate capital inflows and thereby increase liquidity, credit and aggregate demand. A financial boom was inaugurated, in terms similar to those discussed by Minsky (1986), but it ended suddenly when the perception spread that the resultant increase in the current account deficit financed by short-term capital was unsustainable. Problems of illiquidity or financial insolvency then manifested themselves, exchange rates depreciated, inflation rose and aggregate demand, real wages and economic growth all contracted. ${ }^{25}$

25 It is significant that between 1990 and 2002, the countries that were least integrated into the financial markets, such as those of Central America, grew by more than the rest of Latin America (except Chile), a situation that was reinforced by rising remittances. This increase had repercussions for national income similar to those brought in the following decade by the improvement in the terms of trade in South America, especially in countries that were exporters of minerals and hydrocarbons. 
In this context of financial instability, there were a number of episodes that evinced some of the inflation barrier features propounded by Robinson, whose possible occurrence she associated with distributive conflicts involving union organizations preventing real wages from falling and thereby triggering feedback between rising prices and wages that then constrained the capital accumulation process. Table VI.2 presents data indicating that a number of profound inflationary processes were accompanied by a substantial drop in the wage share of GDP, while the opposite situation (sudden contractions in the operating surplus as a share of GDP) did not normally arise in these episodes. ${ }^{26}$

Table VI.2

High inflation episodes and changes in the ratio of wages to GDP (Percentages)

\begin{tabular}{lcccc}
\hline $\begin{array}{l}\text { Inflation } \\
\text { barriers }\end{array}$ & Period & $\begin{array}{c}\text { Inflation rate } \\
\text { (base 2005=100) }\end{array}$ & $\begin{array}{c}\text { Change in ratio } \\
\text { between wages } \\
\text { and GDP }\end{array}$ & $\begin{array}{c}\text { Change in } \\
\text { ratio between } \\
\text { investment } \\
\text { and GDP }\end{array}$ \\
\hline Argentina & $2000-2004$ & 12.7 & -5.1 & -4.5 \\
\hline Brazil & $1991-1995$ & 1099.6 & -1.0 & 4.4 \\
\hline Colombia & $1989-1994$ & 26.3 & 0.8 & 6.4 \\
\hline Honduras & $1990-1994$ & 19.7 & -2.5 & 8.3 \\
\hline Mexico & $1993-1998$ & 20.4 & -1.0 & 5.3 \\
\hline Peru & $1989-1992$ & 2501.2 & -12.0 & -1.6 \\
\hline Uruguay & $2001-2005$ & 10.3 & -3.4 & 7.9 \\
\hline
\end{tabular}

Source: Economic Commission for Latin America and the Caribbean (ECLAC), on the basis of official figures.

However, it is not possible to find a clear link between the redistributive processes associated with inflation and changes in the pace of capital accumulation in the countries affected. Investment carried on rising in a number of cases, and while there were some episodes characterized by lower investment, such as in Argentina between 2000 and 2004 and in Peru between 1989 and 1992, this does not usually seem to have been linked to distributive conflicts but rather to the large financial disequilibria that were a feature of these economies during these stages. This is not to rule out the possibility that some distributive conflicts may have contributed to inflationary pressures and altered the relationship between wages and the operating surplus as shares of GDP. For example, fairly substantial changes in these shares, in both directions, were seen in Brazil in the late 1980s and

26 A more exhaustive analysis of each case would be needed to distinguish between situations where financial disequilibria were driven by distributive conflicts involving unions from those where they were a direct consequence of acute financial disequilibria combined with extreme swings in relative prices (associated with exchange-rate movements) but with no explicit effect from distributive conflicts involving unions. 
early 1990s, with the investment ratio falling sharply relative to earlier years, but this needs to be analysed within broader contexts of institutional and financial instability. ${ }^{27} 28$

Currency imbalances played a fundamental role in this context; in particular, large devaluations like those of Argentina (2002), Brazil (1998), Chile (1997-2000) and Mexico (1994) coincided with a sharp drop in wages as a share of total value added in these sectors. This holds especially true for tradable sectors, as might be expected given their stronger relationship to exports and imports directly associated with exchange rates (see figure VI.4). ${ }^{29}$ Later, when real appreciation occurred, wage shares of value added did not necessarily return to their former levels (prior to depreciation or devaluation), especially in Chile and Mexico. ${ }^{30}$

\section{Figure $\mathrm{Vl.} 4$}

Argentina, Brazil, Chile and Mexico: real effective (reciprocal) exchange rate and ratio between wages and value added in tradable sectors, 1993-2007 (Base year=100)

A. Argentina: $1993=100$

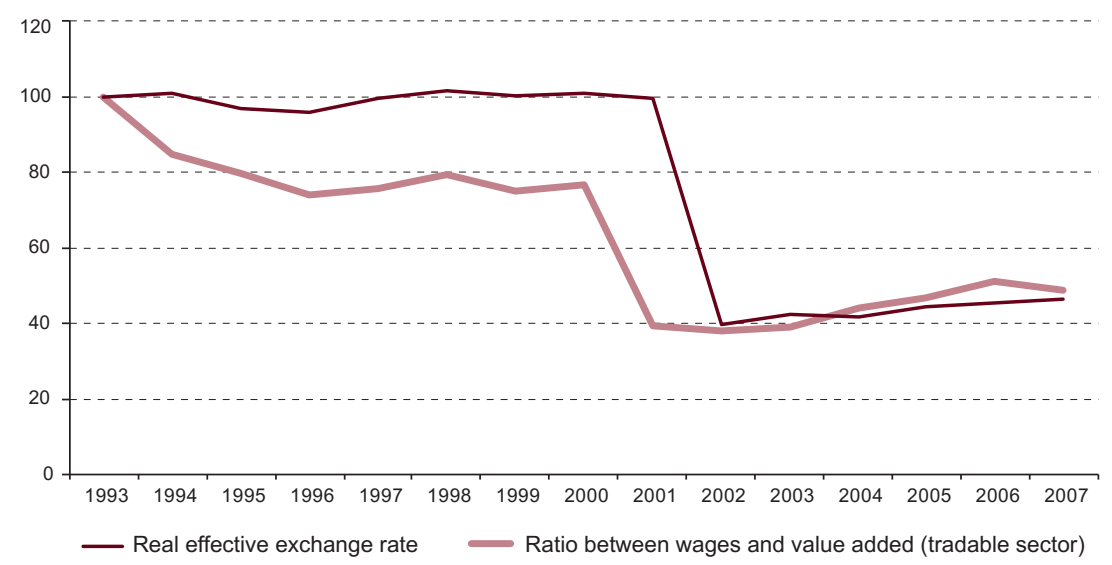

27 In Brazil, the wage share of GDP went from 45\% in 1990 to $42 \%$ in 1991, 44\% in 1992, 45\% in 1993 and $40 \%$ in 1994.

28 Lavoie stresses that this subject was raised by a number of post-Keynesian theorists like Kalecki and Kaldor, but notes that inflation is the result of inefficient institutions, including those that form the background to negotiations between workers and employers (Lavoie, 2009, pp. 129-130).

29 There is a statistically significant correlation between exchange-rate movements and pay as a share of value added in tradable sectors in Argentina, Brazil and Chile. The coefficient of correlation is 0.7976 in Argentina (where $p=0.004), 0.6702$ in Brazil $(p=0.171)$ and 0.4475 in Chile $(p=0.0717)$. Nonetheless, this coefficient was not statistically significant in the case of Mexico.

30 One theory is that real currency appreciation gives rise to a situation akin to a money illusion because the purchasing power of the currency against others increases and thus imports can be acquired on more favourable terms (at lower prices). 
Figure VI.4 (concluded)

B. Brazil: $1996=100$

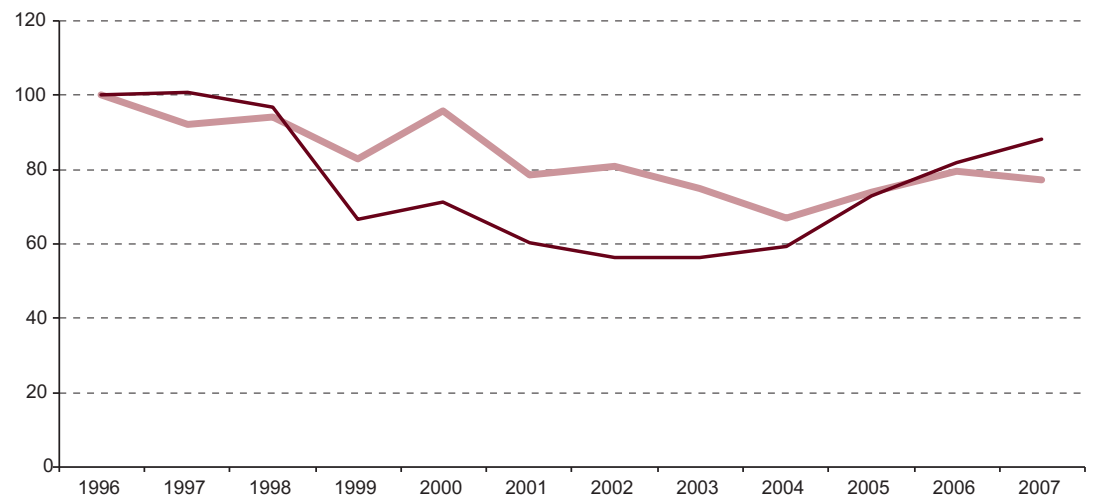

C. Chile: $1993=100$
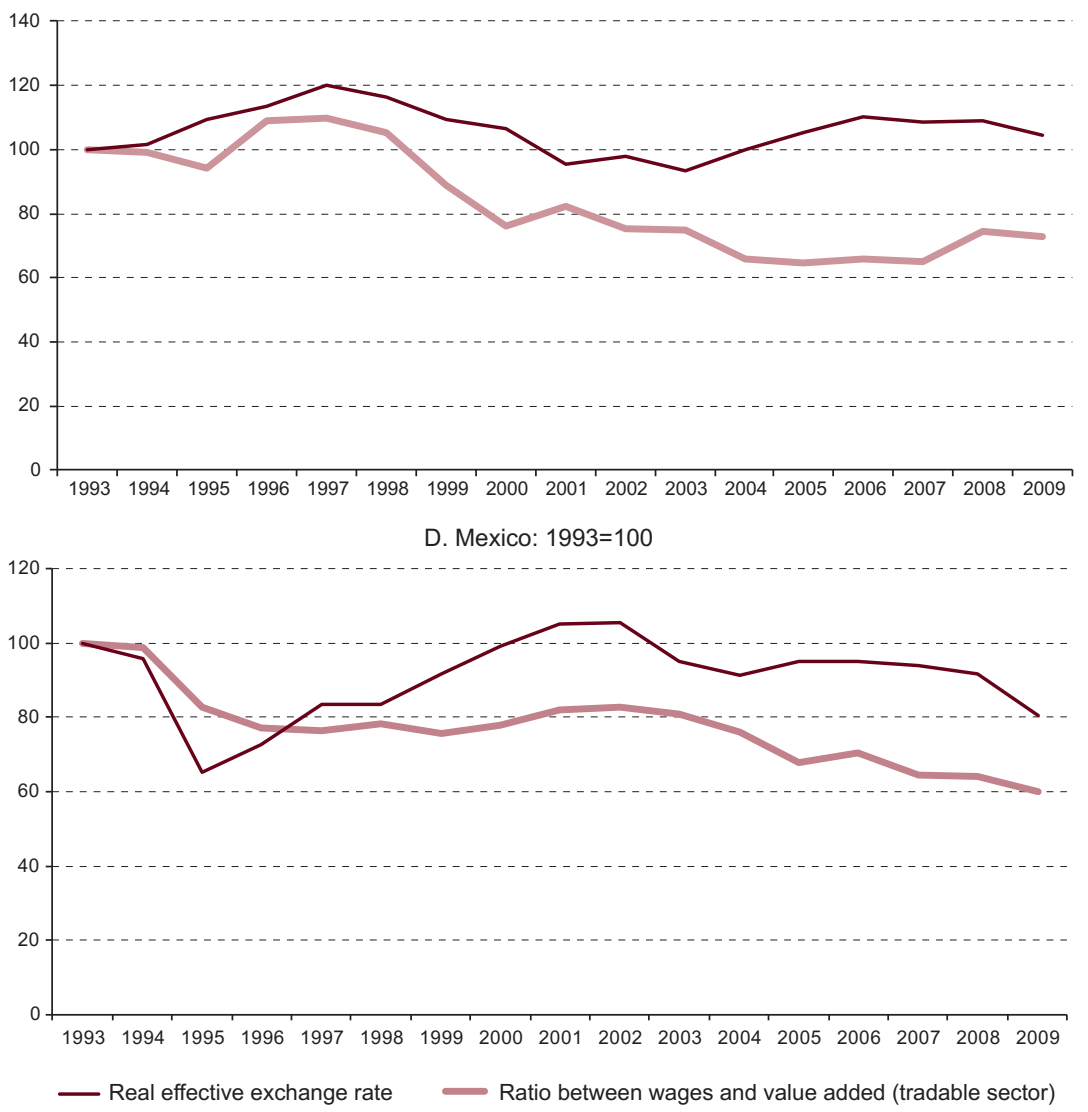

Source: Economic Commission for Latin America and the Caribbean (ECLAC), on the basis of data from the Latin America KLEMS project [online] http://www.worldklems.net/. 
On the whole, the financial instability experienced by a number of Latin American countries between 1990 and 2000 militated against dynamic capital accumulation in the region, despite some recovery in private investment and the gradual erosion of external constraints. Although many features of its growth do not fit the ages formulated by Robinson, there is some resemblance to a bastard age in countries where financial deregulation, perhaps stimulated by redistributive conflicts in some cases, triggered a surge in credit, prices and wages that checked the accumulation of capital and any movement towards full employment.

Nonetheless, there were fewer shocks in other countries that did not have explicit distributive conflicts and were spared the consequences of instability in financial markets because they were not integrated into these (like the Central American countries and the Dominican Republic) or because they were able to gradually liberalize or regulate their financial systems (Stallings and Studart, 2006, pp. 43-44), like Colombia and Chile. Only a handful of countries, such as Chile and the Dominican Republic, avoided financial vicissitudes while at the same time experiencing a high rate of capital accumulation that led to dynamic job creation between 1990 and 1997. This means these economies can be seen as following a path similar to a golden age, albeit a limping one, as full employment was not achieved, something that became particularly apparent after the Asian crisis of 1997-1998. Because Robinson's model does not incorporate financial-sector and exchange-rate variables, its ability to explain what happened in Latin America between 1990 and 2002 is limited.

Again, Latin America made steady progress in 1990-1997 and 19982002 thanks to the adoption of more flexible exchange rates, financial system regulation and increasing flows of foreign direct investment that reduced capital account volatility, as well as fiscal adjustments and monetary policies that brought inflation under control. All these measures helped ward off the worst consequences of the recession and of the virtual cessation of short-term capital flows caused by the Asian crisis of 1997-1998, although they did lead to what has been called the lost half-decade (1997/1998-2002). Nonetheless, and despite slacker growth and a slower pace of capital accumulation, apparently reflecting the weak animal spirits characteristic of Latin America, the macroeconomic underpinnings for a new period of more stable prices and higher growth were strengthened.

\section{Platinum ages and changes in the composition of investment}

Productivity started to improve in many countries after the 1980s, a situation depicted in figure VI.3, where the lines tend to shift upward towards the area corresponding to variables with positive growth, indicative of 
higher productivity at each level of employment. ${ }^{31}$ The changing pace and fluctuations in these increases are also significant. A comparison of the periods selected shows two large increases in labour productivity in Latin America: one between 1980-1989 and 1990-1997, where a situation of negative productivity growth (the leaden age of the 1980s) gave way to a period of financial instability but fairly robust expansion (1990-1997), and another one between 1998-2002, when the region was hit hard by the Asian crisis, and 2003-2008, a period that benefited from the commodity price boom. As will be seen later on, this could be described as a variation on the galloping platinum age of Robinson's approach.

There were also some partial productivity setbacks, however, reflecting the slowdowns and reduced capital accumulation of 1998-2002 and 20092012, following the Asian crisis and the global financial crisis, respectively. During these periods of crisis and adjustment, furthermore, the gap between the performance of countries with higher productivity growth and the rest widened. This dispersion was more limited at the times of greatest progress, however, especially 2003-2008.

Thus, from 2003 most of the Latin American countries experienced quickening growth, particularly those with a greater ability to take advantage of the commodity price rises caused by the boom in Chinese demand. Figures VI.1 and VI.3 show that faster capital accumulation drove rising output, employment and productivity in this stage. Favourable expectations helped bring expected investment closer to potential investment, and this was reflected in a significant rise in the capital accumulation growth rate and the ratio of investment to GDP, even though actual investment apparently remained below potential.

This acceleration of capital accumulation between 2003 and 2008 can be associated with features of what Robinson defines as a galloping platinum age, but with three differences: animal spirits, the evolution of real wages and the composition of capital. The first of the three, as analysed above, refers to the symptoms of weak animal spirits among the region's businesses.

The second difference lies in the fact that, while Robinson's approach posits that the accumulation process can fail to accelerate because of a problem with the composition of capital that arises when this fails to adapt to the new dynamic and the production of capital goods is not sufficient for further goods of the same type to be manufactured, the region's countries

31 The coefficient of correlation between GDP growth deriving from the employment level and the rate of employment growth was -0.52 between 1982 and 1989 (with a statistical significance of $97 \%$ ) and -0.85 between 1990 and 1997 (with a confidence level of 99\%), while it was -0.48 in 1998-2002 (with a significance level of 96\%), -0.38 in 2003-2008 (with a significance level of just $85 \%$ ) and -0.71 in 2009-2012 (with a significance level of $99 \%$ ). 
seem to have had greater flexibility to deal with this problem because their economies were open and they could import such goods, including those for which they benefited from exchange-rate appreciation. ${ }^{32}$ This also means that, in the absence of a constrained capital goods-producing sector and with abundant external savings, accumulation requirements did not create the tensions between wages and the consumption of profits posited as a feature of this age, so that real wages dropped between 2003 and 2008.

A broader interpretation of this approach can be used to analyse its appreciations regarding the basis of capital composition, either because capital was inadequate, especially after at least two decades of limited investment, or because a certain type of investment was. ${ }^{33}$ In particular, changes in the composition of investment partly account for the way this evolved between 1980 and 2012. Public investment declined sharply in the 1980s owing to the implementation of stabilization and adjustment programmes, which compounded existing infrastructure shortfalls in many countries. Public investment was not wholly restored during the 1990s, although the shortfall was partly made up in this stage thanks to higher private investment, comprised in part of foreign direct investment that took advantage of the market opening and privatization pursued during those years. Only after 2003 did investment increase, owing both to higher public investment and to (larger) increases in private investment, in the context of the commodity price boom that bolstered the public finances and expanded available gross income and public and private saving in most of the countries (Jiménez and Manuelito, 2013).

Certain features of the composition of investment suggest differentiated effects on economic growth and productivity. Investment in machinery and equipment, which is the most closely correlated with GDP growth of any investment category, fluctuated more than investment in the construction sector, whose relatively stable growth path kept it at around 10\% of GDP and which accounted for much of the change in private investment.

In turn, the evidence available for four countries of Latin America (Argentina, Brazil, Chile and Mexico) allows three conclusions to be drawn about the possible repercussions of currency appreciation (or relative prices generally) on the composition of investment (see table VI.3). ${ }^{34}$ First, investment increased more quickly in the non-tradable sector than in the tradable sector between 1993 and 2010, and especially between 2003 and 2010, when

32 In other stages, especially the import substitution period and the 1980s, the external constraint was reflected in an inadequate ability to import capital goods, for example.

33 Given its apparently excessive growth in investment relative to consumption in 2010-2013, China seems to have gone through a creeping platinum age.

34 This information forms part of the database of the Latin America KLEMS project [online] http:// www.worldklems.net/, for which ECLAC acts as technical secretariat (ECLAC, 2013, pp. 131-132). 
improving terms of trade were combined with capital inflows and currency appreciation in several of these countries. ${ }^{35}$

Table VI.3

Argentina, Brazil, Chile and Mexico: average annual growth in investment, employment and labour productivity, 1993-2010

(Percentages)

\begin{tabular}{|c|c|c|c|c|c|c|c|c|c|}
\hline \multirow{2}{*}{$\begin{array}{l}\text { Change } \\
\text { by period }\end{array}$} & & \multicolumn{4}{|c|}{ Tradable sector } & \multicolumn{4}{|c|}{ Non-tradable sector } \\
\hline & & $\begin{array}{l}1993- \\
1996\end{array}$ & $\begin{array}{l}1997- \\
2002\end{array}$ & $\begin{array}{l}2003- \\
2010\end{array}$ & $\begin{array}{l}1993- \\
2010\end{array}$ & $\begin{array}{c}1993- \\
1996\end{array}$ & $\begin{array}{l}1997- \\
2002\end{array}$ & $\begin{array}{c}2003- \\
2010\end{array}$ & $\begin{array}{l}1993- \\
2010\end{array}$ \\
\hline \multicolumn{10}{|c|}{ Gross fixed capital formation in machinery and equipment and in construction } \\
\hline & Argentina & 7.01 & -7.89 & 16.02 & 3.84 & 0.46 & -9.52 & 29.79 & 6.66 \\
\hline & Brazil & 0.02 & 1.96 & 5.98 & 3.83 & -0.67 & 1.09 & 8.08 & 4.46 \\
\hline & Chile & 13.25 & 3.80 & 9.30 & 8.50 & 16.05 & 2.75 & 12.71 & 10.16 \\
\hline & Mexico & 0.01 & 4.93 & 3.56 & 3.80 & -2.16 & 7.27 & 5.74 & 4.98 \\
\hline & Average & 5.07 & 0.70 & 8.71 & 4.99 & 3.42 & 0.40 & 14.08 & 6.56 \\
\hline \multicolumn{10}{|l|}{ Man-hours } \\
\hline & Argentina & -3.32 & -2.63 & 1.73 & -0.92 & -1.30 & 0.28 & 8.34 & 2.80 \\
\hline & Brazil & & 1.25 & 0.91 & 1.07 & 2.29 & 2.83 & 2.95 & 2.84 \\
\hline & Chile & -0.23 & -1.29 & -0.64 & -0.54 & 3.68 & 1.95 & 1.87 & 2.48 \\
\hline & Mexico & 0.76 & -0.17 & -0.92 & -0.13 & 1.43 & 2.86 & 2.13 & 2.42 \\
\hline & Average & -0.93 & -0.71 & 0.27 & -0.13 & 1.52 & 1.98 & 3.82 & 2.64 \\
\hline \multicolumn{10}{|c|}{ Value added } \\
\hline & Argentina & 2.43 & -1.86 & 5.87 & 2.33 & 3.20 & -0.57 & 7.72 & 3.77 \\
\hline & Brazil & 0.79 & 1.76 & 3.11 & 2.42 & 2.33 & 2.16 & 4.09 & 3.20 \\
\hline & Chile & 6.08 & 3.08 & 1.90 & 3.65 & 7.05 & 3.49 & 5.16 & 5.27 \\
\hline & Mexico & 2.67 & 2.82 & -0.94 & 1.36 & 0.87 & 3.90 & 1.86 & 2.56 \\
\hline & Average & 2.99 & 1.45 & 2.49 & 2.44 & 3.36 & 2.25 & 4.71 & 3.70 \\
\hline \multicolumn{10}{|c|}{ Labour productivity } \\
\hline & Argentina & 5.45 & 0.88 & 6.44 & 4.02 & 5.84 & -0.67 & 0.38 & 1.05 \\
\hline & Brazil & & 1.00 & 1.32 & 1.17 & 0.03 & -0.56 & 1.16 & 0.28 \\
\hline & Chile & 6.34 & 4.53 & 2.95 & 4.47 & 3.30 & 1.51 & 2.93 & 2.63 \\
\hline & Mexico & 1.90 & 3.08 & -0.05 & 1.51 & -0.59 & 1.11 & -0.27 & 0.16 \\
\hline & Average & 4.56 & 2.37 & 2.66 & 2.79 & 2.15 & 0.35 & 1.05 & 1.03 \\
\hline \multicolumn{10}{|l|}{$\mathrm{I} / \mathrm{L}_{\text {ratio }}{ }^{\mathrm{a}}$} \\
\hline & Argentina & 9.89 & -5.56 & 9.70 & 3.20 & 2.80 & -10.70 & 20.26 & 3.25 \\
\hline & Brazil & & 0.83 & 5.12 & 3.14 & -2.89 & -1.70 & 7.24 & 2.33 \\
\hline & Chile & 13.57 & 4.97 & 10.16 & 9.09 & 11.99 & 0.72 & 10.57 & 7.45 \\
\hline & Mexico & -1.02 & 5.10 & 4.47 & 3.86 & -3.94 & 4.26 & 3.51 & 2.38 \\
\hline & Average & 7.48 & 1.33 & 7.36 & 4.82 & 1.99 & -1.86 & 10.39 & 3.85 \\
\hline
\end{tabular}

Source: Economic Commission for Latin America and the Caribbean (ECLAC), on the basis of data from the Latin America KLEMS project [online] http://www.worldklems.net/.

a $\mathrm{L}=$ employment.

35 For statistical purposes, the agricultural, industrial and mining sectors were defined as tradable and all others as non-tradable. 
Second, the contribution of investment to rising labour productivity tended to be greater in tradable sectors, as is shown by the fact that investment and labour productivity growth coincided in Chile (in all periods) and Argentina (in 1993-1996 and 2003-2010), and that limited productivity growth went together with lower increases in investment, as in Argentina again (1997-2002) and Mexico (1993-1996 and 2003-2010), in particular. This contrasts with the contribution of investment to labour productivity in non-tradable sectors, which was not very noticeable in Argentina, Brazil or Mexico, although it was in Chile.

Third, and following on from the previous paragraph, job creation (expressed in the table by the number of man-hours worked) in the tradable sector in Argentina, Chile and Mexico was negative overall during 1993-2010, while in Brazil there was a fairly modest increase (as there was in Argentina in 2003-2010). This situation contrasts with that in the non-tradable sector, where job creation was positive and significant in all four countries during this period overall and in each of the subperiods analysed. ${ }^{36}$ This greater demand for labour in the region's non-tradable sector, which was not necessarily for high-skilled workers but did include a rising proportion of wage employment, probably accounts for the improvements in real wages during this period. ${ }^{37}$

On the whole, the limited effectiveness of the considerable investments made in the non-tradable sector, which were accompanied by a substantial increase in hours worked and only a modest rise in productivity, probably reflects both the heterogeneous conditions of the sector itself and the nature of each country's labour market. In the case of Chile, it may be hypothesized that when there is less unemployment and underemployment, even in the non-tradable sector, hours worked will increase by less and labour productivity by more than in other countries. ${ }^{38}$ At the other extreme is Mexico, where productivity fell and the number of hours worked rose despite something of an surge in investment in the non-tradable sector.

Thus, a heterogeneous non-tradable sector with low productivity, high employment and rising investment stood in contrast to a tradable sector where investment, by incorporating technical innovations, increased labour productivity, created little or no extra employment and was fairly limited in amount. This danger had already been observed during the 1990s following the upsurge in external capital inflows, which caused exchange rates to

\footnotetext{
Mexico in 1993-1996 was the only exception.

See figure 16 in Weller and Kaldewei (2013), which shows the higher employment growth in non-tradable sectors, and figure 4 , which reflects the rise of wage employment and the reduction in own-account working, especially between 2003 and 2007.

38 Palma (2013), who found evidence of deindustrialization in a number of South American countries (measured by employment), argues that a more restricted labour market favoured productivity in Chile.
} 
strengthen. Although this effect encouraged investment by reducing the local-currency price of imported capital goods, it also favoured investment in non-tradable sectors (Agosin, 1998), and it seems to have recurred after 2003.

Consistently with the broader applications already attempted and some similar initiatives adopted for other post-Keynesian approaches (Pérez Caldentey and Vernengo, 2013), these explanations suggest a need to elaborate Robinson's approach by extending it to the capital account, the exchange rate and two sectors other than those she looked at in her studies (capital and consumer goods), such as the tradable and non-tradable sectors, so that these can be related to the effect of the exchange rate and relative prices in general. Besides incorporating external saving and the fiscal deficit as variables (Lovinsky and Gibson, 2004) in Robinson's basic model, this would make it possible, if the content of the ages were also adapted, to find better explanations for the most recent growth paths in the region.

One might ask, for example, whether a copper age might not be incorporated to reflect the acceleration and slowing of capital accumulation associated with export commodity prices or inflows of remittances or shortterm capital. In this scenario, exchange rates appreciate in upturns and favour investment and wage employment in non-tradable sectors (besides investment in natural resources), thus discouraging production diversification and rapid incorporation of technical progress, even though real wages might increase, while potential imbalances are introduced that can then make it problematic to adjust to a downturn which the same model can include.

\section{Conclusions}

Joan Robinson's growth theory is a useful guide because it places capital accumulation at the heart of the economic growth process, while its two investment functions, one of them looking at past investments to forecast expected returns and the other treating future investment as essentially dependent on certain expectations (animal spirits), are helpful for analysing the capital accumulation process in Latin America. The scenarios (ages of growth), which are based on causal rather than equilibrium relationships, also provide frameworks for analysing the growth process, and the fact that they treat technical progress as endogenous and unemployment as a possible outcome of the model make them more relevant still. Another valuable feature of her model is its flexibility and analytical openness, which makes it easier to approach the subject of growth from an inductive perspective, without its being completely predetermined by a set of relationships between rigid variables defined a priori.

The fact that Robinson's original theory does not incorporate a growth model for an economy open to outside trade and international finance limits 
its potential contribution, and this is true both of the basic model and of the ages of growth. It is possible to find analogies between the leaden age and the stage Latin America went through during the lost decade of the 1980s, and between inflation barriers and what some countries with high inflation experienced during the 1990s, or between a limping golden age and the growth of a small number of countries in 1990-1997. It is also possible to identify traits that the galloping platinum age has in common with the stage of strong growth experienced by a larger group of countries as a result of the commodity price boom between 2003 and 2008. However, Robinson's model and its ages require extensions and adaptations if they are to contribute to a fuller understanding of the basic features of growth in the region.

Some extensions already carried out incorporate the effect of external saving and the fiscal balance into Robinson's basic model, but the exclusion of financial aspects (especially the balance-of-payments financial account and the exchange rate) as fundamental variables linking external-sector developments with the capital accumulation process heavily limits the potential for it to contribute more fully to a better understanding of growth in the region. Both Robinson's basic model and the ages of growth theory would be better if these variables were included in them and if the two sectors traditionally incorporated (capital and consumer goods production) were replaced with alternative categories, such as the tradable and non-tradable sectors. This could make a valuable contribution to our understanding of capital accumulation and growth in Latin America.

\section{Bibliography}

Agosin, M. (1998), "Capital inflows and investment performance: Chile", Capital Flows and Investment Performance Lessons from Latin America, R. Ffrench-Davis and H. Reisen (eds.), Paris, Organization for Economic Cooperation and Development (OECD).

Aravena, Claudio and Juan Alberto Fuentes (2013), "El desempeño mediocre de la productividad laboral en América Latina: una interpretación neoclásica", Macroeconomía del Desarrollo series, No. 140 (LC/L.3725), Santiago, Economic Commission for Latin America and the Caribbean (ECLAC).

Asimakopulos, Athanasios (1991), Keynes's General Theory and Accumulation, Cambridge, Cambridge University Press.

(1984), "Joan Robinson and economic theory", PSL Quarterly Review, vol. 37, No. 15, Banca Nazionale del Lavoro.

(1977), "Post-Keynesian growth theory", Modern Economic Thought, S. Weintraub, University of Pennsylvania Press.

(1970), "A Robinsonian growth model in one sector notation - an ammendment", Australian Economic Papers, $N^{\circ} 9$.

(1969), "A Robinsonian growth model in one-sector notation", Australian Economic Papers, No. 8. 
Backhouse, R.E. (2003), "Concentric circles of limits to the rate of accumulation: an interpretation of Joan Robinson's theory of economic dynamics", Review of Political Economy, vol. 15, No. 3.

Bresser-Pereira,L.C.(2012),Structuralist Macroeconomicsand the New Developmentalism, São Paulo, Getúlio Vargas Foundation.

ECLAC (Economic Commission for Latin America and the Caribbean) (2013), Economic Survey of Latin America and the Caribbean, 2013 (LC/G.2574-P), Santiago. (2012), Economic Survey of Latin America and the Caribbean, 2012 (LC/G.2546-P), Santiago.

Ffrench-Davis, Ricardo (2005), Reformas para América Latina después del fundamentalismo neoliberal, Buenos Aires, Siglo XX editores.

Findlay, R. (1963), "The Robinsonian model of accumulation", Economica, vol. 30, No. 117, February.

Frenkel, R. and M. Repetti (2009), "A developing country view of the current global crisis: what should not be forgotten and what should be done", Cambridge Journal of Economics, vol. 33.

Galor, O. (2012), Unified Growth Theory, Princeton University Press.

Harcourt, Geoffrey (2006), The Structure of Post-Keynesian Economics. The Core Contributions of the Pioneers, Cambridge University Press.

Harcourt, Geoffrey and Prue Kerr (2009), Joan Robinson, Palgrave Macmillan.

Harris, D.J. (1975), "The theory of economic growth: a critique and reformulation", The American Economic Review, vol. 65, No. 2.

Jiménez, Luis Felipe and Sandra Manuelito (2013), "Rasgos estilizados de la relación entre inversión y crecimiento en América Latina y el Caribe, 1980- 2012", Macroeconomía del Desarrollo series, No. 136 (LC/L.3704), Santiago, Economic Commission for Latin America and the Caribbean (ECLAC).

(2012), "La inversión y el ahorro en América Latina: nuevos rasgos estilizados, requerimientos para el crecimiento y elementos de una estrategia para fortalecer su financiamiento", Macroeconomía del Desarrollo series, No. 129 (LC/L.3603), Santiago, Economic Commission for Latin America and the Caribbean (ECLAC).

Johnson, Harry (1960), "A simple Joan Robinson model of accumulation with one technique", Osaka Economic Papers, No. 9.

Kaldor, N. (1957), "A model of economic growth", Economic Journal, No. 67.

Kalecki, M. (1969), Theory of Economic Dynamics. An Essay on Cyclical and Long-Run Changes in Capitalist Economy, New York, Augustus M. Kelley.

Kurdas, C. (1991), "Robinson's dark room: investment in post-Keynesian growth theory", The Joan Robinson Legacy, I.H. Rima (ed.), New York, M.E. Sharp.

Lavoie, M. (2009), Introduction to Post-Keynesian Economics, New York, Palgrave, Macmillan.

Lovinsky, J. and B. Gibson (2004), "A Robinson model for Argentina”, Joan Robinson's Economics. A Centennial Celebration, B. Gibson (ed.), Edward Elgar.

Minsky, H. (1986), Stabilizing an Unstable Economy, New Haven, Connecticut, Yale University Press.

Palma, G. (2013), “Desindustrialización, desindustrialización 'prematura' y un nuevo concepto de síndrome holandés", Radiografía crítica al "modelo chileno": balance y propuestas, Gonzalo Martner and Eugenio Rivera (eds.) Santiago, LOMEdiciones.

Perez Caldentey, E. and M. Vernengo (2013), "Wage and profit-led growth: the limits to Neo-Kaleckian models and a Kaldorian proposal", Working Paper, No. 775, Levy Economics Institute of Bard College. 
Robinson, Joan (1971), Economic Heresies: Some Old Fashioned Questions in Economic Theory, New York, Basic Books.

(1963), Essays in the Theory of Economic Growth, London, Macmillan.

(1961), Exercises in Economic Analysis, London, Macmillan.

(1956), The Accumulation of Capital, London, Macmillan.

Skott, P. (2004), "Mythical ages and methodological strictures-Joan Robinson's contributions to the theory of economic growth", Working Paper, No. 2004-09, Amherst, University of Massachusetts.

Stallings, B. and R. Studart (2006), Finance for Development. Latin America in Comparative Perspective, Washington, D.C., Brookings Institution.

Taylor, L. (2011), Maynard's Revenge. The Collapse of Free Market Macroeconomics, Cambridge, Massachusetts, Harvard University Press.

Uthoff, A. and D. Titelman (1998), "The relationship between foreign and national savings under financial liberalisation", Capital Flows and Investment Performance Lessons from Latin America, R. Ffrench-Davis and H. Reisen (eds.), Paris, Organization for Economic Cooperation and Development (OECD).

Weller, Jurgen and Cornelia Kaldewei (2013), "Empleo, crecimiento sostenible e igualdad", Macroeconomía del Desarrollo series, No. 145 (LC/L.3743), Santiago, Economic Commission for Latin America and the Caribbean (ECLAC). 


\section{Annex}

\section{Joan Robinson's model expressed algebraically ${ }^{39}$}

In Joan Robinson's model where only short-term equilibrium relationships are included, income from workers' wages and capitalists' profits are defined as follows:

(1) $Y=W+P$

Where $Y$ is income, $W$ wages and $P$ profits.

The saving rate, meanwhile, depends on the wage and profit shares of income, so that gross saving will be given by the gross saving of capitalists $\left(S_{P}\right)$ and employees $\left(S_{W}\right)$.

And saving is composed of each of the income types:

(2) $S=S_{W}+S_{P}$

Here, $S_{W}$ is what is saved out of wages and $S_{P}$ what is saved out of profits.

Consequently:

(3) $S_{W}=S_{W} W ; S_{P}=S_{P} P$

$s_{W}$ is the propensity to save wages and $s_{P}$ the propensity to save profits.

Keynesian theory assumes as the equilibrium condition that the saving rate must be equal to the investment rate:

(4) $I=S$

When saving is broken down, we get:

(5) $I=S_{W}+S_{P}=S_{W} W+S_{P} P$

(6) $I=S_{W}+S_{P}=S_{W}(Y-P)+S_{P} P$

When (6) is divided by capital (K), we get the capital accumulation equation denoted by $\mathrm{I} / \mathrm{K}$ :

(7) $\frac{I}{K}=\frac{S_{W}(Y-P)}{K}+\frac{S_{P} P}{K}$

Prepared by Esteban Pérez, although Kurdas (1991) and Backhouse (2003) were also taken into account for the last two equations. 
Reorganizing this algebraically gives the following formula:

(8) $\frac{P}{K}=\frac{I / K}{S_{P}+\left(\frac{1-P / Y}{\frac{P}{Y}}\right) S_{W}}$

From (8) we get the rate of return in the economy, which is given by:

(9) $r=\frac{g}{S_{P}+\left(\frac{1-m}{m}\right) S_{W}} ; r=\frac{P}{K}, m=\frac{P}{Y}, g=\frac{I}{K}$

Here, $r$ is the rate of return, $m$ return over income and $g$ the capital accumulation rate.

Thus, we finally get:

(10) $r=\frac{g}{s}$

Where $s$ is the propensity to save.

The accumulation rate can be represented as follows, although there is less agreement about its representation and even Robinson herself expressed serious doubts about whether it was possible to do this precisely. One option is:

(11) $g^{*}=y(r-i)\left(y^{\prime}>0, y^{\prime \prime}>0\right)$

Where $g^{*}$ is the desired accumulation rate and an increasing function of the rate of return, and $i$ is the real interest rate.

Another way of representing the accumulation rate is to consider the desired rate of return, which is very close to the actual return, where desired investment for period $t$ is defined on the basis of the rate of return achieved in the previous period. Thus, the investment function could also be represented as:

(12) $K_{t}^{*}=f\left(r_{t-1}\right)$ where $f^{\prime}>0$ 
Part III

Structural change and production development 



\section{Chapter VII \\ Productivity and structural change: structuralism and its dialogue with other heterodox currents}

Mario Cimoli

Gabriel Porcile

\section{Introduction}

Two main tributes may be paid to the greats of economic thinking: that they were the first to conceive or systematically present ideas that were ahead of their time, but were corroborated in subsequent years; or that they set forth a research agenda that remains influential to this day. Authors such as Prebisch, Furtado and Fajnzylber deserve both accolades, notwithstanding that some economists may not be fully aware of the extent of their contribution to development theory. This chapter hails the structuralist tradition in another way: by combining it with other currents of thought and seeking points of convergence and cross-fertilization. Where authors and schools are able to identify the key aspects of an economy's performance, their ideas tend to be complementary and harmonious; the ease with which their ideas dovetail is a consequence of their depth and relevance. 
This chapter discusses convergences between the structuralist, evolutionary and Keynesian traditions. To that end, it uses a simple model in which the dynamics of technology and effective demand interact to determine convergence or divergence with developed countries, focusing on a set of changes in innovation and technology diffusion (as emphasized by the evolutionists), the production structure (emphasized by the structuralists) and effective demand (emphasized by the Keynesian school). The model is presented as a graph, and its main findings are summarized in the form of equations; a formal, more comprehensive presentation of the model is given in Cimoli and Porcile (2013). Let it be noted at the outset that this essay discusses theoretical convergences and examines some of the contributions of the aforementioned schools. It is not the intention, nor would it be possible, to encompass all of these contributions. To present the model, determine its chief theoretical findings, and illustrate its most relevant political implications, the chapter is arranged in four sections following this introduction. Section A addresses the link between growth, specialization and technology; section $\mathrm{B}$ looks at the microeconomic foundations of learning and convergence, and section $C$ applies the model to industrial policy. The chapter concludes with some final comments.

\section{A. Economic growth, specialization and technology}

Structuralists take their starting point as the close link between changes in the production structure and the absorption of technology. In The Economic Development of Latin America and its Principal Problems also known as his "manifesto", Prebisch suggested that the emergence and reproduction of a centre and a periphery were chiefly attributable to the slow and unequal international diffusion of technical progress. ${ }^{1}$ For a country to have a diversified production structure with a large component of knowledgeintensive sectors, it must be capable of learning or (at least) being an efficient "follower", and it must prevent the technology lag from widening. At the same time, a production structure with significant knowledge-intensive sectors generates externalities and stimuli that drive learning and productivity gains. Figure VII.1 presents the interaction of these different variables (technology, specialization, growth, employment and distribution). The contributions of different schools of thought help provide an understanding of the relationship between the variables and their movements.

See Rodriguez (1980 and 2007) and Bielshowsky (2009). 
Figure VII.1

Specialization, wages and growth in the centre-periphery system ${ }^{\mathrm{a}}$

A

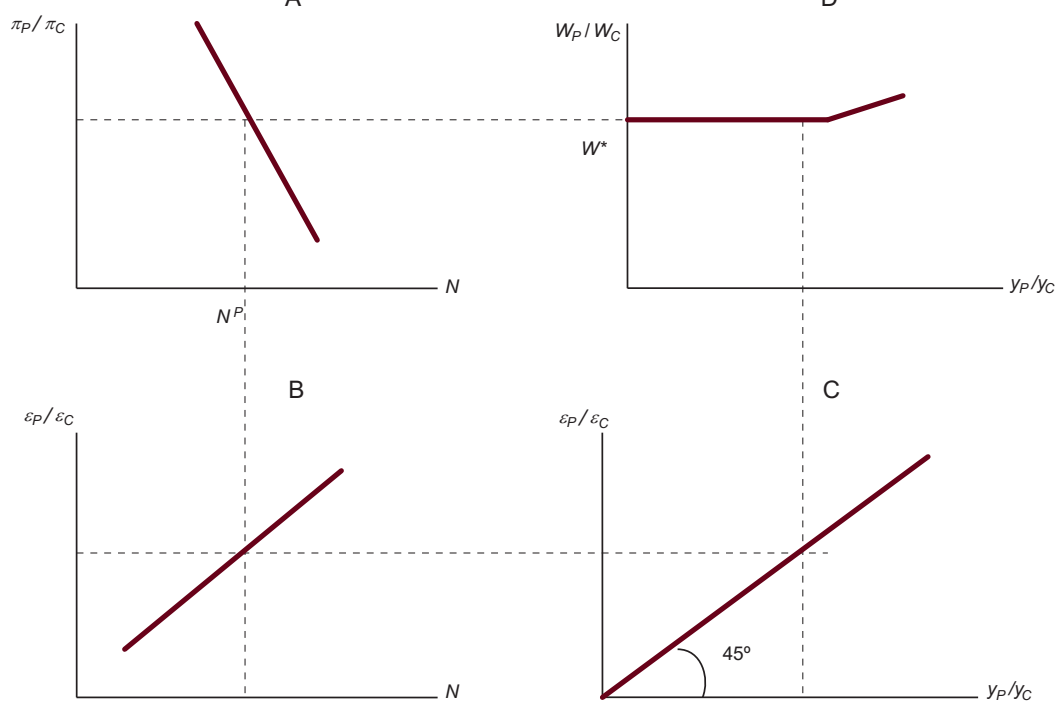

Source: Prepared by the authors.

a Quadrant A: technology gap and relative periphery-centre productivity $\left(\pi_{\mathrm{p}} / \pi_{\mathrm{C}}\right)$ as a function of the technological intensity of the production structure $(\mathrm{N})$; quadrant $\mathrm{B}$ : income elasticities of demand for exports and imports of the periphery $\left(\varepsilon_{\mathrm{p}} / \varepsilon_{\mathrm{C}}\right)$ as a function of $\mathrm{N}$; quadrant $\mathrm{C}$ : relative periphery-centre growth $\left(\mathrm{y}_{\mathrm{p}} / \mathrm{y}_{\mathrm{c}}\right)$ with external balance; quadrant $\mathrm{D}$ : response of relative periphery-centre wages $\left(\mathrm{W}_{\mathrm{p}} / \mathrm{W}_{\mathrm{C}}\right)$ to the relative growth rate.

\section{Quadrant A: the technology gap and relative productivity}

The model is based on the assumption that production uses only labour and technology, that the distribution of technological capabilities is asymmetrical between countries and that there is a wide range of goods that may be represented as a continuum with different levels of labour productivity.

In figure VII.1, quadrant A represents the relationship between production structure, technology and productivity. The horizontal axis represents the number of sectors in the economy, by descending order of labour productivity in the periphery relative to labour productivity in the centre. The sector $N=1$ is that in which the ratio of labour productivity in the periphery $\left(\pi_{\mathrm{p}}\right)$ to labour productivity in the centre $\left(\pi_{\mathrm{C}}\right)$ is at its highest; in other words, the first sector is that in which the periphery has its greatest comparative advantage $\left(\pi_{\mathrm{p}} / \pi_{\mathrm{C}}\right)$, which subequently diminishes as $N$ increases. $^{2}$

2 See Dornbusch, Fischer and Samuelson (1977), Cimoli (1988) and Dosi, Pavitt and Soete (1990). A model that fully accounts for interactions between the micro and macro levels is presented in Ciarli and others (2010). See also Katz (1997). 
In each sector, the relative productivity of the periphery depends on two factors: (i) the technology gap between the centre and the periphery, or the degree of technological superiority of the centre understood as the periphery's distance from the technology frontier, and (ii) the technology intensity of each good's production. The model assumes that the periphery is (for a given gap) less productive in more technology-intensive goods. For that reason, as $N$ increases and the comparative advantages of the periphery diminish, so the technological intensity or complexity of the produced goods increases.

The model therefore gives an indication of the sectors or goods in which the periphery is able to specialize for the purpose of international trade. The price of goods is defined as a function of the unit cost of production, which in turn depends on the relationship between wages and productivity. The periphery may competitively produce all those goods for which the unit cost of wages is lower than in the centre, or those goods that satisfy the formula $\left(W_{P} / \pi_{P}^{N}\right)<\left(W_{C} / \pi_{C}^{N}\right)$ where $W_{P}$ and $W_{C}$ are wages in the periphery and the centre, respectively, and $\pi{ }_{P}^{N}$ and $\pi_{C}^{N}$ represent the labour productivities of the periphery and the centre for the sector or good N. Production at the periphery will be competitive as far as the good $N=N^{P}$, at which point relative wages $\left(W_{p} / W_{C}\right)$ are equal to relative productivity $\left(\pi_{\mathrm{P}} / \pi_{\mathrm{C}}\right)$. The pattern of specialization in the periphery is thus defined by the goods included between $N=1$ and $N=N^{P}$, while the centre will produce the goods beyond the point $N=N^{P} .{ }^{3}$ Goods corresponding to $\mathrm{N}^{P}$ will be produced in both the centre and the periphery, since the cost of production is the same in both.

Quadrant A shows the pattern of specialization of the two poles (centre and periphery). Given the equilibrium relative wage (represented in quadrant $\mathrm{D}$ as $W^{*}$ ) and the curve of relative productivity, it is easy to obtain the degree of diversification of the periphery in equilibrium $\left(N^{P}\right)$. The centre produces the goods with the highest values for $N$. Since these goods are more knowledge-intensive, the production structure will be more complex at the centre than at the periphery. ${ }^{4}$

\section{Quadrants B and C: specialization and growth}

Quadrant B represents the relationship between production diversification and the ratio of the income elasticities of demand for exports $\left(\varepsilon_{p}\right)$ and imports $\left(\varepsilon_{c}\right)$ at the periphery. The ratio of elasticities correlates positively with the diversification of production towards more technology-intensive sectors. This relationship between technology and elasticities depends on two factors.

This is the original view of the centre-periphery system, in which the productivity differences between the poles are largely explained by differences in technological capacity.

4 See ECLAC (2007) and Hausmann and Hidalgo (2010). 
First, a pattern of specialization in which more technology-intensive sectors carry more weight (a higher value of $N$ ) allows the country to create more innovations or to imitate the innovations that emerge in the global economy more quickly. This in turn opens the door to faster-growing markets or a larger share of external and domestic markets. Second, demand for high-tech goods responds more strongly to income gains than demand for commodities or low-technology goods. While the "commodity lottery" may account for brief export booms in countries that are highly specialized in primary goods, both on the supply side (understood as the capacity to exploit opportunities in growth markets or to avoid loss of share) and the demand side (referring to consumption patterns, which respond more to technology-intensive goods as income increases), demand for a country's exports become more income elastic the more it specializes in more technologyintensive goods. ${ }^{5}$

Structuralist authors and Keynesian growth theorists emphasize that the periphery's externally balanced growth rate depends on the ratio of the income elasticities of demand for exports and imports, ${ }^{6}$ as expressed in the following equation:

(1) $y_{\mathrm{p}}=\frac{\varepsilon_{P}}{\varepsilon_{c}} y_{c}$

Under certain assumptions, ${ }^{7}$ equation 1 gives the externally balanced long-term output growth rate for the centre and the periphery: $y_{p}$ is the growth rate of the periphery, $y_{c}$ the growth rate of the centre and $\left(\varepsilon_{p} / \varepsilon_{c}\right)$ the ratio of elasticities. These rates are compatible with external balance, since they ensure that the growth rate of exports from the periphery $\left(\varepsilon_{p} \mathrm{y}_{C}\right)$ will be equal to the growth rate of its imports $\left(\varepsilon_{C} y_{P}\right)$. Recalling that the ratio of elasticities is a function of the degree of diversification of the peripheral production structure, equation 1 may be written as:

(2) $y_{p}=f\left(N^{P}\right) y_{c}, f^{\prime}\left(N^{P}\right)>0$

See Araujo and Lima (2007); Blecker (2011); Botta (2009); Cimoli and Porcile (2011); Dosi, Pavitt and Soete (1990); ECLAC (2007 and 2012) and Gouvea and Lima (2010).

$6 \quad$ See McCombie and Thirlwall (1997) and Moreno-Brid (2003). The topic is reviewed extensively in Thirlwall (2011).

7 The validity of this equation requires a constant real exchange rate and the absence of liquid debt over the long term. The real exchange rate may play a crucial role in the long run, since it affects the diversification of the production structure; however, the topic is not addressed here. See Bresser-Pereira (2008), Freund and Pierola (2008), Eichengreen (2008), Frenkel and Rapetti (2011), McMillan and Rodrik (2011) and Cimoli and others (2012). The equation also requires non-full employment, so that the labour supply can always adapt to demand stimuli. See Cimoli and Porcile (2013) for further details. 
The functional form of $f\left(N^{\mathrm{P}}\right)$ is an empirical question; for the sake of simplicity a linear specification will be assumed for this study. Its curvature depends on the impact of greater production structure complexity and the change in specialization on the country's share of different markets. Equation 1 gives the relative periphery-centre growth rate, which will be exactly equal to the ratio of income elasticities of exports and imports in the periphery, a function of $N^{P}$.

(3) $\frac{y_{p}}{y_{c}}=\frac{\varepsilon_{p}}{\varepsilon_{c}}=f\left(N^{P}\right)$

This equality is represented in quadrant $\mathrm{C}$, where, by means of a $45^{\circ}$ line, the relationship between the ratio of the income elasticities of exports of the periphery and the centre can be represented as the ratio of the equilibrium growth rates of the two economies. In theory, the causality runs from elasticities to growth, while elasticities respond to technical progress and demand patterns.

The periphery could, for a time, post faster growth than that determined by the ratio of elasticities, but such growth would be associated with an increase in external debt (since imports would outpace exports during that period). This raises the possibility of boom and bust cycles, associated with external borrowing and subsequent debt payments in foreign currency -i.e. the stop-go episodes of rapidly alternating expansion and contraction that have occurred frequently in the region's economic history (see FfrenchDavis and Ocampo (2001) and Ocampo and others (2009). In spite of these fluctuations, the long-term trend will be for growth to remain close to the rate determined by the condition of external balance.

\section{Wages, employment and underemployment}

Quadrant D shows the level of the equilibrium relative wage based on growth dynamics and employment. The growth rate of labour demand at the periphery depends on the economic growth rate minus the rate of increase in labour productivity. Insofar as labour demand increases faster than labour supply (given by the population growth rate), then underemployment and structural heterogeneity, defined as large differences in labour productivity between and within sectors, will diminish at the periphery. This happens because a proportion of workers will gradually move from subsistence labour into higher productivity sectors. Conversely, underemployment could increase if the ratio of elasticities provides only weak demand stimuli, owing to a high degree of specialization in goods with low income elasticity of demand. Where technical progress results chiefly in the rationalization of production processes and the reduction of costs, 
without an increase in output, then productivity gains may not translate into faster growth, but could lead to higher unemployment, underemployment, or both.

For that reason, an accurate assessment of the impact of productivity gains and technical progress on employment and underemployment should take account of their impacts on elasticities and on aggregate demand. Reducing structural heterogeneity requires output growth rates in keeping with productivity gains, thus ensuring job creation in higher productivity sectors, shrinking the informal sector and lowering underemployment (Infante and Sunkel, 2009).

Quadrant D shows that relative periphery-centre wages respond positively to higher growth rates at the periphery, which generate increased demand for labour. This response is initially sluggish, owing to the large pool of workers engaged in subsistence activities or low-productivity informal labour. As growth at the periphery gathers pace, however, the labour market may be expected to gradually shift in workers' favour and produce positive impacts on employment and wages. The ascending part of the relative wage curve represents the greater dynamism of the labour market at the periphery as it becomes more diversified.

Greater structural heterogeneity and lower employment growth at the periphery than the centre imply that relative wages will tend to be lower in the former. This is an additional factor driving inequality in the peripheral economy. While it is true that the wage differential could increase the competitiveness of the peripheral economy, which in turn would favour its diversification, the diversification produced by the impact of lower wages will be only slight if the productivity gaps between the two extremes are very wide. ${ }^{8}$ This corresponds to Fajnzylber's concept of spurious competitiveness (1990): the periphery becomes more competitive by accepting lower wages, but this does not have significant impacts on learning. Authentic competitiveness originates in the narrowing of technology and productivity gaps, with increases in relative wages responding to structural at in the periphery based on technical progress.

Changes in relative prices affect the production structure and, consequently, long-run growth. The level of relative prices has an impact on the export pattern and may boost (or reduce) the growth rate. Moreover, exchange-rate appreciation may cause the demise of sectors that cannot recover even after depreciation, giving rise to a hysteresis effect. Although these effects may be significant, their analysis falls beyond the scope of this chapter.

In graphic terms, if the decline in the curve of relative productivity is very steep, then a sharp fall in relative wages produces only a slight change in the pattern of specialization. 


\section{B. Microeconomic foundations of learning and convergence}

The preceding section showed how different variables (technology, specialization, growth, employment and heterogeneity) combine in a hypothetical scenario of externally balanced growth. But the microeconomic dynamics underpinning these outcomes must also be examined. When ECLAC conducted its pioneering studies, it did so in the absence of a microeconomic theory that could have rigorously substantiated the divergence observed at the macroeconomic level. This microeconomic theory is provided by evolutionary economics, which since the mid-1970s has advanced in the understanding of technological dynamics and capacity-building.

Why is the diffusion of technical progress less effective at the periphery than the centre? Understanding the asymmetrical dynamics of innovation and job creation at the periphery and the centre, and within the peripheral structure itself, holds the key to understanding the persistence of the extreme inequality typical of the region. This section discusses the forces that accentuate or mitigate polarization, on the basis of evolutionary microeconomics (inspired by Schumpeter), which offer a natural complement to structuralist-Keynesian macroeconomics. ${ }^{9}$

In stark contrast to the assumptions of the mainstream growth theory that predominated until the mid-1980s, the evolutionary economists did not regard technical progress as a free good, still less an exogenous one provided "by God and the engineers", as Joan Robinson famously remarked. Their vision of the learning process may be summarized as follows:

- Learning is localized, with firms learning within the context of existing technological capacities and abilities.

- Learning is, to a great extent, a tacit process. In many cases the technology cannot be copied or transferred in a codified form (as in manuals or instructions) because actual production experience is of crucial importance.

- Technical progress has marked path-dependency elements, meaning that the shadow of the past is projected onto future capacity development.

\footnotetext{
See Dosi (1988), Cimoli and Dosi (1995), Katz (1997) and Cimoli, Dosi and Stiglitz (2008). In the studies pioneered by ECLAC in the 1950s, it was implicitly assumed that industrialization alone would lead to the absorption of technology and the closing of the gap. The learning process would be protected through the protection of industry. The view of Steindl (1952 and 1976, page 133), according to which technical progress accompanied the accumulation of capital "like a shadow", provides a rough description of how the relationship between industry and technology was generally conceived at the time.
} 
- The foregoing suggest that innovation and the diffusion of technology should be viewed as closely linked processes, since diffusion will not occur unless the firms that are imitating foreign technologies make an effort to improve and adapt them to their production capabilities and the specific conditions existing in their markets. In fact, technological diffusion is accompanied by a sequence of minor innovations which, despite having very little impact individually, will generate significant gains in productivity and international competitiveness over the course of several years.

- Successful cases of convergence, or catching up, are characterized by a continued effort in which the foreign technology is used as the basis for local learning, rather than replacing it.

- Learning includes a dimension of increasing returns, a factor that accounts, on the one hand, for capacity-building and, on the other, for widening lags. Firms that innovate in a given time period are more likely to innovate later on. Increasing returns are associated with different types of complementarity among production assets and technological assets, and with various forms of synergy at the meso- and macroeconomic levels. These synergies may give rise to virtuous cycles of learning, investment and growth.

- The above argument thus extends the Kaldor-Verdoorn law (according to which gains in output induce productivity gains) to cover a wide range of learning processes. These processes have been identified and analysed in the neo-Schumpeterian literature and include not only learning-by-doing, but also learning-by-using, learning-by-interacting and learningby-exporting. ${ }^{10}$

- Technical progress stems from an interactive process of trial and error and from information-sharing among a large, varied group of agents that in many cases have differing objectives, rules and organizational structures (e.g. firms, universities and research centres). The intensity of technical progress is determined largely by the existence of an appropriate formal or informal institutional framework, which coordinates the interaction of these agents and induces them to engage in cooperative behaviour that will encourage innovation and its diffusion.

\footnotetext{
10 See León-Ledesma (2002) and Arthur (1989 and 1994).
} 
- There is no predetermined trajectory for technical progress: by nature it is tacit, idiosyncratic and specific to a certain reality, so that different paths and options are possible. Moreover, institutional design and the design of industrial and technological policies (including education policy) may strongly influence its direction, so that there is space for society to take strategic decisions as to the most desirable pathways.

Together, these factors determine the rate of innovation and technological diffusion internationally and within specific countries, based on the characteristics of their production structures and their institutional arrangements. Ultimately, they form the basis for long-term technological capacity-building. Several authors (Freeman, 1987; Nelson, 1991 and Metcalfe, 2001) adopted the term "national innovation system" to refer to the different ways in which the institutional framework (including industrial and technology policies, as well as macroeconomic policy) and the production structure combine in each country to define the intensity and the direction of innovation. The diversity of potential combinations is an essential part of the various development styles that have been observed in different countries and historical periods.

This discussion also provides a rather unconventional way of looking at the supply side and microeconomics. Technical progress is not manifested as changes in well-defined production functions, but in learning paths that come to fruition in the accumulation of technological capabilities. In particular, the role of public policies is not to achieve more flexible markets or the neutrality of stimuli, but to build institutions that bring about stable, long-term coordination mechanisms between the different agents that promote investment in innovation and technology diffusion. In some cases, these institutions complement the price system, while in others they generate the distortions needed to escape from path-dependency situations.

\section{An example: industrial policy}

This section applies the analytical framework outlined above to examine the impact of policies aimed at promoting learning and structural change.

Figure VII.2 shows the outcome of adopting an active industrial and technology policy that facilitates technological convergence; in other words, narrowing the technology and productivity gap with the leading economies. The effect of a policy of this type is to shift the curve of relative productivity, in quadrant $2 \mathrm{~A}$, to the right, resulting in a change in the pattern of specialization (from $X$ to $Z$ ). The country has increased the complexity of its production structure and better captures growth in global effective 
demand. In other words, there is a shift in the income elasticities of exports and imports (quadrant 2B), as well as in the pattern of specialization. This feeds and strengthens growth (quadrant 2C), learning and structural change. Increasing returns to scale enter the picture by means of a virtuous circle generated by the interaction between productivity gains, diversification, growth and the impact of growth on productivity (Kaldor-Verdoorn law).

Figure VII.2

Impact of industrial and technology policy ${ }^{a}$

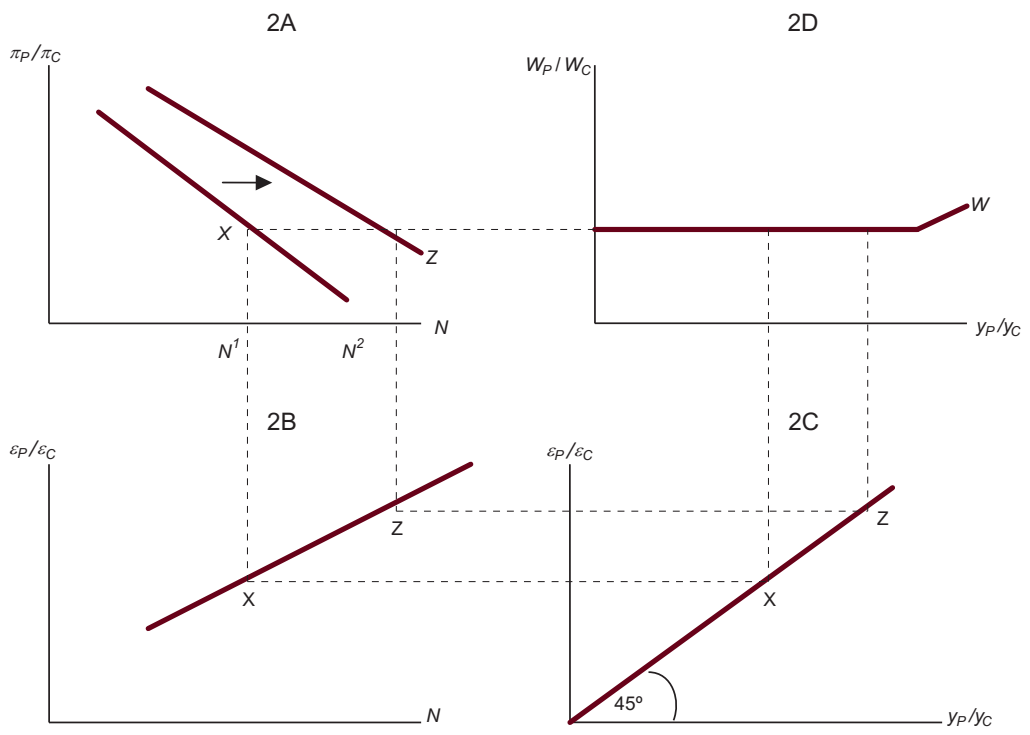

Source: Prepared by the authors.

a Quadrant 2A: relative periphery-centre productivity, where $\pi \mathrm{P}$ is the productivity of the periphery and $\pi \mathrm{C}$ is the productivity of the centre; quadrant $2 \mathrm{~B}$ : income elasticities of exports and imports as a function of the diversification of the production structure; quadrant $2 \mathrm{C}$ : the relationship between the pattern of specialization and growth with current account stability; quadrant 2D: relative periphery-centre wages as a function of economic growth.

At the same time, the reconfiguration of the production pattern entails a change in the employment structure, as structural change allows more workers to move from underemployment into higher productivity jobs. While quadrant 2D assumes no change in relative periphery-centre wages, the drop in underemployment transforms faster growth into a better income distribution.

The structuralist model, with its various links to the Schumpeterian and Keynesian schools, forecasts that countries with more active industrial and technology policies will manage to transform their production base and 
narrow the productivity gaps that separate them from leading economies. Structural change and narrowing gaps go hand in hand, as is neatly illustrated by figures VII.3 and VII.4. The figures show the joint evolution of a proxy for structural change, the relative share of engineering activities in the aggregate value of the manufacturing sector (EIS), compared with an advanced country, ${ }_{11}^{11}$ and relative labour productivity, which is a proxy for the technology gap. The United States is the advanced country taken as the benchmark, although it could be any country close to the technological frontier. A comparison was applied to Argentina, Brazil and the Republic of Korea between 1990 and 2008. Argentina and Brazil were selected because their industry is relatively advanced for the region. The findings are also valid for the smaller countries, where structural change is still weak compared with larger countries. The duration and consistency of the industrial and technology policies of the Republic of Korea has been well documented (for example, see the classic studies by Amsden (1989) and Chang (2002)), while in Argentina and Brazil these policies suffered significant interruptions (Bell, 2006; Peres, 2010). A comparison with a greater number of countries, both outside and within the region, may be found in ECLAC (2012).

Figure VII.3

Selected countries: technology intensity of the production structure, 1990-2008 ${ }^{\text {a }}$

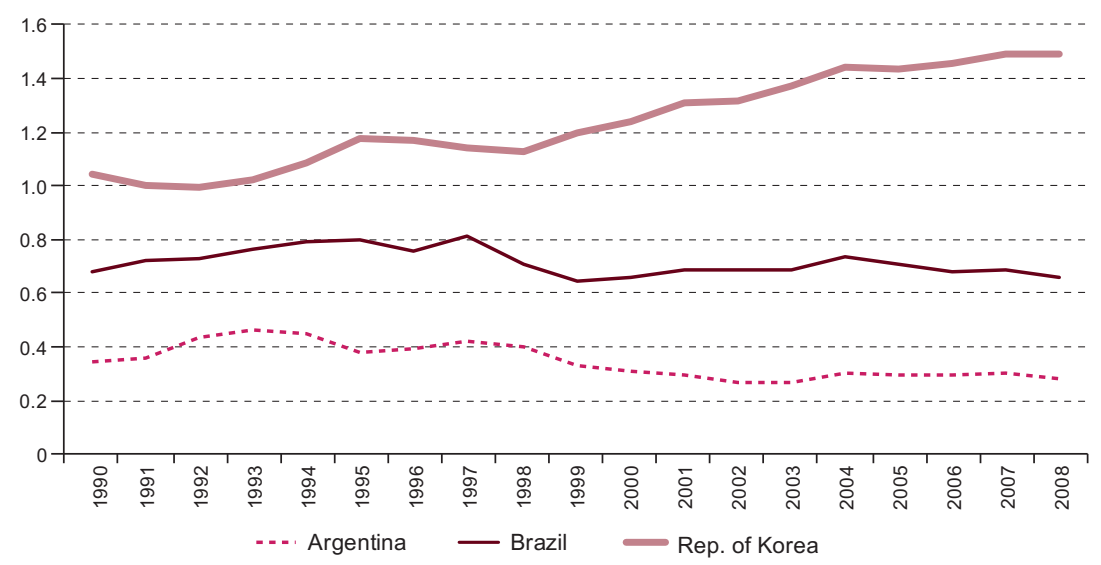

Source: Prepared by the authors.

a Technology intensity is expressed as the index of the relative share of engineering activities in the aggregate value of the country's manufacturing sector, as compared to the relative share in an advanced country (in this case, the United States).

\footnotetext{
11 All the indicators of structural change used in the literature have significant limitations, and EIS is no exception. In any event, the results shown in figure VII.3 do not change when alternative indicators are used, such as the index of economic complexity or research and development expenditure as a percentage of GDP.
} 
Figure VII.4

Selected countries: relative productivity, 1990-2008 ${ }^{a}$

(United States $=100$ )

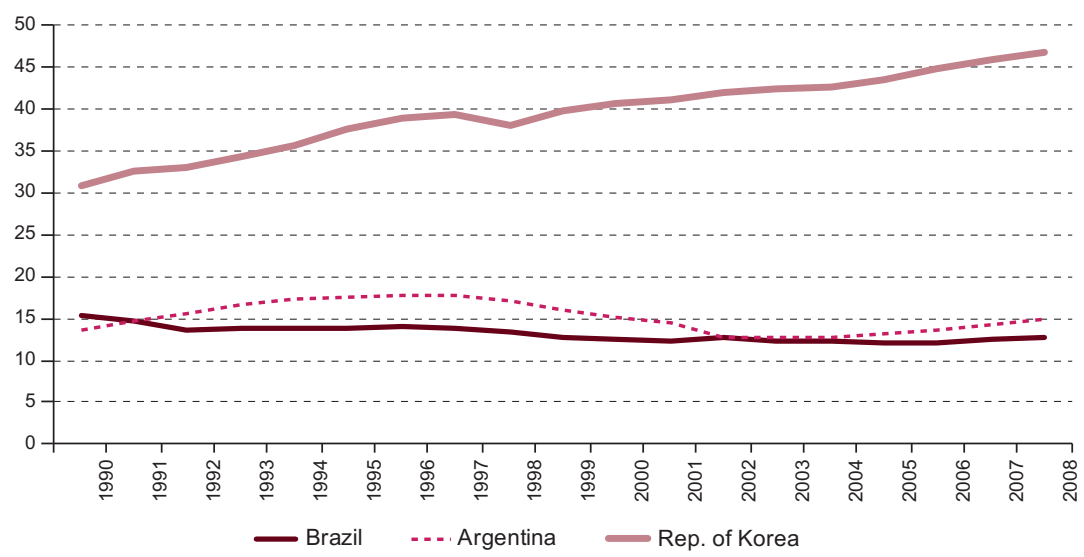

Source: Prepared by the authors.

a Relative productivity refers to the labour productivity of the country divided by the labour productivity of a country at the technological frontier (in this case, the United States)

In the Republic of Korea, the gap with the technological frontier is narrowing as the technology intensity of the production structure increases. Conversely, the two Latin American countries exhibited a tendency towards stagnation or moved in the opposite direction: loss of complexity, relative productivity and growth. As mentioned previously, the dynamic underlying this trend is the considerable difference in the intensity and direction of the respective countries' industrial and technology policies.

\section{Final remarks}

The structuralist theory of development seeks to identify reasons for the persistence or gradual widening of inequalities in productivity, growth and per capita income, both in the international economy and within less advanced economies. According to the theory, these trends result from changes both in production structures and technological learning, and are sustained by the performance of various cumulative capacity-building mechanisms, as studied by the evolutionary school. The significance of these mechanisms means that industrial policy action and, in particular, stronger national innovation systems, are required for countries to escape the traps of low growth and low learning. The impacts of structural change on growth and employment are measured by their consequences for effective demand - as proposed by the Keynesian tradition and by the dynamic Harrod foreign trade multiplier - and, more specifically, for the growth rate compatible with a stable current account deficit-to-GDP ratio. 
Production asymmetries are also reproduced through the performance of non-technological variables. There are social and political dynamics that influence the institutional environment and incentives for learning, and also reinforce the cumulative mechanisms of technical change. While social dynamics are not addressed in this study, it should be said that there is nothing inevitable or immutable about the divergence of the least developed countries. Policies are not completely endogenous to the structure. Rather than a game of chess, in which each piece can only execute a predetermined move, the idea of development is better represented by Jorge Luis Borges' image of the garden of forking paths: different trajectories being discovered and revealing themselves as a result of strategic decisions that require creativity and invention at all times. The perception that there are different development styles, and that society is capable of choosing between alternative futures, needs to be recovered. Progress will undoubtedly meet with specific constraints at each step; both on the technological front and in the production and social structure, so strategic decisions should be taken with the goal of gradually overcoming these constraints instead of confirming and entrechning them. The cornerstone of industrial policy over the coming decades must be to absorb and accumulate capacities under new paradigms, while building institutions to adapt and generate incremental and even radical innovations within those paradigms. It is capacities (or incapacities) in new technologies that will determine who is competitive in which branches of economic activity, and who will have a place in the future international division of labour.

\section{Bibliography}

Amsden, A. (1989), Asia's Next Giant: South Korea and Late Industrialization, New York, Oxford University Press.

Araujo, R.A. and G.T. Lima (2007) "A structural economic dynamics approach to balance of payments constrained growth", Cambridge Journal of Economics, vol. 31, No. 5.

Arthur, B. (1994), Increasing Returns and Path-Dependency in Economics, Michigan University Press/Ann Arbor.

(1989), "Competing technologies, increasing returns and lock-in by historical events", Economic Journal, vol. 99, No. 1.

Bell, M. (2006), "Time and technological learning in industrializing countries: how long does it take? how fast is it moving (if at all)?", International Journal of Technology Management, vol. 36, No. 1-3.

Bertola, L. and J.A. Ocampo (2010), Desarrollo, vaivenes y desigualdad: Una historia económica de América Latina desde la independencia, Madrid, Ibero-American Secretariat (SEGIB).

Bielschowsky, R. (2009), "Sixty years of ECLAC: structuralism and neostructuralism", CEPAL Review, No. 97 (LC/G.2400-P), Santiago, Economic Commission for Latin America and the Caribbean (ECLAC), April. 
Blecker, R.A. (2011), "Long-run growth in open economies: export-led cumulative causation or a balance-of-payments constraint?", Handbook of Post-Keynesian Economics, G. Harcourt and P. Kriesler (eds.), Oxford, Oxford University Press.

Botta, A. (2009), "A structuralist North-South model on structural change, economic growth and catching up", Structural Change and Economic Dynamics, vol. 20.

Bresser-Pereira, Luiz Carlos (2008), "Dutch disease and its neutralization: a Ricardian approach", Brazilian Journal of Political Economy, vol. 28, No. 1, January.

Chang, H.J (2002), Kicking Away the Ladder: Policies and Institutions for Economic Policy in Historical Perspective, London, Anthem Books.

Ciarli, T. and others (2010), "The effect of consumption and production structure on growth and distribution. A micro to macro model", Metroeconomica, vol. 61, No. 1.

Cimoli, M. (1988), "Technological gaps and institutional asymmetries in a NorthSouth Model with a continuum of goods", Metroeconomica, vol. 39, No. 3.

Cimoli, M. and G. Dosi (1995), "Technological paradigms, patterns of learning and development: an introductory roadmap", Journal of Evolutionary Economics, Heidelberg, Springer-Verlag Heidelberg.

Cimoli, M. and G. Porcile (2013), "Technology, structural change and BOPconstrained growth: a structuralist toolbox", Cambridge Journal of Economics.

(2011), "Learning, technological capabilities and structural dynamics", The Oxford Handbook of Latin American Economics, J.A. Ocampo and J. Ros, Oxford University Press.

Cimoli, M., G. Dosi and J.E. Stiglitz (2008), "The political economy of capabilities accumulation: the past and future of policies for industrial development. A preface", LEM Papers Series, No. 2008/15, Pisa, Laboratory of Economics and Management (LEM), Sant'Anna School of Advanced Studies.

Cimoli, M., G. Porcile and S. Rovira (2010), "Structural change and the BOP constraint: why did Latin America fail to converge?", Cambridge Journal of Economics, vol. 34, No. 2.

Cimoli, M., S. Fleitas and G. Porcile (2012), "Technological intensity of the export structure and the real exchange rate", Economics of Innovation and New Technology, vol. 22, No. 4.

Dornbusch, R., S. Fischer and P. Samuelson (1977), "Comparative advantage, trade, and payments in a Ricardian Model with a continuum of goods", American Economic Review, vol. 67, No. 5.

Dosi, G. (1988), "Sources, procedures and microeconomic effects of Innovation", Journal of Economic Literature, vol. 26, No. 3.

Dosi, G., K. Pavitt and L. Soete (1990), The Economics of Technical Change and International Trade, Brighton, Wheatsheaf.

ECLAC (Economic Commission for Latin America and the Caribbean) (2012), Structural Change for Equality: An Integrated Approach to Development (LC/G.2524 (SES.34/3)), Santiago. (2007), "Progreso técnico y cambio estructural en América Latina", Project Document, No. 136 (LC/W.136), Santiago.

Eichengreen, B. (2008), "The real exchange rate and growth", Working Paper, No. 4, Commission on Growth and Development.

Fajnzylber, Fernando (1990), "Industrialization in Latin America: from the 'black box' to the 'empty box': a comparison of contemporary industrialization patterns", Cuadernos de la CEPAL series (LC/G.1534/Rev.1-P), Santiago. 
Freeman, C. (1995), "The national system of innovation in historical perspective", Cambridge Journal of Economics, vol. 19, No. 1.

(1987), Technology Policy and Economic Performance: Lessons from Japan, London, Francis Pinter.

Ffrench-Davis, Ricardo and José Antonio Ocampo (2001), “La globalización de la volatilidad financiera", Crisis financieras en países 'exitosos', Ricardo FfrenchDavis (ed.), Santiago, McGraw-Hill/Economic Commission for Latin America and the Caribbean (ECLAC).

Frenkel, R. and M. Rapetti (2011), "A concise history of exchange rate regimes in Latin America", The Oxford Handbook of Latin American Economics, J.A. Ocampo and J. Ros, Oxford University Press.

Freund, C. and M.D. Pierola (2008), "Export surges: the power of a competitive currency", Policy Research Working Paper, No. 4750, October.

Gouvea, R.R. and G.T. Lima (2010), "Structural change, balance of payments constraint and economic growth: evidence from the multi-sectoral Thirlwall's Law", Journal of Post Keynesian Economics, vol. 33, No. 1, October.

Hausmann, R. and C.A. Hidalgo (2010), "Country diversification, product ubiquity, and economic divergence", CID Working Paper, No. 201, Center for International Development, Harvard University.

Infante, R. and O. Sunkel (2009), "Chile: towards inclusive development", CEPAL Review, No. 97 (LC/G.2400-P), Santiago, Economic Commission for Latin America and the Caribbean (ECLAC), April.

Katz, J. (1997), "Structural reforms, the sources and nature of technical change and the functioning of the national systems of innovation: the case of Latin America", paper presented at the STEPI International symposium on innovation and competitiveness in NIEs, Seoul, May.

Leon-Ledesma, M.A. (2002), "Accumulation, innovation and catching-up: an extended cumulative growth model", Cambridge Journal of Economics, vol. 26.

McCombie, J.S.L and A.P. Thirlwall (1997), "The dynamic Harrod trade multiplier and the demand-oriented approach to economic growth: an evaluation", International Review of Applied Economics, vol.11, No. 1.

McMillan, M. and D. Rodrik (2011), "Globalization, Structural Change and Productivity Growth", International Labour Organization (ILO)/World Trade Organization (WTO), February.

Metcalfe, J.S. (2001), "Institutions and progress", Industrial and Corporate Change, vol.10, No. 3, Oxford University Press, September.

Moreno-Brid, J. (2003), "Capital flows, interest payments and the balance-ofpayments constrained growth model: a theoretical and empirical analysis", Metroeconomica, vol. 54, No. 2-3.

Narula, R. (2004), "Understanding absorptive capacities in an innovation systems context: consequences for economic and employment growth", DRUID Working Paper, No. 04-02, December.

Nelson, Joan M. (1991), “Organized labor, politics, and labor market flexibility in developing countries", World Bank Research Observer, vol. 6, No. 1.

Ocampo, J.A., C. Rada and L. Taylor (2009), Growth and Policy in Developing Countries: A Structuralist Approach, Oxford University Press.

Pacheco-Lopez, P. and A.P. Thirlwall (2006), "Trade liberalization, the income elasticity of demand for imports and economic growth in Latin America", Journal of Post-Keynesian Economics, vol. 29, No. 1. 
Palma, J.G. (2011), “Why has productivity growth stagnated in most Latin American countries since the neoliberal reforms?", Cambridge Working Papers in Economics, No. 1030, July.

Peres, Wilson (2010), "The (slow) return of industrial policies in Latin America and the Caribbean", The Political Economy of Capabilities Accumulation: the Past and Future of Policies for Industrial Development, M. Cimoli, G. Dosi and J.E. Stiglitz (eds.), Oxford University Press.

Prebisch, R. (1950), The Economic Development of Latin America and its Principal Problems (E/CN.12/89/Rev.1), New York, United Nations.

Rodríguez, O. (2007), El estructuralismo latinoamericano, Mexico City, Siglo XXI. (1980), La teoría del subdesarrollo de la CEPAL, Mexico City, Siglo XXI.

(1977), "On the conception of the centre-periphery system", CEPAL Review, No. 3, Santiago, Economic Commission for Latin America and the Caribbean (ECLAC), April.

Stallings, B. and W. Peres (2000), Growth, Employment and Equity: The Impact of Economic Reforms in Latin America and the Caribbean, Washington, D.C., Brookings Institution Press.

Steindl,Josef(1952), Maturity and Stagnation in American Capitalism, New York, Oxford.

Thirlwall, A. (2011), "Balance of payments constrained growth models: history and overview", School of Economics Discussion Paper, No. 1111, University of Kent, May.

Vera, L.A. (2006), "The balance-of-payments constrained growth model: a northsouth approach", Journal of Post-Keynesian Economics, vol. 29, No. 1.

Verspagen, B. (1993), Uneven Growth between Interdependent Economies: An Evolutionary View of Technology Gaps, Trade and Growth, Avebury, Ashgate Publisher.

Wade, R. (1990), Governing the Market: Economic Theory and the Role of Government in East Asian Industrialization, Princeton, Princeton University Press. 



\section{The macro- and microeconomics of natural-resource-based growth ${ }^{1}$}

Jorge Katz

\section{Introduction}

After enduring sluggish growth in the 1980s, which led to heavy drops in gross domestic product (GDP) in the aftermath of the 1982 Mexican moratorium, a sharp downturn in employment and social equity, and considerable destruction of industrial and technological capacity — caused by the unthinking manner in which several governments opened and deregulated the economy following the precepts of the Washington Consensus - the Latin America countries experienced an uneven but encouraging upturn in the 1990s and 2000s.

This recovery was driven largely by growth in exports, terms-of-trade gains and a radical structural change that allowed new sectors (mostly producers of common industrial commodities, such as oil and gasoline, minerals, pulp and paper, soybeans and soy products, and flowers and food)

This chapter is based on the author's presentation at the Seminar on neostructuralism and heterodox economics, held in Santiago by the Economic Commission for Latin America and the Caribbean (ECLAC) on 22 and 23 April 2013. The author would like to thank the organizers for the invitation, as well as for the feedback given both at the seminar and anonymously afterward. The opinions expressed in this chapter are entirely the responsibility of the author and do not necessarily reflect the views of the agencies mentioned. 
to expand at double-digit rates over relatively long periods, which resulted in increased employment, better wages and higher tax revenues.

The primary reason for this economic upturn was the boom in demand from China, India and other Asian countries for these industrial commodities, together with the attendant rise in prices.

Figure VIII.1

\section{Price of industrial commodities}

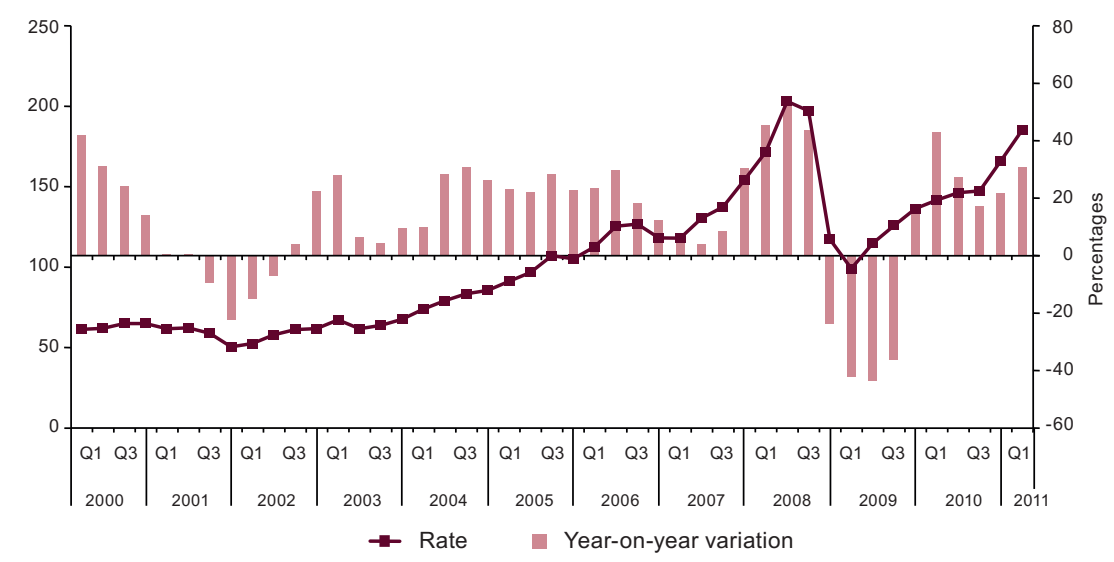

Source: Prepared by the author.

The process was associated with the opening of new manufacturing plants in the aforementioned sectors, which provided modern technologies, brought productivity levels close to the international technological frontier and led to the emergence of business and professional communities, new sectoral institutions and innovative approaches to organization and market analysis, amid a drastic transformation of the production structure. This shift occurred in a period of co-evolutionary technological change, new forms of industrial organization and changes in institutions that provide support to various spheres of community life.

At the same time, service sectors such as banking, telecommunications and the financial industry also underwent profound structural, technological and institutional changes. The gap between high- and low-productivity businesses has widened considerably in all sectors. Therefore, the aggregate calculations - based on total factor productivity and conventional accounting of growth- hide a deep structural heterogeneity that makes them somewhat questionable.

This wide-ranging process has not yet been adequately studied. It could be convincingly argued that different forms of capitalism have emerged in 
the region, some more successful than others. However, all of them -without exception- are different from the post-war models of social and economic organization, in which the State played a central role by steering growth and providing special incentives to producers of manufactures for the national market. This time, growth is driven by common industrial commodities and services, rather than by manufactures, which were the main engine of growth in past decades.

This paper reflects on some of the macro- and microeconomic aspects of this new Latin American development phase and on the questions that will arise in the future.

Although various circles in society undoubtedly have a better quality of life today than in the past, not everything is auspicious and encouraging. While it is true that a portion of GDP - large or small, depending on the country - is much closer to the international productivity frontier today and that companies and employees in these sectors earn much higher wages than the national average, income is also more concentrated than it used to be in the highest decile and the gap between rich and poor has widened. Average wages in the highest quintile are 20 to 25 times higher than in the lowest quintile, which is a much larger gap than exists in the European countries, for example, where the multiple is around six to eight between the same quintiles.

A new middle class has emerged, the size of which varies between countries but encompasses 30 million to 40 million people in Brazil alone, and is also large in Chile, Colombia, Mexico and the Plurinational State of Bolivia. This new middle class is now calling for more and better provision of public goods, such as health care, education and social security. This fact is clearly reflected by the protest movements seen in many of the region's countries.

This emerging middle class is concentrated in the third and fourth income quintiles, and is now heavily indebted to the banking system, owing to its keen demand for rapid access to housing, consumer durables and vehicles. There are signs of long-term weakness that cannot be ignored, inasmuch as the lack of transparency in the functioning of the credit markets could lead to bubbles in the housing and consumer credit markets, as has already happened in many developed countries. The region is headed towards a new mass society, whose structure and behaviour should not be controlled solely by the market but should be subject to oversight by a public authority. Increased transparency of information and ex ante precautionary monitoring is needed, as well as stricter application of the competition regulations, which so far seem inadequate. This situation is a major weak point of the new capitalist model taking shape in the region's countries. 
Alongside the positive developments, segments of the population increasingly experience social exclusion, marginalization and lack of employability. There are several reasons for this, such as lack of public goods, poorly functioning credit markets and lack of initial human capital stock, leaving large groups of the population disenfranchised and showing irrefutable proof that market rules alone cannot achieve equitable development and social inclusion. These excluded communities - euphemistically labelled as terrorists by the mainstream ideology- swell the ranks of those who make a living illegally because they are unable to integrate into society. This entire state of affairs requires deeper reflection on the type of institutions and forms of social organization that should exist in the future.

The path taken by the Latin American economies has been a clear return to their traditional comparative advantages, and a departure from the post-war development path. Their focus has returned to high-quality natural resources and cheap, low-skilled labour. In other words, they have put aside the goal of reaching the international technological frontier and have concentrated on maintaining short-term financial stability and keeping the main economic fundamentals balanced.

Throughout this lengthy episode of creative destruction in the region, after having opened, privatized and deregulated its economic activity, as advised by the ideology of the Washington Consensus, there still remained - aside from a cheap and low-skilled labour supply- a relative abundance of oil and gas, forests with faster maturation cycles than in the northern hemisphere, agricultural land and abundant livestock of peerless quality, and coastlines and lakes capable of supporting the world's finest aquaculture.

This path was traced out by public policy agendas inspired by purely market rules and macroeconomic policy regimes that prioritized inflation control and balancing short-term fundamentals over seeking convergence with the developed world and closing the productivity gap between the region and developed countries.

The notions of a subsidiary State, neutral government and a free-marketdriven growth have prevailed over the lessons of history: the prime examples of convergence - both in the nineteenth century and more recently in the cases of the Republic of Korea and China- have taken place in a context where the State has been proactive in designing, funding and regulating growth, the provision of public goods and the distribution of the fruits of development among its citizens. 
This paper reflects on the macro- and microeconomic implications of the return to natural comparative advantages, low value added activities and supply chains that exploit the region's wealth of natural resources. It analyses the effects of these factors on the production structure, as well as on the use of natural resources and environmental and ecological sustainability. The literature refers to these matters by the exotic names of "Dutch disease" for the macroeconomics, and "the tragedy of the commons", for the microeconomics. Both aspects are discussed here but, by necessity, the picture is painted with broad strokes, as the topics exceed the scope of a work of this nature, and both are addressed elsewhere in this book.

\section{A. Reflections on the new macroeconomic policies}

The literature from the past decade clearly shows the main concerns of Latin American macroeconomists, such as the tremendous macroeconomic volatility in the region's countries (see figure VIII.2). This has been an issue even in those countries that appear to manage their structural fiscal balances and open capital accounts cautiously and meticulously (compared with developed countries that have maintained near-zero interest rates in an attempt to revitalize their weak economies). The literature also admits to the need for a (substantial) degree of currency appreciation with a view to keeping inflation under control (see figure VIII.3).

Figure VIII.2

Latin America: annual growth of GDP and aggregate demand, 1990-2004 (Percentages)

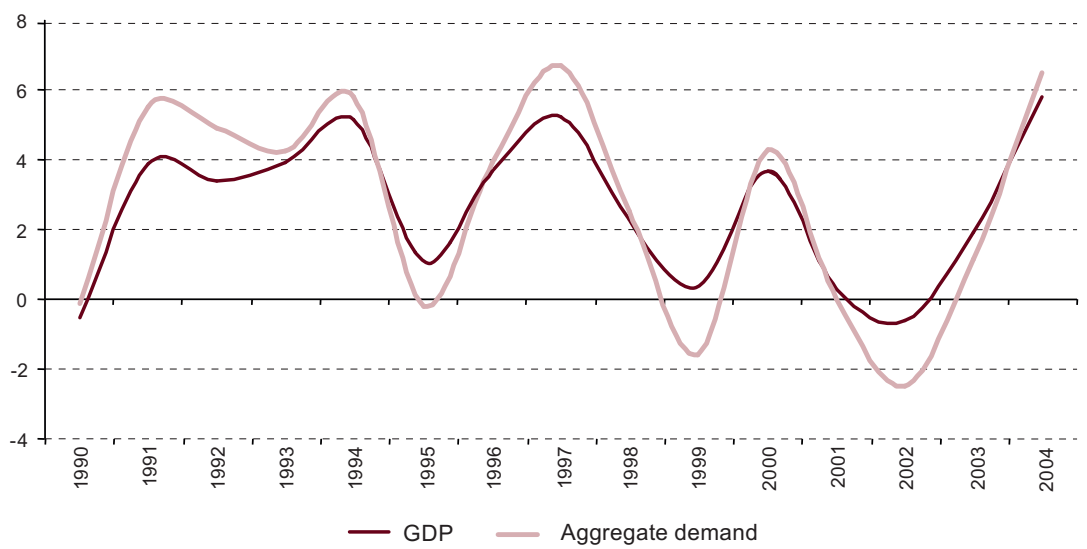

Source: Ricardo Ffrench-Davis, Entre el neoliberalismo y el crecimiento con equidad, Santiago, LOM Ediciones, 2005. 
Figure VIII.3

Currency appreciation before the 2008-2009 crisis

(Percentages)

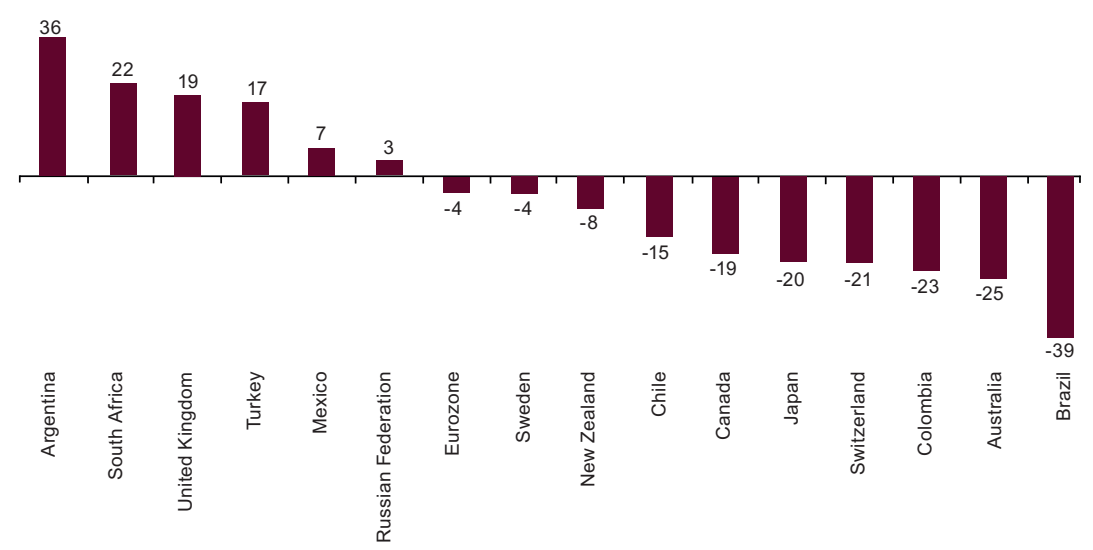

Source: Prepared by the author.

The region's countries have been hard put to cope with the combined impact of: (i) macroeconomic volatility, which speaks to the gut instincts of business owners and encourages defensive behaviour, which shortens business's planning horizons and hinders investment and research and development (R\&D) spending; (ii) currency appreciation; and (iii) the high international prices of common industrial commodities. The response has been a widespread decline in the rate of capital formation, which has fallen below 1970s levels, and — despite a partial recovery in the 1990s- never regained the strength of 20 years ago (see figure VIII.4). Spending on R\&D never met the expectations of those who hoped that market deregulation, increased competition and openness to external markets would take them to levels close to developed countries - between $2 \%$ and $4 \%$ of GDP.

Exchange-rate appreciation drove the commoditization of the production pattern and exports, and increasingly strengthened imports of machinery and consumer durables over domestic production. Local factories have moved towards a higher import content and lower intermediate component use per unit of national production. The growing foreign trade deficit, even in sectors closely linked to exports (such as vehicles), bears witness to this state of affairs. National small and medium-sized enterprises (SMEs) that produce intermediate components have lost ground to imported inputs. The production structure and exports have lost diversity and complexity; production tends to be concentrated in non-tradable goods and in a few commodity sectors that are usually capital-intensive and focused on knowledge-unintensive links of the chain with little domestic value added. This was detrimental to the creation of good-quality and well-paid jobs. The labour market grew hand 
in hand with the economy, particularly in the low value added personal services sector, which has inadequate social protection and high employee turnover rates.

Figure VIII.4

Latin America: gross capital formation, 1971-2011

(Percentages of GDP)

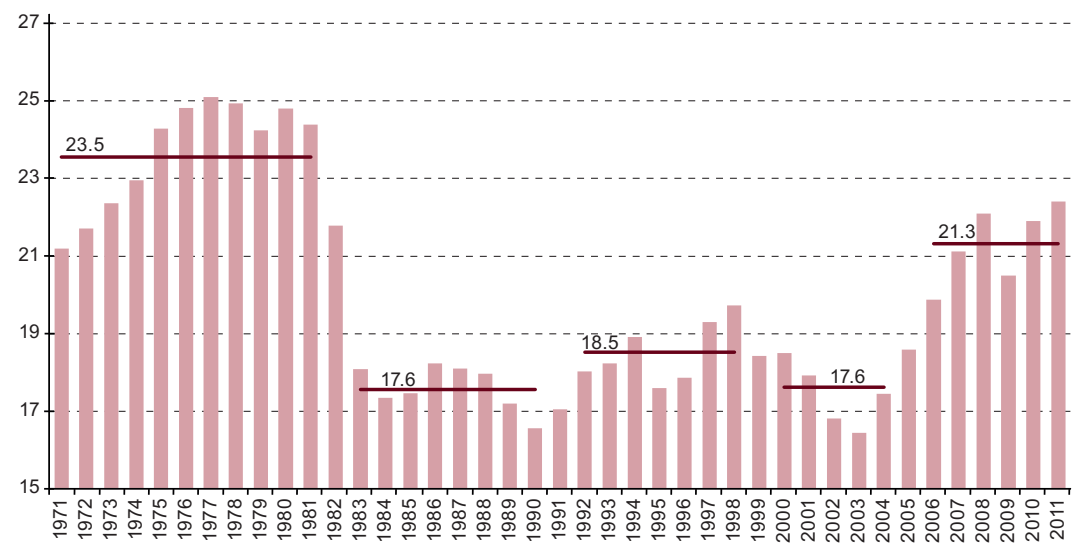

Source: Ricardo Ffrench-Davis, Entre el neoliberalismo y el crecimiento con equidad, Santiago, LOM Ediciones, 2005.

Except in a few very particular areas, national innovation systems made no great progress in this period, as importing machinery and processing international licences were the main pillars for the upgrading of various parts of the production apparatus.

These developments are the outcome of the theory that led successive generations of Latin American economists to place short-term financial balance at the forefront of their macroeconomic policy. The Mundell-Fleming model —an extension to the IS-LM (or Hicks-Hansen) open economy model- is based on an aggregate algorithm that does not take into account the structure of the production apparatus and its heterogeneity, expressed by the distances between various industries and the international productivity frontier, which are therefore not a major concern for government action. Rising inflows of foreign exchange from commodity exports cause currency appreciation and are a disincentive to national production of goods intensive in engineering and in local technical knowledge. This is the theoretical framework that underlies much of the macroeconomic policy formulation and implementation in the region today.

Amid sharp structural heterogeneity, the exchange rate is hardly a suitable instrument to encourage the branches of production furthest from the 
international productivity frontier to compete with imports by investing in new capacity or R\&D (Rapetti, 2011). In this case, exchange-rate appreciation leaves the most efficient sectors of the economy -industrial commodity producers - unaffected, but hinders the convergence of industries that, although far from the international productivity frontier today, could become competitive in global markets in the medium term after a learning phase. Japan would never have become the efficient automobile producer that it is today if in the 1950s it had focused on the silk and textile industries that were its natural comparative advantages at the time. The same can be said for the Republic of Korea during the 1980s (Kim, 1997). However, in these cases the State's role in supporting the creation of new forms of economic competitiveness was clearly not limited to exchange-rate management.

Numerous economists have argued in recent years that if exchange-rate appreciation and lack of incentives persist over long periods, high import propensity and weak instinct of business-owners can become locked in, reflecting the discouragement caused by a macroeconomic policy unsuited to industrial development (Frenkel and Rapetti, 2011). An appreciation of $30 \%$ to $40 \%$ will certainly destroy any possibility of a $3 \%$ or $4 \%$ annual rise in productivity serving to compete with foreign companies. Imports thus become the most direct substitute available to local firms.

This view has inspired much of the macroeconomic policy in Latin America in the past decade, and shows the priority that the region's governments give to low inflation targets and short-term fundamentals, since these confer credibility on the world stage and thus access to foreign direct investment, postponing the discussion on long-term industrial and technological development strategies that would allow the region to close the international production frontier gap. The question remains, however, as to how to attain a well managed macroeconomy with low inflation and a high and stable exchange rate, that encourages exports of high value added products and has industrial policies that take into account the structural heterogeneity of the production apparatus and the difficulty this poses to increasing productivity and incorporating home-grown technological innovations.

The great unfinished business of mainstream economics is how to create and implement fiscal, monetary and foreign-exchange policies that, together with industrial and development policies, will help to close the productivity gap between the region and the developed world. The economic history of the past 50 years provides valuable examples of how to reconcile macro- and microeconomics to create sustained high-growth cycles. For example, the Republic of Korea, Taiwan Province of China, or even Finland 
when faced with the fall of the Union of Soviet Socialist Republics (USSR) (its main buyer of forest products), shifted decisively toward knowledgeintensive sectors and began to push production toward the international technological frontier. Instead of learning from these examples, the region's macroeconomic policy has prioritized short-term financial stability over converging with the international productivity frontier. The quest for greater equity and social inclusion - through the incorporation of value added in the production structure- also fell by the wayside. Poverty reduction efforts are instead based on welfare programmes and subsidies rather than policies for production development, which would result in better jobs and wider social inclusion.

\section{B. More unfinished business: the long-term sustainability of natural resources}

This section will address the microeconomic aspects of natural-resource-based growth. Higher external demand for widely used industrial commodities drives greater exploitation of the country's natural resources (such as oil and gas, pulp and paper, soybeans and soy products). This raises a long list of microeconomic questions concerning environmental sustainability, markets based on shared resources and the origin and nature of technological change in industrial commodities sectors. Can natural-resource-based growth give rise to environmental sustainability, more advanced national technology and wider social inclusion? What new institutions does a natural-resourcebased model need to attain this goal? These questions, raised many years ago within ECLAC by Raúl Prebisch, are now returning to the fore as resource-based industrial commodities have acquired such importance in recent years (Prebisch, 1980).

The experience of the Scandinavian countries, as well as the United States and Canada in the nineteenth century, suggests that such a goal is possible, but requires a co-evolutionary process between the economy, institutions and the environment that is not easy to achieve (Lundvall and Edquist, 1993). This is the crux of the current debate in Latin America. In order to examine this topic in detail, this chapter looks at the Chilean salmon industry during the past two decades as both a success story —rapid growth and convergence of production volumes with leading countries - and a resounding failure, as it was unable to develop collective action (social capital) and national technological capabilities that would have helped avoid the tragedy of the commons suffered in 2008-2009. The main features of this process are shown in figure VIII.5 and in table VIII.1. 
Figure VIII.5

Selected countries: salmon production, 1990-2002

(Thousands of tons)

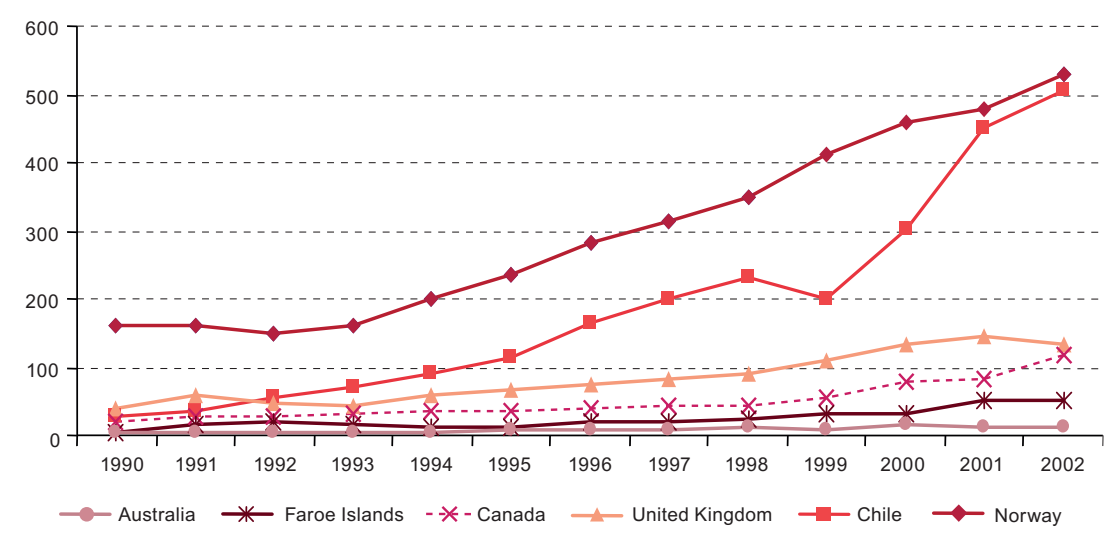

Source: Prepared by the author.

Table VIII. 1

Chile: impact of the tragedy of the commons on salmon farming, 2003-2007

\begin{tabular}{lrrrrr}
\hline & 2003 & 2004 & 2005 & 2006 & 2007 \\
\hline Kilograms of Atlantic salmon & 71856 & 76968 & 82838 & 102015 & \\
\hline Kilograms/smolt & 3.71 & 3.66 & 3.57 & 3.34 & 3.14 \\
\hline Kilograms/egg & 1.30 & 1.28 & 1.25 & 1.17 & 1.10 \\
\hline Average on-site weight & 4444 & 4558 & 4342 & 4219 & 4130 \\
\hline Economic conversion factor & 1.36 & 1.40 & 1.38 & 1.42 & 1.52 \\
\hline Biological conversion factor & 1.24 & 1.27 & 1.28 & 1.30 & 1.34 \\
\hline Harvest length (in days) & 487 & 497 & 484 & 488 & 543 \\
\hline
\end{tabular}

Source: Prepared by the author.

International industrial commodity prices surged during the 2000s (see figure VIII.1). The current fall has led many economists to state that the recent expansionary cycle has concluded, as in previous episodes, but this claim must be treated with caution. ${ }^{2}$

2 The fact that China, thanks to its massive territory and strong growth rate, is the country driving the process raises doubts about whether it will continue. This is the first time in history that a relatively poor country (of 1.5 billion inhabitants and governed by Communist Party bureaucracy) has tried to build capitalist institutions and provide its population with levels of well-being comparable to developed countries. Today, there are dozens of new cities being built, massive migration within the country and an industrial base still growing rapidly because of the enormous potential of the national market. Wages have risen recently, which is difficult to explain in a country with a surplus of people wanting to work in its cities. All of this shows how little is known about China's case and whether (and how fast) it will continue to grow. China is not governed by traditional market rules, which is why it is so difficult to visualize the future of its economy based on a counterfactual market economy analysis. 
Regardless of the truth or otherwise of this statement, at the other end of the production chain through which China voraciously consumes industrial and food commodities are the Latin American countries, which meet Chinese demand by ramping up exploitation of their natural resources. So the questions are: How will this dynamic affect long-term environmental sustainability? How will it affect the national technological capacity needed to meet this demand? What impact will it have on the governance of sectors that are usually based on shared resources and whose exploitation brings significant consequences for the biosphere? And, finally, how does it affect the intergenerational commitment to preserving the value of these resources for future generations?

Intensive natural-resource use means exploiting existing resources more heavily and bringing new areas under production. But increasing production by making more intensive use of natural resources does not necessarily result in greater output of manufactures. Every type of terrain has different ecological factors and forms of social organization associated with the exploitation of its resource, which is why the mainstream microeconomics metaphor of the representative agent does not apply. Each area is a unique case, as the ecology and social organization around natural-resource exploitation are specific to the area and the community, even in regions that are geographically close and have similar environmental characteristics (Ostrom, 2000 and Cardenas, 2009).

Natural resources also have some of the characteristics of a public good, as they are often of shared use, and the conventional market model does not function fully. For example, when two companies farm salmon in the same bay or lake, it is impossible to prevent the horizontal spread of disease, pathogens and marine predators. Something that affects one farm will soon affect any other that shares the body of water. The same occurs with pests in the farming and fruit industries, as well as in related sectors. In market governance models for natural resources, collective action, reciprocity and trust - the social capital expressed in institutions of proactive cooperation - become more important than the mere price signals by which the typical independent producer in the standard market model maximizes individual profits. It is precisely the tension between the two models that has led experts to refer to the tragedy of the commons to describe how individual profit maximization leads to overexploitation of resources and collective failure (see table VIII.1). However, collective failure is not the only possible outcome, as shown by Ostrom, Cardenas and others who demonstrated that, in many cases, the resource users create new forms of collective action, institutions and solidarity mechanisms in an attempt to preserve it. It is often useful to have a legal framework and solid regulations - duly implemented - to support and promote collective action and cooperation mechanisms. 
Overexploitation is not the only concern in the pursuit of naturalresource-based growth. Too little is still known about ecology to fully understand the opportunity costs incurred by increased natural-resource use in relation to biodiversity, soil erosion, desertification, the greenhouse effect, climate change and water resources. Neither the neoclassicists, who address these issues in terms of taxes and externalities, nor the evolutionists, whose metaphors describing microeconomic behaviour are based on the experience of industrial sectors, have made more than limited progress in understanding the complexity of the link between the economy and the environment. More research is needed on what is referred to as the carrying capacity of natural resources found in different geographical areas. It is very difficult to formulate a universal theory, as the institutions and regulations governing the exploitation of natural resources from different regions, countries and cultures are extremely varied. What is sure is that collective action, reciprocity and trust play key roles in the long-term preservation of resources and environmental sustainability. It has been -wronglysuggested that little R\&D is needed for commodity exploitation. In reality, however, long-term environmental and sanitary sustainability requires a vast knowledge of biology, genetics, animal health and the environment, something that has only recently begun to be recognized (Katz, lizuka and Muñoz, 2011).

The environment, genetics and biology have rules that are barely understood. There is a great as yet untapped opportunity to enhance links between business and universities in these fields. The same could be said, for example, about biomining or seawater desalination, which will need to be researched in the coming decades if a natural-resource-based model of growth is still to be pursued.

But the topic does not end there. More intensive exploitation of natural resources raises new questions about the opportunity cost in terms of environmental services and their potential use in production activities, as well as among different sectors of the community, such as indigenous people living in areas with rich oil reserves, forests and coastlines. Thus, questions arise over property rights, the virtual prices of environmental services, royalties and the role of local communities vis-à-vis resource extraction. The co-evolution of industrial development with the support and regulatory institutions tasked with overseeing these issues is extremely fragile in the region, and should be carefully analysed (Iizuka and Katz, 2013). The coevolution between institutions, technological change and the development of a natural-resource-based industrial apparatus base is still virtually unexplored territory among Latin American evolutionary economists. The Nelsonian approach to co-evolution between the production structure and institutions is one route to examining the links between the economy, social organization, the biosphere and ecology. What are the institutions and forms of industrial 
organization in this sector affecting the biosphere and ecology, and in what way? How do they change and evolve as resource extraction proceeds and agricultural, mining and aquaculture frontiers advance?

Natural-resource-based growth should not be seen as a goal that is hostile to industry development. The Scandinavian experience shows how the growth of the primary sector has been accompanied by development of dairy and forestry machinery, agrochemicals, vaccines and fertilizers, and transport and port infrastructure equipment. The old dilemma between the agricultural sector and industry seems to fade when seen from this perspective. However, the institutional and governance frameworks for shared natural-resource-based sectors require an institutional structure and rulebook from outside the industrial sphere; in this respect, much remains to be done.

Nevertheless, it is obvious that market forces are unable to push the production base in this direction. There is too much uncertainty, too many market failures and too little initial capacities and public goods. Links between the consensus and the local reality are too fragile, and understanding of indigenous peoples' issues too limited. All these factors make the market rationale unsuited for treading a path towards something resembling the Scandinavian experience. The State must provide the incentives and establish the institutions to make natural-resource-based development environmentally sustainable and more equitable at the local level. Many public goods are needed throughout the production chains of all the aforementioned sectors. Support is needed for research to develop resources at a rate consistent with an acceptable carrying capacity at the different stages of exploitation. Financial assistance is also required to fund the installation of new production capacities in local SMEs, and legal and logistical support should be provided to open up new international markets. Natural-resource-based growth requires not only implementing governance and regulatory programmes for the producing sectors with different rules to the manufacturing sector, but also adequately providing public goods and supporting institutions throughout the production chain. This goal entails a long-term national strategy that transcends the limits of centralized government and engages the whole community in the decision-making process.

\section{Final thoughts}

It has been argued here that Latin America will have to face new public policy dilemmas at the macro- and microeconomic levels, because of the significance that industrial commodities and food production have acquired within the production structure and exports in recent years. The expansion of the agricultural, mining, aquaculture and fruit-growing frontiers raises new 
concerns about Dutch disease and the tragedy of the commons. Economic policymakers will have to address these conerns - regardless of the absence of much underlying theory-in order to stabilize macroeconomic fundamentals, close the region's technology and productivity gap vis-à-vis the developed countries and achieve environmental sustainability, without losing sight of equity and social inclusion. All of these areas of economic policy are important and must receive due attention. The danger of a partial approach to economic policy is the possibility of high inflation and deterioration of the fiscal accounts if macroeconomic balances are not properly respected; a loss of the ground gained in global markets if production and technological development is neglected; environmental damage if institutional structures and environmental regulations are not followed; and the erosion of democratic governance if growth continues to concentrate wealth in the hands of the richest and a shortage of public goods deepens social exclusion.

The region has positioned itself recently as a major supplier of industrial commodities and foodstuffs to the rapidly growing Asian economies, and this offers great opportunities for the future. But policy strategies thus far have been limited to maintaining short-term macroeconomic stability, and have tended to neglect other areas. The productivity gap, deteriorating environment and clamour for greater equity and social inclusion continue to be largely overlooked amid complacency with the satisfactory performance of macroeconomic aggregates. In other words, Latin America did not make good use of the new opportunities offered by global economic shifts to pursue new routes towards convergence with the international technological frontier, environmental sustainability and fulfilment of the intergenerational compact to preserve the value of natural resources and improve equity and social inclusion. A heterodox - essentially neostructuralist- approach clearly shows the weak fronts that must be addressed in the future.

\section{Bibliography}

Bernat, G., and J. Katz (2013), “Macroeconomic adjustment and structural change: the experience of Argentina, Brazil and Chile in 2000-2010", Journal of Economies and Institutions.

Cárdenas, J.C. (2009), Dilemas de lo colectivo. Instituciones, pobreza y cooperación en el manejo local de los recursos de uso común, Bogota, Centre for Economic Development Studies (CEDE), Universidad de Los Andes.

Ffrench-Davis, R. (2005), Entre el neoliberalismo y el crecimiento con equidad, Santiago, LOM Ediciones.

Frenkel, R., and M. Rapetti (2011), "Fragilidad externa o desindustrialización: cuál es la principal amenaza para América Latina en la próxima década?", Macroeconomía del Desarrollo series, No. 116 (LC/L.3423), Santiago, Economic Commission for Latin America and the Caribbean (ECLAC), November. 
Iizuka, M., and J. Katz (2013), "Globalization, sustainability and the role of institutions", unpublished.

Katz, J., M. Iizuka and S. Muñoz (2011), "Creciendo en base a recursos naturales, 'tragedia de los comunes' y el futuro de la industria salmonera chilena", Desarrollo Productivo series, No. 191 (LC/L.3307-P), Santiago, Economic Commission for Latin America and the Caribbean (ECLAC), April.

Kim, L. (1997), Imitation to Innovation. The Dynamics of Korea's Technological Leadership, Harvard Business School.

Lundvall, B.A., and C. Edquist(1993), "Comparing the Danish and Swedish systems of innovation", National Innovation Systems, A Comparative Analysis, R. Nelson (ed.), Oxford University Press.

Nelson, R. (1994), "The co-evolution of technology, industrial structure and supporting institutions", Industry and Corporate Change, vol. 3, No. 1.

Ostrom, E. (2000), El gobierno de los bienes comunes. La evolución de las instituciones de acción colectiva, Mexico City, Fondo de Cultura Económica (FCE).

Prebisch, R. (1980), "Biosphere and development", CEPAL Review, No. 12 (E/CEPAL/G.1130), Santiago, Economic Commission for Latin America (ECLAC), December.

Rapetti, M. (2011), "Macroeconomic policy coordination in a competitive real exchange rate strategy for development", Working Paper, No, 2011-09, Amherst, University of Massachusetts. 



\section{Chapter IX \\ Development patterns and welfare States in Latin America}

Luis Bértola

\section{Introduction}

This chapter focuses on the relationship between patterns of development in Latin American economies, especially those that have based it on abundant natural resources, and welfare States. It attempts to delineate the specific challenges facing modern economic development in the region, particularly the way in which social demands have been emerging in a context of increasing democratic gains, interacting with production structures that differ greatly from those underpinning welfare States in what are now the developed economies.

First, the chapter looks at "modern" economic development and its relationship with natural resources, seeking to shed light on how the availability of the latter has repeatedly placed constraints on development and how modern society has gone about removing these. The aim is to place the current debate on the environmental limits to growth in a historical perspective.

The interdependence between different regions is also analysed, with special emphasis on the importance of international heterogeneities and their implications for development. The idea is to demonstrate how the existence of large international asymmetries imposes specific demands on 
the development of less advanced regions, which must not only remedy the causes of their relative lack of progress, but do so in a climate of fierce competition with more advanced countries.

Lastly, the chapter examines the demands for well-being that have emerged from the development process and the way the concepts of welfare State and production structure are interwoven, focusing on the challenges this presents for economies that have very heterogeneous and volatile production structures with sizeable informal sectors. A specific conceptualization effort is urgently needed for Latin American countries, as is a creative approach to meeting simultaneously the huge challenges of growth and convergence, economic stability, the development of the welfare State and the exploitation of natural resources without endangering environmental sustainability.

\section{A. Economic growth and natural resources: a long-term perspective}

What is known as "modern" economic growth has represented a giant leap forward in rates of development. Over some 300 years and 15 generations, the dynamic created has been such that each successive generation has produced changes probably surpassing the cumulative advances of any previous millennium, if not the entire history of humanity.

In the nineteenth century, it was still extremely difficult to incorporate the magnitude of the changes that were taking place (and were to go further still) into theoretical approaches and ideological outlooks. Many of the social and economic theories debated took account of the major constraints on economic growth. The idea of reaching a final stage, a stationary state in the economic process, was constantly present as a persistent conception of the end of history. Thus, although David Ricardo and Robert Malthus, for example, clashed over methodology, the dominant concern of both was with the concepts of scarcity and the limits to growth. Malthus saw the scarcity of resources as explaining the recurrent emergence of positive checks that would restore equilibrium by reducing the size of the population to a level compatible with the natural resources available. Similarly, Ricardo saw the scarcity of natural resources and appropriation of the rent from them by social classes that did not generate capital accumulation as leading to a stationary state that could be avoided or delayed by combating the appropriation of rents by these sectors. Even neoclassical theory, which still dominates present-day economics, is based on a firm conception of resource scarcity and has not contributed greatly to an understanding of the dynamics of technological change.

Notwithstanding, the supply of resources has only increased as agrarian revolutions have given way to the expansion of capitalist relations 
in the countryside, the Industrial Revolution and successive revolutions in technology and transport. As the world population rose from 438 million in 1500 to 6.7 billion in 2008 and per capita income increased similarly, total economic output multiplied 205-fold.

It is difficult to overstate the significance of these achievements. Unquestionably, many of the needs that had to be met during these centuries were satisfied by expanding what may be termed "the frontier", i.e., by extracting resources or producing new renewable resources through an increase in the surface area worked. Yet there cannot be the slightest doubt either that a very large proportion of this growth was explained by humanity's immense ability to learn, innovate and develop scientifically and technologically so as to overcome challenges as they arose. Even expanding the frontier and making new regions economically viable were premised on technological change and innovation.

In the case of food production in particular, the agricultural sector has always managed to cope with the demands made on it. While the world population has multiplied almost sevenfold in the last 200 years, food production has increased more than tenfold. That millions still suffer from undernutrition is due not to a lack of food but to its poor distribution, as well as to faulty income distribution and various types of armed conflict. It might even be said that there is currently overproduction of food (Federico, 2005). All this has been achieved with a farming population that has been in constant relative decline, dropping from $75 \%$ of the world population in 1950 to $54 \%$ in 1993 and 48\% in 2011. According to World Bank figures, total food production increased by 59\% between 1993 and 2011, outstripping world population growth (26\%).

This revolution and the urge for growth in recent centuries undoubtedly had and are still having a great many perverse and destructive consequences. Even as the frontier expanded, the subsoil was explored and exploited, growth became intensive, non-renewable resources were consumed without restraint, the atmosphere was polluted and land was degraded. The agrarian population was forced to move to cities where the prospects of work were not always better, or to territories less suited to farming. Thus, not only were resources destroyed and made unavailable to future generations, but there have been alterations and transformations of the biosphere that will be very difficult to reverse. Populations became marginalized and vulnerable, and the effects will be felt for many generations to come, since these environmental impacts differ greatly not only from one country to the next, but between different social strata within countries, with the poorest in society usually worst affected. This is a pattern, then, that will not be sustainable in the future if current levels of development are to be maintained and, above all, if the most disadvantaged regions are to attain the same levels of well-being as those currently best situated. 
It would be unfair, however, to evaluate the legacy those 15 generations have left to posterity solely in terms of these problems, since they also bequeathed a huge wealth of knowledge that can be used to meet future development challenges. There are grounds for believing that human capabilities can again overcome obstacles once thought insurmountable.

\section{B. The unequal and interdependent growth of the centre and periphery}

Almost all the world's regions and societies have benefited from this growth, but they have done so in very different ways. They have also contributed to it in varying degrees and suffered from the excesses and misdirection of development. Moreover, far from merely existing in parallel, these differing levels of performance have formed a systemic, unequal whole with asymmetrical impacts.

Latin America has shown a very clear tendency to diverge from the per capita gross domestic product (GDP) levels of the developed world. The volatile, strongly cyclical nature of Latin American growth sometimes dilutes this tendency, but in the long run it is very clear-cut. The region's current catch-up cycle mirrors similar movements at other points in history.

Much discussion has focused on whether the growth of the centre has been possible thanks to its access to the periphery's resources, and whether the centre's demand for resources inhibited, promoted or conditioned the development of the periphery. Indeed, there has been controversy about whether its development was achieved at the expense of the periphery's.

The answer is complex, but it may be said that, as in so many other areas, impacts have been asymmetrical. Bairoch (1975) maintained that raw material imports from the periphery had not been critical to the Industrial Revolution; they undoubtedly contributed to it, or increased its potential, but it was not really because of them that the process began and advanced. Conversely, though, the development of the centre was decisive for the periphery, and the dynamics of the central countries firmly set the pattern for the performance of peripheral economies, whence the concept of "dependency" in its manifold forms, some more marked than others.

Even the best-established dependency theories, along the lines of Gunder Frank's, have not withstood historical changes or the passage of time. It is not true that accumulation at the centre has given rise to persistent disaccumulation at the periphery. Most countries have experienced a development process which, while not comparable with that of the centre, has been far from deficient. This holds true for Latin America, and even more so for China, India and other countries that have achieved rapid economic growth and 
improvements in education and life expectancy at birth. Moreover, some of the assumptions on which these theories are based have proven wholly unsound. For example, it has been demonstrated that breaking with capitalism and embarking on socialist transformations is not a path to economic and social development, nor has it led to the creation of more democratic societies.

It can be shown, though, that there is a universal trend in economic development: rising physical capital investment relative to the use of natural resources. Physical capital, in turn, has been accompanied by an increasing accumulation of human capital and organizational, social and institutional knowledge. The World Bank has tried to group these components using the concepts of natural capital (i.e., the availability of natural resources), physical capital (machinery, buildings and infrastructure) and intangible capital, which refers to different forms of knowledge and social innovations. The capital structure is not neutral throughout the development process, as there is increasing investment in machinery and equipment that brings with it greater levels of technological knowledge and in turn generates greater economies of scale, a key component of productivity gains. Intangible capital consists in the various kinds of learning that strengthen technological change, reinforce institutional and organizational capacities and lay the foundations of international competitiveness. The countries with the highest per capita income levels are those that have moved fastest to change the capital structure, firstly by boosting physical capital relative to natural capital, and subsequently by increasing intangible capital relative to the other two types (see figure IX.1). Table IX.1 presents this structure by region, highlighting the fragility of development in Latin America, which is lagged only by Africa on this measure.

Figure IX.1

Total wealth and types of wealth per capita, seven regions, 2005 (Dollars)

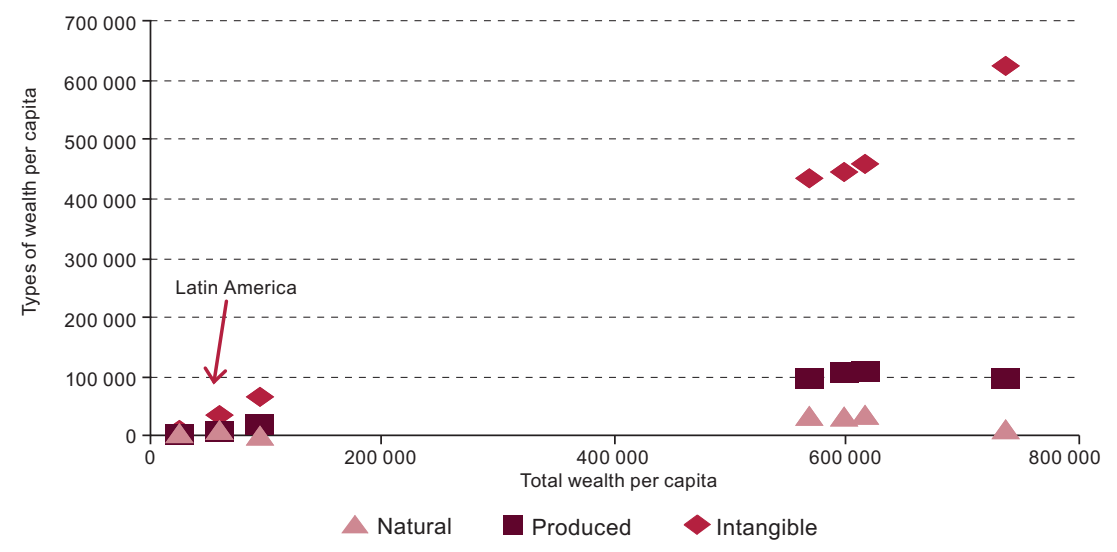

Source: Prepared by the author on the basis of World Bank data for 2012. 
Table IX.1

Structure of per capita wealth, by region, 2005

(Dollars and percentages)

\begin{tabular}{|c|c|c|c|c|c|c|}
\hline & $\begin{array}{l}\text { Total } \\
\text { wealth }\end{array}$ & $\begin{array}{l}\text { Total } \\
\text { wealth }\end{array}$ & $\begin{array}{l}\text { Intangible } \\
\text { capital }\end{array}$ & $\begin{array}{c}\text { Net } \\
\text { external } \\
\text { assets }\end{array}$ & $\begin{array}{l}\text { Produced } \\
\text { capital }\end{array}$ & $\begin{array}{l}\text { Natural } \\
\text { capital }\end{array}$ \\
\hline Selected African countries ${ }^{a}$ & 23324 & 100 & 54 & -2 & 17 & 31 \\
\hline $\begin{array}{l}\text { Latin America and } \\
\text { the Caribbean }\end{array}$ & 57809 & 100 & 65 & -3 & 16 & 22 \\
\hline $\begin{array}{l}\text { China, India and Republic } \\
\text { of Korea }\end{array}$ & 92651 & 100 & 74 & -1 & 24 & 3 \\
\hline $\begin{array}{l}\text { Greece, Italy, Portugal } \\
\text { and Spain }\end{array}$ & 595210 & 100 & 75 & 0 & 18 & 6 \\
\hline $\begin{array}{l}\text { Australia, Canada and } \\
\text { New Zealand }\end{array}$ & 565255 & 100 & 77 & -1 & 18 & 6 \\
\hline $\begin{array}{l}\text { Denmark, Finland, Norway } \\
\text { and Sweden }\end{array}$ & 613205 & 100 & 75 & 0 & 18 & 6 \\
\hline \multirow[t]{2}{*}{ United States } & 734195 & 100 & 85 & -1 & 14 & 2 \\
\hline & $\begin{array}{l}\text { Tangible } \\
\text { wealth }\end{array}$ & $\begin{array}{l}\text { Tangible } \\
\text { wealth }\end{array}$ & & & & \\
\hline Selected African countries ${ }^{a}$ & 10830 & 100 & & -4 & 37 & 66 \\
\hline $\begin{array}{l}\text { Latin America and } \\
\text { the Caribbean }\end{array}$ & 20278 & 100 & & -8 & 46 & 62 \\
\hline $\begin{array}{l}\text { China, India and Republic } \\
\text { of Korea }\end{array}$ & 24306 & 100 & & -4 & 91 & 13 \\
\hline $\begin{array}{l}\text { Greece, Italy, Portugal } \\
\text { and Spain }\end{array}$ & 147137 & 100 & & 1 & 75 & 24 \\
\hline $\begin{array}{l}\text { Australia, Canada and } \\
\text { New Zealand }\end{array}$ & 127826 & 100 & & -6 & 77 & 29 \\
\hline $\begin{array}{l}\text { Denmark, Finland, Norway } \\
\text { and Sweden }\end{array}$ & 151466 & 100 & & 1 & 74 & 25 \\
\hline United States & 106949 & 100 & & -6 & 94 & 13 \\
\hline
\end{tabular}

Source: Prepared by the author on the basis of World Bank data for 2012.

a Congo, Côte d'Ivoire, Democratic Republic of the Congo, Kenya, Nigeria, Senegal, South Africa, Zambia and Zimbabwe.

One way of looking at these structures is to consider education, where Latin America presents a contradictory situation. While the substantial efforts made have yielded significant improvements in the average level of education, international comparisons suggest that more needs to be accomplished in this area. Time spent in the education system in Latin America rose from an average of 1.5 years at the turn of the twentieth century to 7.1 years at its close. Meanwhile, the combined average for France, Germany, the United States and the United Kingdom was 12.5 years (Bértola, Hernández and Siniscalchi, 2011).

One very important peculiarity of Latin America's development pattern is that education levels are lower than in other regions relative to each level of per capita income. In other words, the region's educational performance is worse, but it seems to achieve a better economic performance with less 
schooling. The main ideas that have been put forward to explain this concern social structures and power relations.

\section{Figure IX.2}

Latin America and the "West": per capita GDP at purchasing power parity and average years of education of the population aged 15 and above, 1870-1930

(Years and 1990 dollars)

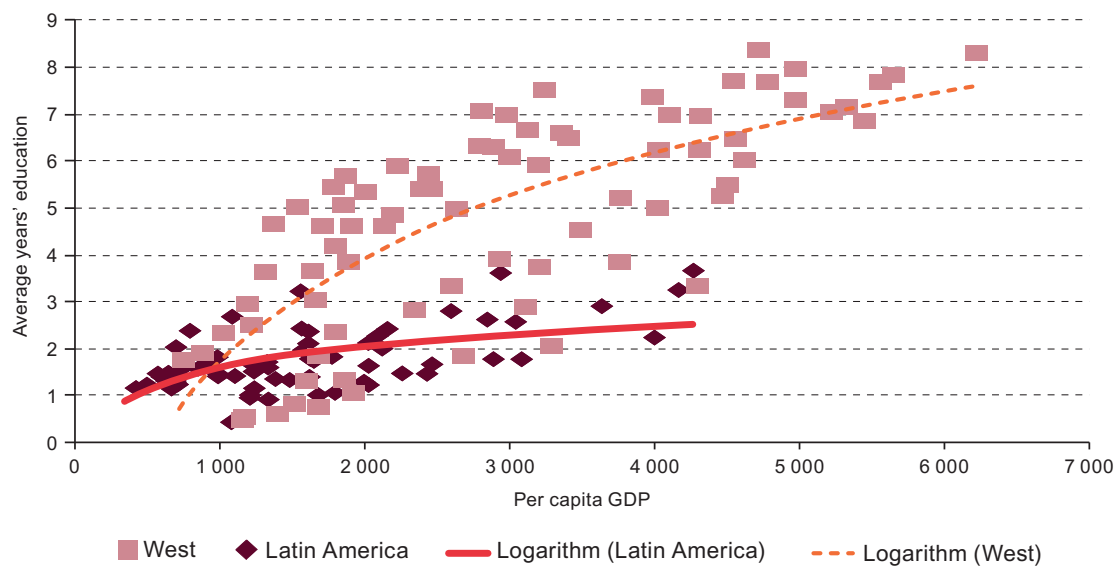

Source: Prepared by the author on the basis of L. Bértola, M. Hernández and S. Siniscalchi, "Un índice histórico de desarrollo humano de América Latina y algunos países de otras regiones: metodología, fuentes y bases de datos", Documentos de Trabajo, No. 28, Montevideo, Faculty of Social Sciences, University of the Republic, 2012.

A large number of approaches have highlighted social structures as an explanation for why Latin America's educational levels are lower than those of other regions relative to income. Yet there is another, complementary interpretation of how a population might be able to produce more than would be expected from its level of human capital: the dominance of natural resources in production. Latin America's traditional reliance on exports of commodities, which have relatively low value added but are able to generate economic rents, is thought to be the main reason for the region's high per capita income relative to its endowment of human capital as measured by education.

This characteristic was an important starting point in the development of many countries, such as the United States itself, the Scandinavian countries and Australasia. However, considering the above-mentioned studies, it is reasonable to conclude that natural resources may also become a factor inhibiting change if those controlling them also wield political power and if the production pattern is geared towards extracting rents from natural resources rather than building innovation capacity based on the development of human capital and structural change in the production sector. 
There is no straightforward causal relationship between natural resource endowments and education. The link between the two will always be influenced by the predominant economic and political power relationships in a given society. For example, the more southerly countries of South America, while having a generous natural resource endowment relative to the size of their populations, succeeded in attracting immigrants and attaining higher wage and social expenditure levels than other regions where the per capita natural resource endowment was not as great. Countries that are rich in natural resources but where ownership is highly concentrated and large sectors of the population are uneducated and have little political power (owing, in part, to racial and cultural discrimination), may lag even further behind in terms of education (Bértola and Ocampo, 2012). In short, the resource curse is not something inevitable in countries where resources are abundant; what makes all the difference are the economic, social and political structures constructed while they are being appropriated and exploited.

\section{Development and welfare States}

Welfare States emerged from a process of drastic structural change, characterized first by industrialization and subsequently by the expansion of services. Radical transformations during that process included changes in the geographical distribution of the population, family structures, the division of labour within households, the distribution of time devoted to leisure, education and work, and the structure and patterns of consumption. Another consequence was a radical alteration in the structure of risks, forcing societies to organize coverage for them.

These changes occurred on a global scale. It is very important to realize that welfare States were not just constructed in response to domestic phenomena in various societies, but began to be developed during the "first globalization" in the midst of major structural change and a great reallocation of resources between different parts of the planet. The Bismarck model, as well as confronting the threats from working class and communist movements, was created in response to the need to retain skilled labour that would otherwise emigrate to the United States or other settler countries. Welfare States also sought to provide guarantees for workers at a time of high job insecurity when a fast-changing economy was undergoing large fluctuations. These trends were apparent in emigration countries such as Germany and those of Scandinavia, but also in immigration countries that included Australia, Canada and even Latin American countries such as Uruguay. The importance of the international dimension should therefore be reiterated (Huberman, 2012; Lloyd, 2013). 
However, it was not until after the Second World War that welfare States developed fully in the more advanced countries. Esping-Andersen's now classic studies on the topic are required reading. His primary classification of three worlds of "welfare capitalism" (Esping-Andersen, 1990) and his extension, review and discussion of further "varieties of welfare capitalism" (Esping-Andersen, 1999) merit detailed examination.

The three worlds of welfare capitalism (liberal, corporatist and social democratic) differ in the way they go about covering similar risks, with different configurations of the market-family-State triad. The role of the market in covering risks is among the key variables for analysis purposes. Liberal welfare capitalism assigns a marginal role to the State, with assistance provided in extreme cases to an extremely vulnerable population that is unable to fend for itself and that is socially marginalized yet further by its very dependence on those services. Under this system, most individuals and families use their own income to obtain the health and pension coverage they need in the market. Conversely, the other two models try to deal with these risks through collective social solutions provided by the State. In corporatist welfare systems as developed in the post-war world during the golden age of capitalism, risks are covered in the context of a labour market that is highly segmented into different economic sectors, with specific forms of organization and highly differentiated risk coverage access and quality levels. On the basis of a Fordist economy, each occupational group has a specific, differentiated form of organization. Benefits go to family units with an assumed structure in which there is a typically male household head who is the breadwinner, with women largely in the home, where they play the central role. The third model, social democratic welfare, is based on extensive universal coverage by the State, accessed regardless of each individual's position in the labour market, with much higher-quality provision than the marginal liberal capitalist welfare system. The social democratic system entails a heavy tax burden, made possible by the large-scale participation of women in the labour market and the different public services provided as part of this labour market structure.

The development of these welfare States has thus had both common and differentiated features. The dynamics that have shaped and differentiated the various models need to be explained, for while the process has some common characteristics, it is important to spell out the differences. Common determinants cannot easily be found for the various approaches. A number of elements have been suggested: the characteristics of campesino movements, the impact of different religions, the various forms of organization of workers' movements and political parties, the varying routes taken towards the creation of modern States because of the differing avenues followed by the bourgeois revolution, different forms of participation in the world economy and the size of countries, among other things. 
Understanding the genesis of these welfare States is critically important since, contrary to what many have claimed in a context of globalization, economies and societies did not advance towards a single pattern of social organization. Rather, the different varieties of capitalism continued to influence the various responses to the crisis of welfare States and their subsequent development.

Esping-Andersen (1999) makes certain claims that merit in-depth examination. One questionable conclusion of his is that, while the crises of the welfare models prevailing until the 1980s were due to their internal problems, the causes of the crisis that has been taking place since the 1980s and 1990s are exogenous, namely globalization (which affects the scope for applying independent monetary and fiscal policies and requires more flexible labour markets) and demographic changes, including both shifts in the structure and stability of families and population ageing, that have shifted the risk structure (Esping-Andersen, 1999, p. 3).

Esping-Andersen also argues that the different forms of welfare capitalism are faced with the great dilemma of having to choose between societies with full employment but growing economic inequality between skilled and unskilled workers, and societies with high unemployment. Interestingly, he claims that this pressure is due not so much to globalization and the rise of developing countries producing industrial goods with much lower labour costs, but mainly to the effects of an orientation of endogenous technological change in developed countries that has tended to reduce the demand for unskilled workers so that they rely instead on their ability to create skilled employment, especially in the service sector.

Esping-Andersen thus seeks to avoid the apparent contradiction between globalization and welfare States, since the very origin of the latter, particularly in small, economically open countries, lies in the need to give stability to populations and economies that are heavily exposed to the vagaries of the international markets.

These two sets of claims seem to be rather contradictory, perhaps because of certain conceptual aspects that are fundamental to this study. It is clear that Esping-Andersen firmly believes welfare States to be tied to a specific production structure possessing particular levels of productivity and undergoing major technological changes. However, it would seem that the characterization of his worlds of welfare capitalism gradually became so detailed and all-absorbing that it gradually turned into a hermetic discussion that lost sight of the link between welfare models and the underpinnings of the production structure. This could have serious implications for analysis.

According to Esping-Andersen (1999, p. 3), "the contemporary crisis differs notably from its forebears. Until now, the crisis was invariably 
endogenous to the welfare State -it was doing things badly or bringing about unwelcome consequences. The present crisis is, in contrast, essentially a manifestation of exogenous shocks that put into question the longerterm viability of the welfare State. The new global economy (...) undercuts polities' discretionary use of fiscal and monetary policy, necessitates greater employment and wage flexibility, and especially the less skilled will be condemned to unemployment unless wages and social benefits are reduced. The ageing of populations means that our commitments to social security must be rethought. Family instability implies (...) that households' traditional caring capacities are eroding and (...) that poverty risks are mounting. (...) such exogenous shocks combine to create painful policy dilemmas (...)." Further on in the same paper, the author adds that "the 'real' crisis of contemporary welfare regimes lies in the disjuncture between the existing institutional construction and exogenous change" (Esping-Andersen, 1999).

Esping-Andersen correctly points out that the inter-war period, with its tendencies towards autarchy and nationalism, was exceptional in the history of the past 150 years. The fact is that welfare models were constructed on the basis of the economic and social determinants of the period. Perhaps most importantly, though, just as the origins of welfare models date back to the first globalization, in Huberman's analysis, the creation of welfare States was part of countries' responses to the collapse of the gold standard and the crisis of the first globalization. Therefore, treating globalization as an external shock to welfare models offers a way of detaching welfare States, as it were, from their productive environment. Globalization provided a way out of a crisis in developed economies, whose welfare models were just one component of their complex economic and social architecture. Globalization is a response to the crisis of Fordism, of which welfare States were a clearly integrated, albeit not wholly functional, part.

Esping-Andersen's second claim is also open to debate. His argument that endogenous technological change is a dynamic force that creates unemployment, especially among the low-skilled, is highly persuasive and valid. Yet, after another 15 years of Asian development, it is now safe to say that industrial mass production in Asia has presented European and North American markets with a greater threat than Esping-Andersen imagined. Among other factors, he did not consider the way Asia has replaced Europe and the United States in some major categories of exports to third markets, to the detriment of export growth and job creation in the most developed countries. Moreover, such offshoring was already under way long before the crisis of the 1980s and 1990s. Scandinavia itself would suffer the consequences, for example, of Asian competition for Swedish shipyards, as studied by Bohlin (1989).

Likewise debatable is the claim that demographic shifts, such as changing household characteristics and population ageing, are unrelated 
to the dynamics of the welfare State; this conclusion can only be reached if they are disassociated from their social and productive environment. Family structures are closely linked to risk structures and labour market opportunities, and also depend on the services provided by society to deal with risk. Obviously, life expectancy at birth is closely associated with economic growth, and the latter with production dynamics. In short, certain aspects of modern economic development - which involve the welfare State and generate changes of their own-can hardly be considered exogenous.

Although not specifically focused on the study of the welfare State, regulationist approaches provide a more comprehensive and fruitful conceptual framework whereby welfare States and recurrent patterns in the reproduction of the different social sectors are articulated with a broader system of accumulation encompassing the technical and social division of labour, the temporal dimension of the different forms of capital accumulation, regularities in the reproduction of the different demand components and patterns of participation in the international economy.

Regulationists, working with the concept of social systems of production as discussed by Hall and Soskice (2001), are as reluctant as Esping-Andersen to believe in a tendency for all modern societies to equalize and converge on a single pattern of social organization. Esping-Andersen argues that the different welfare variants retain their most basic constituent features visà-vis external shocks. Regulation-based approaches, meanwhile, contend that the inertia and path dependence characterizing complex structural and institutional systems leave no place for the idea of a one-size-fits-all capitalism.

Approaches of this kind, according to which different development patterns exist and persist, are complemented by the varieties of capitalism approach (Hall and Soskice, 2001), a set of theoretical frameworks designed for the study of developed countries. While this does not detract from their validity, as will be seen, a great deal of adaptation is required before they can be applied to the Latin American reality.

The varieties of capitalism approach focuses on the fundamental role of business in the competitive process, technological change and social construction. Following Hall and Soskice (2001), five elements will be examined:

(i) Industrial relations are the context for bargaining over wages and working conditions, which are linked to and affect productivity.

(ii) Vocational training and education determine the competitiveness of firms.

(iii) Corporate governance is a complex web of relationships between shareholders, management, family businesses, diversified business groups, vertically integrated business groups, etc. 
(iv) Inter-firm relations are a core component of dealings with customers and suppliers, determining levels of productivity, efficiency and competitiveness.

(v) The coordination of firms' own employees is a central element in cooperative strategies and information-sharing.

Through the study of these five components, two types of capitalism are stylized: liberal market economies and coordinated market economies. The analysis sets out from the concepts of institutions and organizations developed by North (1990), which highlight the importance of the tacit, informal institutions, strongly influenced by the cultural environment, that determine the behaviour of agents.

The fabric of institutions and organizations forms the basis for the development of a matrix of institutional infrastructure that determines corporate strategy. This is not constructed on the basis of market competition and hierarchy within companies alone, as great store is set by the components of cooperation and trust. Institutions, meanwhile, are not the result of selection by individual companies, but constitute a second-order coordination problem of considerable magnitude: "the firms located within any political economy face a set of coordinating institutions whose nature is not fully under their control" (Hall and Soskice, 2001, p. 15). Therefore, a kind of institutional clustering occurs in which different institutions strengthen and condition one another. This means that there are differences even between coordinated market economies, examples being those distinguishing complex Japanese groups, with their great sectoral diversity, from the German model, with its strong sectoral structuring and vertical integration.

Following this approach yields conclusions similar to those of the regulation school in respect of the limits of globalization as a unifier of development models. Countries are distinguished by their particular patterns of development based on institutional comparative advantages. While countries globalize and join larger political units such as the European Union, they do so on the condition that their competitive model, based on their institutional matrix, is not called into question. This does not mean that institutional matrices do not change and evolve. The fact is, though, that countries would hardly destroy the institutional foundations of their competitiveness to join internationalization processes.

A central concept of the varieties of capitalism approach is that there is a very direct correlation between the types of political economy developed and the types of welfare State constructed. This aspect was mentioned earlier in the criticism of Esping-Andersen, and is clearly dealt with by the varieties of capitalism approach. Welfare States form part of the matrix of institutional competitive advantage, and reflect the attitude of key actors in that process. 
The welfare State is not an autonomous set of institutional arrangements but is bound up with the general economic and social environment. The question that is repeatedly asked is whether welfare States were a manifestation of a very particular period of global economic development, dominated by Keynesian strategies in a context of relatively autonomous nation States, or whether they reflect political and social ideals that may be implemented in any era, if that is what citizens prefer. According to Lloyd, the outlook is uncertain. Two negative scenarios for welfare States can be set out: either most existing institutions for the provision of public goods are replaced by a market logic that would be administered by specialists subject to certain regulations and in a position of dependency vis-à-vis capitalist interests, or trust in State institutions declines markedly, to the point where the State withdraws from these functions, relinquishing them to private interests. Alternatively, the possible renaissance of welfare States may draw support from the opportunities presented by the knowledge society, the prevalence of sociobiological impulses towards cooperation and solidarity, the construction of a transnational democracy, progress in economic development and the consolidation of social demands with the presence of new emerging sectors at the global level (Lloyd, 2013).

One possible conclusion is that welfare States cannot be understood outside of a broader context of economic and social determinants. Their future does not seem to be an inevitable outcome of modern economic development, but is open and uncertain, dependent both on economic determinants and on the values developed and choices made by different societies and the global community. Consequently, when discussing the future of welfare States in Latin America, we cannot assume that their development is part of an irreversible universal trend.

\section{Development and the welfare State in Latin America}

As has been extensively discussed, the Latin American production structure still has very specific characteristics. The region's economies are characterized by limited industrial development and early deindustrialization relative to per capita GDP, while primary exports account for a disproportionate share of the total and the import structure is dominated above all by hightechnology goods, for which Latin America presents a clear deficit. In the long term, this has meant a tendency towards trade deficits that have acted as a brake on growth, since as incomes rise, so too does consumption of higher-technology goods. Technological change occurs faster when demand is expanding, while demand itself expands when radical technological changes alter consumption patterns. Rates of export growth are of little 
consequence, since the relevant issue is the rate at which imports increase as a result of income growth.

This trend has not been linear in Latin America. As has now been convincingly shown, it has a strong cyclical component that is linked to a great many factors, such as financial volatility, technology creation and destruction, the political vagaries of the international economy, the recurrent emergence of new growth centres, and the depletion and discovery of natural resources. Thus, Europe's industrialization and the first globalization gave rise to a long, fluctuating cycle of rising terms of trade and growing demand for commodities produced by Latin America, which raised the income elasticity of demand for exports and imports, allowing Latin America to embark on a catching-up process. The inter-war slowdown in global growth forced Latin America to reformulate its role in the world economy and attempt to step up its inward-directed development by radically altering its production structure. The region was thus able to significantly diversify its capabilities, without substantially closing the gap with the leading countries. Unevenly, some countries appropriated mature technologies and managed to narrow the gap in certain strategic industries, but only very rarely did the region manage to construct and develop productive development models that placed it at the forefront of technological change.

Latin America has thus fallen behind over successive waves of technological advances, especially since the 1980s when, broadly speaking, the choice was made to pursue an international trade strategy that once again relied on the exploitation of static comparative advantages. The dynamic of recent decades has again been heavily dominated by large cyclical fluctuations. The current expansionary cycle, fuelled by rising Asian demand for commodities and extremely low interest rates in the developed world, has led to a large influx of capital being directed towards Latin America by investors willing to accept relatively low rates of return, often made possible by the international commodity price situation.

While the future is uncertain and it is not easy to predict how long the expansionary phase will last, it seems clear that for the most part this is not leading to any far-reaching transformation of production structures that would reverse Latin America's particular form of participation in the world economy. Given this, it is essential to accurately diagnose the characteristics of the current production structure and thus understand the region's variety of capitalism, the threats and challenges to it, the predominant types of political economy and the forms that welfare States and social policies might take on. Such a diagnosis seems essential to the task of formulating and developing the matrix of institutional comparative advantages and identifying the key actors in the process. 
Setting aside some large differences that will be discussed later, a cursory analysis of the five core components of the varieties of capitalism in Latin America's organizational and institutional complex indicates the following:

(i) Industrial relations are the context for bargaining over wages and working conditions, and influence productivity. The Latin American production system is notable for its high level of informality, with great structural heterogeneity, large sectors that are not included in systems of wage bargaining, and wages that represent a smaller share of effective demand and the domestic market than in developed countries, since the bulk of exports rely on raw material access advantages and incorporate little value added. There are more formal sectors with different patterns of wage bargaining and productivity, but because productivity gains are often exogenous to firms, being linked to foreign investment or incorporated into capital goods, pay bargaining commonly bears no strict relation to changes in endogenous productivity in the production process.

(ii) Vocational training and education determine the competitiveness of enterprises. Limited demand for highly skilled labour has meant that Latin American education systems have become very disconnected from production systems and, as has been shown, evince comparatively low standards. From another point of view, it may be said that per capita GDP is higher than would be expected from the region's education levels.

(iii) Corporate governance is a complex web of relationships between shareholders, management, family businesses, diversified business groups, vertically integrated business groups and others. Corporate governance in Latin America is severely tested by the structural heterogeneity already referred to. Large companies involved in exporting have more sophisticated structures and in most cases some foreign ownership, like the majority of large companies providing modern services. In some countries, State production has survived the market reforms of the 1980s and 1990s, with some major hubs of accumulation integrated into the production fabric. This is numerically dominated by small and medium-sized enterprises with very little capacity to generate innovation and much lower than average productivity.

(iv) Inter-firm relations are a core component of dealings with customers and suppliers, determining levels of productivity, efficiency and competitiveness. With the exception of some State 
enterprises and home-grown hubs, the production structure is simple, shallow and disjointed, with the most dynamic hubs being subordinated to international value chains. The great mass of small and medium-sized enterprises remain very much cut off from dynamic interaction with the rest of the country's production system.

(v) Lastly, the coordination of firms' own employees is a central element in cooperative strategies and information-sharing. In this regard, large international companies transfer the practices they have developed in their home countries and large State firms have dynamics of their own that are relatively unknown and little studied. In any case, it seems to be very difficult to codify these practices in Latin America.

All these aspects are contained in two key features of the institutional and organizational configuration of the Latin American economy: its structural heterogeneity and the characteristics of its capital.

It could be argued that the competitive foundations of a society depend on the predominant type of capital, which in turn determines pathways of technological change and social organization. This chapter has already analysed how important natural capital continues to be for Latin America and how underdeveloped so-called intangible capital still is.

Everything confirms that Latin America's production structure is more heterogeneous than any other region's. Table IX.2 shows that Latin America's Gini score for inequality of GDP per worker across major sectors is more than double that of most other regions. The table also shows that Latin America's heterogeneity is highly volatile. It is the region that presents most variations in the heterogeneity of output per worker, taking the term to mean the way productivity is affected by radical changes in economic activity levels and by the GDP volatility already referred to, which in turn is linked to the volatility of demand and the prices of the main export goods. In other words, if productivity parameters were compared using different base years, the results would clearly fluctuate, but this would chiefly reflect the impact of prices and not sectoral technological dynamics and changes.

It could be argued that Latin America's great heterogeneity is mainly due to differences between the countries in the grouping. Actually, as table IX.3 shows, it is firmly rooted in the domestic structures of each. Practically none of them, even the least unequal, scores as well as other world regions. 
Table IX.2

Selected country groupings: the heterogeneity of structural productivity

(Gini scores)

\begin{tabular}{|c|c|c|c|c|c|c|}
\hline Grouping & & 1991 & 1996 & 2001 & 2006 & Average \\
\hline 1. Latin America ${ }^{a}$ & 1 & 0.455 & 0.406 & 0.478 & 0.448 & 0.447 \\
\hline 2. Core Europe ${ }^{b}$ & 2 & 0.168 & 0.191 & 0.158 & 0.180 & 0.174 \\
\hline 3. Asia ${ }^{c}$ & 3 & 0.318 & 0.314 & 0.332 & 0.281 & 0.311 \\
\hline 4. Scandinavia ${ }^{d}$ & 4 & 0.198 & 0.220 & 0.234 & 0.259 & 0.228 \\
\hline 5. Latin European peripherals ${ }^{e}$ & 5 & 0.229 & 0.218 & 0.217 & 0.209 & 0.218 \\
\hline 6. Settler ${ }^{f}$ & 6 & 0.269 & 0.278 & 0.286 & 0.286 & 0.280 \\
\hline 7. United States & 7 & 0.211 & 0.211 & 0.221 & 0.233 & 0.219 \\
\hline 8. All Europe & 8 & 0.188 & 0.208 & 0.188 & 0.203 & 0.197 \\
\hline Grouping & \multicolumn{6}{|c|}{ Percentage point changes } \\
\hline 1. Latin America ${ }^{a}$ & -4.8 & 7.1 & -3.0 & & & \\
\hline 2. Core Europe ${ }^{b}$ & 2.3 & -3.3 & 2.2 & & & \\
\hline 3. Asia ${ }^{c}$ & -0.4 & 1.8 & -5.1 & & & \\
\hline 4. Scandinavia ${ }^{d}$ & 2.2 & 1.4 & 2.5 & & & \\
\hline 5. Latin European peripherals ${ }^{e}$ & -1.1 & -0.1 & -0.8 & & & \\
\hline 6. Settler ${ }^{\mathrm{f}}$ & 0.9 & 0.8 & 0.0 & & & \\
\hline 7. United States & 0.0 & 1.0 & 1.2 & & & \\
\hline 8. All Europe & 2.0 & -2.0 & 1.5 & & & \\
\hline
\end{tabular}

Source: L. Bértola, "Informe de proyecto", Santiago, Economic Commission for Latin America and the Caribbean (ECLAC), 2012, unpublished.

a Argentina, Bolivarian Republic of Venezuela, Brazil, Chile, Colombia, Costa Rica, Ecuador, Mexico, Peru and Uruguay.

b Belgium, France, Germany, Netherlands, Switzerland and United Kingdom.

c Japan and Republic of Korea.

d Denmark, Finland, Norway and Sweden.

e Italy, Portugal and Spain.

Australia, Canada and New Zealand.

Table IX.3

Latin America (10 countries): the heterogeneity of labour productivity in major sectors, 1991-2006

(Gini scores)

\begin{tabular}{lccccc}
\hline & 1991 & 1996 & 2001 & 2006 & Average \\
\hline Costa Rica & 0.277 & 0.244 & 0.224 & 0.205 & 0.238 \\
\hline Argentina & 0.279 & 0.276 & 0.291 & 0.308 & 0.289 \\
\hline Uruguay & 0.311 & 0.310 & 0.335 & 0.302 & 0.314 \\
\hline Brazil & 0.353 & 0.290 & 0.338 & 0.355 & 0.334 \\
\hline Peru & 0.393 & 0.288 & 0.266 & 0.464 & 0.353 \\
\hline Colombia & 0.371 & 0.334 & 0.352 & 0.378 & 0.359 \\
\hline Ecuador & 0.394 & 0.374 & 0.322 & 0.417 & 0.377 \\
\hline Chile & 0.405 & 0.372 & 0.396 & 0.452 & 0.406 \\
\hline Mexico & 0.467 & 0.478 & 0.402 & 0.404 & 0.438 \\
\hline $\begin{array}{l}\text { Venezuela (Bolivarian } \\
\text { Republic of) }\end{array}$ & 0.408 & 0.478 & 0.399 & 0.475 & 0.440 \\
\hline
\end{tabular}

Source: L. Bértola, "Informe de proyecto", Santiago, Economic Commission for Latin America and the Caribbean (ECLAC), 2012, unpublished. 
This marked heterogeneity in the more or less formalized production structure is reinforced by the characteristics of the informal labour market and is a major check on the integration of production structures into denser networks of value creation and inter-firm interactions. These characteristics contribute to the persistent heterogeneity of a structure that rests on comparative advantages derived from access to natural resources and hinder the introduction of the kinds of capital that would transform the organizational and institutional fabric and support efforts to participate dynamically in world trade.

These characteristics of the Latin American production system have been among the great challenges for regulationist approaches which, relying on the concepts of the accumulation regime and modes of development as a combination of structural and institutional elements creating scope for regularities that enable a stable accumulation process to be sustained, have had great difficulty establishing an acceptable explanatory framework for the development of Latin American economies. A number of approaches that have analysed the configuration of different endogenous cycles in these economies have encountered potent exogeneities complicating their characterization, whence the many exotic-sounding definitions that have been ventured upon, such as tropical Fordism.

These difficulties should spur creative diagnosis, avoiding the application of analytical models devised and grounded in very different historical situations, such as that of the developed countries (Bizberg and Thèret, 2012).

One way of approaching the dynamic of Latin American development is to identify five possible sources of economic growth and pinpoint the social and economic forces sustaining this, the ways they interact and the predominance of some over others in the growth regime. Evolutionary models of convergence and divergence mention three of these forms of growth.

(i) Kaldorian growth, which is induced by the expansion of demand resulting from specialization and the scaling-up of production, with the increased productivity this fosters. It may be combined with another, more Keynesian type of growth, in the sense that domestic policies to increase demand may also boost the overall economy by using human resources who are not fully employed and inducing increases in production scales or installed capacity usage. Nevertheless, it may be said that the Kaldorian component is the one that predominates in the long run, in terms of the impact of the expansion of demand on economies of scale and new investments. 
(ii) Schumpeterian growth, the result of innovation efforts arising from the accumulation of scientific and technological knowledge and its application to the emergence of new products and processes. This growth is largely down to research activities both within companies and outside them in a country's science and technology system.

(iii) In peripheral or less advanced countries, the two aforementioned sources of growth and higher productivity are complemented by the growth resulting from the international transfer of technology, something that in turn will depend on the size of the technology gap and the ability of the local society to seize the opportunities involved and adopt exogenous technology. Broadly speaking, the greater the gap, the greater the scope for growth based on this component, but the potential for reaching a comparable level is strongly constrained by local capabilities and the structural differences between the technology's origin and destination countries. Catch-up as a development strategy has severe limitations, since the most it can offer is conditional convergence that is often balked before the development level of the leaders is even approached unless the process is conjoined with the Kaldorian or Schumpeterian models and these latter are firmly grounded in the specific conditions of each country.

(iv) In the case of natural resource-rich economies, rent-induced economic growth occurs time and again, this being a process based on exploiting a price differential in the international market which arises not because value is added to the resource by way of technological change but because the supplier has a monopoly at a time of extreme demand growth unmatched by supply. This rentier growth tends to be highly volatile because technical change can contribute to the discovery of new reserves or to higher productivity in the case of reproducible goods. The process is stimulated by economic circumstances in which very high rents are generated, enabling new investments to be made, provided there is no absolute monopoly of the resource. In any event, the ways in which these rents are generated and appropriated vary greatly depending on the characteristics of the sector involved and the structures of ownership, the international market and marketing and transportation networks, among other things. This type of rentier growth model overlaps with Kaldorian dynamics.

(v) Finally, Latin America has experienced episodes of economic growth induced by financial expansion. This type of growth tends to be short-lived and quickly leads to a particular form of 
Dutch disease, perhaps the worst of all, since it does not result from the development of anything that can strictly be called a production sector.

These different forms of economic growth have very diverse dynamic implications and are associated with different actors with distinct behaviours and economic and political cultures. It can be argued that the long-term divergence and volatility of the Latin American economy have been largely due to the predominance of the financial and rentier growth pattern. When this has yielded strong expansions, catch-up growth models have sometimes been implemented, but although Kaldorian and Schumpeterian activities have always appeared at those times, they have never reached the point of becoming dominant growth patterns.

It is important to note that these forms of growth are not associated with different economic sectors, but may overlap or complement each other in the same sector. For example, the petroleum sector may experience a Schumpeterian dynamic if the development of new technologies makes it possible to efficiently reach depths previously regarded as economically unviable and process raw materials that were formerly impossible to exploit. However, this sector can also generate growth from higher prices and production due to a surge in demand without a proportional increase in supply, or because the producers have monopolistic or oligopolistic control of the market. In such cases, revenue is not derived chiefly from innovative activity. In the same way, primary-sector output can be increased by expanding the producing area, or price increases can be achieved through restrictions on supply (typical examples include natural rubber, guano, nitrates and coffee in the early stages). Growth may also be due to major innovations such as new seeds or capital goods (ploughs, tractors, harvesters, irrigation systems and others).

Growth driven by rent-seeking or capital flows is not inherently damaging or perverse, but it has a marked propensity to be so if it is not combined with other, more dynamic activities and if it becomes the prevailing development path. Moreover, unless accompanied by other transformations, this type of growth tends to strongly concentrate income, either through control of natural resources or through the concentration of financial activities.

In political economy terms, then, the key thing is to identify the dynamic that has accounted for this volatile and lagged growth, preventing the development of the sectors which ought to spearhead change in the long run.

To begin with, the non-reproducible natural resource income component should be identified. Although the information in figure IX.3 needs to be reprocessed to properly reflect the concept of rent used here, it is suggestive enough in several ways. First, the sharp fluctuations cannot be said to be 
Schumpeterian-type movements, i.e. increases in income do not seem to be mainly the result of demand shocks or major speculative components. In other words, it seems beyond doubt that a significant rent generation component is at work. Second, there is a very marked procyclical component in the GDP share of these rents. Furthermore, the component does seem clearly procyclical, i.e., it is not that the share of rents increases because the rest of GDP falls, but that the fall in rents explains the drop in GDP. Third, this type of income is obviously much more important in mining and oilproducing countries and less so in countries with a large agricultural base, such as Argentina and Brazil.

Figure IX.3

Latin America and the Caribbean (selected countries): rents captured by the State through taxes on natural resource exploitation, 1970-2010

(Percentages of GDP)

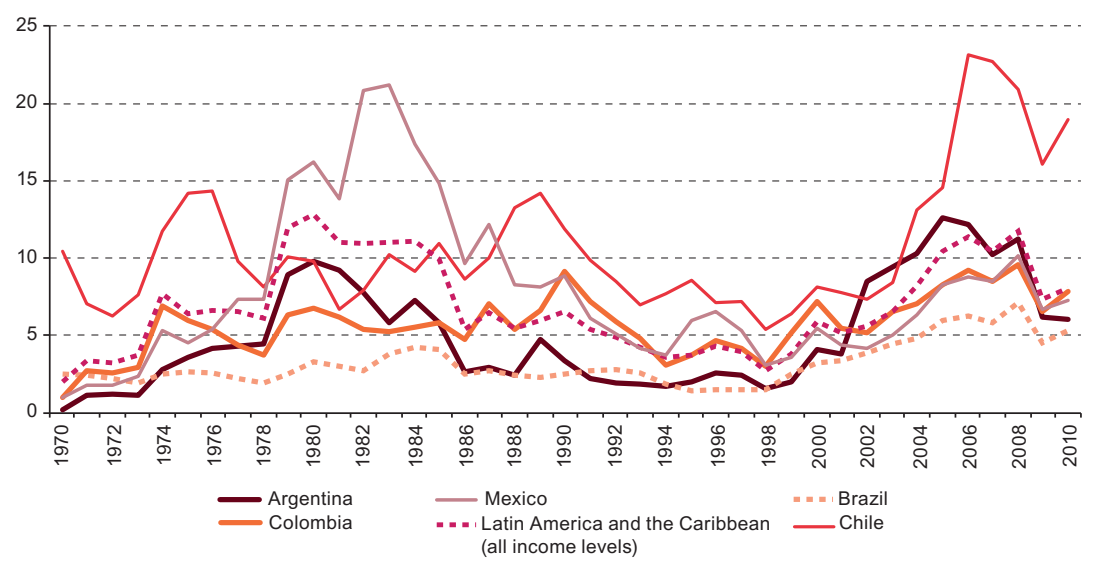

Source: Economic Commission for Latin America and the Caribbean (ECLAC).

There is not so much information available on agrarian-based economies. Purely to show the type of calculation that can be carried out, two examples are provided of a small, agriculture-based economy such as Uruguay, where, judging by figure IX.4, the level of rent seems low.

Figure IX.4 shows trends in land rents and their GDP share in the 19081966 period. The upper line shows the rent component (based on ownership of the natural resource) as a share of total value added in the sector. The series presents strong fluctuations that coincide closely with movements in the terms of trade, especially their sharp decline in the late 1950s and early 1960s. The bottom line shows similar fluctuations, but with a more constant downward trend in land rent as a share of GDP. This may form part of changes made in the growth model, predominantly in pursuit of a technological catch-up strategy involving industrialization and agricultural 
development at the expense of traditional cattle-rearing, which was the main source of rents. The combination of industrialization (largely based on the transfer of land rents to industry) and the deterioration in the terms of trade meant that land rents all but disappeared from the model.

Figure IX.4

Uruguay: land rents as a share of agricultural and total GDP, 1908-1966

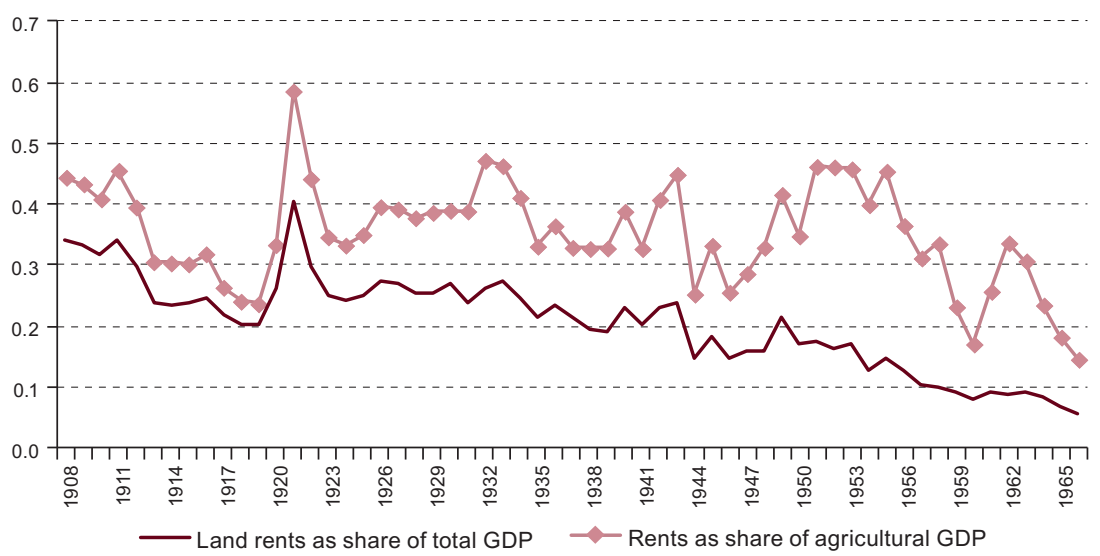

Source: Prepared by the author on the basis of L. Bértola, "A 50 años de la curva de Kuznets: crecimiento económico y distribución del ingreso en Uruguay y otras economías de nuevo asentamiento desde 1870", Investigaciones en Historia Económica, No. 3, Barcelona, Asociación Española de Historia Económica, 2005.

Figure IX.5 presents another perspective on all this. The top line shows an index of land prices deflated by the consumer price index (CPI), while the bottom line shows the same series additionally deflated by an index of land productivity growth, since the price of land may be assumed to reflect in part a Schumpeterian process whereby this asset appreciates as a result of different types of innovation. What is left after this deflation are land price fluctuations that reflect a circumstantial valuation of land as a rent-yielding asset. The fluctuations of this series often match those of the previous ones in the period where they overlap. When extended to the present day, however, it shows many large swings and sharp breaks in the trend. Inflationary periods seen to have affected the value of land, in a process that closely coincides with the deterioration in the terms of trade, partly as a result of oil prices (Uruguay imports all its oil). In this context, the agricultural sector underwent a real crisis that led its representatives to adopt slogans such as "profit or death". However, price stabilization and the appreciation of agricultural goods in the past decade and a half have resulted in strong creation of agricultural rents, far surpassing the large productivity gains that have been driven by the sector's potential and by the introduction of major structural changes in production techniques. For the first time in the history of Uruguay, crop 
production has surpassed that of livestock. To summarize, two interesting developments have taken place in recent decades: first, the creation of large land rents and, second, a major boost to agricultural productivity from the incorporation of various innovations and a structural shift towards more investment- and knowledge-intensive industries. The question arises, of course, as to what might sustain these trends in the long term.

Figure IX.5

Uruguay: real land price deflated by the consumer price index and estimated rents, 1902-2010

(Index: 1913=100)

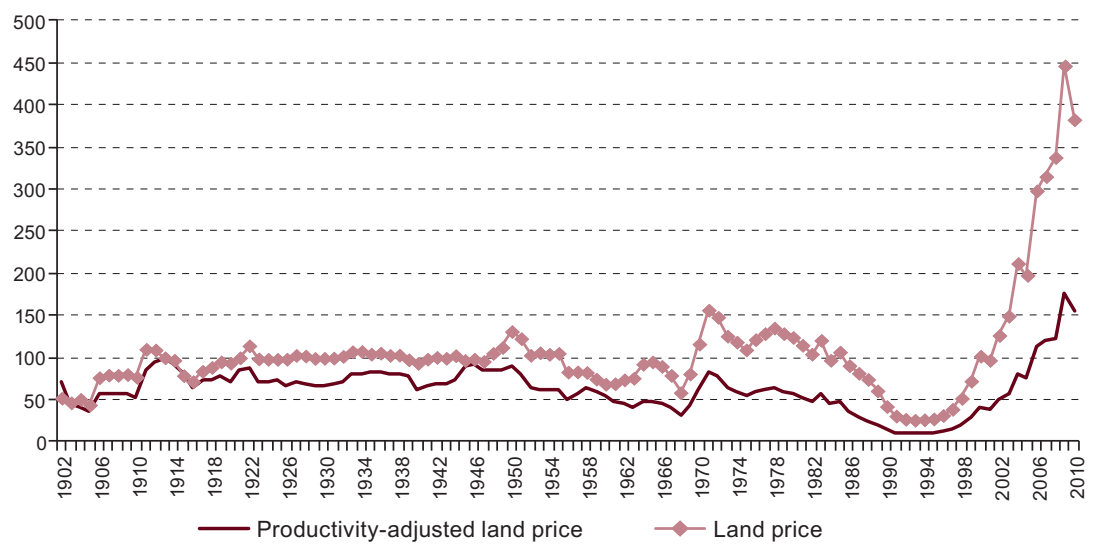

Source: L. Bértola, "Informe de proyecto", Santiago, Economic Commission for Latin America and the Caribbean (ECLAC), 2012, unpublished.

In short, although there are marked differences and each has its own logic, the generation of rents from natural resources is something nonreproducible goods and agricultural production have in common. Rents representing substantial shares of GDP are generated in both sectors and experience similar fluctuations that are clearly procyclical in relation to GDP movements.

When natural resources appreciate, many investors enter the market seeking to appropriate these sources of rent, whose ownership thus tends to become more concentrated. However, their great volatility means that these processes take place in weak institutional contexts, so States are rarely in a position to impose conditions on those exploiting resources. Therefore, in addition to the appropriation of assets and rents, the use made of the resources goes unregulated, with major environmental and social consequences. When climate change effects are added in, the impact of this expansion on the environment and shared natural resources, and the displacement of poorer sectors to more marginal, eroded areas with less access to public 
goods and services, result in a marked increase in inequalities of income and living conditions.

It is essential to understand the political economy of structural change or the lack thereof and of the pattern of development and its institutional arrangements. If the political and social system is organized around rentseeking in the primary sector and the defence of what has been achieved there, this may go a long way towards explaining the limited support for Keynesian, Schumpeterian and even catch-up development strategies. Meanwhile, environmental issues are often seen as less pressing than the need to meet more immediate requirements among the population.

A typology of resources needs to be developed from the point of view of appropriability, reproduction, technological characteristics, access, predominant forms of ownership and environmental and distributional impacts. It would also seem to be important to weigh the economic, social and political importance of development in other sectors by comparison with rentier economies. For example, the domestic and self-consumption economies, expansion of the industrial sector and expansion of services and public functions ultimately shape highly varied economic and social situations with a variety of potentialities and outcomes in political economy terms. There is a need to map economic and social structures in a way that reflects the concepts of structural heterogeneity in output and employment already studied and to extend these analyses to the sphere of political economy.

These processes are part of a long-term trend towards a more thoroughly democratic life. Like many others, this tendency towards expansion of the democratic system has not been linear, but has been interrupted by innumerable authoritarian episodes. Fortunately, Latin America has experienced, Huntington-style, a new wave of democratization in the past decade, so that for the first time in history virtually all Latin American governments are democratic. Aside from its intrinsic value, this situation has decisive implications for struggles over the appropriation, distribution and use of rents. The logic of reproduction of political systems in the context of democracy is very specific and has been extensively studied by the new economics, with a strong emphasis on the concept of the average voter. What the literature has not done is establish the link between these logics and the impact on the different strategies and patterns of economic growth in societies with high and volatile rents and great structural heterogeneity. Or, to put it in the terms of varieties of capitalism theory, there is a need to ascertain how the expansion of democracy in Latin America is related to the various organizational and institutional environments of firms and the State.

Tables IX.4 and IX.5 illustrate the ambiguities of Latin American development, its progress and its weaknesses in the sphere of human 
development and the challenges for welfare States. Taking a sample of countries from different regions, the tables display advances towards equity in the components of the human development index (HDI) and towards human development corrected for equity.

In table IX.4, it can be seen that all regions of the world have substantially improved their equality indices. As might be expected, Scandinavian countries have led the way, followed by the core countries, Italy and Spain and the settler countries. Latin American countries exhibit by far the lowest equality levels and have contributed decisively to the widening of differences between regions. As table IX.5 shows, when the HDI is adjusted for inequality, the relative position of the Latin American countries deteriorates sharply.

Table IX.4

Equality index, 1900-2000

\begin{tabular}{llllll}
\hline & $\begin{array}{c}\text { Southern } \\
\text { Cone }\end{array}$ & Core & Settler & $\begin{array}{c}\text { Italy and } \\
\text { Spain }\end{array}$ & Scandinavia \\
\hline 1900 & & & 0.559 & 0.403 & \\
\hline 1910 & & 0.606 & 0.396 & \\
\hline 1920 & 0.576 & 0.653 & 0.490 & 0.528 \\
\hline 1930 & & 0.641 & 0.711 & 0.548 & 0.562 \\
\hline 1940 & 0.682 & 0.726 & 0.567 & 0.670 \\
\hline 1950 & 0.344 & 0.755 & 0.689 & 0.587 & 0.767 \\
\hline 1960 & 0.369 & 0.768 & 0.785 & 0.661 & 0.830 \\
\hline 1970 & 0.361 & 0.789 & 0.803 & 0.727 & 0.867 \\
\hline 1980 & 0.408 & 0.794 & 0.836 & 0.752 & 0.890 \\
\hline 2000 & 0.428 & 0.768 & 0.798 & 0.794 & 0.887 \\
\hline
\end{tabular}

Source: L. Bértola and others, "A century of human development and inequality: a comparative perspective", Documentos de Trabajo, Montevideo, Faculty of Social Sciences, University of the Republic, 2012.

Table IX.5

Historical human development index (HHDI) and inequality-adjusted historical human development index (IAHHDI), 1920-1990 (Percentages of core countries' index values)

\begin{tabular}{|c|c|c|c|c|c|c|c|c|}
\hline \multirow{2}{*}{ Year } & \multicolumn{2}{|c|}{ Southern Cone } & \multicolumn{2}{|c|}{ Settler } & \multicolumn{2}{|c|}{ Italy and Spain } & \multicolumn{2}{|c|}{ Scandinavia } \\
\hline & HHDI & IAHHDI & HHDI & IAHHDI & HHDI & IAHHDI & HHDI & IAHHDI \\
\hline 1920 & & & 105 & 120 & 57 & 49 & 70 & 64 \\
\hline 1930 & & & 101 & 112 & 42 & 35 & 77 & 67 \\
\hline 1940 & & & 109 & 115 & 46 & 38 & 82 & 81 \\
\hline 1950 & 30 & 14 & 99 & 90 & 42 & 33 & 80 & 81 \\
\hline 1960 & 39 & 19 & 95 & 97 & 56 & 49 & 89 & 96 \\
\hline 1970 & 34 & 16 & 97 & 98 & 65 & 60 & 94 & 103 \\
\hline 1980 & 26 & 14 & 96 & 101 & 67 & 64 & 92 & 103 \\
\hline 1990 & 36 & 20 & 97 & 100 & 74 & 77 & 95 & 109 \\
\hline
\end{tabular}

Source: L. Bértola and J.A. Ocampo, The Economic Development of Latin America since Independence, Oxford, Oxford University Press, 2012. 
Addressing the debate on the characteristics of the welfare State in Latin America, and setting out from Esping-Andersen's descriptions, Filgueira (1997) correctly states that the Latin American tradition is predominantly that of the conservative welfare State. The region developed its welfare models by progressively expanding benefits for various professional groups, starting with the State bureaucracy, especially the military, then rolling them out to different professional groups, with marked differences in provision. The system is based on a formal sector where men are the main breadwinners and the benefits flow through them to the rest of the family, i.e., the general population. The Latin American welfare State developed in stages, starting in more open economies with greater exposure to international migration, in keeping with the way welfare States emerged in developed countries and other settler economies (Huberman, 2010; Lloyd, 2011).

Filgueira (1997) also makes a stronger claim that accords with the viewpoint of this study: strictly speaking, there are no welfare States in Latin America, but only social States. Furthermore, the author rightly seeks to characterize Latin American regimes not just in terms of their level of maturity, after the manner of Mesa-Lago, as though they were stages along a universal continuum, but by trying to identify different structural peculiarities in the functioning of Latin American social States. Thus, one finding is that what existed up to the 1970s were systems of stratified universalism (Argentina, Chile and Uruguay), dual systems (Brazil and Mexico) or exclusive systems (Ecuador, Plurinational State of Bolivia and most of the Central American republics).

As argued throughout this chapter, the characteristics of welfare States cannot be separated from the broader characteristics of the production structure because they form a set of interdependent interactions. The absence of welfare States is the corollary of economic underdevelopment, not only because of any quantitative relationship between per capita income and public social spending but, more broadly, because of the way the welfare system interacts with what is known in varieties of capitalism theory as the institutional comparative matrix.

A systemic examination of these interactions is crucial, not only to characterize the different structures but, more ambitiously, to be able to design and pursue pathways out of development constraints. With that in view, it is necessary to identify the actors, organizations and institutional arrangements that can serve to transform the foundations of institutional comparative advantage.

These forms of welfare State in Latin America are obviously related to the region's high level of inequality compared with others. Very large sections of the Latin American population are excluded from the services provided by welfare States because they belong to mainly unformalized sectors, have 
insecure jobs, carry out subsistence activities in marginal areas, participate in highly seasonal activities, are internal migrants or inhabit areas where the State presence itself is marginal, not only in matters of social policy, but in the provision of public goods, including security.

The plight of marginalized groups is further compounded if the impact of environmental phenomena is added to the now exhaustively studied factors associated with the characteristics of inequality and the regressive tendencies of social spending. The expansion of democracy itself, resulting from the rise of universal political participation, but also from the ability of different groups to apply corporate pressure, means that the most marginalized segments are exposed to environmental damage while large sectors of democratic society remain largely unaffected.

\section{Conclusion}

Latin America is currently experiencing extremely favourable economic circumstances and has thus, generally speaking, been able to show high rates of economic growth, poverty reduction and, in many cases, a large reduction in inequality.

However, it has not achieved all this by choosing and forging a development path. Besides, the current growth pattern is beset by a large range of challenges, whose resolution may prove decisive for longterm performance.

Latin America needs to progress in five key areas. They are almost all interrelated and very difficult to rank or prioritize:

(i) Productive transformation. What is required is to find a way of maintaining the export dynamic of the most competitive sectors while urgently promoting new export sectors, something that will be impossible without a profound transformation in the entire production fabric aimed at markedly reducing structural heterogeneity. These objectives require a great many resources from society to develop industrial policy tools and capabilities.

(ii) Social transformation, the eradication of indigence, the greatest possible reduction of poverty, the reduction of alarming social inequalities. These policies require vast resources, but have the advantage that they can become sources of economic and social dynamism in the long run by creating human capital and capabilities of different kinds. The universality of social benefits, especially access to education and unemployment and occupational accident insurance, and of policies to integrate women more thoroughly into the formal labour market are core development policy objectives. 
(iii) Environmental sustainability has become a cornerstone of any policy. The idea is not to compensate economically for environmental damage but to halt and reverse it, and in particular to reduce its impact on the most vulnerable. This being so, environmental policies are inextricably linked to social policies.

(iv) Economic and social development has not always gone hand in hand with political democracy. However, the continuity of development is ultimately more likely to be maintained under democratic regimes. Again, democratic coexistence is a value that surpasses many other aspirations, probably by far. The region's great dilemma is that it needs to work out how, in democracy, it can build a credible, efficient system for capturing and managing resources that enables it to progress towards the goals of productive transformation, equity and environmental sustainability. Latin America should significantly step up the social mobilization of economic surpluses and orient them towards meeting these three types of needs. This is the key to the process. The great challenge is to convince stakeholders and strike the necessary political balances while trying to find solutions to economic volatility. The volatile and cyclical nature of the economy has led to the development of procyclical instruments and, even more dangerously, social and political equilibria that are unlikely to last. Acquired experience in other parts of the world shows that the development of welfare States is not irreversible. Latin America's own experience bears this out. Political systems must resist the temptation to create short-termist situations of well-being and social policies. Democratic politics can create dangerous pitfalls for policy stability and sustainability. In the long run, well-being may be short-lived unless substantive progress is made in transforming production structures and international competitiveness, and unless social policies are combined with the "matrix of institutional competitiveness". For that reason, policies, which should have a long-term horizon and be resistant to corporate pressures and populist temptations, require a credible, reliable and technically capable State with moral authority.

(v) The fifth critical area, as has been reiterated throughout this study, is the international one, which cannot be overlooked when the effort is made to construct a wide range of policies for exploring and expanding into non-traditional markets and businesses. New products and markets need to be studied, with regional integration processes playing a strategic role. These should have a clear political direction as a way of building up the region's political power and standing with a view to participating in international negotiations. 
It is in this arena that production and trade opportunities gestate and that international regulatory processes should be discussed as relating not only to trade and sovereignty, but also to access to knowledge and environmental protection.

The path to development and prosperity has not been an easy one for Latin America, and there is no guarantee that it will be in future. The region should place its hopes in enhancement of its capacities, social integration, harmony with the natural environment, development of improved forms of political and social life and a strengthened international standing, in a framework of respect and tolerance.

\section{Bibliography}

Bairoch, P. (1975), Revolución industrial y subdesarrollo, Mexico City, Siglo XXI.

Bértola, L. (2012), "Informe de proyecto", Santiago, Economic Commission for Latin America and the Caribbean (ECLAC), unpublished.

(2011), "Institutions and the historical roots of Latin American divergence", The Oxford Handbook of Latin American Economics, J.A. Ocampo and J. Ros (eds.), Oxford, Oxford University Press.

(2005), “A 50 años de la curva de Kuznets: crecimiento económico y distribución del ingreso en Uruguay y otras economías de nuevo asentamiento desde 1870", Investigaciones en Historia Económica, vol. 3, Barcelona, Asociación Española de Historia Económica.

Bértola, L., and J.A. Ocampo (2012), The Economic Development of Latin America since Independence, Oxford University Press.

Bértola, L., and G. Porcile (2006), "Convergence, trade and industrial policy: Argentina, Brazil and Uruguay in the international economy, 1900-1980", Revista de Historia Económica, vol. 24, No. 1, Cambridge, Cambridge University Press.

Bértola, L., M. Hernández and S. Siniscalchi, S. (2012), "Un índice histórico de desarrollo humano de América Latina y algunos países de otras regiones: metodología, fuentes y bases de datos", Documentos de Trabajo, No. 8, Montevideo, Faculty of Social Sciences, University of the Republic.

Bértola, L., and others (2012a), "Relative performance, structural change and technological capabilities in Latin America in historical perspective", Beyond the Global Crisis: Structural Adjustments and Regional Integration in Europe and Latin America, L.F. Punzo, C.A. Feijo and M. Puchet Anyul (eds.), New York, Routledge.

(2012b), "A century of human development and inequality: a comparative perspective", Documentos de Trabajo, Faculty of Social Sciences, University of the Republic.

Bizberg, I., and B. Thèret (2012), “La diversidad de los capitalismos latinoamericanos: los casos de Argentina, Brasil y México", Noticias de la Regulación, No. 61, Buenos Aires, National Council for Scientific and Technological Research.

Bohlin, J. (1989), Svensk varvsindustri 1920-1975: lönsamhet, finansiering och arbetsmarknad, Göteborg. 
Bourguignon, F., and C. Morrison (2002), "Inequality among world citizens", American Economic Review, vol. 92, No. 4, Nashville, Tennessee, American Economic Association.

Cimoli, M. and G. Porcile (2011), "Learning, technological capabilities and structural dynamics", The Oxford Handbook of Latin American Economics, J.A. Ocampo and J. Ros (eds.), New York, Oxford University Press.

Cimoli, M., and others (2005), "Cambio estructural, heterogeneidad productiva y tecnología en América Latina", Heterogeneidad estructural, asimetrías tecnológicas y crecimiento en América Latina, M. Cimoli (ed.), Santiago, Economic Commission for Latin America and the Caribbean (ECLAC)/Inter-American Development Bank (IDB).

Esping-Andersen, G. (1999), Social Foundations of Postindustrial Economies, Oxford, Oxford University Press. (1990), The Three Worlds of Welfare Capitalism, Cambridge, Polity Press.

Federico, G. (2005), Feeding the World. An Economic History of Agriculture, 1800-2000, Princeton, Princeton University Press.

Filgueira, F. (1997), "Tipos de welfare y reformas sociales en América Latina: eficiencia, residualismo y ciudadanía estratificada", paper prepared for the project "Social Policy and Social Citizenship in Central America", Social Science Research Council.

Filgueira, F., and others (2006), "Universalismo básico: una alternativa posible y necesaria para mejorar las condiciones de vida", Universalismo básico: una nueva política social para América Latina, C.G. Molina, (ed.), Washington, D.C., InterAmerican Development Bank (IDB)/Planeta.

Frankema, E. (2009), Has Latin America Always Been Unequal? A Comparative Study of Asset and Income Inequality in the Long Twentieth Century, Boston, Brill.

Hall, P., and D. Soskice (2001), Varieties of Capitalism. The Institutional Foundations of Comparative Advantage, Oxford, Oxford University Press.

Huberman, M. (2012), Odd Couple. International Trade and Labor Standards in History, New Haven, Yale University Press.

Lloyd, C. (2013), "Welfare State and capitalist crisis", Retrenchment or Renewal: Welfare States in Times of Economic Crisis, G. Jonsson and K. Steffanson (eds.), Helsinki, University of Helsinki.

(2011), "The history and future of social democratic welfare capitalism: from modernization to the specters of ultramodernity", Beyond Welfare State Models, P. Kettunen and K. Peterson (eds.), Cheltenham, Edward Elgar.

López-Guzmán, T., G. Millán Vázquez de la Torre and S. Sánchez Cañizares (2007), "Financiación autonómica e incidencia fiscal de los tributos ecológicos: una reflexión en torno al principio de "quien contamina, paga'", Revista de Estudios Regionales, No. 78, Málaga, Universidades Públicas de Andalucía.

Mesa-Lago, C. (1978), Social Security in Latin America: Pressure Groups, Stratification, and Inequality, Pittsburgh, University of Pittsburgh Press.

Milanovic, B. (2011), The Haves and the Have-nots. A Brief Idiosyncratic History of Global Inequality, New York, Basic Books.

North, D. (1990), Institutions, Institutional Change and Economic Performance, New York, Cambridge University Press.

Pommeranz, K. (2000), The Great Divergence. China, Europe and the Making of the Modern World Economy, Princeton, Princeton University Press. 
Prados de la Escosura, L. (2010), "Improving human development: a long-run view", CEPR Discussion Papers, No. 7982, London, Centre for Economic Policy Research.

Reimers, F. (2006), "Education and social progress", The Cambridge Economic History of Latin America, V. Bulmer-Thomas, J. Coatsworth and R. Cortés Conde (eds.), New York, Cambridge University Press.

Reinert, E. (2007), How Rich Countries Got Rich... and Why Poor Countries Stay Poor, London, Constable.

UNDP (United Nations Development Programme) (2011), Human Development Report 2011. Sustainability and Equity: A Better Future for All, New York, Oxford University Press.

UNEP (United Nations Environment Programme) (2011), “Towards a Green Economy: Pathways to Sustainable Development and Poverty Eradication. A Synthesis for Policy Makers" [online] http://www.unep.org/greeneconomy/ Portals/88/documents/ger/GER_synthesis_en.pdf. 
Part IV

The role of the State 



\section{Chapter X \\ Growth, employment and equality: the new role of the State}

Robert Boyer ${ }^{1}$

\section{Introduction}

Following the collapse of the belief in the omnipotence of market mechanisms, reflections on the role of the State are drawn from two observations. The first is the idea of growth with equity, which emerged in Latin America a decade ago, bucking the trend of rising inequality in the rest of the world. The second is that in systemic crises, economic analysis faces radical uncertainty, meaning that — as Joseph Schumpeter acknowledged — if models fail, it means that the macroeconomic theory must be wrong and that therefore a new approach must be adopted that inspires a new concept of development and of the State. This chapter addresses growth, employment, equality and the new role of the State. More specifically, it analyses the reorganization of the role of the State with a view to providing a mechanism whereby inequalities are consistently reduced under a long-term sustainable growth regime.

To explain how a regime of this type was conceived, section A summarizes the evolution of economic models in Europe and the United States after the Second World War. After a period of great success, the socioeconomic system plunged into crisis in the 1970s, which legitimized a

Institut des Amériques (IDA), Paris. 
return to the theory of self-regulating and efficient markets, only for these markets to then suffer a similar fate (see section B). A new phase followed the failure of market fundamentalism, which may lead to a paradigm in which the function of the State is restored through a pragmatic economic policy that heeds the lessons of history. In seeking a socioeconomic system that incorporates the goal of social justice, it is important to clarify the links between the different components of the social protection system, not only with the well-being of the population, but also with the institutional forms that shape the growth regime. Yet these policies cannot simply replicate those applied by developed countries after the Second World War. The opening up of all economic areas at the international level - trade, direct investment, financial capital and intellectual property- has created an unprecedented degree of interdependence between economic policies in the pursuit of growth regimes that are sustainable in terms of social and environmental inequality.

\section{A. Reducing inequality in developed economies with high and stable growth}

\section{The 1950s: equilibrium of economic efficiency and social justice}

In the mid-1950s, one of the most important introductory books on economics was Economics by Paul Samuelson (1948). From the first chapter, the author insists on the necessity of choosing between equality and efficiency: represented by the Soviet Union on one side and the United States on the other. Samuelson suggested that the greater a society's equality, the weaker its economic performance; a dichotomy that surprised those familiar with the situation in France, where strong economic growth, surpassing that of the United States, coincided with falling inequality. There was no theoretical explanation for this situation. Accordingly, regulation theory was developed to interpret this seemingly paradoxical economic system, termed Fordism (Aglietta, 1982; Boyer, 1986), in which income distribution is compressed by strong wage growth and the extended social coverage enjoyed by workers, while profits remain fairly stable and generate high levels of productive investment and productivity, together with near full employment. According to neoclassical theory — which looks only at static equilibria - this highly favourable outcome is impossible, yet by analysing processes of economic institutionalization it may be supposed that new growth models emerge that are not natural systems but social constructions achieved through innovative policies. Thus regulation theory was born. A retrospective interpretation of this process would contribute to the understanding of what is happening or what might happen in Latin America, and to the evaluation of prospects for successfully achieving growth with equality (ECLAC, 2012a). 


\section{The surprising 1960s: symbiosis between inequality reduction and growth}

The instability and stagnation that characterized the inter-war period were overcome thanks to the complementarity between a raft of structural changes and the transformation of the main economic institutions, neither of which, on its own, would have been a determinant cause (see diagram X.1).

\section{Diagram X.1}

Institutional changes in favour of growth and inequality reduction after the Second World War

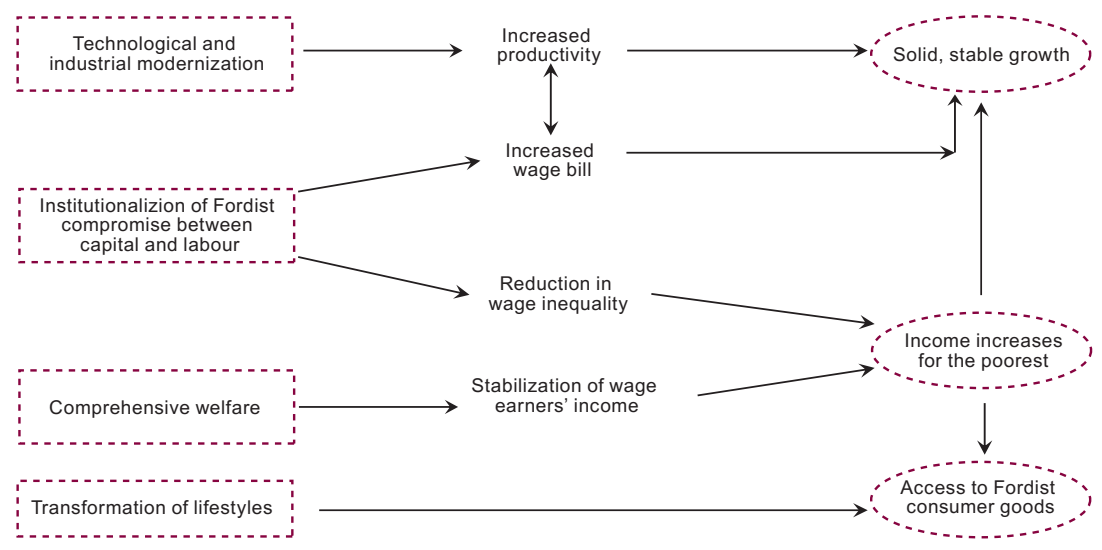

Source: Prepared by the author.

This model envisages a very high production capacity, since numerous innovations had been created between the two world wars, including mass production chains, and the setbacks with the Great Depression and the Second World War had been overcome by extremely high investment in the implementation of new technologies, so that when the new system was established there was enormous scope for boosting productivity, the fruits of which were divided between wages, profits and a drop in the relative prices of new industrially produced goods.

However, the greatest innovation was reaching a compromise with wage earners so that mass production was in tune with mass consumption thanks to the indexation of nominal wages to inflation and productivity, which had not existed previously, when output was absorbed by the social strata with higher incomes and stronger purchasing power, exported to colonies, or simply sold abroad. This key invention arose from the idea that the domestic market should be synchronized with technological progress, and this new approach gave rise to the three institutional changes set out below. 
First, access to education was promoted. For example, in the United States, the Servicemen's Readjustment Act (commonly known as the G.I. Bill) provided access to low-cost education for veterans of the Second World War; in France, access to education was a result of democratization and the formation of human capital became standard in social democratic countries (André and Delorme, 1983).

The second change was the introduction of an extremely progressive personal taxation system: in the United States in the late 1950s, the marginal tax rate for the wealthiest section of society was $83.5 \%$, which is very high compared with today's almost-flat tax rate that radically diminishes the redistribution of wealth to the poorest (Piketty, 2013). Clearly there was a social acceptance of wealth redistribution at the national level.

Lastly, increased social spending disconnected access to health services, vocational training, family benefits and housing from purely market-based mechanisms: some countries progressed towards the decommodification of labour, and others - especially in northern Europe- witnessed the emergence of welfare capitalism (Pedersen, 2008).

In fact, the socioeconomic regime was completely transformed through intensive institution-building, which not only sought to cement the recovery from the losses and setbacks associated with the Great Depression and the Second World War, but which was understood by all political factions and governments, regardless of ideological orientation, as the onset of a new era of capitalism. In France, the liberal President, Giscard d'Estaing, expressed his admiration for social democratic societies, while European Christian democrats and social democrats held a similar view of economic integration. In the United States, Alfred Sloan, the senior manager at General Motors, was the highest paid executive in the country, while Democrats and Republicans shared the same concept and practice of Keynesian economic policy (which might be considered the fourth key institutional change after the 1950s). These facts contrast starkly with the capitalism of today, where investment bank CEOs sit at the top of the wage scale and no longer regard themselves as employees. The social conditions of these regimes must be fully understood: they did not just invent a type of social engineering in pursuit of a Pareto optimal, but constituted a complex post-war process with largely unanticipated consequences. Lastly, full employment was virtually achieved and therefore wage earners had strong negotiating powers: in France, which currently has over $10 \%$ unemployment and more than 5 million people out of work, the negotiating power of wage earners is not so great, so that strategies to increase wage flexibility are in the ascendancy. 


\section{Diversity of national sociopolitical compromises and plurality of capitalism}

The implementation of this abstract model clearly differed according to national trajectories. Statistical research has revealed the coexistence of at least four types of capitalism in the economies of the Organization for Economic Cooperation and Development (OECD), which are described below (Amable, Boyer and Barré, 2008; Amable, 2003).

Market (or liberal) capitalism is characterized by its extensive use of market mechanisms, which are regulated by agencies to ensure that they function correctly. After the Second World War, collective agreements in growth-driving activities and distribution of wage increases in other key sectors of the economy - thanks to almost full employment, achieved through active monetary and fiscal policies inspired by Keynesian theory-delivered a return to growth and a significant reduction in inequalities. This is the United States or British model.

The second configuration is the social democratic model, defined as the permanent negotiation of new social compromises in which all economic actors have a voice and the decision-making power to effect institutional change. Furthermore, given that national solidarity is expressed through universal social coverage, this model was the most effective in reconciling social justice and economic efficiency, even beyond the financial crises that occurred after opening up to international capital. The Nordic countries belong to this model.

The third model is State-led capitalism, in which the economy is managed by the central government (as in France) or provincial governments (as in Germany). Under this arrangement, the previously large public sector now carries out numerous interventions and high social transfers, funded from taxation and social security, allowing a significant redistribution of national income which drives domestic market activity (France) or job creation in the export sector (Germany). In both cases, growth was reconciled with falling inequality, at least until the 1970s.

Lastly, meso-corporatist capitalism is structured around large business groups involved in a wide range of industries. Under this model, adopted by Japan and the Republic of Korea, an initial compromise ensures job security for workers whose skills are essential to production, while the wage structure is constrained by the fact that executives are trained within the company. This is another way of guaranteeing the complementarity between reduced inequality and economic performance. Traditionally, social security was provided mostly by these business groups, but the model's crisis and resulting long-term stagnation led to an increasingly extensive social policy intervention by the State. 


\section{The "trilemma" of responsiveness to market conditions, dynamic efficiency and social justice}

From Paul Samuelson to the real business cycle theorists, capitalism has traditionally been classified in terms of the relationship between static efficiency - meaning the ability to react to changes in productivity or confidence, currency crises or downturns in world trade- and social justice. But why was Fordism successful? First, because it smoothed out business cycles, but chiefly because it was able to reconcile modernization, general improvements in living standards and reductions in inequality.

Returning to the aforementioned configurations was not just a simple process of convergence, but the result of new sociopolitical compromises that gave meaning and legitimacy to an intense institutional constructivism. The models that achieved the best results in terms of complementarity between dynamic efficiency and greater social justice were initially social democratic capitalism and later State-led capitalism (see diagram X.2). It may be recalled that at the end of the 1960s, several experts from the United States travelled to France to witness the French miracle and take some of its lessons back home.

\section{Diagram X.2}

Types of capitalism and relationship between efficiency and equality, until the 1970s

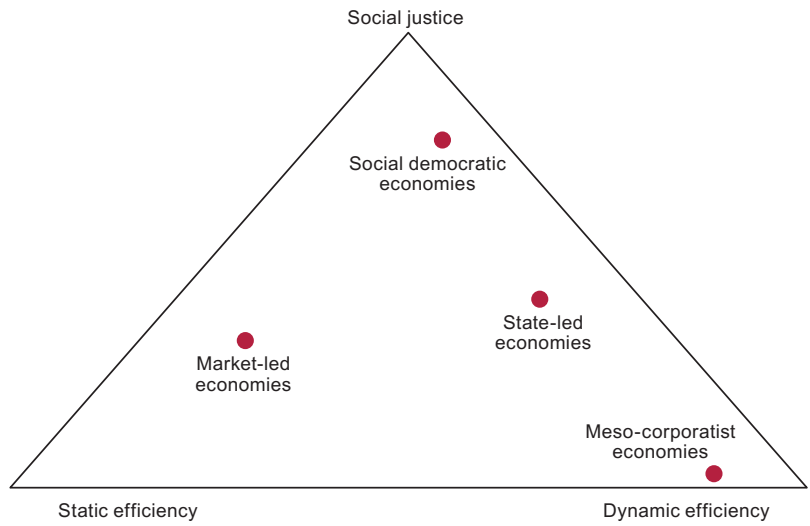

Source: Prepared by the author.

\section{B. The end of the "golden age": the success of market-led regimes and their crises}

\section{The 1980s: a conservative counter-revolution}

The 1980s saw the emergence of a revolution that began at the level of ideas and that probably would not have been so successful were it not for the 
exhaustion and open crisis provoked by the previous model followed by OECD countries.

First, total factor productivity in the United States was at a standstill, so that while the institutions responsible for distributing income remained in place, growth stagnated and distributive conflicts rose to the surface, creating inflation and unemployment.

Second, a wave of internationalization destroyed earlier compromises. Under Fordism, there had been a complementarity between capitalists and wage earners, but when an economy's export growth reaches a certain threshold, the interests of entrepreneurs and wage earners separate: what cannot be sold domestically is exported and wages become a cost, rather than a contribution to domestic demand. For example, German manufacturers did not sell a great deal on the domestic market, but were exporting to the rest of the world: thus the link between capital and labour at the national level was broken.

Lastly, financial globalization exacerbated the process of disconnection between the economic space and the political space, since capital owners could withdraw their money from financial institutions or centres and place it elsewhere, which disintegrated the material basis of growth (mass production and consumption) in the domestic economy.

These changes brought about the endogenous emergence of a new ideology, shared on an intellectual level by conservative and socialist governments alike, which asserted that the market was far better than the State at allocating resources, and that inequalities favoured market incentives, given the significant efficiency gained by rewarding talent with high wages: "the winner takes it all" became the slogan of modern capitalism. The result was a surprising return to classical macroeconomics, in which inequalities are positive because they incentivize work; a lean welfare state allows workers to accept wage concessions; wealthy people benefit the economy because they generate savings and, according to pre-Keynesian theory, will invest these savings, thereby creating more jobs for the poor. Innovators must, therefore, be well remunerated to make the economy grow (see diagram X.3).

Diagram X.3 shows the extent of the economy's core paradigm shift, which acts as a catalyst and justification for changes to laws, remuneration systems and the administration of economic policies, whose aim now is to guard against disruption to market economies that are thought to be structurally stable. 


\section{Diagram X.3}

The paradigm shift of the 1980s: social inequality as an incentive for growth

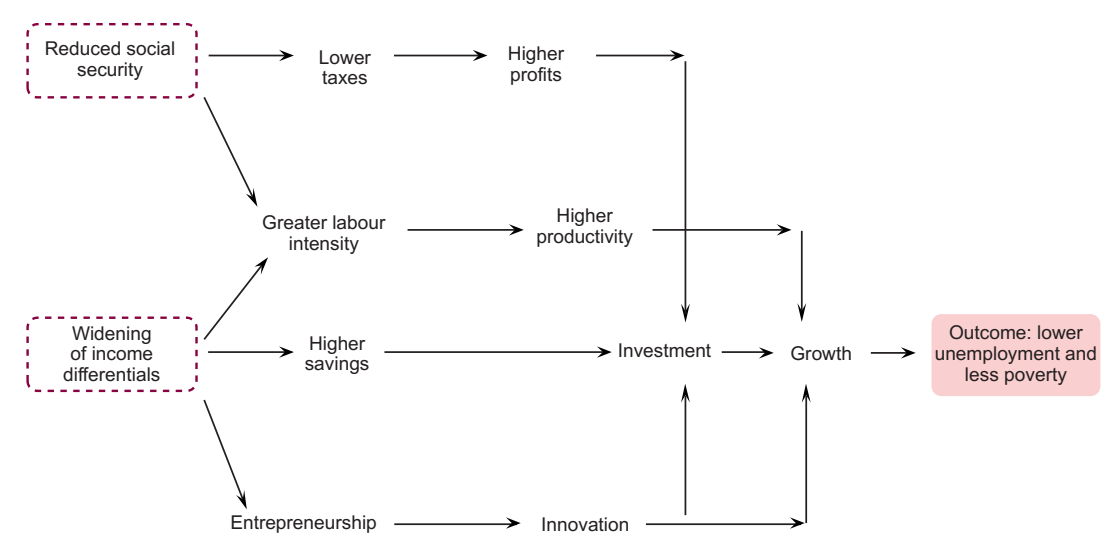

Source: Prepared by the author.

\section{The 1990s: the failure of all alternatives to market capitalism}

For this paradigm - which itself turned out to be quite extreme - to take root, it required the failure of the various alternatives that had emerged as an extension of an institutionalization process that was responding to the shift in the international and technological context.

First, in the mid-1980s the socialist government of France tried to respond to the global recession by increasing public spending, but widening public and external deficits quickly led to the adoption of an austerity plan that had a lasting impact on the economic policy of France and other countries. These events have been interpreted as the end of Keynesianism in the new global economic context. Since then, French capitalism has not been considered a viable alternative to the United States model.

A second episode prompted a re-evaluation of social democratic capitalism: financial globalization caused a banking and economic crisis in Sweden that gave rise to a reform of social security coverage that moved towards the privatization of many services, such as health care, and a reduction in public spending as a proportion of GDP. Although this commodification weakened the social democratic model, it nevertheless retained many of its hallmarks.

The collapse of the Soviet system had even graver repercussions. In fact, with the fall of capitalism's most serious rival, the pressure for reforms in favour of workers' and citizens' rights, under various forms of capitalism, dissipated. The market economy system is all that remains, with democracy 
as its necessary counterpart in the political sphere. This led some analysts to declare that the collapse of the Soviet Union marked the end of an era.

In the 1980s, meso-corporatist capitalism in Japan seemed to threaten the superiority of the United States' market economy model. However, opening to international capital flows created a stock market and real-estate bubble whose rupture ultimately put an end to buoyant growth. Two lost decades of near-total stagnation followed, which destroyed the prestige and appeal of Japanese capitalism. Only the economic policies of Prime Minister Shinzo Abe ("Abenomics") allowed the country to embark on a new phase.

Thus, in the 1990s — a glorious period for the United States economya new type of capitalism seemed to triumph: financial capitalism, which became the sole international benchmark (Fukuyama, 1992).

\section{1990-2006: the triumph of financial capitalism}

Financial capitalism prevailed thanks to the shortcomings of the aforementioned alternatives, in the sense that financial innovation is at the heart of modern capitalism. Consequently, a radical shift was observed in the various types of capitalism; all focused on the privatization of welfare, the lowering of taxes and opening to international competition with a view to arriving at the static efficiency model. Indeed, dynamic efficiency matters little in a context of strong volatility: when a fast response is required market capitalism is the most effective regime. Thus, where it fosters volatility, the capitalist model becomes a virtuous circle for economies that follow its example, and a vicious circle for the rest. For that reason, the rest of the world attempted to emulate the United States strategy.

\section{Diagram X.4}

The emergence of market capitalism in a context of financial instability, 1960-1990

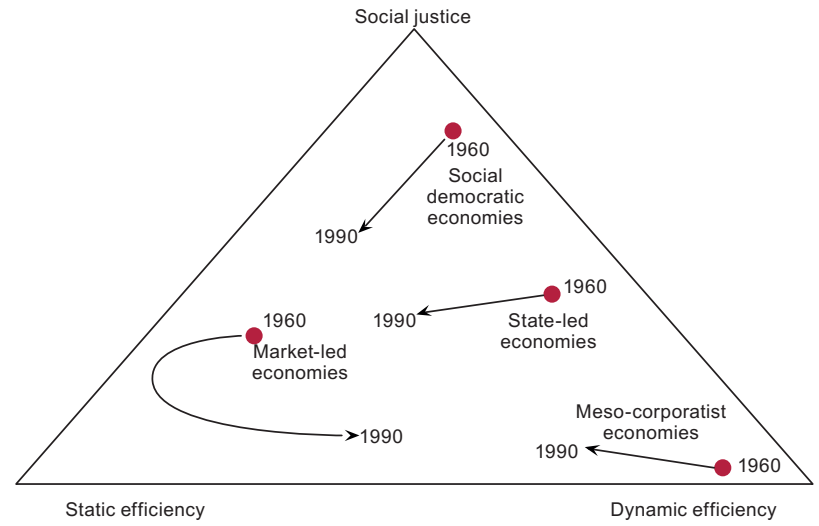

Source: Prepared by the author. 
The establishment of a finance-driven economic system was a paradoxical development, given that the Fordist model was dominated by the logic of value added creation. The finance-led model works by anticipating future wealth - measured by stock exchange performance- which then drives the investment, production and demand process. Expectations and confidence in finances determine the regime's potential. A simulation of this system using a relatively simple model (Boyer, 2000) showed that in the 1990s the conditions for stability in the United States economy had already been met. Great importance was attached to households' financial assets, which account for a large proportion of disposable income, and include the direct or indirect ownership of shares and bonds, sometimes through pension funds (see diagram X.5). For United States citizens, this model seemed to herald a period of unlimited and effortless prosperity: with the prospect of incoming wealth, individuals could request loans to buy property, which could then be pledged as security to buy a vehicle, and then the value of the vehicle could be used to borrow money for a holiday. In this way, it seemed possible to complete the macroeconomic circle without any drawbacks.

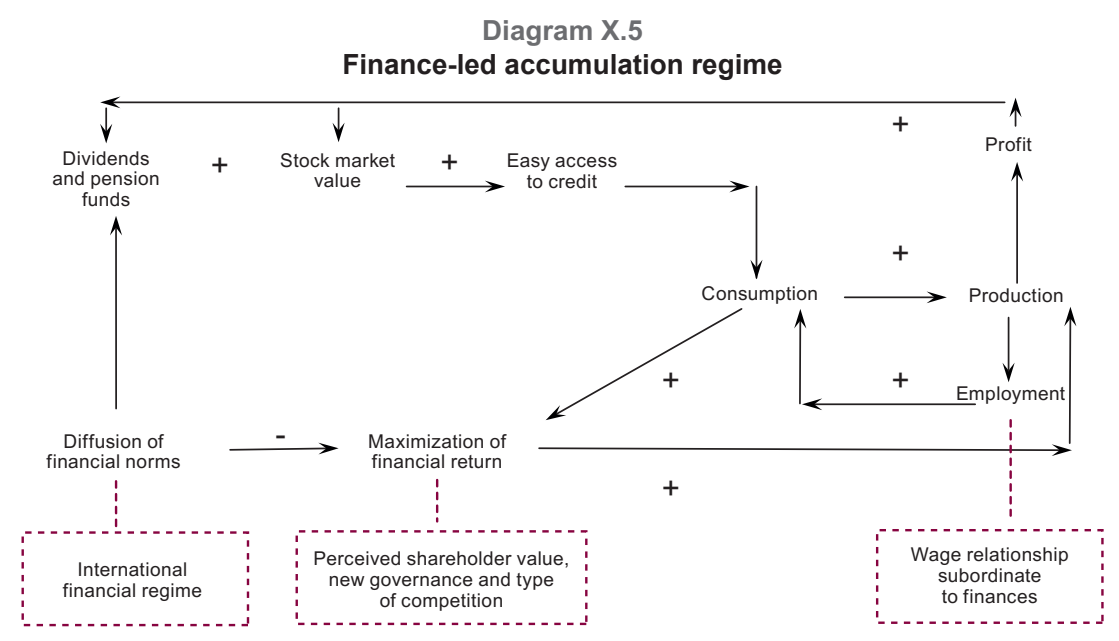

Source: Prepared by the author.

The above explains why so many European macroeconomists have, since the 2000s, advised their respective governments to adopt the United States method whereby lending and finance are the key instruments of economic activity. Such pretentions are naive in that the economic structures of the United States are rather unique and resemble only those of the United Kingdom. For other countries, especially France, Germany and Japan, the production logic of value creation in non-financial companies is much more important than financial value and the process of financialization. Growth and stability in these three economies has thus been weakened by financial 
liberalization and innovation, which are incompatible with other institutional forms built on the pursuit of competitiveness and industrial performance.

\section{2007-2008: the failure of liberalization and financial globalization}

In countries with finance-led growth regimes, the relaxation of lending criteria and mass securitization of subprime loans in the United States caused a structural crisis. In fact, the lack of control over financial innovations created an almost unprecedented speculative bubble that gradually contaminated the domestic and international economy (Boyer, 2013a). A 1930s-style depression was avoided by mass intervention, breaking with the orthodoxy that had formerly prevailed in economic policy. The central bank provided liquidity to insolvent banks and governments accepted the widening of the public deficit (see table X.1). This was the price that had to be paid for a modest recovery that turned out to be short-lived, since the United States had lost an economic driver in credit growth, and exports, consumption and investment failed to take its place.

Table X.1

Types of economic policy, 1945-2014

\begin{tabular}{|c|c|c|c|}
\hline $\begin{array}{r}\begin{array}{r}\text { Growth regimes } \\
\text { and periods }\end{array} \\
\text { Characteristics }\end{array}$ & $\begin{array}{l}\text { Mass production and } \\
\text { mass consumption } \\
1945-1971\end{array}$ & $\begin{array}{l}\text { Globalization and } \\
\text { financialization } \\
1972-2007\end{array}$ & $\begin{array}{l}\text { New developmentalism } \\
\text { and role of the State } \\
\text { 2007-present }\end{array}$ \\
\hline \multicolumn{4}{|l|}{ Overview } \\
\hline $\begin{array}{l}\text { 1. Conceptualization of } \\
\text { the economy }\end{array}$ & $\begin{array}{l}\text { Structural instability } \\
\text { that requires State } \\
\text { intervention }\end{array}$ & $\begin{array}{l}\text { Set of self-regulated } \\
\text { markets }\end{array}$ & $\begin{array}{l}\text { The State as guarantor } \\
\text { of financial stability and } \\
\text { driver of development }\end{array}$ \\
\hline 2. Dominant theory & $\begin{array}{l}\text { Keynesian } \\
\text { macroeconomics }\end{array}$ & New classical theory & $\begin{array}{l}\text { New development } \\
\text { theories } \\
\text { (ECLAC, China) }\end{array}$ \\
\hline $\begin{array}{l}\text { 3. Type of sociopolitical } \\
\text { compromise }\end{array}$ & $\begin{array}{l}\text { Compromise between } \\
\text { capital and labour }\end{array}$ & Dominance of finances & New deal with citizens \\
\hline \multicolumn{4}{|l|}{ Economic policy } \\
\hline 4. Monetary policy & $\begin{array}{l}\text { Optimization of the } \\
\text { balance between } \\
\text { employment and } \\
\text { inflation }\end{array}$ & $\begin{array}{l}\text { Stabilization of low } \\
\text { inflation and subsequent } \\
\text { boost for finances }\end{array}$ & $\begin{array}{l}\text { Return to the lender } \\
\text { of last resort, non- } \\
\text { neutrality of credit and } \\
\text { currency }\end{array}$ \\
\hline $\begin{array}{l}\text { 5. Public spending } \\
\text { and tax system }\end{array}$ & Automatic stabilizers & $\begin{array}{l}\text { Procyclical public } \\
\text { spending }\end{array}$ & $\begin{array}{l}\text { In depressions: } \\
\text { high multipliers, not } \\
\text { Ricardian equivalence }\end{array}$ \\
\hline 6. Income policy & $\begin{array}{l}\text { Collective agreements, } \\
\text { minimum wage and } \\
\text { progressive tax system }\end{array}$ & $\begin{array}{l}\text { Individualization and } \\
\text { decentralization, fixed } \\
\text { rate system }\end{array}$ & $\begin{array}{l}\text { Fight against inequality, } \\
\text { establishment of } \\
\text { financial norms }\end{array}$ \\
\hline 7. Competition policy & $\begin{array}{l}\text { Limited to a group of } \\
\text { national oligopolies }\end{array}$ & $\begin{array}{l}\text { Opening to international } \\
\text { competition and } \\
\text { emergence of } \\
\text { global oligopolies }\end{array}$ & $\begin{array}{l}\text { Softening of the policy } \\
\text { against concentration } \\
\text { of capital }\end{array}$ \\
\hline $\begin{array}{l}\text { 8. Trade and } \\
\text { exchange-rate policy }\end{array}$ & $\begin{array}{l}\text { Slow international } \\
\text { opening, fixed but } \\
\text { adjustable exchange- } \\
\text { rate regime }\end{array}$ & $\begin{array}{l}\text { Spread of flexible } \\
\text { currency regimes, } \\
\text { except in the eurozone }\end{array}$ & $\begin{array}{l}\text { Control of the real } \\
\text { exchange rate to } \\
\text { improve national } \\
\text { development }\end{array}$ \\
\hline
\end{tabular}

Source: Prepared by the author. 
The 2007-2008 bubble did not occur in isolation, but in some measure responded to the crisis in the new economy and financial liberalization, which in the 1980s had translated into property speculation and the savings and loans crisis (events on a smaller and more localized scale, since financial innovations were not yet in mass use). The finance-led accumulation regime now faced a clear structural crisis. The centrality of the United States in international financial intermediation meant that the breakdown of confidence in the stability of the banking system immediately led to a squeeze on lending for international trade, the blocking of investment decisions and plummeting production in almost every country. The system of international relations also descended into crisis, since it had no regulations or instruments at its disposal to control the spread of excess credit, especially to emerging economies.

This was the second failure of financial liberalization. Capital accounts liberalization was intended to stabilize exchange rates and allow better distribution of capital between developed and developing countries. However, the exact opposite occurred: a "currency war" broke out and the savings of developing countries funded the consumption of rich ones.

\section{From 2009 to the present: the structural crisis of all growth regimes}

The most severe crisis occurred in the countries that trusted in the virtues of financial liberalization and left the initiative in the hands of private entities: Iceland, Ireland, the United Kingdom and the United States. These countries should have adopted more heterodox policies, in other words, a total break from what was recommended by the previous theory and implemented by their respective central banks and finance ministries (Boyer, 2011d). Some analysts expected a possible repeat of the lost decade in Japan: medium-term economic stagnation with a risk of deflation.

The recession of 2008-2009 was also particularly serious in countries that had based their growth on exports and dynamic innovation: Germany, Japan and the Republic of Korea. Governments and public opinion took note of the fragility of their development model and their extreme dependence on growth in the world economy, to the point where they considered a transition to a system based on the development of the domestic market and, particularly, consumption.

China seemed to escape the successive recessions that struck other countries in the first phase of the crisis triggered by the collapse of Lehman Brothers. In fact, thanks to credit and exchange-rate controls and an ambitious public infrastructure programme, the Chinese economy 
grew only slightly slower than it had previously (Boyer, 2011a and 2011b). However, the period between 2010 and 2013 marked a turning point, since growth in international trade slowed and the model based on productive investment and the real-estate sector began to run out of steam. This presented an opportunity to refocus policies to transition towards the domestic market and the meeting of social and environmental needs created by the boom.

The European Union faced a different crisis: in the first phase, the magnitude of the automatic stabilizers limited the consequences of the crisis, but in 2010 the size of public deficits aroused such concern among the international finance markets and the authorities in Brussels as to provoke a return to austerity, even before economic recovery was assured (Boyer, 2012b). During this process, a structural weakness emerged that had been underestimated by the architects of the euro: the heterogeneity of eurozone countries' specializations and regulations reflected the inconsistencies and the incomplete nature of the European Union institutions. Consequently the financial crisis segued into an economic crisis that became a political crisis concerning European integration (Boyer, 2013b).

\section{The State and economic policy: a new paradigm}

It is worth highlighting some of the analytical findings that emerged from the re-evaluation of the concept of the State and its aims and instruments. The following proposals are the result of two observations taken from the above analysis. On the one hand, attention should be paid to the lessons of history in order to correct the mistakes that lead to severe economic crises. On the other, the policies that countries need may not always be the same; rather they should be compatible and consistent with the development model and the type of regulation applied in each national economy.

\section{The loss of belief in the efficiency and self-regulation of financial markets grants new legitimacy to State intervention}

That financial markets are bad at allocating capital is evidenced by the succession of financial bubbles that have occurred in the United States (the savings and loans crisis of the 1980s, the new economy and the subprime mortgage crisis), Japan (the asset price bubble of the 1980s), Asia (the 1997 financial crisis) and the European Union (real-estate bubbles in Iceland, Ireland and Spain in the 2000s). Therefore, a new planning mechanism needs to be invented, since corporations continue to plan their activities at 
the national and international levels, while States follow market patterns, in other words, the consequences of strategic decisions taken by multinationals. This model differs from the Keynesian vision in which the State sets the rules of the game, making expectations converge around a growth path in which all actors participate in decision-making and in which private and social capital eventually falls under the control of the State and companies duly adapt. Today, we are living in a period in which the viability of the Greek growth regime is decided by Morgan Stanley or Goldman Sachs. This is clearly a question of national sovereignty and usurpation of the economic power conferred by the democratic system; in short, respect for citizens' decisions poses a serious dilemma.

\section{Collapse of belief in the neutrality of monetary policy}

In academic circles, the triumph of the new classical economy had finally convinced central banks and governments that monetary policy should be used only to keep inflation within strict limits so as to protect real activity at the macroeconomic level in the medium and long term. Important changes went unmade owing to the liberalization and proliferation of financial instruments and the corresponding increase in monetary liquidity. These were the direct cause of a series of financial bubbles, which initially provided rapid growth but later plunged the modern economies into a great systemic crisis. Similarly, central banks induced a crisis by stepping up the refinancing of banks in the hope that they would increase lending and thus boost investment and consumption. In Europe, for example, the mechanism whereby monetary policy is transmitted to the real economy has fallen into a liquidity trap; the fact that monetary policy has it limits does not mean that money is neutral.

To avoid the repetition of these episodes, it is essential that monetary policy be redesigned and recognized as contributing to activity levels, although this is not enough to guarantee financial stability (Boyer, Dehove and Plihon, 2004). Other instruments are needed, such as macroprudential supervision and reform of the aforementioned microprudential methods.

\section{In a depression, public spending becomes an useful tool to boost effective demand}

Contrary to the prevailing theory of Ricardian equivalence - which envisages null or negative multiplier effects - the capacity to boost demand in a depression is very useful. As the International Monetary Fund (IMF) eventually recognized and has demonstrated, multipliers are enhanced in periods of economic depression, which means that fiscal policy functions more 
effectively than monetary policy and can help stave off collapse, although there are limits to its ability to stimulate recovery, as demonstrated by the long period of stagnation in Japan since the 1990s. The clear recessionary effect of austerity policies in Europe since 2011 provides further empirical evidence of the power of Keynesian multipliers and the erroneousness of Ricardian equivalence when the economy is far from full employment (Boyer, 2012b).

\section{Absolute principles of competition policy are compromised, especially to bail out large banks and manufacturers}

It was once thought that competition policy was the sole tool for spurring innovation and growth. This was not the case in the European Union, whose southern economies have not reached the levels of research and development spending implemented in the north. Neither have significant economic and financial liberalization freed Latin America from its dependence on commodity exports or the weakness of its innovation systems.

Competition is the heart and engine of capitalism, but without strong collective control —as foreseen by Marx and confirmed by economic historyit becomes a process that repeatedly creates oligopolies and monopolies. Another question mark sits over the outcome of the Lehman Brothers crisis: an unprecedented concentration of financial institutions that are "too big to fail" or "too connected to fail". The changes witnessed stand in obvious contradiction to neoclassical ideology, in which the system is regulated by competition between small units.

\section{Erratic exchange-rate trends demonstrate the limitations of financial globalization: governments must have an exchange-rate policy}

In today's economy, with high capital mobility and an enormous volume of financial transactions in international trade, exchange rates derive from the process of equalizing the rate of return on mobile capital. This exchange rate has no short- or medium-term connection with the real exchange rate that is based on each country's integration in the world economy; in other words, there is a new understanding of the exchangerate regime (Bresser-Pereira, 2009). It is therefore important to devise one or more instruments to return to an exchange rate that permits viable international economic integration thanks to the resilience of a production system capable of supporting exports and achieving balance-of-payments 
equilibrium (Boyer, 2011c). For a long time, the IMF claimed that any disturbance in the equilibrium of the exchange-rate market undermined the efficient allocation of capital; nevertheless, it recently conceded that capital controls could be effective, at least partially and temporarily, in reducing the instability caused by sudden changes in internal and external capital flows.

\section{A more progressive income tax system is needed to respond to the failure of trickle-down economics}

The idea that high-income groups are conducive to economic development has foundered: were that the case, Latin America would be a highly developed region. Even though the richest man in the world lives in Mexico, it cannot be inferred that the country will develop as a result, since highly mobile capital and the absence of a progressive tax system make it impossible to remedy income inequalities. Consequently, a flat rate system is no longer considered ideal and some countries, notably Brazil, have explored increasing income redistribution and have in fact managed to reduce inequality (Boschi, 2009). Long-term historical studies show that progressive income and inheritance tax systems played an important role in reducing economic and social inequalities after the Second World War. By contrast, implementing a flat tax rate and lowering taxes on capital have contributed decisively to rising inequality since the 1980s (Piketty, 2013).

\section{The welfare State and growth}

Ideological and theoretical representations of welfare exert influence on the reforms implemented in various countries. The argument that Beveridgean systems drive up labour costs and undermine competitiveness and employment is presented as justification for welfare cuts, while Bismarckian systems are facing the tax revolt of the middle classes and the erosion of their tax bases due to high financial capital mobility. Social security is regarded as a pure cost without any positive or significant contribution. This reductionist accounting-based vision totally neglects the fact that social security promotes well-being, generally reduces inequality and may also be the catalyst for dynamic economic efficiency. This trilogy was first pointed out in studies that sought to interpret the "Dutch miracle" (Visser and Hemerijck, 1997) (see diagram X.6). 


\section{Diagram X.6}

How some welfare systems enhance dynamic efficiency

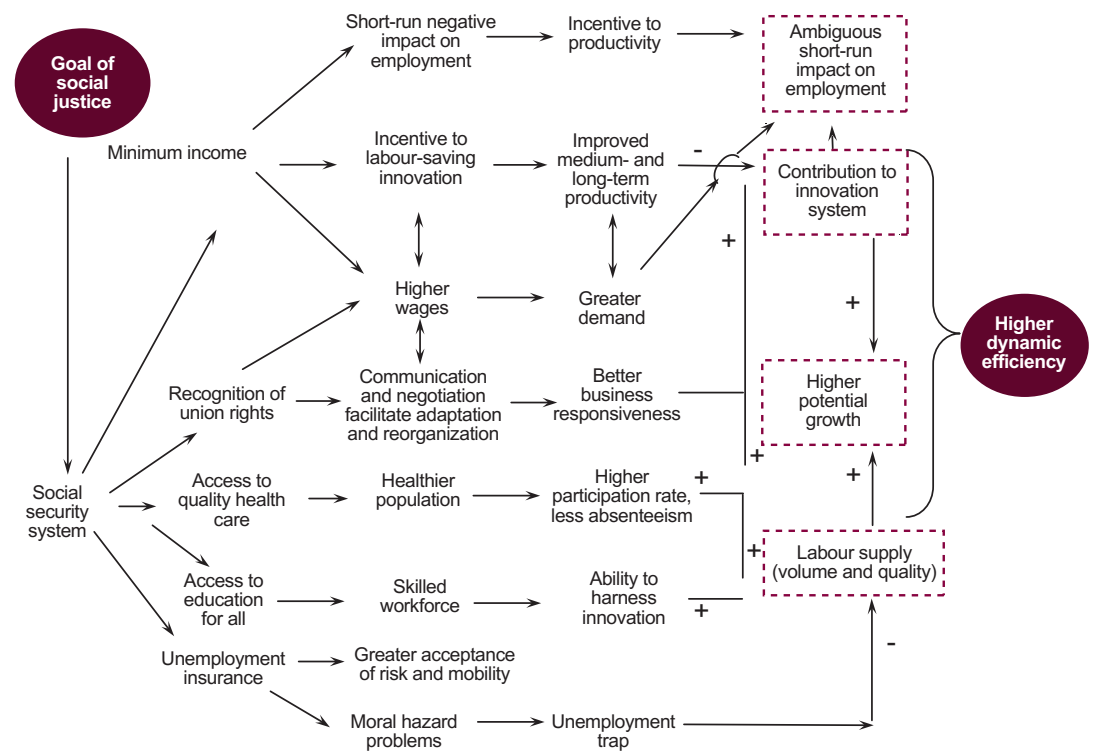

Source: Prepared by the author.

\section{Investment in health and education increases well-being}

Education means nurturing informed citizens who are capable of making decisions; effective health-care systems provide longer lives free of serious diseases; and unemployment benefits and the minimum wage reduce poverty among wage earners. Yet while these services have improved wellbeing, their contribution is not measured by current methods of calculating national accounts.

Where the provision of education, health and insurance against economic risks are collectively organized and financed by society-wide contributions, the welfare and tax systems exert a clear redistributive impact and are tools for reducing inequality. Conversely, the individualization of insurance contracts, the decentralization of many welfare components and the rise of pension funds are sources for diverging trajectories among individuals with quite similar initial characteristics. 


\section{Welfare systems: reconciling the theories of Keynes and Schumpeter}

The impacts of the welfare State on the economy are numerous and may contribute to innovation, growth and economic performance. A dynamic policy of minimum wage increases might temporarily harm less productive firms, but offers an incentive for labour-saving innovations and a long-run increase in productivity. Furthermore, within wage earner societies, salaries are key determinants for consumption and global demand and thus they may offset the labour-saving bias of technological change through the coevolution of demand.

In a sense, the conceptions of Schumpeter and Keynes are more complementary than opposed (Dosi, 2008). Health expenditures contribute to better health, less absenteeism and longer life expectancy, which in turn allow for a higher return on investment in education and training. Education for the majority of the population, conceived as the acquisition of the ability to learn how to solve problems, brings a key ingredient to the dynamism of national systems of innovation. Nordic countries have built on the suggestions that emerged from the aforementioned "Dutch miracle" and now recurrently adjust the complementarity between their welfare and innovation systems (Boyer, 2014).

Both Keynes and Schumpeter propose a similar update concerning unemployment benefits: these do not create an "unemployment trap", but a generous replacement rate, complemented by an active training policy in order to reassign workers from obsolete sectors to rapidly growing, high productivity ones. Thus, with the exception of the Nordic countries, the fundamentals of a universal welfare State in symbiosis with the national innovation system have been abandoned in favour of a crude cost-cutting approach, with complete disregard for the adverse effects on population wellbeing, long-run production capacity and the ability to innovate and explore the upgrading of international specialization (Amable, Boyer and Barré, 2008).

\section{E. The consequences of globalization}

While the above macroeconomic analysis is appealing, it suffers from one important defect: it is based on the assumptions that national economies are implicitly closed and that financing is determined by real factors. These assumptions are out of date in today's world.

\section{The great danger of financial globalization}

It might be assumed that the spectacle of the 1997 Asian financial crisis would serve as a warning for other countries that succumbed to the charms of 
financial globalization and the rapid growth of loans denominated in foreign currency, in this case the dollar. Capital is attracted to emerging economies but flees when adverse events occur, leading banking and exchange-rate crises to erupt simultaneously: the former because credit expands faster than the economy can absorb it, causing speculative, real-estate and stock market bubbles, while the inability to repay foreign-currency-denominated loans feeds widespread mistrust of the local currency. Nearly all studies of financial crises arrive at the same conclusion: opening the capital account and allowing domestic agents to become indebted in foreign currency is extremely dangerous, unless the utmost caution is exercised with regard to prudential regulation and oversight (Boyer, Dehove and Plihon, 2004).

In the late 2000s, a number of countries that had recently joined the international system, particularly new European Union member States from Eastern Europe, adopted the same risky strategy that the Asian countries employed in the 1990s. Bulgaria, Estonia, Hungary and Latvia all saw credit surge as a proportion of GDP, and allowed borrowing in euro-denominated loans, resulting in heightened risk (see table X.2). While international financial institutions were trying to diversify these countries' portfolios and attract direct investment, the national authorities settled for economic growth.

Table X.2

Factors increasing the likelihood of twin crises, 2009

\begin{tabular}{lccc}
\hline & $\begin{array}{c}\text { Foreign-currency loans } \\
\text { (percentages } \\
\text { of the total) }\end{array}$ & $\begin{array}{c}\text { Foreign-currency credit } \\
\text { (percentages } \\
\text { of GDP) }\end{array}$ & $\begin{array}{c}\text { Short-term credit } \\
\text { (less than one year) } \\
\text { (percentages) }\end{array}$ \\
\hline Republic of Korea & 9.5 & 119.0 & - \\
\hline India & 1.4 & 81.0 & - \\
\hline Brazil & 2.0 & 61.0 & - \\
\hline Czech Republic & 8.0 & 97.3 & 5.8 \\
\hline Poland & 24.0 & 58.3 & 18.2 \\
\hline Hungary & 55.0 & 106.7 & 13.2 \\
\hline Slovakia & 35.0 & 107.2 & 28.2 \\
\hline Bulgaria & 53.0 & 90.3 & 19.6 \\
\hline Romania & 54.0 & 66.7 & 14.8 \\
\hline Lithuania & 61.0 & 94.7 & 25.7 \\
\hline Estonia & 82.0 & 161.0 & 33.6 \\
\hline Latvia & 86.0 & 134.2 & 9.1 \\
\hline Turkey & 29.0 & 23.8 & 10.2 \\
\hline Ukraine & 49.0 & 31.3 & \\
\hline Source: Prepared & & \\
\hline
\end{tabular}

Source: Prepared by the author on the basis of International Monetary Fund (IMF).

The crisis in the United States gradually spread to the rest of the world, producing a reversal in direction as capital flowed back towards large financial centres, despite their also being in crisis, since it was believed that they could provide greater guarantees than emerging economies. It may 
be stated that the world is witnessing the re-emergence of twin financial crises in globalized countries. Seemingly the only countries to have learned from the Asian crisis were those that were directly affected, with emerging economies in general paying little heed to that lesson. Yet while the Republic of Korea and Brazil suffered several profound crises, the Eastern European countries did not.

\section{Advantages and disadvantages of the growing interdependence of economies}

If there is no single pattern that development models and inequality regimes follow, then why are they so persistent? Boyer (2014) shows that a rather coherent or at least internationally compatible system is gradually being formed (see diagram X.7).

\section{Diagram X.7}

Complementarity of national inequality regimes and development models

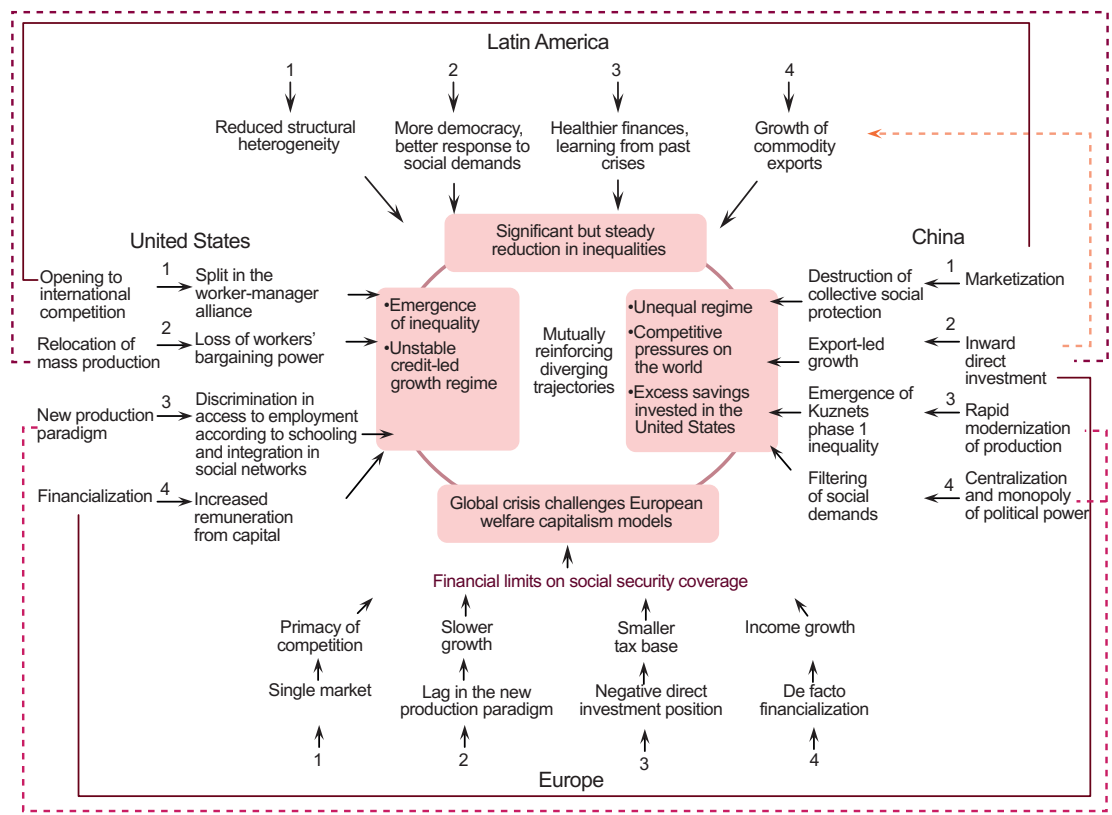

Source: Prepared by the author.

Expanding incomes under the finance-led growth regime in the United States ran parallel to the widening inequality generated by the rapid modernization of production in China. This is not the only co-evolution within the world economy. 
Indeed, the euro crisis, the threat to extended welfare systems and the defence of social solidarity are the consequence of the joint pressure exerted by China's catching-up in most industries and the recurring global financial crises caused by the United States' promotion of liberalization and globalization in trade, capital and finance.

The Latin American paradox - an atypical fall in economic inequality starting from an extreme social polarization - is also explained by the region's specialization (complementary to those of China and the United States), its ability to learn from recent financial crises, and its transition to democracy, as well as the fact that governments have finally responded positively to demands for social protection.

The macroeconomic imbalances driven by widening inequality within each domestic economy are symmetrical in the United States and in China; consequently, only compensating movements in international trade and finance permit the viability of socioeconomic regimes that could not be sustained behind closed borders: abundant credit to sustain living standards despite stagnant average real income in the United States; industrial overcapacity due to shrinking labour participation in China, and low household saving rates in the United States compared with Chinese high savings, partially channelled back to the United States financial system. Thus, the internationalization of production, capital and finance makes contrasted inequality regimes seem compatible and viable, since they are embedded into complementary development models. This also explains opposite evolutions concerning inequality: there is less inequality between countries because globalization permits a variety of finance-dominated growth regimes — such as those led by exports, innovation or commodities- but each of these regimes nurtures widening inequalities for individuals within the same nation-State.

\section{Conclusions}

Widening inequality emerged as one of the main challenges for most countries during the 2010s, threatening social cohesion, eroding political legitimacy and ultimately undermining the resilience of economies. For that reason we must question the premise of the new classical theory that regards inequality as the vector of an emergent growth regime, and which rests on the idea that inequality is needed to motivate workers, stimulate investment and promote innovation as a source of growth and job creation.

In this context, the search for alternative socioeconomic systems could draw inspiration from the experiences of the United States and Europe after the Second World War: strict market supervision and strong public intervention simultaneously reduced inequality and promoted rapid and relatively stable 
growth. However, a return to these experiences cannot be extrapolated, owing to changes in the modern world caused by the internationalization of production, the new productive model and the power of financial globalization. Instead, the conceptual framework developed by economists from social democratic countries should be mobilized to demonstrate the conditions required for an extensive welfare State in which economic efficiency and social justice are compatible and even complementary. This approach could be adapted to the specific circumstances of Latin America.

The goals and instruments of economic policy vary in accordance with the socioeconomic system. As a result, it would be dangerous to keep applying the same policies that led to a succession of crises born of careless liberalization, especially of finances, or to return to the policies of the postwar period without bringing them up to date. What might be the principles of a policy for the twenty-first century and for development? First, it must be recognized that stabilizing inflation through a prudent monetary policy does not guarantee financial stability, but that finances must be regulated. Outside of full employment, unemployment is involuntary, and therefore monetary and fiscal policies can affect the level of activity. In a depression, public spending recovers its efficiency in reducing unemployment. Exchange rates cannot be determined solely on the basis of short-term capital movements, but should allow the national economy to participate in the international system through an efficient production model. Lastly, if the policy game does not allow for the reinstitutionalization of wage distribution, then a progressive taxation of income and capital is needed.

The world has gone through a period of radical transformation of economies, societies and international relations, but the great theories inherited from the past provide only an imperfect analysis of these changes. In the long term, capitalism and its theories should change concurrently. However, almost all economists base their analyses on theories that are out of date - the neoclassical school by a century; Keynesianism by 50 years and regulation theory by a decade- - which is why they should be cautious when evaluating and judging the current economic situation, and when advising politicians. Accordingly, this chapter sets out a global vision that can be applied to theories, then abstract models, and finally in applied models, which would be useful in guiding decisions on economic and social policies and long-term strategies. Today's world has experienced such profound change that the theories of the past have lost relevance. It is to be hoped that a period of great theorization, similar to that of the 1930s, is about to unfold. 


\section{Bibliography}

Aglietta, Michel (1982), A Theory of Capitalist Regulation: The US Experience, New York, Schocken Books.

Amable, Bruno (2003), The Diversity of Modern Capitalism, Oxford, Oxford University Press.

Amable, Bruno, Robert Boyer and Remi Barre (2008), Los sistemas de innovación en la era de la globalización, Madrid, Mino and Davila.

Andre, Christine (2003), "Ten European systems of social protection: an ambiguous convergence", European Social Security and Global Politics, Danny Pieters (ed.), London, Kluwer Academic Publishers.

Andre, Christine and Robert Delorme (1983), "Matériaux pour une comparaison international des dépenses publiques", Statistiques et Etudes Financières, No. 350. (1982), L'etat et l'économie, Paris, Seuil.

Artus, Patrick (2009), "Le problème essentiel pour la régulation financière et pour le système monétaire international: la finance procyclique", Flash Économie, No. 155, Paris, Natixis, 3 April.

Bizberg, Ilan and Theret Bruno (2012), "La diversité des capitalismes latinoaméricains: les cas de l'Argentine, du Brésil et du Mexique", Revue de la régulation, No. 11 [online] http:/ / regulation.revues.org.

Boschi, Renato (2009), "Estado desarrollista en Brasil: crisis, continuidad, incertidumbres", Working paper, University Research Institute of Rio de Janeiro (IUPERJ), unpublished.

Boyer, Robert (2014), "Is more equality possible in Latin America? A challenge in a world of contrasted but interdependent inequality regimes", Working Paper Series, No. 67 Berlin [online] http://www.desigualdades.net/Resources/ Working_Paper/67-WP-Boyer-Online.pdf.

(2013a), "Financial innovations, growth and crisis. The subprime collapse in perspective", Crises of Global Economies and the Future of Capitalism. Reviving Marxian Crisis Theory, Yagi Kiichiro and others (eds.), Routledge, Abingdon. (2013b), "Origins and ways out of the euro crisis: supranational institution building in the era of global finance", Contributions to Political Economy, vol. 32, 7 June [online] http:/ / cpe.oxfordjournals.org.

(2012a), "Diversité et évolution des capitalismes en Amérique latine. De la régulation économique au politique", Revue de la régulation, vol. 11 [online] http://regulation.revues.org/9720.

(2012b), "The four fallacies of contemporary austerity policies: the lost Keynesian legacy", Cambridge Journal of Economics, vol. 36.

(2011a), "A new epoch but still diversity within and between capitalism. China in comparative perspective", Capitalist Diversity and Diversity within Capitalism, Christel Lane and Geoffrey T. Wood (eds.), Routledge, Abingdon. (2011b), Diversity and Transformations of Asian Capitalisms, Hiroyasu Uemura and Akinori Isogai (eds.), London, Routledge.

(2011c), "Aprender de las crisis financieras. Cómo organizar sistemas financieros domésticos desarrollistas?", Las instituciones financieras y el crecimiento económico en el contexto de la dominación del capital financiero, Noemi Levy Orlik and Teresa López González (coords.), Mexico City, National Autonomous University of Mexico (UNAM). 
(2011d), "Les financiers détruiront-ils le capitalisme?", Economica, Paris.

(2004), "Du 'consensus de Washington' a la 'proposition de São Paulo'?", Mondialisation et compétition: pourquoi certains pays émergents réussissent et d'autres non, Luiz Carlos Bresser-Pereira, Paris, La Découverte.

(2000), "Is a finance-led growth regime a viable alternative to Fordism? A preliminary analysis", Economy and Society, vol. 29, No. 1, February. (1986), La théorie de la régulation: une analyse critique, Paris, la Découverte.

Boyer, Robert and Yves Saillard (eds.) (2001), Regulation Theory: The State of Art, London, Routledge.

Boyer, Robert, Mario Dehove and Dominique Plihon (2004), "Les crises financières", Rapport du CAE, No. 50, Paris, La documentation française.

Bresser-Pereira, Luiz Carlos (2009), Pourquoi certains pays émergents réussissent et d'autres non, Paris, La Découverte.

Campbell John, John Hall and Ove K. Pedersen (2008), National Identity and the Varieties of Capitalism. The Danish Experience, Copenhagen, DJOF publishing.

Dosi, Giovanni (2008), "Schumpeter meeting Keynes: a policy friendly model of endogenous growth and business cycles", LEM Paper Series, No. 21, Santa Ana School of Economics.

Duflo, Esther (2011), "Balancing growth with equity: the view from development", paper presented at the 2011 Jackson Hole Economic Policy Symposium: The Facts, Wyoming, 25-27 August.

ECLAC (Economic Commission for Latin America and the Caribbean) (2012a), Structural Change for Equality: An Integrated Approach to Development (LC/G.2524(SES.34/3)), Santiago.

(2012b), Latin America and the Caribbean in the World Economy, 2011-2012 (LC/G.2547-P), Santiago, Chile, October.

Fukuyama, Francis (1992), The End of History and The Last Man, New York, Free Press.

Galbraith, James K. (2012), Inequality and Instability. A Study of the World Economy Just before the Great Crisis, Oxford, Oxford University Press.

Harada, Yuji and Hironori Tohyama (2012), "Asian capitalisms: institutional configurations and firm heterogeneity", Diversity and transformations of Asian Capitalisms, Boyer Robert, Hiroyasu Uemura and Akinori Isogai (eds.), London, Routledge.

Jiménez, Juan Pablo and Isabel López Azcúnaga (2012), “Disminución de la desigualdad en América Latina? El rol de la política fiscal", Working Paper Series, No. 33, Berlin [online] http://www.desigualdades.net/Resources/Working Paper/33_WP_Jimenez_Online.pdf.

Lavinas, Lena (2012), “Brasil, de la reducción de la pobreza al compromiso de erradicar la miseria", Revista CIDOB d'Afers Internacionals, No. 97-98, April.

Lopez Gallardo, Julio (2005), "Income distribution in Latin America. Theoretical considerations and Mexico's experience", Economie Appliquée, vol. 58, No. 3.

Milanovic, Branko (2012), "Global income inequality by the numbers: in history and now", Policy Research Paper, No. 6259, World Bank, November. (2007), "Globalization and inequality", Global Inequality, Held David and Ayse Kaya, Cambridge, Polity Press.

Pedersen, Ove (2008), "Corporatism and beyond: the negotiated economy", National Identity and the Varieties of Capitalism. The Danish Experience, John Campbell, John Hall and Ove K. Pedersen, Copenhague, DJOF publishing. 
Piketty, Thomas (2013), Capital in the Twenty-First Century, Harvard University Press. Prebisch, Raúl (1981), Capitalismo periférico, crisis y transformación, Mexico City, Fondo de Cultura Económica.

Samuelson, Paul A. (1948), Economics: An Introductory Analysis, McGraw-Hill.

Stiglitz, Joseph E. (2012), The Price of Inequality. How Today's Divided Society Endangers our Future, London, WW. Norton \& Company.

Telo, Carlos (2012), Sobre la desigualdad en México, Mexico City, Faculty of Economics, National Autonomous University of Mexico (UNAM).

UNRISD (United Nations Research Institute for Social Development) (2010), Combating Poverty and Inequality. Structural Change, Social Policy and Politics, Geneva.

Visser, J. and A. Hemerijck (1997), 'A Dutch Miracle' - Job Growth, Welfare Reform and Corporatism in the Netherlands, Amsterdam University Press. 



\section{Chapter XI \\ Transformation of the State and development paradigms in Latin America}

René A. Hernández ${ }^{1}$

\section{Introduction}

This essay outlines the relation between the challenges involved in transforming the state and the evolution of the different development paradigms and strategies that have been applied in Latin America. It attempts to demystify the false dilemma of conceptions that view the function of the state and the role of the market in economic activity as mutually exclusive. In particular, the aim is to clarify whether any development paradigm and related strategy involves deciding on and adopting a position on the limits of the state and public policy, as suggested by O'Donnell (2008a). A further aim is to revive an element in Prebisch's cosmovision that seems to be essential for our times, and particularly for Latin America: his balanced view of interventionist measures and respect for the market, along with his high level of pragmatism, always focused on the need to keep a close watch on the changing international order or world development in general.

Latin American and Caribbean Institute for Economic and Social Planning (ILPES) of the Economic Commission for Latin America and the Caribbean (ECLAC). The opinions expressed in this document are the author's responsibility and in no way commit the institutions to which he belongs or the other entities mentioned. 
This essay does not present a formal history of the region's development paradigms or make an epistemological analysis of Latin American development in the history of economic thought. As noted by Ocampo (2008), a history of Latin American economic thought as such does not exist. Instead, the essay aims to put forward a number of interpretations of the different development paradigms and role of the state, and to link Prebisch's thinking to each line of interpretation and its relevance for the current post-developmental debate. ${ }^{2}$

The text is divided into five parts including this introduction. Section A reviews the key concepts of the debate between the state and economic development and invokes the key texts published on the subject by the Economic Commission for Latin America and the Caribbean (ECLAC). Section $B$ reviews the main paradigms and fundamental elements that have characterized it. Section C discusses the current validity of Prebisch's ideas and their influence on Latin American economic thought; and section D sets forth final comments and thoughts.

\section{A. Concepts of state and development: a number of approaches}

The relation between state and development can be established in at least two ways. The first uses a political-economy approach, starting from a theoretical or historical stance. The second is based on one of the various theories of the state - organic, contractualist, institutionalist, or original Marxist, the theory of Gramsci and Poulantzas, or Weberian theory. A similar path can be followed when studying development, by adopting either a theoretical or a historical approach and using one of the theories of economic growth and development —classical, neoclassical, structuralist, neo-structuralist or evolutionist.

This essay adopts an institutionalist theory to justify state intervention in the context of structural change. Stylized proposals are developed and definitions and conceptual clarifications are put forward which, in turn, make it possible to establish the link between state and development. It then reviews the central contributions made by ECLAC in that domain through some of its institutional texts; and, lastly, Prebisch's ideas on the subject are revived to assess their currency in the contemporary debate.

\footnotetext{
As references, the reader is recommended to consult the classic texts: Bulmer-Thomas (2011) on the economic history of Latin America; Sunkel and Paz (1970), Thorp (1998), or the recent text by Bértola and Ocampo (2012) on Latin American economic development since the independence processes. On the evolution of ECLAC thinking and Latin American structuralism, the essential texts include Rodríguez (2006), Rosenthal (2004), Bielschowsky (1998a, 1998b and 2010) or Love (1994), to name a few of the most outstanding. On the renewal of ECLAC thinking since the 1980s, also known as neostructuralism, see the compilations madebySunkel(1991), Ffrench-Davis(2005), Ocampo and Ros (2011), Ocampo (2008), Stallings and Peres (2000) and Fajnzylber (1993).
} 


\section{The concept of State: basic propositions}

The first proposition of this essay entails recognizing that the state and its political economy are decisive variables in economic and social development. The political dimension is included because of the basic assumption that there is a common interest shared by all (the common good). Various solutions to the state-market dilemma and the challenge of development have been proposed, ranging from the populist left to the progressive left, and from the pragmatic centre-right to the neoliberal right and modern centre-left. All of the paradigm shifts in the twentieth and twenty-first centuries have been framed by global capitalist accumulation, and they largely explain the vagaries of the region's economic and social development.

The equilibrated and efficient market of the neoclassical economists has been called into question since the Great Depression of the 1930s, then with the debt crisis of the 1980s and, more recently, as a result of the financial crisis in 2008. Now, even the most vehement neoliberals accept some forms of state intervention as inevitable, owing not only to the presence of externalities but also to the ubiquity of incomplete markets, asymmetric information and incipient institutional development. ${ }^{3}$ The false dilemma between state and market must be rejected in favour of the correct relationship for study: the state's role in the market.

The second proposition concerns the fact that the state, in its broadest conception, is an institutional construction and, thus, a fundamental variable in explaining why some countries are wealthier than others (Chang, 2003). To address that topic, not only is it necessary to adopt a theory of the state, but to do so based on an analysis of the institutional dynamic and a theory of institutional change. This means redefining what is public and constructing or reconstructing institutions founded on the general good, and on something that is distinct from the sum of private interests. On that point, North (1990) states: "I wish to assert a much more fundamental role for institutions in societies; they are the underlying determinant of the long-run performance of economies. If we are ever to construct a dynamic theory of change - something missing in mainstream economics and only very imperfectly dealt with in Marxist theory-it must be built on a model of institutional change".

The key element of the polemic of neoliberalism on this topic is related to the "welfare state" owing to the supposed weakening of institutions that would occur as a result of patronage practices that would subsequently lead to totalitarianism or, as Hayek calls it, to a "road to serfdom". Moreover, in Free to Choose, Milton Friedman claims that "Economic freedom is an essential requisite for political freedom. By enabling people to cooperate with one another without coercion or central direction, it reduces the area over which political power is exercised. In addition, by dispersing power, the free market provides an offset to whatever concentration of political power may arise. The combination of economic and political power in the same hands is a sure recipe for tyranny." (Friedman, 1990). 
Recognition of the state's role in the development process has accompanied the rediscovery of the role of institutions in the economic performance of individual nations. The seminal studies by O. Williamson (1985), The Economic Institutions of Capitalism, and D. North (1990), Institutions, Institutional Change and Economic Performance, are basic references that challenge the assumption that institutions are generated spontaneously as a byproduct of economic growth; when, in reality, institutional improvements are the essential and decisive preconditions for growth. More recently, Rodrik (2002, 2004 and 2007), Chang (2003) and Acemoglu and Robinson (2012) have adopted similar approaches by arguing that institutions are the main variable explaining why some nations are wealthier than others and why some fail in their pursuit of greater well-being, growth and economic development.

The institutionalist theory has been gaining ground and has consolidated its status as an alternative way to interpret the state's role in the development process. It argues that the success of an economy depends on a set of institutions, including those that comprise the market; and it also recognizes that non-market institutions — such as business networks, labour unions, transnational firms, national innovation systems, industrial policies and social corporatism - are key elements of this broad matrix. State intervention is justified in a context of structural change, which means farreaching changes in the productive structure, technology and institutions. The state fulfils two functions in facilitating this structural change: (i) providing a long-term vision of the future and the construction of new institutions; and (ii) mediating the resolution of conflicts that often arise during the structural change process (Chang, 2003).

The third proposition is that the state in Latin America tends to be social-liberal, and increasingly democratic, with various interpretations of globalised capitalism and a growing trade and regional integration. The social dimension responds to the fact that states continue and will continue to have responsibility for protecting social rights such as health, education, and social security. For example, after the 2008 crisis, the plans adopted by the vast majority of countries in the region included lines of action involving care for vulnerable sectors, job loss mitigation, and restoration of the productive fabric, with a view to halting a potential erosion of the previous decade's achievements in combating poverty and reducing income inequality.

The liberal dimension of the state in Latin America can be seen in the way state functions are fulfilled - more competitively and transparently, and with better accountability mechanisms, avoiding the monopoly of state bureaucracy in the budgetary appropriations for education, health and infrastructure. The social-liberal state does not replace the market but complements it (Bresser Pereira, 1998). 
For those reasons, instead of focusing on normative aspect of what the "correct" function of the state should be, according to the various strands of conservativism and social liberalism, or neoliberalism and some forms of radicalism, it is far more interesting to investigate the underlying reasons why some states have more of a developmentalist propensity than others. Ultimately, what is expected of any state is that it should be acceptably effective, legitimate and representative, capable of forging political, economic and social pacts of national scope, socially responsible and with a capacity to develop long-term visions and, in particular, capable of maintaining governability and governance with a strong developmentalist bias. ${ }^{4}$

Before analysing the relation between state and economic development, a number of important clarifications and definitions need to be made and contextualized in Latin America and the Caribbean. ${ }^{5}$ Today much of the region has democratic regimes and governments, which display different degrees of maturity and efficiency, while also suffering from significant failings and shortcomings. In Latin American practice there is no "optimal" or "prototype" state, nor a unique and dominant political model. That situation forms the political backdrop against which development paradigms, strategies and models, democratic processes and changes and, fundamentally, the role and limits of the state, must be debated (O'Donnell, 2008a).

O'Donnell (2008a) defines the democratic regime as the regular and institutionalized holding of free, institutionalized and reasonably competitive elections; and the upholding of a number of "political" freedoms, such as freedom of opinion, expression, association, movement, access to non-monopolized journalistic media, and other similar freedoms. In these spheres, two fundamental rights are exercised: one, voting freely in elections for individuals to occupy high positions of state (governments); and the other, to be elected to occupy the respective posts, if one so wishes.

O'Donnell (2008a) also defines the state as a set of institutions and social relations (most of them sanctioned and backed by the legal system of the state in question), which normally penetrates and controls the territory of the inhabitants which it is intended to define geographically. As a last resort for enforcing their decisions, those institutions have supreme control

Bresser Pereira (1998) argues that governability exists when the government's legitimacy is underpinned by political institutions that are capable of representing and intermediating legitimate sector interests; and that governance exists when the state has financial and administrative capacity to implement the policies decided on by the government.

5 See ILPES (1995) for the best collection of essays on the reform and modernization of the state of that decade. 
of the means of physical coercion that some specialized agencies of that state normally exercise throughout its territory. ${ }^{6}$

In the Latin American case, states have arisen from widely differing historical processes. These differences cannot be ignored, and they largely explain the adoption and adaptation of different "styles of development", uneven speeds in their democratic development processes, unequal institutional progress and differentiated headway in combating poverty and inequality. ${ }^{7}$

States are also changing and dynamic entities that are adapted and transformed within the national and international environment. They make progress but also suffer setbacks. They are not immutable and, ultimately, they are social organizations consisting of institutions which may be weak or strongly constituted and rooted in the social construct. In that sense, any generalization of the state is adventurous, and any prescription oversimplistic (O'Donnell, 2008b).

According to that definition, the state can be explained on the basis of four dimensions. Firstly, it could be seen as a set of bureaucracies, consisting of complex organizations that have legally assigned responsibilities aimed at safeguarding or protecting some aspect of the general public interest. ${ }^{8}$ Secondly, it could be a legal system consisting of legally established and sanctioned rules that are applied to social relations and contracts. Thirdly, it could be considered as a unit of collective identity for the inhabitants of its territory -in other words a state from the perspective of its people. Lastly, the state can be a decanter or sieve that regulates the space and border of the territory, the population and the market that defines it. In synthesis, the

6 Note that this Weberian definition refers to what the state is and not to the extremely broad range of definitions on what it does or should do. The analysis is not only on the state, but also on states that are or self-proclaim to be national. Following O'Donnell (2008b), the nation does not precede the state, but it strives to create it. He defines the nation as an arc of solidarities, a political and ideational construction that postulates the existence of an "us" that entails a claim of loyalty above and beyond other entities and interests and which, if it does not already have it, frequently seeks to settle or define itself in a territory defined by a state.

7 Anibal Pinto (2008) defines the "style of development" as the way in which human and material resources are organized and assigned within a particular system with the object of solving questions such as what goods and services to produce; how; and for whom. More specifically, it notes two sets of features: (i) those which make up the structural basis of the production apparatus, especially the sectoral structure of the product and employment, the various technological strata, and the predominant type of external relationship, and (ii) the dynamic elements of the system, which are revealed by analyzing the level and composition of demand and its basic underlying factors, such as the level and distribution of income. These two sets of features are closely linked by a circle of mutual cause and effect (Cardoso and Faletto, 1979; Cardoso, Prebisch and Green, 1982).

8 In that context, bureaucracy is defined as a set of social relations of command and obedience which is hierarchically governed by formal and explicit rules, which are valid within a complex organization (O’Donnell, 2008b). 
definition refers to the efficiency of state bureaucracies, the effectiveness of the legal system, the role of the state as a focus of identity, and its condition as a sieve regulating the space and territory ( $\mathrm{O}^{\prime}$ Donnell, 2008a and 2008b).

The paradigm shift that Latin America has been confronting for several years, like all changes of that type, is less perceptible and recognized, owing to the delay by state institutions in adopting or implementing changes in ways of "being and doing" things. The need for change arises because the evident mutations of society are not yet adequately matched by institutional changes, nor are comprehensive responses being made to social, economic and environmental problems. Globalization, the profound technological revolution and recent techno-economic paradigms, scientific progress, but also pressure on the environment, demographic changes, migrations, natural disasters, climate change, and territorial disparities, are some of the dimensions that are undergoing changes and represent some of the most important gaps at the present time. But institutions that are capable of addressing or guiding those changes do not yet exist or have not been consolidated. Consequently, demands for greater equality, greater opportunities for a larger number of people, better and greater participation in policy decisions and greater transparency, among others, remain as current as ever on the public agenda.

One interpretation of the current situation of Latin American states is that they face a major deficit and are a reflection of deep contradictions, structural heterogeneity, the long history of inequalities and inequities, convulsed critical paths, and incomplete fiscal reforms that have characterized the region. There are states that lack sufficient credibility in their role as suppliers of public goods, collectors of tax revenue, guarantors of social protection, and promoters of productivity and employment. Nonetheless, the same citizenry is increasingly clamouring for a more central role for the state (ECLAC, 2010).

The state-market equation that has prevailed for the last three decades has proven unable to meet the global challenges of today and tomorrow. Accordingly, the challenge now is to put the state in the place that corresponds to it looking to the future. The debate should focus on the development model and orientation, on the subject and ultimate end of development and on the means to achieve it.

\section{The concept of development and ways of thinking about it}

There are basically two ways of conceiving of development. The first and most intuitive is as a change in people's conditions of life, along with the processes needed to achieve it. This is associated with concepts of progress, prosperity 
and well-being. ${ }^{9}$ The role of actors, institutions and organizations in this process is what is referred to as the strategic development vision. In that sense, development is seen as the outcome of a process involving actors, organizations, and means to achieve a set of pre-defined targets. According to the Hirschman (1980) narrative, more than just combining scarce resources effectively, a development strategy must seek to empower the use of capacities that are hidden and disseminated in society, in a collective development-driven effort.

The second way to approach the concept of development is closer to the Weberian idea of the history of social change, and does not see it as the outcome of a strategy, policy or deliberate public action, but of the functioning of the system composed by its institutional and social structure (Veltmeyer, 2010). In fact, any "development" can be defined on the basis of its strategic or structural factors; and any public policy, irrespective of its origin or conception, has a strategic dimension and another structural one.

The idea of freedom or "development as freedom" as formulated by Sen (1999) was based on the philosophy of social liberalism and can be understood as the merging of ideas of progress, equality and freedom. In that context, development is understood above all as a matter of freedom that expands the choices available to individuals and stimulates them to make the most of their opportunities; in other words, the process of expanding the real freedoms that people enjoy. The state's role is to level the playing field, reform institutions, ensure greater social inclusion, and raise human capital capacities with a view to exploiting opportunities, such as educational ones.

The first Human Development Report published by the United Nations Development Programme (UNDP) defines "sustainable human development" as the process of expanding people's abilities and options so they are capable of satisfying their own needs.

In Latin America, and in the framework of structuralist currents, development consisted of the incorporation of technical progress and its dissemination in the productive and social apparatus, with a view to changing the productive structure as part of a long-term cumulative process. That process included capacities, organization of the state, capital, technology and synergies and complementarities between the public and private spheres. ${ }^{10}$ Development occurred in a given space and time and, as noted over two decades ago by Sunkel (1991), the only development that is possible is "from within"; in other words, it is first and foremost an endogenous process that cannot be imported.

Note that the concept of development has not remained constant through time, as will be seen below (Veltmeyer, 2010). For a notable exposition of the structural factors and modalities of development, see the classic essays of Anibal Pinto (1973).

10 In his 1950s texts, Prebisch states that the productive structure consists of the goods producing sectors, whereas the economic structure adds physical infrastructure and the service sectors (including services provided by the government). Consequently, according to Prebisch narrative, the characteristics of the productive structure condition those of the economic structure. 
In structural terms, following the Veltmeyer (2010) typology, the development process as "long-term change" in the broad evolution of societies, has been conceptualized and periodized on the basis of three "metatheories". The first focuses on the transformation of agrarian society and economy into an industrial system, in a process that can be generically considered as "industrialization". In that context, countries can be divided into three categories according to their stage of evolution: (i) preindustrial (agrarian); (ii) industrializing; and (iii) industrialized. One of the basic assumptions of this metatheory is that the degree of socioeconomic improvement would be a consequence of that change in the structure of economic production.

The second metatheory views the development process in terms of a fundamental transformation in the structure of values that sustain the system's institutional structure. Societies can thus be characterized as traditional, modernizing, or modern. The evolution of the system, or the passage from one system to another, can be conceived as the transition from a traditional society (oriented towards community-type values of self-help and solidarity) to a modern system aimed at individualism in which people seek to achieve a given position, instead of acting on the basis of society's needs.

The third metatheory is that of capitalist development, in other words the change from a pre-capitalist society and economy to a capitalist system. Under to that conception, the fundamental change is a consequence of a social transformation process, in other words from a society of small-scale farmers (peasant and small-scale farmers) into a proletariat, defined according to Marxian concepts such as social class, without means of production, which is forced to exchange its labour for a wage with which to live.

The three metatheories of development based on long-term change (industrialization, modernization and capitalist development) could be interpreted as three dimensions or different starting points of the same process, in other words, the "great transformation" in the narrative of Karl Polanyi (1944), where the market economy and the state should not be understood as separate elements or institutions, but as a joint human creation that Polanyi calls "market society". This process has taken several centuries and continues to unfold in the developing world.

\section{The state and development in the documents of the Economic Commission for Latin America and the Caribbean}

This article does not aim to review all ECLAC institutional documents on the relation between the state and development, since this is unnecessary for its purposes. The aim instead is to highlight documents which, owing to their importance and relevance, define a "before and after" in the debate 
on the state's role in Latin American development. ${ }^{11}$ The intention is to take advantage of the opportunity to display the vitality and currency of Prebisch's ideas in the contemporary debate on the state's role in development.

ECLAC thinking can be characterized as applying a historical-structural method and developing three analytical pillars that have remained in place throughout its intellectual production: (i) analysis of international engagement; (ii) analysis of the internal structural conditions on growth and technical progress, along with the relations between them and employment and income distribution; and (iii) analysis of the possibilities for state action. ${ }^{12}$

The first document is undoubtedly Economic Development of Latin America and its Principal Problems (Prebisch, 1949), which Albert Hirschman considered as the Latin American manifesto. This was the work that laid the theoretical and conceptual foundations for an underdevelopment model led by the state and outlined by Prebisch on the basis of a critique of international trade theory (Pérez Caldentey, Sunkel and Torres, 2013).

The genius of the "manifesto" was the capacity to mould a unique and convincing synthesis by examining the main determinants of economic activity in developing countries. The "centre-periphery" concept of the world economy was proposed to explain the dynamic and structure of global inequality. Development, according to Prebisch, meant adopting a posture and, consequently, the "manifesto" was proclaimed by an active state, in which the industrialization of the periphery was not an end in itself, but the means whereby developing countries could gain access to the benefits of technical progress and thus progressively raise their inhabitants' living standards. That view of industrialization was contrary to the dominant doctrine of comparative advantages and presented an option for Latin America from Latin America (Dosman, 2001; Rodríguez, 2001; Bielschowsky, 2010).

As that process was not expected to occur spontaneously (owing to shortages of foreign or domestic capital), it was inferred that it could only be generated and led by the sole agent of the periphery capable of doing so deliberately, with the aim of changing the productive structure of the

11 The best exposition of ECLAC economic thinking can be found in Bielschowsky (1998b and 2010), Rodríguez (2006), Rosenthal (1998 and 2004) and Love (1994). On Prebisch's thinking, see also Dosman (2006 and 2008), Pérez Caldentey, Sunkel and Torres (2013), Love (1980), Rodríguez (2001) and Iglesias (194).

12 According to Bielschowsky (2010), the historical-structural method is dedicated to the examination of social- productive and institutional specifics, and those pertaining to the international engagement of Latin American and Caribbean countries as (peripheral), in contrast to the characteristics of the "central" economies, and observed from the priority standpoint of their transformation in the medium and long term. Meanwhile, Sunkel and Paz (1970) state that the analysis of the limited applicability in time of economic laws suggest the need to define significant hypotheses for concrete historical situations. In other words, the historical nature of the object of economic science is recognized. 
peripheral economies, namely the state. The practical implication of this in the ensuing decades was broad use of the state's capacity to lead the industrial development process, and to promote planning and investment to generate a form of growth that was more consistent with the peripheral economies' social preference function (Glade, 1992).

The second document, entitled Growth, Disequilibrium and Disparities: Interpretation of the Process of Economic Development, is a work of five chapters that formed the first part of the Economic Survey of Latin America, 1949 (ECLAC, 1951). That document reflected many of the ideas being expressed at that time by the pioneers of development theory, Nurske, Lewis, Myrdal and A. Rosenstein-Rodan, among others, who together with Prebisch defined what many years later Krugman was to call the "High theory of development".

In addition to his critique of the scheme of international engagement and the generation of external vulnerability in the periphery, Prebisch used those two seminal texts to consider the essential ingredients of the Latin American structural school, namely: (i) the initial conditions of the internal structure which, given its underdeveloped status, hindered industrialization and the dissemination of technical progress in the periphery; and (ii) the validity of state intervention owing to the inherent complexity of those structures in the development process (Bielschowsky, 1998a and1998b; Rodríguez, 2006; Pérez Caldentey, Sunkel and Torres, 2013).

As noted by Pérez Caldentey, Sunkel and Torres (2013): convinced of the imperious need to create a set of consistent ideas to analyse and think specifically about Latin American phenomena, Prebisch constructed a new school of thought based on a vision of economic development and the region's international integration; in other words, through a creative, intuitive and inductive act that precedes and also is a prior condition for analytical research, Prebisch intellectually conceives the dynamic of the development process in the region.

The proposals contained in the aforementioned texts gained maturity in the ensuing years and are consolidated in Towards a Dynamic Development Policy for Latin America (ECLAC, 1963) and in The Process of Industrial Development in Latin America (ECLAC, 1966). The central element of those two texts was the broader analysis made of the state's role in the development process and above all in its planning. One of the most important advances made by those documents was the positioning of private enterprise in the social matrix, the analysis of redistribution policies and the reforms needed to the prevailing landholding regimes. This departed from the naive precept of state intervention and was early to recognize the limitations of the state in certain circumstances, since certain state interventions might generate distortions that would act in the opposite direction and perversely in the development process (Glade, 1993). 
In the 1970s, the text Change and Development: Latin America's Great Task (Prebisch, 1970) and the article "Public Enterprises: Their Present Significance and Their Potential in Development" of the Economic Bulletin for Latin America (1971), proved seminal because they systematically outlined the processes of state intervention through state or public enterprises and broadly proclaimed the relation between those processes and market failures and externalities. Although major contributions were made at the macroeconomic level and in public policy formulation, the links with technical progress and income distribution were not yet defined with all the transmission mechanisms, and a more finished proposal for the productive change process remained to be prepared.

Later, Fernando Fajnzylber, in La industrialization trunca de America Latina (1983) and in Changing Production Patterns with Social Equity. The prime task of Latin American and Caribbean development in the 1990s (1990) analysed four basic elements. The first relates to the industrialization strategy through the exportation of industrial products and consequent dynamic effects on job creation, productivity increase and real wage growth. In other words, achieving an "authentic" competitiveness (based on the incorporation of technical progress), instead of "spurious competitiveness" (based on falling real incomes) and promoting a dynamic changing production patterns that involves a growth with equity strategy. In that sense, as noted by Rodrik (2005), the exportation of industrial products with local processing helped to disseminate the industrial logic and, along the way, confirmed Prebisch's claim that the economic structure is important and what countries produce and export is a decisive factor in their economic performance.

The second aspect, in reference to the performance of the Asian tigers, is that industrial and commercial policy in those countries was based on a major import substitution component. Thirdly, in relation to the role of the state, it highlighted its non-neutral nature and its linkage and complementary relation with the business sector. The latter refers to the international context in which the industrialization experiences of the Asian tigers occurred.

Based on the productive change proposal formulated in 1990, ECLAC continued to develop the topic in greater depth, with a view to extending the proposals of the original document. This involved the documents Social Equity and Changing Production Patterns: An Integrated Approach and Population, Social Equity (ECLAC, 1992a) and Changing Production Patterns (ECLAC 1992b).

In 1995, the Latin American and Caribbean Institute for Economic and Social Planning (ILPES) published the text Reforma y modernización del Estado, which highlighted the importance of the quality and selectiveness of state interventions, rather than just the scale of the bureaucratic apparatus. In that way, it launched the debate on the limits of the public and private spheres. ILPES thus made an outstanding and pioneering contribution by 
concluding that there is no prototype state or uniform solution for all, the communities or the territories within the same country, and proposes three groups of emerging public functions of state reform: (i) classical government tasks: the provision of public goods; the management of macroeconomic imbalances; and the accumulation of social, physical, and human capital; (ii) harmonization, through government regulation, of private in relation to public interests; and the negotiation of pacts and agreements on the subject; and (iii) strategic management and the anticipatory role of the state by constructing future and long-term visions with the aim of guiding the development dynamic.

In 2000, the publication Equity, Development and Citizenship comprehensively addressed the multidimensional nature of development and proposed new ways of viewing public action, from the standpoint of the state, and based on greater promotion of citizenship and social cohesion. It starts with an analysis of the legacy of the 1990s and then offers a global view of equity issues: (i) the principles of social policy and the fight against poverty; (ii) educational development, employment and social security; (iii) social public spending; and (iv) social service coverage goals. It also addresses economic issues, viewed from their social and sustainable development dimensions. It fluently addresses stability and economic growth, productive development and the specific problems of the smaller economies, the regulation of public utilities and the consolidation of spaces for sustainable development. It also contains the key reflections of the period on citizenship and social cohesion.

Lastly, in the most recent stage, 2010 saw publication of Time for Equality: Closing Gaps, Opening Trails, which argued that the concept of equal rights provides the framework and basis for promoting social covenants that offer greater opportunities to those who have least. It proposes a fiscal covenant that envisages a tax structure and tax burden with greater redistributive effect, that is capable of strengthening the role of the government and public policy to ensure welfare thresholds are respected. The text puts forward a set of economic policies with a long-term vision of production, labour, social development and territorial development, that seek not only equal opportunities but also concrete achievements in terms of narrowing existing gaps, which constitutes the cornerstone of the equality agenda.

The document fully identifies with the idea that the social equality and economic dynamism that transform the productive structure are not at odds with each other and the challenge is to find synergies between the two. It proposes: grow to equalize and equalize to grow. In the long run, the concept of equality, economic growth and environmental sustainability must support and strengthen each other mutually. Consequently, what is proposed is growth with less structural heterogeneity and more productive development, and the pursuit of equality through the enhancement of human 
capacities and the mobilization of state energies. The aim is to reverse the huge disparities in the region by building more cohesive societies around productive dynamics, constructing positive social and territorial synergies, and strengthening the protection of individuals through improvements in labor markets, stronger financial capacities and better public administration.

In 2012, the publication Structural Change for Equality: An Integrated Approach to Development improved on the postulates of Time for Equality: Closing Gaps, Opening Trails. It starts from the fact that, in today's complex and changing global context, the development of the Latin American and Caribbean region requires perseverance in three directions: structural change to underpin progress towards more knowledge-intensive sectors, convergence to reduce internal and external gaps in income and productivity, and equality of rights.

This implies tackling three major challenges: to achieve high and sustained rates of growth so as to close structural gaps and generate quality jobs; to change consumption and production patterns in the context of a genuine technological revolution with environmental sustainability; and to guarantee equality on the basis of greater convergence in the structure of production, with universal social protection and capacity-building.

Overcoming these three challenges involves the return of politics and the state's role in promoting investment and growth, redistribution and regulation, with a view to structural change for equality through industrial, macroeconomic, social and labour policies.

Lastly, Compacts for Equality: Towards a Sustainable Future (2014), completes the trilogy and outlines basic notions for defining the priorities of the post2015 regional development agenda. This document attaches particular importance to the social covenant owing to the dilemma facing the region given the forecast of slower economic growth and the weakening of its main drivers, and to the political economy context associated with postponed reforms in health, education, infrastructure investment, fiscal issues and social protection. The review of the state-market-society equation, becomes more relevant and current because there is a need to move from the shorttermism of government policies to the long-term visions of state policies.

\section{B. An approach to Latin American development paradigms}

This section makes a stylized presentation of the essential features of the main development paradigms in Latin America. It is not an exhaustive description, let alone a formal presentation of the epistemological evolution of Latin American thought. Nor is it a description of a single precise paradigm, because, throughout the region's development since the independence 
processes, there have been clear differences between countries in the form, intensity, pace, scope, gradualness and sequencing with which the basic and dominant elements of each paradigm have been applied.

The reality is always much more complex and harder to face; and, strictly speaking, the countries have adopted paradigms with different modalities and mechanisms; they have formulated similar policies that have led to different results, and some of the central precepts have not necessarily been applied uniformly, consistently, and systematically, since the contexts and the starting points of each country have been different. Consequently, as noted in the introduction, the aim is to present the broad interpretation of these ideas, the practice and processes of development, while defining the relevance of Prebisch's thinking. ${ }^{13}$ Nor does this interpretive effort lend itself to crude simplifications, since each paradigm in the Latin American development process has its own identity, complexity, and historical-structural specificity. Nonetheless, for exposition purposes, each one is presented through its key features.

\section{The starting point: Latin American development or underdevelopment}

In Latin America, the debate on the different development (or underdevelopment) paradigms relates directly to the capitalist accumulation process, on which both structuralist currents and those of dependency theory conceptually base their formulation.

One element of "essential Prebisch ", as Dosman calls it, which seems crucial for our times and particularly for Latin America, is his balanced conception and high degree of pragmatism. In this context, "balanced" means the following, among other things: (i) a greater role for the state, but without reaching a situation of an omnipresent state (as in the late 1990s); (ii) import substitution, but not at any cost; (iii) more active and growthfriendly monetary policies, although not at the cost of inflation; (iv) controls on foreign exchange and capital movements, but depending on the moment of application and intensity; and (v) discussion with the North, without reaching the point of breakdown.

In that regard, it is appropriate to revive one of Prebisch's three central messages, related to the formation of views of the global order according to the interests of the central countries. According to the Prebisch narrative, there is a "centrist" form of thought which rationalizes the international system. This ranges from the classical theory of international trade to rational

A much more thorough presentation of Latin American development paradigms can be found in Ocampo (2008), Bértola and Ocampo (2013) and Love (1994). 
expectations or new international trade theory, and from free trade to the Washington Consensus.

In the context of that centrist hegemonic thinking and as will be seen below, the Latin American development process has been inextricably linked to its articulation with trade and the international economy, to dominant institutions and power groups and to the development of productive forces. The result has been the profound structural heterogeneity and consequent diversity of economic policies adopted throughout its history ${ }^{14}$ (Ferrer, 2010).

This gives rise to the other two Prebisch messages, based on the claim that change in the productive structure is only possible insofar as the periphery is capable of developing a symmetric relation that is not subordinate to the hegemonic centres of world power. ${ }^{15}$ Moreover, development is impossible without profound structural change, without altering the orientation and strength of the state, and without a change in productive structure that incorporates activities close to the knowledge frontier. All of those claims seem to be confirmed today; the overwhelming evidence is found in recent experiences of growth and industrialization of the Asian tigers, and in recent decades, of China and India (Ferrer, 2010).

The historical and theoretical analysis of development or underdevelopment in Latin America cannot be treated exhaustively in a single essay (Bértola and Ocampo, 2013; Altimir, Iglesias and Machinea, 2008; Ocampo and Ros, 2011). Nonetheless, by way of synthesis, Prebisch understood that underdevelopment cannot be identified as a simple "state of backwardness"; and he visualized it as a pattern of functioning and specific evolution of certain economies, based on three key concepts.

The first relates to the structural heterogeneity that is a key characteristic of the periphery economies. Structural heterogeneity is characterized, first and foremost, by the existence of activities or branches of production in which average labour productivity is normal, as it is relatively close to what available techniques permit or relatively similar to what prevails in the large industrial centres (they generate employment). Secondly, heterogeneity refers to the simultaneous existence of technologically backward activities with very low productivity levels (they generate underemployment). In

14 This gives rise to the widespread idea that the market is the most efficient means of allocating resources. Globalization is so overwhelming that any attempt by the periphery to construct a national development project is doomed to failure.

15 Even in the export stage, Prebisch and structuralist thinking never proposed an auto kick view of trade or development. In fact, Prebisch always aimed to redefine Latin America's articulation with international trade flows and the world economy, not to isolate it from them. In that regard, the "manifesto" was never blindly anti-trade, anti-agriculture, or pro-industrialization. Prebisch questioned the market as the great equalizer, but he reiterated the need to maintain continuous balance between interventionist measures and respect for the market, keeping close watch on the international order (Ocampo, 2008). 
other words, the coexistence of employment and underemployment (of a high- and low-productivity workforce) is the directly visible expression of structural heterogeneity: underemployment tends to last and structural underemployment is transformed from rural into urban.

The second concerns productive specialization. In its origins, the specialization of the productive structure in the periphery reflected the long period in which growth depended on food and raw materials exports. When industry spontaneously became the main source of growth, the initial specialization in commodity exports conditioned the new development pattern. As a result, industrialization evolves from the simple to the complex, and the industrial development pattern peculiar to the periphery implies the maintenance of the specialized nature of its productive structure. Consequently, the level of intersectoral complementarity and vertical integration of production that the periphery is achieving, is meagre or incipient.

Lastly, it concerns unequal development. This relates, first and foremost, to the variable and bipolar nature of development of the centre-periphery system, which relates to the structural peculiarities described above, and produces unequal results because average incomes (per employed person or per capita) tend to be differentiated between the two poles. The secular deterioration of the terms of trade and income differentiation, as well as the uneven behaviour of labour productivity, imply a weakness in the peripheral economies, linked to their capacity to achieve and maintain high rate of accumulation.

Sunkel and Paz (1970) note that underdevelopment cannot be understood as a moment in continuous evolution (the development as growth approach), or in discontinuous evolution (the development as a succession of stages approach), of an economic, political and culturally isolated and autonomous society. On the contrary, based on systematic historical observation, they argue that underdevelopment is part of the global historical development process, that both underdevelopment and development are two aspects of a single universal historical process, and both are historically simultaneous. They are also functionally linked; in other words they interact and condition each other mutually, and their concrete geographic expression can be seen in two major dualisms: firstly, the division of the world between industrial nation states (advanced, developed, central) and underdeveloped nation states (backward, poor, peripheral and dependent); and secondly, the division between national states into advanced and modern areas, social groups and activities, and into backward, primitive and dependent areas, groups and activities.

Development and underdevelopment can be understood as partial but interdependent structures, forming a single system. The key feature that differentiates them is that the developed structure, by virtue of its endogenous growth capacity, is the dominant one, whereas the underdeveloped structure, 
given the induced nature of its dynamic, is dependent. This applies both between and within countries.

The above calls for a reorientation and redefinition of development policy, both domestically and in international relations. For reorganizations of this nature to be effective and permanent, they can only be based on the active social, political and cultural participation of new social groups that were previously excluded or marginalized. Such participation must occur both in the formulation of society's objectives and in the task of achieving them. It involves processes in which new social groups, which were the object of development, become its subject (Sunkel and Paz, 1970).

In the economic domain, the causes of the wealth of some countries and the poverty of others, and the rapid growth of some and slow growth of others, have always been the subject of research; but several interpretations have arisen on the subject since the Second World War. The formal theory of economic growth (based on Solow's neoclassical model and on Romer's "new" endogenous growth models) came to form part of macroeconomics and the dominant current of economic theory. In contrast, the study of poor countries was framed within the topic of economic development. Productivity growth formed part of industrial organization, while the study of how wealthy countries gained their current prosperity was encompassed by economic history.

Over the last two decades, economic growth has re-emerged as an independent field and development theory is not dead, as Krugman suggests in his article The Fall and Rise of Development Economics. Notable progress has been made in modelling its central ideas and in understanding that what is important in the development dynamic is not only factor accumulation, but also productive reallocation, which is the source of technical change, exploitation of externalities, improvements in coordination to overcome the indivisibilities and complementarities of investment, and the potential existence of multiple equilibria with different evolutionary paths that affect the final outcome.

\section{2. "Outward" development}

The paradigm of the export or "outward development" era was associated with the commodity export boom and the concept of progress. The latter was conceived as the result of the integration process of Latin American countries into the world economy as commodity producers. That period spans 1870 to 1929, and ends with the Great Depression (Ocampo, 2008; Cárdenas, Ocampo and Thorp, 2003).

With regard to economic performance in the last century, Bértola and Ocampo (2013) characterize this as a period of sharp fluctuations: between 
1870 and 1980, in very different contexts and with a number of fluctuations, Latin America improved its position in relation to the world average, which stands in contrast to the fall, until the mid-20th century, of the "rest of the world" (excluding the broadly defined west and Latin America). Latin America's share in global production also expanded continuously from $2.9 \%$ in 1870 to $5.6 \%$ in 1929 and $9.8 \%$ in 1980 . Nonetheless, the region was unable to make up ground on the west. The gap between Latin America and the West remained relatively stable throughout that period, and even tended to widen somewhat during certain subperiods, particularly between 1950 and 1973, when the western economies beat their historical growth records during the so-called "golden age" of capitalism, while the region experienced a demographic explosion and the growth of the leading regional economies became more difficult. In more detailed terms, the gap widened in relation to the new settlement economies, but narrowed in relation to industrialized Europe up to 1929, although the opposite occurred after the Second World War.

While this paradigm held sway in the second half of the nineteenth century, the main economic development problems consisted in establishing a modern transport system, facilitating direct access for exporters to natural resources and mobilizing a shift of labour towards modern sectors. As a result of those factors, Latin America significantly expanded its exports, and the economic growth associated with that expansion attracted a considerable flow of capital and new European immigrations to the continent. A distinctive feature of that phase was that, despite the preponderant role of exports, this did not mean that export sectors absorbed a major proportion of the labour force or contributed a large share of GDP, because exports were based on the extraction of natural resources that were not being exploited.

Social progress was unequal, because the gap between the wealthiest and poorest countries of the region widened, and, at the same time, inequality within each country deepened significantly. Moreover, export development generated, in different ways between countries, greater diversification of national economic structures and a certain development of manufacturing industry, communications and transport infrastructures, and financial services, accompanied by an urbanization process. It was in that period that Latin America expanded the gap with other undeveloped regions; and certain countries in the region, such as Argentina and Uruguay, achieved similar or higher levels of income than the wealthy countries of that time (Bértola and Ocampo, 2013).

The profound imbalances in the global economy and international monetary system gave rise to the Great Depression of the 1930s; and the era of export-led or outward development gave way to the advent of the new state-led industrialization paradigm. 


\section{State-led industrialization}

Export-led growth came to an end for various reasons, mainly owing to the Great Depression, the collapse of the gold standard, fluctuations in world trade, and the ravages of the Second World War. In Latin America, all of that laid foundations to launch the transition towards a new development model that was distinguished by adopting industrialization as the engine of growth, promoting state intervention in different domains of economic activity, and developing a strong orientation towards the domestic market. According to the ECLAC precept, this was an "inward development" pattern, or, as known internationally and generally, "import substitution industrialization".

For purely analytical reasons, but also for exposition purposes, the term "state-led industrialization" is preferred to "import substitution industrialization". According to the narrative of Cardenas, Ocampo and Thorp (2003), import substitution was neither the most outstanding element of the model through time, nor a characteristic that was shared by all countries in the period from the end of the Second World War until the 1970s when that development model was applied. In practice, the process consisted of different stages, diversity in the application of instruments and highly differentiated emphases. In some small economies of the region, industrialization did not completely replace the commodity export model, but gave rise to mixed schemes that combined import substitution with export promotion (Rosenthal, 1998 and 2004).

The ideas of industrialization gained increasing strength not only in Latin America but also in the rest of the world, and deeply permeated the region from the 1930s until well into the 1970s, largely owing to the influence of the development ideas originating in Central Europe, the successful economic planning experience and welfare state of the United Kingdom, the Keynesian ideas of a full employment and actively interventionist macroeconomic policy and, without doubt, the powerful influence of the early pioneers of development: Rosenstein-Rodan, Arthur Lewis, Gunnar Myrdal, Ragnar Nurske and, of course, Raul Prebisch (Singer, 1998).

It was in that historical context that the state-led industrialization model gained full force, and economic development and industrialization became equivalent terms. Awareness grew of the role of state intervention in allocating resources for public investment in industries that were considered "strategic", such as energy, iron and steel, mining and petrochemicals. ${ }^{16}$

\footnotetext{
16 Normative, rationalist, indicative, and traditional planning was the par excellence instrument of state intervention. It had its heyday in the 1960s. The Latin American and Caribbean Institute for Economic and Social Planning (ILPES) of ECLAC was the most prominent theoreticalconceptual bastion that the region had in the 1960s and 1970s, and before the retreat of planning in the 1980 s.
} 
Although this paradigm passed through at least four stages, is at least clear that in the earliest phases, the policies were implemented and the model's instruments were applied more by trial and error and by successive approximations than according to a clearly conceived theoretical model. ${ }^{17}$ As Joseph Love (1994) pointed out in masterly fashion, the industrialization of Latin America was a fact before it was a policy, and it was a policy before it was a theory. ${ }^{18}$ ECLAC provided a rationale and the conceptual and analytical foundation for a process that was well under way and widespread throughout the region, giving it also a sense of regional identity. ${ }^{19}$ Management of the balance of payments and the use of tariff protection as development tools were the central components of robust state intervention, based on the asymmetries that existed between the "centre" and the "periphery". ${ }^{20}$

After the late 1950s, as has been widely documented by Bielschowsky (2010), Rodríguez (2006), Bértola and Ocampo (2013), Cárdenas, Ocampo and Thorp (2003) and Rosenthal (1998 and 2004), ECLAC itself criticized the excesses of import substitution and state interventions, and proposed a "mixed" model involving import rationalization with active export promotion policies and greater regional integration. In that period, criticisms of the industrialization model intensified outside ECLAC, particularly from the Bretton Woods institutions and academic circles, involving luminaries such as Jacob Viner and M.W. Corden, to name just two.

Taking a broad view of the process with a long-term time horizon, it can be stated that despite the state-led industrialization model's practical limitations, its anti-export bias and the excesses of state intervention and tariff protection, it was the outstanding and successful model at least during the three decades following the Second World War, since it enabled the region to attain an average GDP growth rate of $5.5 \%$ per year between 1950 and

17 The first stage was characterized by an expansion of exports inherited from the previous model. The second was more pragmatic by supporting sectors that were considered strategic (energy, oil), applying combined policy instruments and promoting the creation of development banks. The third was the "classical" phase in which protection tended to be rationalized through regional trade integration. The last phase was the mature phase, and was the period of the mixed import substitution and export promotion model (Ocampo, 2008).

18 Cited in Ocampo (2008).

19 ECLAC argued in defence of industrialization based on a theory of capital accumulation, rather than a theory of economic efficiency (Ocampo, 2008).

20 Prebisch (1970 and 1973) warned of the risks of excessive protection and argued that the solution was not to sustain a tariff protection that would isolate the countries from the international economy, but to re-formulate the international division of labour to enable the countries of the region to benefit from the technical change directly associated with industrialization. Nonetheless, the ECLAC "import substitution model" was, on the one hand, given that name, and on the other, made banal by some of its features, particularly its domestic sector orientation, its dirigiste nature, and its strongly protectionist inclination. Once again, in practice, the countries perpetuated the use of the model and its instruments beyond what was justified by the prevailing circumstances (Rosenthal, 1998). 
1980 (2.7\% per capita). The manufacturing sector was the region's engine of growth, generating 27\% of GDP in 1973 (Cárdenas, Ocampo and Thorp, 2003).

The model also had repercussions in both the economic and the social, institutional and productive domains, before its practical limitations became clear. The model's results were not the same in all countries, nor uniform over time; and the spread of industrialization depended on the size of their economies and the internal social and political arrangements aimed at expanding the domestic market and confronting the firm rejection of the traditional export sectors (Bértola and Ocampo, 2013). For example, GDP growth was not uniform between the different countries while displaying a degree of convergence between Argentina, Chile and Uruguay. Labour productivity grew and allowed for higher real wages. Institutional development in the broad sense was notable and enabled not only the creation of state institutions, enterprises and strategic industries, but also the development of rules and regulations that steered the role of the state and economic agents. Industrialization was synonymous with development via the transmission of technical progress to the productive structure. The means and instrument was planning, which made it possible to put state intervention into practice.

On this point Ocampo (2008) notes that in the aftermath of the Second World War, the economies of all regions did not face a choice between state intervention and free enterprise, but different modalities of state intervention. State intervention and planning were considered everywhere as the only alternatives to the disorganization of markets that had characterized the preceding decades. The distinctive feature of the new stage is that, in choosing between different intervention modalities, Latin America did not opt for more but for less intervention, in other words for schemes of economic organization in which private enterprise continued to play a predominant role... In that sense, the success of an industrialization model led to the development of a mixed economy that was much closer to that of Western Europe than to the socialist models that had proliferated after the Second World War in much of the world.

The limitations and internal contradictions of the state-led industrialization model, particularly the anti-export and anti-rural bias, excesses of import substitution and external factors such as the debt crisis, the crisis of the welfare state in industrialized countries and the fall of the Berlin Wall and collapse of communism, laid the foundations for the beginning of the end of the inwardlooking model. At the same time, outside Latin America, post-Keynesian precepts suffered head-on attacks from the conservatism and liberalism of the Chicago School, and also from the progressive wing (so-called radical economists). As a result, the conditions and key elements of the next paradigm were developed, with a clear tendency to promote trade liberalization and global economic and financial integration, and to place greater confidence 
in the market as the best way to allocate resources, relegating the state to a marginal and subsidiary role. As had happened in the 1930s when state-led industrialization began with a more protagonist role for the state, the debt crisis gave way to the market-oriented open economies model, which gave rise to what came to be known as the Washington Consensus. ${ }^{21}$

\section{Structural and market reforms}

The transition to the new paradigm of structural and market reforms in the late 1970s and early 1980s took place much more quickly than in the case of the state-led industrialization paradigms; and, unlike the latter, in the market reforms, model theory preceded practice and both were radicalized and ideologized, attaining from a conventional orthodoxy what some called "market fundamentalism" or "liberal fundamentalism" (Ffrench-Davis, 2005; Bértola and Ocampo, 2013; Kozul-Wright and Rayment, 2008).

According to the line of argument proposed by Bértola and Ocampo (2013), to describe the paradigms embedded in the Washington Consensus, the term "market reforms" is preferred to "neoliberal", since the latter does not do justice to the intensity with which the reforms were applied, or the significant differences in terms of gradualness and sequencing adopted in the different countries. For example, there were divergences in the sphere of foreign exchange policies, in counter-inflation programmes, and even in capital-account liberalization, which in some countries took place simultaneously with current-account liberalization, while in other cases it was done consecutively ${ }^{22}$ (Ffrench-Davis, 2005; Stallings and Peres, 2000).

The main descriptive element of that simplified paradigm in the Washington Consensus was the liberalization of market forces through a system based on getting the prices right. The 10 reforms contained in the Decalogue were as follows: (i) fiscal discipline; (ii) redefinition of public expenditure priorities and retargeting in favour of investment in physical infrastructure, education and health; (iii) fiscal reform with a broad tax payer base, simple rules and moderate marginal tax rates; (iv) financial deregulation and liberalization of interest rates; (v) competitive exchange rate that would promote export growth; (vi) liberalization of foreign trade through a sharp reduction in tariffs; (vii) liberalization of foreign direct

${ }^{21}$ On several occasions John Williamson has regretted having used the term "Washington Consensus", firstly because it was not conceived in Washington, and secondly because it does not reveal a consensus. The characterization of the "neoliberal" model is not exact, and there are considerable differences in the form, intensity, pace, gradualness, and sequence in which the different policy instruments were implemented (Williamson, 1990).

22 Market reforms as such (reducing state participation in economic activity and liberalizing markets) coincided with macroeconomic stabilization policies (correct external and fiscal deficits and bring inflation under control). Their separation is essential for analytical purposes, and the fact that they have coincided through time has caused confusion in several analyses of the reform process (Bértola and Ocampo, 2013). 
investment; (viii) privatization of public enterprises; (ix) market deregulation; and $(x)$ guarantee of property rights.

Many countries gradually adopted these policy prescriptions in the 1980s and 1990s. The chronology of the reforms varied, as documented by Morley, Machado and Pettinato (1999), who show that there were two phases of the reforms. The first occurred in the 1970s, differed widely between different countries, and experienced a setback during the debt crisis. The second was much faster and was generalized particularly with trade liberalization and financial deregulation.

With the passage of time, the model's limits became clear: in the macroeconomic sphere, inflation was brought under control to some extent (often at the cost of an overvalued exchange rate) and the fiscal situation was improved; but economic growth from 1990 to 2008 (representative of the reform period) was $3.4 \%$ per year, 2 percentage points below the $5.5 \%$ recorded in 1950-1980. If the years of international financial crisis (2009 and 2010) are included, the growth rate falls to 3.1\% (Bértola and Ocampo, 2013).

Given that situation, orthodox economics did not question the limitations and biases of the model, but adduced implementation failures, lack of property rights and institutional weaknesses to explain the results of the reform process. ${ }^{23}$ As eloquently pointed out by Chang (2005), in the orthodox literature on institutions and development, property rights play the most important role. That literature states that, "good" policies, based on "correct" theories, recommended by orthodox economists, have not worked because many of the developing and transition economies lack a secure and clearly defined system of property rights. From this standpoint, in the absence of suitable guarantee for the fruits of their sacrifices, people will not invest, whatever the policies on macroeconomic balances, trade or industrial regulations.

That gave rise to a "second generation" of reforms (or reforms of the reforms), with the aim of overcoming the implementation failures and institutional weaknesses of the first round. The new reforms included the fight against corruption, liberalization of the labour market, adherence to the rules of the World Trade Organization (WTO), the adoption of greater financial regulation, opening of the capital market, central-bank autonomy, the application of inflation targets and the adoption of fixed or floating exchange rate regimes. On the social front, the most important reforms were the construction of social protection networks and the reduction of absolute poverty.

23 Rodrik (2002 and 2004) has stressed the importance of institutions in economic development, particularly those that protect property rights (known as market-makers). Nonetheless, long-term economic development also requires institutions to regulate, stabilize, and legitimize markets. 
In practice, as mentioned above, individual countries followed different paths and adhered to the Washington Consensus with different degrees of submission and, above all, aggressiveness or caution in implementing the reforms. These had very limited results in terms of regional aggregate averages, but were of differing intensity between countries. Nonetheless, it can be argued that these policies accentuated structural heterogeneity, as reflected in high and low growth rates between countries, high- and lowproductivity sectors, gaps between small and large firms, and significant income differences between those with education and the rest of the population (Stallings and Peres, 2000). In the social sphere and during the last decade, the social effects were regressive in terms of poverty and income distribution. Poverty grew from $40.5 \%$ to $48.3 \%$, owing to the deterioration of real wages, the shrinking of formal employment, and the inflation that dominated the period. The income distribution worsened, because the fiscal adjustments applied during the period ended up suffocating public social spending (Bértola and Ocampo, 2013, p. 257). The effects of the structural reforms on social variables, and on the income distribution in particular, remain a topic of debate. Clearly they generated winners and losers, and the net outcome varied from country to country (Ganuza and others, 2004, 2001).

As noted by Ffrench-Davis (2008): one of the distinctive features of neoliberalism is its globalism; in other words, its ignorance of social problems, the heterogeneity of productive structures and access to power of different sectors, the meaning of market segmentations, and the difficulty in transmitting information to economic agents to enable them to contribute to achieving the objectives of the reforms. Ultimately, it underestimates the frequent presence of destabilising adjustment processes and lags and overshooting, and the incomplete nature of markets and institutions in developing economies. The existence of these elements is an insurmountable obstacle for neutral or indirect global economic policies, alone, to be effective in emerging nations or those in the process of transformation.

In the early 1990s, given the failure of policies that would paradoxically be referred to as "structural adjustment" and the successful development experiences of South-East Asia, a favourable environment was created for the emergence of alternative and heterodox paradigms. In the 1980s, when the Latin American countries were adopting structural adjustment programmes and suffering the adverse effects of stagnation and debt, the emerging Asian economies were achieving unprecedented growth rates and improving their international integration, thanks to their exports of greater technological content, the development of technological capacities, and deliberate state policies to change the structure of incentives and the production vector of their economies. This Asian experience was highly revealing, because it called into question the recommendations that arose under the precepts 
of the Washington Consensus and its structural adjustment programmes (Guillén Romo, 2010).

In the late 1980s and early 1990s, a new current of thought started to develop in ECLAC, known as "neostructuralist" (Sunkel, 1991; Bielschowsky, 1998b). The document Changing Production Patterns With Equity: The Prime Task of Latin American and Caribbean Development in the 1990s (ECLAC 1990) is a faithful reflection of the renewal of this thinking and a fundamental piece in the evolution of the thinking of that international organization.

Three stylized facts stand out in this context: firstly, while the defenders of structural adjustment proposed the withdrawal of the state, the Asian countries were advocating greater regulation and state intervention. Secondly, whereas the structural adjustment plans lauded international integration based on the principle of static comparative advantages (in other words the exportation of labour-intensive products), the Asian countries were building their competitiveness through dynamic engagement with new technologies and the creation of dynamic comparative advantages. Thirdly, when the defenders of the Washington Consensus were advising the Latin American economies to redirect their activity towards external markets, the Asian economies were maintaining close dynamic relations between activities related to the domestic market, the regional market and export activities. Under those conditions, the Asian experience provided an authentic example of the opposite of economic policy practices prevailing in Latin America (Ocampo and Ros, 2011).

In view of this, it is generally argued that the neostructuralist current was presented not only as the alternative paradigm to the market reform model, but as a way to improve on the original structuralist paradigm in which it is inspired. As suggested by Ferrer (2013a and 2013b), this involves adapting it to new times of openness and globalisation. For the neostructuralist, Latin America's main economic problems are not mainly due to the distortions induced by economic policy, but are more of an endogenous, structural nature and of historical origin (Guillén Romo, 2007).

The neostructuralists stress three defining features of the Latin American economies in the late 1980s: (i) the presence of an external integration model that led to an impoverishing form of specialization; (ii) the predominance of a production model that was disarticulated, vulnerable, highly heterogeneous, concentrating of technical progress and unable to absorb the increase in labour supply productively; and (iii) the persistence of a highly concentrated and excluding income distribution, that demonstrates the inability of the system to reduce poverty. Consequently, neostructuralism seeks productive change with equity, based on the structural changes of the economies that allow for development and economic growth with equity, the 
existence of financial balances that sustain those changes in the productive sphere, and social and state support (Lustig, 1998; Ocampo, 2008; ECLAC, 1990, 2010 and 2012).

Neostructuralism arose as an alternative theoretical approach to the structural and market reform model. In its beginnings, it sought less regressive solutions to the problems of inflation and trade deficit, through the heterodox stabilization and adjustment plans of the 1980s. This was, therefore, a short-term approach that had arisen in the midst of the 1980s debt crisis. As noted by Fontaine and Lanzarotti (2001), in an intellectual environment that is hostile to any type of structural consideration, the shortterm was the only way of entering the debate.

Nonetheless, as the orthodox adjustment plans of the neoliberals and the heterodox plans of the start of new structuralism failed, the debate increasingly harked back to original ECLAC thinking. This did not prevent the neostructuralists from making a critical review of that thinking, with the aim of overcoming some of its main deficiencies and limitations. For example: (i) excessive trust in the benefits of state intervention, ignoring problems of corruption, state capture, bureaucracy, and inefficiency in the public sector; (ii) an exaggerated and very prolonged pessimism towards external markets; and (iii) underestimation of the monetary and financial aspects, that leads to a short-term economic policy lacking in any rigour (Sunkel, 1991; Guillén Romo, 2007).

On this last point, Ffrench-Davis (1991) argues that structuralism is characterized by two shortcomings in the economic policy domain: one was the limited concern for managing short-term macroeconomic variables. The analysis of the definition of room for manoeuvre in relation to fiscal deficits, monetary liquidity and regulation of the balance of payments took second place in structuralist thinking. There was no systematic move from diagnosing the origin of the imbalances to the field of adequate policies for regulating markets. The other shortcoming was the weakness of reflection in medium-term policies, relating the short term to national development objectives and planning. For this reason, for the neostructuralists, their predecessors in ECLAC had an insufficient and incomplete analytical vision of short-term problems and of their articulation with the long-term dynamic.

Clearly, state action is at the centre of the new strategy proposed by the neostructuralists. This is not a matter of state intervention replacing market forces with excess action, but instead, selective intervention to sustain and strengthen market activity. As mentioned in the introduction, the debate is no longer based on having more state or more market, but on seeking a better state and a more effective and equitable market. 


\section{An approach to Prebisch's contribution to the current debate}

This essay has made a synthetic review of the main concepts of state and development and, in particular, the key Latin American development paradigms, highlighting some of the key features of the evolution of the ECLAC paradigms along the way. The various conceptions on development or underdevelopment are intermixed with Prebisch's foundational ideas, which were forged from his own experiences as head of the Central Bank of Argentina during the Great Depression and the Second World War, and through time in five stages (plus the final stage in charge of the CEPAL Review).

As Prebisch revealed in Five stages in my thinking on development (1983):

"When I started my life as a young economist and professor during the 1920s, I was a firm believer in neoclassical theories. However, the first great crisis of capitalism - the world Depression - prompted in me serious doubts regarding these beliefs. It was the beginning of a long period of heresies, as I tried to explore new views on development matters. The second great crisis of capitalism, which we are all suffering now, has strengthened my attitude. In the long lapse of time between these two great crises, my thinking on development has gone through five successive stages under the influence of a changing reality and the broadening of my own experience. During those hectic years of the Depression I had some influence on the economic policy of my country, Argentina, first as Under Secretary of Finance and later with the Central Bank. During the 1930s I recommended orthodox anti-inflationary measures to eliminate the fiscal deficit and suppress inflationary tendencies, but at the same time I departed from orthodoxy when I had to face a serious balance of payments disequilibrium and advocated a resolute industrialization policy as well as other measures to this end".

The current vitality of Prebisch's ideas can be expressed through the central messages identified by Aldo Ferrer and Edgar J. Dosman, or through the vision that Prebisch held of Latin American development, which has been developed and interpreted by leading academics and researchers based on his most important analytical contributions. These include Edgar J. Dosman, Octavio Rodríguez, Hans Singer, Joseph Love, Carlos Mallorquin, David H. Pollock, José Antonio Ocampo and Ricardo Bielschowsky. There were also others who worked directly with Prebisch and influenced his thinking or deepened and complemented his ideas, such as Celso Furtado, Adolfo Gurrieri, Enrique V. Iglesias, Osvaldo Sunkel, Victor Urquidi, José Medina Echavarría, Aníbal Pinto, Gert Rosenthal, Enzo Faletto, Jorge Ahumada, 
Jose Serra, Maria da Conceição Tavares and Fernando Henrique Cardoso, among so many others. The two approaches are not exclusive, but make it possible to gain a better understanding of "essential Prebisch" and define why his ideas continue more relevant than ever.

According to Ferrer (2010), Prebisch left three messages which later became his most important legacy. The first is that the countries of the "centre" develop a "centrist" way of thinking that serves their interests. The centre rationalizes the international order, often based on ideological or ideologized formulations, where the "periphery" occupies a residual and "passive" place, incapable of deploying its own capacities. To overcome that perspective, Prebisch proposed an autonomous critical form of thinking, and intellectual rebellion against the dominant current and orthodox economic precepts. He inspired others to conceive of development from Latin America based on its own strengths, obstacles, and historical and structural legacies of the region. He showed that import substitution was also valid when it involved adopting development paradigms originating in the developed centre. The second message stems from the first, and relates to the need for the periphery to maintain a symmetric rather than a subordinated relation with the North and the rest of the world. He urged discussion with the North, not a break with it. The third message, perhaps the most important of all, is the idea of changing the productive structure to incorporate knowledge and technical change, as fundamental tools of development. ${ }^{24}$

Prebisch understood that the main development problem involved the need to raise the productivity level of the labour force as a whole. For that reason, underdevelopment could not be interpreted as a simple state of backwardness, explained by extra-economic factors linked to the social structure. Prebisch saw it as a specific pattern of the functioning and evolution of certain economies, which required a specific development effort of its own (Rodríguez, 2001).

In Prebisch conception on underdevelopment, there are four stylized facts that are clearly differentiated. The first is the growing income gap between countries of the centre and those of the periphery. The second, the persistent unemployment in the periphery. The third, the continuous balance of payments deficits in the countries of the periphery, which impose major constraints on the economic growth process. The fourth, the secularly declining trend of the terms of trade. This gave rise to the conception of underdevelopment in Prebisch on which Furtado (1993) highlights the following with profound elegance: from the theoretical standpoint Prebisch's greatest contribution

24 The "young" Prebisch proposed a development pattern whose main objective would be industrialization, with the aim of promoting changes in the productive structure in response to the high elasticity of demand for manufactures. Thus, industrialization and productivity growth in primary production became complementary (Pérez Caldentey and Vernengo, 2012). 
was the idea of a structural break from the international economy, caused by the slow dissemination of technical progress and maintained by the international system of division of labour that had been established at the start of the Industrial Revolution. In this conception, foreign trade was not considered as a simple extension of the domestic economy, but was thought to have its own dynamic. This structural break became the cornerstone that gave rise to the theory of underdevelopment and which, with time, would occupy a leading place in the history of Latin American development after the Second World War.

In a recapitulation on the evolution of his thinking, Prebisch himself (1984) reveals that the structure of international economic relations which he referred to as a "centre-periphery system" was really a byproduct of his analytical approaches to the business cycle, as shown in the following statement: "The countries producing and exporting raw materials were thus linked with the center as a function of their natural resources, thereby forming a vast and heterogeneous periphery incorporated in the system in different ways and to different extents". He ends by concluding that underdevelopment originates in "the concentration of technical progress and its fruits in economic activities oriented toward exports [which] became characteristic of a heterogeneous social structure in which much of the population remained on the sidelines of development."

Rodríguez (2001) suggests that Prebisch's fundamental ideas can be understood on the basis of three key concepts: structural heterogeneity, unequal specialization, and development (see Section B.1). On that basis, inferences can be made about the relevance of his contributions for the current debate, and throughout the development paradigms experienced in the region. Nonetheless, to capture the "essential Prebisch", and the "pioneer of development", an approach was chosen that went beyond the scope of his theoretical contributions to include the diplomatic domain, the creator of institutions, the formulator of economic policies, the man of action who was open to new ideas and willing to break from current paradigms.

When referring to Prebisch's contributions and their relevance for the current debate, beyond his seminal contributions to the theory of Latin American underdevelopment, at least five key elements need to be considered. Firstly, his insistence that the economists of Latin America, and then social thinkers and scientists generally, should maintain intellectual autonomy. This probably arose from the impact that the Great Depression and the Second World War had on his way of thinking. Moreover, everything indicates that it was nurtured from Keynes's critique of the neoclassical models that had dominated economic debate at that time. Secondly, his permanent interest in development problems: from that standpoint, he was one of the great pioneers of development and, without doubt, the intellectual father of the 
theory of Latin American underdevelopment. Thirdly, his tireless efforts to forge institutions with a developmentalist vocation, the Central Bank of Argentina, ECLAC, the organizations of Latin American integration, the United Nations Conference on Trade and Development (UNCTAD) and the CEPAL Review. Fourthly, his insistence on relating theoretical analysis to policy design and observing reality before thinking, acting, and formulating proposals. Fifthly, his high dose of pragmatism in seeking ideology-free solutions, duly lauding and valuing the state's role in the development process.

Those messages clearly retain their vitality in our times. The ideas associated with changing production patterns with equity, the state's vital role in the development process, sustained growth with social inclusion, environmental sustainability and a fair income distribution, structural heterogeneity, productive specialization, unequal development, structural change, the relation between innovation and inclusive development and the very conception of development as a process of learning, generation and dissemination of endogenous technological capacities, are rooted in Prebisch's thinking, which today is increasingly relevant to the debate on growth and development.

In conclusion, it is worth quoting Joseph Love (1980), when he stressed that Prebisch's thesis is the most influential idea in relation to the economy and society of Latin America in the twentieth century, and possibly in the region's history.

\section{Conclusions}

The state's role in the economy and in the economic and social progress of developing countries, and Latin American countries in particular, has always been controversial. It is a debate that has been present throughout the different development and techno-economic paradigms that have been applied in the region since independence. This essay started by defining the state and contextualizing the recent debate in Latin America. It also attempted to demystify the false dilemma of conceptions that exclusively counterpose the function of the state with the role of the market in economic activity. The aim here was to clarify that any development paradigm and strategy ultimately involves deciding on and adopting a position on the limits of the state and public policy.

The concept of state is clarified from Weberian precepts, and its functions are proposed on the basis of an institutionalist theory of state intervention in a context of structural change. Three basic propositions are developed. The first consists of recognizing that the state and its political economy are decisive variables in economic and social development. The second suggests that the state in its broader conception is an institutional construction 
and, thus, a fundamental variable for explaining why some countries are wealthier than others. The third is that the state in Latin America tends to be social-liberal, and increasingly democratic, with various interpretations of globalised capitalism and an increasing trade and regional integration. ${ }^{25}$

The essay concludes that the neoclassicals' idea of the equilibrated and efficient market has been questioned since the Great Depression of the 1930s, then during the debt crisis of the 1980s, and, more recently, following the international financial crisis of 2008. Even the most vehement neoliberals accept some forms of state intervention as inevitable, owing not only to the presence of externalities, but also to the ubiquity of incomplete markets, asymmetric information and incipient institutional development. Consequently, the false state/market dilemma should be replaced by the correct relationship of study: the state's role in the market. Lastly, it is stated that an institutionalist approach to state intervention makes it possible to understand the relation between market, state and institutions in a unified and analytically consistent framework.

It also proposes the concept of development on the basis of three metatheories and concludes that any "development" can be conceived on the basis of its strategic structural factors; and any public policy, irrespective of its origin or conception, has a strategic dimension and another structural one. Once the central concepts of state and development have been established, the essay analyses the relation by reviewing the key ECLAC institutional documents.

Those documents are used to show that ECLAC thinking is characterized by applying a historical-structural method and developing three analytical pillars that have remained in place throughout its intellectual production: (i) the analysis of international engagement; (ii) the analysis of the domestic structural constraints on growth and technical progress, together with the relations between them, employment, and income distribution; and (iii) the analysis of state action possibilities.

These form the bases for proposing the main Latin American development paradigms. It starts with the debate between development and underdevelopment in the Latin American context, and concludes that the debate is directly related to the capitalist accumulation process. Both structuralist currents and those of dependency theory based their formulation conceptually on that process. In that way, it seeks out the essential Prebisch,

25 There are two "varieties" of market economies which have recently been proposed as alternatives that could give a better result than the Anglo-Saxon model of minimal intervention or laissezfaire. The first is that of the "industrial policy states" of East Asia (Japan, (Japan, Republic of Korea and Taiwan Province of China) and France; the second is that of the Scandinavian "social corporatist" economies (Sweden, Norway and Finland) (Chang, 2003; Hall and Soskice, 2001). 
along with the foundational ideas that subsequently became the bedrock of Latin American underdevelopment theory.

The paradigms were succinctly reviewed on the basis of their most outstanding features. Firstly, the export development or "outward development" model was linked to the commodity export boom and the idea of progress. The latter was conceived as a result of the process of Latin American countries' integration in the world economy as raw material producers. This period spanned 1870 to 1929 and ended with the Great Depression.

The second paradigm of "state-led industrialization" was applied from 1930 and ended in the 1970s. It was characterized by the adoption of industrialization as the engine of development, promotion of state intervention in different domains of economic activity and the development of a strong domestic market orientation. According to ECLAC doctrine, this was an "inward development" pattern, or "import substitution industrialization" as it is known internationally and generally.

The third paradigm of "structural and market reforms" adopted from the 1970s to the 1990s, took as its "manifesto" the Decalogue prescribed in the Washington Consensus. It was characterized by promoting the liberalization of market forces through a system based on allowing prices to attain their due level, and unbounded confidence in the market as the most efficient way of allocating resources (market supremacy). That paradigm relegated the state's role in economic activity; and, according to that vision, non-market institutions (including the state) are the "second-best" solution and are considered only when the "natural" order of the market fails to produce the expected outcome.

It is argued that the neostructuralist current was presented not only as the alternative paradigm to the market reform model, but also as an improvement on the original structuralist paradigm in which it was inspired. The essay concludes by arguing that, according to neostructuralists, Latin America's main economic problems are not basically due to distortions caused by economic policy, but are more of an endogenous, structural and historical nature.

Lastly, an attempt has been made to rescue an element of the "cosmovision" of Prebisch's ideas which seem highly relevant to the current situation of Latin America, namely, his balanced view of interventionist measures and respect for the market. There is also his high level of pragmatism, with an insistence on the need to closely track the changing international order or world development generally. His words, messages, teachings, theories, intuitions and, above all, his vision of a possible development for Latin America, continue to resonate and remain fully valid in the current debate on state and development. 


\section{Bibiliography}

Acemoglu, D. (2009), Introduction to Modern Economic Growth, Princeton, Princeton University Press.

Acemoglu, D. and J. Robinson (2012), Why Nations Fail: The Origins of Power, Prosperity, and Poverty, New York, Crown Publishing Group.

Aguirre, T. (2010), “Estado y desarrollo: hacia una nueva agenda”,Desarrollo y transformación: opciones para América Latina, Mexico City, Fondo de Cultura Económica.

Altimir, O., E.V. Iglesias and J.L. Machinea (eds.) (2008), Hacia la revisión de los paradigmas del desarrollo en América Latina, Santiago, Economic Commission for Latin America and the Caribbean (ECLAC)/Ibero-American General Secretariat.

Bértola, L. and J.A. Ocampo (2013), The Economic Development of Latin America since Independence, New York, Oxford University Press.

Bielschowsky, R. (comp.) (2010), Sesenta años de la CEPAL. Textos seleccionados del decenio 1998-2008, Buenos Aires, Siglo XXI.

(1998a), "Evolución de las ideas de la CEPAL", CEPAL Review, special number (LC/G.2037-P), Santiago, Economic Commission for Latin America and the Caribbean).

(1998b), "Cincuenta años del pensamiento de la CEPAL: una reseña", Cincuenta años de pensamiento en la CEPAL. Textos seleccionados, vol. 1, Santiago, Fondo de Cultura Económica.

Bresser Pereira, L.C. (1998), "La reconstrucción del Estado en América Latina”, CEPAL Review, special issue (LC/G.2037-P), Santiago, Economic Comission for Latin America and the Caribbean (ECLAC).

Bulmer-Thomas, V. (1994), The Economic History of Latin America since Independence, Cambridge, Cambridge University Press.

Cárdenas, E., J.A. Ocampo and R. Thorp (comps.) (2003), Industrializacion y Estado en la America Latina: la leyenda negra de la posguerra, Mexico City, Fondo de Cultura Economica.

Cardoso, F. and E. Faletto (1979), Dependency and Development in Latin America, University of California Press.

Cardoso, F.H., R. Prebisch and R. Green (1982), En torno al Estado y el desarrollo, Mexico City, Nueva Imagen.

Chang, H.J. (2005), “Entendiendo la relación entre las instituciones y el desarrollo económico: algunos aspectos teóricos claves", paper presented at the WIDER Anniversary Conference, Helsinki, 17-18 June. (2003), Globalization, Economic Development and the Role of the State, Zed Books / Third World Network.

Dosman, E.J. (2008), The Life and Times of Raúl Prebisch, 1901-1986, Montreal, McGill Queen's University Press. (2006), Raúl Prebisch: Power, Principle and the Ethics of Development, Washington, D.C., Inter-American Development Bank (IDB)/Institute for the Integration of Latin America and the Caribbean (INTAL). (2001), "Markets and the State in the evolution of the 'Prebisch manifesto'", CEPAL Review, No. 75 (LC/G.2150-P), Santiago, Economic Commission for Latin America and the Caribbean (ECLAC).

ECLAC (Economic Commission for Latin America and the Caribbean) (2014), Compacts for Equality: Towards a Sustainable Future (LC/G.2586(SES.35/3)), Santiago. 
(2012), Structural Change for Equality: An Integrated Approach to Development (LC/G.2524(SES.34/3)), Santiago.

(2010), Time for equality: closing gaps, opening trails (LC/G.2432(SES.33/3)), Santiago.

(2000), Equity, Development and Citizenship (LC/G.2071(SES.28/3)), Santiago.

(1998), Economic Survey of Latin America and the Caribbean 1998-1999 (LC/G.2056-P), Santiago.

(1993), Population, Social Equity and Changing Production Patterns (LC/G.1758/ Rev.1-P), Santiago.

(1992), Social Equity and Changing Production Patterns: An Integrated Approach (LC/G.1701/Rev.1-P), Santiago.

(1990), Changing Production Patterns with Social Equity. The Prime Task of Latin American and Caribbean Development in the 1990s (LC/G.1601-P), Santiago. (1966), The Process of Industrial Development in Latin America, New York, United Nations.

(1963), Towards a Dynamic Development Policy for Latin America, New York, United Nations.

(1951), Economic Survey of Latin America, 1949 (E/CN.12/164/Rev.1), New York. (1949), Economic Survey of Latin America, 1948 (E/CN.12/82), New York.

Fajnzylber, F. (1983), La industrialización trunca de América Latina, Mexico City, Nueva Imagen.

Ferrer, A. (2013a), Historia de la globalización I: orígenes del orden económico mundial, Mexico City, Fondo de Cultura Económica.

(2013b), Historia de la globalización II: la revolución industrial y el segundo orden mundial, Mexico City, Fondo de Cultura Económica.

(2010), "Raúl Prebisch and the dilemma of development in the globalised world", CEPAL Review, No. 101 (LC/G.2455-P), Santiago, Economic Commission for Latin America and the Caribean (ECLAC).

Ffrench-Davis, R. (2008), Chile entre el neoliberalismo y el crecimiento con equidad: reformas y políticas económicas desde 1973, Santiago, Comunicaciones Noreste Ltda.

(2005), Reformas para América Latina: después del fundamentalismo neoliberal, Buenos Aires, Siglo XXI Editores.

(2001), "Formación de capital y marco macroeconómico: bases para un enfoque neoestructuralista", El desarrollo desde dentro: un enfoque neoestructuralista para la América Latina, O. Sunkel (comp.), El Trimestre Económico, No. 71, Mexico City, Fondo de Cultura Económica.

Ffrench-Davis, R., O. Muñoz and G. Palma (1998), “The Latin American economies, 1959-1990", Latin America: Economy and Society Since 1930, L. Bethell (comp.), Cambridge, Cambridge University Press.

Fontaine, J. and M. Lanzarotti (2001), “Le neo-structuralisme. De la critique du Consensus de Washington a l'emergence d'un nouveau paradigme", Mondes en développement, vol. 29, No. 113-114.

Friedman, M. (1990), Free to Choose. A Personal Statement, Harcourt.

Furtado, C. (1993), "La cosmovisión de Prebisch", El legado de Prebisch, E.V. Iglesias (ed.), Washington, D.C., Inter-American Development Bank. (1989), La fantasía organizada, Bogota, Tercer Mundo Editores.

(1971), La economía latinoamericana desde la conquista ibérica hasta la revolución cubana, Mexico City, Siglo XXI Editores. 
Ganuza, E. and others (2004), ¿Quién se beneficia del libre comercio? Promoción de exportaciones y pobreza en América Latina y el Caribe en los 90, Bogota, United Nations Development Programme (UNDP)/Alfaomega Colombiana. (eds.) (2001), Liberalización, desigualdad y pobreza: América Latina y el Caribe en los 90, Buenos Aires, Editorial Universitaria de Buenos Aires.

Glade, W. (1992), "El Estado como capital organizativo en la industrialización”, Los problemas del desarrollo en América Latina: Homenaje a Raúl Prebisch, L. Montuschi and H. Singer (comps.), Mexico City, Fondo de Cultura Económica.

Guillén Romo, H. (2010), "Políticas y estrategias de desarrollo en América Latina y los países del sudeste asiático", Desarrollo y transformación: opciones para América Latina, G. Vidal, A. Guillén y J. Deniz (coords.), Madrid, Fondo de Cultura Económica. (2007), "De la orden cepalina del desarrollo al neoestructuralismo en América Latina", Comercio Exterior, vol. 57, No. 4, Mexico City.

Gurrieri, A. (comp.) (1982), "La obra de Prebisch en la CEPAL", El Trimestre Económico, No. 46, Mexico City, Fondo de Cultura Económica.

Hall, P.A. and D. Soskice (eds.) (2001), Varieties of Capitalism: The Institutional Foundations of Comparative Advantage, New York, Oxford University Press.

Hirschman, A. (1980), "Orto y ocaso de la economía del desarrollo", El Trimestre Económico, vol. 47, No. 188, Mexico City, Fondo de Cultura Económica, October-December.

(1971), "The political economy of import-substituting industrialization in Latin America", A Bias for Hope: Essays on Development and Latin America, New Haven, Yale University Press.

Iglesias, E.V. (2006), "Economic paradigms and the state's role in Latin America", CEPAL Review, No. 90 (LC/G.2323-P), Santiago, Economic Commission for Latin America and the Caribbean (ECLAC).

(ed.) (1994), The Legacy of Raúl Prebisch, Washington, D.C., Inter-American Development Bank (IDB).

ILPES (Latin American and Caribbean Institute for Economic and Social Planning) (1995), Reforma y modernización del Estado (LC/IP/L.107), Santiago.

Kozul-Wright, R. and P. Rayment (2008), The Resistible Rise of Market Fundamentalism: Rethinking Development Policy in an Unbalanced World, London, Zed Books.

Love, J. (1994), "Economic ideas and ideologies in Latin America since 1930", The Cambridge History of Latin America, vol. 6, No. 1, L. Bethel (comp.), Cambridge, Cambridge University Press.

(1980), "Raúl Prebisch and the origins of the doctrine of unequal exchange", Latin American Research Review, vol. 15, No. 3, Chapel Hill, Latin American Studies Association.

Lustig, N. (1998), “Del estructuralismo al neoestructuralismo: la búsqueda de un paradigma heterodoxo", Coleccion Estudios CIEPLAN, No. 23, Santiago.

Morley, S., R. Machado and S. Pettinato (1999), "Indexes of structural reform in Latin America", Reformas Económicas series, No. 12 (LC/L.1166), Santiago, Economic Commission for Latin America and the Caribbean (ECLAC).

North, D.C. (1990), Institutions, Institutional Change and Economic Performance, Cambridge, Cambridge University Press.

Ocampo, J.A. (2008), "Los paradigmas del desarrollo en la historia latinoamericana”, Hacia la revisión de los paradigmas del desarrollo en América Latina, O. Altimir, E.V. Iglesias and J.L. Machinea (eds.), Santiago, Economic Commission for Latin America and the Caribbean (ECLAC)/Ibero-American General Secretariat. 
Ocampo, J.A. and J. Ros (2011), "Shifting paradigms in Latin America's economic development", The Oxford Handbook of Latin American Economics, Oxford, Oxford University Press.

O’Donnell, G. (2008a), "Hacia un Estado de y para la democracia”, Democracia, Estado y ciudadania. Hacia un Estado de y para la democracia en América Latina, New York, United Nations Development Programme (UNDP). (2008b), "Los desafíos actuales de la democracia y el desarrollo", Hacia la revisión de los paradigmas del desarrollo en América Latina, O. Altimir, E.V. Iglesias and J.L. Machinea (eds.), Santiago, Economic Commission for Latin America and the Caribbean (ECLAC)/Ibero-American General Secretariat.

Pérez Caldentey E. and M. Vernengo (2012), "Portrait of the economist as a young man: Raúl Prebisch's evolving views on the business cycle and money, 19191949", CEPAL Review, No. 106 (LC/G.2518-P), Santiago, Economic Commission for Latin America and the Caribbean (ECLAC).

Pérez Caldentey, E., O. Sunkel and M. Torres (2013), “Raúl Prebisch (1901-1986): Un recorrido por las etapas de su pensamiento sobre el desarrollo económico" [online] http:/ / prebisch.cepal.org/sites/default/files/Etapas_pensamiento_Prebisch.pdf.

Pinto, A. (2008), "Styles of development in Latin America", CEPAL Review, No. 96 (LC/G.2396-P), Santiago, Economic Commission for Latin America and the Caribbean.

(1973), "Inflación: raíces estructurales", Ensayos de Anibal Pinto, El Trimestre Economico, No. 3, Mexico City, Fondo de Cultura Económica.

(1970), "Naturaleza e implicaciones de la 'heterogeneidad estructural' de la América Latina", El Trimestre Económico, vol. 37, No. 145, Mexico City, Fondo de Cultura Económica.

Polanyi, K. (1944), The Great Transformation: The Political and Economic Origins of Our Time, New York, Rinehart.

Prebisch, R. (1984), "Five stages in my thinking of development", Pioneers in Development, G. Meyer and D. Seers (orgs.), Washington, D.C., World Bank.

(1979), "The neoclassical theories of economic liberalism", CEPAL Review, No. 7 (E/CEPAL/1084), Santiago, Economic Commission for Latin America and the Caribbean (ECLAC).

(1976), "A critique of peripheral capitalism", CEPAL Review, No. 1, Santiago, Economic Commission for Latin America and the Caribbean (ECLAC).

(1973), Interpretación del proceso de desarrollo latinoamericano en 1949, Santiago, Economic Commission for Latin America and the Caribbean (ECLAC).

(1971), "Public enterprises: their present significance and their potential in development", Economic Bulletin for Latin America, vol. 16, No. 1, New York. (1970), Change and Development. Latin America's Great Task, New York, Praeger. (1950), The Economic Development of Latin America and its Principal Problems (E/ CN.12/89/Rev.1), New York, United Nations.

Rodríguez, O. (2006), El estructuralismo latinoamericano, Mexico City, Economic Commission for Latin America and the Caribbean (ECLAC)/Siglo XXI Editores. (2001), "Prebisch: the continuing validity of his ideas", CEPAL Review, No. 75 (LC/G.2150-P), Santiago, Economic Commission for Latin America and the Caribbean (ECLAC).

Rodrik, Dani (ed.) (2007), One Economics, Many Recipes: Globalization, Institutions and Economic Growth, Princeton, Princeton University Press. 
(2005), Políticas de diversificación económica, Revista CEPAL No.87, Comisión Económica para América Latina y el Caribe, Santiago.

(2004), "Getting institutions right", CESifo DICE Report, CESifo Group Munich, febrero.

(2002), In Search of Prosperity: Analytic Narratives on Economic Growth, Princeton, Princeton University Press.

Rosenthal, G. (2004), "ECLAC: a commitment to a Latin American way towards development", Unity and Diversity in Development Ideas: Perspectives from the UN Regional Commissions, Y. Berthelot (comp.), Bloomington, Indiana University Press. (1998), "Pensamiento y políticas sobre el desarrollo en América Latina y el Caribe: pasado y futuro", El desarrollo económico y social en los umbrales del siglo XXI, L. Emmerij and J. Núñez del Arco (comps.), Washington, D.C., InterAmerican Development Bank.

Sen, A. (1999), Development as Freedom, New York, Oxford University Press.

Singer, H. (1998), "Es aún relevante la economía del desarrollo?", El desarrollo económico y social en los umbrales del siglo XXI, L. Emmerij and J. Núñez del Arco (comps.), Washington, D.C., Inter-American Development Bank.

Stallings, B. and W. Peres (2000), Growth, Employment and Equity: The Impact of the Economic Reforms in Latin America and the Caribbean, Washington, D.C., The Brookings Institution/Economic Commission for Latin America and the Caribbean (ECLAC)/Fondo de Cultura Económica.

Sunkel, O. (comp.) (1991), "El desarrollo desde dentro: un enfoque neoestructuralista para la América Latina", El Trimestre Económico, No. 71, Mexico City.

Sunkel, O. and P. Paz (1970), El subdesarrollo latinoamericano y la teoría del desarrollo, Mexico City, Siglo Veintiuno.

Thorp, R. (1998), Progress, Poverty and Exclusion: An Economic History of Latin America in the 20th Century, New York, Inter-American Development Bank.

Veltmeyer, H. (2010), "Una sinopsis de la idea de desarrollo", Migracion y Desarrollo, No. 14, Autonomous University of Zacatecas.

Williamson, J. (1990), "What Washington means by policy reform”, Latin American Adjustment. How Much Has Happened?, J. Williamson (ed.), Washington, D.C., Institute for International Economics.

Williamson, O. (1985), The Economic Institutions of Capitalism, New York, Free Press. 


\section{Chapter XII \\ The State, heterodoxy and the contribution of feminism}

Sonia Montaño $V^{1}$

This chapter examines three issues raised by feminism — as a political philosophy of equality - and contends that feminist thought is helping to improve the quality of economics and politics. The first issue concerns the application of critical thinking to certain beliefs about the State and the market; the second is the critique of assumptions that underpin public policies; and the third addresses the implications of feminist thought for the role of the State.

The chapter is divided into four sections. Section A analyses the contributions of feminist theory and its policy proposals. Section B examines the relationship between the State, democracy and the economy in the light of gender equality. Section $C$ considers the link between economics and gender equality and the contributions of feminist thought in that connection. Section D reflects on the heterodox perspective and its challenges to economics and the role of the State.

Chief of the Division for Gender Affairs of the Economic Commission for Latin America and the Caribbean (ECLAC). 


\section{A. The contributions of feminism}

Starting from the premise that heterodox thought is largely characterized by undogmatic critical thinking, feminist theory and its resulting policy proposals are part of an innovative, current wave of modernity in the global debate. The different expressions of feminism all retain certain fundamental ideas at their core, based on the concept of the sex/gender system as an analytical framework. ${ }^{2}$ Feminism has redefined the concepts of sexuality and its links with politics and legislation, pushing the frontiers of analysis of democracy and the role of the State towards the private sphere. According to Amelia Valcárcel (1997), feminism is a political philosophy of equality which, all principles being clear and distinct, simply argues as follows: if it is accepted that all human beings are equal in the quest for what are considered to be goods, why should half of the human race, the full collective of women, not have the same recognized rights to such goods as the entire human collective body?

By identifying the aforementioned links and analysing the power relations between subjects, the concept of human rights has been expanded to include the role of the State as guarantor of these rights in the family, thanks to an understanding of the interconnections between the public and private spheres.

The expansion of the concept of equality has been one of the most important contributions of feminist thought to the analysis of inequality. Feminist theory has revealed the distance between normative discourses on equality and day-to-day interactions, throwing into relief the different processes (cultural constructs) that reproduce inequality and highlighting the subtle mechanisms of "creating" others as inferior. In doing so, it has expanded the concept of universalism and has demonstrated the inadequacies of economic and political ${ }^{3}$ models and the human rights system itself (United Nations, 1993). Originally, universalism defined the community of equals on the basis of marital status, property, sex and other characteristics, however, that definition is now changing in favour of a broader human rights perspective. The freedom of the head of the household was based on inequality and the domination of others within the family group. By questioning the limits of universalism and expanding the concept to include women who have been denied those rights or subordinated in marital relationships in order to obtain

2 Gayle Rubin (1975) defines the sex/gender system as "the set of arrangements by which a society transforms biological sexuality into products of human activity, and in which these transformed sexual needs are satisfied".

3 According to Carole Pateman (1995), all democracies are inadequate from the point of view of gender. 
them, feminist theory has identified the structural causes of discrimination, by explaining the subordination of women as a conceptualized sex/gender system (Lamas, 2002) and, by extension, has been influential in securing the recognition of all family members, including children and adolescents, as rights holders.

Revealing the connections between different systems of inequality in the organization of social life and the configuration of experiences has highlighted the uniqueness and specificity of individuals' biographies over the life cycle in different sociocultural contexts (race, gender and ethnicity). Gender inequalities experienced on the basis of women's social background, ethnic and racial origins, age, and where they live combine with other forms of discrimination to create different life experiences. Models of oppression that exist in society do not act independently of each other; on the contrary, they are interrelated, creating a system of oppression that reflects the "intersection" of multiple forms of discrimination. ${ }^{4}$

Differentiated and disaggregated analysis has helped highlight the plurality of social and political actors who should be involved in discussions from which they are currently excluded, despite being directly concerned and recognized as interlocutors by various stakeholders and institutions, including the State. Parity has been one of the strategies used to make women's voices heard by acknowledging them as political subjects.

The equality perspective inscribed in the concept of gender transcends liberal and enlightened thinking. It goes beyond the concept of equal opportunities, by rendering explicit the biases and power constellations in different aspects of social relationships, challenging in particular the private power associated with the exercise of authority and the rationale of affective networks, as opposed to the public power associated with democracy. Feminist analysis has shown how the different approaches to exercising power in different settings are interrelated and thus restrict spaces and, consequently, the involvement of actors and engagement with issues that should be addressed in public arenas where agendas are drawn up. At the same time, it has expanded and enhanced understanding of how to engage in politics from less powerful positions.

By exposing the power relationships within the family, feminism has contributed to the political definition of social phenomena that had been ignored (such as femicide, the care economy and parity) and to the measurement of those phenomena using new statistics, thereby helping to determine development goals and dimensions. Such contributions have been

This is one reason why a gender perspective should be mainstreamed in all areas. 
based on data, knowledge and arguments that use social reality to question dominant representations and stereotypes. In politics, they have been based on the ability to form networks and alliances, to outline political scenarios around new problems and to pursue agendas over time. ${ }^{5}$ Equally important is the wealth of contributions that result from incorporating the criticism from social movements of indigenous and Afro-descendent women, and lesbian, gay, bisexual and transgender (LGBT) persons, and building linkages and assuming responsibility for the political and intellectual tensions created by recognizing all subjects.

Various conceptual tensions and challenges arise from the gender analysis of equality. These include the tensions between the particular and the universal, the individual and the collective, the public and the private, as well as issues related to representation and delegation of power and forms of leadership. The modern paradigm of the public and the private and contemporary understanding of the radical differences between men and women have been crucial in developing the criteria of inclusion, exclusion and classification that have underpinned contemporary forms of citizenship. The modern State is founded on a clear separation of the public and private spheres and on a hierarchical order of gender.

\section{B. The role of the State, democracy and the economy}

An analysis of the State and its relationship with economic and macroeconomic policy calls for an in-depth examination of the role of institutions (legislation, practices and mechanisms). The linkages between these institutions position the State as the supervisor or regulator of the market, without addressing other problems related to issues such as patriarchy, democracy, integration, citizenship and social equality.

Gender equality is an indicator of how democratic a political system is. Feminism criticizes democracy because it does not include women on an equal footing, particularly with regard to the exercise of power, and does not address their specific interests, thus diminishing their ability to act within the market, society and politics.

Increasingly, mechanisms have been developed to include women in elected and mandated posts, with the most important and effective compensatory mechanism being minimum quotas for representation.

The United Nations development agenda of the 1990s highlighted the feminist agenda's capacity for innovation, which is also clear in the post-2015 development agenda. 
In recent years, there has been some debate on and acceptance of parity democracy, which reconsiders the concept of representation as confined to ideological and territorial plurality alone: since the citizenry is made up of men and women, both should be represented in equal percentages in the political system. Achieving parity is thus a process that includes recourse to quotas and other tools but that, above all, requires recognition of women as full citizens in their own right.

Over the last 30 years, Latin America has shown that it is able to administer successful macroeconomic policies. The region has also been able to advance the cause of democracy during the last 25 years. However, both processes have been accompanied, in particular, by growing social and gender inequality. What the region needs, therefore, is an agenda that focuses on inequality, heterogeneity and gaps.

Notwithstanding the fundamental differences between the development models inspired by the welfare State and those based on the free market, one thing remains constant across the region's countries: women, despite their high levels of education and rapid entry into all areas of the labour market, still benefit the least from progress and development. This is related to the political invisibility of these gaps and the lack of awareness of the benefits of gender equality. The question then is, why does this happen? The invisibility of gender relations obscures the subordination of women and reinforces the widespread opinion of economists and politicians that this inequality is not relevant to policymaking, which ensures male hegemony in decision-making spheres. Gonzaga Belluzzo correctly points out that one of the challenges facing the region is that the State is at the mercy of special interest groups, whose clear gender bias is weakening public institutions (Gonzaga Belluzzo, 2013).

From the perspective of social and civic equality, this takeover by special interests refers equally to economic and financial interests (or corruption), and to the influence of religious fundamentalists in public institutions. Strengthening the secular State is crucial for development and restoring the ability of democratic institutions to guarantee effectively the freedom of worship, as well as the enjoyment of sexual and reproductive rights, without which it is impossible to envisage equal opportunities, much less their outcomes.

ECLAC reports (2013 and 2012a) have shown that women living in poverty are those who suffer the most from the lack of access to and enjoyment of those rights and also have fewer job opportunities. As can be seen in figure XII.1, around 50\% of working-age women in the region have no ties to the labour market. 
Figure XII.1

Latin America (18 countries): economic activity rate ${ }^{a}$ by sex, national total ${ }^{\mathrm{b}}$, survey rounds ${ }^{\mathrm{c}}$

(Percentages)

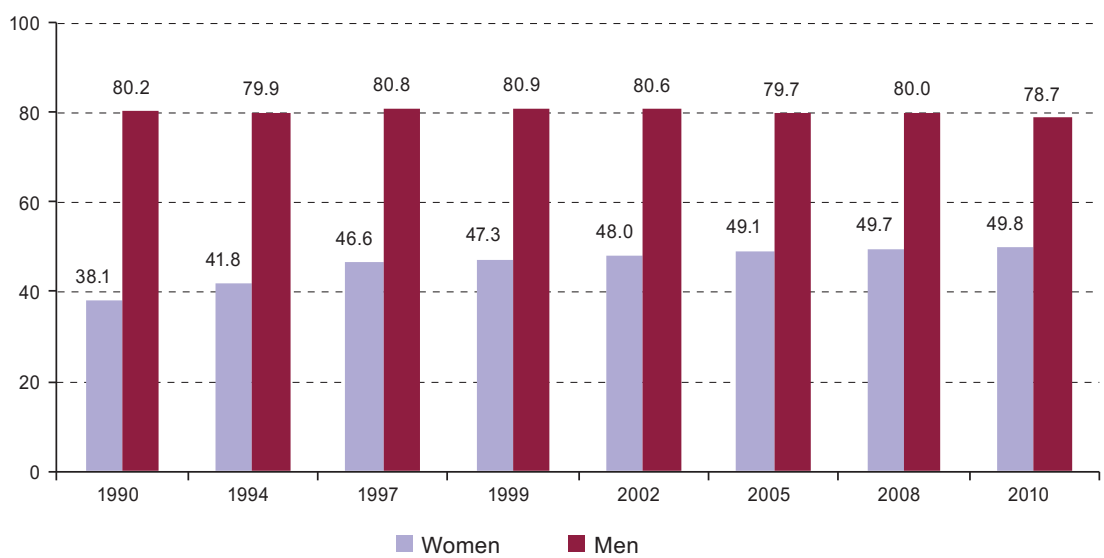

Source: Economic Commission for Latin America and the Caribbean (ECLAC), on the basis of special tabulations of household surveys conducted in the respective countries.

a Population aged 15 years and over.

b National data, except in the following cases: Argentina, urban data from all survey rounds; Plurinational State of Bolivia, urban data from the 1990 and 1994 rounds; Ecuador, urban data from the rounds from 1990 to 2002; Panama, urban data from the rounds from 1990 to 1999; Paraguay, urban data from the rounds from 1990 to 1997; Uruguay, urban data from the rounds from 1990 to 2005.

c Latin America, simple average of 18 countries, except for the following: the 1990 survey round does not include the Dominican Republic, El Salvador or Nicaragua; the 1994 round does not include the Dominican Republic or Guatemala; the 1997 round does not include the Dominican Republic, Guatemala or Nicaragua; the 1999 round does not include the Dominican Republic; the 2005 round does not include Guatemala; the 2008 round does not include Nicaragua; and the 2010 round does not include Guatemala.

One of the critical questions is the extent of the State's role in market regulation. The answer can be seen in the bailout policies employed by States in response to the financial crisis. The strength of the State's response to the crisis means that the State can legitimately be asked to meet demands for equality and redistribution.

\section{Economics and equality}

Neoliberal beliefs about the State playing only a regulatory role were shaken during the last crisis when States came to the rescue of the system. By accepting, legitimizing and encouraging the financial bailout, not only were all acceptable economic limits overridden, but ethical and moral concerns too. ${ }^{6}$

6 A clear example of this can be seen in Europe, with the housing crisis and evictions, among other problems. The consequences of the adjustment in Greece, among other countries, are also illustrative. 
The legitimacy of State intervention in favour of redistribution and equality is more compatible with the feminist economic perspective. In other words, if States can save speculative banking, then it stands to reason that they can invest in equality. The gender equality perspective and universal human rights allow the debate on possible development styles to be broached more clearly. Various "heterodoxies" may be invoked in the discussion on the ineffectiveness of neoliberalism, all of which call for the revaluation of the State. However, these approaches vary dramatically in their conception of development, of which a key dimension for feminism is the visibility, recognition and appreciation of women's work and the biases with which the issue is addressed from an economic and political standpoint. There are still ideological links between orthodox and heterodox views when it comes to gender equality.

Today, these concerns are being allayed by the recognition ${ }^{7}$ of the contributions of feminist thought to a new vision of well-being. This vision highlights the importance of unpaid work, domestic work and the invisible work carried out by women and men to promote well-being, through statistical and political visibility, and by challenging the traditional development paradigm, which links development to growth and, ultimately, to a topdown distribution. ${ }^{8}$

The main contribution of the gender perspective to economics has been to dispel the existing confusion between work and employment. These terms are not synonymous: in developed economies and, perhaps to an even greater extent, in developing countries, employment often absorbs less than half of the labour force. Studies on forms of work other than employment, such as unpaid work in the home or voluntary work, have made a significant contribution to this understanding.

Over the extended course of this intellectual debate, feminism has contributed not only to economic theory, but also to the understanding of the State and to promoting awareness of the structural conditions that differentiate the citizenship of men and women. This has taken place even in the context of welfare states, where women's citizenship and labour rights are linked to men's dominance in the labour market. It has taken a long time - and indeed there is still some way to go- for women to obtain the legitimate right to labour participation with autonomy.

In order to move towards an equal rights agenda, the gender-based approach - which exposes and recognizes the gender relations at play in

The Sarkozy Commission commissioned a report, prepared by Stiglitz, Sen and Fitoussi (2009). One of the most notable proponents of this school of thought is María Angeles Durán (Durán, 2012 and 2007), whose forthcoming contributions, to be published by the Economic Commission for Latin America and the Caribbean (ECLAC), summarize the current thinking on the economy and development. 
a variety of areas in connection with the development of individuals and societies- has identified the sexual division of labour and time-use differences as the basis for women's economic, social and political subordination. To remedy this situation, governments must find the political will to implement changes that will develop women's capacities, provide them with opportunities and guarantee their rights.

Reflections on economics, production, development and sustainable development have also been enriched by the emphasis in feminist thought ${ }^{9}$ on putting a value on and taking into account the costs associated, not only with the contributions of nature and the exploitation of natural resources to the economy, but also with the contributions of unpaid work to the production of a range of goods and services, which, particularly in Latin America, is carried out largely by women living in poverty (see figure XII.2).

Figure XII.2

Latin America (simple average of 17 countries): income distribution inequality by income quintile, by sex, urban areas, around 2012

(Percentages)

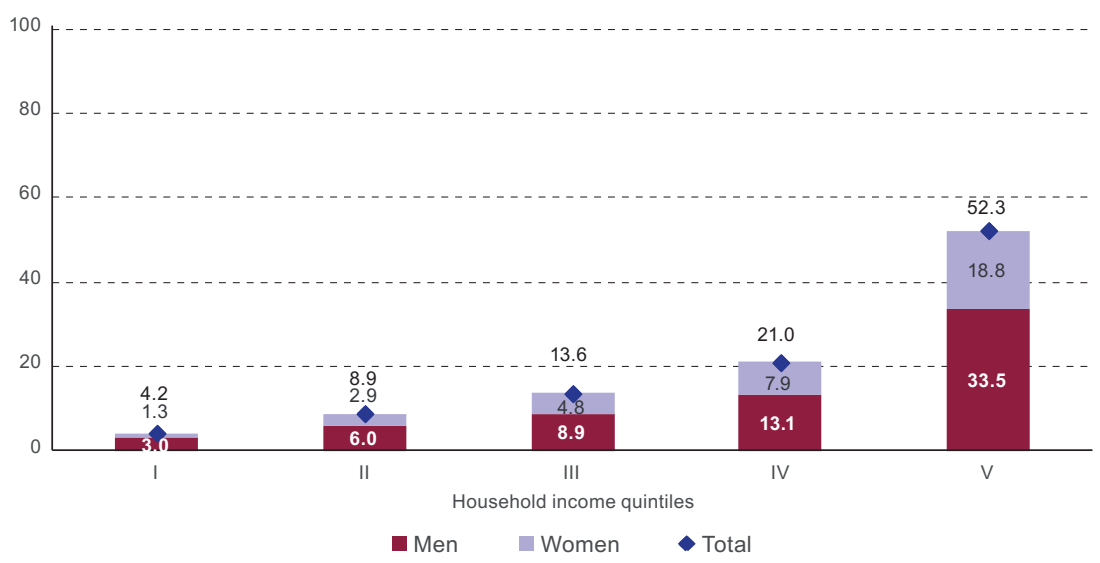

Source: Economic Commission for Latin America and the Caribbean (ECLAC).

A new challenge thus emerges: research and documentation are needed to demonstrate where that contribution comes from, for example, whether it is women working in agriculture or service chains or migrant women sending remittances back to their country of origin. In short, there are a range of factors that are protecting society from social and economic decline, but which are not part of the system of checks and balances established by economic policies to redress the specificities and biases suffered, not by a minority of women, but by half of the population.

9 Hazel Henderson was one of the main exponents of feminist thought in the 1960s and 1970s. 
An approach is needed that recognizes diversity and that also accepts that this means distinguishing between, highlighting, quantifying, redefining and attributing value to a range of subjects. Why should work be redefined? Because to date the notion of work, as accepted by governments, academia and most fields of research, is a commercial concept linked to wage-earning - hence there is no work if there is no salary- when, in reality, there is overwhelming evidence to show that value-creating goods and services are being produced in households for no pay. This, together with the recognition today that the "production" or reproduction of the species is fundamental to productivity growth, means that public policy should not concern itself only with labour matters or social protection, which are already key challenges, but should also expand on the concept of equality from a non-public perspective and not only as part of a policy objective.

The contribution of feminism to critical thinking on the State and the economy cannot be underestimated. By averring that that the personal is political, it seeks to wrest women's bodies, time and voices from State control, questioning the opinion that their work is secondary, either as a supplementary family wage or unpaid work within the home, and to push the limits of rights by extending protection to the domestic arena and demanding that the State guarantee full recognition of those rights.

Demographic changes have foregrounded the scope of care work and its economic value. Statistics show that care is provided primarily by women, who are in some cases poorly paid and in others unpaid. Domestic work has become a transnational issue as women from developing countries emigrate to care for older persons, extending globalization into the private sphere and shifting from the universal to the local perspective, and vice versa. As stated above, the analysis of work and the economy must move beyond the macroeconomic and commercial limits placed on the definitions of those terms, in order to redefine care work in relation to other activities. One question that could be asked, for example, is: why is the value of atomic bombs included in gross domestic product (GDP) when care work is not? Why does building bombs to destroy lives boost economic growth, while the unpaid work of women, who create human beings, values and the skills to learn, to be productive and develop is not measured?

\section{Heterodox economics and the role of the State}

One of the great weaknesses of this heterodox perspective of production and development is the lack of information and data, although several Latin American countries are making efforts to measure and recognize the value of time in these processes. The concept of time poverty also challenges the traditional method of measuring poverty, which is income poverty 
(see figure XII.3). In this connection, the Economic Commission for Latin America and the Caribbean (ECLAC) is working on a new, distinct and multidimensional methodology for measuring poverty. It seeks to include time in the measurement of poverty, not as a modifier, but as a factor that describes the conceptual relationship between income and time, which would make it clear that the capacity of women to generate income is structurally linked to their domestic ties; that is, women lack the freedom to choose where to work, even if they are educated, if there is no investment in infrastructure or active policies to remove the obstacles women face when entering the labour market. Thus, the time factor and the measurement, valuation and integration of such considerations in public policy are a challenge for the new heterodox economics.

Figure XII.3

Latin America (7 countries): total time ${ }^{a}$ spent on paid and unpaid work by sex, by country, latest available data ${ }^{b}$

(Average weekly hours)

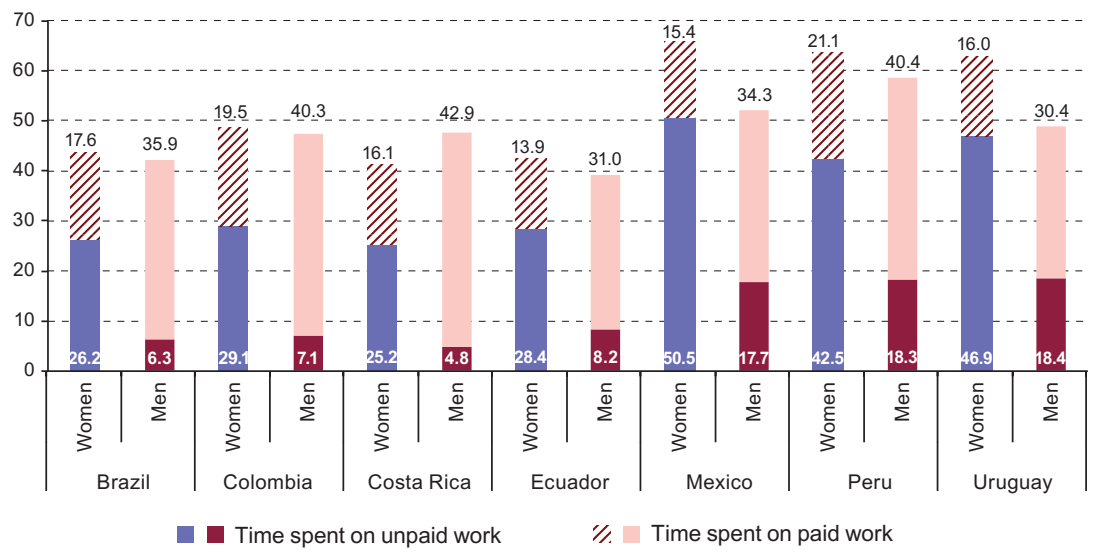

Source: Economic Commission for Latin America and the Caribbean (ECLAC), on the basis of special tabulations of household surveys conducted in respective countries.

a Population aged 15 years and over.

b Data from 2011, except for Mexico (2009), Peru (2010) and Uruguay (2007).

A striking example of this was the pension reform in Chile in 2008. This contradicted the more traditional schools of thought, which affirmed that it was impossible to recognize women's unpaid work. The pension reform established a solidarity fund and vouchers, issued on the basis of the number of live births, so that women might overcome gaps in their pension contributions and provide for their retirement. Here political will prevailed: it took a female President in Chile, Michelle Bachelet, for the pension reform to become a reality. Until she took steps to extend coverage to women who had been previously ignored by pension fund managers, it had been an invisible issue (Arenas, 2010). 
Another significant challenge that calls for affirmative action policies is the matter of averages. Although Latin America has seen a drop in poverty, the poverty gap between men and women has not narrowed. This means that even poverty is distributed according to gender patterns, so the challenge is to ensure that these gaps do not widen while the averages decrease (see figure XII.4).

\section{Figure XII.4}

Latin America (18 countries): femininity index of poverty by country and region, around 2002 and 2012

(Percentages)

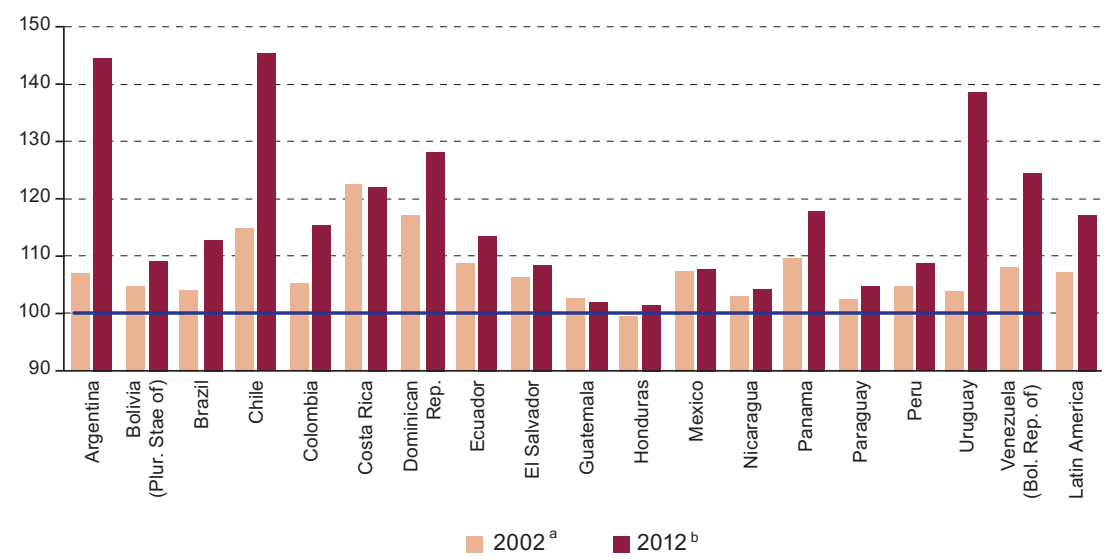

Source: Economic Commission for Latin America and the Caribbean (ECLAC), on the basis of special tabulations of household surveys conducted in the respective countries.

a National data, except for Argentina, Ecuador and Uruguay, where they correspond to urban areas. The national data for Chile are from 2003, and those for El Salvador, Nicaragua and Paraguay are from 2001.

b National data, except for Argentina, where they correspond to urban areas. The national data for Chile, Panama, Paraguay and the Plurinational State of Bolivia are from 2011; those for Honduras are from 2010; those for Nicaragua are from 2009; and those for Guatemala are from 2006.

As for the gender pay gap, it is unacceptable that, in a society where women are more educated than men and where both suffer as a result of the education system's weaknesses with respect to fostering innovation and production, women end up being inexplicably penalized, especially since they are not responsible for the discrimination that they face (see figure XII.5).

As a result, the State faces a number of challenges with regard to its role in society. It must be able to guarantee rights and adopt public policies that are fit for purpose on a range of issues that are not directly related to the economy, but to family, liberty, sexuality, violence against women, fertility and other matters. The implementation of those public policies should be supported by fiscal and tax policies targeting the same issues. 
Figure XII.5

Latin America (simple average of 18 countries): ${ }^{a}$ ratio between women's and men's average labour income, by years of education, national total, around 2012

(Percentages)

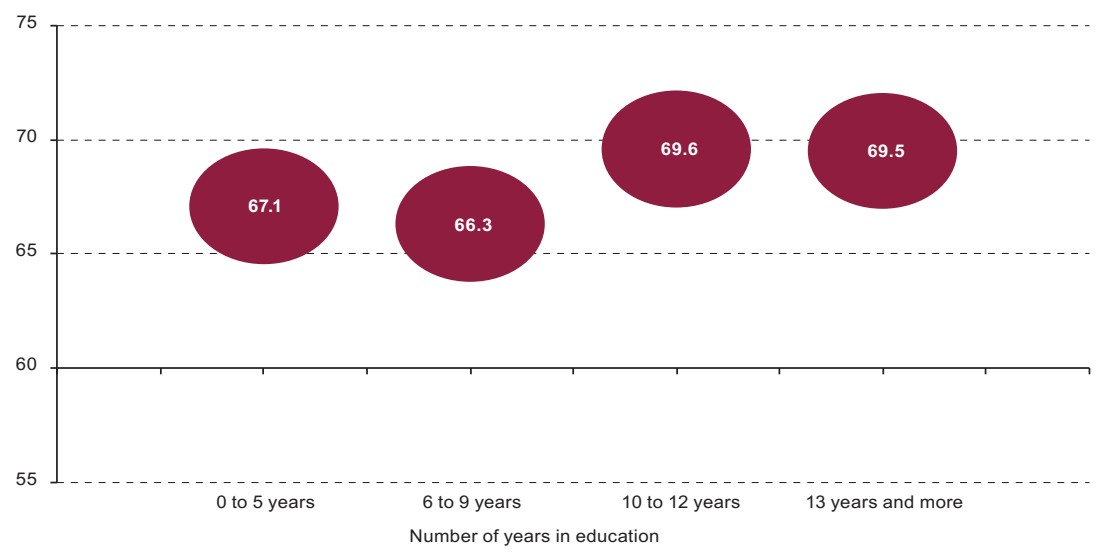

Source: Economic Commission for Latin America and the Caribbean (ECLAC), on the basis of special tabulations of household surveys conducted in the respective countries.

a National data, except for Argentina, where they correspond to urban areas. The data for Argentina, Bolivarian Republic of Venezuela, Brazil, Colombia, Costa Rica, Dominican Republic, Ecuador, El Salvador, Mexico, Peru and Uruguay are from 2012; those for Chile, Panama, Paraguay and Plurinational State of Bolivia are from 2011; those for Honduras are from 2010; those for Nicaragua are from 2009; and those for Guatemala are from 2006.

The idea that the State should play an active role in production and redistribution is making a welcome comeback and, on that basis, a new State-market equation is being sought. However, the State must also be able to overcome obstacles in order to meet its commitments on promoting active citizenship, democracy and the equal participation of men and women in decision-making. The still invisible chains in the areas of the care economy and poverty must be broken in order to implement these and other policies, as well as specific actions by States that address what Isabella Bakker calls the strategic silence.

In the light of the above, development analysis cannot be limited to including women in each subject field, to dedicating a specific area of study to them or to examining the effects of inequalities on women's lives. Rather, it should transcend those boundaries and encompass an understanding of unequal gender relations as power relations and a substantive aspect of development, which affects all economic, political and cultural processes. Only thus will progress be made towards a formal analysis of the complexity of development, which will make it easier to predict the failure of public policies, regardless of the good intentions that inspired them. 


\section{Bibliography}

Albelda, Randy, Mignon Duffy and Nancy Folbre (2009), Counting on Care Work. Human Infrastructure in Massachusetts, University of Massachusetts.

Antonopoulos, Rania and Indira Hirway (eds.) (2010), Unpaid Work and the Economy: Gender, Time Use and Poverty in Developing Countries, London, Palgrave Macmillan.

Antonopoulos, Rania, Nilufer Cagatay and Sara Hsu (2012), Gender Perspectives and Gender Impacts of the Global Economic Crisis, Routledge.

Arenas, Alberto (2010), Historia de la reforma previsional chilena: una experiencia exitosa de política pública en democracia, International Labour Organization (ILO).

Arenas, Alberto and Pamela Gana (2001), "Reforma a los sistemas de pensiones y los desafíos de la dimensión de género", Población y Desarrollo series, No. 18 (LC/L.1614-P), Santiago, Economic Commission for Latin America and the Caribbean (ECLAC).

Bakker, Isabella (ed.) (1994), The Strategic Silence: Gender and economic policy, London, Zed Books.

Beck, Ulrich (2004), Poder y contrapoder en la era global: la nueva economía política mundial, Barcelona, Paidos.

Calderón, Coral (coord.) (2013), "Redistribuir el cuidado. El desafío de las políticas", Cuadernos de la CEPAL, No. 101 (LC/G.2568-P), Santiago, Economic Commission for Latin America and the Caribbean (ECLAC).

Carrasco, Cristina, Cristina Borderías and Teresa Torns (eds.), El trabajo de cuidados. Historia, teoría y politicas, Madrid, Editorial Catarata.

Durán, María Angeles (2012), El trabajo no remunerado en la economía global, Fundacion BBVA. (2007), El valor del tiempo. Cuántas horas te faltan al día?, Madrid, Espasa Calpe.

ECLAC (Economic Commission for Latin America and the Caribbean) (2013), Women in the digital economy: Breaking through the equality threshold (LC/L.3666 (CRM.12/3), Santiago.

(2012a), Gender Equality Observatory of Latin America and the Caribbean. Annual Report 2012. A look at grants support and burden for women (LC/G.2561), Santiago. (2012b), Social Panorama of Latin America, 2012 (LC/G.2557-P), Santiago.

Espejo, A., F. Filgueira and N. Rico (2010), “Familias latinoamericanas: organization del trabajo no remunerado y de cuidado", Project Documents, No. 354 (LC/W.354), Santiago, Economic Commission for Latin America and the Caribbean (ECLAC).

Gammage, Sarah (2010), "Encuestas de uso de tiempo y las politicas de protection social" [online] http://www.mujer.gov.py/userfiles/file/Ponencia $\% 20 \mathrm{de} \% 20$ Sarah\%20Gammage\%20-\%20Chile.pdf.

(2009), Género, pobreza de tiempo y capacidades en Guatemala: un análisis multifactorial desde una perspectiva económica (LC/MEX/L.955), Mexico City, ECLAC subregional headquarters in Mexico.

Gonzaga Belluzzo, Luiz (2013), "Algunos aspectos de los desafíos económicos de América Latina y el Caribe", presentation at the seminar on neostructuralism and heterodox economics, Santiago, Economic Commission for Latin America and the Caribbean (ECLAC), 22-23 April. 
Henderson, Hazel (1996), Creating Alternative Futures: The End of Economics, Connecticut, Kumarian Press Books for a World that Works.

(1991), Paradigms in Progress: Life beyond Economics, Indianapolis, Knowledge Systems.

Lamas, Marta (2002), Cuerpo: diferencia sexual y género, Mexico City, Taurus.

Montaño, Sonia and Coral Calderón (coords.) (2010), “El cuidado en acción: entre el derecho y el trabajo", Cuadernos de la CEPAL, No. 94 (LC/G.2454-P), Santiago, Economic Commission for Latin America and the Caribbean (ECLAC).

Orozco, Mónica and Anitzel Merino (2011), "Pobreza de tiempo de las mujeres", paper presented at the ninth international meeting on public policy, time use and the care economy, National Women's Institute (INMUJERES)/UN-Women, Mexico City, 29-30 August.

Pateman, Carole (1995), El contrato sexual, Ed. Anthropos.

Rubin, Gayle (1975), "The traffic in women. Notes on the "political economy" of sex", Toward an Anthropology of Women, R. Reiter (comp.), New York, Monthly Review Press.

Stiglitz, Joseph E., Amartya Sen and Jean-Paul Fitoussi (2009), "Report by the Commission on the Measurement of Economic Performance and Social Progress" [online] http:/ / www.stiglitz-sen-fitoussi.fr/documents/overview-eng.pdf.

United Nations (1993), Vienna Declaration and Programme of Action. Note by the Secretariat (A/CONF.157/23), 12 July.

Valcárcel, Amelia (1997), La política de las mujeres, Madrid, Editorial Cátedra. 
Part V

Case studies of major economies in the region 



\section{Development and macroeconomics: reflections from the Mexican case}

Juan Carlos Moreno-Brid ${ }^{1}$

\section{Introduction}

The purpose of this article is to draw attention to fundamental elements in the structure of an economy that need to be considered in the design of a macroeconomic policy for development. It draws on contributions from the neo-structuralist approach, particularly its emphasis on the importance of productive heterogeneity as a determinant of economic growth patterns. Also considered are some criticisms of conventional macroeconomic policy from different perspectives prompted by the international financial crisis which broke out in 2008 and 2009. The macroeconomic policy applied in Mexico during the last 30 years and its relationship to the performance of the country's economy have been considered for illustration purposes.

The author is Deputy Director and Officer-in-Charge of Research Coordination at the ECLAC subregional headquarters in Mexico City. He is grateful for the comments of Esteban Pérez, Miguel Torres and Luis Ángel Monroy on a preliminary version of this study presented at the Neo-structuralism and Heterodox Economics seminar held by ECLAC in Santiago on 22 and 23 April 2013. Jesús Santamaría's valuable assistance with the research is also acknowledged. The present chapter is largely based on a preliminary version submitted to Problemas del Desarrollo, a review published by the National Autonomous University of Mexico (UNAM). 
The reference period selected to examine the evolution of the Mexican economy starts in the mid-1980s, when the Mexican government began to implement a series of radical reforms guided by the Washington Consensus in response to the economic contraction the country had experienced in 1981 and 1982, including a moratorium on external payments which triggered the international debt crisis in Latin America. The goal of the reforms was to put an end to the traditional development template followed by the country since the earliest post-war years, based on State-led industrialization and import substitution. Accordingly, the government of De la Madrid (1982-1988) quickly began to dismantle the system of trade protection, liberalize the financial market, shut down industrial policy, shrink the public sector by privatizing or closing many of the more than 1,000 parastatal firms that existed at the time and reduce public spending, especially on investment.

In line with the dominant ideology of the time, a policy of "less State, more market" was believed to be indispensable for achieving a better economic performance, in a context of trade and financial liberalization. The economic authorities decided that the priority of macroeconomic policy was nominal stability, meaning consistently low inflation. With this in view, macroeconomic policy focused on entrenching strong fiscal discipline to close the deficit, with the emphasis on cutting spending rather than enhancing fiscal revenues. A key assumption in this new strategy was that reducing State interference in the economy to a minimum and eliminating the deficit in the public finances would guarantee a low and stable inflation rate. This, in turn, was seen as a necessary and largely sufficient condition for setting the economy on a path of strong and lasting export-led, labour-intensive growth, labour being the most abundant resource in the Mexican economy. This macroeconomic policy orientation has prevailed ever since, and was actually intensified between 2000 and 2012, i.e. during the two six-year terms in which the National Action Party held the presidency.

This macroeconomic policy achieved substantial results in terms of nominal stabilization and the orientation of production towards exports. For years now, Mexico has run only very small fiscal deficits and inflation has been low, moving within the narrow target range of the Bank of Mexico. The country has seen an impressive upsurge in manufacturing exports, which expanded continuously at annual rates of over $10 \%$ until the outbreak of the international financial crisis in 2008 and 2009. Furthermore, they are largely comprised of high-technology products. For some time, then, manufactures have represented more than $80 \%$ of all the country's exports, as against just $10 \%$ in 1980. Meanwhile, the poverty rate is lower now than in 1990, at the end of the lost decade.

However, these undeniable achievements are far from having translated into high and sustained growth, free of financial or balance-of-payments crises, 
in the Mexican economy. Growth rates in the country over the period have been so low that the per capita GDP gap with the United States was larger in 2012 than in 1980. Although poverty has declined, it still affects over $50 \%$ of the population, and more than $80 \%$ of Mexicans live in conditions of poverty or vulnerability. The disappointing performance of the Mexican economy over three decades under a macroeconomic policy based on preserving nominal stability (low inflation and fiscal deficits) and keeping the State out of the economy -with all this has entailed for the orientation of fiscal, monetary and exchange-rate, trade and industrial policy- provides the starting point for a number of reflections on what a macroeconomic policy for development should look like.

\section{A. Progress, unresolved issues and reverses in Mexican macroeconomic policy over the last three decades}

The first point to stress, although this may be unnecessary given its familiarity in ECLAC thinking, is how mistaken the idea underlying conventional macroeconomic policy is, namely that low and stable inflation and healthy public finances, meaning a very low fiscal deficit or none and minimal State intervention in the economy and resource allocation, are necessary and sufficient conditions for high and sustained economic growth. This has been the orientation of fiscal and monetary policy in Mexico for 30 years. A managed float regime for the exchange rate is more conducive to achieving the inflation target than to correcting the medium- or long-run external imbalance. For decades now, fiscal policy has operated under a legal framework (the Federal Budget and Fiscal Responsibility Act) requiring a nominal fiscal balance of zero, excluding investment in Petróleos Mexicanos (PEMEX). This legal constraint, applied regardless of the phase in the economic cycle, gives fiscal policy a procyclical stance, deepening recessions and fuelling expansions. The weak impact of fiscal instruments is compounded by the low tax burden (among the lowest in the region) and its heavy dependence on resources from oil exports, which means that oil trade imbalances feed through directly into fiscal imbalances. Consequently, the Bank of Mexico reference interest rate is the essential instrument for controlling aggregate demand, or rather for influencing inflationary pressures.

Since the 1990s, this macroeconomic policy stance, together with a domestic market held resolutely open to international competition and limited or constrained public-sector intervention in the productive sphere, have entrenched low inflation (about 3\% annually) and a fiscal deficit of less than $3 \%$ of GDP. However, and notwithstanding the manufacturing export boom already mentioned, the Mexican economy has remained mired in low 
growth. The average annual GDP growth rate between 1987 and 2012 was less than half what it had been between 1960 and 1981, and the country's share of world GDP has fallen steadily since the 1980s as a result. Thus, Mexico was responsible for $2.68 \%$ of world GDP in 1990 but only $2.13 \%$ in 2013. This lack of dynamism is even more apparent when per capita GDP is considered. Between 1994 (when the North American Free Trade Agreement came into force) and 2012, real per capita GDP growth in Mexico averaged just $1.1 \%$ a year in constant dollars. Because of this economic slackness, the income gap between Mexico and the United States has widened rather than narrowing. In 1980, real per capita GDP in Mexico was equivalent to $23 \%$ of that of the United States, but by 1994 the figure was just $17.7 \%$, and in 2012 it was down to $16.9 \%$. In other words, today's gap is comparable to that recorded in the 1950s.

Figure XIII.1

Mexico and selected countries: real per capita GDP as a share of United States per capita GDP, 1980-2012 (Percentages)

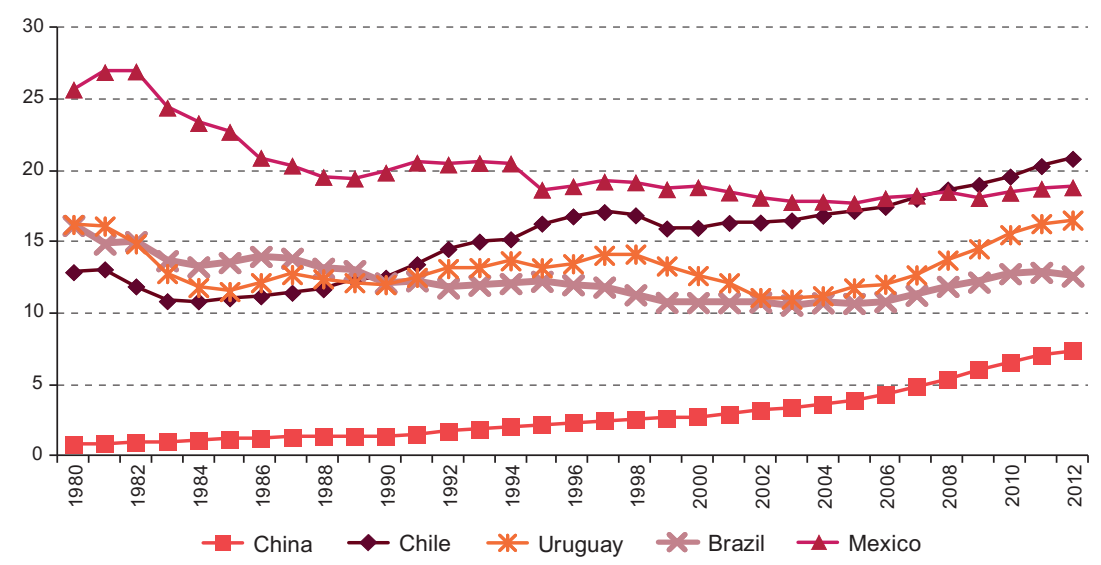

Source: Prepared by the author on the basis of World Bank, World Development Indicators.

a Percentage gaps calculated from data expressed in constant 2000 dollars. The path of the relative gaps of the countries considered for this indicator is sensitive to the base year taken to measure per capita GDP in real dollars.

Once it has been established, with reference to the conventional macroeconomic policy stance, that low and stable inflation and sustainable public finances are necessary but not sufficient conditions for high and sustained economic growth, the next step is to try to ascertain what constraints have prevented and are still preventing the Mexican economy from achieving long-term growth of over 5\%. To what extent has macroeconomic policy in Mexico weakened, ignored or even fortified these constraints? 
To answer this question, the present study will use an unconventional perspective that centres on demand rather than on the manifold growth accounting exercises. From this viewpoint, the underlying causes of the persistent lack of dynamism in the Mexican economy since the mid-1980s are to be found in two closely related factors. The first is the behaviour of investment, in terms both of its aggregate amount as a share of GDP and its relative orientation towards non-tradable activities. Gross fixed capital formation in Mexico has been below 25\% of GDP since the mid-1980s, this being the minimum threshold calculated by ECLAC and the United Nations Conference on Trade and Development (UNCTAD) for average real GDP growth of over $5 \%$ a year to be sustained.

The other factor is the weakening of the internal linkages in the country's production structure, reflected in a very substantial rise in the income-elasticity of imports since the mid-1980s, with a striking diminution in the spillover effects of demand and especially exports in the rest of the production system. The weakening of both forward and backward domestic linkages, which in effect represents a thinning out of Mexico's input-output matrix, can be put down to the speed of trade opening and, most of all, the dismantling of industrial policy. All this, together with the emergence of a tendency towards real exchange-rate appreciation, has resulted in a substantial drop in the Keynesian multiplier for spending (which to some degree is exogenous), investment and exports. ${ }^{2}$ On the aggregate demand side, as indicated earlier, the sharp slowing of Mexico's economy since the late 1980s is explained by the drop in the Keynesian multiplier and the loss of investment dynamism.

For six decades, as figure XIII.2 shows, the Mexican economy has followed a pattern of expansion marked by a significant external constraint. Specifically, trade deficits representing similar proportions of GDP have tended to be associated with lower and lower rates of average annual growth in real GDP. In the 1960s and 1970s, real GDP expanded by an average of 5\% or $6 \%$ a year and there was a trade deficit equivalent to $2.5 \%$ of GDP. Between 1988 and 1994, the first stage in the new development strategy with market reforms, the average annual rate of real GDP growth was about $4 \%$ and the trade deficit was slightly larger as a share of GDP. Between 2001 and 2012, the average rate of increase in production activity was just over $2 \%$, while the trade deficit was similar to that of the 1970s. This behaviour of the trade deficit reflects the relative growth of imports, whose share of GDP rose by about 30 percentage points from just over 5\% of GDP in 1986 to 35\% in 2012.

From the point of view of demand, the effects of a decline in the multiplier need to be separated from the effects of a drop in export or investment dynamism. In the first case, the multiplier $\frac{1}{(1-c+m)}$, may contract because of a rising propensity to import or save, which sets it apart from the second case of waning export or investment dynamism. In the rest of the chapter, only the first situation will be presented as a drop in the multiplier. 
Figure XIII.2

Mexico: annual growth rate of GDP and trade balance as a percentage of GDP, average for selected periods, 1960-2012

(Percentages)

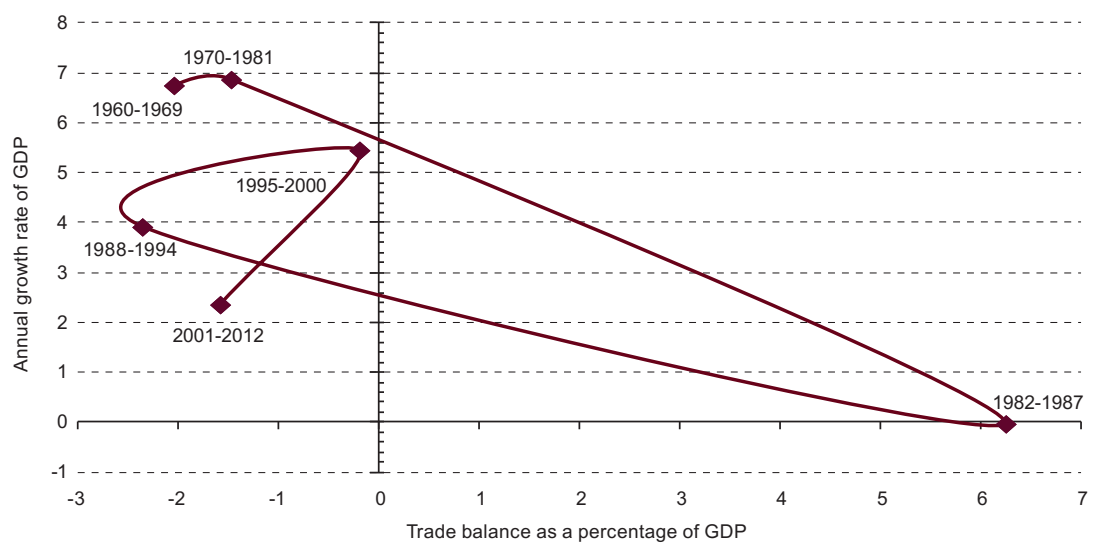

Source: Prepared by the author on the basis of official figures.

While import penetration in the domestic market has risen greatly, the domestic saving rate has followed a very stable path, holding steady at between $20 \%$ and $25 \%$ of GDP over the last 30 years. This rise in the propensity to import has been so large that, in the context of a practically unaltered propensity to save, it has driven down the Keynesian multiplier $\frac{1}{(1-c+m)}$, which determines the impact of investment and exports on GDP growth. According to the author's calculations, the multiplier dropped from an average of 3.1 between 1960 and 1981 to 1.13 between 1987 and 2012. ${ }^{3}$ The contraction of the multiplier, combined with less dynamic investment, was not fully offset by the rise in exports. Consequently, the average real annual GDP growth rate dropped substantially between the two periods, from $6.9 \%$ between 1960 and 1981 to $2.7 \%$ between 1987 and 2012 .

There has been a recent resurgence of the debate about the relative importance of investment weakness and the drop in the Keynesian multiplier as determinants of the slow pace of growth in the Mexican economy since the mid-1980s. Both factors are partially responsible for the loss of economic dynamism in Mexico. On the one hand, as already noted, the multiplier collapsed after 1987 to a third of its average pre-1981 value. On the other, gross fixed investment fell off sharply after the reforms, increasing at a real annual average rate of $9.1 \%$ between 1960 and 1981 but just 4.5\%between 1987 and 2012.

The first subperiod encompasses the closing decades of the State-led industrialization development model in the Mexican economy. The second reflects the economy's performance under the new neoliberal dispensation, taking as its starting year 1987, when Mexico was exiting the worst of the debt crisis and the 1986 balance-of-payments crisis. 
Both elements were factors in the slow rate of GDP growth, but according to the author's calculations, taking account of the decline in the Keynesian multiplier, if investment had risen at the same pace after 1987 as it did between 1960 and 1981, average annual GDP growth would have been $4 \%$, i.e. higher than the $2.7 \%$ actually recorded, but well below the $6.9 \%$ seen in the period between 1960 and 1981. The author's calculations also reveal that if the Keynesian multiplier had remained at the same level, the average annual increase in real GDP between 1987 and 2012 would have been 5\%, although investment growth would have averaged $4.5 \%$, as in fact it did. Indeed, given the drop in the multiplier, sustaining annual GDP growth of $6.9 \%$ between 1987 and 2012 would have required the export boom to be accompanied by an average annual increase in real gross investment of $14 \%$, a rate the Mexican economy has never managed to sustain over a period of years.

The above results indicate that, unless a policy is adopted to create denser domestic linkages within the Mexican production system, thereby reducing the average propensity to import and raising the Keynesian multiplier, real average annual GDP growth of $5 \%$ or $6 \%$ a year would inevitably lead to an unsustainable increase in the trade deficit as a share of GDP, which would be impossible to finance. This is known in the heterodox literature as the balance-of-payments constraint on economic growth. More generally, the dominant role played by the balance of payments in Mexico, as in many other emerging economies that are not yet fully industrialized, is a significant constraint on long-term economic growth. Consequently, unless an active industrial policy is implemented, achieving sustained output growth of more than $5 \%$ a year would entail a large increase in the trade deficit that would sooner or later trigger a currency or balanceof-payments crisis. It is worth stressing that, as things stand, the balanceof-payments constraint affects long-term growth but not necessarily short-term growth.

The importance of the external sector, the balance of payments or, analogously, the continuing decline of the demand multiplier as a fundamental constraint on economic growth in Mexico is an important lesson yielded by a neo-structuralist perspective on macroeconomic policy. It by no means implies that investment is unimportant. On the contrary, the only way of dealing with the external constraint in the long run is by implementing an intensive investment process aimed at bringing about structural change in the Mexican economy. The goal of this change must be to strengthen higher-technology sectors, activities or links with the greatest increasing returns to scale, the best prospects of successful participation in market niches where demand is dynamic and the strongest potential to positively influence the rest of the production system. The first two characteristics have been identified as Keynesian and Schumpeterian efficiencies (ECLAC, 2012). 
They are complemented by the last, defined by the author as Hirschmanian efficiency, which makes for a denser production matrix.

The data indicate that the series of neoliberal or market reforms undertaken by Mexico from the mid-1980s did bring about a radical shift in the composition of exports, but not in their destination. Whereas to begin with they consisted very largely of oil, within a few years over four fifths were manufactures, generally with a high technology content. However, these reforms and the change in the export profile were not accompanied by any major change in the country's production structure. Considering the structural change indicator originally proposed by UNCTAD, MorenoBrid and Ros (2010) note that the change in the composition of the Mexican economy's production structure at the two-digit level after the reforms amounted to less than $20 \%$.

In addition, this limited structural change did little to reduce sectoral heterogeneity as regards the labour productivity gap, for example. As Monroy (2014) shows, from the mid-1980s until 2011 (the latest year for which information was available), the coefficient of variation of relative labour productivity increased systematically in the nine major sectors of activity covered by Mexico's national accounts: agriculture; mining; manufacturing; electricity, gas and water; construction; commerce, hotels and restaurants; communications and transport; finance; and other services. The value of this coefficient was 0.48 in 1986, 0.57 in 1994, 0.76 in 2000 and 0.81 in 2011. The electricity, gas and water sector had the highest labour productivity throughout this process. Furthermore, the gap or divergence widened over the period. Whereas its labour productivity was 2.74 times the average in 1986, by 2011 it was 4.76. Structural divergence in the evolution of relative productivity was reflected in a number of sectors and not just in the growing divide in favour of the electricity, gas and water sector. Thus, labour productivity in mining, in communications and transport and to a lesser extent in manufactures rose by more than the national average.

The relative labour productivity performance of manufacturing was especially significant in this process of very limited structural change in the Mexican economy over the period. While labour productivity in manufacturing was $3 \%$ above the national average in 1986, the gap had risen to $14 \%$ by $1994,20 \%$ by 2000 and $30 \%$ by 2011 . This process of rising labour productivity in manufacturing was combined with a drop in employment and weak fixed capital formation in the sector. This all suggests that the rise in manufacturing productivity was fragile, being driven by personnel cutbacks with hardly any modernization of machinery and equipment stocks. Thus, the manufacturing sector, probably the group of activities with the greatest potential to create productive externalities, barely maintained its GDP share and experienced a large drop in its employment share. The 
lack of dynamism in manufacturing prevented the Mexican economy from absorbing labour from the countryside and from unproductive services, thus holding down overall productivity and sending the country down a path of low long-term growth.

The Mexican economy, then, has undergone a structural change which has exacerbated rather than lifted the external constraints affecting its long-run growth. As the structuralists argued, development is a process of structural change, but structural change also has consequences and costs. This ties in with the idea that the structuralists in general, and Raúl Prebisch in particular, were aware that structural change could cause or exacerbate external constraints and even entail acute foreign-exchange shortages or "external strangulation". In other words, structural change does not always take place in a context of perfect flexibility, nor is it without substantial costs.

Consequently, no strategy for structural change can successfully pursue development unless it narrows intersectoral productivity gaps, enhances forward and backward linkages in the production system and seeks openings in markets with highly dynamic demand. The aim in all this is to break the vicious circle of slow growth, low investment, inadequate expansion of sectors subject to increasing returns to scale, limited productivity, an overlarge informal labour market and all the economic and social problems people suffer as a result. To achieve it, as ECLAC has stressed, there has to be strong investment, both public and private, within the framework of a renewed and active industrial policy geared to this very task of transforming the country's production structure.

The experience of the Mexican economy in the decades analysed indicates that, as emphasized earlier, the amount of gross fixed investment matters when it comes to promoting strong and lasting GDP growth. What may matter even more, though, is its sectoral structure or composition. There have been fairly long periods when investment as a share of GDP in the Mexican economy has been at much the same level, but with very different outcomes where the rate of GDP growth is concerned. This share was about 19\% both from 1960 to 1969 and from 1988 to 1994, for example, but average annual GDP growth was almost $7 \%$ in the first period and 3 points lower in the second. Between 2001 and 2012, investment averaged 21\% of GDP, but real GDP growth was barely $2.5 \%$ a year.

A similar analysis of the evolution of investment in the Mexican economy, distinguishing its public from its private components on the one hand and infrastructure investment from that in machinery and equipment on the other, likewise reveals little correlation with real GDP growth. In other words, the impact of investment on economic growth seems to depend less on its amount and more on its composition and orientation to different sectors or activities. The more it is oriented towards changing the production 
structure in the direction indicated so that Keynesian, Schumpeterian and Hirschmanian efficiencies are strengthened, the greater its impact in promoting long-term economic expansion will be. This reconfirms the importance of the production structure as a determinant of economic growth. It is no coincidence that the slow growth of the Mexican economy since 1987 has been accompanied by a pattern of fixed investment wherein fixed capital stocks have expanded less dynamically in manufacturing than in the other major sectors of activity making up the economy.

On this point, ECLAC (2012) argued in Structural Change for Equality: An Integrated Approach to Development that, in reorienting the industrial system, three fundamental elements need to guide macroeconomic policy so as to ensure not only nominal stability but also strong, lasting growth in the Mexican economy. For the purposes of the present study, these three elements are identified or associated with Keynes, Schumpeter and Hirschman. The first stresses the need for the production system to seek out markets with strong demand in the short and, particularly, the long term. The second focuses on local production and manufacturing processes and recommends that these should depend more and more on technological innovation and sophistication and not on low wages. This transformation would enable the country's different industries and businesses to move up or make a place for themselves in global value added chains. The third, which constitutes the contribution of the author of this study, derived from Hirschman's thinking, states that industrial policy has to aim not only at fulfilling the Keynesian and Schumpeterian recommendations, but at rebuilding forwards and backward linkages in order to build up the interindustry matrix of the Mexican economy. In practice, this factor has been regrettably absent from reflections or considerations regarding the new development strategy followed by Mexico since the mid-1980s. Its absence explains the paradox of the export boom, with its strong Keynesian and Schumpeterian features, but with an increasing duality because of the lack of a Hirschmanian framework, which would have corrected the inability of the export sector to carry the rest of the economy with it in an environment of strong and lasting long-term expansion.

Progressive structural transformation or reconstruction will increase the investment and export multiplier on its own. For this to happen systematically, the country's economy will have to deal successfully with the structural transformation challenge that has been unmet since the stage of trade protection and State-led industrialization. This challenge, which was considered the hardest phase of import substitution and never fully addressed, is the creation or strengthening of a local capital goods industry. Between 2003 and 2012, figures from the National Institute of Statistics and Geography (INEGI) indicate that almost 70\% of Mexican machinery and equipment demand was met from imports. The pressure this places on the 
balance of payments is a cause for concern, since it implies that a strategy of strong and coordinated incentives for capital formation will tend to put pressure on the trade balance and the exchange rate unless it generates currency rapidly.

Lastly, there is another important aspect associated with the real exchange rate as a variable that is fundamental both for international competitiveness, via its effect on unit costs and prices and on real wages, and for the orientation of investment towards tradable or non-tradable sectors. The modern economic history of Latin America, i.e. its history since 1950, shows that strong growth periods, meaning a minimum of five years of annual GDP growth in excess of 3\%, tend to be associated with real currency depreciation, either for the time this growth spurt lasts or before it begins. Very few such periods are associated with real currency appreciation. The rare episodes of this type are to be found in economies whose exports and production structure are natural resource-intensive to a high degree. Under current conditions of open international financial markets and large and volatile short-term capital flows, the application of an exchange-rate policy as part of the toolkit for a strategy of productive transformation for equality needs to include management of the balance-of-payments capital account, and this needs to be seen as something that can legitimately be done at times of relative calm in the international markets, and not just at times of crisis or heavy pressure on the currency market.

Following this review of the mistakes, successes and limitations of macroeconomic policy as applied in Mexico over the last three decades, the following section will study some of the lessons yielded by international data (and not just the Mexican case) on the global financial crisis of 2008 and 2009, from both a structuralist and other perspectives.

\section{B. Some lessons from the international financial crisis on how to apply a macroeconomic policy for development}

The international financial debacle that erupted in 2008 and 2009 not only caused worldwide credit and trade flows and production activity in the developed economies to collapse, but cast serious doubt over some of the analytical underpinnings of conventional macroeconomic policy. In turn, public policy responses to the crisis have also yielded important lessons about the right goals and spheres of action for macroeconomic policy in its different components, namely fiscal, monetary and exchange-rate policy and prudential macroeconomics, with the management of capital inflows and outflows falling into this last category. In the wake of the crisis, special attention was paid to the contributions of the Keynesian revolution and its 
recommendation that countercyclical policies be used to reduce the adverse effects of external shocks, and to the suggestions of Hyman Minsky regarding the intrinsic instability of financial systems in developed economies. These contributions remain relevant for understanding both the genesis of the financial crisis and the advantages and limitations of the different macroeconomic policy options for responding to it.

Paradoxically, even as academia and various international bodies have recognized the relevance of these contributions for understanding and dealing with the challenges posed by the financial crisis to the world economy, governments of Organization for Economic Cooperation and Development (OECD) countries have stubbornly applied contractionary fiscal policies, thereby repeating the historical errors of the macroeconomic policy responses to the Great Depression of the 1930s and unnecessarily exacerbating and prolonging the decline in the rate of economic expansion, with serious repercussions for employment and social cohesion, yet without remedying their fiscal fragility. Meanwhile, the governments of Germany, the United States, the United Kingdom and other members of the European Union have shown a renewed interest since the crisis in applying active industrial policies to bring about change in their production structures and export patterns.

In the first place, long before the 2008 and 2009 crisis broke out, and particularly as a result of the lost decade, economists close to heterodox schools of thought made very relevant criticisms of conventional macroeconomic policy. In Latin America, so-called neoliberal macroeconomic policies, in their most orthodox guise, treated financial and trade opening, deregulation and withdrawal of the State from the economy as the only development strategies valid for all countries and at all times. Market reforms sought to bring this about, and quite quickly came in for strong criticism because of their obvious failure to achieve high long-term growth. There was also criticism of the inability of these strategies to insulate the region from adverse external shocks and their severe social impacts. In practice, the economic policies and reforms applied from the mid-1980s and designed in accordance with the Washington Consensus opened local markets to global competition, shrank the public sector, cut fiscal deficits and sought to consolidate low inflation, as in Mexico. Until the stage from 2003 to 2008, however, and for very different reasons, they were unable to raise economic growth rates substantially and sustainably. Nor could they prevent Latin America from continuing to suffer periodic financial and balance-of-payments crises, as is shown, for example, by the Mexican crisis of 1995 and that of Argentina and its neighbours in the early twenty-first century.

The emphasis on stabilizing prices and variables and the belief that public-sector intervention in the economy merely tends to distort the proper 
and efficient workings of the markets have been fundamental features of conventional macroeconomic policy in the region in general and Mexico in particular for much of their modern history. A point particularly stressed by ECLAC is the need to orient macroeconomic policy towards the attainment of real (and not just nominal) stability in the economy. The Commission has urged that macroeconomic policy be used countercyclically to reduce the impact of external shocks and thereby ensure that the growth of production activity is not held below potential. Another aspect of this form of intervention is that savings can be built up in the public exchequer when private-sector activity is strong and used to finance additional spending growth when it slackens. In this effort, ECLAC also recommends that macroeconomic policy should be applied in a way that ensures public investment does not become the adjustment variable in processes of fiscal cutbacks or contraction. Another feature of the conventional macroeconomic policy perspective that has been strongly challenged is the way it ignores or downplays the structural aspects of economic development and the historical, geographical or political factors conditioning this in its diagnoses and in the implementation of its stabilization or reform programmes.

The recent crisis prompted considerable questioning by experts at the International Monetary Fund (IMF) and the Bank for International Settlements, traditionally associated with conventional thinking. Here, most attention has perhaps been given to the questions raised by Blanchard, Dell'Ariccia and Mauro (2010), who, echoing fundamental objections raised from the heterodox perspective, criticize the emphasis on low and stable inflation as the only goal of macroeconomic policy. This is the very thing that was singled out in the first section as a major limitation, error or omission in the conduct of macroeconomic policy in Mexico. In particular, these authors argue that low and stable inflation is not a sufficient condition for the economy to achieve maximum growth. They emphasize that this exclusive focus of macroeconomic policy is a failing whether or not the index used to measure inflation (be this underlying or core inflation or inflation corrected by oil or construction or other prices) is correct or appropriate, and acknowledge that the conventional models have limitations:

What is clear, however, is that the behavior of inflation is much more complex than is assumed in our simple models ${ }^{4}$ and that we understand the relationship between activity and inflation quite poorly, especially at low rates of inflation.

Secondly, the new criticisms called into question the limited or nonexistent role to which fiscal policy has been progressively relegated, by contrast with the role given to monetary policy, in the quest for macroeconomic

4 Those guiding conventional macroeconomic policy. 
stabilization. This criticism had already been made by the structuralist school. For essentially ideological reasons, conventional macroeconomic policy began to give weight to the mistaken idea that fiscal instruments should not and cannot affect the conduct of the economy beyond: (i) maintaining balance in the public finances (i.e. keeping the deficit as low as possible) and (ii) ensuring that the public debt follows a sustainable path.

In many countries of the region, rejection of the use of fiscal policy as a stabilization tool was accompanied in practice by increasingly complex procedures and barriers to the rapid execution of public spending, especially on investment. The ability to launch new public works projects promptly was hindered yet further by the abolition or political downgrading within the region's national governments of the bodies responsible for economic planning and investment projects. As the State withdrew from the economy and planning was discredited, partly because of the downfall of the socialist bloc, these bodies lost strength and the ability of the State to develop investment projects was weakened.

Even as the legitimacy of public spending on investment and industrial policy and the redistributive capacity of taxation came under attack, monetary policy gained preponderance in the macroeconomic stabilization toolkit. In particular, management of the short-term interest rate by the central bank in a context of inflation targeting became the authorities' main macroeconomic stabilization instrument.

Countercyclical, discretionary or contingent fiscal policy action was erased from macroeconomic policy discourse in developed economies. Its role was restricted still further in emerging economies because of the traditional weakness of their fiscal revenues, aggravated in a number of countries by the dependence of these revenues on resources from export taxes or duties. In these circumstances, as happened in Mexico, certain balance-of-trade crises automatically turn into fiscal crises, which means that there is no possibility of public spending being used to reduce the adverse impact of terms-of-trade or external demand shocks.

Among the fresh criticisms made or acknowledged regarding the macroeconomic policy applied in the developed countries since the 2008 and 2009 crisis that have perhaps been most fully taken on board from the orthodox perspective are those concerning the neglect until recently of the potential macroeconomic impact of the activity, liquidity and solvency of bank or non-bank financial intermediaries. This macroeconomic impact (independent of the microeconomic one) can operate on a catastrophic systemic scale, as the 2008 and 2009 crisis demonstrated. Dismissiveness about the macroeconomic impact or importance of financial intermediation was permeating macroeconomic policy many years before the international crisis. The criticisms, now also from the orthodox camp, have revived (usually 
without acknowledgement) some key contributions from the work of Minsky (2008) on the inherent instability of financial markets and systematic patterns of speculative bubbles forming in vital markets. Sooner or later these bubbles burst, with brutal macroeconomic repercussions.

One area where this financial market instability is manifested with enormous impact in developing countries is in the flow of short-term capital. With financial liberalization, developing economies became subject to sudden, massive and volatile inflows and outflows of short-term finance. The large scale and rapid and unstable movements of these flows can lead to sharp fluctuations in variables that are crucial to economic performance: exchange rates, monetary liquidity and interest rates, as well as credit availability. In consideration of the recent international financial crisis, IMF has now broken with a long tradition of opposition and accepts that management of shortterm capital flows is a legitimate macroeconomic policy tool. This acceptance chimes with the thinking of ECLAC and of a variety of economists in the structuralist school. For some time now, these have urged developing economies to monitor capital flows and be ready to take measures to discourage them or impose restrictions when there are massive inflows that can suddenly be reversed. Unlike IMF, which treats this administrative or regulatory tool as a last resort, ECLAC believes that it should be considered or applied as part of the normal macroeconomic stabilization toolkit. ${ }^{5}$

Conventional inflation-focused macroeconomic policy has prevailed for decades, and is still largely dominant. Its virtues in holding down inflation and focusing public policymakers' minds on the need to maintain equilibrium in the fiscal accounts and preserve nominal macroeconomic stability are undeniable. However, its failings and omissions, like those mentioned earlier in this section and the previous one, are at least as great. These failings hugely restrict the ability of macroeconomic policy to intervene countercyclically in the real economy, and if anything tend to introduce procyclical elements. Furthermore, they mean that due account is not taken of the macroeconomic implications of financial intermediation or the inherent instability of key financial markets, and the potential for strong and lasting economic growth is undermined.

\section{Final reflections ${ }^{6}$}

Returning to the present study's goal of identifying the characteristics a macroeconomic policy for development needs to have today, such a policy should be conceived in terms of the major functional economic

See Ocampo (2005 and 2011), Ffrench-Davis (1996 and 2010) and, for a conventional perspective, Ostry and others (2010).

6 This section draws on Moreno-Brid (2013). 
areas it acts upon. The first is stabilization, meaning reduction in the volatility of key variables or relationships in an economy. This inherent volatility is manifested in local financial and share markets and even in those for investment, real estate and certain commodities, but it can also originate from the impact of adverse shocks arising in international goods, services or capital markets and produce sudden changes in demand volumes or key relative prices and in the conditions of access to new loans or refinancing.

Here it is an essential prerogative and obligation of any government to identify a set of indicators or variables whose stability, whether in terms of levels or growth patterns, can be established as a macroeconomic policy objective. The goal of stabilization during much of the post-war period was to maintain equilibrium on two flanks: domestic equilibrium, which included preserving price stability and maintaining a high rate of economic activity compatible with full employment, and external equilibrium, where the concern was to avoid critical situations with the balance of payments and the availability of currency. Then, partly because of the international debt crisis of the 1980s and the shift in economic policy in line with the socalled Washington Consensus, the orthodox interpretation of stabilization prevailed, as discussed in the first section of the present study, with its narrow focus on preserving low inflation and a low fiscal deficit, if any. This shift in emphasis towards nominal variables resulted sooner or later in full employment and real GDP growth being excluded from the set of direct stabilization policy goals.

The cause of this shift was twofold. First, the notion began to take hold that stabilizing nominal variables was a sufficient (as well as necessary) condition for stabilizing real variables, namely employment, growth in production activity and the balance of payments. ${ }^{7}$ Second, this reasoning was supplemented by the claim that output and employment growth merely reflected the evolution of supply conditions in the economy (factor accumulation and productivity), over which stabilization policy had no influence. Indeed, for some years up to the 1995 crisis in the Mexican economy, stabilization policy ceased to concern itself with the size of the balance-of-payments current account deficit as long as this was not associated with a fiscal deficit

\footnotetext{
I am grateful to Miguel Torres for his comment, which I agree with, about how odd it is that the dominant paradigm (at least until the international financial crisis of 2008 and 2009) should tend to maintain that nominal stability is a necessary and sufficient condition for economic growth and real stability when its more formal models recognize that long- and sometimes short-term neutrality implies, irrespective of nominal factors, that the equilibrium positions of the economy depend more on real-term variables and certain key prices. Given that the evolution of prices is neither stable nor perfectly predictable in practice, however, this evolution affects decisionmaking and can introduce uncertainties and instability that depress investment and influence employment and the purchasing power of wages.
} 
or high inflation (see Corden, 1977,, and Banco de México, 1994). Mexico's 1995 balance-of-payments crisis, which erupted in a context of prudent public finances but rapidly growing private-sector spending and borrowing, showed how mistaken this interpretation was. Consequently, external disequilibria have been brought back into its monitoring remit.

As the opening paragraphs stressed, ECLAC, together with a variety of analysts and academics, has long urged that macroeconomic policy design should be based on a broad conception of macroeconomic stabilization that extends beyond the nominal to the real sphere. Without neglecting the evolution of nominal variables such as inflation, fiscal sustainability and the solvency of financial institutions, this new conception needs to have the growth of production activity and employment as its priority goals. This position has gained growing strength because of the still ongoing international financial crisis that arose in 2008 and 2009 and the macroeconomic policy applied in response, which has had fiscal consolidation as its main instrument.

In practice, this strategy tends to deepen recession, delay recovery and worsen conditions in the labour and job market. Nor does it promptly or adequately relieve the fiscal or balance-of-payments constraint in vulnerable economies. This problem was implicitly acknowledged by the European Central Bank as early as April 2012, when it announced the implementation of a massive investment programme to stimulate economic recovery in the European Union.

The second area where macroeconomic policy has a crucial impact on economic development is transformation of the production structure. Whatever conventional theory might say, macroeconomic policy creates incentives for the orientation and use of production factors or resources by the private sector, even as it affects the corresponding allocation of resources by and for the public sector (particularly for gross fixed capital formation) in economic activity and its different branches or sectors. Macroeconomic policy, working through different instruments, has a significant capacity to orient, incentivize or stimulate economic activity in some areas to the relative detriment of others, such as producers of tradable goods and services versus producers of non-tradable ones. ${ }^{9}$ This resource allocation can influence the path of long-term economic expansion insofar as these sectors differ in the

Corden wrote in his original 1977 text that, since the different balance-of-payments components were the outcome of both public- and private-sector supply and demand, these were not the figures that should be considered. He changed his position significantly in the 1990s in the light of different crises in Latin America and came to recognize that the existence of country risk meant that the balance-of-payments current account deficit was important and should be monitored irrespective of whether an imbalance in public or private spending underlay it.

See Frenkel (2006), Frenkel and Taylor (2008) and Ros (2013). 
prevalence within them of branches or activities with growing returns to scale as compared to those where returns are constant or decreasing. ${ }^{10}$

This conception of enduring economic growth as the outcome of a virtuous circle or process of transformation in the production structure is of fundamental importance in macroeconomic policy design. It sets out by recognizing that the current or short-term composition of production and employment, i.e. the structure of production activity, will make its mark on long-term performance and growth, for better or for worse. The perspective of development as a process of structural change deriving from, on the one hand, the interdependence between the economic growth rate and the country's role in the international economy and, on the other, the composition of the production fabric and employment, particularly in activities subject to increasing returns to scale, is at the core of structuralist development theory and sets this apart from the traditional view, which treats macroeconomic policy as having just two goals: (i) keeping the economy at its production boundary, and (ii) extending that boundary.

Thus, from the viewpoint of a macroeconomic policy for development, fiscal and monetary policy have goals and functions transcending those assigned to them by the consensus prevailing before the crisis. Fiscal policy in particular, acting through the composition and amount of spending (especially public infrastructure investment), is an important instrument for promoting structural change and thence economic growth and employment. Likewise, if its countercyclical interventions are successful and it can induce sustained spells of high capital stock and production capacity usage, it will act as a stimulant to private investment. Monetary policy needs to go further in its priorities than the control of inflation. It also needs to pay attention to credit volumes, interest rates and conditions of access and the main borrowing sectors, and to regulate for the proper functioning of both bank and non-bank financial intermediaries. ${ }^{11}$

The third and last area deemed important in a macroeconomic policy for development is income distribution. ${ }^{12}$ Its effect here is manifested in part through its influence on key variables such as inflation, fiscal performance and tax revenues, and current or investment spending. ${ }^{13}$ In particular, various studies by OECD, the Inter-American Development Bank and ECLAC, among other institutions, have shown that the tax burden, including its composition, incidence and legal applicability with the fewest special regimes, is a fundamental determinant of income distribution in the different economies

\footnotetext{
See ECLAC (2012).

See Nayar (2011).

See Musgrave and Musgrave (1989), who distinguish three essential functions of economic policy: (i) resource allocation, (ii) macroeconomic stabilization in the face of external shocks and (iii) income redistribution.

13 For background, see Taylor (1991).
} 
of the world. It is striking and rather sad that personal income distribution as measured by the Gini coefficient is very similar before and after tax in the vast majority of Latin American and Caribbean countries. By contrast, in the European Union and the industrialized world in general the Gini coefficient drops substantially when measured for after-tax incomes. The same is true of public expenditure, whose influence on income distribution can also be significant, with much depending on the progressive or regressive orientation of its main programmes and on its efficiency and efficacy in promoting growth and employment.

Macroeconomic policy also affects factorial income distribution by influencing three crucial relative prices: the exchange rate, the minimum wage (including its effect on the average wage and pay) and the interest rate. These effects do not necessarily work in the same direction or on the same scale in the short and long term. For example, a substantial currency depreciation can result in a drop in real wages in the immediate or short term. The mediumand long-term effect may be exactly the opposite, however, if by forestalling a drawn-out process of real exchange-rate appreciation it succeeds in bringing about structural change conducive to greater investment in tradable activities and improved international and domestic competitiveness, with technological innovation and greater spillover effects from the export sector to the rest of the economy. Thus, macroeconomic policy helps determine the distribution of national income between different classes, production factors and sectors, groups, regions, families and individuals.

As ECLAC (2010) has been stressing since publication of Time for equality: closing gaps, opening trails, the quest in Latin America for a more equitable distribution of income and wealth combined with high and sustained economic growth is far from contradictory. On the contrary, the two objectives have an interdependence that means they feed directly back into each other and that makes it indispensable to progress simultaneously with both, i.e. towards greater equality in income distribution and robust and stable long-term economic growth. ${ }^{14}$ The ECLAC motto "grow to equalize and equalize to grow" is particularly relevant under today's conditions of limited or reduced dynamism in the global economy. The fact is that the drop in external demand associated with the recession in much of the developed world is forcing a number of medium-sized and large Latin American economies to rely more on the domestic market for their expansion because of the slackness of external demand.

It is up to governments to specify the priority goals of macroeconomic policy in relation to the three areas where they influence the performance of the economy. It is also up to them to select and use both short- and long-term instruments in accordance with their own particular historical context and

14 See ECLAC (2010 and 2012). 
the different goals set for macroeconomic policy. This process of instrument selection assumes a prior diagnosis of the "binding constraints"15 that have hindered or still hinder the attainment of priority goals. An indispensable requirement here is for the specification of macroeconomic policy goals and instruments to be coordinated, with explicit consideration of the institutional framework. In other words, the design and application of macroeconomic policy need to take great account of the set of restrictions operating, be these formal (legal, regulatory, etc.) or informal (standards, customs, practices or codes of behaviour), as these shape economic interactions at that particular moment in history. To put it another way, differences in institutional contexts mean it must be recognized that there are no macroeconomic policy recipes that are uniformly applicable in all countries at all times.

Regarding objectives and, as we have said, the development agenda (and macroeconomic policy within this), the fundamental priority is to bring about structural change in order to set the economy on a path of high long-run growth with equality. Crystallizing this long-range objective in day-to-day policy, sometimes in emergency situations or in the wake of what can be highly damaging external shocks, must involve governments adopting both a short-term and a long-term perspective as they select and apply macroeconomic policy instruments. For this, it is essential to identify the fundamental obstacles preventing robust expansion in production activity and more progressive distribution of its benefits from taking hold or being sustained, both in the immediate term and over an extended time horizon.

Lastly, but very importantly, while macroeconomic policy affects different areas of an economy's functioning, it is clear that the various instruments used can have opposing, not necessarily complementary effects on some of the goals set. Recognizing these trade-offs and coming up with ways to fully or partially reconcile them is the daily responsibility of macroeconomic policymakers and requires governments to have not only technical capabilities but also political ones and a grasp of the conditioning factors that derive from the economic situation and the institutional context within which macroeconomic policy acts. To what extent are the current macroeconomic policy and any possible or desirable reforms conducive to or at least consistent with an agenda of structural change for development to promote equality and high economic growth? This is a crucial question, and the economic future of many Latin Americans largely depends on the answer.

15 See, for example, Hausmann, Rodrik and Velasco (2005). 


\section{Bibliography}

Arestis, P. and M. Sawyer (2009), Path Dependency and Macroeconomics, Basingstoke, Palgrave MacMillan.

Arndt, H.W. (1985), “The origins of structuralism”, World Development, vol. 13, No. 2. Banco de México (1994), Informe Anual, Mexico City.

Beteta, H. and J.C. Moreno-Brid (2014), "Cambio estructural y crecimiento en Centroamérica y la República Dominicana: un balance de dos décadas, 1990-2011", Libros de la CEPAL, No. 122 (LC/G.2600-P), Santiago, Economic Commission for Latin America and the Caribbean (ECLAC).

Blanchard, O., G. Dell'Ariccia and P. Mauro (2010), "Rethinking macroeconomic policy", IMF Position Note, No. SPN/10/03, Washington, D.C., International Monetary Fund (IMF).

Botta, A. (2012), Is Latin American Structuralism Still Relevant? A Theoretical Dissertation on Structural Change and Economic Development, Berlin, Lambert Academic Publishing.

ECLAC (Economic Commission for Latin America and the Caribbean) (2012), Structural Change for Equality: An Integrated Approach to Development (LC/G.2524 (SES.34/3)), Santiago.

(2010), Time for equality: closing gaps, opening trails (LC/G.2432(SES.33/3)), Santiago.

Corden, Max (1994), Economic Policy, Exchange Rates, and the International System, Oxford, Oxford University Press.

(1977), Inflation, Exchange Rates and the World Economy, Chicago, Chicago, The University of Chicago Press.

Ffrench-Davis, R. (2010), "Macroeconomics for development: from 'financierism' to 'productivism'”, CEPAL Review, No. 102 (LC/G.2468-P/E), Santiago, Economic Commission for Latin America and the Caribbean (ECLAC).

(1996), "Macroeconomic policies for growth", CEPAL Review, No.60(LC/G.1943-P/E), Santiago, Economic Commission for Latin America and the Caribbean (ECLAC), December.

Frenkel, R. (2006), "An alternative to inflation targeting in Latin America: macroeconomic policies focused on employment", Journal of Post Keynesian Economics, vol. 28, No. 4.

Frenkel, R. and L. Taylor (2008), "Real exchange rate, monetary policy and employment: economic development in a garden of forking paths", Beyond Inflation Targeting. Assessing the Impacts and Policy Alternatives, G. Epstein and E. Yeldan, Cheltenham, Edward Elgar.

Hausmann, R., D. Rodrik and A. Velasco, (2005), “Growth diagnostics", Working Document, Harvard University.

Monroy, L.A. (2014), "La heterogeneidad de la economía mexicana”, Paradigmas Economía, 6 January.

Moreno-Brid, J.C. (2013), "Política macroeconómica para el desarrollo", Economía UNAM, vol. 30, National Autonomous University of Mexico (UNAM).

(2001), "Essays on the balance of payments constraint, with special emphasis on the case of Mexico", Ph.D. thesis (Ph.D.), Faculty of Economics, University of Cambridge.

Moreno-Brid, J.C. and J. Ros (2010), Desarrollo y crecimiento de la economía mexicana: una perspectiva histórica, Mexico City, Fondo de Cultura Económica. 
Minsky, H. (2008), Stabilizing an Unstable Economy, McGraw-Hill Professional.

Nayar, D. (2011), "Rethinking macroeconomic policies for development", Brazilian Journal of Political Economy, vol. 31, No. 3.

Ocampo, J.A. (2011), “Macroeconomy for development: countercyclical policies and production sector transformation", CEPAL Review, No. 104 (LC/G.2498-P/E), Santiago, Economic Commission for Latin America and the Caribbean (ECLAC), August.

(2005), "The quest for dynamic efficiency: structural dynamics and economic growth in developing economies", Beyond Reforms, Structural Dynamics and Macroeconomic Vulnerability, J.A. Ocampo (ed.), Washington, D.C., Stanford University Press, Economic Commission for Latin America and the Caribbean (ECLAC)/World Bank.

Ostry, J. and others (2010), "Capital inflows: the role of controls", IMF Staff Position Note, No. 04, Washington, D.C.

Perez Caldentey, E., J.C. Moreno-Brid and P. Ruiz Napoles (2004), "The Washington Consensus: A Latin American perspective fifteen years later", Journal of Post Keynesian Economics, vol. 27, No. 2.

Pinto, A. (1973a), "Heterogeneidad estructural y el modelo de desarrollo reciente de América Latina", Inflación: raíces estructurales, Mexico City, Fondo de Cultura Económica.

(1973b), "Concentración del progreso técnico y sus frutos en el desarrollo latinoamericano", Inflación: raíces estructurales, Mexico City, Fondo de Cultura Económica.

Prebisch, R. (1950), The Economic Development of Latin America and its Principal Problems (E/CN.12/89/Rev.l), New York, United Nations.

(1963), Hacia una dinámica del desarrollo latinoamericano, Mexico City, Fondo de Cultura Económica.

(1984), "Five stages in my thinking on development", Pioneers in Development, G. Meier and D. Seers (eds.), New York, Oxford University Press.

Rapetti, M. (2013), "Macroeconomic policy coordination in a competitive real exchange rate strategy for development", Journal of Globalization and Development, vol. 3, No. 2.

Razmi, A., M. Rapetti and P. Skott (2012), "The real exchange rate and economic development", Structural Change and Economic Dynamics, No. 23.

Ros, J. (2013), Rethinking Economic Development, Growth and Institutions, Oxford, Oxford University Press.

Serra, J. and M.C. Tavares (1974), “Mas allá del estancamiento. Una discusión sobre el estilo de desarrollo reciente en Brasil", Desarrollo latinoamericano. Ensayos críticos, J. Serra (ed.), Mexico City, Fondo de Cultura Económica.

Taylor, L. (1991), Income, Distribution, Inflation and Growth. Lectures on Structuralist Macroeconomic Theory, Cambridge, The MIT Press. 


\title{
Chapter XIV \\ Where next for Brazilian development? ${ }^{1}$
}

\author{
Francisco Eduardo Pires de Souza \\ João Carlos Ferraz ${ }^{2}$
}

\section{Introduction}

The currency and financial crises experienced by emerging economies in the second half of the 1990s seem to have put paid to the economic policy recipes known as the Washington Consensus. True, some of their ingredients survived, but only as part of new economic policy structures that were built up and put to the test in places ranging from Asia to Latin America to create the conditions for more vigorous growth that would be less vulnerable to international turbulence, especially that originating in the financial markets (see, for example, Frenkel, 2010).

It was not only criticism of past recipes that determined the new directions taken by emerging economies, however. The new global economic situation of the 2000s unleashed a wave of prosperity for

This article is dedicated to Antônio Barros de Castro, a peerless intellectual and tireless optimist and seeker after the essence of Brazilian development.

2 The authors are (unsalaried) professors with the Institute of Economics at the Federal University of Rio de Janeiro. João Carlos Ferraz is an unsalaried ECLAC staff member. At the time this article was prepared, the authors were working as senior adviser and director, respectively, of the Brazilian Development Bank (BNDES). The views expressed herein do not reflect the position of BNDES. 
developing economies, and Latin America in particular, that influenced their development and external trade and investment strategies. The region's countries benefited from the strong growth in international demand for their export products, thanks to improved terms of trade and a plentiful flow of external resources. This boom seemed to mark the start of a new era, that of the supposed "great moderation" in the advanced economies and substantial growth in the Chinese economy, with its insatiable hunger for commodities.

At the time of publication, however, the glorious 2000s look more like a supercycle, now over, than a long-term trend. What is the legacy of the recent past, and what is to be done after the ending of the "supercycle"?

Although emerging economies generally performed well in the last decade, growth patterns and the use to which the benefits of this expansion were put varied greatly from one country to another. These differences produced disparate starting points in the search for possible ways of reinvigorating development in a new international context. Differences in structural conditions and factor endowments have also influenced, for example, the choice of the new development and international trade and investment strategies best suited to the new global environment. If a return to the Washington Consensus seems to make no sense, persisting with the model of the 2000s cannot be viable either. Development entails processes of change that are both place- and time-specific. Thus, we are once again at a crossroads, and the alternative routes to follow are not ready-made but must be constructed.

The purpose of this study is to reflect on the challenges facing Brazil's development, setting out from the international context and the successes and limitations of the model implemented in the last decade. Section A, which comes next, briefly reviews the background to the current situation, showing specifically how the external boom of the 2000s affected the Brazilian economy. We then discuss the characteristics of the model applied in the last decade, which we call the "inclusive growth" model, highlighting its virtues and limitations and the use made of the windfall gains resulting from the international situation. Section $C$ evaluates some changes that are taking place, not least in the economic policy orientation of Dilma Roussef's government, arguing that they may point to the emergence of a new model whose aims are to capitalize assets and to reform, unify and sustain the inclusive growth model. Section D reflects on the challenges involved in consolidating this new model, and the concluding afterword offers brief consideration of whether some elements in the Brazilian experience may be relevant to other countries of Latin America and the Caribbean. 


\section{A. Background: from the Real Plan to the external boom}

It has become commonplace to characterize the Brazilian economy as one that produces and exports commodities. Although natural resources are plentiful in Brazil, and its agroindustrial and mining industries are highly competitive, this is a caricature. Taken at face value, it gives a very oversimplified picture of the production structure. It has also given rise to superficial analyses of the way the country's economic growth was renewed from 2004 and of the breadth of the fronts on which expansion and diversification can be achieved.

To avoid the cliche that this growth was driven by exogenous factors, the first thing to consider is that the 10 years prior to its resumption were a time of far-reaching transformations in the country's institutions and economic policy approach, spanning different governments. These transformations put an end to the high inflation and innumerable other anomalies that had condemned Brazil to stagnation. They began with economic opening and stabilization and continued with the ordering of the public finances (under the Fiscal Responsibility Act) and the exchange-rate and monetary regime, while the financial system was reformed to deal with the dearth of lending to families (for both consumption and housing). Lastly, consolidation of the fiscal and external accounts (with public debt set on a clear downward path and net external debt heading into negative territory) created the conditions for putting an end to stop-go growth and freeing up the drivers of prosperity that had been suppressed for so many years.

When the benefits of the external boom were felt in Latin America, an endogenous process of expansion was getting under way. Actually, the boom reached Brazil very late. At least as far as terms-of-trade improvements were concerned, Brazil benefited only very modestly up until 2008 by comparison with other Latin American countries, as can be seen in figure XIV.1 and table XIV.1 below.

As will be seen, Brazilian economic growth up to the eve of the 2008 crisis was driven more by endogenous factors than by the beneficial effects of the international situation. With this important proviso, which many analysts have overlooked, it can be acknowledged that the terms of trade of the Brazilian economy did in fact rise vigorously from 2009. In addition, this improvement in the terms of trade played a crucial role in containing the inflationary pressures and external imbalances which began to arise at an advanced phase of the expansionary cycle initiated in the second half of 2003. This was the main contribution of Brazil's favourable terms of trade at the end of the last decade. 
Figure XIV.1

Brazil and Latin America: terms-of-trade index, 2002-2012

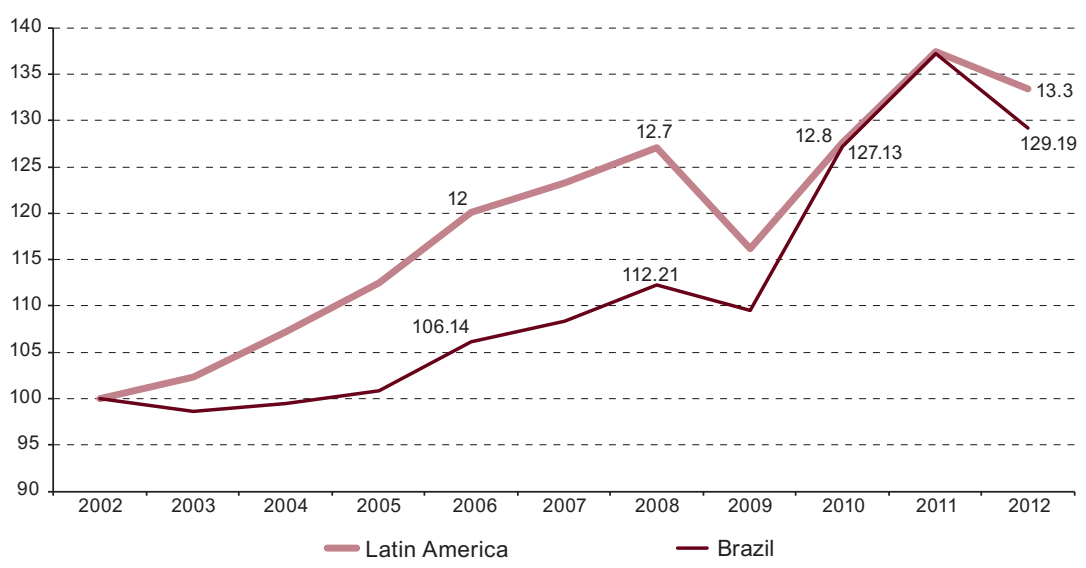

Source: Economic Commission for Latin America and the Caribbean (ECLAC).

Table XIV.1

Latin America: terms of trade, selected years (Index 2002=100)

\begin{tabular}{lccc}
\hline Country/region & 2002 & 2008 & 2011 \\
\hline Argentina & 100.0 & 134.9 & 136.8 \\
\hline Bolivia (Plurinational State of) & 100.0 & 149.6 & 181.9 \\
\hline Brazil & $\mathbf{1 0 0 . 0}$ & $\mathbf{1 1 2 . 2}$ & $\mathbf{1 3 7 . 2}$ \\
\hline Chile & 100.0 & 169.6 & 211.3 \\
\hline Colombia & 100.0 & 149.3 & 162.4 \\
\hline Peru & 100.0 & 138.8 & 174.6 \\
\hline Latin America & $\mathbf{1 0 0 . 0}$ & $\mathbf{1 2 7 . 0}$ & $\mathbf{1 3 7 . 5}$ \\
\hline
\end{tabular}

Source: Economic Commission for Latin America and the Caribbean (ECLAC), CEPALSTAT database.

In fact, had the terms of trade not risen as they did between 2009 and 2011, the trade surplus of US\$ 30 billion in the latter year (the high point for the terms of trade) would have been a deficit of US\$ 18 billion under 2009 conditions, and the current account deficit of $2.1 \%$ of gross domestic product (GDP) would have been $4.1 \%$. In other words, the country would have been heading very quickly back into a situation of external vulnerability. Furthermore, the strong appreciation of the exchange rate made possible (and driven) by the terms-of-trade improvement helped to hold inflation down to the government's target level.

Lastly, an ingredient of the external boom that had large repercussions on Brazil's development in the period, for better and for worse, was the sizeable 
influx of external capital. Inflows of direct and portfolio investment were so large that they exceeded the financing needs deriving from the current account deficit by an amount averaging the equivalent of $2.5 \%$ of GDP a year from 2003 to 2012. Reserves increased by US\$ 335 billion as a result, from US\$ 38 billion in December 2002 to US\$ 373 billion in December 2012.

In summary, this brief account of the background to the new Brazilian growth model shows that, contrary to what many of its critics have claimed, the redistributive growth that characterized it was not simply a by-product of an extremely favourable international situation. Nor can it be concluded from the data that the benefits of the external boom, which in Brazil's case were most substantial from the late 2000s onward, were simply squandered. As we shall now try to show, the opportunity created by favourable international conditions was used to strengthen the external fundamentals (reserves) and apply policies that made the transition to an inclusive growth model viable.

\section{B. The inclusive growth model: virtues and limitations}

After two decades of near-stagnation, the Brazilian economy entered upon a cycle of vigorous and sustained growth in the second half of 2003. More importantly still, it was able to reconcile growth with a substantial improvement in income distribution while controlling inflation and achieving a reasonable balance-of-payments equilibrium. As part of the institutional and policy structure that underpinned this performance, net public debt was held on a downward path, international reserves were kept high and rules and behaviours (both public and private) that contributed to stability while leveraging growth were consolidated.

Highly successful though it was, no consensus has yet been reached on the mechanisms that made the economic model of that time work, or on how sustainable it was. To examine its main strengths and weaknesses, we shall concentrate on two pillars of the economy's growth pattern in the period between 2003 and 2012.

On the demand side, the main pillar of growth in the economy was family consumption, which in turn was sustained and driven by two factors: rising real family incomes and strong growth in personal lending.

Consumers' real income rose most in the low-income population strata. The real per capita income of the poorest $10 \%$ of the population grew at an annualized rate of $6.5 \%$ from 2001 to 2011 , as against a rate of $1.5 \%$ a year for the richest 10\% (SAE, 2013). The rise in incomes for these population strata resulted from both public policies (especially the Bolsa Família conditional cash transfer programme and minimum wage policy) and progressive depletion of the labour market surplus. The latter, in turn, was due to developments 
that affected the supply of and demand for labour. On the labour demand side, low productivity growth meant greater absorption of workers for a given level of production growth. Meanwhile, the expansion of the labour supply was slackening because of the rapid demographic transition that has been taking place in the country: working-age population growth fell from $2 \%$ a year at the beginning of the last decade to about $1.1 \%$ in the early years of the current decade.

Personal lending growth was due to the consolidation of stable conditions and the creation of new instruments and rules (particularly crédito consignado, a type of loan with repayments taken directly from borrowers' wages), and it had the effect of leveraging consumption capacity, which rose from $7 \%$ of GDP in early 2005 to $16 \%$ in late 2012 . Over the same period, families' debts as a proportion of income rose from $18 \%$ to $43 \%$. $^{3}$

These two factors meant that family consumption grew at an average rate of $5.1 \%$ from 2005 to $2012,{ }^{4}$ well above average annual GDP growth of $3.6 \%$, thereby increasing its share of the economy from $60.0 \%$ to $65.8 \%$ (at constant 1995 prices) over the period. Given that the GDP share of consumption was large to begin with, this strong expansion meant that it was responsible for $86 \%$ of real GDP expansion over these years.

In summary, from 2005 to 2012 the economy went through a cycle of expansion driven by family consumption. With demand having begun to increase steadily, however, gross fixed capital formation could likewise be expected to recover and begin to make its own contribution to growth. And indeed, the investment rate increased from a low of 15.3\% of GDP in 2003 to $19.1 \%$ in 2008, after which it fluctuated at around $19 \%$ until 2012. Because this variable had a relatively small share to begin with, however, its positive contribution to real GDP increase was only about a third as great as that of consumption. ${ }^{5}$

Focusing now on the supply side, it transpires that economic growth in the Lula era (and the early part of the Dilma administration) was increasingly dominated by the service sector and producers of mineral and agricultural commodities. It is safe to say that the dynamism of the latter resulted from the combination of Brazil's great efficiency in the natural resource sector and the exceptional growth in international demand led by the expansion of the

Data available in the Time Series Management System (SGS) of the Central Bank of Brazil [online] https://www3.bcb. gov.br/sgspub/localizarseries/localizarSeries.del?method=prepa rarTelaLocalizarSeries.

4 We shall use data for the period between 2005 and 2012 to characterize the new model because the initial burst of growth between mid-2003 and late 2004 was heavily influenced by the very weak exchange rate of the time, which resulted in an expansion that was based (temporarily) on investment and net exports and did not match the pattern that would become established thereafter.

5 Net exports made a heavily negative contribution. 
Chinese economy. That this sector became the driver of the growth cycle, however, was due not so much to any policy choice as to exogenous factors. The role of services, meanwhile, resulted from a combination of aggregate domestic demand growth (in a sector that is mainly non-tradable and so did not see demand leak abroad) and a shift in relative prices (because of the exchange rate) that favoured the production of services over industrial goods.

Conversely, the growth in demand for industrial goods did not create comparable incentives for manufacturing production, since a large part of that increase "leaked abroad" via rising net imports. Thus, while apparent consumption of industrial consumer goods increased by $40 \%$ in real terms from 2004 to 2012, domestic production of these goods grew by just $20 \%{ }^{6}$

Table XIV.2 below shows average annual growth by sector in the period from 2005 to 2012. The second row presents growth up to 2011, thereby excluding the extremely low growth of 2012, a year of particularly bad harvests whose inclusion misrepresents the agricultural sector's dynamism. The numbers show that extractive mining, construction, electricity and the service sector led economic growth if expansion rates alone are considered. When the size of these sectors is factored in, however, the finding is that, because of its small share of the economy (just $2.5 \%$ of value added in 2005), the extractive industry accounted for barely $1 \%$ of the economy's expansion in the period, while at the other extreme the service sector, representing $65 \%$ of value added, was responsible for $63 \%$ of the rise in GDP over those eight years.

Table XIV.2

Brazil: supply-side GDP growth, 2005-2012

(Annualized percentages)

\begin{tabular}{lcccccc}
\hline Period & Agriculture & $\begin{array}{c}\text { Mineral } \\
\text { extraction }\end{array}$ & Processing & Construction & $\begin{array}{c}\text { Electricity, } \\
\text { water and } \\
\text { others }\end{array}$ & Services \\
\hline $2005-2012$ & 2.6 & 4.1 & 1.1 & 4.3 & 4.1 & 3.9 \\
\hline $2005-2011$ & 3.3 & 4.8 & 1.6 & 4.8 & 4.2 & 4.2 \\
\hline
\end{tabular}

Source: Brazilian Geographical and Statistical Institute (IBGE), quarterly national accounts, second quarter of 2013.

The supply-side role played by the service sector as the mainstay of growth makes it easier to understand another two characteristics of the growth model of recent years, namely the low productivity and high

Authors' calculation based on the value in reais of output, exports and imports in 2008, with values for the other years calculated (at constant prices) by multiplying these figures by the respective quantum indices of the Monthly Survey of Industry conducted by the Brazilian Geographical and Statistical Institute (PIM/IBGE) and the Centre for Foreign Trade Studies Foundation (FUNCEX). 
rate of employment growth mentioned earlier. Although the service sector encompasses some highly efficient segments, its operation and growth are still characterized, on average, by low productivity. Thus, the service sector was responsible for $82 \%$ of all new jobs in the country's metropolitan regions between 2005 and 2012.

One consequence of this labour-intensive services-driven growth, in combination with the change in the population dynamic already referred to, was a steady decline in the unemployment rate from $12.4 \%$ in 2003 to $5.5 \%$ in 2012. In this context of a tight labour market (reinforced by wage policy), real returns to labour increased by a cumulative 38\% from 2005 to 2012, while labour productivity grew by $10 \%{ }^{7}$

Continuous currency appreciation (and the associated rise in net imports) offset the potentially inflationary effects of domestic demand that was expanding more quickly than output and of wages that were rising faster than productivity, so that inflation was kept within the bounds set by the government.

Lastly, the negative effects of currency appreciation on the trade balance were partially offset by rising international prices for the commodities exported by the country. Even so, the current account balance deteriorated by the equivalent of 4.2 percentage points of GDP, from a surplus of $1.8 \%$ of GDP in 2004 to a deficit of $2.4 \%$ in 2012. At 2005 prices, however, the current account deficit would have been $4.3 \%$ of GDP in the latter year.

When Brazil's recent development is observed from the perspective of the pillars of demand (family consumption) and supply (the service sector), it really is possible to discern the outlines of a growth model, underpinned by both the domestic market and the external one (the latter being exogenous and commodity-centred), which are a departure from historical paradigms, particularly on the domestic side, as a consumption pattern formerly confined to the (old) middle class has extended to a huge swathe of the population. ${ }^{8}$

To sum up, this demand-driven but macroeconomically prudent model enabled the Brazilian economy to return to growth for a prolonged period, taking the labour market very close to full employment and bringing about a substantial improvement in income distribution, while lifting some 8.4 million people out of absolute poverty and 28.4 million out of poverty between 2002 and 2012 (IPEA, 2013). For all these reasons, the model has historical merit.

\footnotetext{
Measured by the evolution of the real return to labour in the National Household Survey (PNAD) and by the GDP index of the quarterly national accounts divided by the total employment index of the PNAD, respectively.

8 Antônio Barros de Castro (2011), to whom we pay tribute here, actually saw the importance of mass consumption as a driver of growth in Brazil in earlier periods. The phenomenon took place on a new scale in the period we are dealing with.
} 
Nonetheless, it must be regarded as obsolete, suited to the conditions prevailing at one particular time. Unless it is transformed in future, the model will become unsustainable for at least four reasons, namely:

- For consumption growth in excess of GDP growth to continue without producing a continuous deterioration in the current account (inevitably leading to a currency crisis), investment would have to grow more slowly than GDP. ${ }^{9}$ However, if investment grew more slowly than GDP (and the investment rate fell), the economic growth rate would be set on a downward path;

- The large rise in the terms of trade that offset the growing current account deficit was the result of a unique and unrepeatable international situation, and the deficit would rise considerably if this were reversed;

- Currency appreciation, made possible by capital inflows and the improving terms of trade, held down inflation in the context of this model but progressively undermined the growth capacity of the economy (especially in tradable sectors other than commodities) while further worsening the trade balance;

- An "extensive" form of output growth based on strong absorption of labour by the service sector has been tending to deplete the "industrial reserve army", increasingly pushing up the cost of labour.

Besides the factors mentioned, there is more and more evidence that the vigorous growth of consumption caused an acute imbalance between the availability of private goods and the supply of public goods, especially infrastructure goods, compromising productivity and creating a high level of social discontent.

In summary, if all the characteristics of the inclusive growth model were kept intact, there would be an endogenous decline in the growth rate and a progressive deterioration in the current account that would ultimately lead to a balance-of-payments crisis, while any attempt to offset the endogenous decline in growth with greater incentives for consumption would end up accelerating the currency crisis (or inflationary process). ${ }^{10}$

Given the basic macroeconomic identity, and without considering government consumption, if $(\Delta \mathrm{C} / \mathrm{C})>(\Delta \mathrm{Y} / \mathrm{Y}), \mathrm{C} / \mathrm{Y}$ is increasing, so that $(\mathrm{M}-\mathrm{X}) / \mathrm{Y}$ has to rise unless $\mathrm{I} / \mathrm{Y}$ falls. If the government consumption $(\mathrm{G})$ variable is incorporated, the primary surplus as a percentage of GDP will have to increase progressively to prevent I/Y from falling.

10 If an exchange-rate depreciation mitigated the currency crisis, the problem would show up in higher inflation driven by that depreciation. 


\section{C. (The early signs of) an emerging model}

Falling international commodity prices from 2011 to 2013 limited the potential for currency appreciation to act as a mechanism that could reconcile strong growth in demand and costs with subdued inflation. In the event, the Dilma government began to correct the course of economic policy in mid2011, building on initiatives already set in motion towards the end of the Lula administration. ${ }^{11}$

The most significant movement concerned investment support policies. Following reassertion of industrial policy as a priority State policy under the Lula government (Kupfer, 2013), and with instrumentalization of the commodity industry to attain global leadership complete, attention turned to reducing industrial costs and stimulating productivity (including a strong emphasis on innovation) with a view to re-establishing the competitiveness that manufacturing industry had forfeited and encouraging investment in the sector (Souza, 2013). More importantly still, infrastructure investment was moved up the scale of priorities for government action. Energy investments were given continuity and progress was made with logistics. Changes made (with some difficulty) in the benchmark model for infrastructure investments were given the same priority. If the value of concessions was the cornerstone of policy under the Cardoso government and tariff affordability during the Lula period, the latter continued to be a priority in the Dilma management model, but willingness to invest was made a decisive consideration when concessions were awarded.

The focus on policies to support investment was matched by macroeconomic policy. Perhaps for the first time, in other words, an effort was made to formulate industrial, macroeconomic and infrastructure policies as part of a single strategy. ${ }^{12}$

In fact, the macroeconomic policy mix was altered by cutting the interest rate, which bottomed out once the Real Plan was implemented, lowering financing costs for firms. The measures introduced in 2009 to reduce investment costs by means of programmes operated by the Brazilian Development Bank (BNDES), such as the Investment Maintenance Programme

11 When the change in United States monetary policy was announced in May 2013, there was upheaval in the world's financial and currency markets and large repercussions in Brazil, clearly showing that alterations in the "equilibrium levels" of commodity prices and the exchange rate had closed the release valves that had enabled inflation to be contained and the external accounts kept at levels which could be financed under the previous economic model. Two years earlier, when the government began to introduce new policies, there was far from being a consensus on the limits of this model.

12 This is a first step towards full exploration of the "three powerful sources of expansion" referred to by Bielschowsky (2012), namely mass consumption (whose effects leak into the external sector when domestic competitiveness is lacking), local and global demand for abundant natural resources, and demand for infrastructure investment. 
(PSI), were maintained. ${ }^{13}$ Lower interest rates and the introduction of taxes on external capital inflows caused the exchange rate to depreciate by $28 \%$ between mid-2011, when the real peaked against the dollar, and the average level of about 2 reais per dollar from mid-2012 to May 2013, when the exchange rate moved away from this level as a result of external shocks.

These measures helped to transform the earlier model. However, macroeconomic policy still has two weak points.

The first is that, lacking a macroeconomic tool (especially fiscal policy) to offset the inflationary effects of the new combination of a weaker exchange rate and low interest rates, the government resorted to ad hoc measures such as subsidies for wage goods and cuts in indirect taxes, whose anti-inflationary effects are inevitably limited and temporary. The pick-up in inflation in 2013 forced the central bank to raise interest rates again (although this upward cycle should peak at a much lower level than earlier ones).

The second weakness is that inflation worries, along with demands in the political sphere, ultimately led to a partial loss of focus in cost reduction policies as measures were extended to a wide range of sectors, many of them producing non-tradables. This distortion of the original measures has given rise to two problems: (a) since one of the main objectives was to shift the relative prices of tradables and non-tradables, extending the range of sectors affects the functionality of the policy itself, and (b) the rising fiscal cost has increased the macroeconomic imbalance referred to in the previous paragraph.

The exogenous shocks of mid-2013, with large popular demonstrations in the political sphere and sharp swings in asset prices (the exchange rate, shares and interest rate futures) resulting from the shift in the international context, dealt a severe blow to business and consumer confidence that blocked the way to a new growth model, as described earlier.

From the perspective of late 2013, however, the political and financial shock of mid-year seems to present a unique opportunity to extend society's involvement in deciding the country's future direction and the very meaning and priority attached to the term "inclusion". On a strictly economic level, the negative impacts were probably no more than a temporary reverse.

If this is granted, the country could be on its way to a new kind of development. However, some of the underpinnings for this remain to be constructed. The following section will reflect on these.

13 Implemented in mid-2009 as part of the government's response to the crisis, the PSI consisted in the creation of credit lines at BNDES, with low fixed interest rates and extended repayment terms, for the purchase of capital goods in the domestic market. 


\section{The underpinnings and challenges of an inclusive and productive development model}

In extending the scope of reflection from an economic development model to the broader field of a new development model, we have to reconcile the idea of a model that is consistent, dynamic and sustained in strictly economic terms with the imperatives of sustainability and equal opportunities (ECLAC, 2012). In other words, we have to bear in mind simultaneously the dimensions of competitiveness, social inclusion and sustainability, within a democratic political framework. This study will now look at the first two dimensions (growth and equality), in the strong conviction that a complete view of the development process cannot be arrived at unless the socioenvironmental aspect is included.

The earlier sections argued that a new growth model could not be sustainable in the long run unless it were led by investment and, to a lesser extent (at least until the current account settles at a level compatible with long-run equilibrium in the balance of payments), by net exports. Again, wages cannot carry on rising faster than productivity without undermining the external competitiveness of the economy. The question, then, is how to achieve this without cutting short the ongoing gains from the previous model.

The key answer (although not the only one) is productive development - productivity. One reason is that it is only if the economy grows at least as quickly as consumption that a high rate of consumption growth (which has to come from increased incomes among the poorer strata of the population) can be combined with a reduction in external vulnerability, without forestalling higher investment. However, as unemployed surplus labour is depleted, rapid economic expansion can only be achieved through vigorous productivity growth. As we saw earlier, this would have to be much faster than it was in past decades.

That is not all, though. If the current account deficit is not to grow as a percentage of GDP and, particularly, if the economy is to be able to absorb the dynamism imparted by demand without this leaking abroad, it is vital for competitiveness to improve. In the short term, competitiveness depends almost entirely on the exchange rate. A weak (and stable) exchange rate is an indispensable spur to growth. Nonetheless, depreciation of the local currency has drawbacks and entails substantial costs for the domestic economy that make it harder to reconcile the multiple objectives of inclusive and sustainable development. By way of example, as was seen earlier, a depreciated exchange rate requires a more austere fiscal policy than would be needed otherwise, and this reduces the scope for taxation and spending policies to achieve the other goals. 
Nonetheless, once the exchange rate is at a competitive level, and provided the country's economy is able to increase productivity more quickly than the average for its competitors, it is possible to allow the currency gradually to appreciate without compromising the competitiveness of the economy, as stated in the Balassa-Samuelson theorem. At this point, a virtuous circle begins to operate.

Fajnzylber (1992, p. 24) used the term "spurious competitiveness" for competitiveness achieved by a combination of geographical or natural resource rents at the expense of pay, where the resources generated in the early stages are moved abroad or go into consumption instead of being employed to incorporate technical progress via investment. In the present context, we can redefine this idea by applying the term "spurious exchangerate competitiveness" to the competitiveness resulting from excessive capital inflows and exceptionally high commodity prices, ${ }^{14}$ by contrast with a genuine currency appreciation that occurs when productivity growth outstrips the international average, as discussed above.

Increasing productivity more quickly than trading partners is a more feasible goal than might appear at first sight, given the "catch-up advantage" of the productivity gap that currently exists relative to the advanced economies. However, it is hard to create the institutions and policies needed to stimulate vigorous productivity growth and capitalize on this advantage.

For these pro-productivity institutions and policies to be created (an issue that will only be touched upon in this study, with a particular focus on the political sphere), the first thing to note is that productivity has three aspects, namely: (a) systemic productivity, (b) structural productivity and (c) business productivity.

Where the first of these is concerned, the Brazilian economic policy agenda has been making considerable progress, despite lapses and even reverses. The main component of this agenda at present is investment in infrastructure, especially logistics, which includes urban logistics. Strong consumption and production growth in the last decade left a legacy of numerous infrastructure shortfalls that are compromising productivity and increasing systemic costs. In addition, rising quality of life in the private sphere has begun to contrast with deteriorating public services in urban areas, this being one of the underlying discontents that sustained the

14 Bresser-Pereira defended the thesis that there was a structural tendency towards currency appreciation (in the sense labelled spurious here) caused by Dutch disease and capital flows and aggravated by a set of mistaken policies. He set out from this diagnosis to propose a policy aimed at neutralizing this tendency towards excessive appreciation as one of the pillars of the new developmentalism. See, for example, Bresser-Pereira and Gala (2012). 
large popular protest demonstrations on the streets of Brazil in mid-2013. Infrastructure reform and expansion are thus required to deal with two challenges: increasing productivity and coping with the growing social demand for new and better public services so that the inclusion process becomes consistent and sustainable.

Besides matters relating to financing and the regulatory framework, which are essential when it comes to unleashing infrastructure investment, there is a central issue that was absent at other periods of strong infrastructure investment growth in Brazilian history, namely the political issue. In a fully democratic society, especially in a context where political representation is highly fragmented, there is a risk that decision-making may be paralysed, distorted or rendered completely dysfunctional by the opposing demands of different sectors, regions or social forces, delaying progress or thwarting it altogether. Demands for infrastructure service price freezes or cuts, pressure groups that oppose new rules to preserve their privileges and political disputes that prevent particular investments from being sited where it makes most geographical sense are just some of the obstacles to infrastructure expansion under a regulatory framework that combines tariff affordability with investment.

A new kind of development, involving increased democratization, thus requires a political system that can properly process the different demands and conflicts inseparable from any democratic society so that they do not trammel decision-making and effective implementation of public policies. This task tends to become more achievable when governments are capable of uniting the political forces most directly concerned around a clearly delineated project that fulfils the prerequisites for reconciling competitiveness with equity and sustainability. If such a project wins "hearts and minds" and is embraced by society, the government's task of arbitrating between different forces and interests with the project as a reference standard becomes more viable.

This political imperative is just as important in dealing with the second front on which the issue of productivity has to be addressed. The structural approach to raising productivity consists in designing and implementing a productive development strategy within which there is movement towards activities and capabilities with greater potential for productivity improvements than more traditional activities. Although few might disagree that the structure of the economy needs to be developed in a way that favours more productive sectors, implementation of this inevitably generates political reactions from possible "losers". This is because favouring more advanced capabilities and stages in value creation chains can result in the elimination or disappearance of more traditional activities that may have considerable and very entrenched political influence, such as those that depend on low wages and cannot remain competitive with other low-income countries. 
Lastly, the challenge of raising productivity within firms may be the most difficult of all, since it is actors in the private rather than the public sector that have to lead the process and make the decisions. It will have to involve new incentives and regulations to encourage the acquisition of capabilities conducive to higher productivity and innovation. This is not all, however. There need to be educational and training institutions and specialized technical services that help to develop a culture of efficiency and innovation. For all the considerable progress made, chiefly in quantitative terms (between 2001 and 2011 the number of people enrolled in Brazilian universities rose from 3.0 million to 6.7 million), the country still has a large capabilities shortfall and results will only be seen in the long term. However, the greatest challenge, a political one, is to mobilize public and private agents in order to inject a high degree of social value into society, professional bodies and public and private policies for high-quality education and meritocracy in order to create a systemic environment of equal opportunities.

At the start of this section, we argued that the main answer to the limitations of the inclusive model lay in increasing investment and productivity. A second requirement is to increase the saving rate to match the large increase in the investment rate that vigorous economic growth requires. The subject cannot be dealt with in the present study either, but it needs to be said that this is an absolutely indispensable condition for a viable development process of the kind envisaged, especially in a country like Brazil, where the investment rate (currently around 19\% of GDP) will need to rise by over 5 percentage points of GDP, and where the current account deficit is already very large.

This is not to call into question the Keynesian precept that higher investment will generate its own saving, but leaving the task wholly up to the markets could trigger processes that would translate into higher inflation (and pay erosion) or an increase in the current account deficit, or even a combination of the two. In any event, the continuity of development would be called into question. Raising the public saving rate or developing institutions and policies to stimulate private-sector saving is something that needs to be undertaken to increase the saving and investment rate without the negative effects on the stability of prices and the external accounts referred to.

\section{Final reflections}

In this study, we have tried to point to signs of the emergence of an inclusive and productive new development model and have reflected on its underpinnings and the essentially political challenges confronting it, setting out from the model of inclusive growth seen in the last 10 years, with all its successes and limitations. 
As was argued at the start of this chapter, development processes and the strategies associated with them are time- and place-specific and depend on the structural, institutional and historical characteristics and even the size of each country. Nonetheless, and bearing this caveat in mind, it seems obvious that some of the elements of the inclusive and productive model that we have been discussing on the basis of the Brazilian situation may also be relevant to other countries of Latin America and the Caribbean.

The diversity of potential fronts for economic expansion is paralleled only in the region's largest economies, if there. Similarly, not all countries are experiencing the effects of the demographic transition on the labour market to the same degree, and raising labour productivity is therefore essential if robust GDP growth is to be achieved. These are structural characteristics that need to be taken into account in any consideration of the diversity and leeway that are possible for each national strategy.

Nonetheless, inclusion, efficiency and productive development (all doubtless dependent on the degree of development of each economic activity in the different countries) as a model for dealing with the dilemma between the need for a higher quality of life, economic growth with macroeconomic stability and the maintenance of a low level of external vulnerability can be seen as shared pillars.

The emphasis on infrastructure investment and the production of public goods more generally seems to be another trait common to almost all the economies of Latin America, where the imbalance between the production of private and public goods has led to great economic inefficiency and social discontent.

Lastly, financing higher investment is a common challenge, in both macroeconomic and microeconomic terms (financing tools and channels), especially in a world where the terms of trade and external financing conditions will not be as favourable as they were in the last decade.

Similarly, some generalizations can perhaps be made about the political factors obstructing inclusive and productive development. It should be anticipated that structural change will meet with resistance from vested interests that will have to be very well understood if they are to be coped with. There will be marked differences in this respect between the region's countries, since nothing could be more specific than the creation and consolidation of interest groups.

Likewise, we should be clear that a key difference between the region's countries lies in the differing degrees to which public institutions are capable of formulating and implementing effective policies for inclusion and productive development. Understanding these differences is essential when discussing consistent national development strategies, as ECLAC has 
done throughout its history. More importantly still, we need to recognize and respect the differences between the political decisions taken democratically by the citizens of the region's countries. There is no single, unalterable pathway to inclusive and productive development.

\section{Bibliography}

Bielschowsky, R. (2012), "Estrategia de desenvolvimento e as tres frentes de expansão no Brasil: um desenho conceitual", Economia e Sociedade, vol. 21, special issue, December.

Bresser-Pereira, L.C. and P. Gala (2012), “O novo desenvolvimentismo e apontamentos para uma macroeconomia estruturalista do desenvolvimento", Macroeconomia do Desenvolvimento, J.L. Oreiro, L.F. de Paul and F. Basilio (orgs.), Editora Universitária, Universidade Federal de Pernambuco (UFPE).

Castro, A.B. (2011), "O Brasil a caminho do mercado de consumo de massa" and "Consumo de massa e retomada do crescimento", $O$ desenvolvimento brasileiro, da era geisel ao nosso tempo, J.P.R. Velloso (org.), National Institute of Higher Studies (INAE).

ECLAC (Economic Commission for Latin America and the Caribbean) (2012), Structural Change for Equality: An Integrated Approach to Development (LC/G.2524 (SES.34/3)), Santiago.

Fajnzylber, F. (1990), "Industrialization in Latin America: from the 'black box' to the 'empty box': a comparison of contemporary industrialization patterns", Cuadernos de la CEPAL series (LC/G.1534/Rev.1-P), Santiago.

Frenkel, R. (2010), “Lecciones de política macroeconómica para el desarrollo, a la luz de la experiencia de la última década", Centre for the Study of State and Society (CEDES), November [online] http:/ /www.itf.org.ar/pdf/documentos/72-2010.pdf.

IPEA (Institute for Applied Economic Research) (2013), “Duas décadas de desigualdade e pobreza no Brasil medidas pela PNAD/IBGE", Comunicado do IPEA, No. 159, October.

Kupfer, D. (2013), "Dez anos de política industrial", Valor Econômico, 8 July.

SAE (Strategic Affairs Secretariat) (2013), Determinantes da produtividade do trabalho para a estratégia sobre sustentabilidade e promoção da classe média, Federal Government, September.

Souza, F.E.P. (2012), “A Macroeconomia da Reindustrializaçao" [online] http://www. ie. ufrj.br/images/conjuntura/A_Macroeconomia_da_Reindustrializao.pdf. 



\section{Structural change trajectories and industrial policy approaches: a proposal based on the Argentine experience ${ }^{1}$}

Fernando Porta ${ }^{2}$

\section{Introduction}

From early 2003 to late 2011, the Argentine economy followed a path of sustained, rapid growth, with a brief hiatus from late 2008 to mid-2009 owing primarily to the repercussions of the international crisis. This period included an initial post-crisis recovery phase, which both preceded and followed the collapse of the convertibility regime, and a later phase of genuine and equally solid growth. By late 2005, and after more than 10 consecutive quarters of overall expansion, GDP growth had matched the high recorded in 1998, a

The themes covered in this document were debated during the seminar on neostructuralism and heterodox economics held in Santiago by the Economic Commission for Latin America and the Caribbean (ECLAC) on 22-23 April 2013. To prepare the article, the author benefited in particular from the thoughts and contributions of Fernando Peirano, Gustavo Baruj, Cecilia Fernandez Bugna, Carlos Bianco, Patricia Gutti, Jesica De Angelis, Pablo Sanches and Florencia Pizzarulli. The author is especially grateful for the comments received from an anonymous referee and the suggestions made by the editors of this volume. Any remaining errors are the sole responsibility of the author.

2 National University of Quilmes and the Interdisciplinary Centre of Studies in Science, Technology and Innovation (CIECTI) of the Ministry of Science, Technology and Productive Innovation (MINCyT), Argentina, ferporta.arq@gmail.com. 
clear indication of the gravity of the domestic situation at the start of the century. After equalling that historic high, economic activity continued on its path of vertiginous growth, posting annual rates on a par with China for over five years. Several factors contributed to this performance: the way in which the convertibility crisis was resolved resulted in favourable supply-side conditions, while demand was driven by an excellent international climate and by deliberate, effective expansionary policies at home. The latter two factors were particularly true of much of this period and set up a virtuous growth dynamic.

The main features of the new macroeconomic regime that followed the collapse of the convertibility regime, and which was consolidated from 2003, were initially the maintenance of a relatively depreciated (competitive) exchange rate and a monetary policy that validated the expansion of the money demand on the basis of recovery and growth. ${ }^{3}$ In light of the primary and financial fiscal surplus, tax policy was aimed at the steady expansion of public spending through a renewed role for public investment (in infrastructure and housing) and higher wages, pensions, social benefits and widespread public services subsidies. The asymmetrical conversion of foreign-denominated debt into pesos ("pesification"), the explicit or implicit renegotiation of business loans and the subsequent external debt restructuring enabled the sanitization of public and private balances. Both private expectations and the public sector's capacity to intervene benefited from all of these decisions.

The main goal of the policies implemented from the beginning of the Kirchner administration was to sustain aggregate demand. The reasoning behind this, which has not always been made explicit, seems to have been that, as long as demand expanded, growth could be sustained and could absorb unemployment and improve distribution. To a large extent, the measures implemented with that aim in mind during this period benefited the big macroeconomic mechanisms. The international crisis that struck in 2008 therefore had a paradoxical effect on Argentina: although alarms were initially sounded regarding the sustainability of that dynamic, its recessive effect quickly faded, and confidence was restored along with the official preference for expansionary macroeconomic policies, with little selectivity at the meso- and microeconomic levels.

However, even in late 2007, this growth trajectory, in part owing to the way it was being handled, was showing signs of considerable imbalances, most of which were rooted in the Argentine production structure. A resurgence of the effects of the international crisis since late 2011 and the subsequent slowdown suggest that something other than exogenous, short-term problems is at work. It has also become increasingly obvious that policies promoting

From 2008, the real exchange rate showed a tendency to appreciate in the context of gradually rising inflation. 
macroeconomic stability and a competitive exchange rate are necessary, but not enough: to overcome the current restrictions and create dynamic competitive advantages, production policies must be diversified and capable of closer coordination.

This article is divided into three parts. Section A presents brief comments on the performance of the Argentine economy since the macroeconomic regime changed in 2002, with an emphasis on the manufacturing sector. Section B analyses the production dynamic in Argentina from a neostructural perspective, while section C evaluates a conceptual and methodological proposal to support the formulation of an industrial policy that is also an inclusive development strategy. The recent Argentine experience does present some specificities, above all with regard to exchange-rate policy, the limited access to external financing and the bitterness of the internal dispute over income distribution, all of which make it very difficult to formulate general theories or conclusions. Be that as it may, in addition to analysing the specifics of the Argentine situation, this paper aims to propose methodological criteria for putting the neostructural approach into practice and to discuss the impact of such an approach on production development policies. In so doing, it endeavours to contribute to the current Latin American debate on development.

\section{A. Recent manufacturing performance}

The manufacturing sector was one of the main drivers of economic growth, supported by an expansion in private consumption, while gross fixed investment was the most powerful component of aggregate demand and external demand played a favourable and complementary role. Unlike the aggregate growth trends of the 1990s, industrial growth during this period was characterized by a general expansion of the various branches of manufacturing, in particular those most affected by the context and the earlier recession, which had a positive impact on the recovery of small and medium-sized enterprises and the growth of employment in manufacturing. Nevertheless, there were no changes in the per-unit content of employment, as may have been expected on the back of a relative lowering of the cost of labour owing to sharp currency depreciation in real terms. The use of the high levels of idle capacity and the subsequent expansions facilitated the creation of new jobs, while average labour productivity continued to rise (see figure XV.1). ${ }^{4}$

Data from the monthly industrial survey conducted by the National Institute of Statistics and Censuses (INDEC). According to the data on formal employment gathered by the Employment and Business Dynamics Observatory of the Ministry of Labour, Employment and Social Security (MTEySS), employment in private manufacturing firms during the fourth quarter of 2005 was already $4.2 \%$ higher than during the same quarter of 1998 , although this figure is only $0.2 \%$ if the averages for each year are compared. 
Figure XV.1

Argentina: production, employment and average productivity

in manufacturing, 1992-2011

(Index 1997=100)

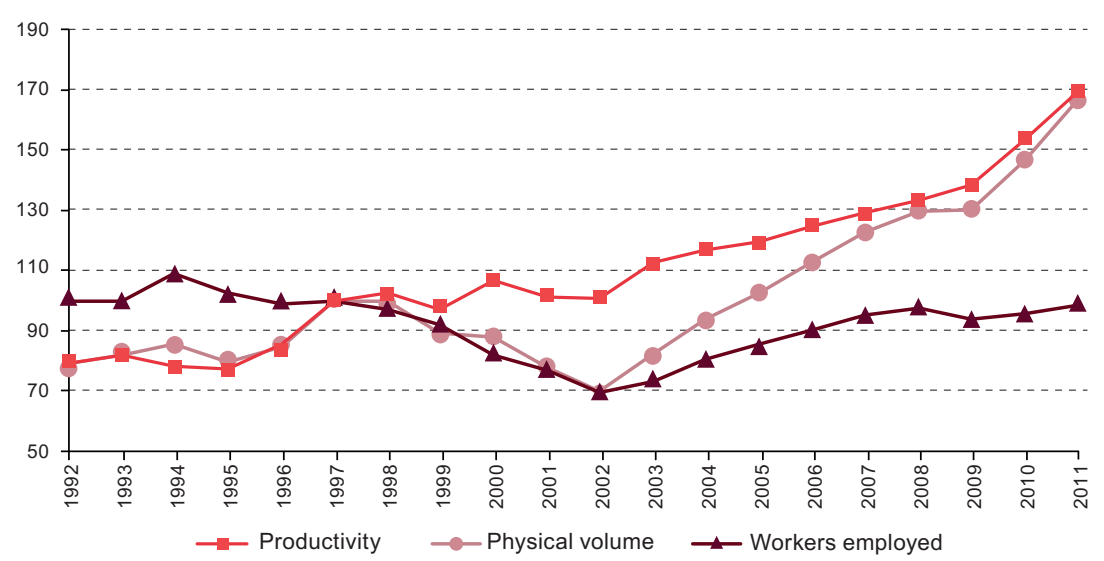

Source: Prepared by the author on the basis of National Institute of Statistics and Censuses (INDEC), monthly industrial survey.

Although the new macroeconomic incentives promoted the growth of the various branches and agents, the situation in the industrial apparatus varied according to the destination market of production and the share of wages and imported or exportable inputs in the cost structure, together with the size, the degree of concentration of supply and the ability to fix prices. Thus, the share in the profits of basic and chemical metal industries, first, and the branches with a high level of concentration, such as petrochemicals and cement, second, was greater than their share of manufacturing's value added, while the opposite is true of engineering- and labour-intensive branches, which benefited from convertibility and recorded their highest profits during this period thanks to non-recurring income from currency devaluation (Tavosnaska, 2010).

Alongside healthier profit margins, investment in all industrial sectors rallied and grew. In general, the economy's investment rate swiftly recovered and became the engine of domestic demand and a determining factor in the pace of growth. The investment rate stood at $23.3 \%$ of GDP in 2008 , surpassing the previous high of $20 \%$ in 1998. Although construction was initially the strongest sector, spending on durable production equipment recovered, especially around 2007, reaching $63 \%$ and $73 \%$ of the increase in gross domestic fixed investment in 2007 and 2008, respectively. Relatively speaking, SMEs were the best-performing business sector in investment terms and their average annual outlays grew by $23 \%$, fostered by a restructuring of their own cash flow (Kulfas, 2009; Porta and others, 2009). This also encouraged the creation of new enterprises and the growth of many others. 
Nevertheless, although the production networks most severely affected by relative de-industrialization regrouped somewhat, there was no real improvement in the linkages between large and small businesses. The restructuring of the manufacturing industry in previous decades not only disproportionately affected some sectors, but it also further engrained the structural heterogeneity of businesses. Several large enterprises had established themselves in the productive sectors and were trading internationally, but the SMEs network weakened markedly. Large companies tend to become entrenched as hubs of very hierarchical networks, with no significant multiplier effects on the production chain in question. ${ }^{5}$ The tendency to import parts and components had remained largely unchanged since the 1990s, as had the way profits were distributed along the chain.

The rapid expansion of manufacturing exports from 2004 was another notable feature of recent industrial growth and was the reason for a further jump in the value of exports and an almost doubling of the sectoral export openness ratio as compared with the 1990s. This was mainly due to an increase in export volumes of both agricultural and industrial manufactures (see figure XV.2). However, Argentina's export pattern continues to be dominated by a small number of natural-resource-based products (oils and waste produced by the food industry), processing and scale-intensive industries (steel and aluminium, paper and petrochemicals) and the automotive sector (promoted by a special regime established by the Southern Common Market (MERCOSUR)). Furthermore, the evidence suggests that Argentine industrial exports still primarily consist of low-tech goods.

Greater competitiveness, thanks to the lower prices that resulted from radical changes in the exchange rate, and a favourable international climate fostered the growth of a new set of goods, which heralded the nascent diversification of manufacturing exports (Bianco, Porta and Vismara, 2008; Herrera and Tavosnaska, 2009). This is also related to SME export performance, whose sales increased at a similar pace to the large exporters. The main companies capitalizing on the new macroeconomic regime to launch exports or deepen their external participation were those making capital goods and other metallurgical products, machinery, electrical goods, metallic manufactures, medical and precision instruments, and chemical and pharmaceutical products.

The automotive sector is an excellent example of this. Owing to the very high percentage of imported components used by end-stage companies in assembly, the typically strong growth of this segment and the market is only weakly passed along to the rest of the chain. No explicit policy has been implemented to bring together the agents of the different networks and modify the nodes of accumulation. 
Figure XV.2

Argentina: exports by line of business, 1991-2011

(Millions of dollars)

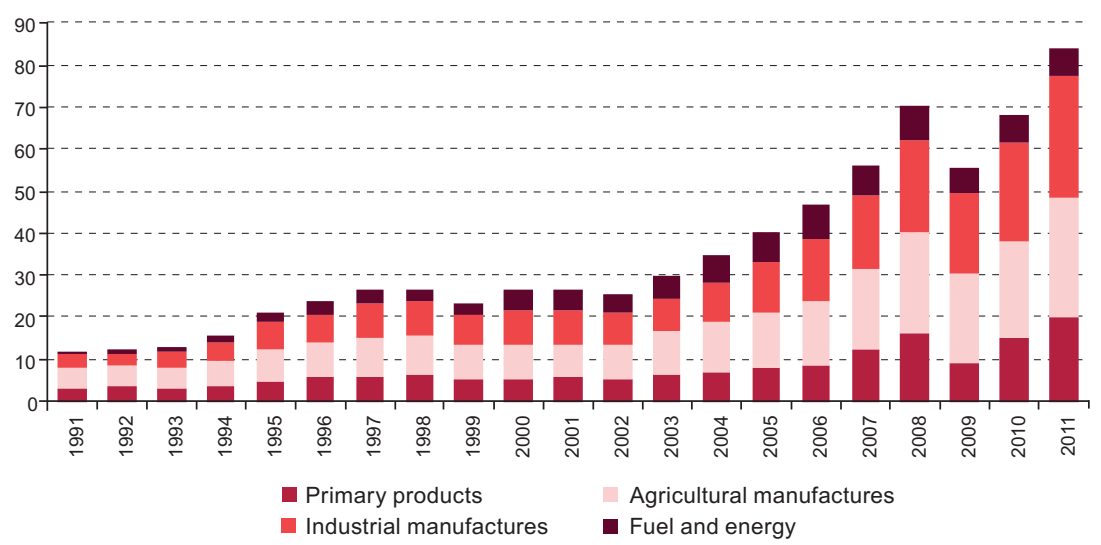

Source: Prepared by the author on the basis of data from the National Institute of Statistics and Censuses (INDEC).

Moreover, and despite the change in relative prices, the imports-toGDP ratio continued to rise, in line with the growth in domestic economic activity, the investment process and the remaining structural rigidities in supply owing to the absence of a local network, given that the production pattern had essentially remained the same (see figure XV.3). Similarly, in order to understand the rapid growth in imports, other factors must be taken into account, such as the sunk cost of the learning previously acquired as importers and not compensated by the new macroeconomic regime, the positioning of Brazil as supplier in the context of integration among transnational companies, the consolidation of consumption habits centred on products subject to rapid market obsolescence and the preference for flexible economic agents.

Despite rising production, employment, exports and investment, the amount and the composition of investment, in conjunction with the weak technological emphasis in manufacturing enterprises, has translated into insufficient productivity growth at the international level. According to data from the Industrial Performance Analysis Program (PADI) of the Economic Commission for Latin America and the Caribbean (ECLAC), Argentina's growth rate remains below that of the developed economies (with average annual productivity growth in Argentina of 3.7\% compared with $4.6 \%$ in the industrialized economies during the period 2002-2007). As a result, industrial output per worker in Argentina, which had stood at $45.1 \%$ of United States output in 1993, fell to $42.6 \%$ in 2001 before plunging to $37.7 \%$ in 2002 and dipping further to $36.1 \%$ in 2007 (see figures XV.4 and XV.5). Although Argentina had begun to close its internal gaps in productive and social terms, 
the sharper increase in the productivity of the United States manufacturing industry indicates that the technological gap between the Argentine economy and other countries had widened. By sector, the performance was mixed; while the gap narrowed somewhat in the automotive and food, beverages and tobacco industries, the disparities grew in the remaining engineeringintensive and labour-intensive sectors.

Figure XV.3

Argentina: total imports and their composition by economic use, 1991-2011 (Millions of dollars)

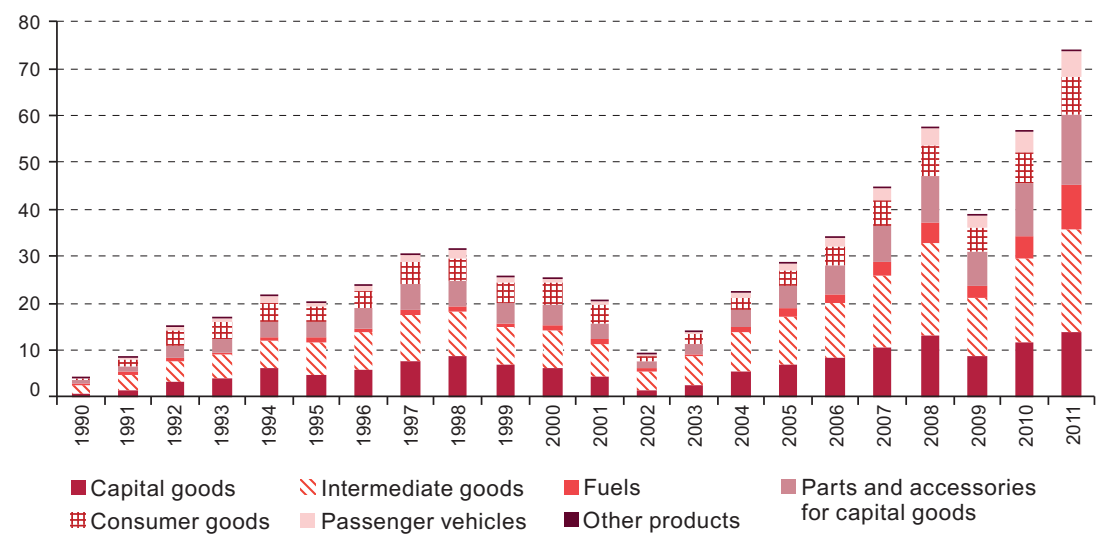

Source: Prepared by the author on the basis of data from the National Institute of Statistics and Censuses (INDEC).

Figure XV.4

\section{Argentina and United States: industrial output in selected sectors,} by worker, 1993-2007

(Thousands of constant dollars at 1985 prices)

A. Food, beverages and tobacco

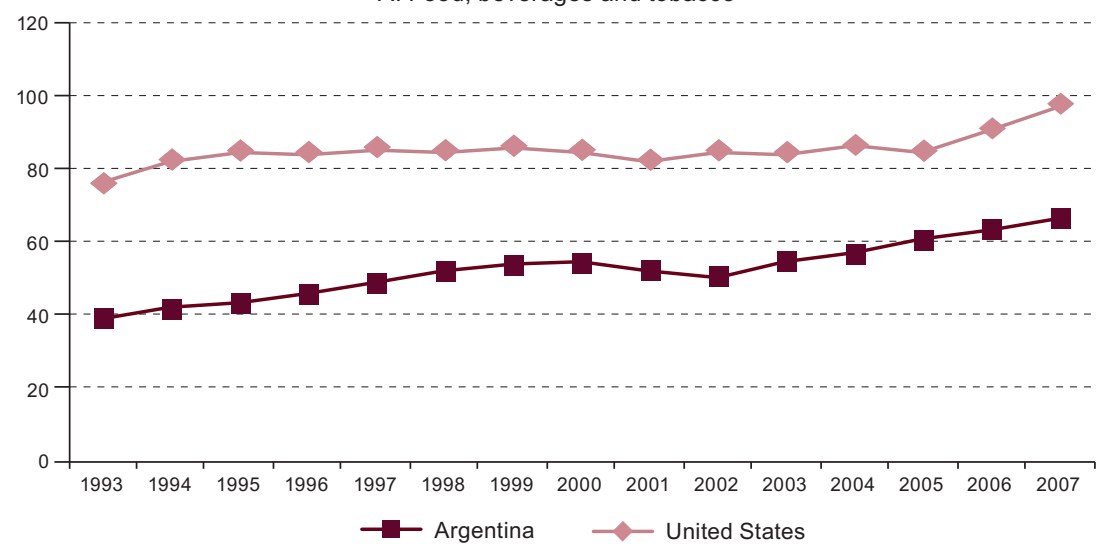


Figure XV.4 (concluded)

B. Automotive industry

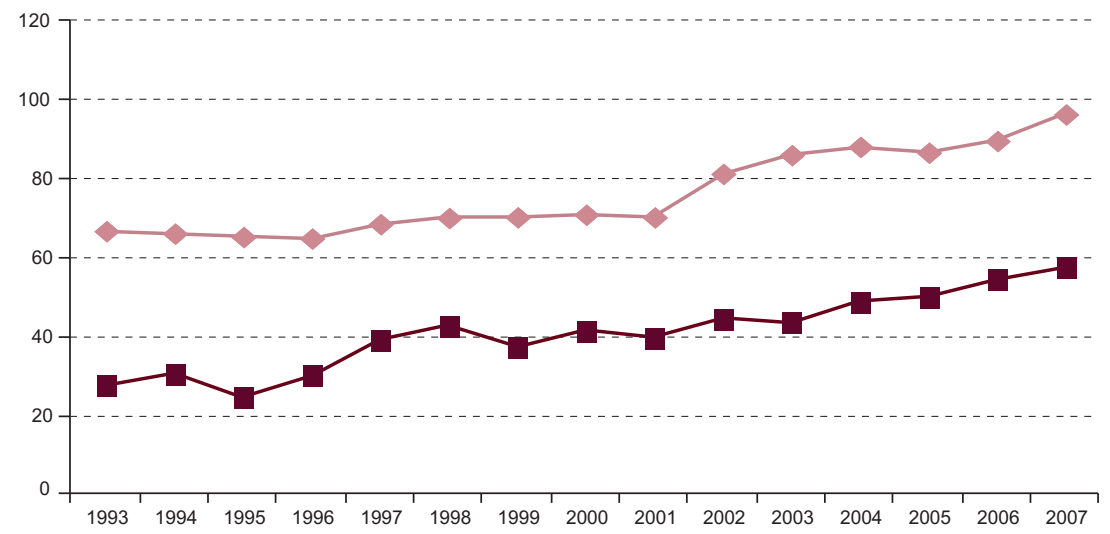

C. Engineering, excluding the automotive sector
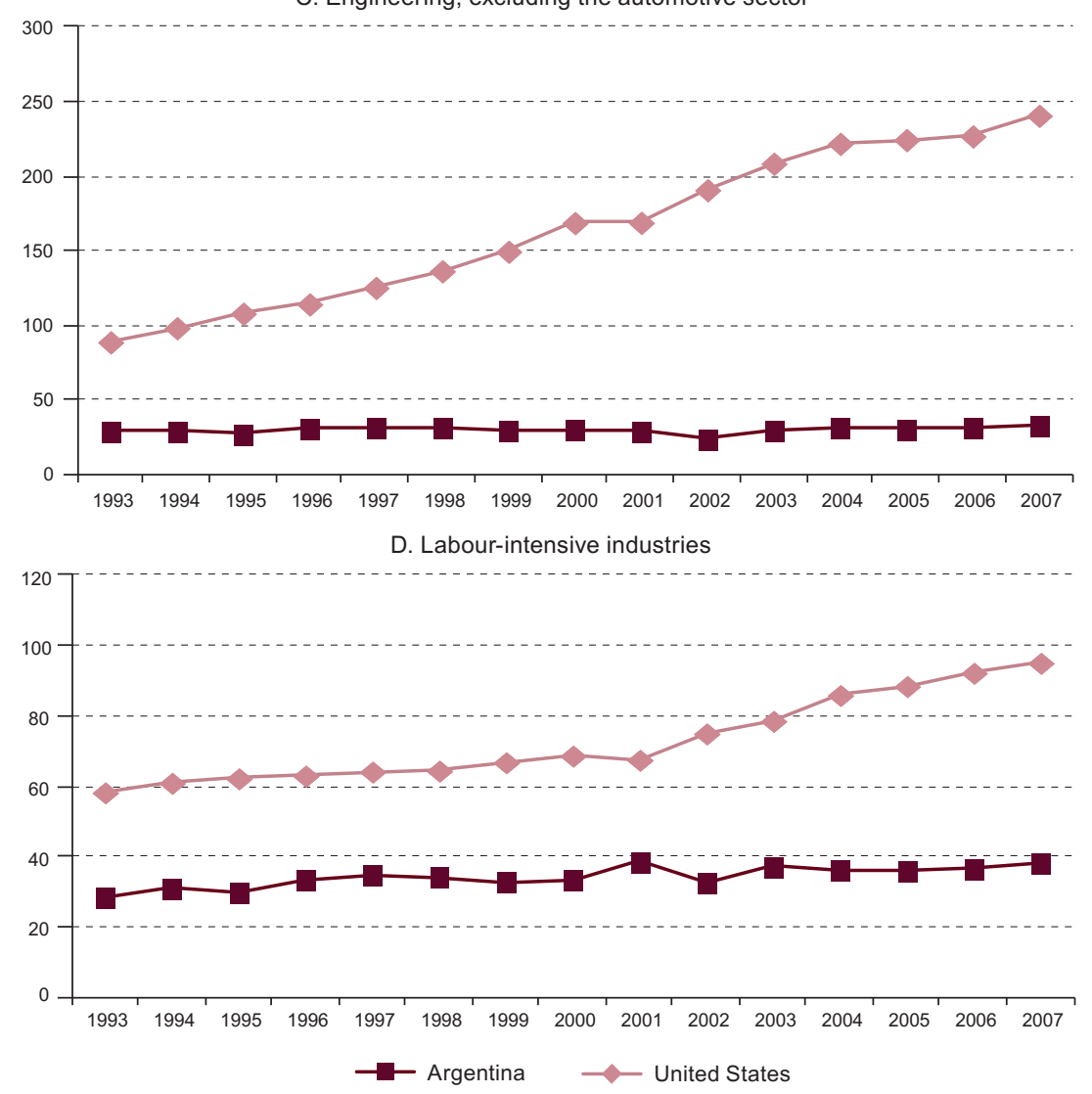

Source: Prepared by the author on the basis of Economic Commission for Latin America and the Caribbean (ECLAC), Industrial Performance Analysis Program (PADI). 
Figure XV.5

Argentina: growth in productivity and comparison with the United States, 2000-2010 (Percentages)

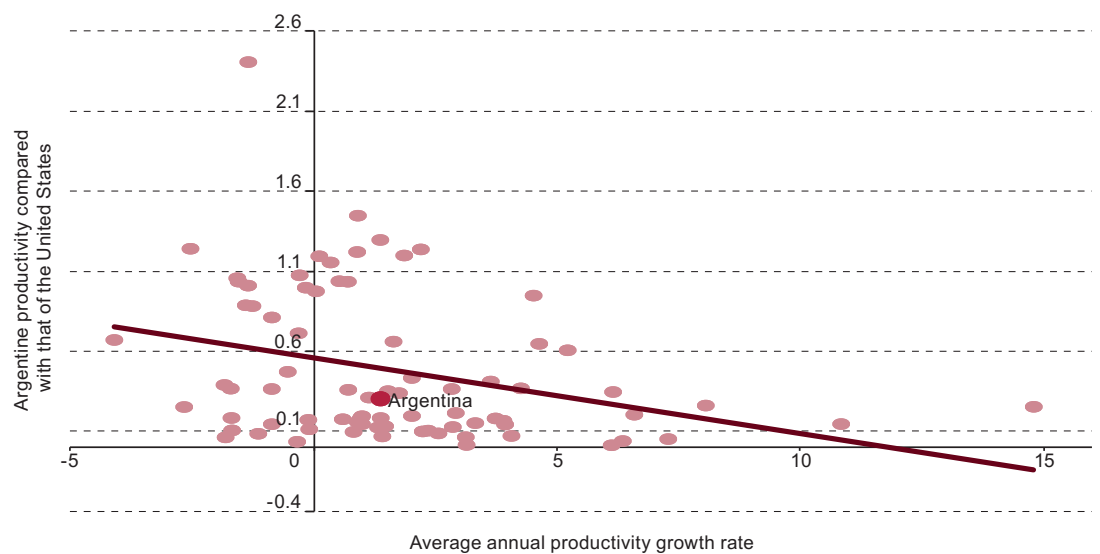

Source: Prepared by the author on the basis of World Bank.

Coremberg (2012) presents total factor productivity (TFP) estimates for Argentina during the period 1990-2010 and compares the figures for each decade's boom cycle. The evidence suggests that, during both periods, growth was attributable more to factor accumulation (capital and labour) than to increases in TFP. Capital accumulation was responsible for $42 \%$ of GDP growth from 2002 to 2010, and 40\% of GDP growth between 1990 and 1998. In both cases, the capital stock did not belong to the information and communications technologies sector and had been imported, although following currency devaluation, the share relating to domestic equipment and non-residential public investment increased. The incorporation of the labour factor, meanwhile, represents $49 \%$ of aggregate growth from 2002 and $42 \%$ of growth during the convertibility regime to 1998, which is generally based on the quantity rather than the quality of employment. Greater efficiency in factor use also made only a small contribution during both periods.

\section{B. Limitations of productive specialization}

The new macroeconomic regime was not enough of an incentive to encourage more sophisticated production or significant product or process innovation. In general, there has been no change in the industrial landscape and no progress towards capturing a larger share of export markets or advances in the new sectors of software and biotechnology. The first surveys conducted in Argentina on innovation in the late 1990s revealed that, even then, companies' spending on this area was significantly below international standards. According to the latest figures, this situation has changed little. 
This suggests that many firms have capitalized on the prevailing conditions to boost their sales and activity levels, but have failed to formulate a strategy for competitive, sustainable and cumulative participation. ${ }^{6}$

Rather than structural change, the recent process of relative reindustrialization has been characterized by a new growth regime, in which most branches of industry and average labour productivity and labour use have expanded. There are gaps in the sectoral composition of the Argentine production structure, which focuses on low-tech activities, while within each branch, there is a tendency to specialize in low-tech production. This is a hangover from the structural change pursued in the 1990s, whereby low-tech activities gained ground and the industrial apparatus adopted the modernization strategy of replacing employment and local capacity with imported inputs, components and capital goods. As a corollary, endogenous productive and technological capacities were discouraged, local linkages were dismantled and production heterogeneity increased.

However, the sectoral make-up of industry is not, by itself, an adequate indicator of the technological characteristics and the value added of local production. Other factors that should be taken into consideration are the classes of products and activities in each industry, the complexity of the production processes and the application of knowledge to production, the value added and the integration with the local production framework, as well as the kinds of markets or the links in the value chains in which it is inserted. Ocampo (2005) picks up on a long theoretical tradition among authors and heterodox schools of economic thought when he suggests that the dynamic of a production structure is an outcome of the interaction between two different forces: innovation, and learning more generally; and the complementarities, linkages and networks between companies, production activities and institutions that support dynamic externalities.

On the basis of this theoretical definition, Porta (2006), Bianco and Fernandez Bugna (2010), and Porta and Fernandez Bugna (2011) came up with proposals and methodologies for classifying and identifying the relative positioning of production activities according to the factors suggested by Ocampo. ${ }^{7}$ In Argentina, the industrial sectors that combine the highest levels of learning and linkages are those responsible for the production

6 Only a few manufacturers (less than $10 \%$ ) have a long-term innovation strategy, and one fourth carry out few or no innovation activities (Lugones, Suarez and Moldovan, 2008). This phenomenon is seen across all industrial sectors. The same authors also point out that some companies in each sector act more dynamically and more positively, and in those cases the respective ratio is closer to that of European firms and above that of Brazilian industry, since spending on innovation exceeds $3 \%$ of sales, a performance that is well above average $(1.12 \%)$. See the methodological issues in Porta and Fernandez Bugna (2011). Since national surveys on innovation and technological behaviour are based on a sample of manufacturers, the lack of data on innovation activities in the primary and services sectors means that this methodology cannot be applied to production activities. 
of construction materials (269), motor vehicles (341) and other chemical products (242) (see figure XV.6). These activities are not usually classed as high-tech (with the exception of pharmaceuticals, which are included in the chemical products branch). The automotive industry has in particular shown a growing tendency to import higher-tech parts and components, which has reduced its integration in the local economy in both quantitative and qualitative terms.

\section{Figure XV.6 \\ Argentina: indicators of innovation and learning and linkages in manufacturing sectors, $2005-2007^{\text {a }}$}

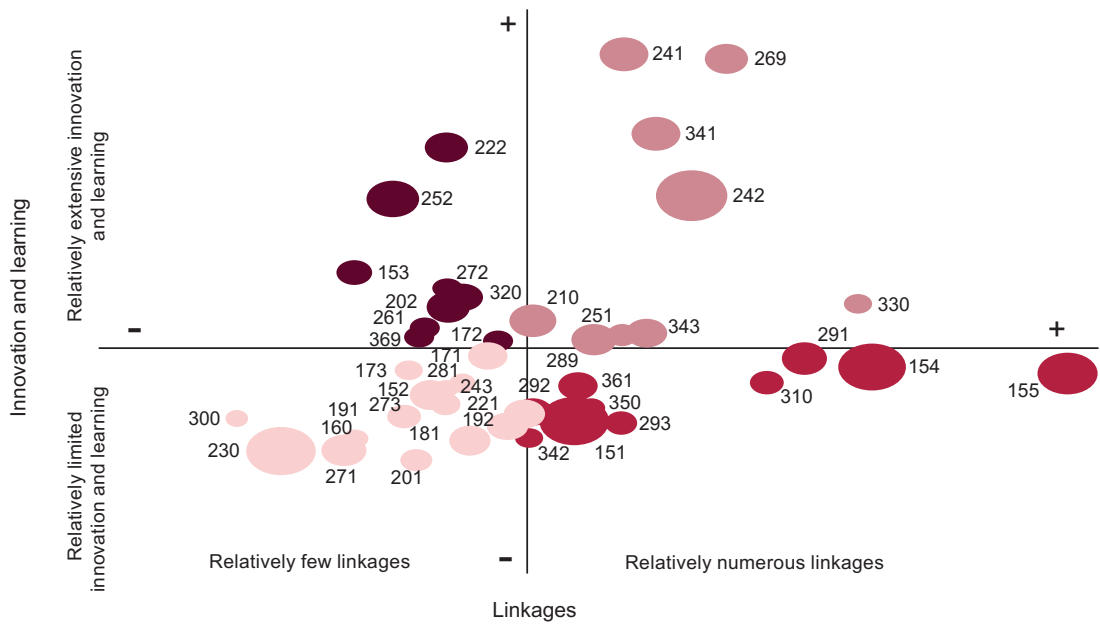

Source: Prepared by the author on the basis of information from the Production Research Centre (CEP), and National Institute of Statistics and Censuses (INDEC), Matriz Insumo Producto Argentina 1997 [online] http://www.mecon.gov.ar/peconomica/matriz/cuadros/mip.pdf.

The bubbles reflect the importance of each manufacturing sector relative to the value added of the industry.

Most branches of industry are located in the middle-low quadrants for both indicators; oil refining (230) and the food processing industry (151), for example, both of which represent a large share of the industrial structure, are found in the less virtuous quadrants. This indicates that major naturalresource-based activities are still fundamentally based on static advantages, spend little on innovation and learning, and have developed and diversified few links with the rest of the economy.

This calculation methodology, which uses aggregate averages, may overlook high levels of intra-sectoral heterogeneity (Bianco and Fernandez Bugna, 2010). Several studies have published data on sectors in which companies playing a very active role in product development co-exist with others specializing in low-quality, poorly differentiated goods (such as the 
milk industry), while yet other companies and segments have recognized research and development centres, such as the iron and steel industry or the specialized machinery industry (see, for example, Stumpo and Rivas, 2013). Although technology surveys in Argentina show that private spending on innovation is low, there is also evidence of dynamic agents with explicit innovation and external engagement strategies in various sectors (Lugones, Suarez and Moldovan, 2008; Suarez, 2013). However, these publications also confirm that such cases are in a minority, which explains the average figures obtained.

If the contentions of Ocampo (2005) are applied, virtuous structural change can be defined as a process through which innovation-, learningand complementarity-intensive production sectors increase their share. Trajectories of this nature lead to micro- and macroeconomic efficiency, generate systemic competitiveness, reduce heterogeneity and raise people's incomes. In contrast, processes in which certain firms, activities or sectors demonstrate high levels of innovation or learning but little development of complementarities have a poor outlook. The competitive advantages are specific to those activities or firms. Given that they are only weakly integrated with the rest of the production apparatus, their expansion requires significant import flows, creates growth leaks, cancels out multiplier effects, and makes them vulnerable to offshoring.

During Argentina's recent phase of industrial growth, sectors exhibiting greater innovation, learning or linkages tended to increase their share, which points to an interesting trend in terms of structural transformation. Nevertheless, the activities that combine the highest indicators on both axes represent less than $15 \%$ of industrial output. In addition, Porta and Fernandez Bugna (2011) apply a similar methodology and compare the production structures of Argentina and Brazil, taking Germany as their reference. ${ }^{8}$ Most manufacturing sectors in Argentina display relatively low levels of innovation, learning and linkages. This contrasts in part with Brazil, which evidences more sectors with deep structural characteristics and seems to support the theory put forward by Porta (2006), who suggests that a quadrant is missing in Argentina's production structure (see figure XV.7).

On the basis of the harmonized matrices of inputs and products prepared by the Organization for Economic Cooperation and Development (OECD), and the respective surveys on innovation, the methodology described was used to compare industrial specialization in Argentina, Brazil and Germany. Germany was taken as the point of reference for absolute levels of innovation, learning and linkages in order to rate the production specialization of the Argentine and Brazilian economies. Argentina's performance was also compared with Brazil's to capture technological asymmetries with another intermediate developing economy in the region. The differences between Germany and Argentina and Brazil were calculated using these indicators, taking account of the intensity of innovation and learning, the level of research and development, and the linkages between the German branches of industry as an indirect indicator of the ceiling. 
Figure XV.7

Argentina and Brazil: differences between the indicators of innovation, learning and complementarities in manufacturing sectors compared with Germany, 2005 (Percentages)
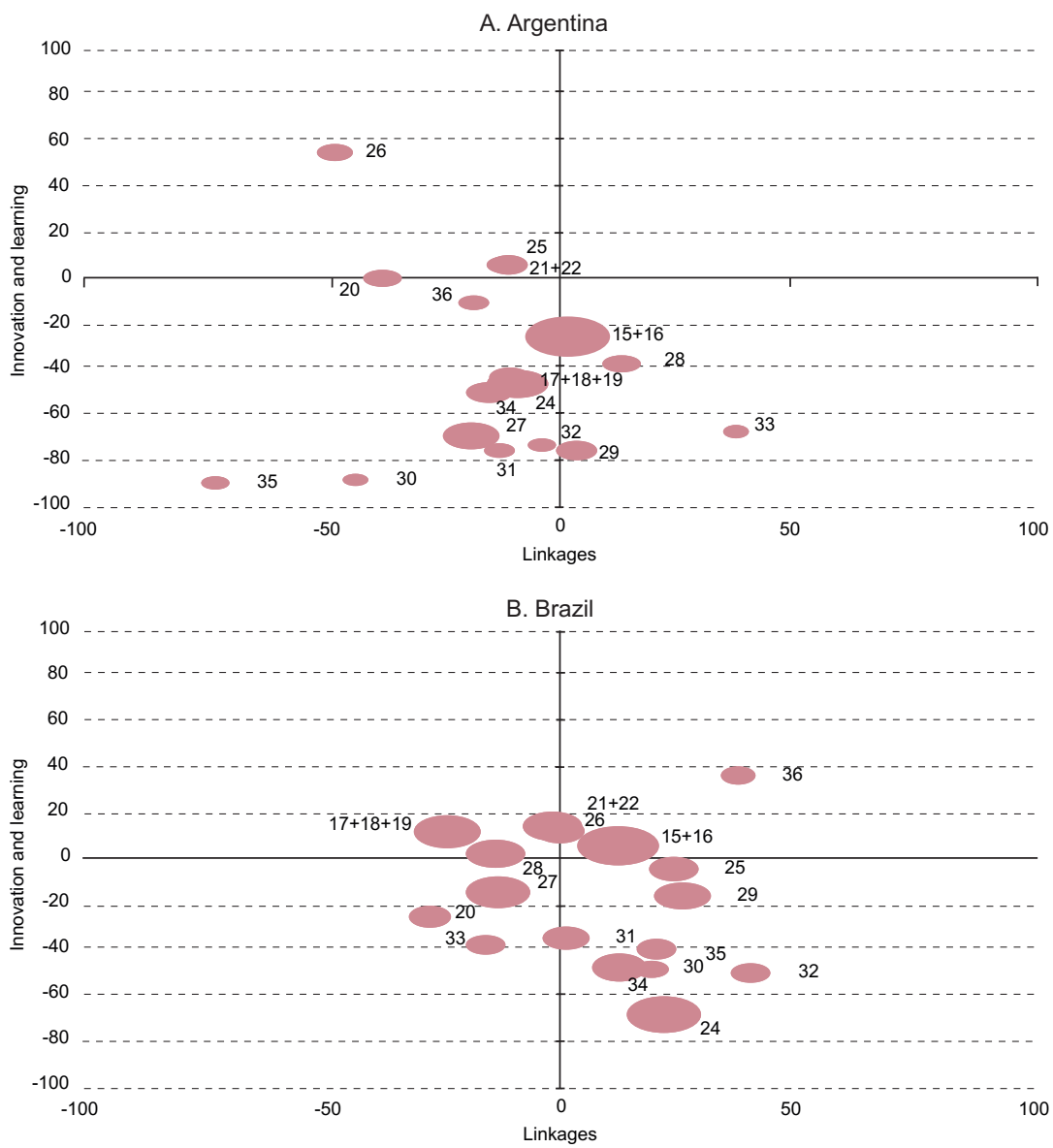

Source: Prepared by the author on the basis of data from the National Institute of Statistics and Censuses (INDEC), the Brazilian Geographical and Statistical Institute (IBGE), the Statistical Office of the European Communities (EUROSTAT) and the Organization for Economic Cooperation and Development (OECD).

a The bubbles represent the share of each sector in industrial output corresponding to 2005 on the basis of information from the National Directorate of National Accounts of the National Institute of Statistics and Censuses (INDEC), in the case of Argentina, and the Industrial Performance Analysis Program (PADI) of ECLAC, in the case of Brazil.

According to these indicators, in terms of the intensity of innovation and learning, the sectoral distribution confirms the extent of the gaps in innovation and learning in Argentine and Brazilian industrial sectors compared with the German structure; the only sectors not affected are rubber and plastics (25) and other non-metallic products (26), while the disparities are particularly 
marked for machinery and equipment (29), office machinery (29), electrical equipment and materials (31), and other transport (35). The data show that the technological gap between the industrial sectors of Argentina, Brazil and Germany is not just a question of sectoral specialization, but rather goes hand in hand with weak endogenous innovation capacities, and becomes even more pronounced when absolute spending on innovation and learning and on research and development is taken into account (Peirano, 2008).

In short, the structural determinants of growth in Argentine industry tend to be weak: its expansion tends to require an ever-increasing flow of imports, while not producing any greater demand-side multiplier effects, yet it does not create sufficient external economies of scale to sustain progress towards systemic competitiveness. The growth process is not being supported by the development of knowledge- and differentiation-intensive activities, with dynamic demand, high investment rates and positive effects on the rest of the production apparatus. As a result, the rise in productivity is insufficient and the production structure is itself a limitation on attaining the sustainable development goals, improving quality of life and achieving better income distribution. Sooner or later, depending on the domestic or external situation, it also tends to precipitate or exacerbate external and fiscal restrictions, and affect exchange-rate policy.

From the perspective of the structural dimensions examined in this paper, the Argentine economy's profile as a country that specializes in exports is somewhat paradoxical. Porta and Fernandez Bugna (2011) analysed the participation of Argentine industrial sectors in external trade according to the revealed comparative advantage index proposed by Lafay (1979 and 1980). ${ }^{9}$ The results show comparative advantages during the period 1993-2008 under various food and beverages headings (food, milk products, milling and beverages) (15), leather products (191), oil refining (23), iron and steel (271), precious and non-ferrous metals (272) and printing (222), the latter explained by very low import levels (see figure XV.8). Almost all of these are naturalresource-based sectors, or sectors that have benefited from longstanding, ongoing industry promotion regimes. As figure XV.8 shows, none of these activities are located in the most virtuous quadrant.

However, it could be argued that some sectors enjoy potential comparative advantages, since they have gradually reduced their revealed comparative disadvantages and present the characteristics set out in this paper (Nassif, 2003; Briner, Sacroisky and Bustos Zavala, 2007). In general, these sectors have high export and intra-industry trade ratios and include some industrial inputs, such as chemical products (241 and 242), paper products (210) and rubber (251), or in some cases are capital-intensive sectors based on

$V C R_{i}=\frac{1000}{P B I}\left[\left(X_{i}-M_{i}\right)-\left(\frac{X_{i}+M_{i}}{X+M}\right)(X-M)\right.$ 
economies of scale, whose activities display the highest levels of innovation and learning and linkage development in Argentine industry (see figure XV.9). Furthermore, with very few exceptions, the comparative advantages of sectors with lower levels of innovation and learning and linkages tend to deteriorate in the period under consideration.

Figure XV.8

Argentina: sectors with comparative advantages according to indicators of innovation and learning and linkages, 2005-2007 ${ }^{\text {a }}$

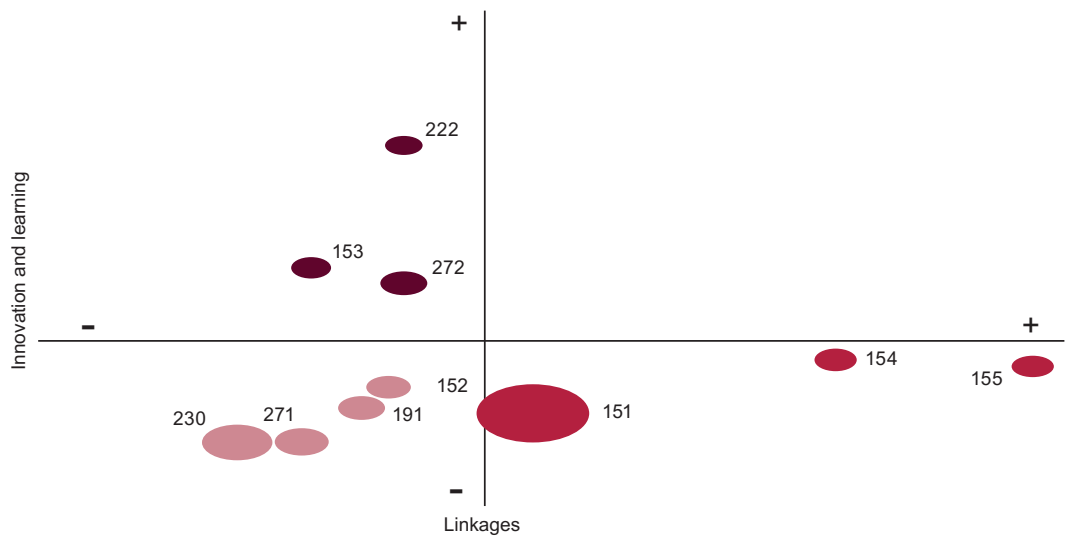

Source: Prepared by the author on the basis of information from the Production Research Centre (CEP), and National Institute of Statistics and Censuses (INDEC), Matriz Insumo Producto Argentina 1997 [online] http://www.mecon.gov.ar/peconomica/matriz/cuadros/mip.pdf.

a The bubbles reflect the importance of each of the manufacturing sectors in total manufacturing exports.

Figure XV.9

Argentina: sectors with potential comparative advantages according to indicators of innovation and learning and linkages, 2005-2007

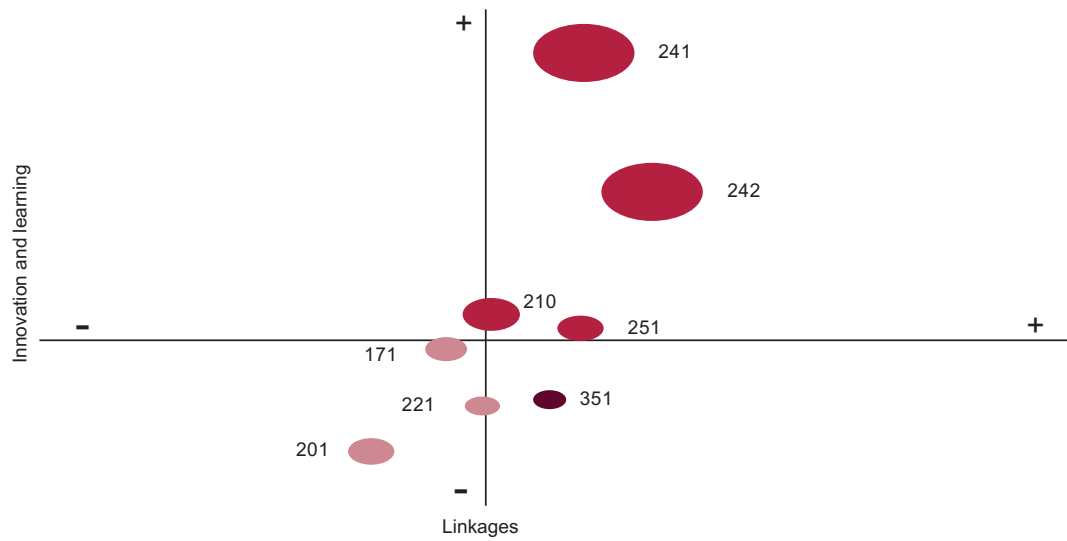

Source: Prepared by the author on the basis of information from the Production Research Centre (CEP), and National Institute of Statistics and Censuses (INDEC), Matriz Insumo Producto Argentina 1997 [online] http://www.mecon.gov.ar/peconomica/matriz/cuadros/mip.pdf.

a The bubbles reflect the importance of each of the manufacturing sectors in total manufacturing exports. 
This pattern of international integration - based on activities that are not labour intensive and demonstrate limited potential for the creation of production linkages - results in a tight elasticity between exports and employment (Stumpo, 2009). The vast majority of jobs created during the recent period of economic and export growth were generated by companies selling exclusively to the domestic market. This calls into question the automatic nature of the benefits that may be expected from an export-driven growth strategy, as has been frequently highlighted in the current debate (Katz and Stumpo, 2001). It also speaks to the importance of more effective links between greater international participation and diversification of the production structure, as well as the ability to create links at both ends of the chain and to carry out more advanced and complex technological processes.

\section{Industrial policy approaches: towards a post-neoliberal agenda}

The key to transforming a growth cycle into economic development lies in the mesoeconomic dimension. The sectoral composition of production, the market structures, the functioning of the factor market and the institutional framework of the production apparatus all determine its evolution. Any development path will be modelled by the dynamic of the changes experienced by the production structure, which will in turn be the result of the interaction between the incorporation of innovation into processes, products, the organization or the institution (with the accompanying dissemination of learning), and the density of complementarities present or induced in the production structure. The ability of an industrial system to devise new activities is certainly a fundamental component of fast economic growth, but transformation of the production structure will depend, above all, on their dissemination and on the creation of production linkages.

The recent reindustrialization process in Argentina was driven by proactive policies that stimulated production, and in particular, by an expansion in demand. Nevertheless, the main technoproductive and socioproductive characteristics of the economic structure did not change significantly, and their functioning tends to produce imbalances that compromise the goals of income redistribution and the recovery of economic policy's room for manoeuvre. Structural change as a goal requires an explicit strategy and production development policies that foster the scaling up or updating of products, processes and functions (here, the intrasectoral dimension is fundamental) while simultaneously promoting more interconnections between companies, activities and sectors. The aim is to reconstruct a grid of production relationships that favour a steady increase in productivity and consolidate socio-labour institutions in order to be able to improve distribution and create new markets without jeopardizing growth. 
To consolidate an inclusive development path, mesoeconomic intervention by the State must be overhauled. Argentina's production system is highly diversified, but it is stymied by intense distributive conflicts and has a limited ability to -inclusively_- bring together the interests of all relevant actors in pursuit of a strategic goal. The size of its population and its stock of accumulated capacities are incompatible with a niche, or very specialized, strategy, while resolution of the conflict over distribution requires a systematic and significant increase in average productivity and the prevention of abuses by those in positions of power. The selection of any intervention should promote a general upgrading of production activities, and industrial policy in the broad sense would have to be defined according to certain criteria and meet the necessary conditions for maximum effectiveness.

The challenge lies in advancing towards a denser, more complex and better integrated production fabric, which will not necessarily result from aggregate growth. On the contrary, this kind of structural change requires intense collective action on a mesoeconomic level, because the main obstacles are coordination and value chain governance. Just as production policies are not powerful enough to compensate for macroeconomic inconsistencies or imbalances, it is not enough to establish a system of supposedly favourable incentives and rely on a pricing system for coordination. The primary function of production development policies must be to intervene in the sectoral composition of production and to regulate inter-firm and intersectoral relations, which define how income is generated, owned and distributed.

Policies must be formulated using objectives that will identify, for each production chain, the transformation path required to implement the options for upgrading production and developing complementarities. Industrial policy should be not be thought of as a reaction to market failures aimed at resolving the coordination or information problems caused by a pricing system, nor should it consist of purely compensatory interventions. The crux of a production policy must be the definition of a strategic scenario that is feasible (based on accumulated and potential capacities) and desirable (based on the goal of inclusive development). This task cannot be delegated by the State: the overarching strategy must be explicitly stated and the targets and the trajectories of the structural change in mind must be defined. It is also an opportunity to redefine public-private relations: a transition from the present situation to the desired goal requires a fluid interaction with the business and trade union sectors to ensure that the specific policies are correctly implemented.

On the operational side, a matrix of objectives and policy strategies can be drawn up to chart the course for the changes that need to happen in sectors or production chains, taking account of the impact that monetary and non-monetary externalities could have in social terms, and seeking the best possible outcomes in that regard (see diagram XV.1). A diagnostic assessment, prepared on the basis of the upgrading and complementarity 
set forth above, should identify the positioning of the sector (any of the possible $\mathrm{Ai}$ ), taking account of the starting point of the intervention with a view to reaching the higher quality area within the axes of the structural change desired (B).$^{10}$ In general, progression from the current state of affairs for one of the sectors (Ai) to the virtuous state adopted as the goal (B) can be effected through action in various technoproductive and socioproductive arenas, and through different, specific impetuses.

\section{Diagram XV.1 \\ Structural change trajectories and policy action}

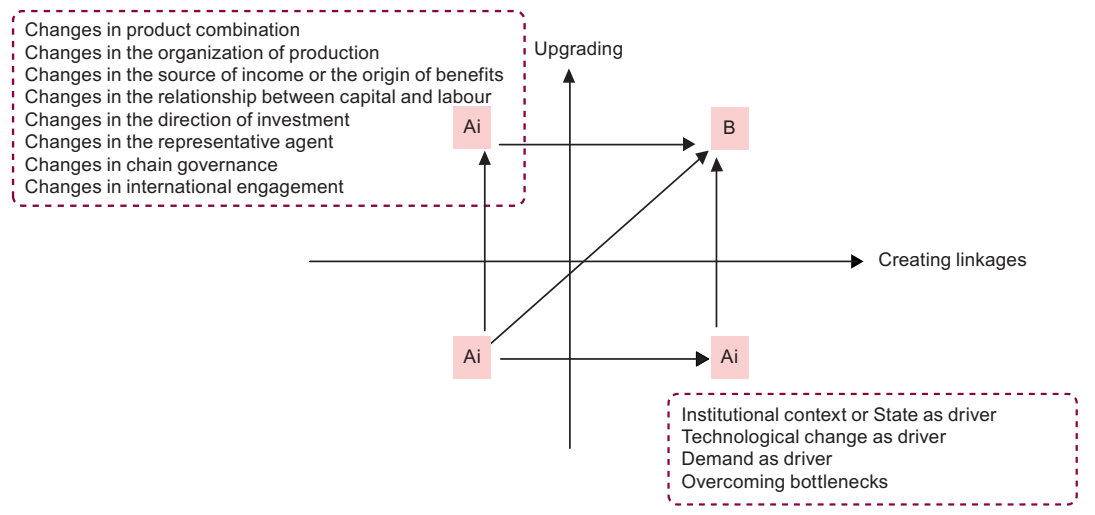

Source: Prepared by the author.

The aim of the matrix is to propose a virtuous pathway towards greater sectoral competitiveness on the basis of real options for sectoral transformation, reconversion or structural change. The ideal goal (B) should be the most desirable scenario possible and it should respond to the historical potentialities of the sector and the specific needs of the economic context. As far as possible, it is understood that the journey to a better position depends on a series of factors.

10 Upgrading can refer to a more efficient production process (process upgrading), a move towards products with a higher unit value (product upgrading), or a shift towards tasks that require greater capacities (functional upgrading). Any skill that is acquired and leads to the superior performance of a function can be applied to other sectors (intersectoral upgrading). Upgrading seeks to avoid sectors or functions in which competitiveness depends on cost and which have few entry barriers. Functional upgrading in particular can reduce the vulnerability of a firm or sectors' competitive position, since focusing solely on the manufacturing phase restricts competition to parameters associated with the cost of the factors and transforms wages into the adjustment variable. In short, for the production sectors, this strategy means focusing on activities or functions where competitive advantages can be demonstrated that are unrelated to price. Both quantitative and qualitative indicators can be used to analyse this dimension, namely: (i) the variety and differention of raw materials, inputs, parts and components; (ii) the quality of the raw materials, inputs, parts and components; (iii) the cost of the raw materials, inputs, parts and components; (iv) the availability of the human resources; (v) the aptitude and training of the human resources (vi) the use of installed capacity; (vii) the characteristics of the technological equipment and facilities; (viii) firms' technological behaviour; (ix) product quality; and ( $\mathrm{x}$ ) the incorporation of design and engineering activities. 
Evaluation of each of these factors will produce a combination of features and attributes on the basis of which the best course for each sector may be charted.

The matrix offers a set of strategic initiatives leading to the best trajectories for developing genuine competitiveness, and highlights in a stylized way the options (in terms of objectives and policy strategies) that open up when development policies are shaped to upgrade production and create linkages (see diagram XV.2). The dashboard may be used to frame a strategy for sectoral transformation, reconversion or structural change. Policy implementation that is consistent with the paths recommended in this matrix should produce results that support the systemic competitiveness of the economy. Thus, a better production structure will translate into more innovations and linkages (making it possible to disseminate them); a higher degree of production upgrading; greater sophistication in the production of goods and services; the incorporation of design, technology and processes; a higher proportion of national value added; and a higher-quality labour market and hence a lower level of informal employment.

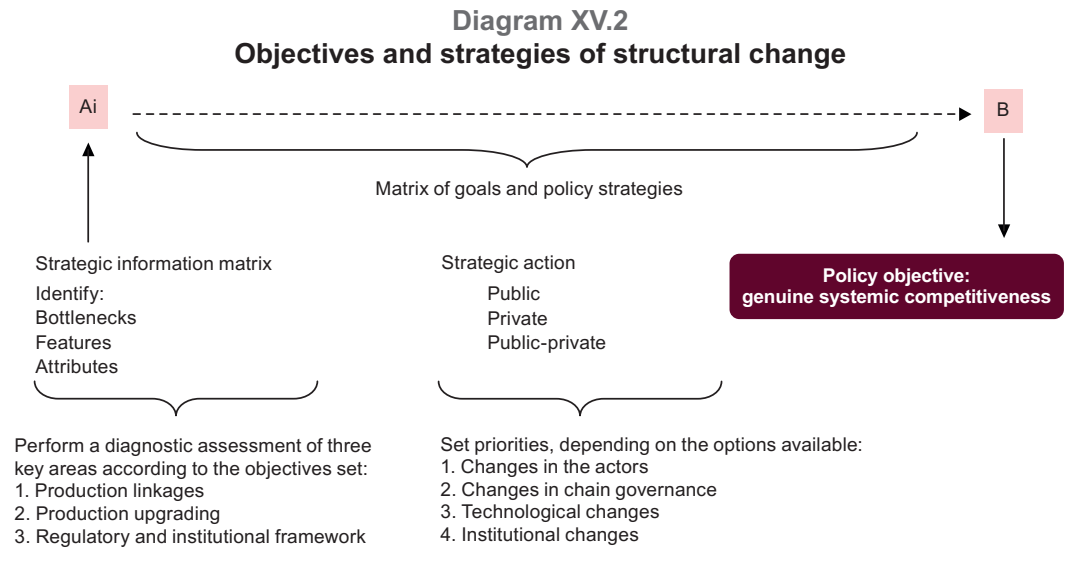

Source: Prepared by the author.

Developing and strengthening complementarities and production linkages is at the heart of systemic competitiveness. Complementarities must be created to improve competitiveness throughout the system, since they are present in the development of vertical linkages in both directions (upwards and downwards), and in horizontal links with other production sectors. They are the structural determinant of the multipliers of investment, and thus represent a direct link between the production structure and macroeconomic development. An abundance of linkages enhances the density of the production structure and prevents the growth leaks that are produced when higher numbers of imports are required. Both quantitative and qualitative indicators can be used to analyse this dimension, namely: (i) the amount and level of exploitation of national raw materials, inputs, parts and components; (ii) the development of linkages with the suppliers of machinery and tools; (iii) the development of linkages with other sectors supplying inputs and services; (iv) the level of activity coordination along the chain; (v) the importance of the sector within the hierarchy or governance; (vi) the asymmetry of positions in the chain; (vii) the creation of links with marketing chains and other forward links; (viii) the existence of production plants; and (ix) the degree to which the physical and technological infrastructure is appropriate for the sector's development. 
Presented below is a tentative version of the objectives and policy strategies matrix (see table XV.1). The first two rows comprise what would be the sectoral assessment, depending on the objectives set. Within the assessment, the first row sets out the different results and goals that can be expected in terms of modernizing the different sectors and which, in some way, make up the desired scenario. The second row identifies the main bottlenecks that may arise from a proposed expansion of the sector. The other rows detail the actions that are recommended to achieve the objectives, according to the diagnostic assessment. They show the different channels through which sectoral change can be driven, namely, (i) changes in knowledge and technology sources; (ii) changes in the actors; (iii) changes in chain governance; and (iv) changes in the regulatory and institutional framework.

This methodological tool does not establish sectoral priorities; rather, it sets out pathways for achieving specific objectives. The matrix offers a limited number of options for each column and provides a range of objectives and policy strategies, together with lines of action for which priorities must also be established. In that regard, primary and secondary options can be identified, taking into account the diagnostic assessment and the desired outcome.

The diagnostic assessment should present and organize at the chain, sector or production-line level a wide set of strategic data, which will allow for evaluation and lay the groundwork for the necessary intervention or public policy to attain the objectives pursued under the general strategy. This is the aim of such matrices. To that end, the information required will be used to evaluate the competitive strengths and weaknesses of each production segment in order to pinpoint the most coherent and useful production trajectories. The desirable and feasible pathway to structural change for each chain or sector depends on various factors, some of which are specific to the activity while others are inherent to the environment. Thus, general technoproductive characteristics must be taken into consideration, in addition to the forms of international competition and the production situation. In this methodological approach, each sector or activity has its own expansion, modernization or inclusion trajectory. Public policy must adapt its instruments and its modes of intervention accordingly. 


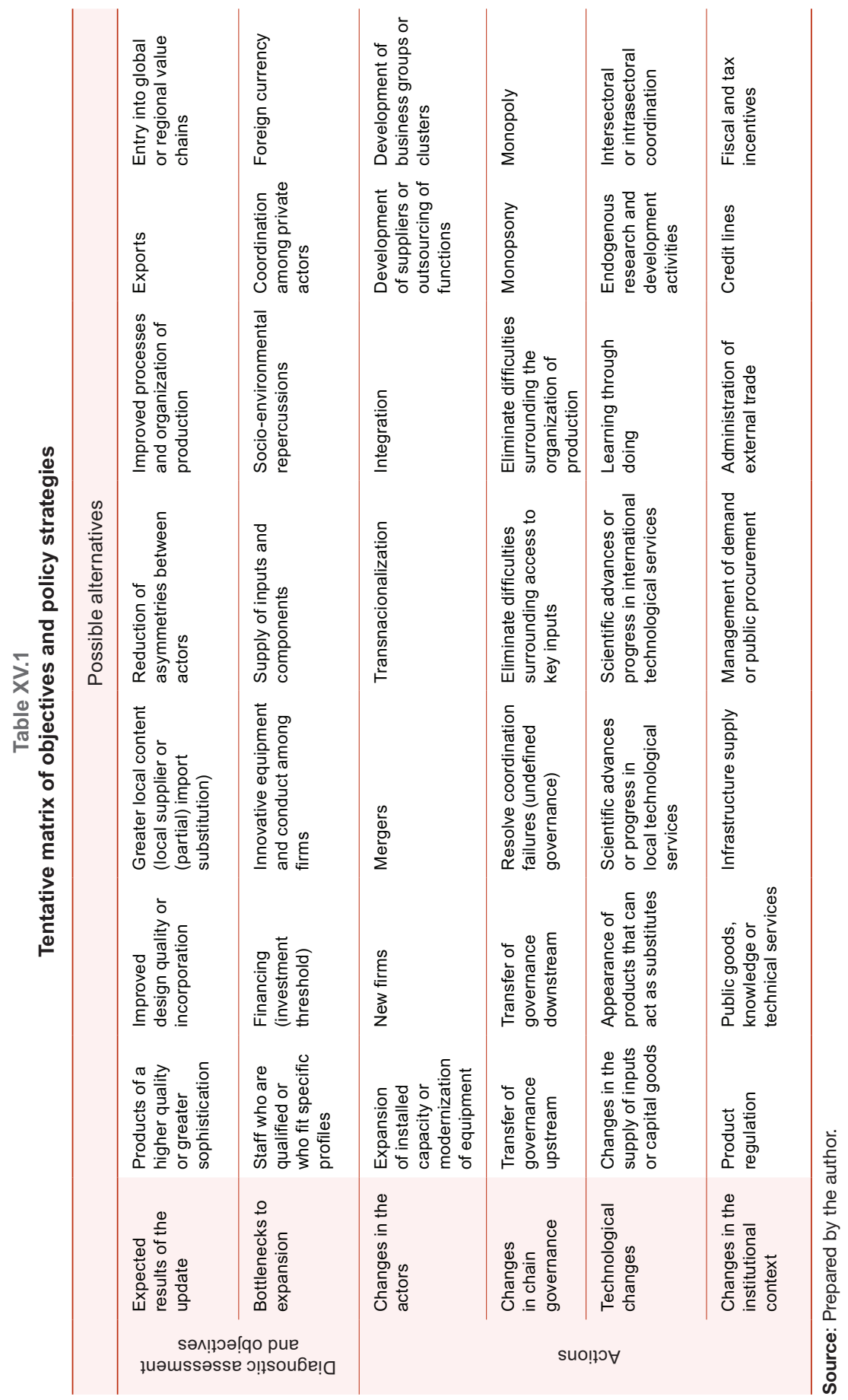


Such a conceptual redefinition of industrial policy also requires us to take account of the role of demand as a vector of industrialization, which means finding the right place for the State as a source of real and monetary externalities. In some cases, in order to leverage demand in the processes of creating linkages and upgrading, it may be necessary to prioritize access to external markets, with the aim of encouraging the incorporation of more sophisticated designs or finer materials, or to rely on high-income consumers to defray the costs of more complex production processes. In other cases, the dynamizing role of demand can be channelled through income policies, which enable the potential scale to be expanded through the incorporation of new consumers and the formation of new markets. Public spending is, of course, another powerful tool to dynamize production processes: housing plans, expenditure on medical equipment and investment in transport and energy all offer magnificent opportunities for supply-side sectors to enjoy conditions that will enable them to progress along the lines proposed for channelling structural change.

\section{Conclusions}

The progressive resolution of specialization problems entails driving sectors, segments, activities and ultimately firms towards a path of greater knowledge and complementarities. These trajectories must be sector-specific, in the sense that they make it possible to impact learning, externalities and linkages to varying degrees, both potential and feasible. As far as these trajectories are followed (reconversion and restructuring of the existing production apparatus) and new activities are able to exert dynamic effects of scale, the whole system can become more competitive. Public intervention and production policies would need to be approached from another conceptual angle, which would in turn lead to new forms of intervention and modes of management and to the design of different instruments. To overcome the problems of social heterogeneity currently afflicting the Argentine economic structure, the State must, in addition to stimulating growth, be able to intervene actively in the definition of a production profile that rises effectively and sustainably to the challenge of achieving equity. 


\section{Bibliography}

Bianco, C. and C. Fernandez Bugna (2010), "Transformación estructural: una aproximación cuantitativa de la industria argentina 1993-2007", Revista Iberoamericana de Ciencia, Tecnología y Sociedad, No. 15, vol. 5, September.

Bianco, C., F. Porta and F. Vismara (2008), “Evolución reciente de la balanza comercial argentina. El desplazamiento de la restricción externa", Project Documents, No. 165 (LC/W.165), Buenos Aires, ECLAC office in Buenos Aires.

Briner, M.A., A. Sacroisky and M. Bustos Zavala (2007), "Desafíos de la reconfiguración productiva en Argentina. Aportes para el debate actual", Project Documents, No. 16, Economic and Financial Center for Development of Argentina (CEFID-AR), July.

Coremberg, A. (2012), "Measuring productivity in unstable and natural resources dependent economies: Argentina", paper presented at the Second World KLEMS Conference, Cambridge, Massachusetts, Harvard University, 9-10 August.

Herrera, G. and A. Tavosnaska (2009), "La industria argentina a comienzos del siglo XXI. Aportes para una revisión de la experiencia reciente", first Annual Congress of the Economic Association for Argentine Development (AEDA), Buenos Aires, 24-25 August.

Katz, Jorge and Giovanni Stumpo (2001), "Sectoral regimes, productivity and international competitiveness", CEPAL Review, No. 75 (LC/G.2150-P/E), Santiago, Economic Commission for Latin America and the Caribbean (ECLAC), December.

Kulfas, M. (2009), "Cambio de régimen y dilemas del largo plazo. La economía argentina entre 2003 y 2007", first Annual Congress of the Economic Association for Argentine Development (AEDA), Buenos Aires, 24-25 August.

Lafay, R. (1990), «La mesure des avantages comparatifs révèles», Economie Prospective Internationale, Paris.

Lafay, G. and C. Herzog (1989), «Commerce international: la fin des avantages acquis», Economica, Paris, Centre for International Prospective Studies and Information (CEPII).

Lugones, G., D. Suarez and P. Moldovan (2008), "Innovation, competitiveness and salaries: a model of combined growth at the firm level", paper presented at the sixth Globelics International Conference, Mexico City, 22 - 24 November.

Nassif, A. (2003), “Uma contribuição ao debate sobre a nova política industrial brasileira", Textos para Discussão, No. 101, Rio de Janeiro, Brazilian Development Bank (BNDES), September.

Ocampo, José Antonio (2005), “The quest for dynamic efficiency: structural dynamics and economic growth in developing countries", Beyond Reforms: Structural Dynamics and Macroeconomic Vulnerability, Jose Antonio Ocampo (ed.), Palo Alto, Stanford University Press/World Bank

Peirano, F. (2008), "La contribución del sector industrial al cambio tecnológico. Un análisis comparado de los casos de Argentina y de Brasil", Documento de Trabajo, No. 28, Buenos Aires, Centro Redes, August.

Porta, Fernando (2006), “Especialización productiva e inserción internacional. Evidencias y reflexiones sobre el caso argentino", Enfoques y metodologías alternativas para la medición de las capacidades innovativas, G. Lugones and F. Porta (comps.), PICT 02-09536 Project, Buenos Aires, Fund for Scientific and Technological Research (FONCYT)/National Agency for the Promotion of Science and Technology of Argentina (ANPCYT). 
Porta, F. and C. Fernandez Bugna (2011), "La industria manufacturera: trayectoria reciente y cambio estructural", La Argentina del largo plazo: crecimiento, fluctuaciones y cambio estructural, R. Mercado, B. Kosacoff and F. Porta (eds.), Buenos Aires, United Nations Development Programme (UNDP).

Porta, F. and others (coords.) (2009), Tendencias y determinantes del proceso de inversión en Argentina. 2002-2007, Buenos Aires, United Nations Development Programme (UNDP).

Stumpo, G. (comp.) (2009), "La especialización exportadora y sus efectos sobre la generación de empleos. Evidencia para Argentina y Brasil", Project Documents, No. 264 (LC/W.264), Giovanni Stumpo (comp.), Santiago, Economic Commission for Latin America and the Caribbean (ECLAC).

Stumpo, G. and D. Rivas (2013) (comps.), La industria argentina frente a los nuevos desafíos y oportunidades del siglo XXI (LC/R.3637), Santiago, Economic Commission for Latin America and the Caribbean (ECLAC).

Suarez, D. (2013), "Innovative strategies in unstable environments: the case of Argentinean firms", Ph.D. thesis, Aalborg University/National University of Quilmes.

Tavosnaska, A. (2010), “Crisis, devaluación y después. Breve historia de la recomposición de las ganancias empresariales en la post-convertibilidad", second Annual Congress of the Economic Association for Argentine Development (AEDA), Buenos Aires, 20-21 September. 


\section{Author profiles}

Alicia Bárcena assumed office as the Executive Secretary of the Economic Commission for Latin America and the Caribbean (ECLAC) on 1 July 2008. She had previously served as Under-Secretary-General for Management at United Nations Headquarters in New York, Chef de Cabinet and Deputy Chef de Cabinet to the former Secretary-General, Kofi Annan. At ECLAC, she held the post of Deputy Executive Secretary and Director of the Environment and Human Settlements Division. Prior to her time at ECLAC, Ms. Bárcena served as coordinator of the Latin American and Caribbean Sustainable Development Programme of the United Nations Development Programme (UNDP), and coordinator of the Environmental Citizenship Project of the United Nations Environment Programme (UNEP). She was also the founding director of the Earth Council in Costa Rica, a non-governmental organization in charge of follow-up to the agreements reached at the United Nations Conference on Environment and Development (UNCED), held in Rio de Janeiro, Brazil, in 1992. Ms. Bárcena has taught and conducted research at the National Autonomous University of Mexico and she has published numerous articles on sustainable development, public policy, environmental issues and public participation. Ms. Bárcena holds a Bachelor of Science degree in biology and a master's degree in public administration from Harvard University. She has completed courses for a master's degree in ecology and has initiated studies for a PhD in economics at the National Autonomous University of Mexico.

Antonio Prado, a Brazilian economist specializing in the analysis of technological changes in industry and their impact on economic development, the labour market and Brazil's industrial relations, has held the post of Deputy Executive Secretary of the Economic Commission for Latin America and the Caribbean (ECLAC) since 1 November 2009. Prior to that he was Head Officer for Government Affairs of the Presidency of the Brazilian National Bank for Economic and Social Development (BNDES) (2005-2009) and adviser to the leader of the Government caucus in the Brazilian Senate (2003-2004). He was also a board member of the Brazilian Agency for Export Promotion (APEX), the Brazilian Agency for Industrial Development (ABDI) and the Celso Furtado Centre, among other institutions, including civil society organizations. Between 1990 and 2000, Mr. Prado was a member of the technical board of directors and was responsible for the research division of the Inter-Union Department of Statistics and Socioeconomic Research (DIEESE), a research centre on labour issues in Brazil. There, he prepared statistical surveys on the cost of living and employment and studies on income distribution, racial and gender issues, strategic planning, industrial changes and macroeconomics. In the 1990s, Mr. Prado coordinated research projects at the National Council for Scientific and Technological Development (CNPq-Brasil) and at the Rio Branco Institute (IRBr) of the Ministry of Foreign 
Affairs of Brazil. He holds a master's degree in industrial economics and a $\mathrm{PhD}$ in economic development policies from the State University of Campinas. Mr. Prado has also published books and contributed to articles featured in Brazil's specialized press.

Esteban Pérez Caldentey is currently Chief of the Financing for Development Unit of the Economic Development Division of the Economic Commission for Latin American and the Caribbean (ECLAC). He previously worked at the ECLAC subregional headquarters in Mexico and the ECLAC subregional headquarters for the Caribbean in Port of Spain, where he was Economic Affairs Officer and Coordinator of the Economics Unit. He has also worked for the United Nations Development Programme (UNDP) and the United Nations Children's Fund (UNICEF). He holds a master's degree and a PhD from the New School for Social Research in New York, where he was a teaching assistant. He also teaches at the University of Santiago de Chile and the University of Chile. He is a member of the editorial board of the journal, Investigación Económica, of the National Autonomous University of Mexico, the International Journal of Political Economy and the Review of Keynesian Economics. He is also co-editor of the World Economic Review. His most recent publications include "Raúl Prebisch and economic dynamics: cyclical growth and centre-periphery interaction" (CEPAL Review, No. 118, April 2016, with Matías Vernengo), "Reading Keynes in Buenos Aires: Prebisch and the Dynamics of Capitalism" (Cambridge Journal of Economics, November 2015 with Matías Vernengo) and "Inversión, financiamiento y la paradoja de la deuda en Minsky. Un análisis microeconométrico aplicado a América Latina" (Ensayos económicos del Banco Central de la República Argentina, No. 73, December 2015 with Alejandro González Castillo).

José Antonio Ocampo is currently Professor of Professional Practice in International and Public Affairs and Director of the Economic and Political Development Concentration of the School of International and Public Affairs of the University of Columbia. Previously, he served as UnderSecretary-General for Economic and Social Affairs, Executive Secretary of the Economic Commission for Latin America and the Caribbean (ECLAC), and Minister of Finance and Public Credit and Minister of Agriculture and Rural Development of Colombia. He graduated in economics and sociology from the University of Notre Dame in 1972 and received a PhD in economics from Yale University in 1976. In the academic sphere, he was Executive Director of the Foundation for Higher Education and Development (FEDESARROLLO), Colombia's main economic think tank, Director of the Centre for Economic Development Studies (CEDE) of the University of the Andes, Professor of Economics at the University of the Andes and Professor of Economic History at the National University of Colombia. He has been 
a Visiting Professor at the universities of Cambridge, Oxford and Yale and has spoken at many other institutions while participating in various policy and academic conferences around the world. Mr. Ocampo is the author and editor of over 40 books and has published more than 300 academic articles on macroeconomic theory and policy, international financial issues, economic and social development, international trade, and the economic history of Colombia and Latin America.

Luiz Gonzaga Belluzzo graduated with a bachelor's degree in law from the University of São Paulo in 1965. He also studied social sciences at the Faculty of Philosophy, Literature and Human Sciences of the same University and completed a post-graduate degree in economic development at the Latin American and Caribbean Institute for Economic and Social Planning (ILPES) of the Economic Commission for Latin America and the Caribbean (ECLAC). He was an assistant professor at the State University of Campinas, where he received his doctorate and became a tenured professor in 1986. He was economic adviser to the Brazilian Democratic Movement Party (PMDB) between 1974 and 1992, Economic Policy Secretary at the Ministry of Finance of Brazil (1985-1987), Science and Technology Secretary for the state of São Paulo (1988-1990) and Head of the Special Secretariat for Economic Affairs of the Ministry of Finance during the government of José Sarney. He is one of the founders of the Campinas College (FACAMP) and, in 2005, he received the Juca Pato Prize as intellectual of the year in Brazil. He is considered the best heterodox economist in Brazil, on account of his interpretations and criticisms of and suggestions for Brazilian society, from the perspective of Karl Marx and John Maynard Keynes.

Ricardo Ffrench-Davis Muñoz is a Chilean economist who won the National Social Sciences and Humanities Award presented by the Government of Chile in 2005 and professor at the Faculty of Economics and Business of the University of Chile. He holds a PhD (1971) and a master's degree (1961) in economics from the University of Chicago. He also has a commercial engineering degree (1962) from the Pontifical Catholic University of Chile; holds degrees in both economics and administration; and was teaching coordinator between 1963 and 1964 and professor between 1962 and 1974. $\mathrm{He}$ is also one of the founders of the Research Corporation for Latin America (CIEPLAN), where he carried out research from 1976 until 1990, when he was appointed Research Director of the Central Bank of Chile. He held that position until March 1992, when he joined the Economic Commission for Latin America and the Caribbean (ECLAC) as Regional Adviser. He is renowned for his contribution to the study on cyclical capital flows to emerging markets, mainly to Latin America. He is an advocate of mechanisms that prevent strong capital inflows, such as the bank reserve that worked 
in Chile for much of the 1990s. He has been appointed by the Presidents of Algeria, Brazil, Chile, France, Germany and Spain to represent the Technical Group on Innovative Financing Mechanisms in an effort to combat hunger and poverty in the world. Together with the 2001 winner of the Nobel Prize for Economics, Joseph Stiglitz, he co-chairs the Macroeconomic Policy Task Force of the Initiative for Policy Dialogue at the University of Columbia. He has also been a Visiting Professor at the universities of Oxford and Boston, at the Complutense University in Madrid and Stanford University in Chile, as well as institutes in France, Italy, Spain and Sweden.

Daniel Titelman has a bachelor's degree in economics from the University of the Andes in Colombia. He also holds a diploma in political science from the Latin American Faculty of Social Sciences (FLACSO). He is currently Chief of the Economic Development Division of the Economic Commission for Latin America and the Caribbean (ECLAC). Prior to that, he was Chief of the Financing for Development Division, Expert on Monetary and Financial Policies and Coordinator of the Special Studies Unit of ECLAC. He has extensive experience in macroeconomic and financial matters and has published numerous papers on the subject. He has also worked on issues related to social security financing, particularly health and pension reform. He has been involved in preparing various ECLAC reports on topics pertaining to macroeconomics, financing for development and social protection, and has provided technical assistance to various Latin American and Caribbean countries.

Juan Alberto Fuentes Knight is an economist and was Minister of Public Finances of Guatemala between 2008 and 2010. He holds a PhD in economics from the University of Sussex and a master's degree in the same subject from the University of Toronto. He was Chief of the Economic Development Division of the Economic Commission for Latin America and the Caribbean (ECLAC) between 2012 and 2014. He previously worked as research coordinator and regional adviser at the ECLAC subregional headquarters in Mexico. Prior to that he worked at the General Secretariat of Planning and Programming of the Office of the President of Guatemala, the Centre for Latin American Monetary Studies (CEMLA) in Mexico, the Secretariat for Central American Economic Integration (SIECA) and the United Nations Development Programme (UNDP), where he coordinated the Human Development Report of Guatemala for several years. He was also a member of the investigation team that prepared the report of the Guatemalan Historical Clarification Commission. He founded and was director of the Central American Institute for Fiscal Studies (ICEFI). He is the author of several publications on economic integration and fiscal policy. 
Mario Cimoli is Chief of the Division of Production, Productivity and Management of the Economic Commission for Latin America and the Caribbean (ECLAC) and Associate Professor of Economics at the Ca' Foscari University of Venice, Italy. He received his $\mathrm{PhD}$ in economics from the University of Sussex (1992) with a thesis that examined the effect of technological gaps and trade on developing economies' growth. Since 2004, he has been co-chair, together with Giovanni Dosi and Joseph Stiglitz, of two of the task forces (industrial policy and intellectual property) of the Initiative for Policy Dialogue at the University of Columbia. He was awarded the Philip Morris Endowed Chair in International Business (2004) at the Sant'Ana School of Advanced Studies of the University of Pisa. He lectures and publishes articles and books on issues related to economic development policies in both the area of industry and of science, innovation and technology.

Gabriel Porcile is Economic Affairs Officer of the Division of Production, Productivity and Management of the Economic Commission for Latin America and the Caribbean (ECLAC). He holds a master's degree in economic sciences from the State University of Campinas and a PhD in economic history from the London School of Economics and Political Science. He is also a professor in the Department of Economics of the Federal University of Paraná and a researcher with the National Council for Scientific and Technological Development (CNPq-Brasil). He has published numerous papers on issues related to technology, growth in Latin America and heterodox theories of growth. His last two studies were entitled "Technology, structural change and BOP-constrained growth: a structuralist toolbox", Cambridge Journal of Economics, and "Technological intensity of the export structure and the real exchange rate", Economics of Innovation and New Technology.

Jorge Katz received his degree in economics from the University of Buenos Aires in 1964 and his PhD in economics from Nuffield College, University of Oxford, in 1967. His doctoral dissertation "Production Functions, Foreign Investment and Growth" was published by North Holland Publishing Company in 1969. After returning to Argentina, he was appointed Professor of Economics at the University of Buenos Aires, where he lectured on industrial organization and economic development for almost 20 years. During that period he conducted a long-term research project for the Economic Commission for Latin America and the Caribbean (ECLAC) and the Inter-American Development Bank (IDB) on the development of domestic technological capabilities in Latin America. The results of that project have been published in numerous books and articles in Spanish and English. In 1994 he was appointed Chief of the Division of Production, Productivity and Management of ECLAC, a position that he held until his retirement from the 
United Nations system in 2003. Since then, he has been Professor of Economic Growth and Innovation at the University of Chile. His publications include 18 books on technological issues and the industrial sector in Latin America and around 80 papers in scientific journals.

Luis Bértola, holder of a PhD in economic history from the University of Gothenburg, is Professor of Economic History and Development at the University of the Republic, Uruguay, where he is also the head of the Academic Committee for the PhD programme. He manages the MontevideoOxford Latin American Economic History Database and the project, "Raúl Prebisch and the challenges of the twenty-first century", an initiative of the Economic Commission for Latin America and the Caribbean (ECLAC). $\mathrm{He}$ is a member of the Board of Trustees of the Journal of Iberian and Latin American Economic History and a member of the editorial board of many other scientific journals. He has taught postgraduate courses and led seminars at several universities around the world. His most recent publications were two books on Latin American economic history: Desarrollo, vaivenes y desigualdad: una historia económica de América Latina desde la independencia and Dos siglos de transformación productiva y social en América hispana. His main areas of research are comparative development over the long-term, with a focus on Latin America, technical and structural changes, inequality, living standards and international relations.

Robert Boyer is French economist known for being one of the main authors of the regulation school. He studied at the École polytechnique in Paris, the Paris Institute of Political Studies and the École des ponts ParisTech (ENPC). He currently holds various scientific and administrative roles, including as Researcher at the French Institute for Latin America (IFAL), a member of the European Union - Latin America and Caribbean Foundation (EU-LAC Foundation), Economist at the French Centre for Economic Research and its Applications (CEPREMAP), Director of Research at the French National Centre for Scientific Research (CNRS) attached to the École normale supérieure (ENS), and Director of Studies at the French School for Advanced Studies in the Social Sciences (EHESS). He is also a former member of the French Economic Analysis Committee (CAE), a member of the Saint-Gobain Centre for Economic Studies, an Honorary Fellow of the Executive Council of the Society for the Advancement of Socioeconomics (SASE), and a former member of the Executive Board of the French Economic Association. He was previously a Research Associate at the Institute for Advanced Study (Wissenschaftskolleg) in Berlin and a Visiting Professor at the International Centre for Business and Politics in Copenhagen, the School of Postgraduate Studies of the National Autonomous University of Mexico, and the College of Economics of the Yokohama National University, Japan. In his book, 
La théorie de la régulation: une analyse critique, he sets out an alternative to the neoclassical general equilibrium theory. He seeks to understand how economic and social structures evolve over time by adopting an institutionalist approach, namely that economic phenomena can be understood only from an interdisciplinary standpoint.

Sonia Montaño is a Bolivian sociologist who served as Chief of the Division for Gender Affairs of the Economic Commission for Latin America and the Caribbean (ECLAC). Her professional career began in 1983 when she founded and headed the Women's Information and Development Centre (CIDEM) in the Plurinational State of Bolivia, where she drafted the first public policy proposal on gender in 1989. Between 1993 and 1995 she was Undersecretary of Gender Affairs at the Ministry for Human Development of the Plurinational State of Bolivia and she worked as an adviser and consultant in various Latin American countries. She has published numerous papers on public policy, citizenship and women's political participation. She coordinated Millennium Development Goals 2006 Report: A look at gender equality and empowerment of women in Latin America and the Caribbean and authored Una mirada a la crisis desde los márgenes (ECLAC, 2011).

René A. Hernández, a Salvadoran national, completed his post-graduate studies in economics at the University of Warwick, United Kingdom of Great Britain and Northern Ireland. He also holds a master's degree in economic development from Vanderbilt University, United States of America. He is currently Head of the Education and Training Area of the Latin American and Caribbean Institute for Economic and Social Planning (ILPES) of the Economic Commission for Latin America and the Caribbean (ECLAC). Prior to that he held the post of Economist in the Division of Production, Productivity and Management of ECLAC, where his work focused on technical progress, heterogeneity and structural change in Latin America. $\mathrm{He}$ is a professor in economics at the University of Chile and the United Nations University Maastricht Economic and Social Research and Training Centre on Innovation and Technology (UNU-MERIT) and was the former Academic Coordinator of the Summer School on Latin American Economies of ECLAC. He is the author and co-author of several books and has made numerous contributions to scientific and academic journals specializing in Latin American economics; he has also worked as an editor for economic development journals. He was one of the main co-authors of the book Structural Change and Productivity Growth - 20 Years Later. Old problems, new opportunities, his most recent publications include Latin America's emergence in global services: a new driver of structural change in the region? (2014), Global value chains and world trade: prospects and challenges for Latin America (2014), 
Internationalization and innovation in Latin American services (forthcoming), and The impacts of China on economic growth: evidence for Brazil, Chile and Peru (forthcoming).

Juan Carlos Moreno-Brid holds a PhD from the University of Cambridge, a master's degree in economics from the Economic Research and Teaching Centre (CIDE) of Mexico and a bachelor's degree in mathematics from the National Autonomous University of Mexico. He is a professor at the National Autonomous University of Mexico (Mexico), having previously at the ECLAC subregional headquarters in Mexico, which he joined in 2000 after years working at the David Rockefeller Center for Latin American Studies at Harvard University, where he held the posts of Research Coordinator and Deputy Director. A specialist in economic development, he has published numerous articles in international journals. His most recent books are Cambio estructural y crecimiento en Centroamérica y la República Dominicana: un balance de dos décadas, 1990-2011 and Desarrollo y crecimiento en la economía mexicana. Una perspectiva histórica. He participates in specialized forums as a speaker and is a member of the editorial board of El Trimestre Económico, CEPAL Review and ECONOMIAunam. He is also a founding member of the World Economics Association, a group with more than 13,500 members. $\mathrm{He}$ is a member of the Nuevo Curso de Desarrollo group of the National Autonomous University of Mexico.

João Carlos Ferraz is a Brazilian economist and expert on issues related to industrial organization and competition, innovation, business strategies, financing and production development policies. Before joining the Board of the Brazilian National Bank for Economic and Social Development (BNDES), he held the post of Chief of the Division of Production, Productivity and Management of the Economic Commission for Latin America and the Caribbean (ECLAC). He graduated with a degree in economics from the Pontifical Catholic University of Minas Gerais in 1977 and with a degree in journalism from the same institution in 1978. Six years later he was awarded a $\mathrm{PhD}$ in innovation, economics and public policy from the University of Sussex. He is a professor at the Federal University of Rio de Janeiro, where he was Director of the Institute of Economics between 1998 and 2003. He was also a Visiting Professor at the University of Tsukuba, Japan. He has supervised doctoral theses and dissertations, and written journal articles, books and book chapters.

Fernando Porta graduated in economic policy from the University of Buenos Aires (1970) and obtained a postgraduate degree from the University of Sussex (1980). He is a tenured professor at the National University of 
Quilmes and the University of Buenos Aires, and a lead researcher at the Centre for Studies on Science, Development and Higher Education (Centro REDES). He teaches postgraduate courses at various universities in Argentina and abroad. A specialist in international economics and industrial economics, he works as a consultant for the Economic Commission for Latin America and the Caribbean (ECLAC), the Inter-American Development Bank (IDB), the United Nations Development Programme (UNDP) and the United Nations Conference on Trade and Development (UNCTAD). He is a member of the editorial board of the journal, Desarrollo Económico, and the Revista Iberoamericana de Ciencia, Tecnología y Sociedad. He also oversees the Administración y Economía series of the National University of Quilmes. He has published several books and articles on specialization and development patterns, international competitiveness, economic integration, the Southern Common Market (MERCOSUR), industrial restructuring and the strategies of transnational corporations. 



\section{Publicaciones recientes de la CEPAL ECLAC recent publications}

\section{www.cepal.org/publicaciones}

\section{Informes periódicos / Annual reports}

\section{También disponibles para años anteriores / Issues for previous years also available}

- Estudio Económico de América Latina y el Caribe 2015, 204 p. Economic Survey of Latin America and the Caribbean 2015, 196 p.

- La Inversión Extranjera Directa en América Latina y el Caribe 2015, $150 \mathrm{p}$. Foreign Direct Investment in Latin America and the Caribbean 2015, $140 \mathrm{p}$.

- Anuario Estadístico de América Latina y el Caribe 2015 / Statistical Yearbook for Latin America and the Caribbean 2015, $235 \mathrm{p}$.

- Balance Preliminar de las Economías de América Latina y el Caribe 2015, 104 p. Preliminary Overview of the Economies of Latin America and the Caribbean 2015, 98 p.

- Panorama Social de América Latina 2015. Documento informativo, 68 p. Social Panorama of Latin America 2015. Briefing paper, 66 p.

- Panorama de la Inserción Internacional de América Latina y el Caribe 2015, 102 p. Latin America and the Caribbean in the World Economy 2015, 98 p.

\section{Libros y documentos institucionales / Institutional books and documents}

- Panorama fiscal de América Latina y el Caribe 2016: las finanzas públicas ante el desafío de conciliar austeridad con crecimiento e igualdad, 2016, 90 p.

- Reflexiones sobre el desarrollo en América Latina y el Caribe: conferencias magistrales 2015, 2016, 74 p.

- Panorama Económico y Social de la Comunidad de Estados Latinoamericanos y Caribeños, 2015, 58 p. Economic and Social Panorama of the Community of Latin American and Caribbean States 2015, 56 p.

- Desarrollo social inclusivo: una nueva generación de políticas para superar la pobreza y reducir la desigualdad en América Latina y el Caribe, 2015, 180 p.

Inclusive social development: The next generation of policies for overcoming poverty and reducing inequality in Latin America and the Caribbean, 2015, 172 p.

- Guía operacional para la implementación y el seguimiento del Consenso de Montevideo sobre Población y Desarrollo, 2015, 146 p.

Operational guide for implementation and follow-up of the Montevideo Consensus on Population and Development, 2015, $139 p$.

- América Latina y el Caribe: una mirada al futuro desde los Objetivos de Desarrollo del Milenio. Informe regional de monitoreo de los Objetivos de Desarrollo del Milenio (ODM) en América Latina y el Caribe, 2015, $88 \mathrm{p}$.

Latin America and the Caribbean: Looking ahead after the Millennium Development Goals. Regional monitoring report on the Millennium Development Goals in Latin America and the Caribbean, 2015, $88 \mathrm{p}$.

- La nueva revolución digital: de la Internet del consumo a la Internet de la producción, 2015, 98 p. The new digital revolution: From the consumer Internet to the industrial Internet, 2015, 98 p. 
- Globalización, integración y comercio inclusivo en América Latina. Textos seleccionados de la CEPAL (2010-2014), 2015, 326 p.

- El desafío de la sostenibilidad ambiental en América Latina y el Caribe. Textos seleccionados de la CEPAL (2012-2014), 2015, 148 p.

- Pactos para la igualdad: hacia un futuro sostenible, 2014, $340 \mathrm{p}$. Covenants for Equality: Towards a sustainable future, 2014, 330 p.

- Cambio estructural para la igualdad: una visión integrada del desarrollo, 2012, 330 p. Structural Change for Equality: An integrated approach to development, 2012, 308 p.

- La hora de la igualdad: brechas por cerrar, caminos por abrir, 2010, 290 p. Time for Equality: Closing gaps, opening trails, 2010, 270 p.

A Hora da Igualdade: Brechas por fechar, caminhos por abrir, 2010, 268 p.

\section{Libros de la CEPAL / ECLAC books}

138 Estructura productiva y política macroeconómica: enfoques heterodoxos desde América Latina, Alicia Bárcena Ibarra, Antonio Prado, Martín Abeles (eds.), 2015, 282 p.

137 Juventud: realidades y retos para un desarrollo con igualdad, Daniela Trucco, Heidi Ullmann (eds.), $2015,282 \mathrm{p}$.

136 Instrumentos de protección social: caminos latinoamericanos hacia la universalización, Simone Cecchini, Fernando Filgueira, Rodrigo Martínez, Cecilia Rossel (eds.), 2015, 510 p.

135 Rising concentration in Asia-Latin American value chains: Can small firms turn the tide? Osvaldo Rosales, Keiji Inoue, Nanno Mulder (eds.), 2015, 282 p.

134 Desigualdad, concentración del ingreso y tributación sobre las altas rentas en América Latina, Juan Pablo Jiménez (ed.), 2015, 172 p.

133 Desigualdad e informalidad: un análisis de cinco experiencias latinoamericanas, Verónica Amarante, Rodrigo Arim (eds.), 2015, 526 p.

132 Neoestructuralismo y corrientes heterodoxas en América Latina y el Caribe a inicios del siglo XXI, Alicia Bárcena, Antonio Prado (eds.), 2014, 452 p.

\section{Copublicaciones / Co-publications}

- Gobernanza global y desarrollo: nuevos desafíos y prioridades de la cooperación internacional, José Antonio Ocampo (ed.), CEPAL/Siglo Veintiuno, Argentina, 2015, 286 p.

- Decentralization and Reform in Latin America: Improving Intergovernmental Relations, Giorgio Brosio and Juan Pablo Jiménez (eds.), ECLAC / Edward Elgar Publishing, United Kingdom, 2012, 450 p.

- Sentido de pertenencia en sociedades fragmentadas: América Latina desde una perspectiva global, Martín Hopenhayn y Ana Sojo (comps.), CEPAL / Siglo Veintiuno, Argentina, 2011, 350 p.

\section{Coediciones / Co-editions}

- Perspectivas económicas de América Latina 2016: hacia una nueva asociación con China, 2015, 240 p. Latin American Economic Outlook 2016: Towards a new Partnership with China, 2015, 220 p.

- Perspectivas de la agricultura y del desarrollo rural en las Américas: una mirada hacia América Latina y el Caribe 2015-2016, CEPAL / FAO / IICA, 2015, 212 p. 


\section{Documentos de proyecto / Project documents}

- Complejos productivos y territorio en la Argentina: aportes para el estudio de la geografía económica del país, 2015, $216 p$.

- Las juventudes centroamericanas en contextos de inseguridad y violencia: realidades y retos para su inclusión social, Teresita Escotto Quesada, 2015, 168 p.

- La economía del cambio climático en el Perú, 2014, 152 p.

\section{Cuadernos estadísticos de la CEPAL}

42 Resultados del Programa de Comparación Internacional (PCI) de 2011 para América Latina y el Caribe. Solo disponible en CD, 2015.

41 Los cuadros de oferta y utilización, las matrices de insumo-producto y las matrices de empleo. Solo disponible en CD, 2013.

\section{Series de la CEPAL / ECLAC Series}

Asuntos de Género / Comercio Internacional / Desarrollo Productivo / Desarrollo Territorial / Estudios Estadísticos / Estudios y Perspectivas (Bogotá, Brasilia, Buenos Aires, México, Montevideo) / Studies and Perspectives (The Caribbean, Washington) / Financiamiento del Desarrollo/ Gestión Pública / Informes y Estudios Especiales / Macroeconomía del Desarrollo / Manuales / Medio Ambiente y Desarrollo / Población y Desarrollo/ Política Fiscal / Políticas Sociales / Recursos Naturales e Infraestructura / Seminarios y Conferencias.

\section{Revista CEPAL / CEPAL Review}

La Revista se inició en 1976, con el propósito de contribuir al examen de los problemas del desarrollo socioeconómico de la región. La Revista CEPAL se publica en español e inglés tres veces por año.

CEPAL Review first appeared in 1976, its aim being to make a contribution to the study of the economic and social development problems of the region. CEPAL Review is published in Spanish and English versions three times a year.

\section{Observatorio demográfico / Demographic Observatory}

Edición bilingüe (español e inglés) que proporciona información estadística actualizada, referente a estimaciones y proyecciones de población de los países de América Latina y el Caribe. Desde 2013 el Observatorio aparece una vez al año.

Bilingual publication (Spanish and English) proving up-to-date estimates and projections of the populations of the Latin American and Caribbean countries. Since 2013, the Observatory appears once a year.

\section{Notas de población}

Revista especializada que publica artículos e informes acerca de las investigaciones más recientes sobre la dinámica demográfica en la región. También incluye información sobre actividades científicas y profesionales en el campo de población.

La revista se publica desde 1973 y aparece dos veces al año, en junio y diciembre.

Specialized journal which publishes articles and reports on recent studies of demographic dynamics in the region. Also includes information on scientific and professional activities in the field of population. Published since 1973, the journal appears twice a year in June and December. 
Las publicaciones de la CEPAL están disponibles en: ECLAC publications are available at:

\section{www.cepal.org/publicaciones}

También se pueden adquirir a través de:

They can also be ordered through:

\section{www.un.org/publications}

United Nations Publications

PO Box 960

Herndon, VA 20172

USA

Tel. (1-888)254-4286

Fax (1-800)338-4550

Contacto / Contact. publications@un.org

Pedidos / Orders: order@un.org 


\section{Neostructuralism and heterodox thinking in Latin America and the Caribbean in the early twenty-first century \\ ALICIA BÁRCENA ANTONIO PRADO}

The thinking that has unilaterally dominated economic science for over five decades has recently come under intensive scrutiny and its validity and

conceptual and empirical coherence are the subject of controversy. Thus the limitations of the prevailing paradigm for addressing the failures of free market economies have been laid bare.

For Latin America and the Caribbean, these failures are structural in nature, as indeed structuralism proposed in its time. Neostructuralism delves more deeply into the issues addressed in structuralism, aiming to improve positioning in the international economy, boost productive employment creation, reduce structural heterogeneity and improve income distribution, while maintaining financial balances capable of sustaining changes in the sphere of production by means of social and State support. Far from being an insular system of thinking, neostructuralism is an open system that lends itself to dialogue with other philosophies that recognize the limitations of the dominant paradigm and object to its methodological monism.

This book offers a fresh look at neostructuralism and heterodox thinking at the start of the twenty-first century. In a context shaped by the impacts of the worst economic and financial crisis since the Great Depression and by paradigmatic changes at the global level, it aims to carve out arenas for discussion between alternative lines of thinking in order to lay the foundations for a socioeconomically inclusive and environmentally sustainable model of development for the region. 